


\section{EL GUSTO EN EL MUSEO}

\section{ACTAS III CONGRESO INTERNACIONAL SOBRE PATRIMONIO ALIMENTARIO Y MUSEOS}

Edición científica: Núria Ramón-Marqués 
Congresos UPV

III Congreso Internacional de Patrimonio Alimentario y Museos

Los contenidos de esta publicación han sido evaluados por el Comité Científico que en ella se relaciona y según el procedimiento doble ciego.

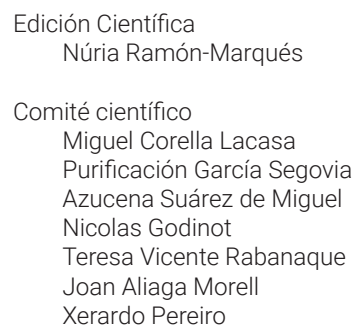

Enrique Mateo, Triskelion Diseño Editorial.

ISBN: 978-84-9048-996-3

Imagen de portada: Bodegón con melón y brevas, manzanas, bota de vino y cesta de merienda en un paisaje. Meléndez, Luis Egidio. Copyright de la imagen (c) Museo Nacional del Prado.

\section{GENERALITAT VALENCIANA}

Conselleria d'Innovació, Universitats, Ciència i Societat Digital AORG/2021/90

III Congreso Internacional de Patrimonio Alimentario y Museos / Editorial Universitat Politècnica de València https://doi.org/10.4995/EGEM2021.2021.14900

\section{(c) (1) (8)}

Se permite la reutilización de los contenidos mediante la copia, distribución, exhibición y representación de la obra, así como la generación de obras derivadas siempre que se reconozca la autoría y se cite con la información bibliográfica completa. No se permite el uso comercial y las obras derivadas deberán distribuirse con la misma licencia que regula la obra original. 


\section{I| PRESENTACIÓN}

El Gusto en el Museo. Patrimonio Alimentario y museos forma parte de un proyecto que se inició en el año 2019 y que se enmarca en las actividades del Centre de Investigación Medieval y Moderna (CIMM) dentro de la línea de investigación que abarca los estudios sobre museología, museografía y los proyectos expositivos.

Desde nuestro centro de investigación consideramos que los conocimientos museográficos deben ayudar a transmitir y facilitar nuevas investigaciones con el fin de compartirlas con la sociedad y el resto de la comunidad científica, dando a conocer los recientes avances tecnológicos en la materia.

En esta tercera edición, hemos querido abordar dos objetivos fundamentales. Un primer objetivo se ha centrado fundamentalmente en exponer la particular casuística de los museos alimentarios como espacios patrimoniales en los que, a través del estudio antropológico de la alimentación, se ponen de manifiesto identidades locales que pasan inadvertidas o son subordinadas en el contexto de la globalización. Es, por tanto, la reivindicación de estos museos como lugares fundamentales para proporcionar un canal de diálogo entre los diferentes agentes el patrimonio alimentario y la sociedad. El patrimonio alimentario se caracteriza por su constante adaptación, su transversalidad y su utilización como elemento para promover valores culturales, sociales, igualitarios y de desarrollo local. Los museos han ido incorporando paulatinamente la alimentación en sus discursos expositivos, llegando a surgir nuevos espacios que abordan la alimentación de manera específica, revalorizando, promocionando y difundiendo distintos productos del patrimonio alimentario local.

En cuanto a nuestro segundo objetivo, éste se ha centrado en vincular las obras de arte como fuentes de documentación alimentaria, y es en este apartado donde se aportan varias investigaciones que abarcan desde el estudio de los saleros y especieros aragoneses de Época Moderna, hasta el análisis de la uva y el vino en la Antigüedad a través de los paneles de Sorolla, pasando por las alegorías de Francisco Barrera, el recorrido visual a través de la alimentación en las obras de arte, los diálogos entre arte y gastronomía del museo de Mallorca o la polémica del chocolate a través del arte de la Edad Moderna; todo ello hasta llegar a la experimentación de la alimentación a través del arte contemporáneo y la experiencia performática. 
Con la lectura de las aportaciones que aquí se presentan, el lector entenderá que la alimentación, con sus prácticas sociales y los procedimientos técnicos es transversal a la cultura y de manera bidireccional la cultura lo es con la alimentación. A través de estos textos se pretende reflexionar, debatir ideas, e intercambiar experiencias con los museos que tienen los alimentos como elemento común y la importancia de los alimentos en las obras de arte a través de los siglos.

Por último, como editora del libro, no puedo dejar de agradecer a todos los participantes de esta edición, al apoyo de la Generalitat Valenciana y del Departamento de Comunicación Audiovisual, Documentación e Historia del Arte, así como al equipo de personas que ha hecho posible este trabajo. Y por ello, mi especial agradecimiento a Rosa, María, Alejandra, Gerardo y Joan.

Nuria Ramón-Marqués 
Dirección y Editora científica

Nuria Ramón-Marqués

\section{Comité científico}

Joan Aliaga Morell. Catedrático de Historia del Arte. Universitat Politècnica de València.

Azucena Suárez de Miguel. Directora de la Fundación Herdez. México.

Nicolás Godinot. Doctor en Neurociencia. Director del Museo de la alimentación Alimentarium -Fundación Nestlé-. Suiza.

Teresa Vicente Rabanaque. Profesora de la Universitat de València. Secretaria de l'Associació Valenciana d'Antropologia (AVA).

Miguel Corella Lacasa. Profesor Titular de Historia del Arte. Universitat Politècnica de València.

Purificación García Segovia. Catedrática en Tecnología de los Alimentos. Universitat Politècnica de Valencia.

Xerardo Pereiro. Profesor Universidade de Tras-os-Montes e Alto Douro. 



\section{ÍNDICE}

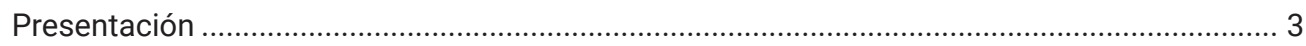

Dirección y Comité científico …………………………………………………………...... 5

\section{CONFERENCIAS}

El museo etnológico como laboratorio sociocultural de la alimentación. 9 Xerardo Pereiro

L'alimentation et le vin dans la vie et l'œuvre de Toulouse-Lautrec. Valoriser le patrimoine alimentaire et viticole au Château Malromé, en Gironde

Pauline Leclercq

\section{COMUNICACIONES}

Arte en la mesa: saleros y especieros aragoneses de Época Moderna.

Marc Millan Rabasa

Vinum vivat! La uva y el vino en la Antigüedad a través de los paneles que Sorolla pintó para Rafael Errázuriz.....

José Fenoll Cascales

La pintura y otras fuente de documentales para la construcción de un relato vi-

sual de la alimentación.

Gerardo Jesús García Olivares

Alimentos del futuro: la ciencia ficción culinaria a través del arte

Francisca Ramón Fernández, Cristina Lull Noguera, María Desamparados Soriano Soto

Génesis de una identidad visual: creación de la imagen para el Congreso

Internacional de Patrimonio Alimentario y Museo

Maricha Martínez Sosa

Ilustración, diseño y patrimonio alimentario

María Fragoso Mora

Manjares de seda: frutos y bordado en los museos de Lorca.

David Francisco Torres del Alcázar

Reflexiones en torno a la revalorización del patrimonio alimentario marítimo pesquero de Mallorca: la exposición temporal "Del mar a la taula".

Diana Borràs Rhodes, Joana Cifre Borràs

El Museu de Mallorca apuesta por el arte y la gastronomía

Maria Gràcia Salvà Picó, Pablo José Acover Cateura 
“Liquidum non frangit jejunum": la polémica religiosa en torno al chocolate y su reflejo en el arte de la Edad Moderna Vanesa Quintanar Cabello

La alimentación como acción, una experiencia performática. Nuria Faba Muñoz

El exilio compartido. Comida, arte y nostalgia. Javier Leñador González-Páez

Las cocinas y la comida en la obra cinematográfica de Pedro Almodóvar Gerardo Jesús García Olivares

La cultura de la alimentación. Patrimonio gastronómico de las sociedades en proceso de cambio y su difusión.

José Aniorte Pérez, Borja Guilló Soler, Rafael Martínez García, Isabel Picó Ledesma, Marian Tristán Richarte

Pasta, un arte con mucha ciencia.

Andrea Ainsa, Adrián Honrado, Pedro Marquina, J. Antonio Beltrán, Juan Calanchea

Comunicación culinaria en República Dominicana: tecnología, chefs, food stylists y foodies Maricha Martínez Sosa, Lucero Liriano, Georgina Batista Schrils

Residuos de coco. Arte y vermicompostado para su reutilización 281 Maria Desamparados Soriano, Francisco García, Laura Garcia-España 


\section{CONFERENCIAS}

III Congreso Internacional sobre Patrimonio Alimentario y Museos

25-26 Noviembre, 2021, Valencia 



\section{EL MUSEO ETNOLÓGICO COMO LABORATORIO SOCIOCULTURAL DE LA ALIMENTACIÓN}

\section{Xerardo Pereiro}

Universidade de Trás-os-Montes e Alto Douro (UTAD), Vila Real, Portugal

Investigador del CRIA (Centro em Rede de Investigação Antropológica).xerardopereiro@utad.pt

Resumen: Presento en este texto una mirada y un breve recorrido sobre la evolución del museo etnológico y la necesidad actual de convertirlo en un laboratorio sociocultural. A lo largo del mismo revisamos la diversidad de tipos de museos etnológicos, sus formas de cambiar y de adaptarse a los nuevos tiempos en este siglo XXI. Finalmente presentamos una propuesta para incluir la alimentación en la misión del museo en su transición a laboratorio sociocultural de la vida humana.

Palabras clave: museos etnológicos, laboratorios socioculturales, museos de la alimentación.

Citar como: Pereiro, X. (2022). "El museo etnológico como laboratorio sociocultural de la alimentación". En: Actas del III Congreso Internacional sobre Patrimonio Alimentario y Museos. 25-26 noviembre, 2021, Valencia, España. pp. 11-27. https://doi.org/10.4995/EGEM2021.2021.14898 


\section{Los museos etnológicos ante su historia}

La institución social "museo etnológico" es una organización socioespacial y sociosistémica donde el patrimonio etnológico se conserva, representa y gestiona. En el museo etnológico podemos analizar la continuidad conceptual entre folclore, cultura tradicional, artes populares, cultura popular, patrimonio etnológico y patrimonio cultural inmaterial. El museo etnológico es por excelencia un lugar para debatir el patrimonio etnológico. A lo largo del texto mostraremos dialécticas y dialógicas pero también aspiraciones y posibilidades de presentación de los patrimonios etnológicos en los museos etnológicos, considerando estos como laboratorios socioculturales de la memoria social y de la alimentación.

El coleccionismo ha estado en el origen de los museos (Riviére, 1989; Alonso Fernández, 1993). El museo es una institución social y cultural que ha servido a lo largo de su existencia como un certificado de antigüedad de países, regiones, territorios y grupos humanos. El origen etimológico de la palabra museo radica en dos acepciones de significado: a) el de templo de las musas y la inspiración, y b) el de lugar o edificio destinado al estudio de las humanidades, las ciencias y las artes, con biblioteca, salas de docencia, estudio, zoológico, jardín botánico, alojamiento para profesores, comedor, observatorio y anfiteatro (Riviére, 1989; Nabais, 1984). Por lo tanto, en su origen etimológico e histórico griego hay que diferenciar entre el museo como colección o templo de materiales culturales e históricos, y el museo como centro de investigación, comunicación, encuentro, debate y docencia.

Otro antecedente de la institución museo lo situamos a finales de la Edad Media y a inicios del Renacimiento, con la creación de los gabinetes de curiosidades, gabinetes del mundo, cámaras de maravillas, galerías de los reyes, o "tesoros" de reyes, aristócratas y burgueses (ej. la galería del papa Sixto IV en Roma). Sus contenidos pueden ser definidos como artísticos, naturalísticos o etnográficos y representaban una mirada occidental del otro no europeo (Riviére, 1989). Cada una de sus piezas adquirió la capacidad de representar y conocer el mundo (Iniesta, 1994) pero también proyectaban la visión del mundo de su coleccionador.

En el siglo XIX, con la llegada de la revolución burguesa e industrial, los museos nacen como instituciones modernas, muchos de ellos ligados al estado-nación. Su función fue entonces la de convertirse en referentes identitarios de las nuevas naciones-estado, educar a sus ciudadanos y crear la nación de ciudadanos y no ya de súbditos como en la época anterior (ej. absolutismo). El museo nace como un aparato simbólico y mítico de la nación, que pasa a ser el sujeto y objeto colectivo del museo. El museo va a vehicular un discurso ideológico de las identidades de un grupo social étnico-nacional y tendrá la misión de concientizar y educar al pueblo. Pero paradójicamente, e inicialmente, tendrá que utilizar elementos materiales y culturales de la monarquía y de la aristocracia, contra las cuales se luchó en la Revolución Francesa.

Es entonces que nace el concepto de exposición temporal, el de exposición individual, y el de conservación de objetos como campo de especialización y formación en el museo (Iniesta, 1994; Valdés Sagues, 1999). En esta época decimonónica nacen varios tipos de museos especializados: de arte, de arqueología, de ciencias naturales, de historia, de ciencia y técnica, de etnología, etc. Y es también en ese contexto que se definen las funciones fundamentales del museo: coleccionar, crear, investigar, educar, reconocer y proteger los patrimonios culturales.

A inicios del siglo XX se produce un cambio en la institucionalización de los museos. Se regionalizan, se redefinen, se descentralizan y representan identidades locales y regionales. Un 
ejemplo son los “Heitmatmuseen” alemanes, museos plurisciplinares del terruño. En el año 1937 se crea el Museo del Hombre en París, hoy desaparecido y reabierto en el 2016 como Museo du Quai Branly - Jacques Chirac (http://www.quaibranly.fr/es/), con una función de entender y respetar las culturas del mundo. A mediados del siglo XX, los museos se vuelven más especializados, dando más importancia a la dinamización de actividades que a las colecciones de objetos y materiales. Es así que se elaboran los kits o mini exposiciones itinerantes, las maletas museo (Riviére, 1989).

Después de la segunda guerra mundial, en el año 1947 nace el ICOM (International Council of Museums), quien rápidamente se preocupa por definir científicamente el concepto de museo:

\begin{abstract}
"The word "museums" includes all collections open to the public, of artistic, technical, scientific, historical or archaeological material, including zoos and botanical gardens, but excluding libraries, except in so far as they maintain permanent exhibition rooms." (ICOM -Comisión Internacional de Museus-, 1946; citado en Alonso Fernández, 1993: 28).

"The word of museum here denotes any permanent establishment, administered in the general interest, for the purpose of preserving, studying, enhancing by various means and, in particular, of exhibiting to the public for its delectation and instruction groups of objects and specimens of cultural value: artistic, historical, scientific and technological collections, botanical and zoological gardens and aquariums. Public libraries and public archival institutions maintaining permanent exhibition rooms shall be considered to be museums." (ICOM, 1956; citado en Alonso Fernández, 1993: 28)
\end{abstract}

En el año 1958, la UNESCO reconoce el museo como una institución educativa formal y complementaria de la escuela. Un poco más tarde aparecerán los ecomuseos, que recuperan la vieja idea de los museos al aire libre escandinavos, y los museos integrales que unen diferentes tipos de patrimonios culturales y contenidos (Mesa de Santiago de Chile de 1972), teniendo en cuenta el desarrollo social de las comunidades. Igualmente será en ese momento que nacen los museos de sociedad, los museos de comunidad (ver las obras de Mario Vázquez e Iker Larrauri en México) y el movimiento internacional de la nueva museología (MINOM). El MINOM se centrará más en los problemas de la comunidad que en los problemas del objeto museológico, e implicará un cambio de mentalidad de los museólogos, pero también de lenguaje, funciones y contenidos (Alonso Fernández, 1999)

La nueva museología tiene orígenes discutibles, pero muchos consideran que la Declaración de Quebec de 1984 fue su punto de partida oficial. En esa declaración definen, frente a lo anterior, la interdisciplinaridad del museo, la museología social y el desarrollo comunitario como ejes del museo. Un año más tarde, en 1985 se creará en Lisboa el MINOM (Movimiento Internacional de Nueva Museología), un movimiento más preocupado por responder a las necesidades sociales de las comunidades que se encuentran en el contexto del museo, por empoderar y dar protagonismo la gente, y menos por hacer de los museos receptores del discurso y prácticas del museo. Participación, crítica, conceptos (en vez de objetos) y consciencia reflexiva de la realidad son palabras de orden para la nueva museología.

En el año 1974 la museología se imparte como disciplina académica en 160 universidades (Riviére, 1989), y el ICOM, en su $11^{\mathrm{a}}$ asamblea general celebrada en Copenhague (Dinamarca), definirá el museo de esta forma:

“(...) es una institución permanente, no lucrativa, al servicio de la sociedad y su desarrollo, abierta al públi$\mathrm{co}$, que adquiere, conserva, investiga, comunica y principalmente expone los testimonios materiales del Hombre y su medio ambiente, para fines de estudio, educación y placer." (ICOM, 1974, título 2, artículo 3, citado en Alonso Fernández, 1993: 31) 
En ese mismo año se incluyeron en la definición de museo: a) los institutos de conservación, las galerías de exposición de archivos y bibliotecas; b) los lugares y monumentos arqueológicos, etnográficos y naturales, y también los sitios y monumentos históricos; c) Los jardines botánicos, los zoológicos y los acuarios.

En el año 1983 el ICOM (XIV Asamblea en Londres), añade a la categoría museo los parques naturales, arqueológicos e históricos, y también los centros científicos y planetarios. Desde entonces, el museo ha evolucionado en varios sentidos, se ha mercantilizado, se ha turistificado y se ha espectacularizado (Valdés Sagues, 1999). Además, ha cambiado su discurso científico y político-identitario, de un museo nacional, imperial y colonial hemos pasado a una idea de museo intercultural, transnacional, cosmopolita y postcolonial. De un museo temático y especializado estamos transitando cara a un museo de las convergencias y a nuevas especializaciones (ej. los museos de la alimentación), del museo escaparate al museo interactivo, del museo visual al audiovisual y al museo de los sentidos, emocional, multisensorial y digital. Estos cambios han supuesto desafíos en el modelo de gestión de la institución-museo que no todos los museos han asumido. Las adaptaciones, resistencias, ritmos de cambio y progresos han sido diferentes y desiguales en los contextos de aplicación y desarrollo. Así, por ejemplo, muchos museos locales y regionales se han convertido en museos de la historia local en la forma de "congeladores" de la memoria.

De acuerdo con los nuevos estatutos del ICOM, aprobados por la $22^{\mathrm{a}}$ asamblea celebrada en Viena el 24 de agosto del año 2007:

"El museo es una institución permanente sin fines lucrativos, al servicio de la sociedad y de su desarrollo, abierta al público, que adquiere, conserva, investiga, comunica y expone el patrimonio material e inmaterial de la humanidad y de su medio envolvente con fines de educación, estudio y deleite." (http:// icom-portugal.org/2019/09/10/sobre-a-proposta-da-nova-definicao-de-museu/ ).

En la conferencia trienal del ICOM, realizada en Milán en el año 2016, fue designada una nueva comisión permanente para estudiar y presentar una nueva definición de museo, que tenía como objetivo ofrecer una perspectiva crítica sobre la vigente definición y crear otra con alcance internacional. Después de tres años de trabajo y 269 propuestas (https://icom.museum/es/ news/la-definicion-del-museo-la-columna-vertebral-del-icom/ ), en el año 2019 se presentó en la conferencia de Quito (Japón) una nueva definición de museo, que finalmente no fue aprobada por falta de consenso, pero que reproducimos aquí por su gran interés para el debate:

\footnotetext{
"Los museos son espacios democratizantes, inclusivos y polifónicos, orientados al diálogo crítico sobre los pasados y los futuros. Reconociendo y lidando con los conflictos y desafíos del presente, detienen, en nombre de la sociedad, la custodia de artefactos y especímenes, por ella preservan memorias diversas para las generaciones futuras, garantizando la igualdad de derechos y de acceso al patrimonio a todas las personas. Los museos no tienen fines lucrativos. Son participativos y transparentes; trabajan en cooperación activa con y para comunidades diversas en la recogida, conservación, investigación, interpretación, exposición y profundización de los varios entendimientos del mundo, con el objetivo de contribuir para la dignidad humana y para la justicia social, la igualdad global y el bienestar planetario." (https://icom. museum/en/news/icom-announces-the-alternative-museum-definition-that-will-be-subject-to-a-vote/)
}

Llegados a las primeras décadas del siglo XXI podemos referirnos a un estado de "museomanina" (Segalen, 2003: 46), es decir, una sobreabundancia de museos por todo el mundo. Un museo que ya no es simplemente un almacén o exposición de patrimonios culturales, sino un medio de desarrollo económico y turístico. Y en su diversidad encontramos museos oficiales con un discurso dominante, museos críticos que actúan como instrumento de denuncia y de 
inversión de las categorías y estereotipos negativos (ej. Museos amerindios del Quebec), museos postcoloniales, museos como nueva fábrica de identidades, museos creativos, educativos y divertidos, etc.

El museo se ha popularizado y convertido en el siglo XXI en un centro de exposición del conocimiento, lugar de encuentro social, comunicación, investigación y educación permanente, y no solamente en un lugar erudito para iniciados (ej. investigadores). De la crítica al museo pasamos al museo crítico (cf. Lorente, 2006), y de tener espectadores a públicos y visitantes empoderados, de mostrar la homogeneidad y la unidad a representar las desigualdades, la diversidad, los conflictos, las dialécticas, las dialógicas, las aspiraciones y las posibilidades de desarrollar diversos modos de vivir. Algunos ejemplos de estos procesos de cambio de paradigma en la museología, especialmente de un museo colonial a un museo intercultural, son:

- Museo de Historia de la ciudad de Helsinki: https://finland.fi/es/arte-y-cultura/la-historia-de -helsinki-vive-el-renovado-museo-de-la-ciudad/

- Museo de las relaciones rotas: https://brokenships.fi/

- Ellis Island National Museum of Imigration (1989- ): https://libertyellisfoundation.org/ immigration-museum

- Museo de la Historia de la Inmigración de Catalunya (2004- ): http://www.mhic.net/?lang=es

- Museo de Amberes (Bélgica): https://www.mas.be/en

En relación con estos cambios que se están a producir en los museos del siglo XXI recomendamos ver y analizar la entrevista con Jette Sandahl (ICOM) (Ver en https://www.youtube. com/watch?v=e6eROC9Lk0A). Ella es la fundadora de dos museos innovadores, uno de ellos el museo de la mujer de Dinamarca, el otro el museo de las culturas del mundo en Gotemburgo (Suecia), y según ella los museos en el siglo XXI deben descolonizarse y adoptar el lenguaje, las necesidades y perspectivas propios de este siglo. Lo cierto es que la institución museo puede ser vista como un campo de tensión entre la conservación y el cambio, entre la permanencia y la innovación.

\section{Museología, museografía y museos}

Como hemos visto, la definición de museo ha estado en redefinición permanente a lo largo de su historia, pero mantiene y conserva algunas ideas clave, como la de diferencia del museo (institución) con una simple colección. El estudio del museo corresponde a la museología (Riviére, 1989; Alonso Fernández, 1993; Nabais, 1984). La museología es un campo de estudios multidisciplinar del museo que trata de los principios filosóficos, epistemológicos y teóricos que orientan la práctica de la museística, pero también su papel en la sociedad y sus funciones sociales (ej. conservación, educación, investigación, comunicación...). La museología liga el continente con el contenido, el edificio con el proyecto museológico, y produce la planificación del museo.

La museología no debe ser confundida con la museografía, que es el conjunto de técnicas y prácticas de aplicación de la museología. La museografía es más ejecutora y trata de los aspectos administrativos y técnicos del museo (ej. humedad relativa de las salas, identificación de las obras, iluminación, seguridad, etc.). La museografía está al servicio de la museología y ayuda a convertir el museo en espejo, ventana y escaparate de la cultura y del patrimonio cultural en 
general. El museo debe ser un espejo de las comunidades y sus identidades plurales, y también una ventana para observar y pensar el mundo, pero también un escaparate para revernos y compararnos reflexivamente con otros (Riviére, 1989).

En este sentido, el museo es cada vez más un instrumento de reflexión, educación, entretenimiento y comunicación, y un laboratorio sociocultural de todo eso, también de la alimentación (eje central de la vida de la gente), lo que complica la propia identidad y función del museo. Los museos son un instrumento de reproducción simbólica de la sociedad (Iniesta, 1994), creadores de imágenes culturales colectivas y una fábrica de representación de las identidades. Pero lo cierto es que hay una gran diversidad de museos.

\section{La variedad y la diversidad de museos etnológicos}

Los museos de antropología, etnológicos u "etnográficos", a los cuales los antropólogos siempre han estado ligados, se pueden definir por sus contenidos, por el perfil científico de sus profesionales, por sus discursos y prácticas museológicas y antropológicas, pero también por su relación con sus comunidades y públicos. El museo antropológico u etnológico suele anteponer el interés cultural al cronológico en la presentación de las obras, objetos e ideas. El mismo ha estado anteriormente ligado al concepto de gabinete de curiosidades y al de museo de "artes y tradiciones populares". La historia del museo etnológico ${ }^{1}$ es la de un museo dedicado a la presentación de objetos del pasado por medio de una pintura de las costumbres populares, la representación de lo considerado auténtico, rural, tradicional, campesino, marinero, popular, lo que se pierde o desaparece... Pero esto ha ido cambiando con el paso del tiempo como hemos indicado más arriba.

Es pertinente diferenciar aquí entre antropología museológica, que es la antropología del y para el museo, hecha por profesionales de la antropología desde fuera del museo; y la museología antropológica, realizada por museólogos que se encuentran formados en antropología y que aplican antropología en el museo antropológico o etnológico, u otros. La museología antropológica ha experimentado varios cambios a lo largo de su historia que podemos resumir por medio de un breve análisis de algunas tipologías de museos (Llopart, 1994: 10-13; Calvo Serraller, 1996):

1. Gabinetes de curiosidades: colección de materiales exóticos guardados en arcas especiales. Ejemplo: El de Carlos III en el Palacio Goyeneche de Madrid (1776).

2. Museos de historia natural. Exhibieron humanos a principios del siglo XX, como una especie más de los ecosistemas. Siguieron un discurso de la antropología física vinculada a la antropología cultural. Consideraron los humanos como animales, eligiendo los que pensaban "primitivos", algo criticado y cuestionado después por antropólogos y museólogos por su racismo y xenofobia implícita. Ejemplos: Museo de Historia Natural de New York, Museo Nacional de Etnología (Madrid).

3. Museos de artes exóticas. A partir de los años 1920, algunos museos exhiben piezas como si fueran obras de arte y sin tener en cuenta el modo de vida de la sociedad que representan.

\footnotetext{
Los museos de antropología más antiguos de Europa son: el Museo de Leyden (1831), el Museo de Berlín (1873), el Museo Pitt Rivers, de Oxford (1874), el Museu del Hombre, de Paris (1878) y el Frilandamuseet a Sorgenfri, de Copenague, (1890), como indica Llopart (1994).
} 
Presentan lo que denominan "arte primitiva", especialmente africana. Ejemplo: algunas colecciones del Museo Etnológico de Barcelona.

4. Museos interdisciplinares. Dedicados a la historia, la tecnología y la cultura de un territorio concreto. Exhiben permanentemente testimonios materiales de la vida y del trabajo campesino (indumentaria, objetos familiares, mobiliario, etc.). Ejemplos varios en museos locales.

5. Museos escolares. Museos como instrumentos educativos para niños, jóvenes y mayores. Educan en la convivencia y en la tolerancia. Ejemplos: Museo Horniman's (Londres).

6. Museos de lugar real o museos de la memoria. Son construidos en zonas de conflicto social y represión. Ejemplo: Museo del Campo de Concentración de Mauthausen (Alemanha), Museo de la Isla de Staten (Nueva York).

7. Museos al aire libre. Reconstruyen in situ actividades artesanales e industriales con la teatralización de personas reales. Ejemplos: Nordiska Museet (Skansen-Estocolmo, 1891), Museo al aire libre de Arnhem (Holanda).

8. Ecomuseos. De origen francés, están vinculados con la política francesa de desarrollo rural iniciada en el año 1963. Son museos de territorio con interpretación de los patrimonios culturales en su propio contexto.

Claro está que las tipologías de museos no son los propios museos, y éstas divergen en las variables utilizadas para definir los diferentes tipos y categorías, pero ayudan a explicar y a comprender estos en su diversidad y cambio. El antropólogo portugués Paulo Castro Seixas (1997) consideró la existencia de tres tipos de museos etnológicos:

1. El museo etnográfico u etnológico clásico, de edificio cerrado, de espacio "caverna", centrado en los objetos, con las funciones de almacén y laboratorio muy destacadas, con mayor atención al pasado y a un visitante pasivo que recibiría un mensaje ilustrado de forma linear. Coincidiría con el concepto de museo cementerio o museo anticuario del que hablan Prat y Comelles (1992), en el cual la finalidad última es coleccionar objetos, no sin descontextualizar bastante estos objetos fuera de su nicho sociocultural original. Aquí la antropología funciona como una especie de arqueología museu (Pais de Brito, 2006). Este tipo de museo podía seguir una clasificación y representación cultural con criterio comparativo tipológico, como por ejemplo el Museo Pitt Rivers de Oxford, o una clasificación etnológica-geográficaterritorial, como, por ejemplo, el Museo Etnográfico de Berlín.

2. El museo de sitio, al aire libre o ecomuseo, promovido por la nueva museología. Éste se caracterizaría por ser abierto, territorial, de la población, de la identidad y del testimonio de una memoria, menos centrado en edificios y con más atención a los valores del presente. El visitante de este modelo de museo es más activo y participante, y el proyecto museológico no es solamente realizado por especialistas o peritos, sino que suele ser una propuesta con integración de la comunidad en la interpretación de sus patrimonios culturales. Este modelo de tipos de museo es resultado de una crisis de la representación museológica de la cultura.

3. El museo de ruptura o museo dialógico es un modelo en el cual el visitante es un agente activo del museo, ya más interactivo, dialógico y multisensorial. Lo que importa aquí no es el mensaje linear, sino el proceso de descubrimiento guiado y orientado. Es un museo de 
las personas y para las personas, en el cual el objeto no es tan importante, sino un pretexto para hablar de la vida de la gente y sus ideosistemas. Este modelo de museos sigue una orientación más polifónica y además escucha a la gente y no solamente habla.

Otra buena tipología de referencia para comprender los museos etnológicos es la que creó el antropólogo catalán Xavier Roigé (2007):

a. Los museos al aire libre (Johnson e Thomas, 1992): Skansen (Suecia), Beamish (Reino Unido), Nederlans Openluchtmuseum (Países Bajos).

b. Los ecomuseos (Riviere, 1989; Walsh, 1992; Davis, 1999; Fernández de Paz, 2003; Pereiro, 2009). Estos presentan concepciones y objetivos diferentes de los anteriores. Promovidos por la "nueva museología" en los años 1970, y definidos por Rivière como un museo de los humanos y de la naturaleza.

c. Los economuseos, que reconstruyen unidades ecológicas preexistentes y no desplazan edificios y objetos de lugar (Museu Ferrari en Módena - Itália: https://musei.ferrari.com/en/ modena).

d. Los museos regionales y los museos de síntesis, que pretenden realizar una presentación general de una sociedad o comunidad en sus aspectos geográficos, sociales y culturales de una forma sintética y de acuerdo con el modelo monográfico o propio de los estudios de comunidad. Muchos de ellos parecen clones con el mismo esquema expositivo: el medio, la historia, la cultura tradicional.... La renovación de contenidos, actividades y puntos de vista son escasos en ellos. Buenos ejemplos de museos que se encuadran en este tipo son: el "Musée Dauphinois", el museo de la "Civilisation de Québec" y el "d’Ethnographie de Neuchâtel".

Otro tipo importante de museo etnológico es el de economuseo (Simard, 1989, 1991; Roigé i Ventura, 2007). El economuseo ha sido inventado en Canadá por Ciril Simard, y es un concepto que articula economía y cultura, empresa y representación cultural en un espacio que sirve para que el patrimonio cultural se gane la vida, es decir, genere financiamiento propio para el museo. Los economuseos mercantilizan la idea de museo, pero también reflexionan sobre el papel del patrimonio etnológico en el desarrollo social, económico y comunitario.

Por otro lado, autores como Hooper-Greenhill (2000) refieren al postmuseo, que Marstine (2006) ha definido como:

"El post-museo articula claramente sus agendas, estrategias y procesos de toma de decisiones y los re-
evalúa continuamente, reconociendo así la política de representación; el trabajo del personal del museo
nunca se naturaliza, sino que se considera que contribuye a estas agendas. El post-museo busca acti-
vamente compartir el poder con las comunidades a las que sirve, incluidas las comunidades de origen.
Reconoce que los visitantes no son consumidores pasivos y conoce a sus constituyentes. En lugar de
transmitir el conocimiento a una audiencia masiva esencializada, el post-museo escucha y responde
con sensibilidad, ya que alienta a diversos grupos a participar activamente en el discurso del museo. No
obstante, en el post-museo, el museólogo no es un mero facilitador, sino que asume la responsabilidad
de la representación cuando se dedica a la investigación crítica. El post-museo no escapa a los proble-
mas difíciles, sino que se expone al conflicto y la contradicción. Afirma que la institución debe mostrar
ambigüedad y reconocer múltiples identidades en constante cambio. Lo más importante es que el post-
museo es un sitio desde el cual se pueden corregir las desigualdades sociales... el post-museo puede
promover el entendimiento social." (Marstine, 2006: 19).

En esto se despolitiza la diferencia cultural, se practica un multiculturalismo lúdico, la interculturalidad y de la lógica de la investigación científica se pasa a una lógica de la comunicación 
(visitantes y públicos). Se adopta una perspectiva de diversidades culturales locales, de la globalización, del cosmopolitismo, de una historia colonial crítica, de la mezcla y el hibridismo cultural, del postmulticulturalismo y de la descolonización. En estos nuevos museos o viejos museos renovados, la cultura es algo más que un inventario de objetos, se descolonizan los museos y sus representaciones, y los museos se vuelven más críticos, contestatarios y disidentes. Ejemplos internacionales de esto último que afırmamos son los siguientes:

- Quai Branly (París, 2006- ): http://www.quaibranly.fr/fr/expositions-evenements/au-musee/ expositions/

- Museo de las culturas (Basilea, Suiza, 2010- ): https://www.mkb.ch/en/programm.html

- Museo de las Culturas del Mundo, Rautenstrauch-Joest (Colonia, Alemania, 2011- ): https://museenkoeln.de/rautenstrauch-joest-museum/Visitors

- Linden-Museum Sttugart (2011-): https://www.lindenmuseum.de/en/

- Museo Real de África Centrla (Tervuren, Bélgica, 2011- ): http://www.africamuseum.be/

- Museo de las culturas del mundo (Gotemburgo, Suecia, 2004- ): http://www. varldskulturmuseerna.se/en/varldskulturmuseet/

- Museo de los Trópicos (Amsterdam, Holanda): https://www.tropenmuseum.nl/en

- Tenement Museum (New York) - Museo de Inmigración: https://www.tenement.org/

\section{El museo etnológico como laboratorio sociocultural (también de la alimentación)}

Referirnos al museo etnológico como laboratorio es destacar su función social investigadora, es decir, a como el museo etnológico debe cumplir un papel social de centro de investigación social, de pensamiento y de dinamización comunitaria (cf. Pereiro y Vilar, 2002). En la perspectiva de Riviere (1989) esto es inexcusable, especialmente en los ecomuseos, que en su perspectiva deben ser laboratorios, conservatorios y escuelas. Como laboratorio, el museo etnológico debe tener en cuenta:

a. Una exposición permanente sobre la historia de la comunidad a quien sirve.

b. Equipamientos: centro de documentación, centro de trabajo, hemeroteca, fototeca y videoteca.

c. Atelier técnico de conservación

d. Almacenes.

e. Salas de exposiciones temporales.

f. Auditorios.

g. Talleres para estudiantes.

h. Una red de caminos para visitar las diferentes antenas, polos o secciones.

i. Alojamiento para investigadores.

j. Acceso a internet. 
Podemos considerar el museo etnológico como un laboratorio de patrimonio etnológico (ej. alimentar). Lo cierto es que la gran "natalidad" de museos etnológicos ha producido una relación compleja entre el museo etnológico y sus patrimonios etnológicos. Basándonos en la obra de la antropóloga Montserrat Iniesta (2002), podemos referirnos a cuatro tipos de relaciones:

a. Patrimonio etnológico dentro de los museos. Esta relación tiene como base la idea de que tenemos que conservar todo o lo máximo posible, y se expresa en un síndrome de arca de Noé.

b. Patrimonio etnológico fuera de los museos "almacén". En este caso, el patrimonio etnológico se encuentra organizado, presentado e interpretado fuera del tradicional museo-edificio (ej. en un ecomuseo), por ejemplo, a través de antenas o polos del propio museo central en los cuales se contextualizan los patrimonios culturales.

c. El museo como patrimonio etnológico. El museo se valoriza como arquitectura, edificio o espacio capaz de dinamizar socioeconómica y políticamente sin gran contenido patrimonial etnológico. El envoltorio es sobrevalorizado en relación con el contenido.

d. Elmuseo sin patrimonio etnológico, resultado de la crisis patrimonial (todo es patrimonializable), donde se convierte en centro de investigación y documentación, pero también en centro de actividades culturales y educativas. Aquí se da menos importancia al contenedor y a sus colecciones y más a la plantilla de trabajadores- investigadores del museo, que reconocen los procesos de patrimonialización y ponen sus conocimientos e investigaciones al servicio del bien público.

Los museos etnológicos son una forma de producción de patrimonio etnológico, al cual dan una segunda vida (Kirshenblatt-Gimblett, 1998, 2001), pero también pueden ser considerados como centros de interpretación cultural y laboratorios de investigación sociocultural donde la comunicación (ver https://www.visitorstudies.org/) se vuelve muy importante (Lumley, 1988:; Hooper-Greenhill, 1998). Los museos etnológicos tienen el desafío de ser algo más que una lección de cátedra de un museólogo o antropólogo.

Según Claude Lévi-Strauss (1973) el museo etnológico debe ser la prolongación del trabajo de campo antropológico, un museo laboratorio o un museo seminario de investigación y debate. Pero, en realidad, son muchos aun los que piensan el museo etnológico como un frigorífico donde congelar y fosilizar elementos culturales. Esa versión del museo como panteón lleva a una cristalización de objetos e identidades, presentadas como fijas, permanentes e inmutables. Ello es debido en parte a que en muchos contextos museológicos la teoría antropológica contemporánea penetra muy lentamente y a que la presencia de antropólogos con suficiente poder es relativamente baja.

La museología crítica de Jacques Hainard (1989) ha criticado la idea de que el objeto debe ser central en el museo. La alternativa es que los objetos estén al servicio de la idea. El museo no es un libro de texto o una tesis doctoral y el museo etnológico no debe presentar objetos como si fuesen museos de arte. De acuerdo con la propuesta de Xavier Roigé (2007), el museo etnológico debe dejar de ser un templo de nostalgia, conservatorio de diferencias culturales o cementerios para llorar la diversidad perdida. El museo etnológico tiene que ser un lugar de preguntas, debates y democracia cultural, de explorar el presente, el pasado y el futuro (Pomian, 1996). 
El museo etnológico (ej. de la alimentación) debe convertirse en un laboratorio sociocultural crítico en el cual se exploren nuevos lenguajes expositivos (ej. diversas subjetividades y autorias), nuevos temas, nuevas voces críticas, perspectivas cuestionadoras y disidentes, miradas descolonizadoras, estrategias de integración social y oportunidades para la participación social y cohesión, innovaciones tecnológicas y didácticas que permitan crear nuevos marcos de convivencia. Además, debe ser más interdisciplinar y menos mausoleo (Witcomb, 2003). El museo etnológico debe crear una complicidad con su sociedad local hasta el punto de que ésta se sienta orgullosa del museo (Carvalho, 2011) y en ese sentido la alimentación es un nexo de unión humana y de posibilidades inmensas de cooperación entre el museo y la sociedad. Además, el museo etnológico como laboratorio sociocultural debe garantizar recursos, y mantener un equilibrio entre la dirección del museo, el turismo y la comunidad local.

\section{El museo de la alimentación como laboratorio sociocultural}

Aquí hay que diferenciar entre los museos etnológicos que tratan parcialmente la alimentación como uno de sus ejes temáticos de reflexión y comunicación, y los museos temáticos de la alimentación o de los procesos alimentares como eje central discursivo y experiencial. Entre los primeros tenemos un buen ejemplo en el Museo de la Pesca de Palamós (Catalunya) (ver: www.museudelapesca.org), dirigido por Miquel Martí. Este museo envuelve la comunidad local y los visitantes por medio del uso de las memorias sociales y del patrimonio cultural marítimo (ej. paseos en barcos pesqueros, tertulias de taberna, etc.). Tiene una exposición permanente sobre el pescado como alimento, que atrae, enseña y emociona a muchos visitantes.

Los museos de la alimentación se centran en la comida, bebida y alimentos como eje temático de su discurso museológico. Ellos han aparecido con fuerza en las últimas décadas y han servido como atractores de muchas regiones y localidades, ello es debido a que la alimentación es un tema transversal a toda la humanidad, muy inserida en los cotidianos de la gente y que motiva mejor el acercamiento de los públicos porque es un tema muy popular. Por otro lado, las clases medias occidentales utilizan la alimentación y sus refinamientos como una estrategia temática de afirmación de clase y de estatuto, la alimentación es un asunto de exhibición, distinción y presunción social (ej. los vinos y sus museos). Los ejemplos de museos de alimentación son muchos y diversos, pero por poner un ejemplo me gustaría subrayar el museo del chocolate de Barcelona (ver http://www.museuxocolata.cat/) promovido por el gremio de pastelería de la ciudad capital catalana.

Proponer que los museos de alimentación sean laboratorios socioculturales críticos significa que deben cumplir funciones sociales investigadoras, para lo que se necesitan recursos humanos y materiales específicos según la orientación que se le quiera dar. Como vimos esta es una vieja idea anclada ya en la mente y obra de museólogos como Riviere (1989) y otros. En cuanto laboratorio sociocultural, el museo de la alimentación debe tener idealmente lo siguiente:
a. Los profesionales con los que cuenta.
b. Los voluntarios con los que puede contar.
c. Un consejo científico-técnico.
d. La comunidad y el territorio próximos. 
e. El trabajo en red con otros museos.

f. La producción-distribución-consumo de alimentos.

g. El viaje de los alimentos.

h. La lucha contra el hambre.

i. La comida como placer social.

j. Un programa de actividades que envuelva a la comunidad local.

k. Una exposición permanente sobre temáticas de alimentación y desde una perspectiva integral.

I. Salas de exposiciones temporales.

m. Equipamientos para investigación interna y externa: centro de documentación, centro de trabajo, hemeroteca, fototeca y videoteca digitales.

n. Una cocina y una sala de prueba de alimentos para actividades educativas comunitarias.

o. Un laboratorio de análisis sensorial si es posible.

p. Restaurante - café - bar como espacio de encuentro intercultural alrededor de la comida y la bebida.

q. Algún espacio para almacén.

r. Sala de videoconferencias.

S. Auditorios para reuniones y encuentros.

t. Talleres para estudiantes.

u. Una red de caminos para visitar las diferentes antenas, polos o secciones del museo.

v. Alojamiento para investigadores visitantes si es posible.

w. Acceso a internet.

Siendo conscientes de que muchos museos de la alimentación generan o pueden generar sus propios recursos sin necesidad de financiamiento público, lo cierto es que muchos tienen recursos limitados y se han mercantilizado en su gestión y misión. Y es en función de esos recursos que cada museo hace y puede hacer su propuesta museológica, sin descuidar que la comunicación y la creación de lazos son un capital para el museo. El museo de la alimentación es un excelente cronotopo para cruzar enfoques de investigación biotecnológicos con enfoques socioculturales y humanísticos, más aún si conseguimos relacionar este con las universidades y centros de investigación alimentar. Y más allá de su mercantilización y mercantilismo, por veces inevitables por la falta de apoyo público, estos deben tener una función social, educativa y transformadora de los modos de vida de la gente hacia un mundo más habitable, sostenible, justo y solidario, en el cual la palabra hambre sea un mal recuerdo del pasado. Además, los museos de la alimentación son lugares excelentes para educar en valores que defiendan una alimentación saludable. Y es más, los museos en general deberían de tener en cuenta como la alimentación en general (ej. los restaurantes de los museos) es un tema que atrae, engancha y motiva el uso de los museos por locales 
y visitantes, como es bien el caso del museo de las culturas del mundo en Gotemburgo o el de etnología en Estocolmo. En ellos la nutrición se une con la alimentación, el conocimiento cultural con el placer de comer y beber, pero también unas generaciones con otras, y los locales con los visitantes por medio de un laboratorio social y cultural de la comida como eje vital.

\section{Propuesta de guion de trabajo para convertir el museo etnológico (de la alimentación) en laboratorio sociocultural}

Como propuesta de reflexión-trabajo que ayude a transitar el museo etnológico para un museo laboratorio sociocultural proponemos tener en cuenta los siguientes aspectos:

Datos básicos del museo

- Nombre:

- Dirección:

- Ubicación en el mapa:

- Número de teléfono:

- Correo electrónico:

- Web:

- $\quad$ Tipo de entrada (gratis, pagado, ¿cuánto es el billete?)

- Tipo de museo: público / privado / sociedad civil - organización / comunidad

- Institución que gestiona el museo:

- Presupuesto anual del museo:

- Fuentes de ingresos del museo (públicas, privadas, metate, asociadas, entradas...):

- Historia y memorias del museo:

- ¿Quién lo diseñó? Ej. arquitecto. ¿Ha teniendo en cuenta la orientación museológica?:

- Descripción de las instalaciones (por ejemplo, recepción, salas de exposiciones, tienda, oficinas, restaurante...):

- Funciones del museo (colección, conservación, exposición, educación, investigación...):

- Describir las colecciones y contenidos del museo:

- Tipos de patrimonio cultural que integra:

- Tipo de exposiciones y programas:

- Actividades que lleva a cabo:

- ¿Servicio educativo?

- Tienda de souvenirs - recuerdos? ¿Qué tipo de souvenirs se venden más y cuánto facturan anualmente? ¿Han cambiado con el tiempo? ¿Por qué? 
- ¿Tiene visitas guiadas? ¿Qué pasa con las audioguías?

- ¿Ofrece un tour virtual por Internet?

- ¿Tiene un guión braille para los ciegos?

- ¿Qué tan accesible es para las personas con movilidad reducida?

- ¿Tienes un libro de visitas en papel o en digital? (Analizar su contenido y mensajes).

- ¿Tiene un mapa - planta del museo?

- ¿Tiene algún folleto?

- ¿Trabaja en red con otros museos?

- ¿Qué asociaciones tiene con otras instituciones y organizaciones?

Información sobre la dirección del museo y su visión del mundo

- Nombre:

- Género:

- Fecha y lugar de nacimiento (naturalidad):

- Dirección o lugar de residencia:

- Nacionalidad:

- Edad:

- Estado civil:

- Número de hijos:

- Área de formación:

- Percurso educativo - nivel educativo

- Idiomas hablados

- Orientación religiosa - credencial: (por ejemplo, católico, agnóstico, ateo,...)

- Orientación política: (derecha, centro, izquierda, apolítica, apartidista, otras...)

- Ocupaciones y profesiones anteriores:

- ¿Información de migración personal? (Historia residencial y lugares donde recuerdas haber vivido, en qué lugares, en qué barrios, fechas de cambios y razones, personas que compartieron la casa contigo, cambios temporales, destinos y razones,)

- ¿Qué tipo de contrato tiene actualmente?

- ¿Qué países conoce?

- ¿Qué museos conoces y cuáles están inspirados en el museo que diriges?

- ¿Qué ha hecho y ha aprendido de trabajos anteriores? 
- Si ha cambiado de trabajo - actividad, ¿cuáles son las razones?

- ¿Qué opina del territorio donde se encuadra su museo?

- ¿Qué opinión tiene del papel de los museos en su región y su relación con el turismo?

- ¿Cuáles son sus objetivos a corto, mediano y largo plazo?

- ¿Te gusta lo que haces? ¿Te sientes satisfecho?

- ¿Cómo se ve el turismo en la región?

- ¿Qué fortalezas tenemos? ¿Qué debilidades encuentras?

- ¿Cómo podría mejorar el museo?

- ¿Cuál es la relación entre el turismo y el museo?

- ¿Qué tipo de turistas recibe?

- ¿Qué visitantes atraer?

- ¿Qué ofrecen a los visitantes?

Información sobre el público del museo, visitantes y usuarios

- ¿Hay un registro de visitantes?

- ¿Cuál es la evolución del número de visitantes? (número, perfil social, tipos...)

- Distribución anual, mensual y semanal de visitantes:

- Origen, nacionalidad, región, género, edad, profesión, clase... de los visitantes y usuarios del museo.

- ¿Cuál es la diferencia y relación - ratio entre los turistas/residentes locales en las visitas al museo?

- ¿Cuánto dura la visita debido a la diversidad de visitantes?

- ¿Cuánto dura la visita?

- ¿Qué imagen, impresión y experiencia se llevan los visitantes del museo? (por ejemplo, ver libro de visitas, preguntar a los guías...)

- ¿Qué compran los visitantes en el museo? ¿Qué diferencias se observan?

- Además de visitar el museo, ¿qué otras actividades realizan los visitantes en la localidad del museo?

Estos aspectos han servido como esquema de trabajo en una de las líneas de conocimiento en el proyecto Dourotur (ver https://dourotur.utad.pt/) para conocer la función social de la red museística y patrimonial de la región del Douro (ver https://www.museudodouro.pt/redemuseus-douro). Creemos que puede servir de base reflexiva para convertir el museo etnológico en un laboratorio que integre las funciones de foro de debate y cuestionador crítico de los cambios sociales y culturales (cf. Arrieta, 2021). El museo etnológico como laboratorio significa que 
el museo es un centro de investigación sobre la realidad social y cultural, un buen vecino con sus próximos y también un lugar donde el conocimiento y los saberes sobre los patrimonios culturales se debaten, dialogan y comparten con los diferentes usuarios del museo.

\section{Referencias bibliográficas}

Alonso Fernández, L. (1993). Museología. Introducción a la teoría y práctica del museo. Madrid: Istmo.

Alonso Fernández, L. (1999). Introducción a la nueva museología. Madrid: Cátedra.

Arrieta, I. (ed.) (2021). Museos en transformación. Bilbao: Universidad del País Vasco.

Calvo Serraller, F. (1996). El Museo alejandrino. En: El museo, historia, memoria y olvido. Revista de Occidente, 177, 141-147.

Carvalho, A. (2011). Os Museus e o Património Cultural Imaterial. Estratégias para o desenvolvimento de boas práticas. Lisboa: Edições Colibri - CIDEHUS - Universidade de Évora.

Castro Seixas, P. (1997). Património, Museu e Dialogia. Trabalhos de Antropologia e Etnologia, $37(1-2), 21-40$.

Davis, P. (1999). Ecomuseum. A sense of place. London: Leicester University Press.

Fernández de Paz, E. (2003). "La museología antropológica ayer y hoy".. En: E. Fernández de Paz (Coord.), Antropología y Patrimonio: Investigación, Documentación e Intervención (pp. 30-47). Sevilla: IAPH (Instituto Andaluz de Patrimonio Histórico).

Hainard, J., Sabelli, F., Kaehr, R., Milliet, J., y Minkoff, G. (1989). Le salon de l'Ethnographie. Neuchâtel: Musée d’Ethnographie Neuchâtel.

Hooper-Greenhill, E. (1998). Los museos y sus visitantes. Gijón: Trea.

Hooper-Greenhill, E. (2000). Museums and the Interpretation of Visual Culture. Londres - New York: Routledge.

Iniesta I González, M. (1994). Els Gabinets del món. Antropologia, museus i museologies. Lleida: Editorial Argentviu.

Iniesta I González, M. (2002). "Museos y patrimonio cultural". En: VII Coloquio Galego de Museus. Santiago de Compostela: Colóquio Galego de Museus (comunicación no publicada).

Johnson, P., y Thomas, B. (1992). Tourism, Museums and the Local Economy. The Economic Impact of the North of England Open Air Museum at Beamish. Aldershot: Edward Elgar.

Kirshenblatt-Gimblett, B. (1998). Destination Culture. Tourism, Museums, and Heritage. Berkeley: University of California Press.

Kirshenblatt-Gimblett, B. (2001). La cultura de les destinacions: teoritzar el patrimony. Revista de Etnologia de Catalunya, 14, 44-61.

Lévi-Strauss, Cl. (1973). Antropología Estructural. Buenos Aires: Eudeba.

Lorente Lorente, J. P. (2006). Nuevas tendencias en teoría museológica: a vueltas con la museología crítica. Museos.es, 2: 24-33. 
Llopart, D. (1994). Patrimoni etnològic versus museus etnològics. Aixa: Revista Anual del Museu Etnològic del Montseny, La Gabella, 6, 7-14.

Lumley, L. (Ed.) (1988). The Museum Time-Machine. London: Routledge.

Marstine, J. (2006). New Museum Theory and Practice. London: Blackwell.

Nabais, A. (1984). Museologia, museografia, museus... Centro de Arqueología de Almada, 3, 44-45.

Pais de Brito, J. (2006). Patrimónios e identidades. A difícil construção do presente. E. Peralta, E. y M. Anico (Orgs.), Patrimónios e identidades. Ficções Contemporâneas (pp. 43-51). Oeiras: Celta.

Pereiro, X. y Vilar, M. (2002). "Autoimágenes y heteroimágenes en los museos etnográficos gallegos". En: AA.VV. (ed.), Actas del IX Congreso de Antropología de la Federación de Asociaciones de Antropología del Estado Español, Barcelona: Universidad de Barcelona - FAAEE.

Pereiro, X. (2009). Turismo cultural. Uma visão antropológica. La Laguna (Tenerife): PASOS. Recuperado de http://www.pasosonline.org/es/colecciones/pasos-edita/36-numero-2-turismo-cultural

Pomian, K. (1996). "Nation et patrimoine". En: D. Fabre (Ed.), L'Europe entre cultures et nations (pp. 8595). Paris: Editions de la Maison des sciences de l'homme.

Prat, J., y Comelles, J. M. (1993). La noción de patrimonio. En: Grupo de trabajo sobre la Recomendación de la UNESCO para la salvaguarda de la cultura tradicional y popular. Madrid: Ministerio de Cultura.

Rivière, G. H. (1989). La museología: curso de museología, textos y testimonio. Madrid: Akal.

Roigé, X. (2007). La reinvención del museo etnológico. I. Arrieta (Ed.), Patrimonios culturales y museos: Más allá de la historia y del arte (pp. 19-42). Bilbao: Euskal Erriko Unibertsitatea.

Segalem, M. (2003). "Cuestiones de identidad y alteridad. La experiencia francesa del patrimonio". En: J. A. González Alcantud, J. A. (Ed.), Patrimonio y pluralidad. Nuevas direcciones en antropología patrimonial (pp. 41-62). Granada: Centro de Investigaciones Etnológicas Angel Ganivet.

Simard, C. (1989). L'économuséologie: Comment rentabiliser une entreprise culturelle. Montréal: Centre éducatif et culturel.

Simard, C. (1991). Le patrimoine au temps présent: les économusées. Cap-aux-Diamants: la revue d'histoire du Québec, 25, 64-66.

Valdés Sagués, Maa del C. (1999). La difusión cultural en el museo: Servicios destinados al gran público. Gijón: Trea.

Walsh, K. (1992). The representation of the past: museum and heritage in the post-modern world. London: Routledge.

Witcomb, A. (2003). Re-Imagining the Museum. Beyond the Mausoleum. London: Routledge. 



\title{
L'ALIMENTATION ET LE VIN DANS LA VIE ET L'CEUVRE DE TOULOUSE-LAUTREC. VALORISER LE PATRIMOINE ALIMENTAIRE ET VITICOLE AU CHÂTEAU MALROMÉ, EN GIRONDE
}

\author{
Pauline Leclercq
}

Responsable du Pôle Culturel chez Château Malromé

Résumé: Depuis son achat par la famille Huynh en 2013, Château Malromé, situé en Gironde dans le vignoble bordelais, s'est développé de manière considérable. Aujourd'hui, le château est à la fois une propriété viticole, une demeure historique et un restaurant. Adèle de Toulouse-Lautrec, la mère du peintre Henri de Toulouse-Lautrec, achète la propriété en 1883. La présence du peintre, grand amateur de vin, au Château Malromé permet de mettre en place des actions de valorisation de nos trois patrimoines: le patrimoine culturel, viticole et gastronomique.

Mots clefs: culture, patrimoine gastronomique, patrimoine viticole, peinture, cuisine, art, vin, gastronomie.

Citar como: Leclercq, P. (2022). "L'alimentation et le vin dans la vie et l'Oeuvre de Toulouse-Lautrec. Valoriser le patrimoine alimentaire et viticole au Château Malromé, en Gironde". En: Actas del III Congreso Internacional sobre Patrimonio Alimentario y Museos. 25-26 noviembre, 2021, Valencia, España. pp. 29-36. https://doi.org/10.4995/EGEM2021.2021.14901 


\section{Introduction}

Le Château Malromé est une propriété viticole située en Gironde. Le vignoble existe depuis le $\mathrm{XIV}^{\mathrm{e}}$ siècle, il s'est agrandi et développé au fil du temps et des propriétaires. Au XIX ${ }^{\mathrm{e}}$ siècle, la mère du peintre Henri de Toulouse-Lautrec s'y installe. Le château devient alors pour l'artiste un lieu de vacanceset de création. II s'y éteint le 9 septembre 1901.

Propriété privée, elle a été acquise par la famille Huynh en 2013 et entièrement rénovée de 2014 à 2017. La famille Huynh, passionnée d'art, a récemment constitué une collection d'œuvres originales du peintreToulouse-Lautrec et d'artistes contemporains. Ces œuvres sont visibles au château dans le cadre des visites guidées.

Aujourd'hui, le Château Malromé est entouré d'un vignoble de 43 hectares, pour une production annuelle d'environ 220000 bouteilles. Il produit des vins rouges d'appellation Bordeaux Supérieur, desvins blancs d'appellation Bordeaux Blanc et des rosés d'appellation Bordeaux Rosé. Cette année, le château entame sa seconde année de conversion vers l'agriculture biologique.

Le restaurant gastronomique, Les Abeilles, a vu le jour le 20 mai 2021. II propose une alimentation saine,goûteuse et de proximité, en accord avec le respect de l'environnement et le bien-être. Le Château est aussi, depuis 2020, un lieu d'accueil de séjours yoga et bien-être.

Le peintre Henri de Toulouse-Lautrec est une figure majeure, car transversale. Elle concerne à la fois l'art, le vin et la gastronomie. Ainsi le Château Malromé a la chance de pouvoir promouvoir et lier à lafois un patrimoine culturel, viticole et gastronomique.

La notion de patrimoine, dans sa première définition, renvoie à un «bien d'héritage » transmis de génération en génération. En France, depuis 1980, la notion s'est étendue, si bien que l'on ne parle plus d'un patrimoine, mais « des patrimoines » voire des «nouveaux patrimoines ». La patrimonialisation naît d'une volonté mémorielle, d'une volonté de sauvegarde, de conservation et de préservation du patrimoine.

En 1972, I'UNESCO signe une convention pour la protection du patrimoine mondial. Cette convention implique une nouvelle définition du terme. II y a en effet, aujourd'hui, le patrimoine physique, c'est-à- dire le patrimoine bâti, les collections d'objets, les œuvres d'art, les manuscrits et archives conservés dans les musées et bibliothèques. Le patrimoine immatériel, incluant les signes et les symboles qui reflètent les expressions artistiques et littéraires transmises oralement (savoir, savoir-faire, mode de vie,croyances, mythes). Et, pour finir, le patrimoine naturel qui concerne le règne animal, végétal et minéral.

Ainsi, en 2010 « le repas gastronomique des Français », en tant que pratique sociale, est reconnu commepatrimoine culturel immatériel de l'humanité, et en 2011, le vin est déclaré patrimoine immatériel de l'humanité par I'UNESCO. La loi 2014 en France dispose dans l'article L. 665-6 que "Le vin, produit de la vigne, les terroirs viticoles ainsi que les cidres et poirés, les boissons spiritueuses et les bières issus des traditions locales font partie du patrimoine culturel, gastronomique et paysager protégé de laFrance. $»^{1}$. Ainsi, on peut considérer le patrimoine viticole comme faisant partie du patrimoine gastronomique.

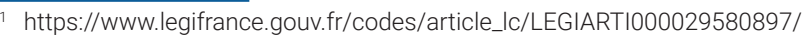


L'objectif de cet article est de montrer comment le patrimoine viticole et gastronomique est valorisé auchâteau Malromé au travers de la figure du peintre Henri de Toulouse-Lautrec. Quelles sont les actionsde médiation mises en place au château?

Dans un premier temps, la figure de Toulouse-Lautrec dans la valorisation du patrimoine viticole sera traitée puis, dans un second temps, celle du patrimoine gastronomique. Les projets de développement du château dans le sens de ces deux valorisations feront l'objet de la conclusion.

\section{Toulouse-Lautrec dans la valorisation du patrimoine viticole}

« Tu me demandes ce qui me ferait plaisir ! Du vin » écrit Lautrec à son cousin Raoul Tapié de Céleyranen 1885.

Tel un satyre disgracieux dans son apparence et beau dans la création, le peintre Albigeois Henri de Toulouse-Lautrec est connu pour son amour immodéré des bonnes et belles choses, et particulièrementdu vin.

Henri de Toulouse-Lautrec a connu dans sa vie deux domaines viticoles. D’abord celui de son enfance,Le Château de Céleyran. Un domaine situé près de Narbonne, dans le sud de la France, qui appartenaità son oncle Amédée Tapié de Celeyran.

Puis, le domaine viticole acheté par Adèle de Toulouse-Lautrec, sa mère, en 1883. II s'agit du ChâteauMalromé, situé en Gironde dans le vignoble bordelais. Le Château était en 1883 entouré de 34 hectares de vignes. Au XIX ${ }^{\mathrm{e}}$ siècle, la crise du phylloxéra sévit en France. Dans une lettre écrite à sa mère en 1883, Adèle annonce « Je vais replanter les 34 hectares de vigne en plant américain. $»^{2}$ Le plant américain était la solution trouvée pour lutter contre le phylloxéra. Cette année-là, Henri de Toulouse-Lautrec assiste aux vendanges et réalise un croquis: Vendanges à Malromé, retour au chai (Figure 1) sur lequelon reconnaît l'un des coteaux de la propriété.

Henri de Toulouse-Lautrec a pu profiter de ces deux vignobles familiaux, comme des lieux de vacanceset de création, sans oublier qu'il se faisait livrer régulièrement à Paris des barriques de vin qu'il mettaitlui-même en bouteilles.

Henri de Toulouse-Lautrec était considéré, par ses amis, comme un bon connaisseur du vin, « II dégustait, en connaisseur, les vieux crus et les alcools. Et lorsque, faisant claquer sa langue contre son palais, il décrétait que tel Bourgogne faisait queue de paon dans la bouche, on était fixé, par cette épithète magnifique, sur le savoureux et riche bouquet du vin. »³

Au Château Malromé, cette année, une visite thématique intitulée « Toulouse-Lautrec \& le vin » a été proposée. II s'agit d'une visite œnologique proposant une découverte des chais et des cuviers sur la thématique de Toulouse-Lautrec.

Pour cette visite, un support numérique est utilisé: une tablette, sur laquelle ont été mêlés des éléments de la vie et de l'œuvre de Toulouse-Lautrec, avec des informations concernant le vignoble (cycle de viede la vigne, méthode de vinification).

Il s'agit d'une visite œnologique et artistique au cours de laquelle la présence du vin dans les tableaux de Lautrec est évoquée.

\footnotetext{
2 Attems (Comtesse) née Tapie de Celeyran (Mary), Notre Oncle Lautrec, 1990 Albi, Atelier Graphique Saint-Jean, p. 26.

3 Leclercq (Paul), Autour de Toulouse-Lautrec, 1954 Genève, Pierre Cailler éditeur, p. 82.
} 
L'amour que Lautrec portrait pour le « jus de la treille » apparaît dans son œuvre. Dans le cadre de cettevisite, plusieurs tableaux sont présentés où apparaissent bouteilles et verres de vin.

La thématique du vin convivial apparaît dans le tableau Ces dames du réfectoire (1893-1894) conservé à Budapest. Trois femmes sont accoudées à une table, des prostituées dans une maison close. Henri de Toulouse-Lautrec considérait la maison close comme une seconde maison. II aimait «ce qu'il y trouvait de vie de famille » et particulièrement les « repas en commun ॥ $^{4}$. L'artiste leur apporte des « vins magnifiques » comme en témoigne ce tableau où, accoudées à une table du réfectoire, les femmes boivent le vin au pichet. Thadée Natanson raconte: « II ne leur faisait pas trinquer pour s'amuser. II ne payait pas à boire pour payer. II buvait avec elles pour le plaisir de boire. $\aleph^{5}$ Ainsi, la contemplation de ce tableau invite le spectateur à s'installer à la table de ces dames comme l'a fait le peintre.

L'artiste avait la particularité de toujours avoir avec lui, où qu'il aille, un carnet de croquis. II crayonnaitsans arrêt, dans les restaurants, les bars et les cafés où il se rendait. En 1891, il réalise le tableau À la mie, conservé à Boston. La thématique du vin festif, du plaisir et de l'ivresse apparaît sur ce tableau où son ami Maurice Guibert, représentant en champagne Moët et Chandon, est attablé à une table de restaurant devant une bouteille de vin. La bouteille de vin trône sur le coin de la table devant une miche de pain à côté de deux verres de rouge.

Le Château Malromé est un domaine viticole depuis le XIV ${ }^{\mathrm{e}}$ siècle. De nombreux propriétaires s'y sont succédé jusqu'à l'arrivée de la famille Huynh en 2013. Les affiches de Toulouse-Lautrec ont souvent été choisies pour figurer sur les bouteilles de vin du domaine.

Aujourd'hui, deux gammes de vin sont proposées: un premier vin élevé en fût de chêne français, nommé Château Malromé, Toulouse-Lautrec et un second vin nommé Esprit de Malromé.

L'œuvre de Toulouse-Lautrec apparaît dans la communication des bouteilles, sur les étiquettes de Espritde Malromé. Un partenariat a été établi avec le musée Toulouse-Lautrec à Albi qui fournit les fichiers informatiques des trois affiches publicitaires apparaissant sur les étiquettes des vins.

Ainsi, l'affiche Moulin Rouge la Goulue (1891) est utilisée pour le rouge Esprit de Malromé, l'affiche du Divan japonais (1892) pour le blanc Esprit de Malromé, et l'affiche de La passagère du 54 (1896), pour le rosé Esprit de Malromé.

Le vin se déguste toujours mieux accompagné d'un bon plat. Le restaurant du château est là pour répondre à ce désir gustatif. Henri de Toulouse-Lautrec, en plus d'être amateur de vin, était un gourmandfin gourmet.

\section{Toulouse-Lautrec dans la valorisation du patrimoine gastronomique}

Pour Henri de Toulouse-Lautrec, la gastronomie est d'abord une affaire de famille. Descendant d'une noble lignée, le jeune peintre a grandi dans une famille aristocratique et traditionnelle. Chez les Toulouse-Lautrec, on pratique la chasse, la pêche, et la gastronomie tient une place essentielle.

\footnotetext{
4 Natanson (Thadée), Toulouse-Lautrec un peintre, une vie, une œuvre «Au bordel», 1951 France, Belfond Paris pour l'édition française, p. 179.

5 Natanson (Thadée), Toulouse-Lautrec un peintre, une vie, une œuvre "Au bordel », France, Belfond Paris pour l'édition française, 1951, p. 179.
} 
En effet, dans cette famille aristocratique tout le monde cuisine, et ce n'est pas qu'une affaire liée à la domesticité. Henri de Toulouse lui-même n’hésite pas à « ceindre un grand tablier blanc » et à « confectionner lui-même avec la précision de chimiste et une extrême minutie des plats de haut goût dont il gardait le secret. ${ }^{6}$ Ainsi, Henri de Toulouse-Lautrec savait cuisiner avec brio une « bouillabaisse compliquée et savante », un steak «à la Lautrec » cuisiné au feu de sarment, copieusement poivré et « moutardé », ou encore le « homard à l'américaine ».

Mais, la gastronomie ne va pas sans l'art. La grand-mère d'Henri affirmait d'ailleurs « si mes fils tuentla bécasse, elle leur donne trois plaisirs: le coup de fusil, le coup de fourchette, et le coup de crayon ». Avant de déguster un bon mets, il faut donc d'abord le dessiner.

Ainsi, celui pour qui « dans l'art culinaire le moindre grain de sel prend une valeur capitale », était-il surnommé dans sa famille: « Henri le cuisinier », bien avant de devenir « Henri le peintre »

Édouard Vuillard (1868-1940) un ami du peintre et fondateur du mouvement Nabis, réalise en 1898 unportrait intitulé: Portrait de Toulouse-Lautrec à Villeneuve-sur-Yonne, chez les Natanson. Sur ce tableau, aujourd'hui conservé au musée Toulouse-Lautrec à Albi, Henri de ToulouseLautrec estdebout, il porte des vêtements de couleurs vives et son chapeau en feutre vert qu'il ne quitte jamais, pasmême pour peindre. II s'apprête ici à pratiquer son autre passion: la cuisine.

En 1882, Henri de Toulouse-Lautrec se rend à Paris et commence sa vie d'artiste. C'est là qu'il prend rapidement l'habitude de fréquenter régulièrement les restaurants et dînait fréquemment en ville avec ses amis. II rejoignait souvent son ami Paul Leclercq chez sa mère pour dîner. II y retrouvait une atmosphère familiale qu'il aimait: "Ma mère fut un instant en correspondance avec la comtesse de Toulouse-Lautrec, la mère d'Henri, à propos d'une recette de confiture de marrons que Lautrec, très gourmand, appréciait beaucoup et dont sa mère possédait le secret qu'elle divulgua à la mienne. ${ }^{8}$

Pour Henri de Toulouse-Lautrec, la cuisine et l'art sont liés. Édouard Vuillard raconte l'anecdote suivante: en 1897, un repas a lieu chez Lautrec avenue Frochot. Comme la tradition française le veut, le repas commence par l'apéritif, puis l'entrée, le plat et au moment des fromages, Henri de Toulouse- Lautrec conduit mystérieusement ses amis à l'appartement de Désiré Dihau (1833-1909) bassoniste à l'opéra de Paris. Arrivé à cet appartement, où au mur était accroché un chef-d'œuvre de Degas L'orchestre de l'opéra, Lautrec leur présente le tableau et leur lance: « Voilà votre dessert ».

Au Château Malromé, le dessert proposé est celui de la visite culturelle de la demeure historique. Depuis2020, il existe une salle avec les œuvres originales de Toulouse-Lautrec, acquises par les propriétaires du château. On y trouve, en dépôt exceptionnellement depuis cette année, une pierre lithographique du musée Toulouse-Lautrec à Albi sur laquelle Henri de ToulouseLautrec a représenté son ami Désiré Dihau.

Henri de Toulouse-Lautrec est mort au Château Malroméle 9 septembre 1901. Il est aujourd'hui enterrédans le cimetière de Verdelais, avec sa mère, situé à quatre kilomètres du Château. Cette

\footnotetext{
${ }_{6}$ Attems (Comtesse) née Tapie de Celeyran (Mary), Notre Oncle Lautrec, 1990 Albi, Atelier Graphique Saint-Jean.

7 Attems (Comtesse) née Tapie de Celeyran (Mary), Notre Oncle Lautrec, 1990 Albi, Atelier Graphique Saint-Jean.

8 Leclercq (Paul), Autour de Toulouse-Lautrec, 1954 Genève, Pierre Cailler éditeur, p. 33.
} 
année, les 120ans de sa mort ont été fêtés. À cette occasion des évènements sur la thématique de Toulouse-Lautrec, enlien avec le restaurant du Château Les Abeilles, ont été proposés.

Le chef, Sébastien Piniello originaire du sud-ouest, s'est lancé dans la cuisine en 2010 en ouvrant son premier restaurant: La cabane du Résinier, à Mimizan. Il a ensuite voyagé en Australie puis aux Pays-Bas afin d'enrichir sa formation. Durant tout le mois de septembre, il a proposé à sa carte des menus inspirés de recettes inventées en partie par Toulouse-Lautrec.

$\mathrm{Au}$ XIX ${ }^{\mathrm{e}}$ siècle la publication de périodiques culinaires prend son essor. En 1930 Maurice Joyant (1864-1930) publie chez Pellet, un livre intitulé La cuisine de Monsieur Momo célibataire. Cet ouvrage est illustré de vingt-quatre aquarelles et dessins de Toulouse-Lautrec et d'un frontispice réalisé par Vuillardreprésentant Henri de Toulouse-Lautrec aux fourneaux.

Maurice Joyant rencontre pour la première fois Henri de Toulouse-Lautrec au lycée Fontanes à Paris (actuel lycée Condorcet) vers 1872-73. En 1890, il devient directeur de la galerie de tableaux Boussod Valadon à Paris, prenant la place de Théo Van Gogh. À la mort d'Henri de Toulouse-Lautrec, la famillecharge Maurice Joyant de trouver une collection publique pour les œuvres et la ville d'Albi accepte le don. Ainsi naît le musée Toulouse-Lautrec à Abli regroupant la plus grande collection publique au monde consacrée à l'artiste.

Pour Maurice Joyant dans l'art tout comme dans la cuisine « le grand raffinement consiste en la synthèse et la simplicité: on doit évidemment se réclamer de la tradition; mais lorsqu'on la possède, l'oublier [...]. »9. II en est de même pour le chef du restaurant du château, Sébastien Piniello, qui propose des assiettes épurées et des plats tout en finesse. II s'inspire de l'harmonie et de l'esthétique de la cuisine japonaise et allie des produits du « pays du soleil levant » avec des saveurs locales. Henri de Toulouse-Lautrec, inspiré par les estampes japonaises, maîtrisait lui aussi l'art de synthétiser et d'aller à l'essentiel.

Ainsi cet ouvrage de Maurice Joyant peut être vu comme la référence, l'ouvrage de base conduisant à la publication d'une multitude de rééditions. En effet, cet ouvrage hétéroclite et polyphonique où règnele « flou artistique » ${ }^{10}$, aucun grammage n'apparaît, peut être considéré comme une œuvre d'art à part entière.

En 1966 est publiée une nouvelle édition de cet ouvrage avec un nouveau titre La cuisine de Toulouse-Lautrec Maurice Joyant (197 recettes nouvelles, 400 illustrations), la volonté étant de mettre en avant l'artiste en enrichissant l'ouvrage d'un plus grand nombre d'illustrations.

En 2011, une nouvelle édition très intéressante est publiée et intitulée, Maurice Joyant et Henri de Toulouse-Lautrec la cuisine de Monsieur Momo permet une rencontre entre la cuisine de Maurice Joyantavec celle d'un chef Antoine Westermann. Cet ouvrage permet la rencontre de deux univers culinaires,entre tradition et modernité. II met en évidence la modernité de la cuisine de Maurice Joyant et l'universextravagant d'Henri de Toulouse-Lautrec.

La publication la plus récente intitulée Les Carnets de cuisine de Toulouse-Lautrec (2019) est une réécriture, une réinterprétation des recettes du livre initial. Les auteurs, Muriel Lacroix

\footnotetext{
9 Joyant (Maurice), La cuisine de Monsieur Momo, 1930 Éditions Pellet, p. 7.

10 Joyant (Maurice) et de Toulouse-Lautrec (Henri), la cuisine de Monsieur Momo, 2011 imprimeries Chauveau (réédition), préface Ory (Pascal), p. 11.
} 
et Pascal Pringarbe, ont réalisé les recettes et proposé des grammages. Avec cet ouvrage, on s'éloigne du « flou artistique » et on se rapproche de la réalité de la table.

C'est à partir de ce livre, mis à l'honneur dans la boutique du Château, que le chef Sébastien Piniello a réalisé les recettes proposées en septembre dernier au restaurant Les Abeilles.

Les plats, inspirés des Carnets de cuisine de Toulouse-Lautrec retrouvés à la table du restaurant, sont représentatifs et en lien direct avec l'histoire du Château Malromé.

Dans l'avant-propos de l'ouvrage initial, Maurice Joyant explique qu'il a été " picorer », « récolter » et « glaner » au fils des années des recettes de cuisine. Ainsi, chacune des recettes est attribuée à une personnalité différente.

Le Bœuf à la Malromé est attribué à la comtesse Adèle de Toulouse-Lautrec, et le plat est localisé au Château Malromé en Gironde. Le chef a proposé une adaptation de ce plat en accord avec ses principes,c'est-à-dire en limitant la quantité de viande, environ 100 grammes, et en accordant ce plat au vin rougede la propriété (Esprit de Malromé Rouge, 2014). L'accompagnement de ce plat était un écrasé de pomme de terre aux Girolles. La préparation des Girolles est une recette attribuée à Adèle de Toulouse-Lautrec dans l'ouvrage de référence de Maurice Joyant.

Le second plat emblématique rattaché à Malromé est Le Pet-de-nonne. II s'agit d'un dessert attribué aucouvent de Notre-Dame de Verdelais, situé à quatre kilomètres du Château Malromé. Henri deToulouse-Lautrec et sa mère Adèle sont enterrés dans le cimetière de Verdelais, haut lieu de pèlerinagemarial au XIX ${ }^{\mathrm{e}}$ siècle.

En septembre dernier, d'autres plats ont été intégrés dans le menu, toujours sur la thématique du peintreHenri de Toulouse Lautrec, par exemple le tourin à l'ail rose de Lautrec, ou encore la tarte aux pruneauxinspirés du livre Les carnets de cuisine de Toulouse-Lautrec.

Ainsi, la cuisine est, et a toujours été, affaire de transmission de génération en génération, de livre de cuisine en livre de cuisine, jusqu'à leur arrivée dans la cuisine de nos chefs qui, à leurs tours, transforment ces recettes. C'est ce qui passionne le chef Sébastien Piniello: la transformation est l'alchimie propre à ce métier.

\section{Conclusion}

Au Château Malromé, l'art, la gastronomie et le vin se rencontrent dans le cadre d'évènements organisésautour de la figure de celui qui vint, chaque été, trouver l'inspiration et s'asseoir à la table du foyer maternel. La mère n'est-elle pas finalement la première cuisinière ? L'oubliée de l'histoire de la gastronomie?

Selon Maurice Joyant après avoir contemplé le spectacle de dame nature et «Enfin, lorsqu'on s'est dépensé en commentaires et méditation devant des chefs-d'œuvre d'art, rien n'est plus complet commesensation de vie que de déguster, de lamper, en compagnie de choix, un bon plat marié avec sa bonne bouteille. $»^{11}$

Le Château Malromé invite donc à la découverte gustative et culturelle. Si le premier restaurant du château portait le nom de la mère du peintre, Adèle, aujourd'hui le choix a été fait de

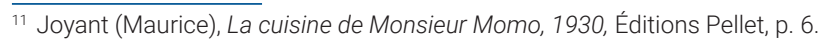


prendre le nom Les Abeilles en résonance avec le dérèglement climatique et la volonté affichée de préserver l'environnement. Nous avons pour projet, entre autres d'installer un potager à caractère pédagogique.

\section{Bibliographie}

\section{Livres}

Attems (Comtesse) née Tapie de Celeyran (Mary), Notre Oncle Lautrec, 1990, Albi, Atelier.

Diégo-Dortignac (Geneviève), Toulouse-Lautrec les plaisirs d'un gourmand, 1993, SPADEM.

Joyant (Maurice), La cuisine de Monsieur Momo, 1930, Éditions Pellet.

Joyant (Maurice), La cuisine de Toulouse-Lautrec et Maurice Joyant, 1966, Edita Lausanne (réédition).

Joyant (Maurice) et de Toulouse-Lautrec (Henri), la cuisine de Monsieur Momo, 2011, imprimeries Chauveau (réédition).

Lacroix (Muriel), Pringarbe (Pascal), Les carnets de cuisine de Toulouse-Lautrec, 2019, les éditions du Chêne.

Poulot (Dominique), Patrimoine et musée, l'institution de la culture, 2014, Graphique Saint- Jean, Hachette supérieur.

Serroy (Jean), Le vin des peintres, une histoire hédoniste de l'art (XVe et XXle siècle), 2016, presse de Gorenjski.

Toulouse-Lautrec correspondance, 1992, Gallimard. 


\section{COMUNICACIONES}

III Congreso Internacional sobre Patrimonio Alimentario y Museos

25-26 Noviembre, 2021, Valencia 



\title{
ARTE EN LA MESA: SALEROS Y ESPECIEROS ARAGONESES DE ÉPOCA MODERNA
}

\author{
Marc Millan Rabasa \\ Investigador predoctoral en la Universidad de Zaragoza.marcmillanrabasa@unizar.es
}

\begin{abstract}
In this paper we focus on salt and spices cellars, a kind of object we will study from a gastronomic, artistic and socioeconomic perspective. To achieve this purpose, we will make a catalogue with pieces from art from museums, private collections, cathedrals and parishes, so we'll get to know the important role spices had in the aragonese tables and kitchens in the 16th, 17th and early 18th centuries. In addition, a large amount of notarial documentation, graphic and pictorial representations and literary testimonies will be presented to illustrate certain artworks that have disappeared.
\end{abstract}

Keywords: silver smithery, gold smithery, feast, Aragon, Zaragoza, pottery, spices, salt, eating, gastronomy.

Resumen: En esta comunicación centramos nuestra atención en los saleros o especieros, una tipología de objetos que abordaremos desde una perspectiva tanto gastronómica como artística y socioeconómica. Recogiendo obras conservadas en museos, colecciones particulares, catedrales y parroquias vamos a conocer el importante papel que las especias tenían en las mesas aragonesas de los siglos XVI, XVII e inicios del XVIII. Con este objetivo aportamos numerosa documentación procedente de los archivos notariales, con especial énfasis en la aparición de estos recipientes en inventarios y tasaciones. Así mismo, también nos serviremos de su representación pictórica y gráfica y algunos ejemplos literarios, todo ello con el objetivo de ilustrar aquellos ejemplares que no se han conservado.

Palabras clave: platería, orfebrería, banquete, Aragón, Zaragoza, cerámica, especias, sal, alimentación, gastronomía.

Citar como: Millan Rabasa, M. (2022). "Arte en la mesa: saleros y especieros aragoneses de Época Moderna". En: Actas del III Congreso Internacional sobre Patrimonio Alimentario y Museos. 25-26 noviembre, 2021, Valencia, España. pp. 39-59. https://doi.org/10.4995/EGEM2021.2021.13302 
En 1643 la vizcondesa de Torresecas, Magdalena Cortés y Sangüesa, recibió en su casa al sacerdote Francisco Lafiguera. Este había invitado a comer al conde de Pliego y se veía incapacitado para desplegar el ajuar y la vajilla necesarios para agasajar a tan importante comensal. Entonces, el clérigo pidió a la vizcondesa que le prestara todo lo necesario para dar un toque de distinción a su mesa. Ella accedió entregándole platos, fuentes, cubertería, copas, manteles, servilletas, toaIlas, un salero e incluso joyas y algún reloj que, si bien no estaban directamente relacionados con los usos gastronómicos, podían impresionar al invitado. Desgraciadamente, la buena voluntad de la noble no se vio correspondida, pues el sacerdote nunca le llegaría a devolver tales objetos (Postigo, 2015, pp. 157-166).

Esta historia, rescatada de entre las causas criminales del Archivo Diocesano de Zaragoza por Juan Postigo para su libro La vida fragmentada, muestra la importancia de los banquetes como herramienta de representación social. Como hemos visto, el salero formaba parte de los objetos entregados por la vizcondesa de Torresecas para que el presbítero pudiese celebrar una comida digna de un conde, una persona de gran relevancia social y política, con el presunto objetivo de fortalecer una relación personal con la que obtendría ciertos beneficios. En las próximas páginas vamos a centrarnos tanto en estos recipientes como en los ingredientes que solían guardar y exhibir, la sal y las especias.

\section{El papel de las especias en las cocinas aragonesas de Época Moderna}

La sal y, especialmente, las especias eran muy valoradas por su sabor, su aroma y sus propiedades terapéuticas desde época romana. Encontramos estos sazonadores en libros de medicina (Eberenz, 2018, p. 1078) y en numerosos recetarios para enriquecer un sin fin de platos, tanto cárnicos como vegetales, así como bebidas analcohólicas y vinos (Pérez, 1997). Dejando atrás las hipótesis que sugieren que su principal uso se limitaba a la conservación de los alimentos, actualmente sabemos que los comensales que nos precedieron deseaban que sus platos fuesen sorprendentes y fragantes, que exudaran lujo y exotismo gracias a los productos traídos desde los confines de la tierra conocida (Riera, 2004).

La sal era el más común de estos condimentos y, en consecuencia, el más fácil y económico de adquirir. El principal factor que permitía esta abundancia en el mercado era su producción en varios enclaves del propio reino de Aragón. Su extracción a nivel industrial era controlada por la nobleza o asignada a monasterios, órdenes religiosas y compañías comerciales particulares, como en el caso de las salinas de Ojos Negros (Martín, 2009).

Gracias a los inventarios de boticarios y mercaderes podemos conocer cuáles eran las especias más comunes en el comercio aragonés. El azafrán es un caso particular al ser la única producida en territorio hispánico (Garrido/Hidalgo/Ramírez, 2004). Rescatamos en este lugar un contrato para su cultivo firmado entre Martín de Peralta, canónigo de la Seo de Zaragoza, y el labrador Gil de Xubierre en 1605, del que el religioso salía muy beneficiado económicamente. ${ }^{1}$ Sin embargo, este hecho no lo convertía en un producto más económico. Tal era su valor que, como si de un metal precioso se tratase, se adulteraba para aumentar las ganancias. Para controlar dicha falsificación el concejo de Zaragoza contaba con la figura del veedor de azafrán. Se trata de un cargo totalmente efectivo pues Juan Domingo Navarro, quien lo ocupaba en 1606, incautó

\footnotetext{
Archivo Histórico de Protocolos Notariales de Zaragoza [AHPNZ], Nicolas Cascarosa, 1602-1605, ff. 565 r.-569 v. (1-VI1605, Monegrillo).
} 
un cargamento adulterado con una tercera parte de almidón, miel y flor de cardo (San Vicente, 1988, pp. 69-70, doc. 378).

Igual o más popular que el azafrán era la pimienta, de importación en cualquiera de sus variedades, que no podía faltar en la mesa de los más adinerados. Como en el caso anterior, el concejo de Zaragoza atendía a su correcta comercialización. Por ejemplo, en 1639 la corporación municipal procedió a la regularización de su precio. Fue fijado en "siete reales por cada libra", pues los mercaderes adquirían los granos a un precio muy bajo y luego especulaban aumentándolo desmesuradamente, considerando que hacían "exceso y daño grande [...] en esta ciudad". Cualquiera que la vendiese a un precio mayor se enfrentaba a una pena de 60 sueldos de multa y se le requisaría toda la pimienta que poseyese (San Vicente, 1988, p. 188, doc. 451). En otras memorias e inventarios también hemos encontrado canela, clavos de girofle o "de Romanía", nuez moscada, diversos tipos de jengibre, comino, mostaza, cilantro y algunas hierbas aromáticas. $^{2}$ Todos estos ingredientes se podían comercializar en grano o molidos (San Vicente, 1988, pp. 104-113, doc. 77; pp. 329-340, doc. 173) y su mera consecución ponía de relieve la capacidad económica del anfitrión que las ofreciese en el banquete.

En los documentos que hemos referido hasta el momento encontramos las especias en las tiendas de los boticarios y las cocinas de los ciudadanos almacenadas en orzas, cajitas, cestas u otros recipientes cerámicos situados cerca de la fuente de calor (Abad, 2005, p. 169). Yelgo de Bázquez escribe en 1614 que los condimentos se deben guardar en bolsas (Yelgo, 1614, p. 155). No será ninguno de estos objetos cómodos a la hora de trabajar, pero lejos de la opulencia de las mesas nobles, los que centren nuestra atención. Los saleros y especieros que analizaremos a continuación no almacenaban los condimentos, sino que los hacían visibles y accesibles al comensal una vez el banquete se había iniciado.

\section{Una doble expresión del lujo: especias y especieros en las mesas aragonesas}

Los objetos que protagonizan esta comunicación se encuentran en la intersección de dos factores que condicionan su existencia. Por una parte, habían de contener y exhibir productos alimenticios que, por lo general, solo podían permitirse las familias acaudaladas. Además, ocupaban su espacio sobre la mesa en actos de gran importancia social. Esto motivó que las tipologías de saleros y especieros se desarrollaran acordes tanto a los usos gastronómicos como a los determinantes sociales y económicos de su época.

En el filo del año 1500 no existe todavía un tipo fijo de salero en el ámbito hispánico, cosa que favorece el reaprovechamiento de algunos objetos. Estos intercambios entre el ámbito civil y el religioso eran muy comunes, como ejemplifican las navetas "para incienso o saleros" que se hallan en el inventario de bienes de Isabel la Católica (Andrés/Naya, 2012, p. 383). También encontramos este fenómeno documentado en Aragón en las décadas cercanas al cambio de siglo, en este caso "un salero de argent dorado do[nde e]sta el Corpus Christi con su velo encima" en la iglesia de San Felipe de Zaragoza, "un salero blanco de plata con titulo de IHS" entre los bienes de Antón Lobera (Gómez, 2017, p. 161, doc. 102 bis; p. 199, doc. 133) e incluso "un salero

\footnotetext{
2 Para esta lista de especias también se han consultado los documentos siguientes. AHPNZ, Pablo de Gurrea, 1530, ff. 374 r. y ss. [s.f.] (12-V-1530, Zaragoza); AHPNZ, Pablo de Gurrea, 1537, ff. 757 r.-772 v. (9-V-1537, Zaragoza); Francisco Moles, 1606, ff. 48 v.-50 r. (6-I-1606, Zaragoza); Archivo Histórico Provincial de Teruel [AHPT], Francisco Malo, 1613, ff. 126 r.-128 r. (25-X-1613, Teruel). Agradecemos a Juan Carlos Calvo Asensio que nos haya facilitado los documentos de origen turolense que nos han servido para confeccionar esta comunicación.
} 
grande de plata a modo de sepoltura" de Tomás Fort, arcediano de la Seo de Huesca (Cardesa, 1993, p. 313, doc. 35). En cualquier caso, parece tratarse de recipientes que podían adaptarse a las circunstancias de sus propietarios.

Este fenómeno tuvo como consecuencia que diversos ejemplares civiles de gran opulencia entrasen durante siglos, a modo de donación, en tesoros catedralicios y parroquiales. El caso mejor estudiado es la preciosa naveta gótica con caracol nautilus de la catedral del Salvador donada por el caballero Juan de Torrellas en 1481, que no podemos obviar pese a ser temprana respecto a la cronología que aquí tratamos (Andrés/Naya, 2012). Encontramos otra pieza similar en la parroquia de san Pablo de la capital aragonesa (Figura 1). Cuenta en la parte inferior de su pie con el punzón de José Godó y de Zaragoza, con una datación del primer tercio del siglo XVIII (Esteban, 1981, t. I, p. 123; t. II, p. 184).

Este incensario perteneció, en origen, al ámbito civil, como marcan el escudo a modo de tapa y la iconografía marina de su pie formado por la unión de una concha, un delfín y un angelote que sostiene el caracol. Los temas acuáticos eran muy frecuentes en las piezas de vajilla, recipientes y otros elementos de ajuar de mesa. Además, los saleros permiten explotar especialmente estos motivos por el sabor salado del agua del océano. No se trata de una relación iconográfica exclusiva del ámbito hispánico como demuestran el célebre salero que Benvenuto Cellini labró para Francisco I de Francia con Neptuno y la personificación de la tierra, expuesto en el Kunsthistorisches de Viena, y el salero de ónice con sirena de oro del tesoro del Delfín, obra maestra de la orfebrería francesa en el Museo del Prado.

Sin embargo, podemos apuntar otra relación simbólica con el mundo náutico que encaja con las motivaciones sociales de la celebración de un banquete y con la utilización de las especias. Como hemos indicado, la mayoría se importaban desde territorios lejanos, especialmente desde Asia. En los inventarios se enumeran numerosos navíos decorativos, sin función aparente, pero guardados junto a vajillas, copas y saleros. También hemos documentado que Tomás Fort, canónigo de la Seo de Huesca, poseía "dos otros medios saleros a modo de barca" (Cardesa, 1993, p. 313, doc. 35). Por ello pensamos que estaban destinados a evocar sobre la mesa los largos viajes que los ingredientes, con énfasis en las especias, habían realizado hasta la boca de los comensales. La presencia de estas naves se documenta en diversas crónicas desde la Baja Edad Media como elemento de fastuosidad (Andrés/Naya, 2012, pp. 377-378) y la presencia de nautilus sacados de las aguas y manufacturados en Europa Central apunta en la misma dirección (Cruz, 1997, pp. 186-193).

Encontramos otros recipientes de origen aragonés con llamativas caracolas en museos y el mercado artístico, aunque sus formas encajan más con una copa que con un salero. ${ }^{3}$ En cualquier caso, muestran el interés que causó esta tipología de manera ininterrumpida hasta finales del siglo XVIII. En el Museo Nacional de Artes Decorativas de Madrid se conserva una copa en la que el caracol va engarzado en una pieza de origen germánico (Figura 2). Sin embargo, el pie presenta los punzones de Barbastro y Francisco Subías (Alonso, 2015, p. 182; Castillón, 2002, p. 73) que nos permiten datarla en la primera mitad del siglo XVII. Composición muy similar

\footnotetext{
3 También se han localizado piezas a nivel documental. La primera de ellas en el testamento del canónigo Francisco de Herbas. Se trata de "un baso de nacre o de concha guarnecido de plata sobredorada con pie alto y su basera". En AHPNZ, Francisco Martín Antich Bagés, 1605, ff. 1746 r.-1761 v. (23-IX-1605, Zaragoza). En segundo lugar, entre los bienes que Juan de Funes Villalpando dio a su hijo Francisco en 1640 había "un caracol de Indias con una cabeza y garra de agila de plata dorada tassado en cinquienta libras jaquesas" (Latorre, 1984, doc. 2995).
} 


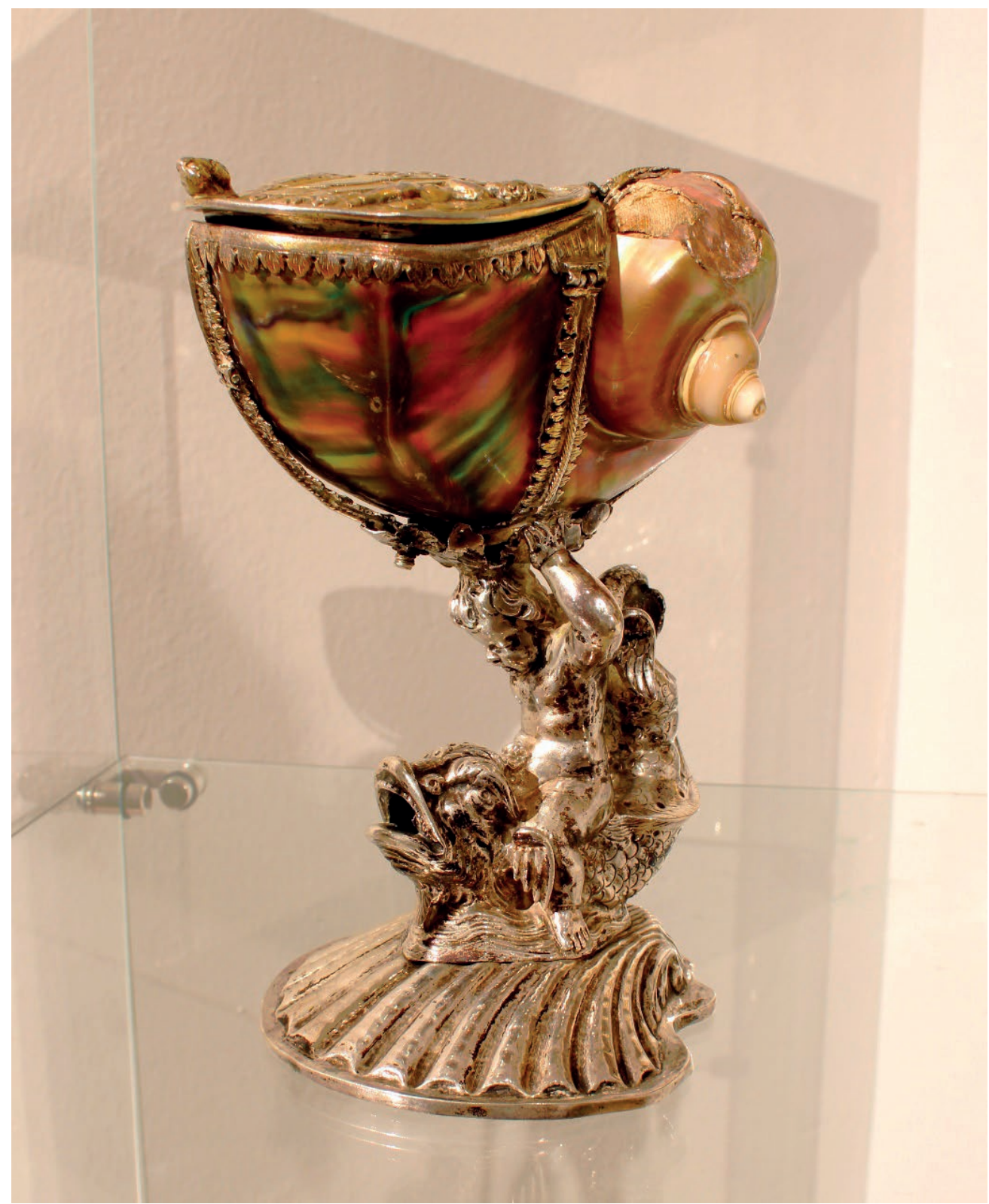

Figura 1. Salero o incensario de la parroquia de san Pablo de Zaragoza. José Godó, primer tercio del siglo XVIII. Fuente: elaboración propia.

presenta la copa expuesta en 1979 en la sala de arte Daedalus. En este caso la pieza del caracol dataría del siglo XVII, pero el nudo y el pie presentan los punzones de Zaragoza y del platero Domingo Estrada que corresponden a la segunda mitad del siglo XVIII (Maldonado/Montuenga, 1979, cat. 21). También se le puede imputar otra copa que apareció en subasta en Christie's, con 


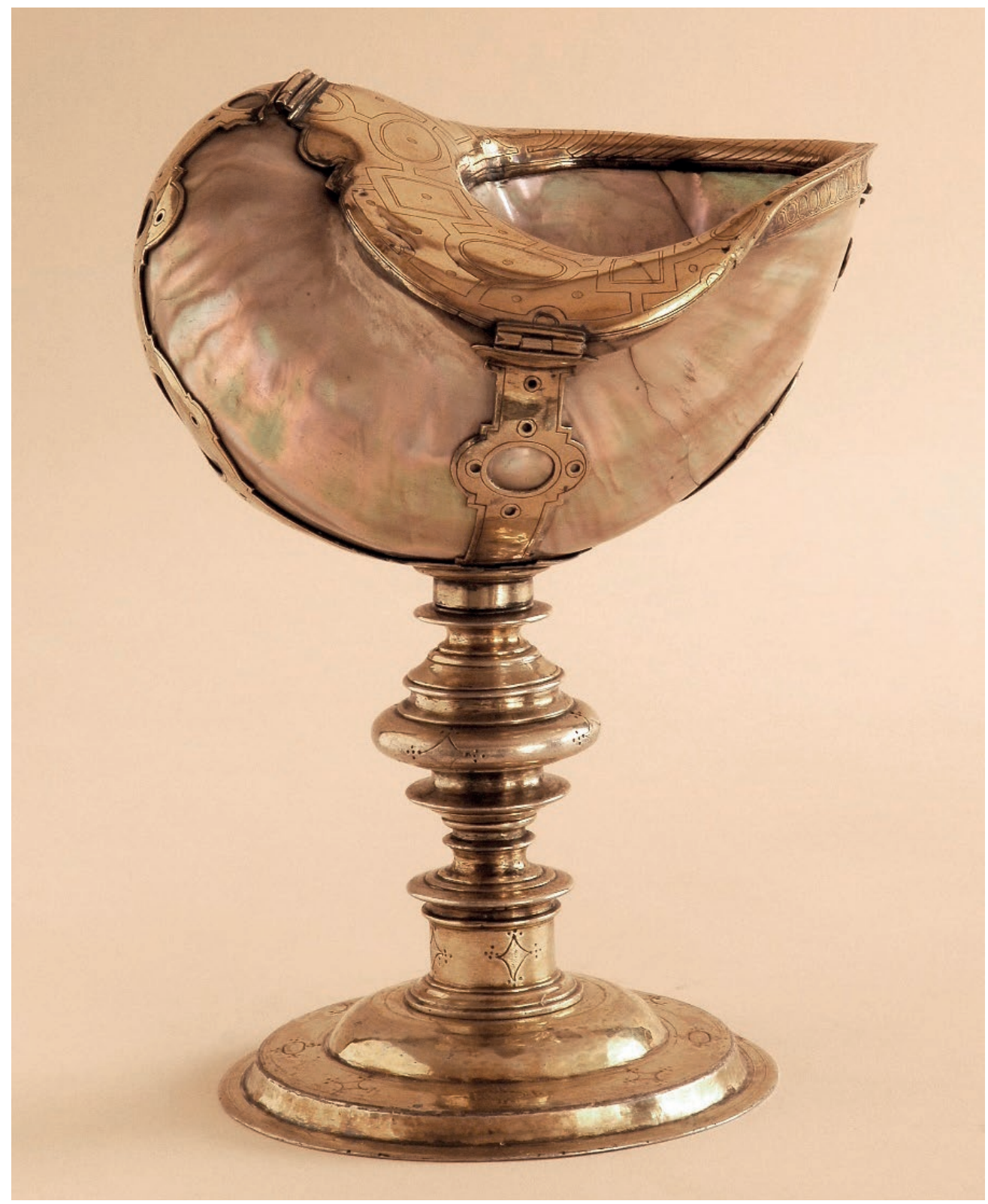

Figura 2. Copa. Taller alemán y Francisco Subías, siglo XVI e inicios del XVII. Fuente: Museo Nacional de Artes Decorativas.

una datación más cercana al año 1800 (Cruz, 2014), que cerraría cronológicamente esta serie de obras aragonesas donde el nautilus es el protagonista.

Un último ejemplo de estos saleros extraordinarios conservados en el ámbito eclesiástico es la naveta de la catedral de Albarracín (Figura 3), manufactura de taller milanés realizada en el 


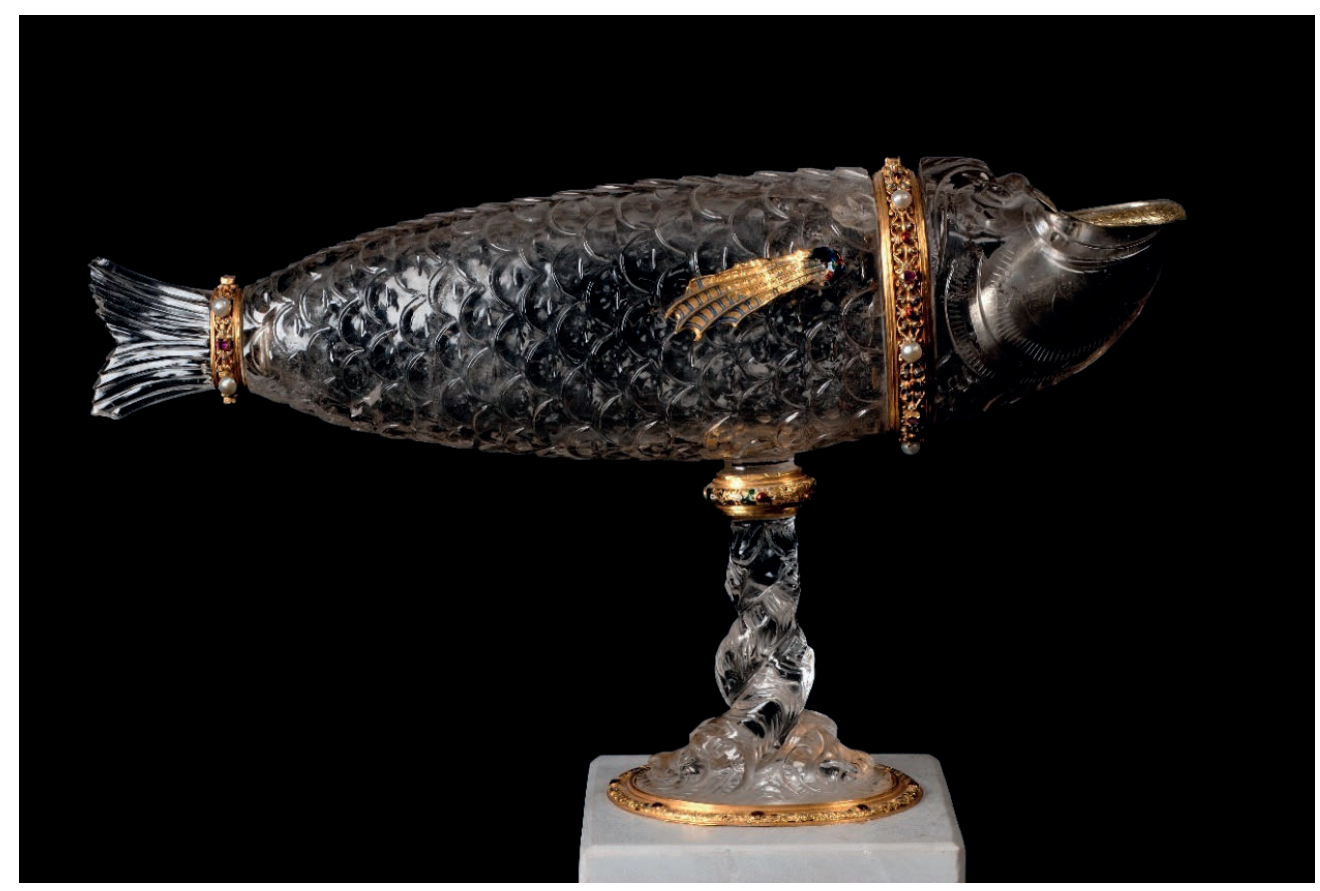

Figura 3. Salero o naveta de cristal de roca. Taller milanés, siglo XVI.

Fuente: Fundación Santa María de Albarracín.

último cuarto del siglo XVI. Pese a la divergencia material, coincide con las piezas anteriores por la variedad y riqueza de los elementos que la conforman. En este caso el protagonista es el cristal de roca tallado en forma de pez. En su cuerpo se engarzaron perlas, piedras de colores y piezas de oro y plata torneadas, moldeadas, grabadas y cinceladas. Pese a la cronología indicada, no tenemos noticias de la pieza hasta 1743, cuando aparece por primera vez en los inventarios catedralicios indicando que fue donada por el deán Agustín Roa, presumiblemente a inicios del siglo XVIII. Originalmente, el religioso usaría el recipiente como salero, pero al llegar a la catedral fue convertido en incensario o salero bautismal, cosa que como hemos indicado era del todo usual (Cruz, 1997, p. 164; Esteras, 1975, pp. 108-109; Esteras, 1980, cat. 194; Arce, 2015).

Todos los especieros que hemos visto hasta ahora pertenecen a la variante más lujosa, que en ningún caso era la más popular. Los inventarios que hemos recogido para esta investigación, especialmente los del primer tercio del siglo XVI, muestran una gran variedad material que abarataría el producto. Esta gama más económica iría dirigida a aquellos comerciantes, altos artesanos u otros ciudadanos que pudiesen adquirir especias con mayor o menor frecuencia o bien serían usados como contenedores de sal, ingrediente más común en las cocinas. Hemos 
hallado saleros y pimenteras de plomo, ${ }^{4}$ estaño, ${ }^{5}$ bronce, ${ }^{6}$ madera, ${ }^{7}$ cristal blanco o de colores, ${ }^{8}$ piedra $^{9}$ y cerámicos. ${ }^{10}$

Esta gran diversidad nos indica que eran producidos por numerosos gremios como herreros, vidrieros o ceramistas; por lo que asumimos una demanda relativamente elevada. Contamos con un documento que atestigua la fabricación de saleros de tierra en Morata de Jalón. Se trata de un contrato firmado en 1576 entre un grupo de escudilleros de esta localidad y el mercader zaragozano Gaspar Serra para la producción y el suministro de diversas tipologías de vajilla, entre las cuales unas "salericas, a razon de tres sueldos y quatro dineros" (San Vicente, 1991, pp. 266-269, doc. 217). Para conocer como son formalmente estos elementos de mesa tenemos que acudir a la producción alfarera turolense. Se conservan varios ejemplares en el Museo Nacional de Artes Decorativas de Madrid, en el antiguo Museo de Cerámica de Barcelona (Abad, 2005, p. 170) y en el Museo Diocesano de Teruel (Figura 4). En todos los casos se trata de piezas de formas muy sencillas con uno o dos espacios para colocar la sal y alguna otra especia y cuyos motivos decorativos se integran en las series típicas de la producción local. En la pintura La Cena de San Benito de fray Juan Andrés Rizi, en las colecciones del Museo del Prado, vemos representado un sencillo salero que refrenda este uso (Figura 5).

Hasta este momento hemos visto los objetos más caros y extravagantes, creados con los materiales más exclusivos, y otros más humildes que formaban parte de la cotidianeidad de un grupo más amplio de aragoneses. Sin embargo, los saleros y especieros que encontramos con más frecuencia en la documentación son aquellos que, careciendo de la espectacularidad de los primeros, seguían siendo un objeto de valor por el material con el que estaban hechos: la plata. Los inventarios de época aportan pocos datos respecto a su forma, aunque imaginamos que se equiparaban a los saleros cerámicos y tenían entre uno y cuatro espacios para las especias. ${ }^{11}$ En algunas ocasiones sí se indica su apariencia, siendo los cilíndricos y los de planta cuadrada los más comunes. ${ }^{12}$ En la colección del Instituto Valencia de don Juan se conserva un ejemplar punzonado en Zaragoza, datado en el primer tercio del siglo XVII (Montalvo, 2009, fig. 10) y con una sencilla decoración de volutas y óvalos o espejos (Figura 6).

\footnotetext{
4 Inventario de bienes de María San Martín. En AHPNZ, Jerónimo Sora, 1538, ff. 603 r.-610 r. (7-X-1538, Zaragoza).

5 Inventario de Catalina Fabra y Ana de Alfaro. En AHPNZ, Jerónimo Sora, 1532, ff. 24 r.-27 v. (5-III-1532, Juslibol). Inventario de bienes de la casa de Catalina Cresti, viuda del pelaire Joan Polo. En AHPNZ, Juan Arruego, 1530, ff. 404 r.-410 v. (26-IV-1530, Zaragoza). Agradecemos a Pablo Cercós Maícas que nos haya facilitado la referencia de este último documento.

6 Tasación de los bienes que Juan Pérez, ciudadano de Teruel. En AHPT, Miguel Jerónimo Escobedo, 1651, ff. 6 v.-21 v. (3-I-1651, Teruel).

7 Inventario de Inés de Villaraça. En AHPNZ, Pablo de Gurrea, 1534, ff. 473 v.-479 r. (5-X-1534, Zaragoza).

8 Inventario de los hijos de Juan de Navas, mercader. En AHPNZ, Jerónimo Sora, 1534, ff. 108 r.-114 v. (27-III-1534, Zaragoza). Inventario de bienes de Juan de Paraíso, labrador. En AHPNZ, Jerónimo Sora, 1540, ff. 65 v.-72 r. (2-III-1540, Zaragoza). Inventario de bienes de Pedro de Çaffra, bonetero. En AHPNZ, Pablo de Gurrea, 1540, ff. 228 v.-231 r. (29-V-1540, Zaragoza).

9 Inventario de bienes de Juan de Usón menor, labrador. En AHPNZ, Jerónimo Sora, 1550, ff. 106 v.-112 v. (1-V-1550, Peñaflor).

10 Inventario de los hijos de Juan de Navas, mercader. En AHPNZ, Jerónimo Sora, 1534, ff. 108 r.-114 v. (27-III-1534, Zaragoza). Inventario de bienes de Miguel Clemente. En AHPNZ, Jerónimo Sora, 1549, ff. 184 v.-193 r. (23-VIII-1549, Zaragoza).

${ }^{11}$ Sirva a modo de ejemplo el "salero hecho en quatro piecas" del inventario del infanzón zaragozano Jaime Salvador. En AHPNZ, Jerónimo Sora, 1544, ff. 227 v.-233 v. (27-VIII-1544, Zaragoza).

${ }^{12}$ En el sorteo realizado para el convento de la Santa Cruz de Jaca se subastaron dos saleros "dorado[s] y quadrado[s] de tres pieças" con los números 21 y 33 y otro "de tres pieças dorado redondo" con el 41. Como en la mayoría de ocasiones, no se indica si eran de torre o más sencillos. En AHPNZ, Lupercio Andrés, 1607, ff. 636 r.-652 v. (6-X-1607, Zaragoza).
} 


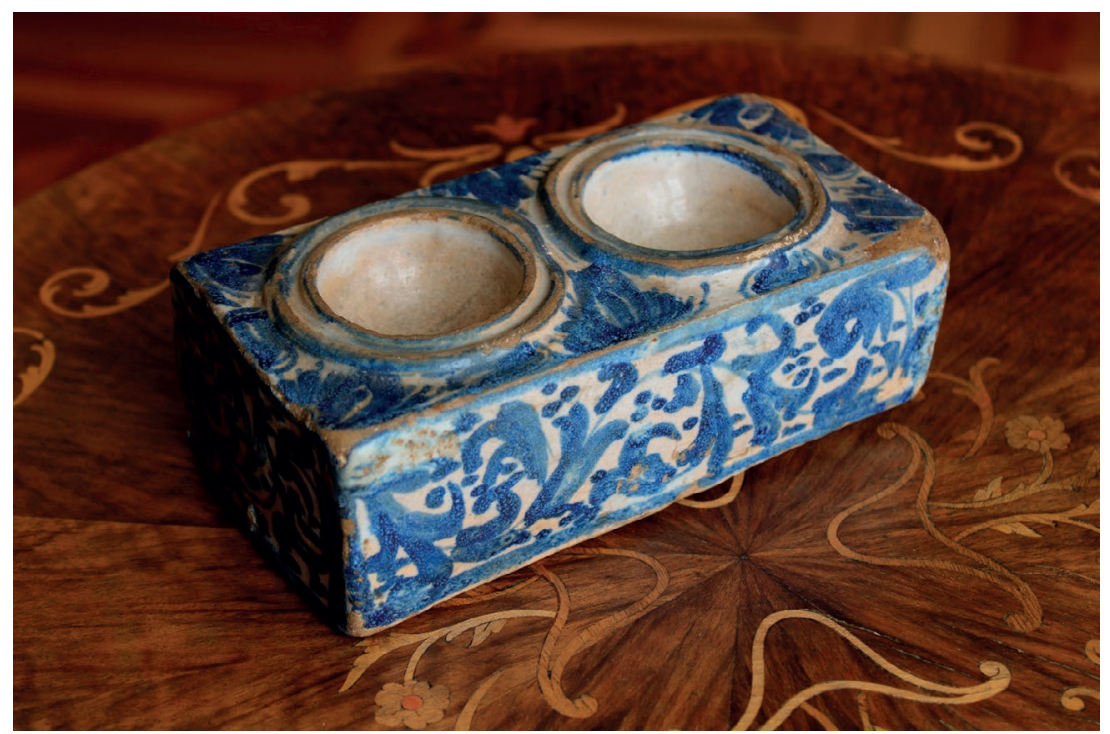

Figura 4. Especiero cerámico del Museo Diocesano de Teruel. Taller turolense, segunda mitad del siglo XVII o inicios del XVIII.

Fuente: Juan Carlos Calvo Asensio.

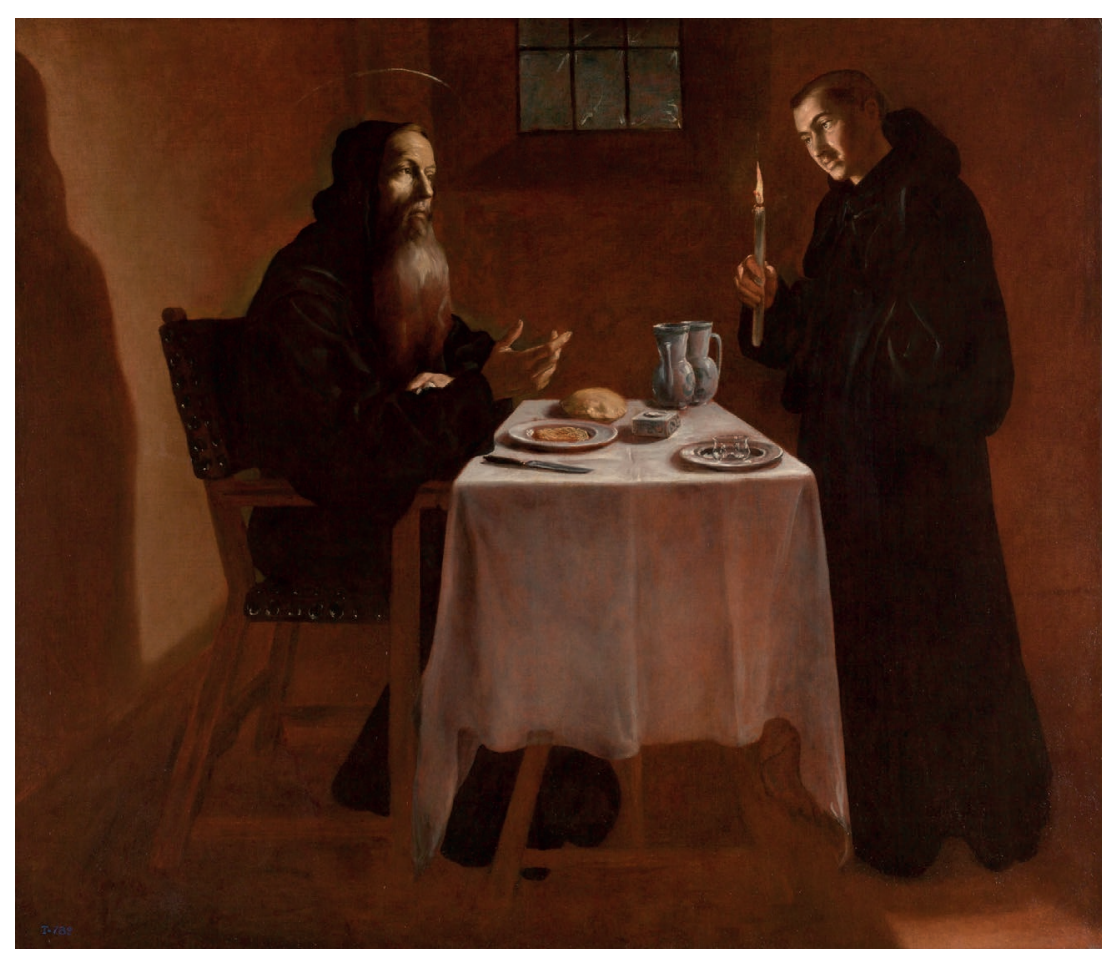

Figura 5. La cena de San Benito [detalle]. Fray Juan Andrés Rizi, siglo XVII.

Fuente: Museo Nacional del Prado. 


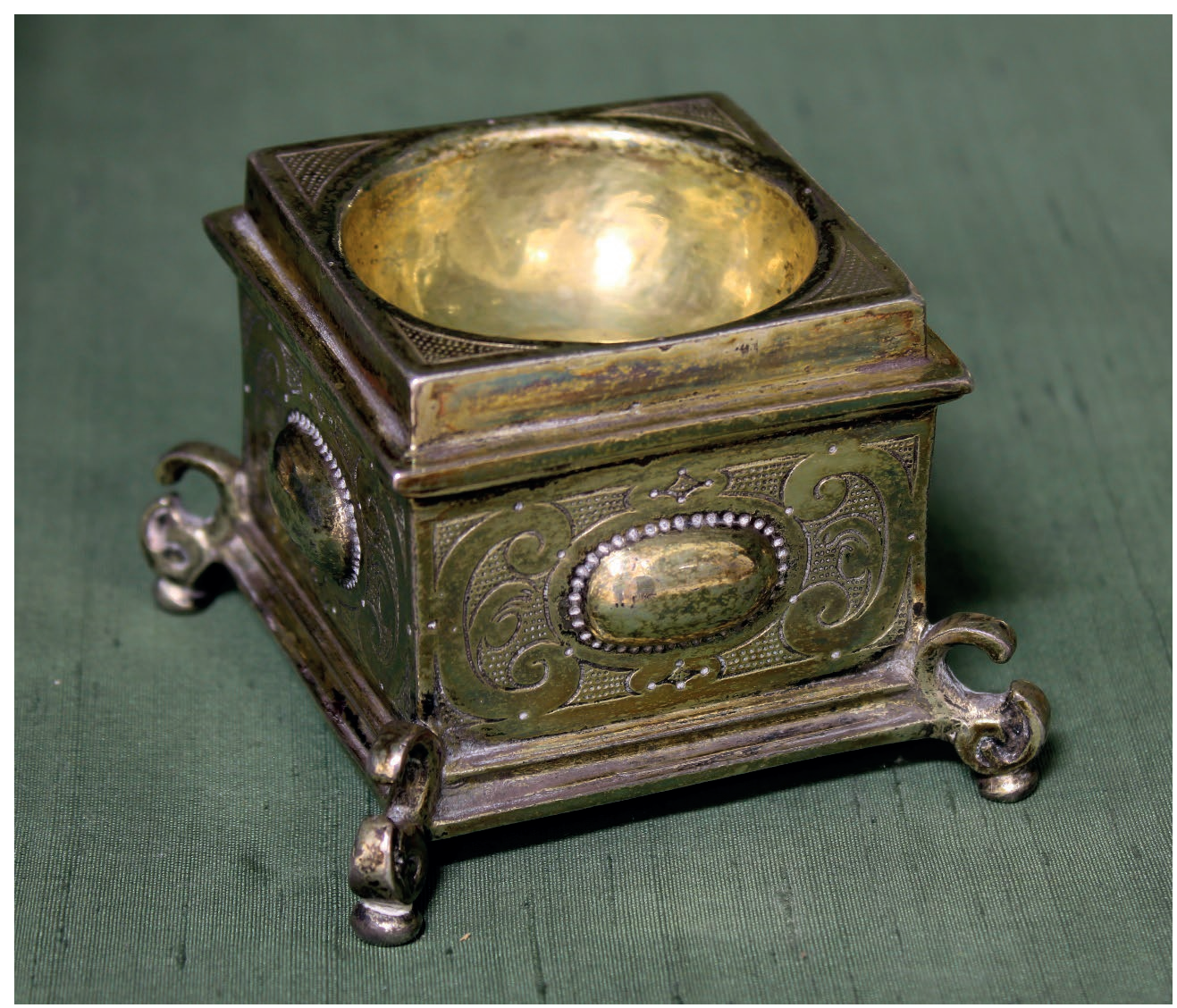

Figura 6. Salero del Instituto Valencia de Don Juan. Taller zaragozano, primer tercio del siglo XVII. Fuente: el autor.

Se acentúan todavía más las semejanzas con los modelos cerámicos en otro salero que conserva el Museo Arqueológico Nacional, con la misma marca de ciudad y cronología ligeramente anterior, alrededor del año 1600 (Figura. 7). Se ha indicado que su forma triangular con tres pocillos es excepcional en el ámbito de la platería, con la única referencia de otro ejemplar germánico en el Victoria \& Albert Museum (Mañueco, 2002). Sin embargo, su estructura es idéntica a la producida en los talleres de Talavera de la Reina, entre otros centros cerámicos, con ejemplos conservados en el Museo Nacional de Artes Decorativas (Figura 8). En todo caso, su hechura en plata y la iconografía de raíz clásica nos llevan a un mercado más restringido que el de los productos de alfarería.

Hasta ahora hemos visto que la sal y las especias debían descansar encima de la superficie del objeto, pero en el tercer cuarto del siglo XVI se desarrollará otra tipología llamada salero de torrecilla o mendocino. El primer término hace referencia a la forma de torre resultado de la superposición de varios cuerpos, culminando con uno más pequeño donde se sitúa un receptáculo para dosificar la sal o la pimienta cómodamente. En cambio, el segundo parece tener que ver con una antigua superstición de la familia noble de los Mendoza, que creía que derramar 


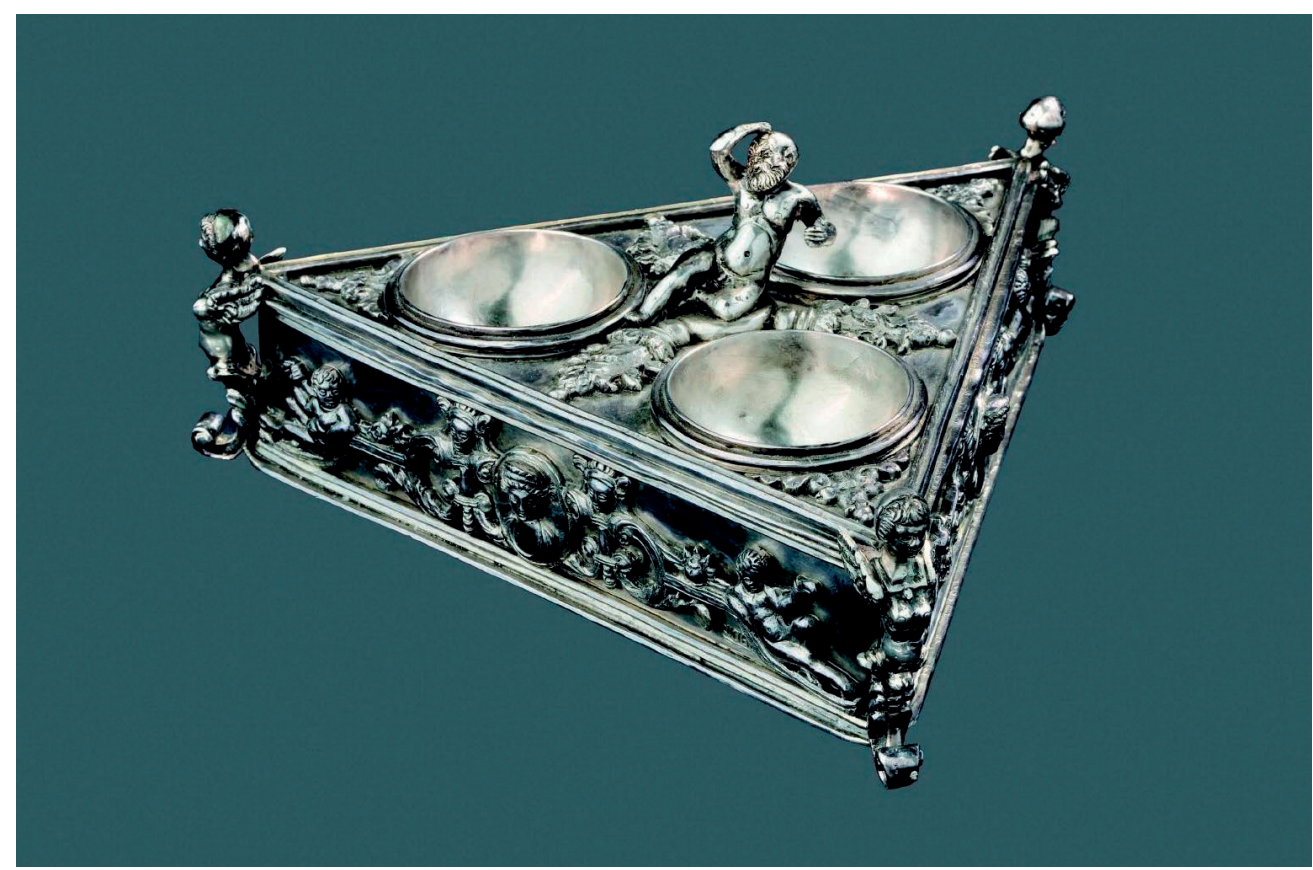

Figura 7. Especiero. Taller zaragozano, c. 1600.

Fuente: Museo Arqueológico Nacional, José Luis Municio Bacía.

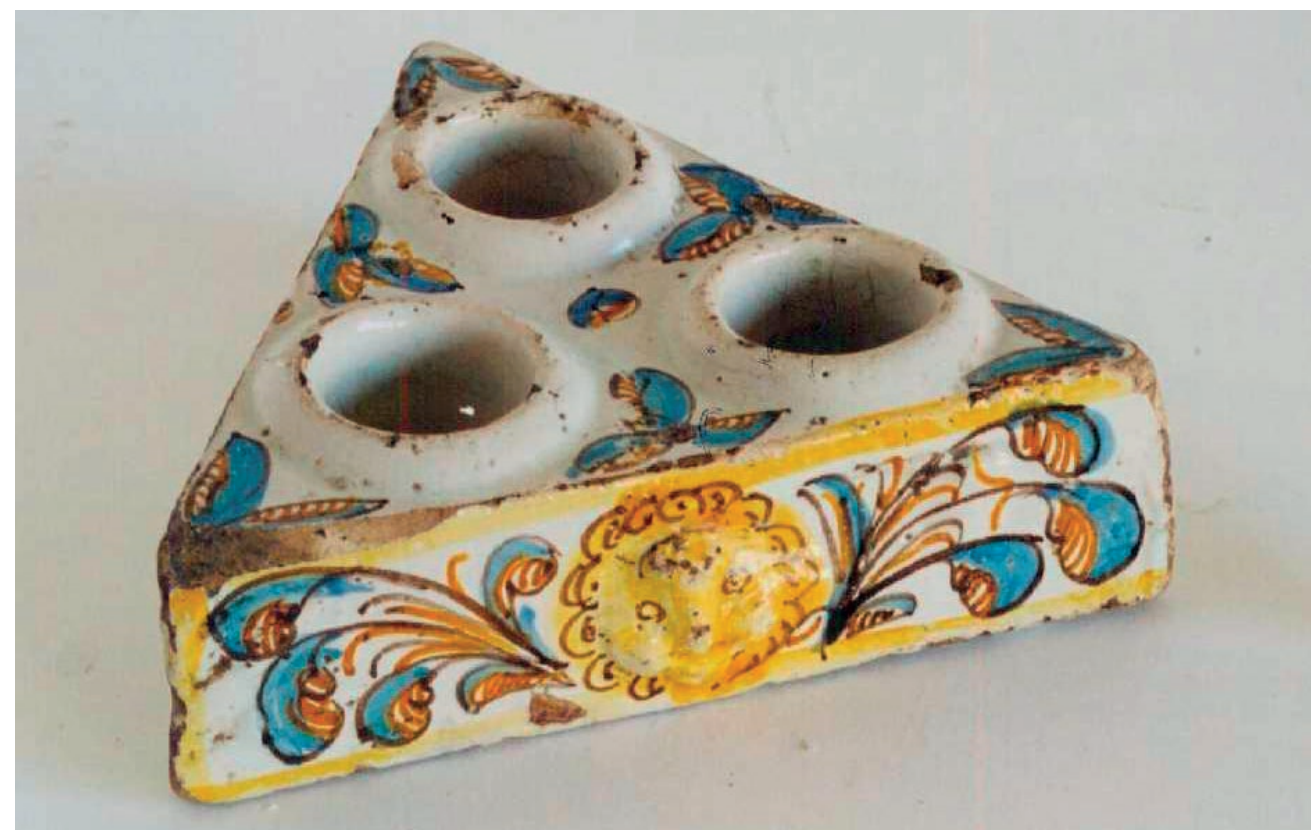

Figura 8. Especiero. Taller de Talavera de la Reina, segundo cuarto del siglo XVII. Fuente: Museo Nacional de Artes Decorativas. 
sal sobre la mesa era síntoma de mal agüero. De hecho, actualmente el diccionario de la Real Academia Española sigue recogiendo mendocino como sinónimo de supersticioso, aunque en desuso. Contamos con dos interesantes testimonios literarios que muestran la popularidad que llegó a tener esta creencia. El primero de ellos viene de la mano de Cervantes, quien aprovechó para hacer una crítica de las supersticiones en el Quijote:

Se le derrama a un Mendoza la sal encima de la mesa y se le derrama a él la melancolía por el corazón. ¡Como si la naturaleza estuviese obligada a dar señales de las desgracias venideras con cosas de tan poca importancia como las referidas! (Cervantes, 1605, t. VI, p. 165)

Recogemos en este mismo sentido otra cita de Quevedo en su Libro de todas las cosas y otras muchas más:

Si se te derrama el salero y no eres Mendoza, véngate del agüero y cómetele en los manjares. Y si lo eres, levántate sin comer y ayuna el agüero como si fuera santo, que por eso se cumple en ellos el agüero de la sal, porque siempre sucede desgracia, pues lo es no comer. (Quevedo, 1699, p. 461)

La documentación no aporta datos concretos acerca de la fecha en que se popularizó esta nueva tipología. En los inventarios la hemos hallado por primera vez en el año 1589 entre los bienes de Pedro de Herbas, camarero de la Seo de Zaragoza. ${ }^{13}$ Sin embargo, podemos aventurar que ya se comercializaba en la década de 1570 gracias a los exámenes de los plateros zaragozanos, barceloneses y valencianos. Aunque los dibujos de los primeros no se han conservado, las actas nos indican que los saleros fueron una de las piezas favoritas entre los aspirantes a maestros a partir de 1573 (San Vicente, 1976, t. II, pp. 38-270) y durante todo el siglo XVII (Esteban, 1981, t. I, pp. 95-149), habiéndose presentado en un total de veintitrés ocasiones. ${ }^{14}$ Los dibujos de los exámenes catalanes y levantinos, que sí podemos consultar total o parcialmente, muestran en las mismas fechas gran abundancia de saleros de torrecilla que debían ser similares a los producidos en Aragón (Cots, 2003, pp. 111, 369-374). ${ }^{15}$

Creemos que un vistazo a los dibujos de la Ciudad Condal nos permitirá acercarnos a las piezas aragonesas contemporáneas. Por ejemplo, en la documentación zaragozana hallamos un salero "con seys leoncicos por pies" (San Vicente, 1994, doc. 3) y otro "de dos piezas sobredorado con unos leones". ${ }^{16}$ El dibujo de maestría hecho por Francesc Vidal en 1595 nos muestra una pieza que debía ser ciertamente muy similar a las citadas, con garras y cabezas de león en el cuerpo inferior del salero (Figura 9).

Nuevamente, en el Instituto Valencia de don Juan se conservan dos saleros mendocinos o de torrecilla de ámbito aragonés, uno de dos cuerpos con punzón de Zaragoza perteneciente al segundo tercio del siglo XVI (Figura 10) y otro carente de punzón datado a finales de la misma centuria (Figura 11) (Montalvo, 2009, figuras. 1 y 3). Ambos cuentan con una decoración muy

\footnotetext{
${ }^{13}$ AHPNZ, Jerónimo Andrés, 1589, ff. 403 v.-430 v. (15-III-1589, Zaragoza).

${ }^{14}$ Añadimos a los exámenes conocidos con anterioridad los de Luis Lanzarote con "un salero de tres pieças de plata blanca quadrado", Miguel Cubels con un "salero de tres pieças quadrado" y Francisco Vinierta con "un salero quadrado de plata sobredorada de tres pieças con obalos". En AHPNZ, Diego Miguel Malo, 1600, ff. 259 v.-261 r. (6-V-1600, Zaragoza); AHPNZ, Diego Miguel Malo, 1602, ff. 52 v.-53 v. (10-I-1602, Zaragoza); y AHPNZ, Diego Miguel Malo, 1603-1604, ff. 361 v.-362 V. (29-VIII-1603, Zaragoza); respectivamente.

${ }^{15}$ El primero de los saleros dibujados en las pasentías barcelonesas es obra de Joan Gonsalvo y data de 1571. En Arxiu Històric de la Ciutat de Barcelona [AHCB], Llibre de Passenties, vol. II (18-IV-1571, Barcelona).

${ }^{16}$ Capitulaciones matrimoniales entre Antonio Fernández de Híjar, caballero de la orden de Calatrava, y Juana Sobrino, viuda de Juan de Marcilla. En AHPNZ, Juan Domingo Navarro, 1602, ff. 80 r.-125 v. (10-I-1602, Zaragoza).
} 


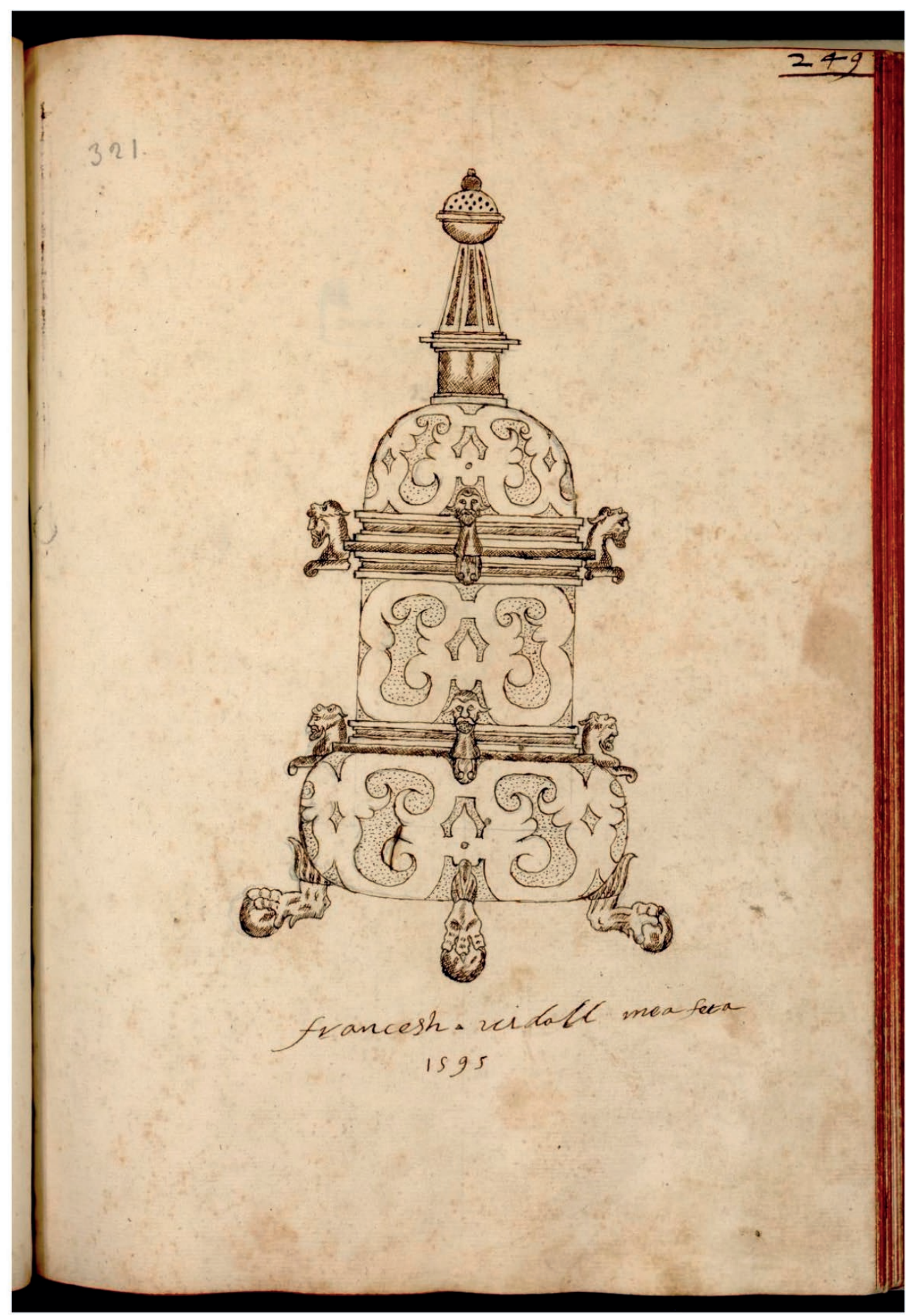

Figura 9. Dibujo de salero de torrecilla o mendocino. Francesc Vidal, 1595. Fuente: Arxiu Històric de la Ciutat de Barcelona. 


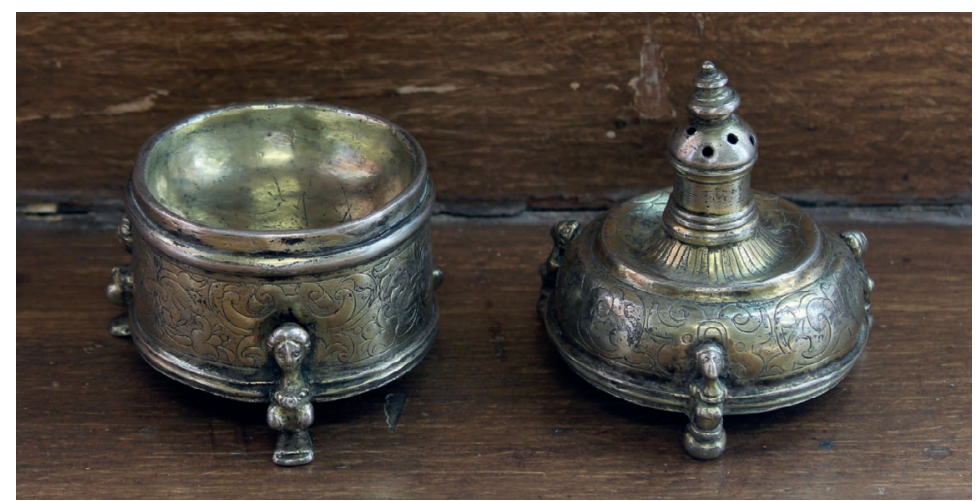

Figura 10. Salero del Instituto Valencia de Don Juan. Fuente: elaboración propia.

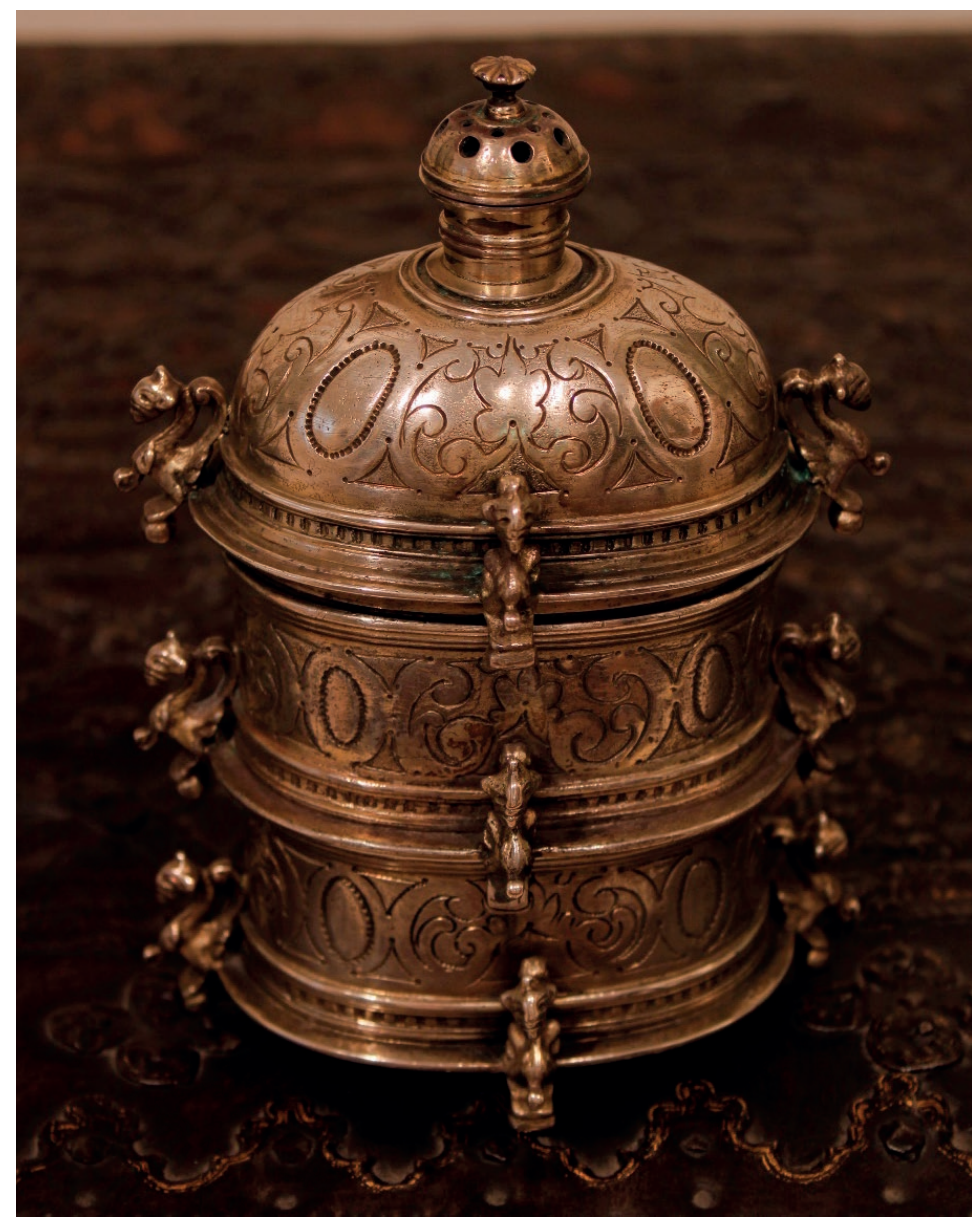

Figura 11. Salero del Instituto Valencia de Don Juan. Posible taller aragonés, finales del siglo XVI. Fuente: elaboración propia. 
sencilla de carácter vegetal, geométrico y con pies antropomorfos y zoomorfos. Si atendemos a la documentación, encontramos palabras y expresiones que describen otras decoraciones posibles como labrados a la morisca (Cardesa, 1993, p. 313, doc. 35), canalado (Lanaspa, 2005, p. 102, doc. 2235(2.500)), çicelado, de medio relieve (Longás, 2006, p. 203, doc. 7-9504(10328)) y sobredorados o de plata blanca, estas dos últimas opciones en relación con el tratamiento cromático de la pieza. Por último, citamos un curioso salero "ahobado con su cobertor que sirve de pimentero y encima del como por chapitel un niño con un escudo y en el un coraçon con una saeta atravesado y unos agujeros en que se ponen palillos para los dientes" (Lanaspa, 2005, p. 200, doc. 2-2783(3.190)), detallada descripción de un objeto de bella iconografía que pone de relieve la variedad de productos que se podían encontrar en el mercado.

\section{El salero en el contexto del banquete: mesas, aparadores y talleres}

Una vez definidas tipológicamente las diferentes formas que podían adquirir los saleros y especieros, vemos necesario exponer cómo se presentaban ante los comensales. En el Estilo de servir a príncipes de Yelgo de Bázquez encontramos la explicación más sencilla al respecto:

Puestos los manteles, lo primero se pondra el salero o saleros, y a un lado el pimentero, y a otro lado el açucarero, y luego empeçara a poner servicios, empeçando por la cabecera, baxando por el lado derecho de la mesa (Yelgo, 1614, p. 159).

Encontramos documentado en Teruel este tratado sobre el servicio de las casas nobles en fechas tan tempranas como 1626, en el inventario de los bienes de Lorenzo Gamir Palomar e Inés Guillén Pérez Cardona. ${ }^{17}$ Según sus indicaciones, el salero se colocaba en primer lugar en el centro de la mesa, acompañado de los respectivos receptáculos para la pimienta y el azúcar, hecho que también podemos confirmar a través de la representación pictórica.

Hemos escogido dos obras de autor aragonés con el mismo tema, la Última Cena, en las que los artistas aprovecharon para representar un banquete. ${ }^{18}$ En primer lugar, en el Museo Diocesano de Albarracín se conserva un lienzo atribuido al alcorisano Pedro García Ferrer (Almagro/Arce, 2011). Efectivamente, en el espacio central de la mesa y frente a Cristo se sitúa un salero dorado, mendocino y desmontado (Fig. 12). En la segunda pintura, ejecutada por Pedro Rabiella y Diez de Aux y custodiada en el Museo de Zaragoza, el salero guarda una disposición muy similar, junto al pan (Fig. 13). ${ }^{19}$

Colocarlos en el centro de la mesa no era la única posibilidad. Los saleros también encontraban su lugar en aparadores y reposteros junto a otros objetos de gran belleza estética y lujo que buscaban remarcar el poder del anfitrión. El Diccionario de Autoridades describe un aparador como "el conjunto de alhájas [...] que se ponen sobre una mesa con sus gradillas, assi para servirse de ellas quando sea necessário, como para que sirvan de adorno [...] en las mesas de los Príncipes" (Diccionario de Autoridades, 1726-1739). Por lo tanto, su inclusión en estos conjuntos

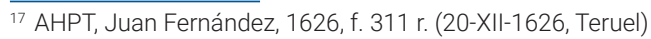

${ }^{18}$ Agradecemos a Álvaro Vicente Romeo su ayuda en la selección de estas dos pinturas.

${ }^{19}$ En este caso cabe destacar la similitud de la pieza representada con el dibujo que el platero Pedro Vespín, natural de Oliete (Teruel), realizó para acceder al gremio de plateros de Valencia en 1669. Se trata de un modelo carente de tapa y decoración, mucho más simple que el mendocino o de torrecilla, que se repite en la segunda mitad del siglo XVII e inicios del XVIII (Cots, 2003, pp. 371-372). También se encuentra producido en cerámica, como la pieza turolense con el número de inventario CE03435 del Museo Nacional de Artes Decorativas.
} 


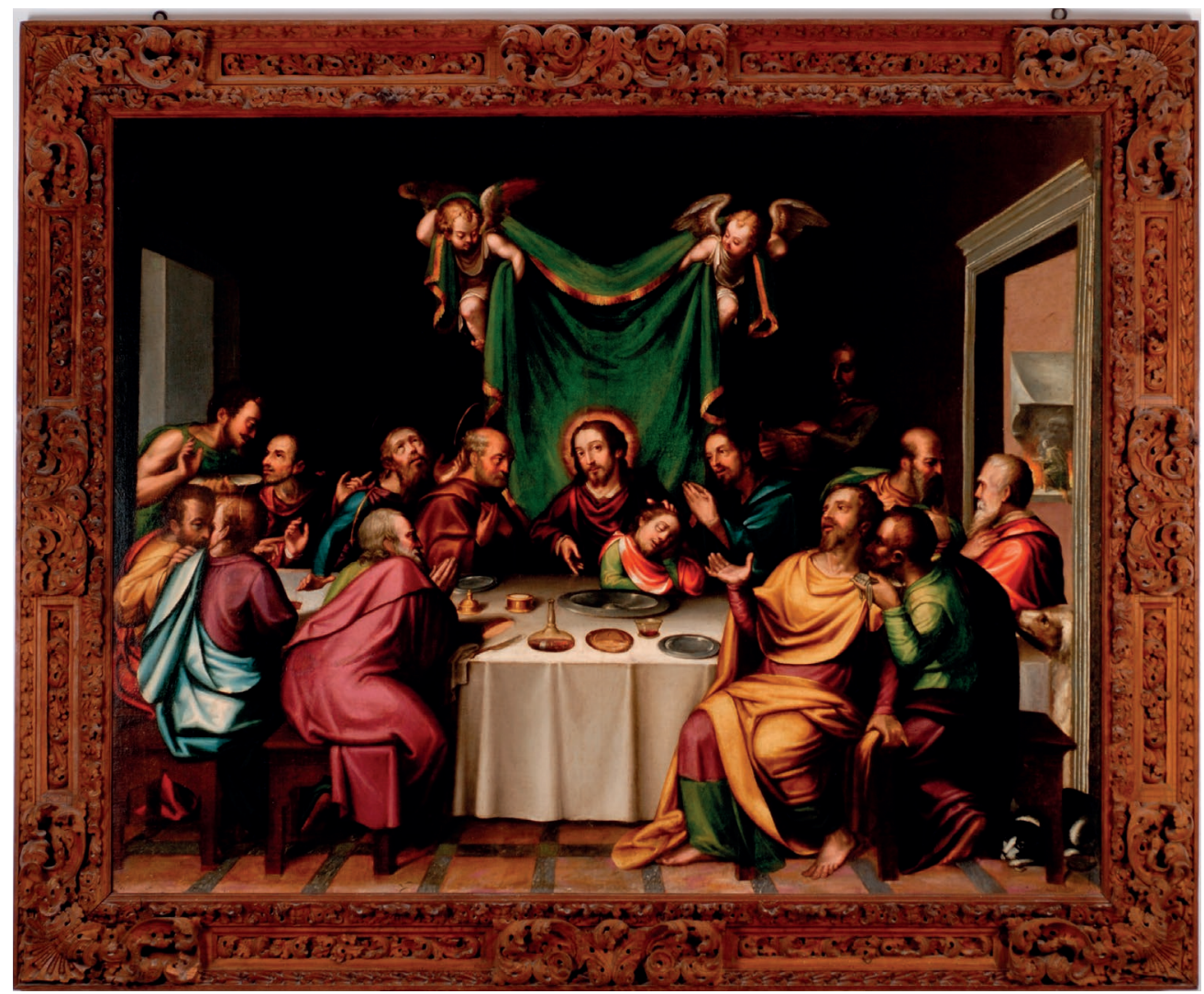

Figura 12. Última Cena [detalle]. Atrib. Pedro García Ferrer, primera mitad del siglo XVII. Fuente: Fundación Santa María de Albarracín.

nos da una nueva nota de que tanto las especias como sus contenedores eran elementos con una función no solo utilitaria, sino también simbólica y representativa de la capacidad económica del anfitrión. Acudimos por segunda vez a la pintura para poder ilustrar este fenómeno, en este caso a la Naturaleza muerta con objetos de orfebrería de Juan Bautista de Espinosa. El artista representó sobre el lienzo un conjunto de aparador formado por múltiples platos y bandejas de plata sobredorada, una copa bernegal, recipientes de diversos materiales, parte de la cubertería y, en primer plano, una pareja de salero y pimentero desmontados.

El componente social que tiene la exhibición de estos objetos y la consecuente demostración de poder económico explica que muchos de ellos puedan ir complementados con la heráldica de sus propietarios, como en el caso de la naveta conservada en la iglesia de San Pablo de Zaragoza. De esta manera, serían inmediatamente reconocidos como poseedores de tan exclusivos productos. En la documentación encontramos "una torreçilla en quatro piezas donde ay salero, azucarero, canelera y pimentera todo dorado con su caxa y armas del Vizconde" entre los bienes de Ana de Aragón, vizcondesa de Ébol, en 1595;20 y un salero "quadrado llano con

${ }^{20}$ AHPNZ, Diego Miguel Malo, 1595, ff. 226 r.-226 v. (30-III-1595, Zaragoza). 


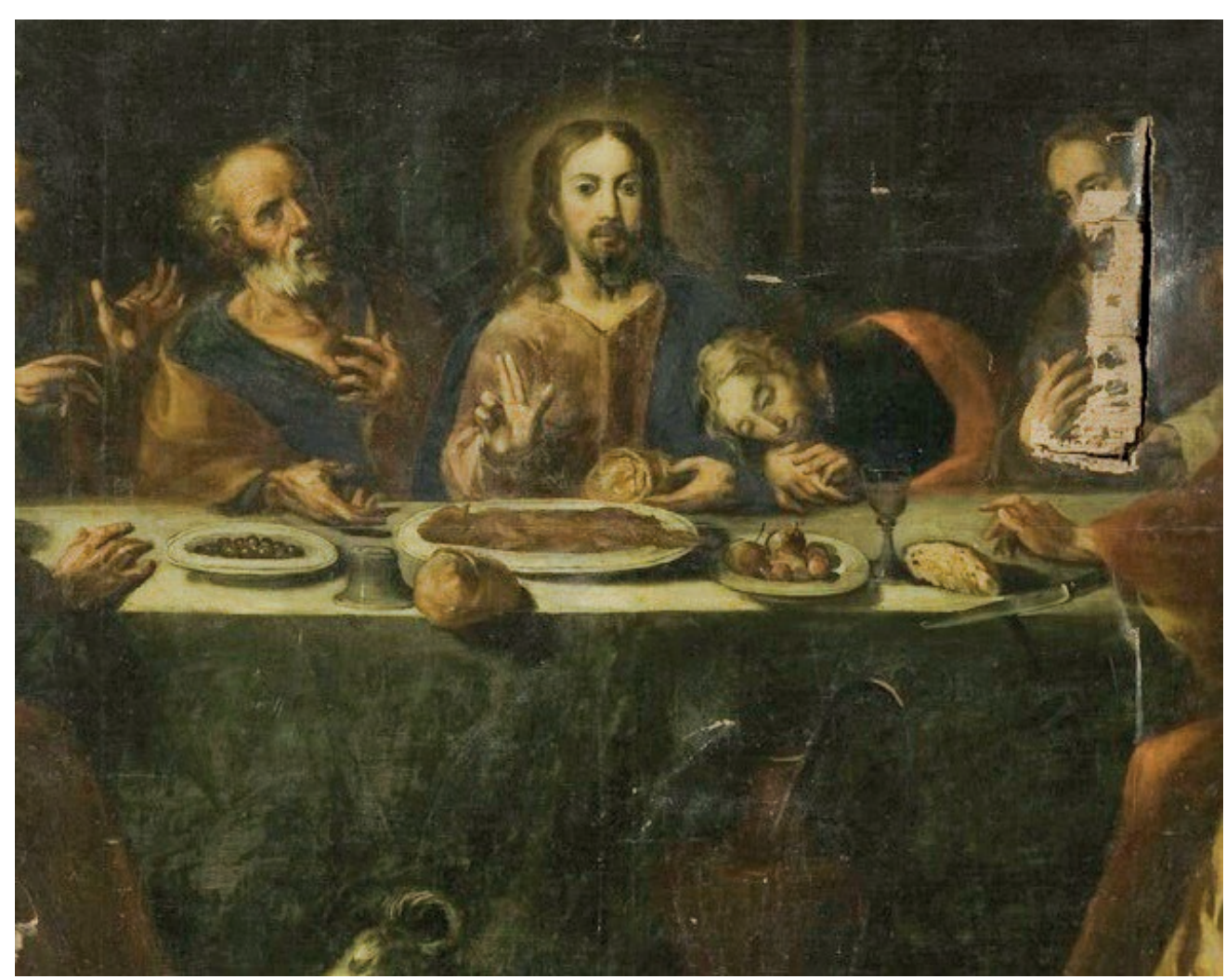

Figura 13. Última Cena [detalle]. Pedro Rabiella y Diez de Aux, 1704. Fuente: Museo de Zaragoza.

nuestras armas y unas bolas redondas en cada esquina que sirven de pies" de Antonio Ximénez de Urrea, conde de Aranda (Lanaspa, 2005, p. 200, doc. 2-2783(3.190)) en 1618.

Una tercera posibilidad eran los talleres, donde se situaban diversos recipientes para especias y aderezos. ${ }^{21}$ El Diccionario de Autoridades indica que un taller es "una pieza como una salvilla de plata, ù oro, que se pone en los aparadores de las mesas de los Señores: en medio un saléro, y à los quatro lados dos vasijas para azéite, y vinagre, y dos cubillos para pimienta, y azucar" (Diccionario de Autoridades, 1726-1739). Generalmente los talleres se restringen a las cinco piezas referidas en el diccionario, aunque en los documentos hemos encontrado algunos ejemplos extraordinarios.

El que cuenta con una descripción más completa perteneció a Francisca Luisa de Luna, marquesa de Camarasa. En su inventario post mortem realizado en 1585 se describe como "un plato dorado con pie y en el ay seis guecos y en medio ay un salero grande dorado con el cobertor de un toro de bulto. Ay en el plato una acucherera y una pementera y una torreçuela para canela y

${ }^{21}$ La palabra taller no se documenta en el ámbito hispánico hasta 1617, pero la tipología ya se utilizaba con anterioridad (Cruz, 1979, pp. 145-144). Hemos hallado dicho término en la documentación aragonesa por primera vez en 1618 en referencia a cinco talleres propiedad de Antonio Ximénez de Urrea, conde de Aranda (Lanaspa, 2005, p. 200, doc. 2-2783(3.190)). 
una azeytera y vinagera y otra de gengibre. Cada cofre destas tiene sus tapaderas y su letra y altas y todo ello dorado y todo el a pesado deziseis marcos", que se acompaña de nueve saleros adicionales. ${ }^{22}$ También podemos citar la "salva imperial de plata lisa con ocho pieças, con el joiello que sirve de remate al salero" que el arzobispo Tomás de Borja donó a su sobrino el duque de Lerma en 1608 (Abad, 2009, p. 358). Por último, los talleres también podían contar con elementos heráldicos, como "las armas de Yxar y Pinos" que ostentaba el de Francisca de Pinós y Fenollet, duquesa de Hijar y Condesa de Belchite (Longás, 2006, p. 203, doc. 7-9504(10328)). Por desgracia, no hemos hallado ningún taller, por completo o en estado fragmentario, de origen aragonés.

Finalmente, hemos documentado tres conjuntos de camino o de viaje en los que se repiten los parámetros domésticos, todos ellos pertenecientes a religiosos. Se trata de "una pila de plata redonda de camino dorada dentro en una capsa y una cuchara de plata dorada y una pimenterilla de plata" de Juan de Urrea, abad de Montearagón; ${ }^{23}$ "un baso de camino que ay en el dos tacas, dos candeleros, dos cucharas, dos orquillas, salero, pimentera y açucarera" de Juan de Paternoy, comendador de la orden de San Juan;24 y "un adreço de camino con un jarillo de plata, dos gobaletes, çucarera, salero y pimentera, tres cucharas y dos cuchillos dentro de su caxa" de Diego de Ramellori, canónigo de la Seo de Zaragoza (Jodrá, 2007, pp. 243-245, doc. 8-1016(1031)).

\section{Conclusión}

En las páginas anteriores hemos visto una gran cantidad de obras con formas, materiales y modos de uso diversos que parecen servir a un mismo objetivo muy simple: disponer la sal y las especias en la mesa. Esta acción puede parecer carente de interés a ojos del cocinero y del comensal contemporáneos por su precio asequible y fácil acceso. Sin embargo, en tiempos pasados su consecución era un acto restringido a una élite privilegiada. Las capas altas de la sociedad subordinaban todos los medios de producción con el objetivo de importar desde tierras lejanas unos condimentos que dotaban a sus manjares de un sabor, un color, un aroma y unas propiedades que les parecían extraordinarias.

La realeza, las familias nobles, la jerarquía eclesiástica y los comerciantes y ciudadanos más afortunados no restringían el uso de las especias a la cocina. Todos ellos querían disponer algunos de estos alimentos sobre la mesa para evidenciar sus posibilidades. Las fuentes documentales indican que la más popular era la pimienta, pero también el jengibre y la canela podían ofrecerse a los invitados junto a la sal y al azúcar. Por este motivo no se puede entender el papel de las especias desde una perspectiva únicamente gastronómica, sino también sociológica e incluso política. En un acto tan importante socialmente como el banquete, todos los sentidos formaban parte del despliegue de poder: el sabor de los platos, el aroma de las especias y otras sustancias fragantes y, por último, pero no menos importante, la belleza de la vajilla, de los objetos de arte y de los artilugios desplegados estratégicamente sobre la mesa para evocar los largos y costosos viajes que había sufragado el anfitrión, directa o indirectamente, para poder contentar a todos sus invitados.

\footnotetext{
${ }^{22}$ AHPNZ, Jerónimo Andrés, 1585, ff. 410 r.-536 r. (24-VI-1585, Zaragoza).

${ }^{23}$ AHPNZ, Pablo de Gurrea, 1547, ff. 37 v.-51 v. (12-I-1547, Zaragoza).

${ }^{24}$ AHPNZ, Juan Martín Sánchez de Castelar, 1604, ff. 1775 r.-1781 r. (1-XI-1604, Zaragoza).
} 
Finalmente, en este texto hemos incorporado una serie de objetos con la misma función primordial, pero menos exclusivos, realizados con técnicas cerámicas o con metales comunes, que utilizaba un grupo más amplio de la sociedad aragonesa para servir la sal sin la compañía de otras especias, al menos no con frecuencia. No obstante, los paralelismos formales entre las piezas de plata y las más modestas nos indican que había un cierto conocimiento de las prácticas gastronómicas de élite que se quisieron incorporar, ya sea por comodidad o por apariencia, en las mesas más humildes.

\section{Bibliografía}

ABAD ZARDOYA, C. (2005). La casa y los objetos. Espacio doméstico y cultura material en la Zaragoza de la primera mitad del XVIII. Zaragoza: Delegación del Gobierno en Aragón.

ABAD ZARDOYA, C. (2009). "Por el bien y beneficios que de su mano hemos recibido: estudio documental de una donación de bienes muebles hecha por Tomás de Borja a su sobrino el duque de Lerma en 1608". En: Artigrama, 24, pp. 341-371.

Almagro gORBEA, A. y ARCE OLIVA, E. (2011). El Palacio Episcopal de Albarracín. Albarracín: Fundación Santa María de Albarracín.

ALONSO BENITO, J. (2015). Platería. Colecciones del MNAD. Madrid: Ministerio de Educación, Cultura y Deporte.

ANDRÉS CASABÓN, J. y NAYA FRANCO, C. (2012). "Del deleite de los sentidos al ornato del culto divino: la naveta gótica del Museo de Tapices de La Seo de Zaragoza”. En: Artigrama, 27, pp. 375-393.

ARCE OLIVA, E. (2013). “La platería renacentista de la catedral de Albarracín: génesis de una colección”. En: Álvaro Zamora, M. I., Lomba Serrano, C., Pano Gracia, J. L. y Borrás Gualis, G. M. (coords.). Estudios de historia del arte: libro homenaje a Gonzalo M. Borrás Gualis. Zaragoza: Institución Fernando el Católico.

CASTILLÓN CORTADA, F. (2002). "Inventario litúrgico de la catedral de Roda de Isábena (Huesca)". En: Sobrarbe, 8, pp. 65-76.

CERVANTES SAAVEDRA, M. de (1605). El ingenioso hidalgo don Quijote de la Mancha, edición de 1839. Madrid: D. E. Aguado.

COTS MORATÓ, F. de P. (2003). El examen de maestría en el arte de plateros de Valencia (1595-1882). Valencia: Ajuntament de València.

CRUZ VALDOVINOS, J. M. (1979). "Plata de vajilla: talleres castellanos". En: Archivo Español de Arte, 206, pp. 145-168.

CRUZ VALDOVINOS, J. M. (1997). Platería europea en España (1300-1700). Madrid: Fundación Central Hispano.

CRUZ VALDOVINOS, J. M. (2014). "Piezas de platería aragonesa de Época Moderna en subastas internacionales recientes (2008-2011)". En: Ars Renovatio, 2, pp. 154-163.

DICCIONARIO de AUTORIDADES (1726). Diccionario de Autoridades - Tomo I (1726) - Aparador. <https://apps2.rae.es/DA.html< [Consulta: 29 de septiembre de 2021] 
EBERENZ, R. (2018). "Discurso y léxico de la alimentación en los tratados médicos medievales y renacentistas". En: Arnal Purroy, M. L., Castañer Martín, R. M., Enguita Utrilla, J. M., Lagüéns Gracia, V. y Martín Zorraquino, M. A. (coords.). Actas del X Congreso Internacional de Historia de la Lengua Española. Zaragoza: Institución Fernando el Católico, vol. II, pp. 1075-1088.

ESTEBAN LORENTE, J. F. (1981). La platería de Zaragoza en los siglos XVII y XVIII. Madrid: Ministerio de Cultura.

ESTERAS MARTÍN, C. (1975). "Inventario artístico de la orfebrería religiosa en la ciudad de Albarracín”. En: Teruel, 53, pp. 105-146.

ESTERAS MARTíN, C. (1980). Orfebrería de Teruel y su provincia. Teruel: Instituto de Estudios Turolenses.

GARRIDO ARANDA, A., HIDALGO NUCHERA, P. y RAMíREZ PONFERRADA, M. D. (2004). "Papel de hierbas aromáticas y especias en la alimentación española de los tiempos modernos". En: Garrido Aranda, A. (comp.). El sabor del sabor. Hierbas aromáticas, codimentos y especias. Córdoba: Servicio de publicaciones de la Universidad de Córdoba, pp. 121-152.

GIL ASENJO, M. I. (1984). Documentación artística en los años 1652, 1653 y 1654, según el Archivo Histórico Provincial de Zaragoza. Tesina. Zaragoza: Universidad de Zaragoza.

GÓMEZ DE VALENZUELA, M. (2017). Platería y joyería en Zaragoza (1412-1513). Zaragoza: Institución Fernando el Católico.

LANASPA MORENO, M. A. (2005). Las artes en Aragón en el siglo XVII según el Archivo de Protocolos notariales de Zaragoza, de 1616 a 1618. Zaragoza: Institución Fernando el Católico.

LATORRE GRACIA, N. (1984). Documentación artística en los años 1640, 1641 y 1642, según el Archivo Histórico Provincial de Zaragoza. Tesina. Zaragoza: Universidad de Zaragoza.

LONGÁS LACASA, M. Á. (2006). Las artes en Aragón en el siglo XVII según el Archivo de Protocolos notariales de Zaragoza, de 1631 a 1633. Zaragoza: Institución Fernando el Católico.

MALDONADO NIETO, M. T. y MONTUENDO BARREIDO, A. (1979). Plata espanyola des del segle XV al XIX. Barcelona: Sala d'Art Daedalus.

MAÑUECO SANTURTÚN, C. (2002). "Especiero”. En: Flórez Plaza, P. (coord.) y González Martínez, R. (coord.). Arte y Poesía. El amor y la guerra en el Renacimiento. Madrid: Ministerio de Educación, Cultura y Deporte, p. 437.

MARTíN DOMINGO, F. (2009). "Las salinas de Ojos Negros". En: Cuadernos del Baile de San Roque, 22, pp. 61-72.

MONTALVO MARTÍN, F. J. (2009). "Especieros de plata hispanos del Instituto Valencia de Don Juan”. En: Goya, 329, pp. 352-361.

PÉREZ SÁMPER, M. de los Á. (1997). “Los recetarios de mujeres y para mujeres. Sobre la conservación y transmisión de los saberes domésticos en la época moderna". En: Cuadernos de Historia Moderna, 19, pp. 121-154.

POSTIGO VIDAL, J. (2015). La vida fragmentada, experiencias y tensiones cotidianas en Zaragoza (siglos XVII y XVIII). Zaragoza: Institución Fernando el Catíólico. 
QUEVEDO, F. de (1699). Obras de Francisco de Quevedo Villegas. Amberes: Henrico y Cornelio Verdussen.

RIERA MELIS, A. (2004). "Las especias en el Mediterráneo noroccidental en la Antigüedad tardía y la Alta Edad Media”. En: Garrido Aranda, A. (comp.). El sabor del sabor. Hierbas aromáticas, codimentos y especias. Córdoba: Servicio de publicaciones de la Universidad de Córdoba, pp. 47-69.

SAN VICENTE PINO, Á (1976). La platería de Zaragoza en el bajo Renacimiento, 1545-1599. Zaragoza: Pórtico.

SAN VICENTE PINO, Á, (1994). "Diez documentos escogidos sobre precios de bienes y servicios en Zaragoza en el siglo XVI”. En: Lobo Cabrera, M. y Suárez Grimón, V. El comercio en el Antiguo Régimen, III reunión científica de la asociación española de historia moderna. Las Palmas de Gran Canaria: Universidad de Las Palmas de Gran Canaria, pp. 261-275.

SAN VICENTE PINO, Á. (1988). Instrumentos para una historia social y económica del trabajo en Zaragoza en los siglos XV a XVIII. Zaragoza: Real Sociedad Económica Aragonesa de Amigos del País.

SAN VICENTE PINO, Á. (1991). Lucidario de bellas artes en Zaragoza, 1545-1599. Zaragoza: Real Sociedad Económica Aragonesa de Amigos del País.

YELGO DE BÁZQUEZ, M. (1614). Estilo de servir a principes, con exemplos morales para servir a Dios. Madrid: Cosme Delgado. 



\title{
VINUM VIVAT! LA UVA Y EL VINO EN LA ANTIGÜEDAD A TRAVÉS DE LOS PANELES QUE SOROLLA PINTÓ PARA RAFAEL ERRÁZURIZ
}

\author{
José Fenoll Cascales \\ Universidad de Murcia. Departamento de Historia del Arte. jose.fenollc@um.es
}

\begin{abstract}
The present paper studies how grape harvesting and wine production were developed in ancient times from a set of panels made by the Valencian painter, Joaquín Sorolla Bastida. This series of four large-format paintings commissioned by the wine entrepreneur Rafael Errázuriz, reflect the different conceptions of this food in the Greco-Latin world, from its cultivation in the interiors of domus, to the consumption of wine in the festivities associated with Baco. The pressing system following the Minoan press model and the storage of the precious liquid in a Dressel amphora provide a careful study of real archaeological references when composing the scenes. Especially in La Vendimia and La Prensa de la Vid where the painter approached in a very exact way two images that perfectly reflect how the wine production procedures were in the Ancient Mediterranean.
\end{abstract}

Keywords: Joaquín Sorolla Bastida, Wine, Vintage, Rafael Errázuriz, Panels, Vine Press, Classical Antiquity, Classical Archeology.

Resumen: El presente trabajo estudia cómo se realizaba la recolección de uva y la producción de vino en la Antigüedad a partir de un conjunto de paneles realizados por el pintor valenciano, Joaquín Sorolla y Bastida. Esta serie de cuatro pinturas de gran formato encargadas por el empresario vinícola Rafael Errázuriz, reflejan las distintas concepciones de este alimento en el mundo grecolatino, desde su cultivo en los interiores de las domus, hasta el consumo de vino en las festividades asociadas a Baco. El sistema de prensado siguiendo el modelo de prensa minoica y el almacenamiento del preciado líquido en un ánfora Dressel, atisban un cuidado estudio de referencias arqueológicas reales a la hora de componer las escenas. Especialmente en La Vendimia y La Prensa de la Vid donde el pintor se acercó de manera muy exacta a dos imágenes que reflejan de perfectamente como fueron los procedimientos de producción de vino en el Mediterráneo Antiguo.

Palabras clave: Joaquín Sorolla Bastida, Vino, Vendimia, Rafael Errázuriz, Paneles, Prensa de la vid, Antigüedad Clásica, Arqueología Clásica.

Citar como: Fenoll Cascales, J. (2022). "Vinum vivat! La uva y el vino en la Antigüedad a través de los paneles que Sorolla pintó para Rafael Errázuriz". En: Actas del III Congreso Internacional sobre Patrimonio Alimentario y Museos. 25-26 noviembre, 2021, Valencia, España. pp. 61-72. https://doi.org/10.4995/EGEM2021.2021.13312 


\section{Introducción. Un encargo de cuatro paneles}

En 1895 Joaquín Sorolla Bastida recibió un encargo de Rafael Errázuriz. El vinicultor chileno se había puesto en contacto con el pintor valenciano a través del marchante de arte José Artal, quien había introducido la pintura del Realismo Español en Hispanoamérica a finales del siglo XIX (Pons-Sorolla, 2001: 148). Así es como se inicia la materialización de los cuatro paneles que compondrán la serie objeto de estudio, integrada por: La Parra, La Vendimia, La Prensa de la Vid y Bacanal (Díez y Barón, 2009: 122 - 123). En estos cuatro quatri riportati Sorolla plasma el proceso de producción y consumo del vino en el Mediterráneo Antiguo desde una óptica múltiple, en la que los objetos arqueológicos gozan de relevante importancia a la hora de componer escenas fidedignas.

Estudiar el fenómeno vinícola es una tarea ciertamente compleja debido a la multitud de ámbitos en los que la uva y el vino tienen una especial relevancia en la Antigüedad. Desde la gastronomía hasta los cultos rituales, el vino es un fenómeno consustancial al Mediterráneo Antiguo que goza de notable entidad y atraviesa toda la cultura clásica. Sin ir más lejos, el cultivo la vid y el consumo de vino fueron considerados síntomas de desarrollo cultural durante este periodo (Suarez, 2005: 44).

\section{Objetivos}

La presente comunicación establece como objetivo principal el estudio de la uva y el vino en la Antigüedad grecolatina, tomando como fuente visual principal los paneles que Sorolla pintó para Rafael Errázuriz.

Analizar las referencias visuales de objetos arqueológicos que Sorolla tomó para concebir cada una de las imágenes.

Vincular a Joaquín Sorolla Bastida con la realidad arqueológica de su tiempo, como conocedor de la cultura material procedente del Mediterráneo Antiguo.

\section{Sorolla y los paneles para Rafael Errázuriz}

\section{1 "La parra”}

En este primer panel (Figura 1) Sorolla representa una escena emplazada en la intimidad de una vivienda, en el peristilo (peristylium) o patio ajardinado de las domus romanas. La joven protagonista alza sus brazos a la parra para recoger los frutos, para depositarlos seguidamente sobre una pequeña repisa de mármol que se sitúa frente a ella.

Este hecho no es de extrañar, pues en lugares como Pompeya se han documentado pequeños viñedos asociados a las viviendas (Jashemski, 1973) y emparrados que cubrían las pérgolas de los jardines domésticos tal y como sucede en este caso. Nada es baladí en la escena, pues en primer plano aparece un bronce procedente también de Pompeya que representa a Baco desnudo y tocado con una corona de flores. En efecto se trata del dios del vino, que ubicado sobre una fuente parece proteger el acto de la recolecta de la uva. Al otro lado de la joven, enmarca la escena el herma de Homero que en la actualidad se conserva en el Museo Arqueológico Nacional de Nápoles. 


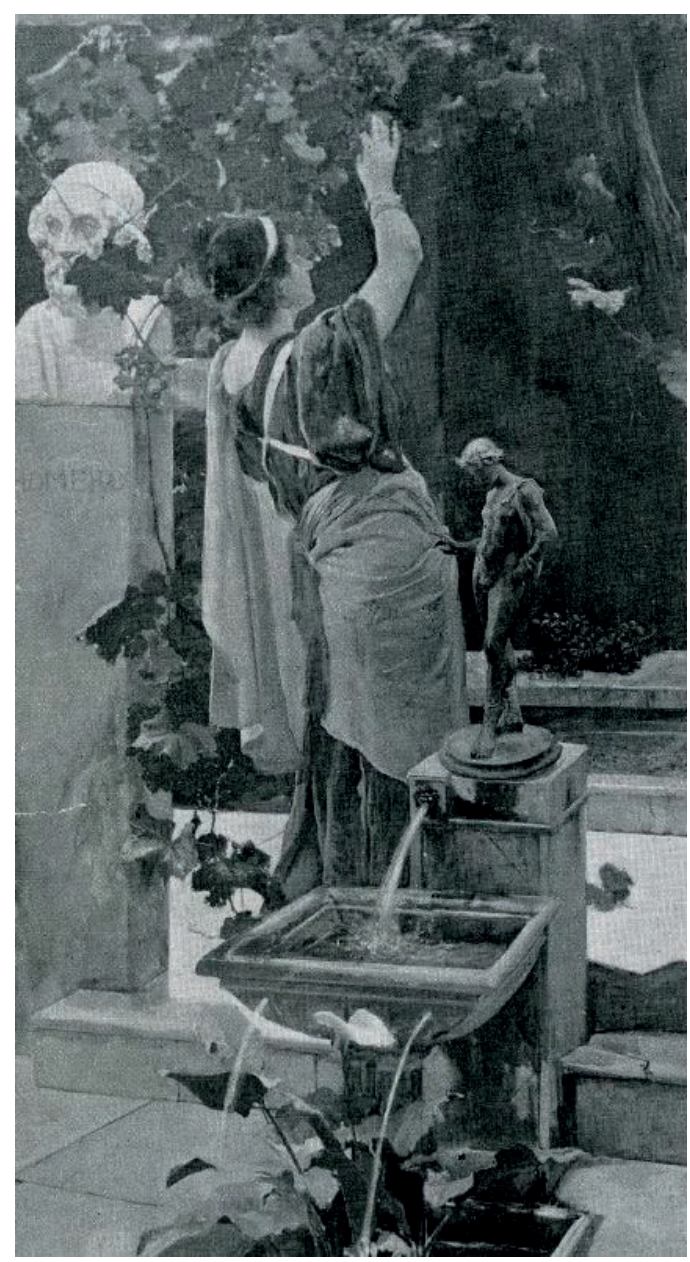

Figura 1. Joaquín Sorolla, La parra, 1897, Paradero desconocido.

Reproducido en la revista Hispania [15/VI/1901]. Fuente: Revista Hispania [15/VI/1901]

Así es como en este panel el valenciano se centra en ofrecer una visión de la uva en el ambiente privado, en el interior de hogar, la del cultivo para el consumo propio de la fruta fresca. En un fresco de la Casa de Julia Félix en Pompeya aparece esta circunstancia representada, un cuenco de cristal repleto con un racimo de uva fresca dispuesta para ser consumida (Ling, 1991:157). Así pues, Sorolla abre con este primer panel una ventana a los espacios exteriores de una domus, donde el vergel vegetal se ve acompañado de acequias y fuentes habitadas por esculturas en bronce. En el patio de la casa del pintor sucede mismo e incluso se puede encontrar una réplica de ese mismo Baco (o Dionisos) que Sorolla conservó en su colección de reproducciones artísticas (Ruíz Bremón, 1993: 74) que también procede de Pompeya y aparece en este panel. Poniendo todo esto en conjunto resulta evidente la enorme influencia pompeyana que se respira en esta escena. 


\section{2 "La vendimia"}

Entre ramas y hojas de viñedos llenos de uva Sorolla coloca a dos mujeres encargadas de recoger la fruta (Figura 2). Vestidas con quitones blancos de manga corta se asemejan a otras figuras que el valenciano había pintado ese mismo año en otro panel decorativo, "Muchachas griegas en la orilla" (Pantorba, 1981:178; Diez Barón (coord.), 2009: 122 y 141). A los pies de la joven que se encuentra agazapada y recolectando un racimo de uva, se dispone un cesto de mimbre, en el que va colocando los racimos recogidos.

El kalathos fue el recipiente contendor por antonomasia en la Antigua Grecia, su forma cilíndrica o ligeramente troncocónica y su comedido tamaño lo convierte en un cesto manejable y de muchísima utilidad. Su forma funcional y su realización en fibra vegetales como el mimbre, permitía que fuese porteado por las mujeres sobre sus cabezas (Lillo, 1999: 371 -372).

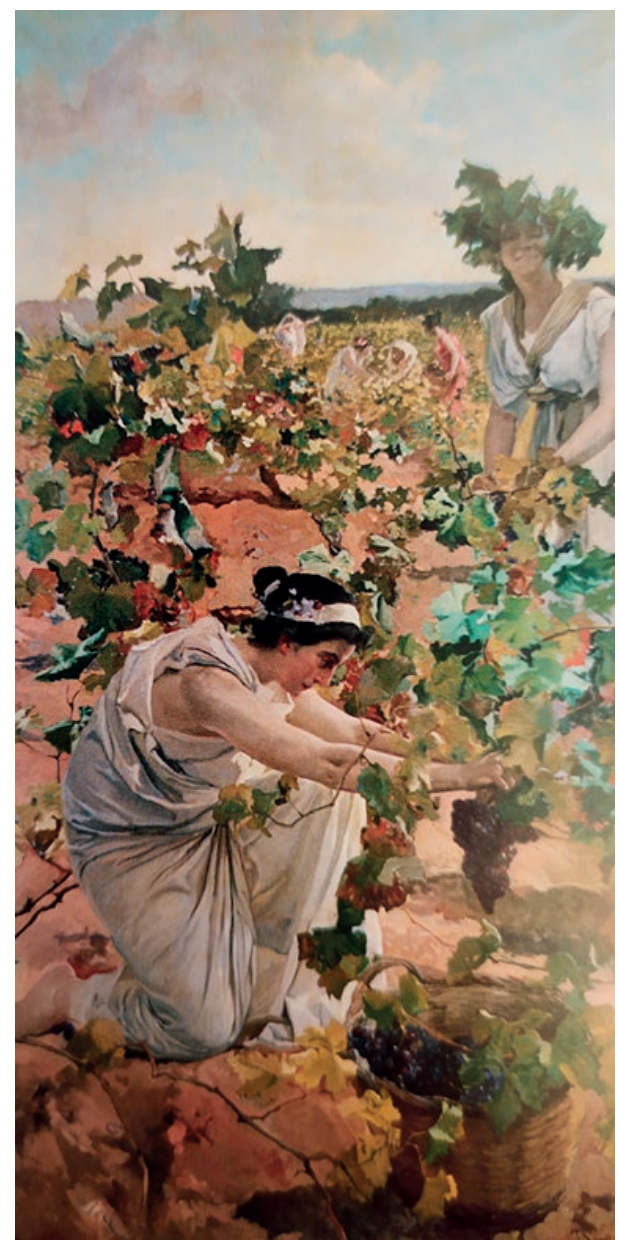

Figura 2. Joaquín Sorolla, La vendimia, 1897, $280 \times 140 \mathrm{~cm}$. Viña del Mar, Museo de Bellas Artes. Fuente: Díez y Barón, 2009: 123. 
Aunque en realidad, el termino kalathos tiene toda una serie de connotaciones asociadas a él, puesto que se trata tanto de un recipiente contendor de uso agrario como de uso votivo. Es un elemento que es símbolo de abundancia, al ser contenedor de frutos y que por tanto está irremediablemente asociado a las fiestas de primavera de Coré o a las otoñales de Deméter, erigiéndose como un testimonio de los cultos agrarios realizados para la protección de la siembra y la recolección (Ruiz de Arbulo, 1994: 167 y ss.). En este sentido es abundante la aparición de los kalathos con racimos de frutos y espigas sobre las cabezas de los pebeteros femeninos en terracota que aparecen en el Mediterráneo occidental (García Cano y Page, 2004: 42 - 43).

Teniendo en cuenta estas consideraciones resulta fácil avistar que lo que Sorolla está representando no es realmente un kalathos, puesto que este tipo de cesta antigua a menudo carece de asas. El maestro valenciano pinta en efecto el tipo de cesta en mimbre que se utiliza en su contemporaneidad para la recolecta de frutas, siendo esta el cofín o el cuévano.

En realidad, la vendimia se trata de un proceso que poco ha cambiado en más de dos mil años, buena cuenta da de ello los estudios que Sorolla realizó sobre la vendimia jerezana en 1914. En ellos vemos como las jóvenes seguían recolectando la uva manualmente con sus cuévanos, siguiendo el mismo proceso que también refleja una crátera de columnas atribuida al pintor de Orchard conservada en MET (Richter, 1936: 117, 90-91, 170; Beazley, 1942: 346). En el caso de la escena que aparece en el vaso de cerámica ática en figuras rojas no se trata de uvas sino de manzanas y vemos como una escena agrícola cotidiana se puede transmutar en un tema mitológico con relativa facilidad, puesto que estas jóvenes muchachas se han interpretado tradicionalmente como las Hespérides. En cualquier caso, la delicadeza y las posturas de los cuerpos de las jóvenes griegas que aparecen en la crátera de columnas es similar a la que encontramos en el caso del panel de Sorolla, un mismo tema con dos mil cuatrocientos años de distancia en el tiempo, el de la recolecta del fruto.

Tal y como sucedía en la escena anterior, al encontrarse la fruta fresca, el pintor nos sitúa entre los meses de agosto y octubre, cuando la uva se encuentra en un punto de maduración óptimo para su recolección.

\section{3 "La prensa del vino"}

Es en el tercero de estos paneles (Figura 3) es donde se puede realizar un estudio algo más complejo sobre la relación de Sorolla con el vino en la Antigüedad. A la sombra de un gran árbol un hombre deja caer todo su peso sobre la palanca de la prensa, mientras a sus pies una niña identificada como la alegoría del trabajo del vino recoge el caldo en un recipiente troncopiramidal. Tras los personajes aparece un campo repleto de lo que se intuyen como vides, enmarcadas por el cabo San Martín en Jávea (Alicante) (Gutiérrez Pulido, 2018).

En concreto el modelo de prensa que Sorolla utiliza para representar el acto de extracción del zumo de la uva es el prensado con palanca sobre lecho, una tipología que nace en el mundo minoico. En este ejemplo en concreto se trata de un lecho de prensa Tipo I de E. Pratt (2021: 48), los cuales aparecen en Creta con frecuencia, en contextos urbanos o en lugares de producción como las granjas. Este tipo de lecho de prensado se articula en dos niveles. El superior queda integrado por un gran vaso cerámico de forma cilíndrica con un pico vertedor colocado sobre una plataforma o banco artificial. Las dimensiones de estos vasos oscilan entre los 20 y los 50 centímetros de altura y los 47 y los 77 centímetros de diámetro (Pratt, 2021: 49). Mientras 
en la parte inferior se coloca el vaso en el que se vierte el líquido tras el prensado, en este caso un pithos piriforme de boca ancha, lugar en el que se fermentará el zumo para convertirse en vino. Aunque el registro arqueológico ha evidenciado que en multitud de casos este primer contenedor estaría anclado al suelo y sería inamovible (como sucede por ejemplo en la ciudad de Valthypetro) (Pratt, 2021: 49), parece que en el caso del ejemplo que pinta Sorolla si pudiera tratarse de un pithos transportable, pese a la dificultad que conllevaría el hacerlo por el peso del mismo estando lleno de líquido. Este contratiempo se solventaría una vez fermentando el vino, puesto que el preciado jugo se trasladaría a recipientes más propios para su transporte como lo son el ánfora (una forma Dressel 1) o los odres de piel que el valenciano representa en la parte inferior del lienzo. Por tanto, nos encontramos ante una escena que aglutina todo el proceso de elaboración del vino per se, reflejándose aquí el conjunto de procesos de mecánicos que convierten la uva en vino.

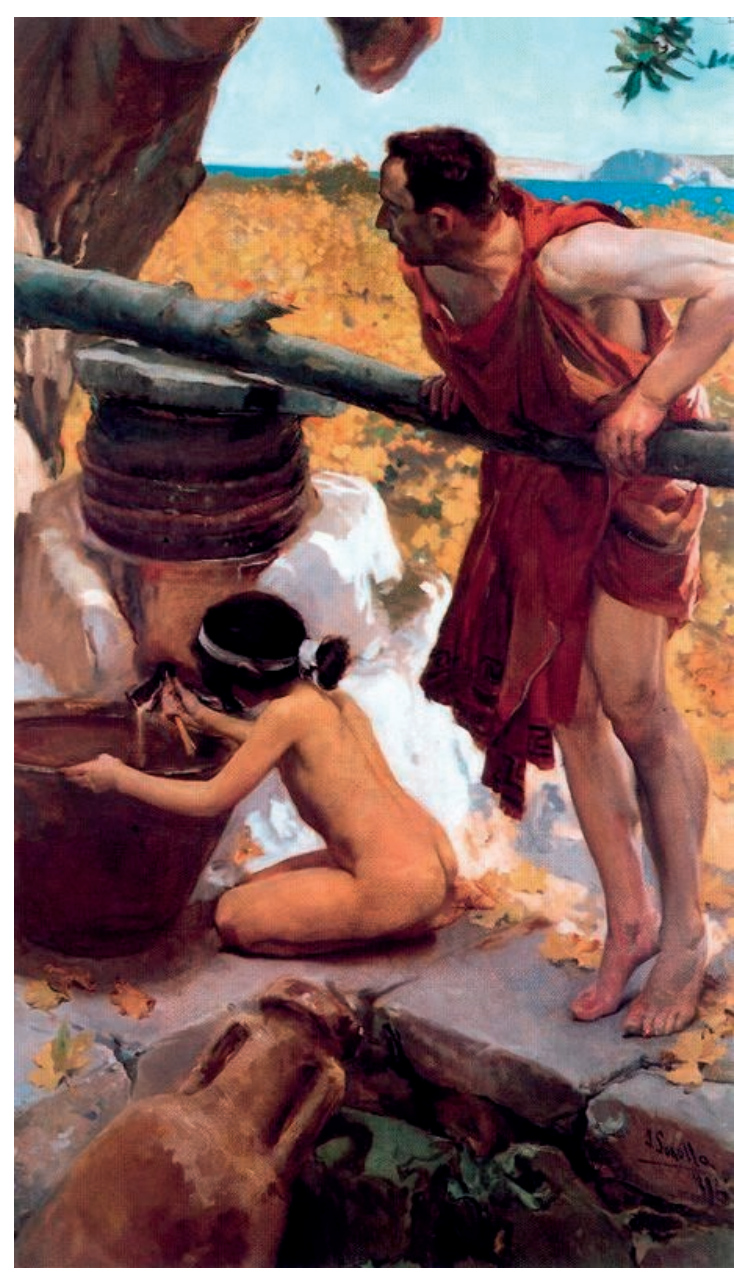

Figura 3. Joaquín Sorolla, La prensa, 1897, 280 x 140 cm. Viña del Mar, Museo de Bellas Artes. Fuente: Díez y Barón, 2009: 123. 
Se ha de apuntar que tradicionalmente se han asociado a este tipo de prensas multitud de usos, en la actualidad algunos de ellos, como la prensa de la oliva, han sido descartados, puesto que no sería posible machacar el hueso del fruto en una prensa de estas características. Además, y como apuntaba Hamilakis (1996: 5) el proceso de extracción de aceite de la oliva es muchísimo más complejo que el de la uva, puesto que requiere de un mayor tratamiento. Sin embargo, nos encontramos con dos procesos que utilizan maquinaria y contenedores muy parecidos, por lo que cuando este tipo de artefactos se encuentran a nivel arqueológico se solían interpretar de forma ambivalente (Hamilakis, 1996: 5).

\section{4 "La bacanal”}

Los paneles se articulan con un sentido narrativo de izquierda a derecha, por lo que el último de los paneles, "La bacanal" (Figura 4) supone la parte final en la vida del vino, su consumo. En realidad, se trata de una escena muy simple, protagonizada por una pareja en actitud de danza sobre los odres de piel llenos de vino. La escena se emplaza en lo que parece un espacio cerrado con un trampantojo arquitectónico al fondo, tan común en la pintura mural romana. La posición

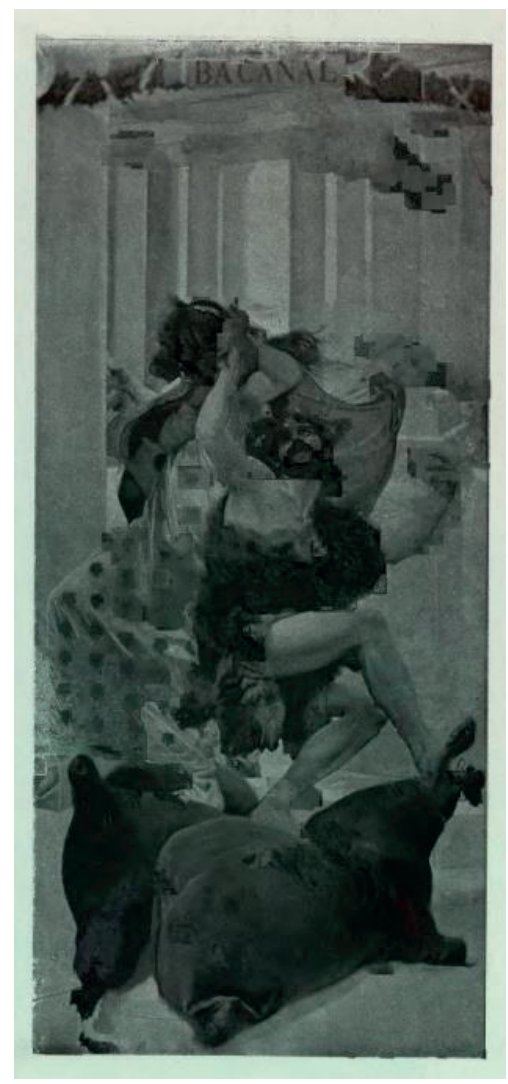

Figura 4. Joaquín Sorolla, La bacanal, 1897, Paradero desconocido.

Reproducido en la revista Hispania [15/VI/1901].

Fuente: Revista Hispania [15/VI/1901]. 
del cuerpo del hombre evoca al fauno en bronce que da nombre a la Casa del Fauno en Pompeya, escultura de que Sorolla adquirió una reproducción para su colección (Ruíz Bremón, 1993: 74 y 75), algo que no es de extrañar, puesto que el pintor ya había utilizado otras esculturas pompeyanas para componer estos paneles (vid. supra). Tampoco es esta la primera vez que Sorolla había pintado una bacanal, pues en 1887 ya había realizado la pieza "Danza báquica", obra que regaló a su suegro Antonio García Peris (Pons-Sorolla, 2001: 85).

Las bacanales fueron un tipo de festividad dedicadas al dios Baco/Dionisio, en las que mediante el vino se llevaba al cuerpo al ámbito de los dionisiaco, es decir, al placer. El vino servía en estas célebres fiestas para establecer un contacto con lo divino. Por medio de la enajenación se produce un acercamiento a una realidad distinta de la propia, identificada esta como de una naturaleza propia de los dioses (Suarez, 2005: 48, con bibliografía).

\subsection{Bocetos y referencias visuales}

El Museo Sorolla conserva en sus fondos varios bocetos en los que el pintor ensayó las figuras y la composición de esta serie de paneles. Así es como en origen el conjunto habría tenido cinco paneles, añadiéndose a los aquí estudiados "El regreso" (Rodríguez Subirana, 2015: 9). Sin embargo, ya en esta aproximación inicial Sorolla descartó este panel en el que parece poder entreverse como dos figuras comparten el peso de una cesta llena de uva. Este estudio (Museo Sorolla, No Inv. 11554) alberga también todo un corpus de posturas en las que el valenciano investiga acerca de las posibilidades compositivas del gesto de las jóvenes que recogerán el fruto en el panel de "La Vendimia". En la esquina superior derecha ya se vislumbra un segundo acercamiento a "La prensa", en el que el esfuerzo masculino de cuerpos hercúleos es el protagonista, al igual que sucede dentro de la miniatura en la que por primera vez deja registro de su idea del panel.

Parece que una parte importante de ese primer boceto de "La prensa" (Figura 5) llegó hasta la obra final, se puede apreciar como el tronco con el que se ejerce presión en la prensa sigue siendo uno de los ejes transversales del cuadro. Al igual que el sistema de prensado, que, aunque se encuentre esbozado, en él se pueden identificar claramente todas las partes que han persistido en la obra final. No obstante, Sorolla si parece contemplar otros sistemas de prensado distinto al que aparece en estos estudios y en el cuadro final, tal y como atestigua, el boceto "Prensa del
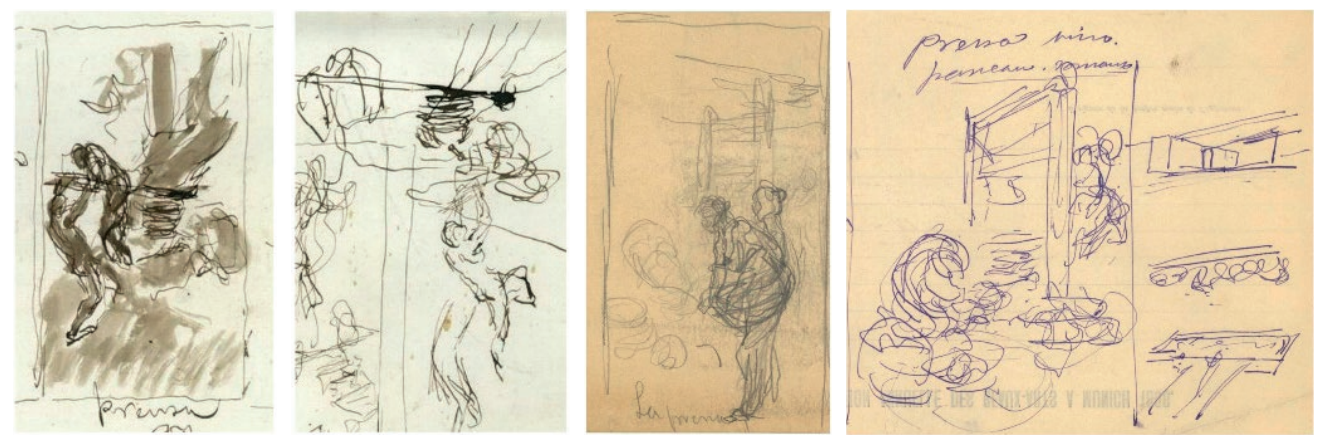

Figura 5. Joaquín Sorolla. Detalles de los Estudios para los paneles decorativos de Rafael Errázuriz. 1896-1897.

Conservados en el Museo Sorolla. (De izquierda a derecha) ( $N^{0}$ de Inventario: 11554; 11554; 10571; 10473). Fuente: Museo Sorolla. 
vino. Paneau Romano" (Museo Sorolla, No Inv. 10473) u otro con mejor acabado en el que se vislumbra mejor la escena a la que el artista quería llegar (Museo Sorolla, No Inv. 10571). El eje en torno al que Sorolla articula estos ensayos es un tipo de prensa distinto al que utilizará finamente y que estudió de manera individual en otro apunte (Museo Sorolla, No Inv. 15205) en el que copia una prensa de jaula de aceite de Herculano tomada del Diccionario de antigüedades griegas y romanas de Daremberg y Saglio (Gutiérrez Pulido, 2018) (Figura 6).

Gutiérrez Pulido también apuntó a que el modelo de prensa final que Sorolla utiliza pudiese haber sido extraído de otra lámina de este diccionario en la que se representa el desarrollo de un vaso cerámico griego pintado en el que aparecen dos figuras utilizando una presa de oliva
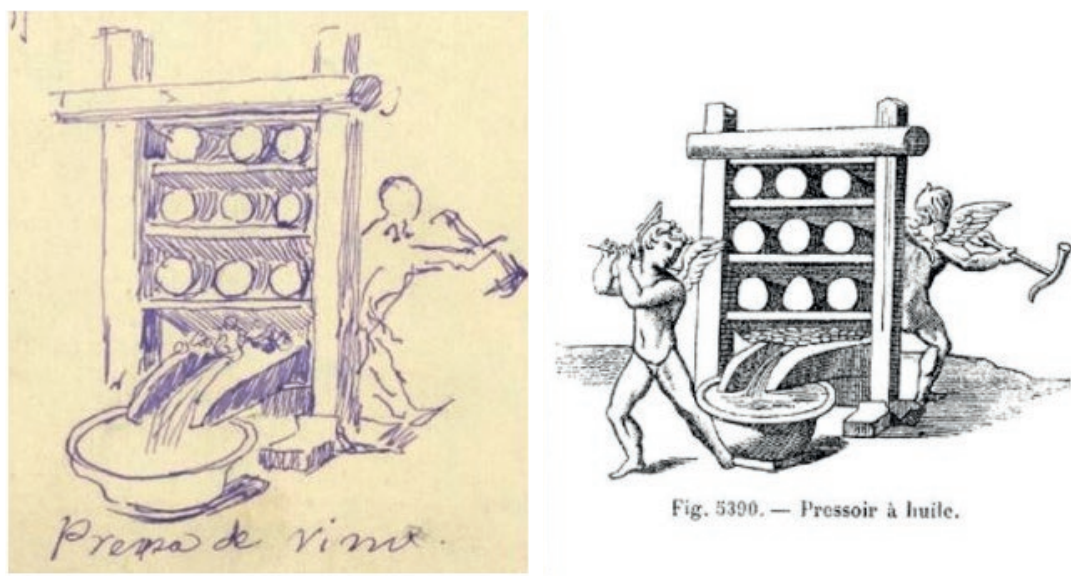

Fig. 5390. - Pressoir à huile.

Figura 6. (Izq.) Joaquín Sorolla. Detalle de los Estudios para los paneles decorativos de Rafael Errázuriz. 1896-1897. Conservados en el Museo Sorolla. No de Inv.: 15205. (Der.) Charles Victor Daremberg y Edmond

Saglio. Grabado de prensa de oliva. Diccionario de antigüedades griegas y romanas, Tomo IV, Primera

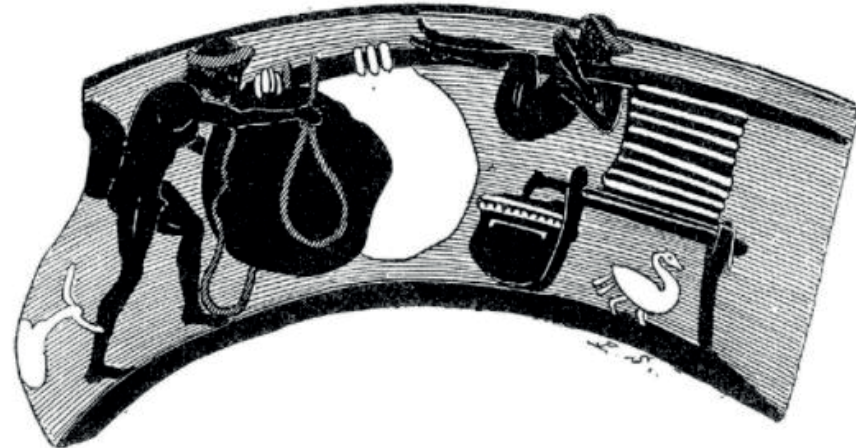

Fig. 5388. - Pressoir à huile.

Figura 7. Charles Victor Daremberg y Edmond Saglio. Grabado de prensa de oliva. Diccionario de antigüedades griegas y romanas, Tomo IV, Primera parte, p.166. Fuente: Diccionario de antigüedades griegas y romanas de Daremberg y Saglio. 
muy parecida a la escogida finalmente por Sorolla (Gutiérrez Pulido, 2018) (Figura 7). Esto no es de extrañar, pues la influencia de temas y escenas de la cerámica ática es una práctica bien documentada en otros pintores a finales del siglo XIX, entre ellos destaca el caso paradigmático de Lawrence Alma-Tadema, quien se inspiró notablemente en una crátera de figuras rojas del Museo Nacional de Nápoles a la hora de componer su célebre óleo "La siesta" (G. Navarro, 2009: 87). No obstante, aún parece que hubo una opción más para pintar "La prensa", pues se presta atención a la parte inferior derecha del estudio anteriormente mencionado como "Prensa del vino. Paneau Romano" (Museo Sorolla, No Inv. 10473), aparece una pequeña balsa con canalización para dejar correr el líquido, que Sorolla también descartó finalmente.

Para el caso de los bocetos de la Bacanal (Museo Sorolla, No Inv. 15205) Sorolla realiza un dibujo con una leyenda en la que se puede leer: "borracho, músico, ...." Teniendo esto en cuenta parece que a la izquierda del panel quedaría una figura tocando el aulós como sucedía en su anterior "Danza Báquica", pero que en la obra final desaparece. Así lo hacen también los espacios al fondo de la escena que el pintor quería dejar a contraluz o en los que habría insertado almacenes repletos de ánforas (según las inscripciones), enmarcado todo ello en una arquitectura de columnas o pilastras jónicas rematadas con guirnaldas. En otro de los ensayos, el valenciano estudia el movimiento de la figura masculina que articula el panel (Museo Sorolla, No Inv. 11551).

Para "La vendimia" también estudia detenidamente las figuras de las jóvenes (Museo Sorolla, $N^{0}$ Inv. 11554) al igual que lo hace con la postura de la mujer que se alza para coger el fruto en "La parra (Museo Sorolla, No Inv. 11553 y 11535).

En definitiva, Sorolla estudia de manera concienzuda las distintas escenas, sistema de producción y posturas de los personajes para estos paneles, en un intento de alcanzar aquello con lo que dio en la composición final: Un serie de cuatro paneles compuestos de forma armoniosa y equilibrada en los que se establecen toda una serie de diálogos compositivos entre ellos.

\section{Resultados y conclusiones}

Este trabajo se trata en efecto de un primer y sucinto acercamiento a la relación que Sorolla tuvo con la uva y el vino al pintar estos excelsos paneles decorativos de temática clásica. A través del estudio de ellos se puede llegar a varias conclusiones:

La primera de ellas es que se ha de tener en cuenta el estado de la cuestión del conocimiento sobre el vino en la antigüedad para el momento en el que Sorolla pinta los paneles. Así pues y aunque los elementos que incluya en los cuadros tengan distintas procedencias y periodos que haría imposible la confluencia de estos objetos en la misma escena, si se puede apreciar un profuso estudio con las fuentes de la época a fin de presentar escenas fidedignas y verosímiles a los ojos del espectador. El objetivo del pintor fue crear un ambiente grecolatino propio de los cuadros de época, en el que los objetos y la escenografía fuesen creíbles. Es indudable el detallado estudio que el pintor realizó sobre los objetos arqueológicos que va a pintar, tal y cómo venía sucediendo al menos desde su periodo de formación en Roma (Diaz, 2013: 93; Fenoll y Robles, 2021). Además, y cómo ya había apuntado Gutiérrez Pulido (2018), parece indudable que Sorolla toma referencias visuales del Diccionario de antigüedades griegas y romanas de Daremberg y Saglio, lo que no hace sino reforzar esta tesis de estudio concienzudo por parte del pintor sobre aquello con lo que va a ambientar sus cuadros. 
En segundo lugar, no son de extrañar las múltiples referencias a las piezas del Museo de Nápoles procedentes de Pompeya, pues estas habían constituido una parte importante de la producción del artista durante sus años como pensionado en Roma escasos años atrás. Estos estudios que el pintor conservaba aún y las múltiples fotografías que adquirió a su paso por Italia son sin duda una fuente de documentación a la que Sorolla parece recurrir durante la realización de estos paneles, en los que como se ha visto con anterioridad se respira una fuerte carga pompeyana.

Y, por último, este conjunto de paneles se trata de una representación que abarca íntegramente el ciclo de la vida de la uva en el Mediterráneo Antiguo: desde el culto a los dioses del vino en el interior de las domus, a la recolecta de la uva (tanto para el consumo propio, como para la producción masiva), pasando también por la producción de vino y el consumo de este asociado a festividades religiosas. Al final, el proceso de recolección de la uva y el de elaboración del vino, son temas muy presentes en la producción de los años centrales de la vida de Sorolla, entendiéndose esto casi como el reflejo de un elemento propio de la cotidianidad de la España de finales del siglo XIX y principios del siglo XX que el pintor habita. Y es que hay que entender a Sorolla en la plenitud de sus facetas, tanto como un pintor que capta la realidad de su tiempo inmediato de manera excepcional, pero también como un erudito y estudioso artífice capaz de componer con suma elegancia escenas que con su verosimilitud consiguen convertirse en ventanas que permiten al espectador sumergirse en el consumo y producción de alimentos como el vino o la uva en un pasado remoto, como lo es en este caso en el de la Antigüedad Clásica.

\section{Referencias}

BEAZLEY, J. D. (1942). Attic Red-figure Vase-painters. Oxford: Clarendon Press.

Díaz Pena, R. (2013). Sorolla y la Fotografía. Tesis doctoral, Universidad Rey Juan Carlos. <burjcdigital.urjc.es/handle/10115/12093> [Consulta: 15 de agosto 2021].

DÍEZ-BARÓN, J. L. (coord.) (2009), Joaquín Sorolla (1863-1923). Madrid: Museo Nacional del Prado, 2009.

FENOLL CASCALES, J. y ROBLES MORENO, J. (2021). "Tras los pasos de Sorolla en Roma: La identificación arqueológica de una crátera en su pintura”. En: Ars Longa, Revista del Departamento de Historia del Arte de la Universidad de Valencia, № 40. (En prensa).

G. NAVARRO, C. (2009). "A propósito de un lienzo de Lawrence Alma-Tadema: noticias sobre el marchante Ernest Gambart y su donación de pinturas al Museo del Prado". En: Boletín del Museo del Prado, No 27, p. $85-99$.

GARCÍA CANO, J. M. y PAGE DE POZO, V. (2004). Terracotas y vasos plásticos de la necrópolis del Cabecico del Tesoro, Verdolay, Murcia. Murcia: Dirección General de Cultura.

GUTIÉRREZ PULIDO (2018). "La prensa de la vid (1897)" Sorolla en Jávea. <https://sorollajavea. wordpress.com/2018/10/16/la-prensa-de-la-vid-1897/> [Consulta: 10 de agosto de 2021].

HAMILAKIS, Y. (1996). "Wine, oil and the dialectics of power in Bronze Age Crete: A review of the evidence" en Oxford Journal of Archaeology, vol. 15, issue 1, p. 1 - 32. 
JASHEMSKI, WILHELMINA F. (1973). "The Discovery of a Large Vineyard at Pompeii: University of Maryland Excavations, 1970, from American”. En: Journal of Archaeology, Vol. 77, № 1 (Jan. 1973), pp. 27-41.

LILLO CARPIO, P. A. (1999). "El kálathos como vaso de contenido cultural”. En: Ladrón de Guevara Mellado, P. L., Mascali, G., Zamora Muñoz, P. Homenaje al profesor Trigueros Cano, Vol. 2, pp. 365-377.

LING, R. (1991). Roman Painting. Cambridge: Cambridge University Press.

PANTORBA, B. DE, (1981) La vida y obra de Joaquín Sorolla: estudio biográfico y crítico. Madrid: Extensa.

PONS-SOROLLA, B. (2001). Joaquín Sorolla, vida y obra. Madrid: Fundación de Apoyo a la Historia del Arte Hispánico.

PRATT, E. (2021). Oil, Wine, and the Cultural Economy of Ancient Greece. Cambridge: Cambridge University Press.

RICHTER, G. M. A. y LINDSLEY F. H. (1936). Red-Figured Athenian Vases in the Metropolitan Museum of Art. New Haven: Yale University Press.

RUIZ BREMÓN, M. (1993). Catálogo de escultura. Museo Sorolla. Madrid: Ministerio de Cultura.

RUIZ DE ARBULO BAYONA, J. (1994). "Los cuernos figurados en cabeza de Core: nuevas propuestas en torno a su denominación, función y origen." En: SAGVNTVM, vol. 27 pp. 155-171.

SUAREZ PIÑEIRO, A. M. (2005) "El vino en la antigüedad romana y su introducción en el Noroeste peninsular". En: García Tato, I., Suárez Piñeiro, A. M., Actas de La cultura del vino: Primer Congreso Peninsular: O Barco de Valdeorras, 10 al 12 de mayo de 2002, pp. 43-66. 


\title{
LA PINTURA Y OTRAS FUENTES DE DOCUMENTALES PARA LA CONSTRUCCIÓN DE UN RELATO VISUAL DE LA ALIMENTACIÓN
}

\author{
Gerardo Jesús García Olivares \\ Doctor en Industrias Culturales y de la Comunicación. Universitat Politècnica de València.
}

\begin{abstract}
Looking at painting as other visual sources of documentation to build a visual story about food is of great importance since with them we build an ideology of what current food is and how it has been transformed over time. In rock art, painting, advertising, graphic design, contemporary art, digital creation, we find clear evidence that we ate, how we ate it, and ate it with. This article aims to show that the history of art has been accompanying the history of food and that at present the latter finds in them one of the fundamental bases for the construction of a story that gives consistency to analyzing food in its historical aspect. and that help to build and sustain a story about food widely used in museums dedicated to this topic.
\end{abstract}

Keywords: painting, food history, visual arts, art history.

Resumen: Mirar la pintura como otras fuentes visuales de documentación para construir un relato visual sobre la alimentación es de gran importancia ya que con ellos construimos un ideario de lo que es la alimentación actual y como ha ido transformándose a lo largo de los tiempo. En el arte rupestre, pintura, publicidad, diseño gráfico, arte contemporáneo, creación digital encontramos clara evidencia de que comíamos, como lo comíamos y con comíamos. Este artículo pretende mostrar que la historia del arte ha ido acompañando a la historia de la alimentación y que en la actualidad esta última encuentra en ellas una de las bases fundamentales para la construcción de un relato que de consistencia a analizar la alimentación en su vertiente histórica y que ayudan a construir y sostener un relato sobre la alimentación muy usado en los museo dedicados a este tema.

Palabras clave: museos, pintura, imágenes, historia de la alimentación, artes visuales, historia del arte.

Citar como: Jesús García Olivares, G. (2022). "La pintura y otras fuente de documentales para la construcción de un relato visual de la alimentación". En Actas del III Congreso Internacional sobre Patrimonio Alimentario y Museos. 25-26 noviembre, 2021, Valencia, España. pp. 73-84. https://doi.org/10.4995/EGEM2021.2021.13339 


\section{Introducción}

Los alimentos, su forma de producirlos, la forma de comerlos, el lugar donde se cocinan y se comparten, los objetos con los que se elaboran, sus múltiples combinaciones, la comida como marcador de clases sociales entre otros temas están reflejada en la pintura y en otras artes o técnicas visuales como la pintura, el grabado, los manuscritos y la publicidad. En otras palabras la Historia del arte va de la mano de la Historia de la alimentación y la construcción de una historia de la alimentación se hace por medio de diversas fuentes entre ellas las visuales que da la pintura y otras artes visuales como por ejemplo publicidad. Esto ha sido utilizado en los museos de la alimentación para la construcción de los guiones museográficos construyendo un ideario, esencializado sobre la alimentación de determinadas localidades.

En este artículo se presentarán algunas consideraciones en la utilización de las obras de arte, manuscritos y otras piezas como valor artístico como fuente documental para construir un relato visual de la alimentación tan usados en los museos de la alimentación por medio de la reproducción de obras de arte, esculturas, fotografías y publicidad.

Así la pintura se transforma en documento de determinada época en la que el museo dedicado a la alimentación desea hacer referencia en su relato museográfico sobre la utilización de determinados alimentos. Con estas imágenes se explican hambrunas, crisis alimentarias, recetas o la incorporación de alimentos a la dieta cotidiana. También la distinción social que tenían determinados alimentos o vajillas o enseres empleados en su preparación o las personas que se dedicadas a la producción de esa comida. Para la historia de la alimentación la pintura se transforma en un elemento de constatación de las fuentes escritas o arqueológicas sobre la dieta y la comensalidad. La escultura o la alfarería en forma de monumento o restos arqueológicos sobre la constatación de la producción de determinados alimentos en la zona y la publicidad una forma de entender la velocidad de los cambios en los hábitos alimentarios contemporáneos y sus discursos. No hay que dejar de lado la fotografía de la que también tiene una marcada presencia en los museos relacionados con la alimentación.

Con la invención de la fotografía y su insipiente popularización podemos encontrar en los museos de la alimentación ya sea cuando han hecho recogida de fotos para componer sus exposiciones o han decidido ampliar sus colecciones excelentes documentos que han permitido la constatación de fuentes orales debido a la veracidad que da la fotografía así en muchos museos de la alimentación es posible encontrar representado por medio de fotografías una número importante de acciones dedicada a ese alimento en particular. En otras ocasiones se han hecho recreaciones para poder obtener esas imágenes.

La historia de la alimentación va de la mano de la historia del arte la primera toma la pintura o demás disciplinas artísticas como documento con valor de certificación de determinada realidad ya que las fuentes documentales salvo algunos recetarios ilustrados o sobre todos tratados médicos de le época antigua o medieval son escasos. Ya en la época moderna los recetarios culinarios se hicieron más números y han ido constantemente corroborándose con las obras pictóricas. En el caso de otras fuentes visuales como la publicidad y la fotografía ambas muy presentes en los museos de la alimentación, permiten tener elementos visuales y objetos de gran impacto testimonial sobre como era al alimentación en tiempos recientes y han sido fuentes para disciplinas como la Antropología. 


\section{Objetivos}

Determinar el paralelismo que existe entre representación artística de algunos hechos alimentarios como la llegada de alimentos de las colonias, hambrunas, cambios tecnológico, gustos, ceremoniales o protocolos y otros ejemplos que conforman la historia de la alimentación además de imágenes producto de la publicidad o la fotografía.

Constatar que existe una relación simbiótica entre la Historia del arte y la Historia de la alimentación. Esta última usando la pintura como fuente documental de corroboración y documentación de hechos fundamentales en la historia de la alimentación. Y la primera explicando lo representado por medios de fuentes documentales escritas como recetarios, inventarios, o relatos de las que también se nutre la historia de la alimentación.

También se quiere mostrar como la publicidad y la fotografía fuentes visuales de gran popularización utilizadas en los dos últimos siglos contribuyen enormemente a enriquecer los fondos de los museos de la alimentación contribuyendo a dar una imagen en ocasiones folclorizadas de la cultura alimentaria local.

\section{Desarrollo}

Somos uno mono que cocina, el cocinar nos hizo humano, asegura el primatólogo Richard Wrangham. A esto había agregar que en paralelo al cocinar también se dio el simbolizar y representar alimentos y su forma de obtenerlos. Sin entrar en detalle sobre las dimensiones evolutivas y antropológicas que tiene este proceso ya que no es el objetivo central de este trabajo es posible decir que junto con el registro fósil y arqueológico junto con lo que se representado en el arte, la recolección, obtención elaboración y la comensalidad de los alimentos desde lo inicios de la humanidad hasta la actualidad testimonian como nos hemos alimentados y los profundos cambios que la alimentación ha tenido a lo largo de los siglos.

Entre las representaciones de arte parietal como Las leonas de las cuevas de Chovet, las pinturas de Lascaux o Altamira y los selfis actuales en un restaurante han pasado más de 20.000 años. En ese largo periodo se ha ido recogiendo miles de ejemplos de representación de partes de nuestro sistema alimentario en las artes visuales el que se ha recurrido como fuente para documentar o explicar determinados proceso alimentarios o finalmente para construir una Historia de la alimentación.

Existen varios puntos de inflexión en la Historia de la alimentación y de la Historia de arte que se entrecruzan. Una de las primeras representaciones es el arte parietal que muestra escenas de caza o de recolección de determinados alimentos que se puede considerar el génesis de las representaciones artísticas contemporáneas fueron alimentos.

Las representaciones de la época egipcia son ricas visualmente y permiten la elaboración de un relato visual del comer de esa época. En los enormes frisos se pueden ver personajes sentados comiendo, personas dedicas producción de alimentos como el trigo o representación de comida como las hallada en la tumba de Menna del 1400 aC.

Durante la Época clásica de los simposium griegos por medio de las fuentes escritas nos llegan algunos relatos, pero sobre todo por los mosaicos o las representaciones en la cerámica negra. En estas copas podemos ver la forma de comer, los roles atribuidos a cada uno de los 
participantes, con motivo de que se celebraban. Junto con la cerámica negra uno de los más conocidos es el mural del buceador del Museo Nacional de Paestum del siglo Vac.

De la Antigua Roma nos llega la representación de los desperdicios de los alimentos como el Asàrotos òikos o suelo sin barrer, mosaico confeccionado con pequeñas teselas de pasta de vidrio y esmaltes coloreados. Este mosaico decoraba el suelo de un triclinio en una villa de la época de Adriano, en el Aventino. El tema decorativo ideado por Sosos de Pérgamo es representado en este caso por el artista Heráclito, lo sabemos porque incluyó su firma: "Eraclito fece". Actualmente se encuentra en los Museos Vaticanos y ejemplifica claramente que la comida es retratada por su valor, no solamente por su estética sino como muestra de distinción social. El mosaico es una suerte de trampantojo que quería mostrar la condición social de la familia y la abundancia de sus comidas diarias y las sobras que caían al suelo.

La fuentes arqueológicas sobre todo las relacionadas con la cerámica producto del gran intercambio comercial vivido en el mediterráneo ha sido unas de las principales fuentes de documentación de la alimentación en los tiempos que prosiguieron a la romanización. Se sabe del lugar que ocupaban las cocinas, el utillaje que se dedica a la producción de alimentos o las bases de la alimentación pero las fuentes visuales son escasas. El reciente termopolio un auténtico puesto de comida callejera, hallado en Pompeya en el 2019 en que se pueden ver algunos murales ricos en imágenes como aves, peces y alegorías a la abundancia.

En el Museo del Louvre dentro de los fondos de la cultura árabe se encuentra una miniatura de la segunda mitad del siglo XVI que sugiere la elaboración de la pasta y ha servido para construir un relato un poco forzado sobre los inciertos orígenes de este producto. Los tratados sobre dietética eran importantes en la cultura árabe, pero las ilustraciones que han llegado no son numerosas y no permiten construir una imagen de la alimentación de la época. Aunque de los tratados médicos árabes se han luego traducido e ilustrados obras como el Tacuinum Sanitatis.

Durante la Edad Media los manuscritos y tratados médicos como el fechado en Renania en el siglo XV conocido como el Tacuinum Sanitatis una verdadera recopilación sobre la utilización de alimentos como el aceite de oliva, trufas, perejil o castañas. O el Tacunum de Viena también de origen árabe en que podemos encontrar claras referencias a la elaboración de la pasta son obras de un incalculable valor desde el punto sobre la representación visual de la alimentación hace siglos. Durante la Edad Media la mayoría de las representaciones están centrada en escenas bíblicas especialmente en la Última Cena donde podemos observar tipos de vajillas, distribución y tipo de alimentos. En algunos casos la comida es austera en otros casos copiosa pudiendo ver algunas veces pescados y otras veces carnes como cordero o conejo.

Durante la Edad Media en multitud de obras pictóricas vemos representaciones del vino debido a su valor religiosos. Son muchos lo artistas que dejan verdaderos documentos sobre la producción de vino por medio de representaciones religiosas como se puede observar e en el tapiz The Knights' Banquete del siglo XI ene el Musée de la Tapisserie.

La mayoría de las referencias visuales de la alimentación en la Edad media se centran en los banquetes o en la comida del campesinado, mientras en los primeros podemos observar el tipo de vajilla utilizado, la mantelería y sus plegaturas, la distribución de los invitados y los roles de las personas dedicadas a la producción de alimentos. En los segundos solo vemos comiendo a 
personas con mínimos enceres. Una de la obras también mineada como los tratados anteriormente citados es el Banquete de París de 1378 ofrecido por Carlos V de Francia iluminado por Jean Fouquet Tour entre 1455 y 1460.

El descubrimiento de América junto con la Revolución Industrial son otros de los puntos de inflexión en la relación de la imagen con la comida. El primero supuso todo un choque cultural pero sobre todo una confrontación alimentaria al encontrar el otro alimentario. Las fuentes de la representación de la comida consumida en el nuevo mundo tienen varia fuentes entre las que se puede destacar los manuscritos de historia natural como Francisco Hernández que en 1572 fue enviado por Felipe II para realizar una compilación en materia botánica. Su obra publicada de manera póstuma recoge algunas ilustraciones de los alimentos de la Nueva España como la del jitomate o tomate.

La pintura certifica de tal manera la presencia de los alimentos y su domesticación en el nuevo mundo que el tomate o jitomate recogido por Francisco Hernández entre 1572 y 1574 aparece en la pintura europea recién en 1646 en la obra de Bartolomé Murillo (1618-1682) El sueño de los ángeles que se puede observar en el Louvre en el que se puede observar muy en detalle la presencia del tomate que ya figuraba en la lista de compra de algunos monasterios de Sevilla lo que hace suponer que el tomate había comenzado su andadura de popularización.

Mientras que en Europa la pintura se centraba en algunos casos puntuales en los alimentos a hasta que el bodegón se constituyó un género propio desde las colonias se producían otras obras fuentes visuales como las pinturas de castas esta reproducía los nuevos tipos sociales con los alimentos que estos consumían como si de un taxonomía vegetal y humana se tratase. Entre los siglos XVI y XVII destaca Miguel Mateo Maldonado y Cabrera (1695-1768) pintor novohispano, caracterizado por ser uno de los máximos exponentes de la pintura barroca del Virreinato de Nueva España. E sus pinturas en obras como Mujer mameluca bajo un anacardo fructífero o Hombre mulato con pistola y espada bajo un árbol de papaya. El Bodegón con yuca o el también Bodegón con cocos, piña, papaya y otras frutas entre las que se pueden observar calabazas y melones. También se representaban bananas, guayaba y otras frutas de América. Este tipo de obras no solo pretendían hacer una taxonomía de lo que se entendían que daría como resultado el mestizaje cultural sino que a modo de herbario visual mostraba los productos originarios de las colonias.

Fueron numeroso los naturalistas, viajeros y misioneros que con una amplia vocación científica los que destinados a los territorios recién descubiertos los que construyeron no solo una historia natural de Las Indias sino que esa historia natural en ocasiones eran auténticas recopilaciones de los alimentos y de la forma de comer en el Nuevo mundo. Es de destacar unas de las primeras referencias a productos como la vainilla,o el aguacate de Giovanni Francesco Gemelli Careri (1651-1725), hiciera en el libro Giro del Mundo publicado entre 1699 y 1700. O los llegados de la colonia como la obra Storia Antica del Messico cavata da'mighori storici spagnuoli e da' manoscritti: divisa in dieci libri, de (1780-1781) en que podemos encontrar detalles sobre la elaboración de las tortillas de maíz a partir de la nixtemalización.

Destaca la obra de Guaman Poma de Ayala de 1616 que ilustra Incas cosechando papas, con las técnicas de labrar la tierra propia de la época. Este manuscrito descubierto en 1909 en la Biblioteca Nacional de Dinamarca muestra es un extraordinario documento de gran valor histórico y visual que muestra no con fines estéticos ya que la vocación de Guaman Poma de Ayala no 
era el crear un material artístico sino documentar las características culturales y religiosas que se estaba viviendo en Virreinato del Perú pero la riqueza y la voluntad ilustrativa del autor permite obtener gran información visual de los modos y medios de producción de le época (Figura 1).

Mientras la patata no viajó tan rápido a Europa, los primeros europeos dieron con ella en el siglo XVI en el 1530 cuando llegaron a los altiplanos colombianos como explica en la obra Las primeras cocinas América de Sophie Coe obra de 2004.

La patata Ilegada a manos de Felipe II y luego al Papa Alejandro VII fue más difícil de domesticar, y su incorporación a la dieta y su representación pictórica en Europa fue más tardía. Aparece en herbarios del siglo XVIII algunos elaborados en las colonias y otros en los intentos de las crecientes colecciones botánicas a modo de jardines botánicos que surgían en la Europa de la Ilustración. En la pintura europea, la representación de la patata llega tardíamente desde la icónica obra de Los comedores de patatas de Vincent Van Gogh (1853-1890) pintada en 1855 luego le siguió el Bodegón con patatas y plato amarillo de 1888 luego podemos encontrar obras como la del suizo Albert Anker (1831-1910) Niña pelando patatas.

Hay que destacar en tierras americanas artistas como el holandés Albert Eckhout (1610-1664) Frans Janszoon Post un artista expedicionario conocido por pintar los paisajes de Sudamérica, concretamente de la zona de Pernambuco, en Brasil y el delta del río São Francisco y en cuyos bodegones es posible encontrar frutos que todavía no habían llegado a Europa como el Bodegón

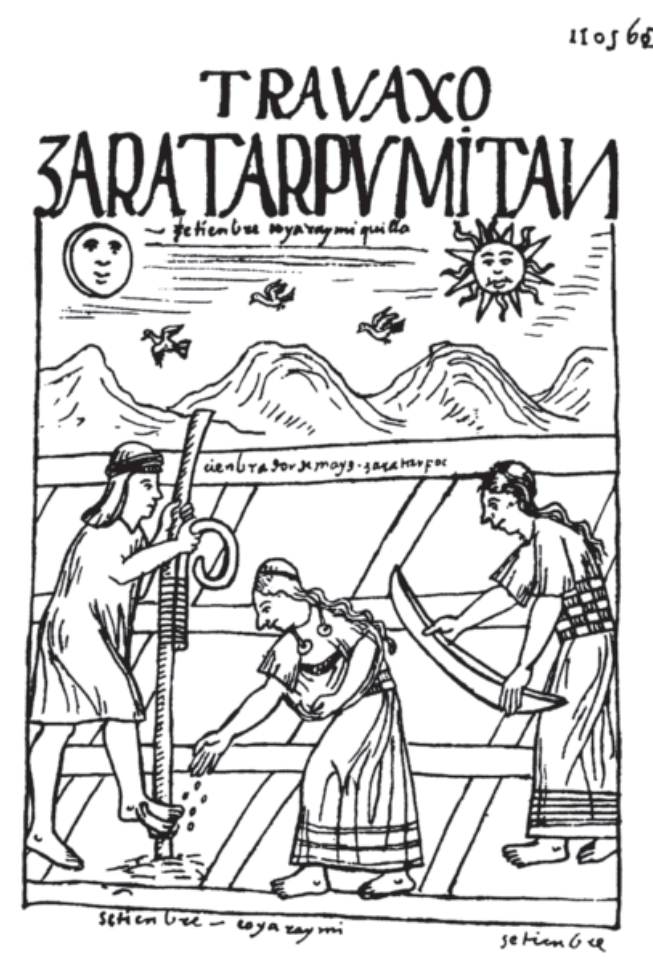

Figura 1. Guaman Poma de Ayala - El primer nueva corónica y buen gobierno (1615-1616). Fuente: Det Kongelige Bibliotek. 
con yuca o Bodegón con cocos, piña papaya y otras frutas. Especialmente con la piña hay un relación especial ya que su consumo era un símbolo de estatus social debido a la complejiadd de su domesticación de la Inglaterra del s.XVIII en el Fitzwilliam Museum podemos encontrar la obra Pineapple grown in Sir Matthew Decker's garden at Richmond, Surre de, Theodorus Netscher (Burdeos, 1661-Hulst, 1728) una de la primera representaciones visuales de la piña (Figura 2).

En la segunda mitad de la Edad Moderna la comida irrumpe en las arte especialmente en la pintura bien por las escenas representando banquetes, estaciones del año, bodegones, escenas de caza, mercados, interiores de cocina o mesas delicadamente puestas con manteles donde se aprecia las marca de la piegatura una técnica desarrollada sobre todo en conventos en que los manteles eran exquisitamente plegados y cuyas marcas eran un elemento decorativo como la que se puede apreciar en el El encuentro de San Francisco de Asís y Santo Domingo de Guzmán y el Milagro en el refectorio, óleo de1644 Felipe Gil de Mena que se puede apreciar en el Museo Nacional de Escultura de Valladolid.

Mientras en Europa la pintura de bodegón se consolidaba como un género propio y que aparezcan representadas en ellas en varias ocasiones cajas de dulces y mermeladas no es de extrañar ya que la conservación de alimentos siempre ha despertado el interés de científicos

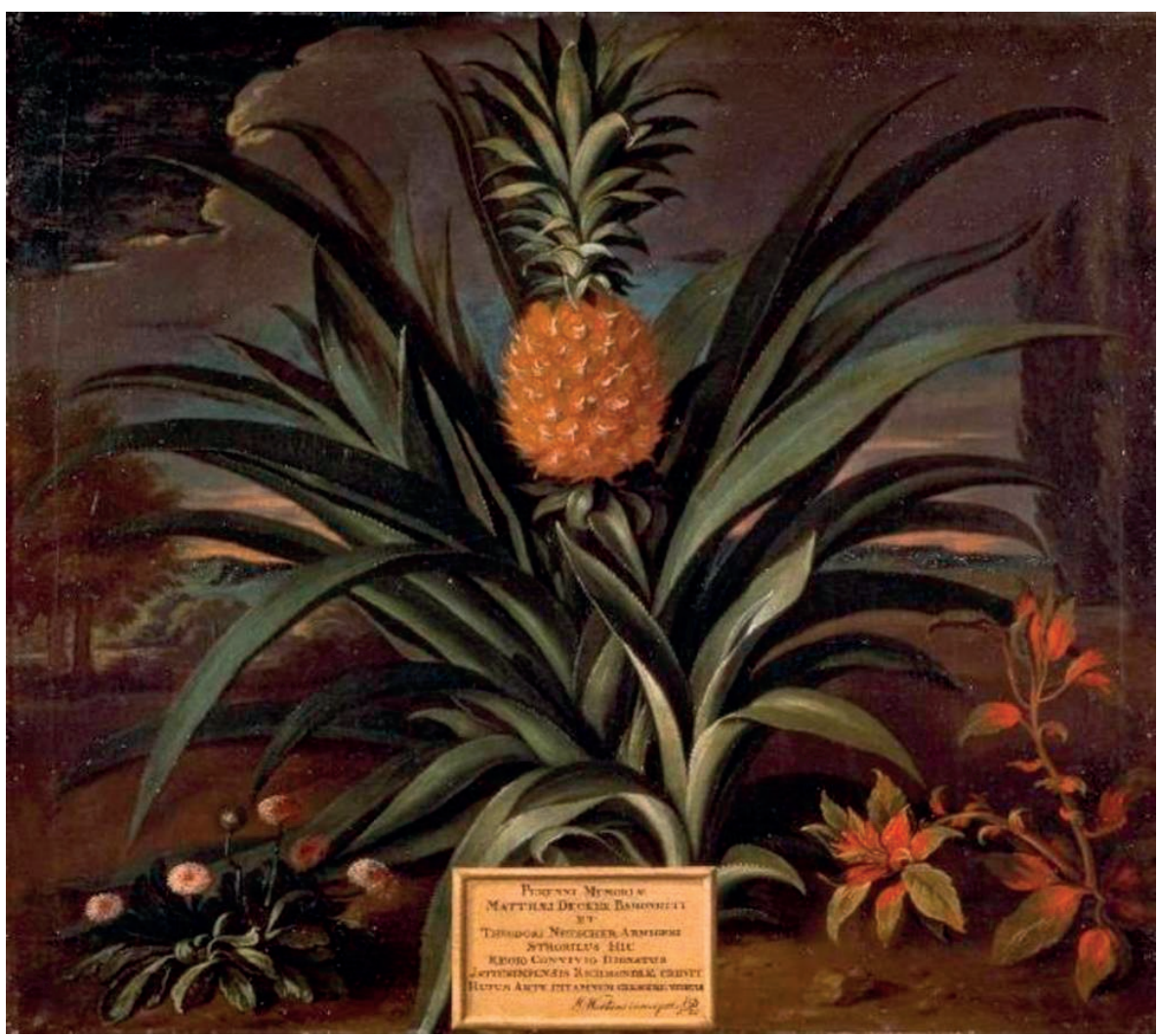

Figura 2. Pineapple grown - Theodorus Netscher (1661-1728). Fuente: Fitzwilliam Museum. 
del momento y en 1654 Nicolas de Bonefons publica Le jardinier français y en su segunda parte constituye todo un tratado sobre los procedimientos de conservación de las frutas por medios de azúcar, clasificándolas en dos tipos "las mermeladas secas y las mermeladas liquidas y las secas. Estas técnicas novedosas en el siglos XVII constituye toda una revolución en la mesa, debido a la popularización por las clases dirigentes de toda Europa de los productos provenientes de América y que el postre como parte de un servicio era casi un requisito fundamental en cualquier banquete y un regalo real con que muchos monarcas obsequiaban a sus agasajados. Así podemos encontrar obras como Bodegón con manzanas, nueces, cajas de dulces y otros recipientes de1759 de Luis Egidio Meléndez, (1716-1780) en que se observan esas cajas de dulces.

Mientras que en las obras de una gran bodegonista como fue Clara Peeters encontramos referencias a las pautas culinarias y los modos de compartir los alimentos en la época. Y sobre dodo platos preparados. Así el consumo de sal era un producto que en las clases acomodadas de la aristocracia de los Países Bajos alcanzaba el grado de distinción social. En obras como Mesa con mantel, salero, taza dorada, pastel, jarra, plato de porcelana con aceitunas y aves asadas (Hacia 1611), un salero que pintara en otras obras. Este salero era una pieza de moda en la época ya que los volvemos a ver en la obra Fin de una colación de 1637 Willem Claesz Heda también de los Países Bajos.

La historia de la alimentación es también la historia del hambre no todas las representaciones corresponden a la abundancia. Artistas como Velázquez y Murillo dedicaron varias obras con lo que consiguieron retratar con extraordinaria maestría la forma de comer y que comían el campesinado o las personas al margen de la nobleza. Vieja friendo huevos y Niños comiendo melón y uvas respectivamente muestra desde el costumbrismos otras realidades alimentarias al margen de la que retrata el bodegón. Hay que resaltar que los bodegones especialmente eran destinados para el comedor de la aristocracia y la monarquía y que acompañaba a los aparadores donde se exhibía la vajilla que se iba utilizar como se puede apreciar en algunas obras que se visualizan comedores.

Con respecto a la escases hay que destacar que obras como las cuatro estaciones pintadas por Giuseppe Arcimboldo por encargo de Maximiliano /l de Habsburgo en 1573 aparece el maíz lo que hace suponer que ya se había popularizado su consumo en Europa paliando en ciudades como Venecia la gran hambruna vivida en 1528. No es casualidad que el pintor milanés le dedicara en su composición un lugar preferente ya que este producto llegado de ultramar había paliado el hambre en las hambrunas de años anteriores.

El ejemplo más claro de la representación de la polenta es la obra del pinto veneciano Pietro Longhi (1701-1785) obra pintada en 1740 y que refleja el interior de lo que podría ser una taberna donde dos mujeres ofrecen a dos músicos el suculento plato surgido en plena pandemia unas décadas antes.

La polenta no era la única comida de pobres anterior a la polenta la elaboración de gachas era común la pintura La boda de campesina fechada en 1568 de Pieter Brueghel el Viejo se pueda ver la comida de los pobre también algo parecido a la polenta o gachas que se sirve en el banquete quizás no de maíz como aconteció en Italia sino de trigo u otro cereal ya que de unas de las paredes del granero donde se celebra la boda se puede apreciar espigas como referencia el tiempo estival cuando ocurre la ceremonia. 
En América el maíz ya había sido representado sobre el 600 dC en el yacimiento arqueológico de Cacaxtla donde se encontraron mazorca de maíz tanto de cerámicas o representadas en murales o los mismos depósitos de grano, pero en Europa estas representaciones no fueron posible hasta la aclimatación primero de la semilla y luego de su cultivo, domesticación, producción de semillas y popularización entre el campesinado. Un proceso que entre la llegada de tierras de ultramar por Colón, una crisis alimentaria y sanitaria, la extensión de la semilla por Europa, la llegada a Italia y hasta la obra de Longhi acontecieron unos 250 años. Hoy existen en la Lombardía festivales dedicados a la polenta como seña de identidad y altocultural en el que se le rinde homenaje en banquetes colectivos a este alimento de la escases.

El alimento en las artes tiene sobre todo en este periodo, un gran valor para documentar la utilización de determinados alimentos y utensilios, o la domesticación de nuevas especies como el tomate que lo encontramos por primera vez representado en una pintura como es La cocina de los Ángeles de 1646 de Esteban Murillo que se encuentra en el Louvre y en el que un pequeño tomate aparece entre calabazas.

El siglo XVIII va a ser un momento muy rico en la producción visual de elementos pictóricos de la alimentación por la proliferación de recetarios, protocolo, normas de uso, tratados de saludos algunos citados anteriormente. Francia se consolida como la gran potencia gastronómica Europea y va a ser desde donde partan las normas y las modas para el resto de Europa. La producción visual de esa época estará en cosas tan dispares como las normas para doblar servilletas de lo que existen auténticos tratados hasta la pintura en donde se representan fastuosos banquetes y se puede apreciar ostras, champagne y hielo que era un producto solo utilizado por la alta aristocracia detalle que se pueden apreciar en la pintura de Jean François de Troy, The Oyster Lunch hacia 1735 depositada en el Chantilly Musée Conde.

Sin haber seguido un orden por periodos históricos, sino más bien centrado en el tipo de alimentos y su importancia para la sociedad y la difusión de su consumo y el número importante de imágenes que generó, es posible construir, de manera en algunos casos cronológica y en otro momento temática sobre el comer y lo que le rodea nos adentramos en el siglo XIX. En este momento la producción visual relacionada con la alimentación va estar dedicada a la comida como elemento plástico aunque hay verdaderas obras que permiten documentar la forma de comer de la época. La pintura se mezcla con la publicidad y las fuentes visuales son variadas desde las publicidades de bebidas alcohólicas hasta la representación de espacios de comercialización de alimentos como bares, mercados, tabernas o mesones.

En la historia reciente sobre todo durante el siglo XX y parte del siglo XXI la publicidad relacionada con los alimentos nos permite analizar como han ido cambiando los gustos en relación con los alimentos la cada ve más creciente utilización de productos alimentarios industriales y como nuevas técnicas de elaboración como la deshidratación y lo instantáneo ha surgido a partir de la segunda Guerra Mundial para dotar a los soldados de alimentos en el frente.

Con las vanguardias a principio del siglo XX y todo el arte posterior a este movimiento y también en el arte contemporáneo actual la comida transmuta como fuente de documentación y se transforma en un elemento para la denuncia, la provocación o la reflexión. Hoy en las reproducciones artísticas la alimentación sigue presente documentando otros aspectos de la cultura contemporánea como las obras del artista Herny Hargreaves que denuncia la pena de muerte por medio de la última comida pedida por los reos reproducida y luego fotografiada acompañada 
de la información de la víctima. Son muchos los artistas actuales en que los alimentos se transforman en sus manos en un elemento plástico como la obra Bread Hause de 2004-2006 del artista Urs Fisher una casa completamente construida en pan, o las grandes hamburguesas de Tom Friedman denunciando el impacto de la comida rápida.

Finalmente cabe decir que se ha producido una alternancia de la pintura, las ilustraciones históricas en guías botánicas o escritos de viajes llegados del viejo mundo como fuente de documentación de la alimentación a la obra artística como fuente de reclamo sobre algún tema social en concreto, ya no documenta procedencia de un alimento, zona de consumo sino un discurso mucho más complejo y tentacular sobre distintos aspectos de la cultura contemporánea en temas relacionado con el hambre, la exclusión social, la obesidad, el desperdicio de alimentos, el cambio climático o como en el caso lejanos a la alimentación como la pena capital aún presente en algunos estados de Estados Unidos.

La producción visual relacionada con la alimentación permite la producción material de la alimentación de otras épocas. El especialista en la historia de la alimentación Ivan Day por medio de la documentación pictórica y de otras fuentes documentales recrea los platos comidos por la monarquía y la alta aristocracia. Su casa museo es un auténtico laboratorio de reproducción de la comida de tiempos pasados.

El valor de las imágenes para la construcción de una historia ya no visual sino también física de la alimentación como la recreación de algunos platos ha quedado demostrada en la exposición Fiesta y ayuno: el arte de la comida en Europa entre 1500 y 1800 en el Fitzwilliam Museum, Cambridge, en esta exposición multisensorial se exhibieron piezas de gran valor conservados en el Fitzwilliam Museum y otras colecciones. En la exposición se presentaba cuatro espectaculares reconstrucciones históricas con comida en su centro, incluido un banquete de azúcar jacobeo, una mesa de banquete europea y un taller de repostería georgiano. Por medio de piezas y documento se pudo descubrir temas contemporáneos y no libre de controversias, como los orígenes de la alimentación y la seguridad alimentaria, el consumo excesivo en tiempos de austeridad y nuestra relación con los animales y la naturaleza, vinculando así el pasado con nuestro presente y alentando a los visitantes a cuestionar y repensar nuestra relación con la comida.

Toda representación visual es usada para la que en nuestra cabeza se produzca un representación de la comida en tiempos pasados y también presentes en muchos museos dedicados a la alimentación utilizan por medio de reproducciones en paneles explicativos o facsímiles estas imágenes y esto permite que como espectadores construyamos un ideario de la comida en tiempos pasados.

\section{Resultados}

Luego de observar obras visuales de diferentes procedencias es posible constar la estrecha relación que existe entre la historia de la alimentación y la historia el arte incluida la fotografía y la publicidad. Podemos decidir hablar de arte como documento y documento como si obra de artes se tratase. Las obras artísticas producidas en Europa tuvieron inmediatamente el tratamiento de obras artísticas y con el surgimiento de la historia de la alimentación en documento de constatación sobre comensalidades y alimentos. 
Mientras que los documentos llegados de las colonias han sido tratados como meros documentos antropológicos e históricos sobre el modo de ser de los pueblos originarios de América. Esta colonialidad no solo de los manuscritos, los libros de viaje, o las obras compilatorias sobre especies animales y vegetales sino también de las obras artísticas de movimientos como el Barroco Virreinal ha fortalecido la diferenciación entre lo estrictamente artístico y lo documental de las obras artísticas creadas en América.

En donde mayor utilidad se le da al valor del uso de imágenes sobre la alimentación adquiere es en los museos de la alimentación transformándose en auténticas piezas visuales que permiten construir y sostener un relato sobre la alimentación. En los museos visitados es común en los de vocación vinícola representaciones de la eucaristía el uso de imágenes donde aparecen vides o elementos escultóricos de templos en donde se hacen claras referencias al vino para sostener un relato que la región tiene una larga e histórica vocación vinícola. O como en el Museo del Pimentón de la Vera de Jaráiz de la Vera en donde la colección de latas de pimentón puede apreciarse el diseño gráfico y la publicidad en el siglo pasado o finalmente como la recolectora de miel de Bicorp una auténtica pieza de gran valor no sólo arqueológico sino documental que es usada en el Museo Valenciano de la Miel para explicar que en la zona se recogía miel de tiempo pretéritos.

Este uso de la imagen relacionada con la alimentación como testimonio de la existencia de un producto en una época determinada no sólo es usado como recurso visual en los museos dedicados a la alimentación sino también en las obras compilatorias sobre la comida y en ocasiones hasta en las mismas etiquetas y publicidad de los productos.

\section{Conclusiones}

La comida sigue produciendo imágenes de gran potencia visual y simbólica lo que demuestra es que ya no es una fuente de documentación para la construcción de un relato ordenado de la Historia de la alimentación como lo fue sobre todo al comienzo de Edad Moderna con el descubrimiento y colonización de América y hasta la revolución industrial. La publicidad relacionada con algunos alimentos propia del siglo XIX hasta la actualidad está permitiendo documentar la gran velocidad que acontecen los cambios alimentarios, la globalización alimentaria en la que nos encontramos inmersos, la homogeneización de los gustos y las consecuencias de la producción a gran escala de alimentos para el medio ambiente. Esto ultimo lo esta referenciando y representando el arte contemporáneo que usa la comida como elemento para promover la subversión y el debate sobre determinadas prácticas alimentarias.

Las disciplinas próximas a la comunicación visual no se han detenido en el estudio sobre el uso de las imágenes en cualquier formato y de cualquier origen para la investigación en el campo de la historia de la alimentación y es un campo de estudio a explorar y que permitirá enriquecer, comprender y analizar nuestro devenir alimentario.

Las producciones visuales relacionadas directa o indirectamente en cualquier formato e intencionalidad son la bases en que todo especialista de la cultura de la alimentación debe indagar para la elaboración de un relato sobre la comida, sean estas artísticas, publicitarias o meros objetos decorativos o funcionales vinculados con la comida son como nuestra huella histórica sobre que hemos comido, como lo hemos comido y con quién compartíamos nuestros alimentos y sobre todo una forma casi de arqueología visual de la alimentación. 
Además hay que analizar sobre todo en la en la última mitad del siglo XX y hasta la actualidad el metadiscurso que se esconde debajo de los alimentos. De la misma manera que sobre las marcas de los raspadores dejadas por esos "monos que cocinan" sobre los huesos encontrados en los yacimientos paleontológicos como el de Atapuerca una publicidad de una tostadora de mediados de los 40 es un documento visual de extraordinario valor para construir un relato no solo cronológico si no también visual de la alimentación para encontrar pistas sobre quienes cocinaban, porque lo hacía y debido a que discurso.

\section{Bibliografía}

\section{Libros}

Avery, V., \& Calaresu, M. (2020). Feast \& Fast: The Art of Food in Europe, 1500-1800. London: Philip Wilson Publishers.

De Ayala, F. G. P., \& GY, F. P. (1980). Nueva corónica y buen gobierno (Vol. 1). Fundación Biblioteca Ayacuch.

Montanari, M., \& Lima, M. D. F. F. D. (2009). Comida como cultura. Madrid: Ed. Trea, SL

Montanari, M., \& Flandrin, J. L. (2011). Historia de la alimentación. Madrid: Ed. Trea, SL.

Wrangham, R. (2009). Catching fire: how cooking made us human. California: Basic Books.

\section{Peliculas}

Vatel (Roland Jofré) Coproducción Reino Unido-Francia. 2000. 


\title{
ALIMENTOS DEL FUTURO: LA CIENCIA FICCIÓN CULINARIA A TRAVÉS DEL ARTE
}

\author{
Francisca Ramón Fernández a, Cristina Lull Noguera b ${ }^{b}$ María Desamparados \\ Soriano Soto ${ }^{c}$ \\ a Departamento de Urbanismo. Universitat Politécnica de Valencia. frarafer@urb.upv.es \\ ${ }^{b}$ Departamento de Química. Universitat Politécnica de Valencia. clull@upvnet.upv.es \\ c Departamento de Producción Vegetal. Universitat Politécnica de Valencia. asoriano@prv.upv.es
}

\begin{abstract}
The proposal related to the study of different works of art is presented in which the socalled "futuristic food" is reflected. After the publication in 1930 of the Manifesto of Futurist Cooking, in which a gastronomic revolution began with the appearance of dishes such as "Pollo Fiat", "Carneplástico", or sensory experiences such as "Aeroabanquete", there are numerous occasions in which the avant-garde in gastronomy has been reflected in an artistic work, mainly in painting. Based on this consideration we will analyze from different points of view such well-known works as Campbell's soup cans, by Andy Warhol; Nedick's, 1970, by Richard Estes, Floor Burger, by Claes Oldenburg; Cakes, by Wayne Thibaud; Ham and egg sandwich, Tjalf Sparnaay, or Figure with meat, by Francis Bacon. From the aforementioned analysis, valid conclusions have been obtained regarding the use of food in the pictorial work, and its social connotation and sensitive perspective, in addition to its influence on the time in which it is located.
\end{abstract}

Keywords: futuristic food, museum.

Resumen: Se presenta la propuesta relativa al estudio de distintas obras de arte en las que se plasma la denominada "comida futurista". Tras la publicación en 1930 del Manifiesto de la Cocina Futurista, en la que se inicia una revolución gastronómica con la aparición de platos como el "Pollo Fiat", el "Carneplástico", o experiencias sensoriales como el "Aeroabanquete", son numerosas las ocasiones en las que la vanguardia en la gastronomía se ha plasmado en una obra artística, principalmente en la pintura. Partiendo de esta consideración analizaremos desde distintos puntos de vista obras tan conocidas como las latas de sopa Campbell, de Andy Warhol; Nedick's, 1970, de Richard Estes, Hamburguesa de piso, de Claes Oldenburg; Pasteles, de Wayne Thibaud; Sándwich de jamón y huevo, Tjalf Sparnaay, o Figura con carne, de Francis Bacon. Del análisis indicado se han obtenido unas conclusiones válidas respecto a la utilización de los alimentos en la obra pictórica, y su connotación social y perspectiva sensitiva, además de su influencia en la época en la que se sitúa la misma.

Palabras clave: comida futurista, museos.

Citar como: Ramón Fernández, F., Lull Noguera, C., Soriano Soto, M. D. (2022). "Alimentos del futuro: la ciencia ficción culinaria a través del arte". En: Actas del III Congreso Internacional sobre Patrimonio Alimentario y Museos. 25-26 noviembre, 2021, Valencia, España. pp. 85-97. https://doi.org/10.4995/EGEM2021.2021.13927 


\section{Introducción}

La comida ha constituido una fuente de inspiración para los artistas, quienes según la época la han interpretado desde perspectivas muy distintas, dando como resultado obras categóricamente opuestas. Todos los atractivos que los alimentos tuvieron para los antiguos creadores siguen vigentes en las vanguardias y llega hasta el arte más actual de la mano de artistas que otorgan a estos materiales dimensiones nuevas y dispares que alientan nuevos relatos

Desde la pintura meramente ilustrativa o documental que nos muestra maneras de cocinar, platos típicos y banquetes referentes de épocas como la egipcia o la romana se ha realizado un viaje por la representación del alimento en las distintas religiones. Ya en los siglos XVI y XVII la llegada del bodegón haría que ésta saltara a un primer plano y se convirtiera en la protagonista de la escena. Pero dependiendo de la época de la obra, la comida se ha introducido con diversas intenciones, ya fuera como indicativo de una posición social en Vermeer o Van Gogh, como elemento caricaturesco de sátira o ironía en los geniales retratos de Arcimboldo o a modo de única protagonista de la composición ya en bodegones llenos de detalle como los de Luis Meléndez o Paul de Vos. Posteriormente, Cézanne, fue precursor de las formas abstractas, más tarde Picasso presentará otra evolución en los objetos y alimentos de estas naturalezas muertas. Autores como Charlesp, Gauguin, Matisse, Salvador Dalí, Juan Gris o Luis Fernández se servirán también de la potencia expresiva de la comida y sus elementos para plasmar sus imaginarios en el soporte artístico.

Finalmente la tendencia tiende a incluir platos concebidos en impresoras 3D, granjas verticales, microencapsulados con nutrientes decisivos, hongos que curan el medio ambiente... etc.

Es precisamente tras la publicación del Manifiesto de la Cocina Futurista, en 1930, en las que aparecen platos como el Pollo Fiat, el Carneplástico o experiencias sensoriales como el Aerobanquete, que hacen replantearse el concepto del alimento y se genera una discusión sobre el futuro de la alimentación influida por la ciencia ficción.

Nuestro objeto en este trabajo es estudiar la relación de la comida futurista con el arte mediante el estudio de distintas obras de arte en las que en ocasiones la vanguardia en la gastronomía se ha plasmado en una obra artística, como las latas de sopa Campbell, de Andy Warhol; Nedick's, 1970, de Richard Estes, Hamburguesa de piso, de Claes Oldenburg; Pasteles, de Wayne Thibaud; Sándwich de jamón y huevo, de Tjalf Sparnaay, o Figura con carne, de Francis Bacon. Junto a ello, estos ejemplos pueden servirnos para una innovación docente en la asignatura de Derecho alimentario y protección del consumidor, en la titulación del Grado en Ciencia y Tecnología de Alimentos, ya que se muestra la evolución del alimento y su representación gráfica.

La metodología que vamos a emplear es el análisis de las distintas obras pictóricas seleccionadas, así como el estudio de los alimentos del futuro, en un escenario de ciencia ficción mediante las aportaciones doctrinales más recientes.

Del análisis indicado se han obtenido unas conclusiones válidas respecto a la utilización de los alimentos en la obra pictórica, y su connotación social y perspectiva sensitiva, además de su influencia en la época en la que se sitúa la misma. 


\section{Los alimentos del futuro: un escenario de ciencia ficción}

El futurismo es una corriente artística contemporánea de principios del siglo XX, se creó como movimiento artístico y cultural y se abre a todas las formas de expresión: pintura, escultura, literatura, música, arquitectura, danza, fotografía, cine y, gastronomía. Se cree que el futurismo italiano fue el único movimiento artístico que se atrevió a repensar la tradición culinaria de su país, el único que elaboró "un programa de renovación total de cocinas"

Para los futuristas, cocinar era una forma de expresión artística, que ofrecían platos que definían apetitosos complejos plásticos, o esculturas para comer. Podríamos resumir la relación entre futurismo y cocina diciendo que en todos los aspectos la cocina era una expresión artística. El plato primero debe ser hermoso a la vista, con combinaciones de colores particulares.

Los problemas actuales incluido el covid19 junto al cambio climático, y el agotamiento de recursos están originando una transformación que hace más eficiente el cultivo de productos vegetales, la producción de alimentos más respetuosos con el medio ambiente y el bienestar animal, el favorecimiento de la acuicultura como alternativa a la sobreexplotación de los mares. Y la más extrema que es la obtención de insectos para el consumo humano.

Las microcápsulas es una de las revoluciones que procede del microencapsulado, un conjunto de técnicas mediante las cuales en pequeñas partículas, gotas de líquido o gases da lugar a microcápsulas o partículas agregadas para desarrollar alimentos más seguros, con mayor extensión de su vida útil, más saludables y con nuevas propiedades. Aunque parece, no es ciencia ficción: la microencapsulación permite mantener la estabilidad de nutrientes como la vitamina C (una proteína decisiva en la producción y regeneración de piel, tendones, ligamentos y vasos sanguíneos) o los omega 3 (ácidos grasos trascendentes para fortalecer las neuronas y mantener el corazón sano) o incorporar calcio en bebidas vegetales.

Daniel Rivera, responsable de Tecnologías de Microencapsulación de Ainia, un centro tecnológico de referencia en $1+d+i$ alimentaria asegura que el futuro no se puede concebir sin esta revolución. "Esta tecnología transcurre paralela al desarrollo de nuevos materiales que permitan cumplir con más requerimientos, soportar mejor determinadas condiciones y liberarse en aspectos y límites concretos", como aumentar su vida útil, prolongando la fecha de caducidad, y contribuir a un menor desperdicio de alimentos, o permitir flexibilizar condiciones de conservación (por ejemplo, reduciendo su permanencia en sistemas de refrigeración).

La metagenómica y la microbiología tradicional posibilita el control sanitario de los alimentos evitando microorganismos patógenos como la Salmonella y abre camino como una técnica que permite un examen exhaustivo de los patógenos existentes para identificar qué especies microbianas están presentes y en qué porcentaje, gracias a un análisis de ADN en la muestra para analizar. Los resultados son mucho más completos que en un análisis microbiológico, porque ofrecen información sobre todos los patógenos existentes en la muestra, y no solo sobre las bacterias que se buscan en el otro sistema.

Carne de laboratorio como hamburguesas que evitan el consumo de carne de ganado y el abuso de la ganadería. Hamburguesa vegetal que parece de carne y al cocinar suelta liquido parecido a la sangre que es el jugo de la remolacha que lleva. Carnes in vitro, creadas con células madres y sin productos químicos, aún está en proceso, buscando cómo reducir costes, Cuhi con algas sustitutivo a la ensalada con pescado fresco marinado, comidas líquidas y en barrita con todos los nutrientes necesarios. 
Videos como La Comida del Futuro - Bing vídeo de planeta vivo, inventos como burbuja de agua, helado negro hecho de carbón y almendras en una heladería de Los Ángeles, café transparente que protege la placa dental sin dañarla, evitando manchas.

Dentro de la biotecnología fúngica las setas y los hongos tienen un poder más allá de la temporada de cesta y mercado. Estos frutos del campo protagonizan una importante línea de investigación para dar respuesta al desarrollo de una industria alimentaria con capacidad para proporcionar sustento a todo el planeta, a partir de la eliminación de daños medioambientales. La clave de la biotecnología fúngica está en el ciclo de vida de los filamentos de los hongos y de sus transformaciones celulares partiendo de las esporas, una tecnología reconocida como motor de innovación dentro de los Objetivos de Desarrollo Sostenible de la ONU, con múltiples aplicaciones en la industria química, textil y alimentaria.

Hay proyectos como el denominado PECOSAIN, llevado a cabo por AZTI - un centro científico y tecnológico que desarrolla proyectos de transformación de alto impacto-, que persigue mejorar la calidad de los productos de pescado mediante la generación - vía biotecnología fúngica- de coberturas (empanados y/o rebozados) innovadoras, crujientes y saludables. Y a más corto plazo, un proyecto que ya desarrolla el Instituto de Agroquímica y Tecnología de Alimentos del Consejo Superior de Investigaciones Científicas (CSIC), con aplicación en el campo de la enología: se desarrollan vinos con mejores condiciones organolépticas o funcionales.

La revolución de las máquinas descubre a tiempo real defectos en pleno proceso de producción y favorecerá la reducción de excedentes de producción y otorgar a las empresas un conocimiento profundo sobre los alimentos.

¿Nutrición individualizada con alimentos impresos en 3D? Algunos investigadores están creando estos productos. La población mundial está envejeciendo rápidamente y existe una necesidad urgente de analizar las necesidades de alimentos y nutrición para este sector de la sociedad, se espera que la proporción de personas de más de 65 años haya aumentado del 25 al $40 \%$ en 2030.

Estrategias que se verán aceleradas con el nuevo programa de I+D+i de la Unión Europea denominado Horizonte Europa 2021-2027, que busca impulsar la ciencia abierta, la competitividad industrial y la innovación, con especial atención a aspectos de nuestra vida cotidiana como la salud, el medio ambiente y la alimentación. En definitiva, una evolución de la comida cuyo respaldo a través de tecnologías como la impresión 3D, el loT (Internet de las cosas, integración de todo tipo de objetos informáticos o electrónicos a través de la red gracias a sensores) o el big data (el poder que otorgan los datos de los usuarios) permiten transformar nuestros menús a un ritmo de vértigo.

La disfagia afecta a más de un tercio de ancianos y deteriora su capacidad de consumir alimentos normales, motivo por el que las personas mayores a menudo rechazan las comidas, comen porciones muy pequeñas y prefieren alimentos fáciles de comer, en detrimento de aquellos que les proporcionan los nutrientes que necesitan en las cantidades adecuadas. La textura se adapta para ser más fácil de tragar y también permite calibrar la cantidad de azúcar, sal y grasas, ya que la preparación de la comida sigue siendo de la forma tradicional. La idea es que platos como la carne de cerdo con patatas, se puedan llegar a imprimir a gran escala directamente en un plato con las impresoras 3D ubicadas en las cocinas de las residencias de ancianos. 
Granjas verticales: agricultura a ras del cielo. La afectación del cambio climático sobre los cultivos, junto a la creciente demanda de productos consecuencia del crecimiento de la población, exigen nuevas formas de abordar la agricultura. Una de las propuestas más prometedoras son las granjas verticales, grandes extensiones de cultivo de plantas dentro de edificios denominados farmscapers, que funcionan con la mayor eficiencia energética. Son verdaderos museos de cultivos controlados y protegidos.

Eso es posible utilizando la energía LED (Light Emiting Diode, diodo emisor de luz) como herramienta de fotosíntesis y su cultivo en hidropónico (en una solución mineral, en lugar de en suelo agrícola). A su vez, se consigue reducir un $95 \%$ el consumo de agua con respecto a un cultivo tradicional. Además, la automatización del big data evita depender de las inclemencias climáticas y tener varias cosechas al año de productos de calidad y cercanía. Sin embargo, las críticas a este sistema surgen de la desvinculación de la agricultura del entorno rural.

Uno de los proyectos más emblemáticos es Aerofarms, en Nueva York: desde un edificio de 6.500 metros cuadrados se producen 900 toneladas de verduras de hoja al año. Europa tiene ya varios planes señeros en agricultura vertical y, en el caso de España, este novedoso sistema empieza a dar los primeros pasos. Entre sus grandes impulsores se encuentran gigantes tecnológicos como Google o Tesla, así como países de Oriente Medio.

El consumo de algas no es tradicional en nuestro país, pero en la globalización, se produce al auge de la gastronomía japonesa y cada vez mayor disponibilidad de productos en las tiendas, las algas se van haciendo un hueco en la dieta de los españoles. Delicias como los maki rolls de sushi, la ensalada sunomomo o la sopa de miso contienen algas como ingrediente importante, y son platos de mucho éxito. Esta fama se ha reforzado por cierta corriente que sitúa a las algas como el "superalimento" de moda, atribuyéndoles todo tipo de propiedades y recomendando su consumo habitual. Pero ¿es acertado? Estas "verduras" marinas no son un alimento insano, pero pueden no ser seguras en dosis altas por algunas de sus características, como su elevado contenido en yodo.

En el contexto del creciente interés de la población referente a la salud y el bienestar, los alimentos funcionales (surgidos en los años 80, en Japón) juegan un papel clave en la dieta. Esta tendencia hace que la producción de ingredientes funcionales, con actividad demostrada y estabilizada para su incorporación a un mayor número de matrices de alimentos, sea un área de estudio de gran interés y muy demandado por la industria de alimentaria.

Reducir la contaminación de los suelos es otro de los objetivos del programa Horizonte Europa, que fija como meta la reducción de pesticidas y fertilizantes en los cultivos del continente. Gemma del Caño, experta en I+D e Industria, recuerda que, en general, los fitosanitarios son necesarios para evitar plagas o microorganismos que estropeen la producción, por lo que hay que intentar que contaminen lo menos posible. "Sería fantástico no tener que utilizar ninguno, pero eso va a llevar tiempo", explica. "También es muy importante diferenciar entre los problemas que pueden provocar en su entorno laboral -dadas las investigaciones recientes sobre el riesgo de cáncer de los trabajadores agrícolas al entrar en contacto con ciertos herbicidas y los que llegan al consumidor, que nada tienen que ver. Hoy podemos decir que los fitosanitarios no están en los alimentos en cantidades perjudiciales para las personas".

En los próximos siete años, el consorcio europeo EIT Food, compuesto por 50 empresas, universidades y centros de investigación, invertirá cerca de 1.600 millones de euros para desarrollar 
los alimentos del futuro: impulsará la transformación del sector alimentario centrándose en el consumidor y en la eficiencia de los recursos. Ajustar la producción alimentaria a las nuevas necesidades y adaptarla para utilizar menos materias primas y reducir los desperdicios.

Si hablamos de moléculas bioactivas debemos recurrir al trabajo de Aora Health y su amplio catálogo de nutracéuticos de última generación, que combina para generar efectos sinérgicos positivos junto con una aproximación científica que de la selección de los ingredientes adecuados, el control de la cantidad de molécula absorbida por el organismo (biodisponibilidad). Entre sus componentes destacan el AOX® (Extracto de Amla-Extracto de Polygonum-Extracto de Zanahoria), el Extracto de Pasiflora, el Extracto de Amapola, el Extracto de Azafrán, la Vitamina B6 y la Melatonina.

¿Cómo serán los alimentos dentro de 25 o 50 años? ¿Y dentro de un siglo? ¿Triunfarán los insectos? ¿La comida se administrará en píldoras? ¿Podremos comer todo lo que queramos y no engordar un gramo?

Los cuadros, las películas y las novelas de ciencia ficción contienen algunas propuestas interesantes. De momento, pensamos que los cambios no serán tan drásticos, lo único que se puede avanzar en el futuro más próximo, que será una continuación de las tendencias actuales.

Pero sí que aparecerá la búsqueda de nuevas zonas de cultivo, existen propuestas de cultivar en Marte, ¿primero habrá que llegar no?, pero como ya se conocen las condiciones se están preparando cultivos aptos para su desarrollo en Marte cuando se pueda llegar (National Geographic, 2016). Dentro del proyecto SomosFuturo que impulsa el talento de los jóvenes implicando la nanotecnología para el cultivo de granjas inteligentes utilizando robots. Experiencias en países bajos han tenido éxito con 9 verduras y cereales.

También interesa destacar la figura de Ángel León, que al mando de su restaurante Aponiente, desarrolló plancton para el consumo humano, y que recientemente ha mostrado su descubrimiento con un cereal marino sostenible cultivado (Fuchs, 2021).

\section{Los alimentos del futuro en el arte: principales obras pictóricas y escultóricas en la que se plasma una visión de ciencia ficción}

Son muchas las obras pictóricas que representan un alimento o comida. Los bodegones son muy habituales y han sido representados a lo largo del tiempo. La comida ha sido considerada como un espacio esencial dentro del arte contemporáneo (Díaz Ruiz, 2017).

El movimiento futurista que se inició con Filippo Tommaso Emilio Marinetti, con la publicación de su Manifiesto futurista, de 1909, en el que propugnaba una exaltación al amor, al liderazgo, al peligro y la agresividad y que influyó en el ámbito del arte. Uno de sus representantes más conocidos fue Giacomo Balla que se adhirió al movimiento con la firma de La pittura futurista Manifesto técnico, en 1910.

Marinetti, en 1931 abrió un restaurante llamado El Paladar Sagrado, que se caracterizaba por una decoración fría y metálica, y en el que los platos que se servían eran manifestaciones de ese futurismo (Miño, 2020). 


\subsection{Las latas de Sopas Campbell, de Andy Warhol}

Una de las primeras obras seleccionadas son las Latas de sopa Campbell's, 1962, de Andy Warhol (Figura 1), realizada en pintura de polímero sintético sobre tela, 50,8 cm x 40,6 cm. y que se encuentra en el Museum of Modern Art, más conocido por su acrónimo MoMA, en Nueva York. Se trata de una obra representativa del denominado pop art.

Es un icono dentro del arte, y contempla la comida enlatada, como símbolo del futuro, con una clara intención de facilitar un consumo a futuro de un alimento, ya que se incrementa la conservación a través del enlatado.

\subsection{Nedick's, 1970, de Richard Estes}

La obra de Richard Estes que se encuentra en el Museo Nacional Thyssen-Bornemisza, es un óleo sobre lienzo, 121,9 x 167,6 cm, y pertenece a la Colección Carmen Thyssen-Bornemisza (Figura 2).

Esta obra es representativa de la denominada "comida rápida", ya que representa un paisaje urbano muy característico de la ciudad de Nueva York. Se observa la presencia de alimentos como las hamburguesas y los hot dog (perritos calientes), además de zumos de frutas. Denota una comida que actualmente es muy consumida principalmente por el público adolescente, por la rapidez y las connotaciones sociales. Importante hacer mención del logotipo del refresco, Coca Cola, que está asociada a la modernidad. Esta obra se enmarca dentro del movimiento del Fotorrealismo.
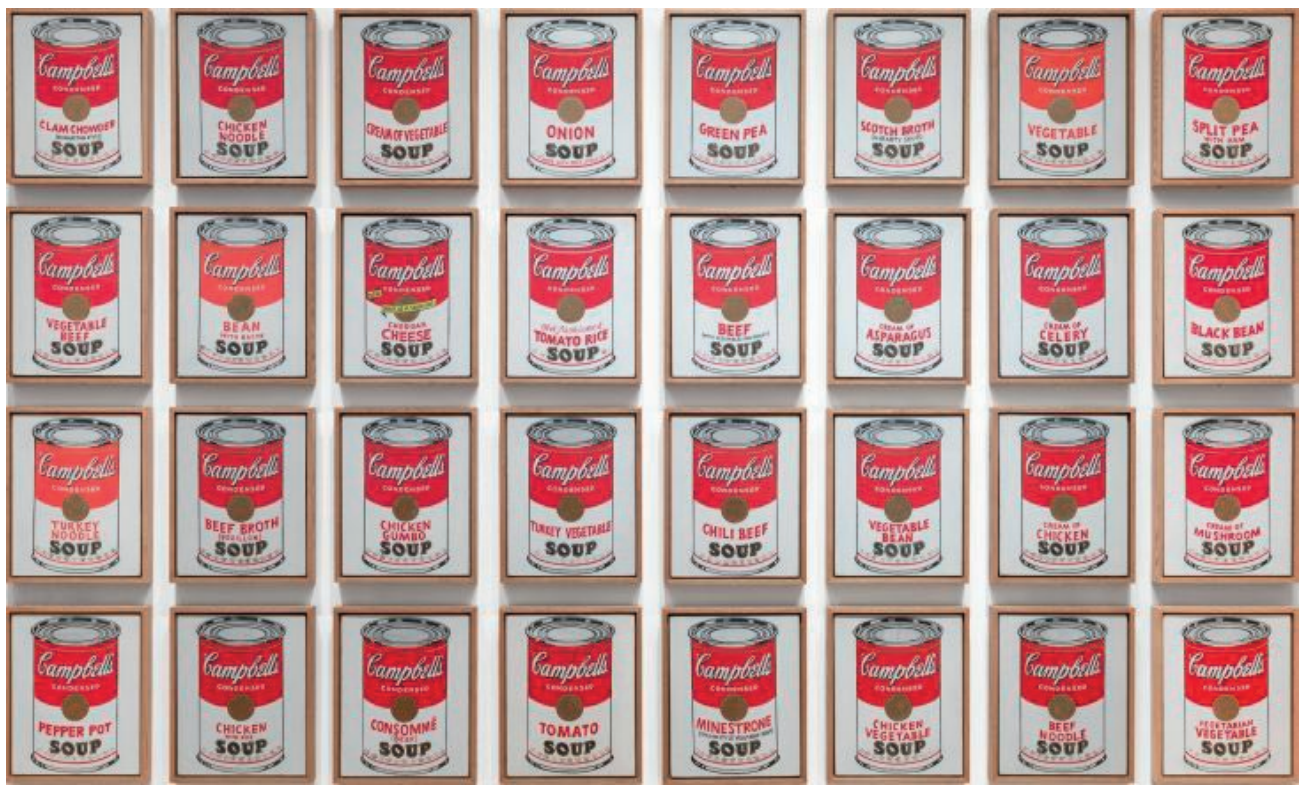

Figura 1. Imagen de Latas de sopa Campbell's, de Andy Warhol (1962).

Fuente: 3minutos de arte: https://3minutosdearte.com/cuadros-fundamentales/latas-de-sopa-campbells-1962-andy-warhol/ 


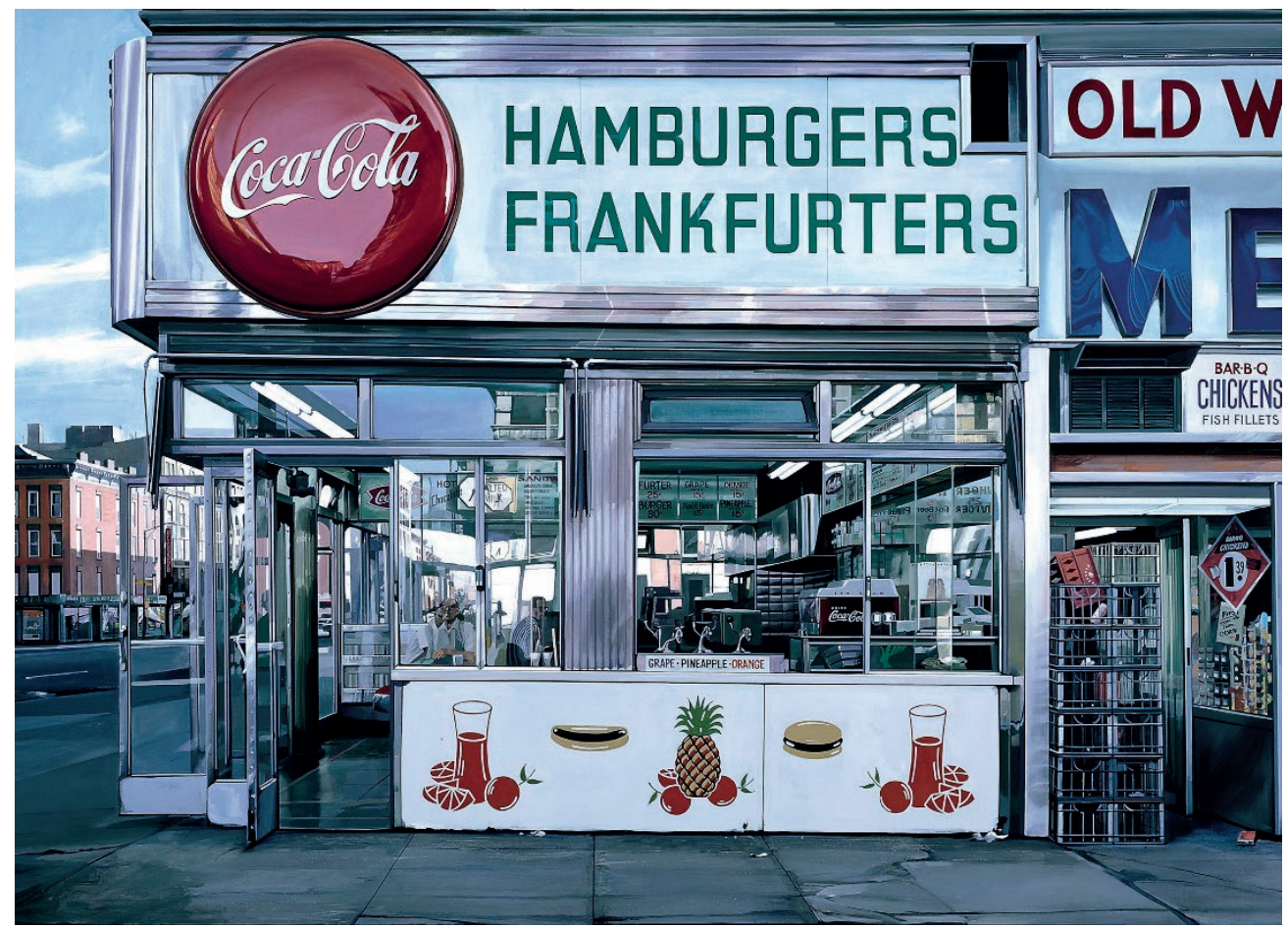

Figura 2. Imagen de Nedick's, de Richard Estes (1970).

Fuente: Museo Thyssen-Bornemisza. https://www.museothyssen.org/sites/default/files/styles/full_resolution/public/imagen/2017-03/ CTB.1993.10_0.jpg

\subsection{Hamburguesa de piso, de Claes Oldenburg}

La obra de Claes Oldenburg, Hamburguesa de piso, también conocida como Hamburguesa gigante, del año 1962, se trata de una lona estampada, rellena de gomaespuma, de dimensiones 132 x $213 \mathrm{~cm}$, y que se encuentra en el Art Gallery of Ontario, en Toronto, Canadá.

Representa un superlativo de consumo de comida rápida, la hamburguesa, a través de una imagen exageradamente grande que provoca incredulidad y rechazo. Es un ejemplo de imagen kitsch, y representa la cultura americana de la comida rápida o fast-food. Una de sus cualidades es que se trata de una escultura "blanda" y no rígida (Figura 3).

\subsection{Pasteles, de Wayne Thibaud}

La obra de Wayne Thibaud, denominada Cake (pasteles), se realizó en el año 1963, y se encuentra en la National Gallery, Washington D.C., Estados Unidos. La técnica es óleo y las dimensiones $152 \times 183 \mathrm{~cm}$. (Figura 4).

Se trata de una obra realista que se enmarca dentro de la tendencia colorista, en la que se muestran pasteles con volumen y asemejados a la imagen real de los mismos. Se diferencia de la obra de Warhol y Lichtenstein porque no se presenta de forma mecánica una imagen, sino una imagen de alimentos que incrementa el deseo de consumo. Muestra, a modo de un escaparate 


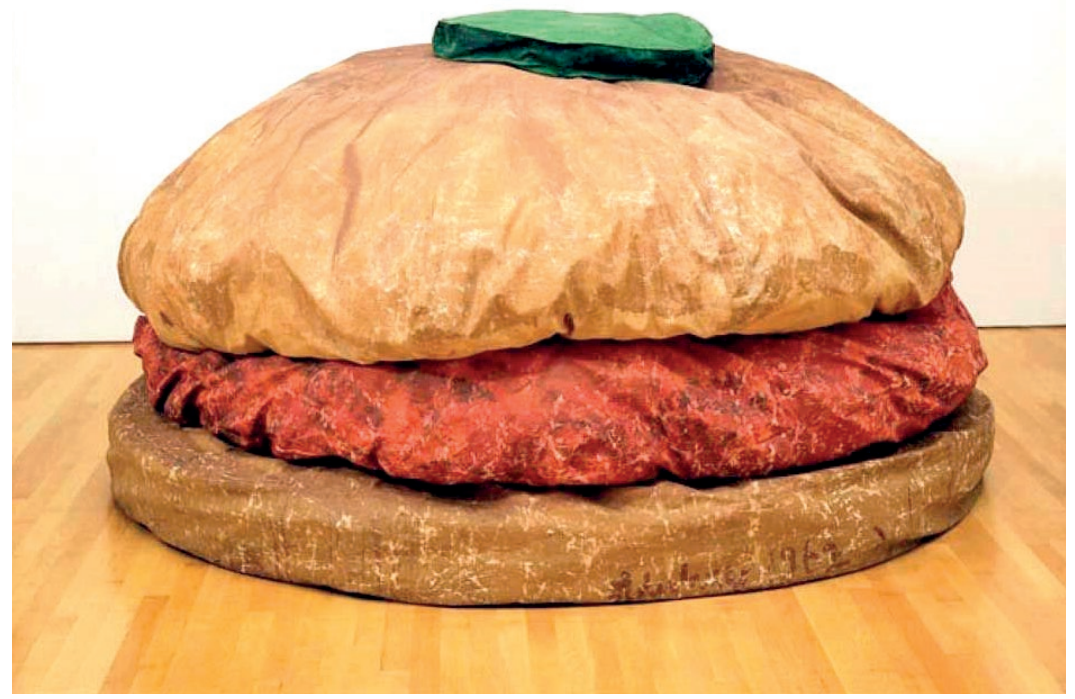

Figura 3. Imagen de Hamburguesa de piso, de Claes Oldenburg (1962).

Fuente: Art \& Life. http://theartandlife.blogspot.com/2012/11un-paseo-por-el-arte-hamburguesa-gigante.html

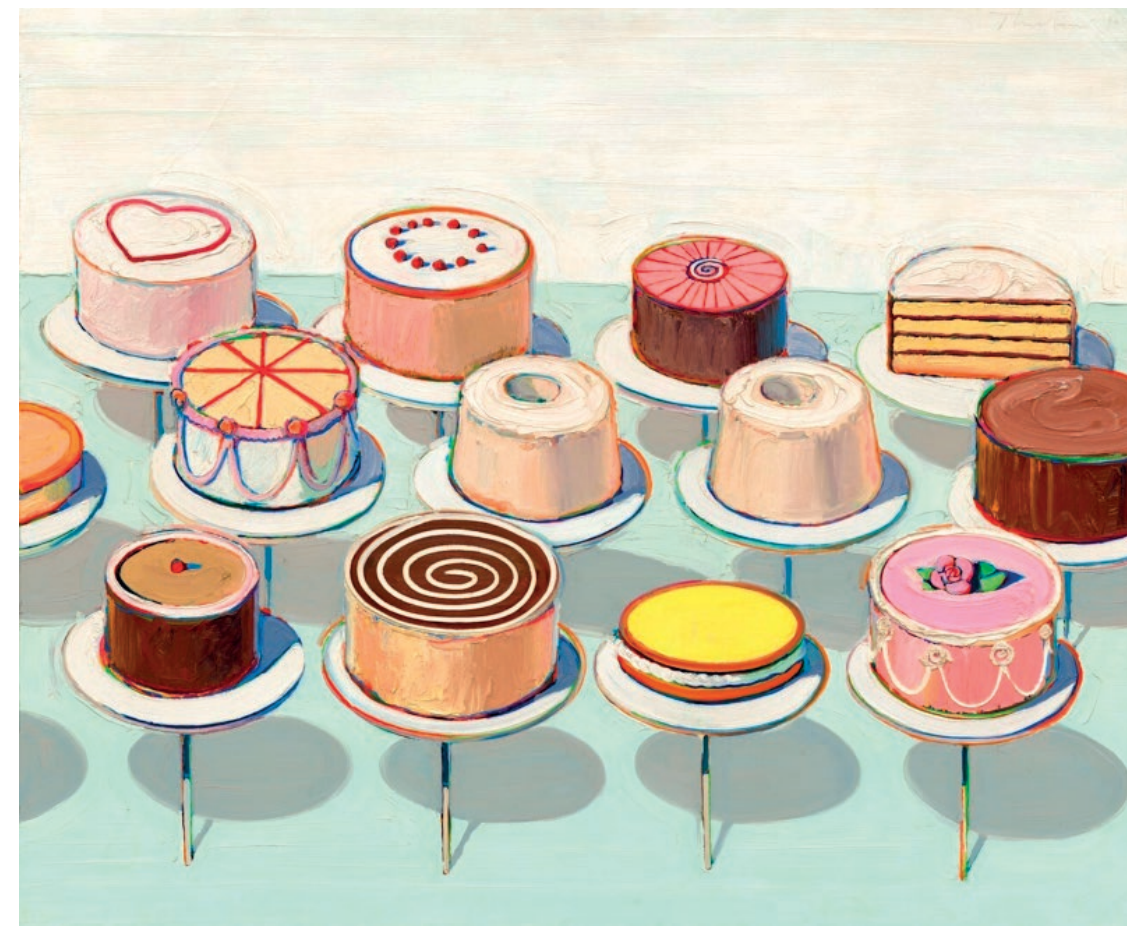

Figura 4. Imagen de Cakes, de Wayne Thibaud (1963).

Fuente: Historia con arte. https://historia-arte.com/obras/pasteles 
de una pastelería, y encima de los soportes, distintos pasteles recubiertos de crema y adornados de guindas y rosas, con excepción de un pastel que ya está cortado, mostrando su interior relleno de chocolate el bizcocho.

Se relaciona con la idea americana de la celebración, y con las formas geométricas incluyendo símbolos como corazones y espirales. Los platos que muestran los dulces parecen suspendidos en el aire, que suma un componente etéreo al conjunto.

\subsection{Sándwich de jamón y huevo, de Tjalf Sparnaay}

Setratadeunaobrahiperrealistadelartistaholandés, TjalfSparnaay (https://www.tjalfsparnaay.nl/). Representa en este caso a un sándwich de jamón y huevo y se inspira en las naturalezas muertas, pero con una técnica muy perfeccionada que muestra los alimentos con una realidad asombrosa (Figura 5). Llega a confundirse su obra pictórica con una imagen fotográfica por la perfección de los detalles. Los colores que utiliza son muy saturados y la obra alcanza unos límites reales altamente conseguidos.

Se enmarca también en la comida del futuro, comida rápida siguiendo el ejemplo de las anteriores obras seleccionadas.

La obra Figura con carne, de Francis Bacon data del año 1954 y refleja un estilo caracterizado por la deformación del personaje, en este caso, el Papa Inocencio X, que lo representa tras de

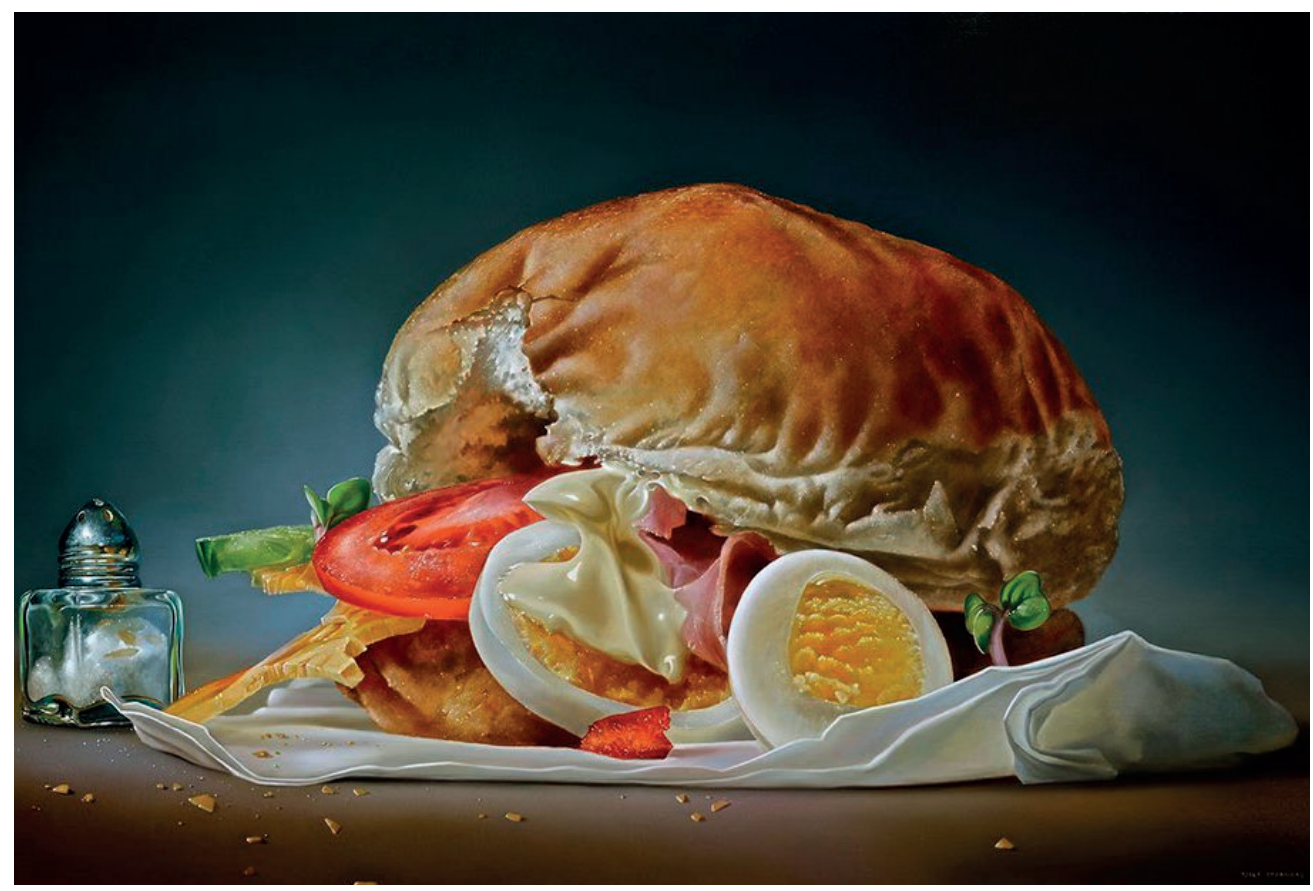

Figura 5. Sándwich de jamón y huevo, de Tjalf Sparnaay (2014).

Fuente: El Universal. https://www.eluniversal.com.mx/menu/obras-de-arte-iconicas-sobre-comida 
sí con dos piezas de carne de vaca (Figura 6). Se encuentra la obra en el Instituto de Arte de Chicago, Chicago, Illinois, Estados Unidos.

Esta obra pictórica muestra el alimento en un segundo plano, mostrando la descarnación de la pieza, y especialmente con las costillas sobresaliendo con una luminosidad que contrasta con la oscuridad del personaje. La presencia de la carne con la figura Papal es de un gran contraste y muestra la relación entre lo sagrado y lo carnal.

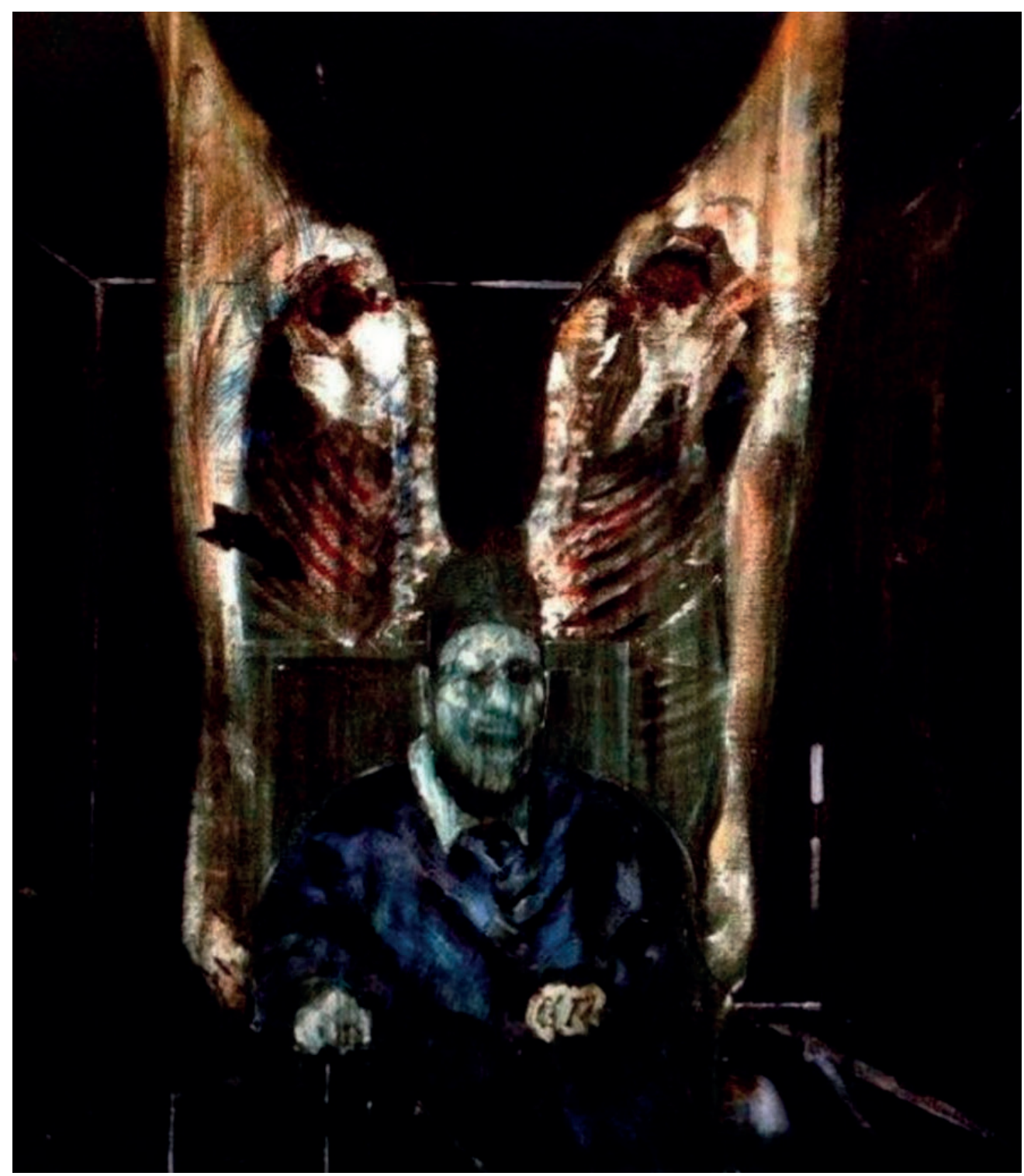

Figura 6. Figura con carne, de Francis Bacon (1954).

Fuente: https://es.wahooart.com/@@/6E3SVB-Francis-Bacon-figura-con-carne-1954- 


\section{Desarrollo de la Innovación: su aplicación a la asignatura Derecho alimentario y protección del consumidor en el Grado en Ciencia y Tecnología de los alimentos, en la Universitat Politècnica de València}

El estudio de los alimentos y su presencia en el arte puede tener una gran aplicación al ámbito de la docencia para mostrar al alumnado la evolución de la presencia de los alimentos en el arte. En el caso de la asignatura de Derecho alimentario y protección del consumidor, que se imparte en el Grado en Ciencia y Tecnología de los alimentos, con una carga docente de $4.5 \mathrm{cr}$. ECTS se puede realizar una actividad enfocada a que el alumnado selecciones obras de arte en la que aparezcan alimentos, que puedan estar relacionados con la ciencia ficción, y ver el tratamiento que el/la artista concede a la representación gráfica. Mediante esta actividad se lograrían diversos objetivos:

a. Conseguir una involucración del alumnado en la búsqueda y conocimiento del arte aplicado a la asignatura;

b. Determinar qué tipo de alimentos aparecen en una obra artística y su razón de ser, para analizar la conexión en relación con el tiempo de la obra y los aspectos sociales que tienen los alimentos (por ejemplo, vino, dulces, etc.).

c. Mostrar la evolución en el consumo de los alimentos a través de las distintas épocas históricas (por ejemplo, durante la mitad del siglo XX se incrementó el consumo de bebidas refrescantes asociadas a la felicidad o bienestar).

Esta actividad consistiría en formar distintos grupos de alumnado que seleccionarán distintas obras de arte en las que esté presente el alimento, y se determinarán sus características y peculiaridades. Cada alumno/a rellenará una ficha facilitada por la profesora en la que explicará sus experiencias, así como las motivaciones que le sugiere la obra en relación con el alimento (funcionalidad, relación social, características del mismo, y componentes nutricionales).

Al finalizar la actividad, se realizará un foro de debate en que cada grupo explicará la obra seleccionada y los alimentos que aparecen en la misma, motivando las opiniones formuladas.

\section{Conclusiones}

Los alimentos y el arte han estado estrechamente vinculados a lo largo de los siglos. Son numerosos los ejemplos que podemos extraer de la representación de los alimentos en las obras, principalmente pictóricas. Abundan en los museos las pinturas de bodegones, de naturaleza muerta, que han sido representados en las diversas corrientes artísticas.

En el caso de los alimentos del futuro, entendiendo por tales alimentos que han supuesto un consumo en las nuevas generaciones, y que han estado influidos por la ciencia ficción a través de diversos hitos, por ejemplo, cinematográficos, nos encontramos con la representación de la denominada comida rápida o fast food. El hiperrealismo también ha contribuido a plasmar en la obra de los artistas pertenecientes a este movimiento la comida americana, representada por refrescos, sándwiches, y también los pasteles altamente edulcorados y con una visión atractiva para el consumidor. 
Se echa en falta la representación de los denominados nuevos alimentos, alimentos obtenidos por las tecnologías, que no han sido objeto de tratamiento pictórico, pero que en un futuro podrán ser objeto de atención por parte de los artistas.

Todos los ejemplos que hemos elegido para representar el futurismo, se encuentran expuestos en los museos, y forman parte de la creación artística de pintores que han plasmado el alimento en relación a su visión del mundo, por ejemplo, en el caso de Francis Bacon, cuya enigmática obra relaciona la figura de un Papa, con dos pedazos de carne de vacuno.

La exposición de las obras y su análisis puede ser también utilizado en el ámbito docente, a través de una actividad en la que el alumnado reflexiona sobre la representación de los alimentos a lo largo del tiempo.

\section{Agradecimientos}

Trabajo realizado en el marco del Proyecto de Innovación y Mejora Educativa (PIMEs) "Gamificación y TICs: diseño de actividades audiovisuales basadas en la ciencia ficción para la dinamización docente en un entorno presencial, semipresencial y virtual", presentado en el marco de la convocatoria de Proyectos de Innovación y Mejora Educativa (PIMEs) llevada a cabo en la Universitat Politècnica de València para el curso 2020-2022 obteniendo resolución favorable de la Comisión de Evaluación y Seguimiento de Proyectos de Innovación y Convergencia (CESPIC) en su sesión de septiembre de 2020 y concedido por el Vicerrectorado de Estudios y Convergencia Europea de la Universitat Politècnica de València. Años 2020-2022. Investigadora principal: Francisca Ramón Fernández. y en el marco del Proyecto I+D+i «Retos investigación» del Programa estatal de I+D+i orientado a los Retos de la Sociedad del Ministerio de Ciencia, Innovación y Universidades: RTI2018-097354-B-100 (2019-2022).

\section{Bibliografía}

DÍAZ RUIZ, Ma. DEL C. (2017). Arte y comida en la creación contemporánea desde un enfoque de género. Málaga: Universidad de Málaga.

FUCHS, L. (2021). "Ángel León anuncia su último gran descubrimiento: un cereal marino sostenible cultivado por primera vez en Aponiente". Directo al paladar. El sabor de la vida. https://www. directoalpaladar.com/actualidad-1/nuevo-alimento-revolucionario-angel-leon-cereal-marinosostenible-cultivado-primera-vez-aponiente [Consulta: 16 de septiembre de 2021].

MIÑO, M. A. (2020). "Desde las vanguardias al arte contemporáneo latinoamericano: la comida como elemento transformador". En: Index. Revista de arte contemporáneo, núm. 1, pp. 60-66. http://www.revistaindex.net/index.php/cav/article/view/330 [Consulta: 18 de septiembre de 2021].

NATIONAL GEOGRAPHIC (2016). Verduras en Marte: cada vez más cerca de la comida marciana. https://www.nationalgeographic.es/espacio/verduras-en-marte-cada-vez-mas-cerca-de-lacomida-marciana [Consulta: 16 de septiembre de 2021]. 



\title{
GÉNESIS DE UNA IDENTIDAD VISUAL: CREACIÓN DE LA IMAGEN PARA EL CONGRESO INTERNACIONAL DE PATRIMONIO ALIMENTARIO Y MUSEO
}

\author{
Maricha Martínez Sosa \\ República Dominicana.info@marichams.com
}

\begin{abstract}
Graphic design, when assumed professionally, is a research process from which visual results are obtained. This paper addresses the connection between graphic design and intellectual production for academic purposes, and presents the concept of design methodology. From the methodological perspective, and following the 5 steps of the scientific method, the process and motivations behind each decision are presented, detailing the approach to the project for the creation of the visual identity of the Congreso Internacional de Patrimonio Alimentario y Museos El Gusto en el Museo (EGEEM). By taking as an example the way in which the visual identity of this congress was developed, readers are allowed to witness the process that led to its creation, and the brushstrokes that can serve as a guide for the development of projects with similar characteristics are laid.
\end{abstract}

Keywords: communication, brand, corporate, graphic design, identity, image, manual, methodology, research.

Resumen: El diseño gráfico, cuando se asume de forma profesional, es un proceso de investigación del cual se obtienen resultados visuales. En este documento se aborda la conexión que tienen el diseño gráfico y la producción intelectual con fines académicos y se presenta el concepto de metodología del diseño. Desde la perspectiva metodológica y siguiendo los 5 pasos del método científico, son presentados el proceso y motivaciones detrás de cada decisión tomada en el abordaje del proyecto para la creación de la identidad visual del Congreso Internacional de Patrimonio Alimentario y Museos El Gusto en el Museo (EGEEM). Al tomar como ejemplo la forma en que se realizó el desarrollo de la identidad visual de este congreso, se permite a sus lectores ser testigos del proceso que llevó a su creación y se dejan las pinceladas que pueden servir de guía para el desarrollo de proyectos con características similares.

Palabras clave: comunicación, corporativa, diseño gráfico, identidad, imagen, investigación, manual, marca, metodología.

Citar como: Martínez Sosa, M. (2022). "Génesis de una identidad visual: creación de la imagen para el Congreso Internacional de Patrimonio Alimentario y Museo". En: Actas del III Congreso Internacional sobre Patrimonio Alimentario y Museos. 25-26 noviembre, 2021, Valencia, España. pp. 99-118. https://doi.org/10.4995/EGEM2021.2021.13421 


\section{Introducción}

Las marcas que gozan o desean gozar de cierta estabilidad buscan formas de ofrecerle a sus clientes, audiencias o usuarios una imagen sólida y coherente que comunique sus valores y principios. Estas deben poder ser representadas en todos sus productos y estar presentes en los distintos momentos y puntos de contacto. La creación de una imagen corporativa es, como indica el título de este artículo, la génesis de una identidad visual pues su correcto desarrollo conlleva entrevistas, indagación, experimentación y prueba y error. Hay quienes pecan de entenderla como algo sencillo y fácilmente automatizable, obviando que, más que convertir la inspiración de las musas en trazos vectoriales o píxeles, asumir la creación de una imagen es embarcarse en un problema de investigación cuya solución aplica muchos, si no todos, los pasos del método científico.

Como dato curioso, cabe destacar que no es tan común encontrarse con publicaciones del resultado de una imagen de marca ya que estas suelen limitarse a los manuales de identidad corporativa, los cuales son generalmente de uso interno. Esto se aplica no solo en el área de alimentación, sino al diseño de identidad corporativa en general. Con base en la experiencia profesional como diseñadora gráfica por más de una década, quien suscribe intuye que esto se debe, entre otras, a dos razones:

1. Que el diseñador rara vez tiene la oportunidad de publicar respecto a su proceso creativo, pues son escasos los medios destinados a estos fines y no existe una cultura de producción intelectual académica en este gremio.

2. Que honrar los acuerdos de confidencialidad cliente-proveedor limita significativamente los derechos editoriales sobre el trabajo resultante de las creaciones gráficas.

Ante esto se entiende prudente iniciar con la síntesis de una evaluación de la relación del diseño gráfico con la publicación académica. Analizar cuáles han sido, históricamente, las posturas dominantes en torno al desarrollo de una metodología del diseño y qué tan común es el tipo de análisis que pretende hacerse en las siguientes páginas.

Para entender si es correcta la percepción de que, efectivamente este tipo de publicaciones no es la norma, el presente documento muestra el concepto de metodología del diseño y une múltiples ideas en torno al mismo. Se toma como ejemplo la forma en que se realizó el abordaje del desarrollo de una identidad visual que vincula al diseño gráfico con la alimentación, la museografía y la producción académica. Permitiendo que la audiencia misma de su producto resultante, por tratarse en este caso de la imagen de este congreso, sea también testigo del proceso que llevó a su creación.

Luego de vincular el binomio diseño gráfico - metodología se describe el proceso de creación de una identidad visual particular y se utiliza la imagen del Congreso Internacional de Patrimonio Alimentario y Museos El Gusto en el Museo (EGEEM) como ejemplo y guía. Se presenta un análisis, desde la perspectiva metodológica, del proceso y motivaciones detrás de cada decisión tomada en el proceso de creación de esta identidad, y se dejan pinceladas que pueden servir de guía para el desarrollo de proyectos con características similares.

En el presente documento se abordan preguntas como:

¿Qué conexión tienen el diseño gráfıco y la producción intelectual con fines académicos? 
¿Cómo se aborda el diseño de una marca que abarca diversas áreas temáticas y que pertenece a un entorno institucional?

¿Cómo abordar proyectos que ya son conocidos y tienen una reputación?

\section{Objetivos}

\subsection{Objetivo general}

Presentar el proceso de creación de una pieza de diseño gráfico como ejercicio de producción académica, tomando como ejemplo la creación de una identidad visual vinculada con la museografía y alimentación.

\subsection{Objetivos específicos}

- Demostrar que el diseño es un proceso de investigación que se vale de los pasos del método científico.

- Analizar la relación histórica del binomio diseño gráfico - producción académica.

- Ilustrar la metodología de diseño utilizada para la creación de una imagen visual, la del Congreso Internacional de Patrimonio Alimentario y Museos El Gusto en el Museo (EGEEM).

\section{Desarrollo de la innovación}

Para conectar al diseño gráfico con la producción intelectual con fines académicos y la alimentación, se analizarán antecedentes de la relación diseño - investigación. Se presentará el diseño de una identidad visual y se tomará como caso de análisis el desarrollo la realizada para la serie de conferencias sobre patrimonio alimentario en las cuales se enmarca este artículo.

\subsection{Metodología del Diseño: antecedentes}

El deseo de 'cientificar' el diseño se remonta a las ideas del movimiento moderno de la década de 1920. Benet (2006) describe que "los primeros ejemplos de investigación empírica en la historia del diseño gráfico fueron cuando, en 1923, Wassily Kandinksy realizó un experimento de investigación sobre la relación del color con la forma en la percepción humana [...] Sus descubrimientos contribuyeron al modernismo y a la perspectiva ontológica de que la interpretación del lenguaje visual es universal en todas las culturas".

Sin embargo, la aparición de los que serían considerados como "nuevos métodos de diseño" data de algunas décadas después. Según afirma Nigel Cross en su obra "Science and Design Methodology: A review" (1993), en el período de 1950-1960 estas ideas fueron ganando popularidad hasta consolidarse a modo de concurridas conferencias y diversas publicaciones impresas. Y, hacia 1962, fue realizado en Londres un evento que dicho autor considera "el nacimiento de la metodología de diseño moderna y del movimiento de métodos de diseño". Inicialmente, estas líneas de pensamiento se centraban en el hecho de que la ciencia se ocupa de lo que existe, mientras que al diseño le atañe lo inmaterial y lo que ha de ser creado. Desde los primeros días, las metodologías de diseño han tratado de establecer distinciones entre el diseño y la ciencia. 
Un ejemplo es la cita de Gregory (1966) afirmando que: mientras "la ciencia es analítica; el diseño es constructivo".

La dicotomía expresada en los años 60 fue sustituida por un reconocimiento más complejo de la red de interdependencias entre el conocimiento, la acción y la reflexión. Y ya para la década de 1970 reconocidas voces se elevaban en rechazo de los intentos de encajar la creatividad en frameworks y métodos estandarizados. Hay quienes presentaron puntos de análisis contrastados de la relación entre ciencia y diseño. De los escritos de Grant (1979), se extraen frases como que "el acto de diseñar en sí mismo no es ni será nunca una actividad científica", pero que su estudio sí. "Es decir, el diseño como actividad puede ser objeto de investigación científica".

Otros, como Green (1985), señalaron que los científicos, al igual que los diseñadores, crean sus hipótesis y teorías y las utilizan para orientar su búsqueda de información. También en 1985, Levy invitó a ver la ciencia más como una "racionalidad expandida para la identificación de problemas estructurales y la resolución de actividades [...] haciendo que la metodología científica suene indistinguible de las metodologías de diseño". Y hacia 1990 Willem afırmaba que "el diseño hace a la ciencia visible", destacando que los orígenes de los métodos de diseño se encuentran en los métodos científicos y que los resultados del diseño solo existen gracias a ser aplicaciones de la ciencia.

Por su parte, Cross (1993) invita a hacer una distinción crítica ante la idea de que "el método puede ser vital para la ciencia (donde se validan los resultados) pero no para el diseño (donde los resultados no tienen que ser repetibles)". Señalando también que no existe un método de diseño único y universal, basado en lenguajes y teorías formales ${ }^{1}$ y afirmando que: La ciencia del diseño aborda el problema de determinar y categorizar todos los fenómenos regulares de
los sistemas que se diseñan y del proceso de diseño. [...] Se refiere a un enfoque explícitamente organi-
zado, racional y totalmente sistemático del diseño; no sólo la utilización del conocimiento científico de
los artefactos, sino el diseño en cierto sentido como una actividad científica en sí misma. Por tanto, la
ciencia del diseño es el estudio del diseño.

Sobre la metodología y la ciencia del diseño, el mismo Cross (1993) destaca que:

La ciencia del diseño se refiere al conjunto de trabajos que intentan mejorar nuestra comprensión del diseño mediante métodos "científicos" de investigación. [...] Incluye el estudio de cómo trabajan y piensan los diseñadores, el establecimiento de estructuras adecuadas para el proceso de diseño, el desarrollo y la aplicación de nuevos métodos, técnicas y procedimientos.

\subsection{Diseño e investigación}

Cuando se habla de investigación es prudente recurrir a uno de los más destacados autores de habla hispana: Roberto Hernández Sampieri (2014), quien la define como "un conjunto de procesos sistemáticos, críticos y empíricos que se aplican al estudio de un fenómeno o problema". Es bien entendido que el desarrollo de una investigación se vale del método científico, el cual es definido por Gargantilla (2020) como "un conjunto de pasos ordenados que se emplean para adquirir nuevos conocimientos". Una mirada crítica permite apreciar que las aplicaciones del método científico trascienden la ciencia pura y pueden ser ampliamente encontradas en la vida cotidiana. Y, aunque la forma de llamarle a las etapas del método científico pueden diferir entre

\footnotetext{
Como una de las primeras generaciones de licenciados egresados de la carrera de Diseño Gráfico, quien suscribe verifica la validez de estas ideas de Cross a la fecha de sus estudios formales de grado, los cuales fueron realizados entre 20032008 en la Universidad Apec de la República Dominicana.
} 
un autor y otro, es ampliamente entendido que consta de 5 pasos: observación, formulación de hipótesis, experimentación, emisión de conclusiones y publicación.

Para abordar la investigación desde la mirada del diseño gráfico se recurre a Heller (2006) quien afirma que más que tener una teoría que requiere ser probada y examinada desde varios puntos de vista para lograr un resultado, en el caso que nos atañe el resultado rige la forma en que se ejecutará una solución de diseño. Por todo lo anterior, para los fines de este artículo se asume como correcta la afirmación de Bennett (2006) de que los diseñadores gráficos son en realidad productores de conocimientos interdisciplinarios, y no sólo traductores visuales de las necesidades, conocimientos y expectativas de un cliente. Se entiende además como verdad, que el diseño se vale del método científico de forma inherente y que los diseñadores hacen uso de sus pasos ya sea de manera consciente o inconsciente.

Finalmente y partiendo de que lo que se hará es teorizar sobre soluciones gráficas, habría que definir ¿en qué consiste teorizar sobre diseño? Para ello, vale rescatar lo expresado por Bennett (2006): "tradicionalmente, la teoría del diseño gráfico ha privilegiado la intuición y la creatividad sobre la investigación empírica”. De hecho, ante la pregunta de "¿cuáles son las teorías del diseño gráfico?" esta académica aborda interesantes posturas como que:

Se puede argumentar que los principios del diseño gráfico basados en el arte -incluyendo (pero no limitándose a) el contraste, la jerarquía, la repetición, la alineación y el color- son de hecho teorías probadas a través de una larga historia de experimentación exitosa en la práctica. Sin embargo, dentro de la disciplina del diseño gráfico estos principios no se consideran teorías "probadas", porque el diseño gráfico carece históricamente de una agenda de investigación sólida. Por el contrario, el diseño gráfico -en parte debido a su aglomeración artística- ha desarrollado una reputación de práctica alimentada por la intuición, basada principalmente en el talento.

Sobre la producción bibliográfica dentro de la disciplina del diseño, la misma Bennett (2006) afirma que salvo notables distinciones, esta se ha limitado a analizar diseños en el mercado y a alimentar la experiencia práctica profesional. Que pese a la existencia de:

Revistas académicas que informan de los resultados de la investigación y de las perspectivas teóricas sobre temas de diseño gráfico [...] debido a su naturaleza intuitiva, los profesionales del diseño gráfico no han seguido el ejemplo de sus académicos. En su lugar, existe un abismo intelectual entre la práctica y la investigación [..] Pocas veces, o ninguna, el contenido real está escrito por los diseñadores gráficos que produjeron la estética, en parte porque los diseñadores gráficos no suelen tener el control editorial de su trabajo.

Así pues, esta puede ser considerada una de esas raras veces en las que un equipo de diseño tiene el privilegio de presentar su trabajo y de reivindicar, en cierto modo, el silencio habitual de casi todo un gremio.

\section{Resultados}

Dentro del proceso agotado para la creación de la imagen de EGEEM se optó por seguir un estilo democrático y fundamentado en el análisis. Sobre este, la autora Elizabeth Throop (2006) afirma que: "aboga por un proceso de diseño más riguroso, basado en la investigación, que no se limita a preguntar al público lo que piensa de un prototipo de diseño", haciendo alusión a que va más allá de presentar opciones finales y que busca involucrar al cliente. Por su parte Bennet (2006) afirma que: 
"La disciplina del diseño gráfico debe equilibrar su meritocracia con una democracia que dé poder a todos los participantes [...] Los enfoques colaborativos del diseño facilitan un proceso de diseño democrático que valora las diversas opiniones y fomenta la participación del público [...] incluyen la participación, el contexto y otros subconjuntos del diseño centrado en el usuario.

En la experiencia profesional de quien suscribe, la gran mayoría de las veces no se hace al cliente parte del proceso de decisión hasta casi el final, cuando se le presentan dos o tres propuestas a elegir. En el caso particular de EGEEM, se integró al equipo coordinador del congreso de distintas formas:

- A través de sus insights.

- Con la expresión de sus gustos.

- Escuchando y entendiendo su visión del proyecto.

- Vía su retroalimentación sobre las propuestas.

- Dándoles el poder de la decisión final.

\subsection{Fase de Observación}

En un proyecto gráfico la fase de observación conlleva analizar la empresa, entidad o proyecto, su estructura y objetivos. Estudiar la competencia e identificar las tendencias de la misma. Escuchar (o leer, en caso de que se haga de forma asíncrona) las respuestas del cliente a cada pregunta. En este paso el equipo de diseño debe estar preparado para leer entre líneas y anteponer siempre las necesidades del cliente. Considerando que estas últimas incluyen tanto las necesidades que son claramente expresadas, como las que se hacen evidentes al ojo experto en cada interacción y ante cada pesquisa.

El desarrollo de una marca puede implicar desde la creación de sencillos elementos únicos, hasta complicadas intervenciones técnicas. Puede ser tan simple como una sola pieza o tan compleja y minuciosa como sea posible imaginarse. Por ello, junto a la aprobación de los términos de contratación es necesario determinar la amplitud del abordaje que desea hacerse.

\section{Primeros contactos}

El inicio del proceso agotado para la creación de la imagen de EGEEM tuvo los siguientes momentos clave: establecimiento de contacto, presentación del abordaje del proyecto, aprobación de los términos de contratación y definición de roles y equipo de trabajo. A continuación se detalla en qué consistieron:

- Establecimiento de contacto: se conversa con el cliente, por los medios de su preferencia, sobre sus necesidades y expectativas, se obtiene toda la información necesaria para preparar un acuerdo. Esto puede conllevar múltiples interacciones tales como llamadas, correos y reuniones.

- Presentación del abordaje del proyecto: se entrega el plan de trabajo incluyendo los tiempos estimados de desarrollo y, en caso de tratarse de un proyecto remunerado, se integra también el presupuesto.

- Aprobación de los términos de contratación: ambas partes acuerdan los términos de contratación, el plan de trabajo y el presupuesto (en caso de haberlo). Deben aclararse 
variables como la forma de pago, productos entregables, fechas clave y tipo de contrato, entre otras.

- Definición de roles y equipo de trabajo: como no todos los proyectos se abordan de igual forma, es prudente definir los roles tanto del cliente como del equipo. Mientras hay quienes tienen una idea clara de lo que quieren y solo necesita quien la ejecute, hay quienes tienen clara su necesidad, pero no las características de la misma. En este sentido, es válido cuestionar y aclarar con antelación si lo que se busca es quien ejecute de manera formalmente correcta mandatos o si, por el contrario, se desea un equipo creativo, crítico, analítico y con espíritu investigador.

Para el abordaje de EGEEM se optó porque el liderazgo del proyecto lo tuviera una dupla creativa de la República Dominicana constituida por quien suscribe, Maricha Martínez Sosa y el diseñador gráfico Sergio Elías Taveras.

\section{Banco de preguntas}

Para facilitar esta etapa del proyecto, junto al diseñador gráfico Sergio Taveras, se compiló una serie de preguntas, las cuales fueron retroalimentadas por la diseñadora Laura Angelina Calderón, en un esfuerzo de que el mismo fuera revisado por pares. Este cuestionario puede servir de guión para abordar un primer encuentro con el cliente y preparar un brief informado.

1. ¿Cuál es el nombre de la compañía?

2. ¿A qué se dedica la empresa?

3. ¿A quiénes van dirigidos los servicios o productos que esta ofrece?

4. ¿Cuál es la filosofía corporativa? (Misión, visión, valores)

5. ¿Qué intentó plasmar en el logo actual de su marca? (Si tiene uno actualmente)

6. ¿Qué significa el nombre de su empresa?

7. ¿A cuál tipo de logo aspira? Ejemplos

- Logotipo: Es la representación tipográfica o caligráfica de la marca.

- Símbolo o isotipo: Es la representación gráfica o visual de la marca.

- Logosímbolo o imagotipo: Es la combinación entre logotipo e isotipo.

- Isologo: Es la combinación de logotipo e isotipo, pero, no pueden ser desligados sin que pierdan su sentido.

- No lo sé.

8. ¿Cuáles logos de otras marcas son sus favoritos? (Agradecemos que comparta links donde podamos verlos)

9. ¿Cuáles logos del mercado NO le gustan? ¿Por qué? (Agradecemos que comparta links donde podamos verlos) 
10. ¿Qué desea representar en el logo?

11. ¿Cuáles atributos o elementos desea destacar en el logo?

12. ¿Cuáles atributos o elementos desea evitar en el logo?

13. ¿Cuáles colores NO le gustaría tener en su logo?

14. ¿Cuáles colores cree que son óptimos para representar su marca?

15. ¿Tiene algún tipo de tipografía (tipo de letra) de preferencia? Ejemplo: Serif / Sans Serif / Slab Serif

16. ¿No le gusta algún estilo de tipografía (tipo de letra)?

17. ¿Quiénes son sus principales competidores en el mercado?

18. ¿Para cuándo le gustaría que tengamos lista su solicitud?

Favor indicar la fecha idónea / deseada para la finalización de este proyecto.

19. Favor adjuntar cualquier archivo que considere pueda ayudarnos a entender mejor su negocio: imagen actual, referencias, etc.

Luego del inicio del proyecto de desarrollo de imagen para El Gusto en El Museo se agotaron tres pasos: lluvia de ideas, identificación de conceptos clave y comunicación de preferencias. Se inició con una reunión virtual con representantes del Congreso. En esta se escucharon las necesidades, deseos y objetivos. Luego de indagar sobre múltiples temas, se realizó la lluvia de ideas y se asumió como punto de partida la visión y posibles respuestas a la pregunta de: ¿qué se quiere comunicar? De ahí surgieron:

- Conceptos clave, como producción intelectual, alimentos, nueva museografía, visibilidad, miradas distintas e integración de los sentidos (Figura 1).

- Factores gráficos relevantes, como lo que no se deseaba. En este caso las directrices a nivel tipográfico incluyeron que la fuente a elegir no fuera serif, cursiva ni decorativa.

- Elementos gráficos de interés, como el socarrat y la cerámica de manises.

\section{Conceptos clave}

ALIMENTOS

NUEVA MUSEOGRAFÍA
LOS SENTIDOS

VISIBILIDAD /

MIRADA DISTINTA
SOCARRAT

CERÁMICA

(MANISES)

Figura 1. Conceptos clave.

Fuente: Elaboración propia. 


\section{Investigación de antecedentes}

A partir de ahí se inició una investigación para responder ¿qué se ha estado haciendo? Tanto en el caso particular de EGEEM como de otras entidades con algún tipo de similitud. Como este Congreso ya ha sido realizado anteriormente, se identificaron sus publicaciones previas, incluyendo el material de la convocatoria para la primera y segunda edición (Figura 2).

Luego se procedió a buscar referencias internacionales y locales. Dentro de las primeras se optó por destacar el Museum Of Food And Drink (MOFAD) y las jornadas gastronómicas realizadas por el Instituto Smithsoniano. Para el caso local se seleccionaron ejecuciones realizadas en Valencia (España) por L’Etno (Museo Valenciano de Etnología ) y por el Museu de Ceràmica de Manises (Figura 3).

A continuación se procedió a evaluar el contexto en el cual se enmarca el congreso: la Universidad Politécnica de Valencia (UPV), el Departamento de Comunicación Audiovisual, Documentación e Historia del Arte (DCADHA) y el Máster Oficial Interuniversitario en Gestión Cultural (Figura 4).
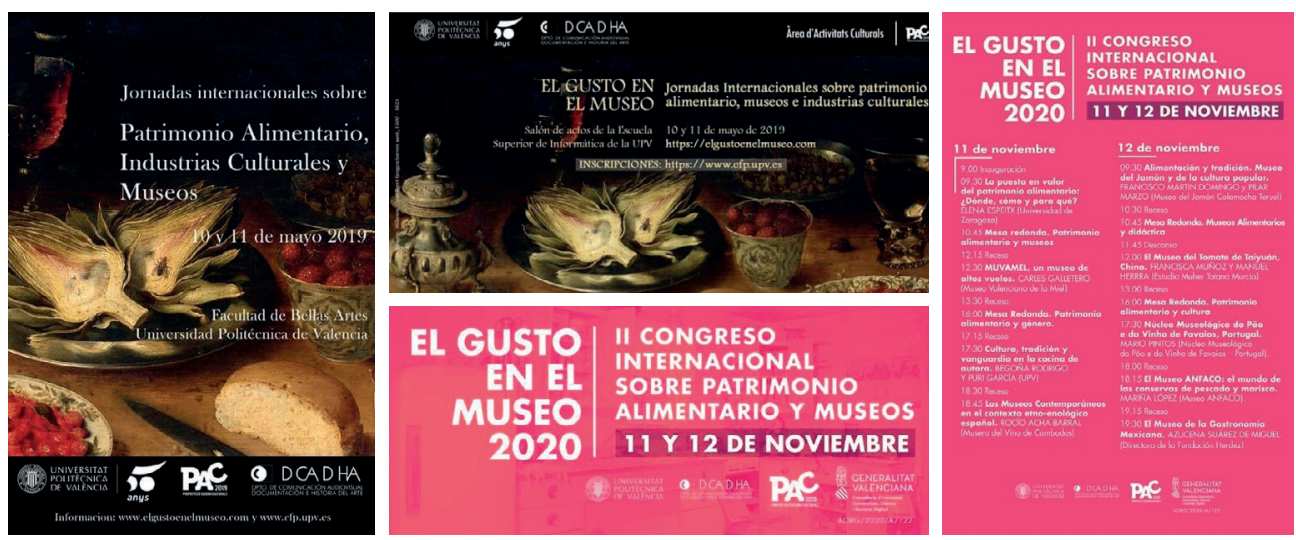

Figura 2. Composición de imágenes: antecedentes gráficos del proyecto. Fuente: Elaboración propia.
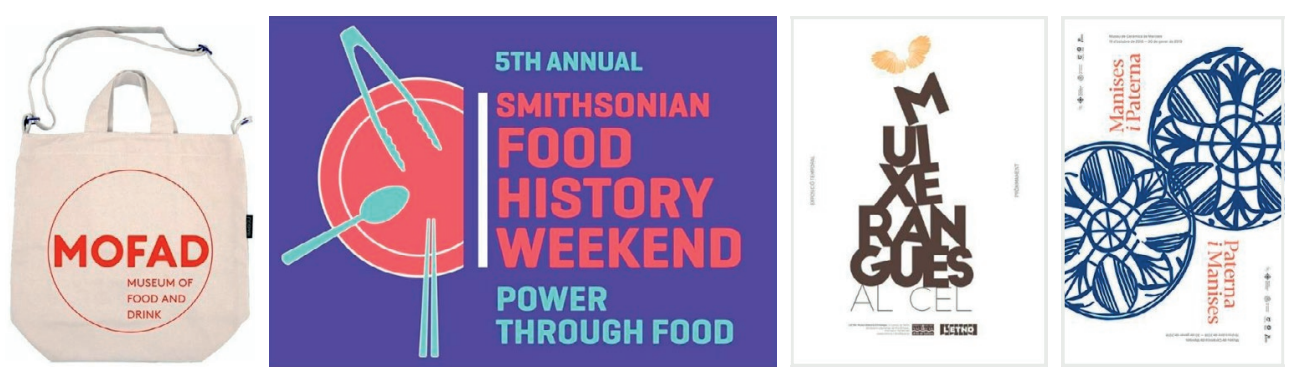

Figura 3. Composición de imágenes: referencias locales e internacionales.

Fuente: Elaboración propia. 


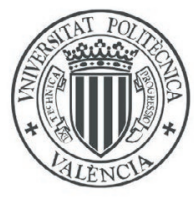

\section{UNIVERSITAT POLITĖCNICA DE VALÈNCIA}

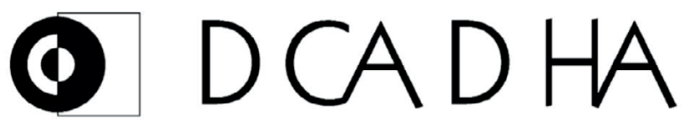

DPTO. DE COMUNICACIÓN AUDIOVISUAL DOCUMENTACIÓN E HISTORIA DEL ARTE

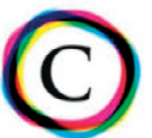
GESTIÓN CULTURAL Màster Oficial Interuniversitario

Figura 4. Composición de imágenes: contexto institucional en el cual se enmarca el congreso. Fuente: Elaboración propia.

\subsection{Fase de Formulación de Hipótesis}

Es probable que esta sea la etapa en la cual el diseño gráfico diste más de los resultados que tradicionalmente se obtienen de la producción intelectual. Más que enunciados escritos, lo que se obtiene en esta etapa es el racional, esa justificación conceptual que puede perfectamente ser entendida como la hipótesis que precede a lo visual. Aunque con frecuencia no se redacten, estas son las que establecen el punto de partida de las elecciones que se realizarán a continuación y al igual que otras hipótesis son sometidas a procesos de cuestionamiento, validación y, en caso de ser necesario, iteración.

\section{Concepto gráfico}

Se planteó la posibilidad de que el resultante de este proceso de diseño fuera un logotipo (representación tipográfica), un isotipo (representación gráfica o visual de la marca, sin texto) o un imagotipo (combinación entre logotipo e isotipo). Por ello, se optó por plantear un concepto gráfico que englobara múltiples significados: el ojo o la visión, la naranja de Valencia y el patrimonio cultural alimentario de la Cerámica de Manises.

Se plantearon propuestas, además con conceptos como cubertería, museo y el marco que suele acompañar las obras de arte expuestas.
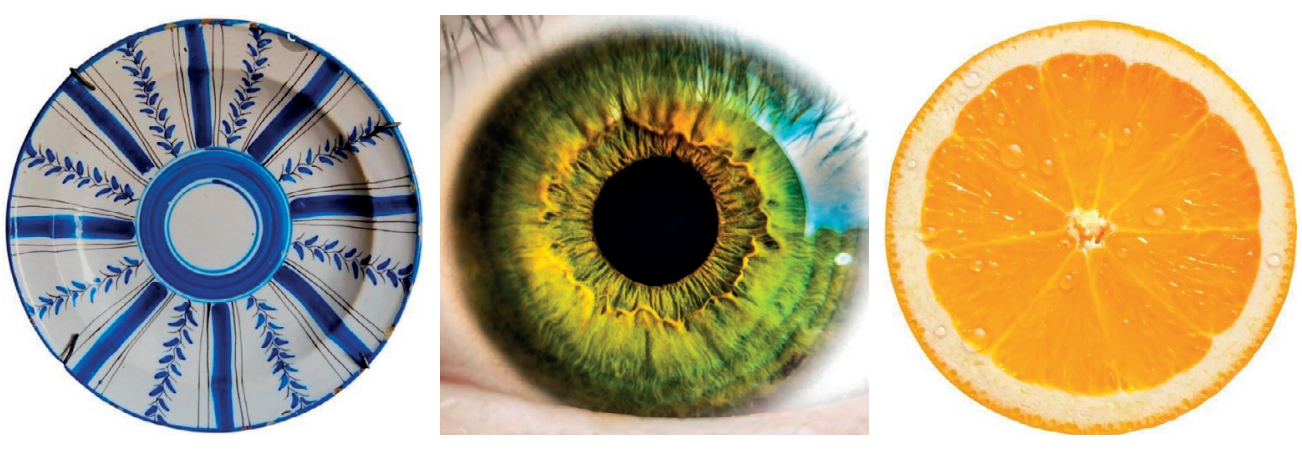

Figura 5. Conceptos visuales conectados. Fuente: Elaboración propia. 

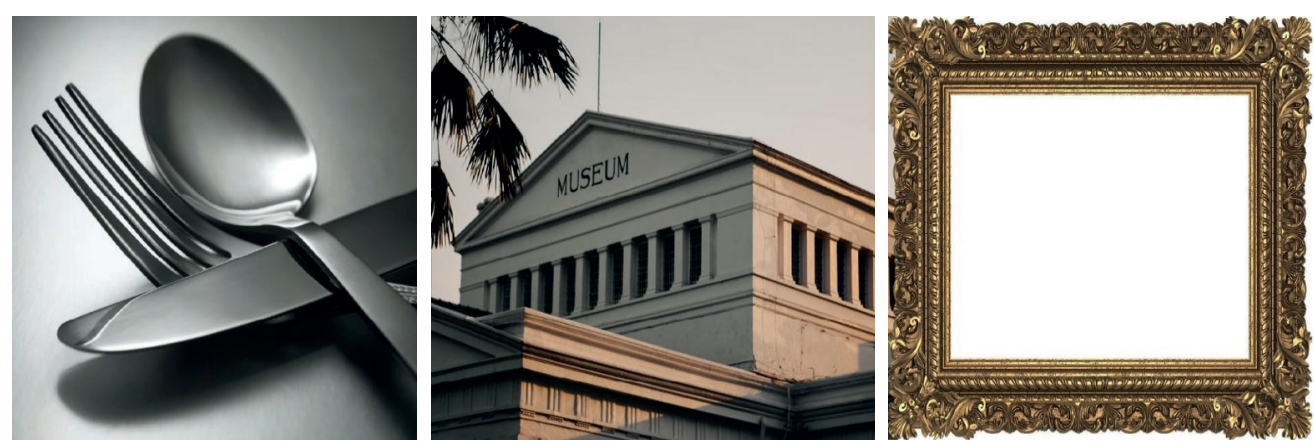

Figura 6. Conceptos visuales individuales.

Fuente: Elaboración propia.

\subsection{Fase de Experimentación}

Partiendo del racional establecido en la fase anterior, se integran el resultado de la investigación con la experiencia y la intuición. Esta combinación es la que define los criterios a utilizar durante las elecciones: tipográfica, cromática y estética, las cuales se detallan a continuación.

\section{Elección tipográfica}

Partiendo del 'feeling' descrito en la primera reunión, se inició la búsqueda de las distintas fuentes tipográficas que respondieran a los criterios acordados: san serif (palo seco), con aires de modernidad y fácil lectura. Se procuró además buscar tipografías que encajaran con los conceptos de gastronomía, museografía y producción intelectual.

La prueba realizada consistió en escribir en múltiples fuentes la frase "el gusto en el museo" en 3 versiones: mayúscula, tipo título y en minúscula. Las tipografías finalistas fueron: Kopius, Quiksand Bold, Dunbar Text, Semplecita Pro Medium, Atten New y Serenity Medium. Adicionalmente, se optó por la fuente Adorn Garland para la realización de experimentaciones con elementos en cursiva. La figura 7 muestra algunos de los ejemplos.

Se procedió entonces a seleccionar las favoritas del equipo de diseño y, finalmente, se optó por Serenity Medium como fuente primaria y Proxima Nova como fuente secundaria. La figura 8 presenta todos los caracteres que componen ambas tipografías.

Kopius

EL GUSTO EN EL MUSEO

El Gusto en el Museo

el gusto en el museo

Atten New

EL GUSTO EN EL MUSEO

El Gusto en el Museo

el gusto en el museo

Quiksand Bold
EL GUSTO EN EL MUSEO
EI Gusto en el Museo
el gusto en el museo
Serenity
EL GUSTO EN EL MUSEO
El Gusto en el Museo
el gusto en el museo

Dunbar Text
EL GUSTO EN EL MUSEO
EI Gusto en el Museo
el gusto en el museo
Canto
EL GUSTO EN EL MUSEO
El Gusto en el Musco
el gusto en el museo

Semplicita Pro

EL GUSTO EN EL MUSEO

El Gusto en el Museo

el gusto en el museo

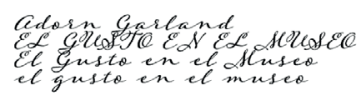

Figura 7. Experimentación con 8 familias tipográficas.

Fuente: Elaboración propia. 
Serenity medium

ABCDEFGHIJKLMNÑOPQRSTUVWXYZ1234567890 abcdefghijklmnñopqrstuvwxyzi!"\#\$\%\&/()='¿?'+* \{\}[]$, ; .:$

Proxima Nova Regular

ABCDEFGHIJKLMNÑOPQRSTUVWXYZ1234567890 abcdefghijkImnñopqrstuvwxyzi!"\#\$\%\&/()=' ¿?'+*\{\}[],;:

\section{Proxima Nova Bold}

\section{ABCDEFGHIJKLMNÑOPQRSTUVWXYZ1234567890 abcdefghijkImnñopqrstuvwxyz;!" \#\$\%\&/()=' ¿?'+*\{\}[],;:}

Figura 8. Detalle de las 2 tipografías seleccionadas: Serenity y Proxima Nova. Fuente: Brandbook de EGEEM.

\section{Elección cromática}

Estaba claro que este trabajo tendría dos tonalidades predominantes: azul y magenta, conclusión a la cual se llegó en una de las reuniones virtuales con el cliente, en donde se expresó la voluntad de mantener un vínculo cromático con el Máster en Gestión Cultural.

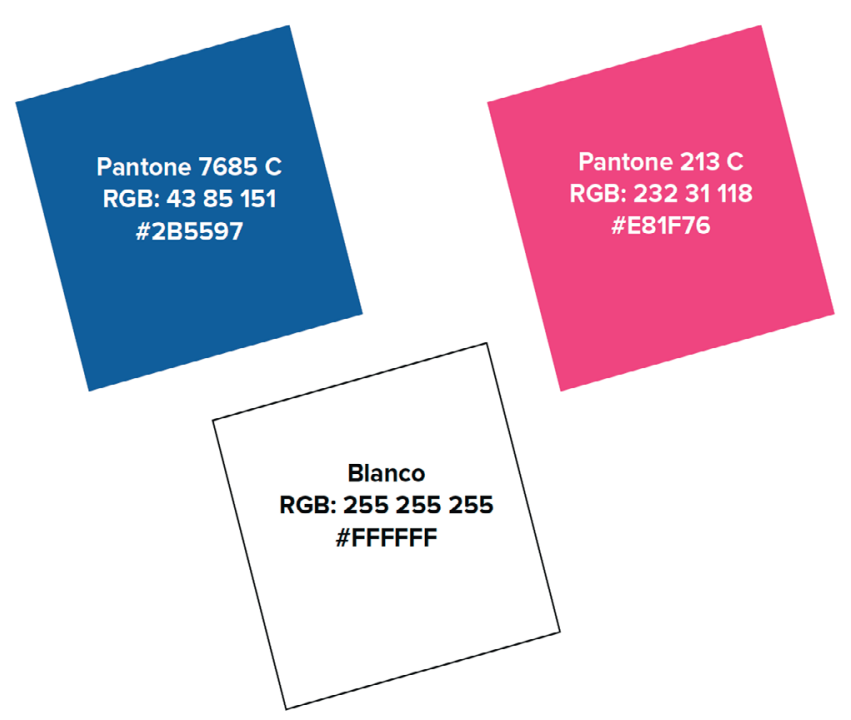

Figura 9. Elección cromática. Fuente: Brandbook de EGEEM. 
En el manual de identidad de EGEEM se expresa que:

"El color azul representa el color original que tenían los platos de cerámica de Manises, los cuales tienen un gran peso cultural e histórico en la gastronomía valenciana. El color fucsia representa la sensación de armonía y plenitud que sentimos al tener una buena alimentación, además, al ser un color enternecedor da sensación de bienvenida y amistad, siendo exactamente lo que todo museo quiere transmitir a sus visitantes. En adición, destaca las palabras "Gusto" y "Museo" para resumir las temáticas principales de la jornada".

\section{Bocetos}

Tomando como guía la intuición, se aborda la creación de propuestas preliminares que sirven para rejugar con las combinaciones de elementos, conceptos y requerimientos. No se busca lo
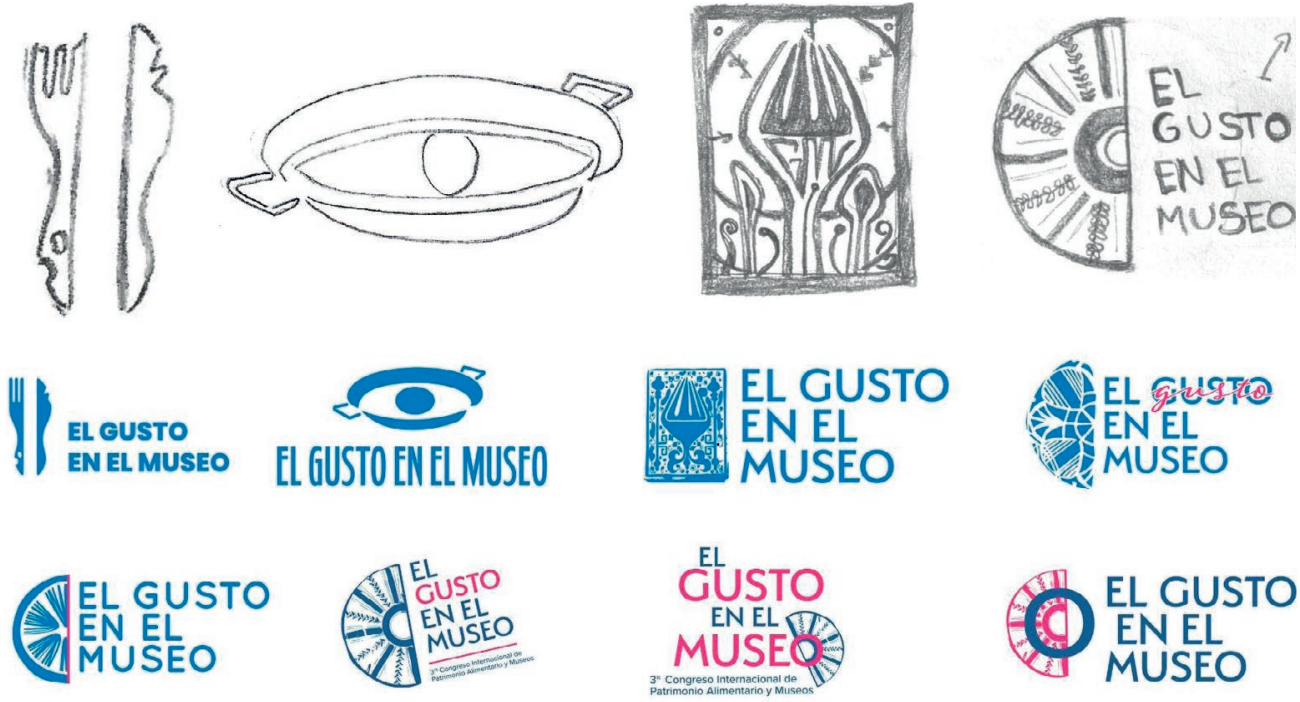

Figura 10. Selección de bocetos manuales digitales realizados para este desarrollo de marca. Fuente: Elaboración propia.
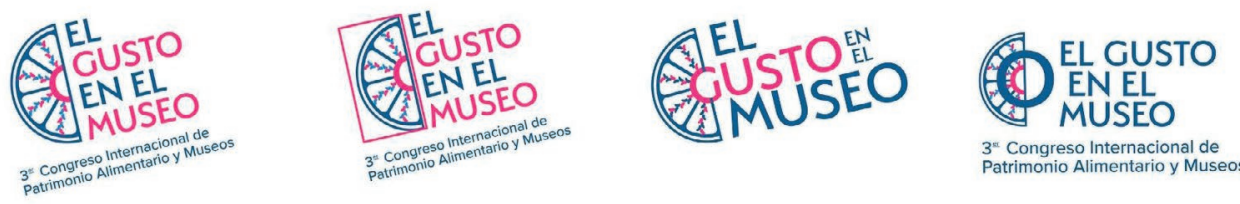

$3^{\text {s. }}$ Congreso Internacional de
Patrimonio Alimentario y Museos
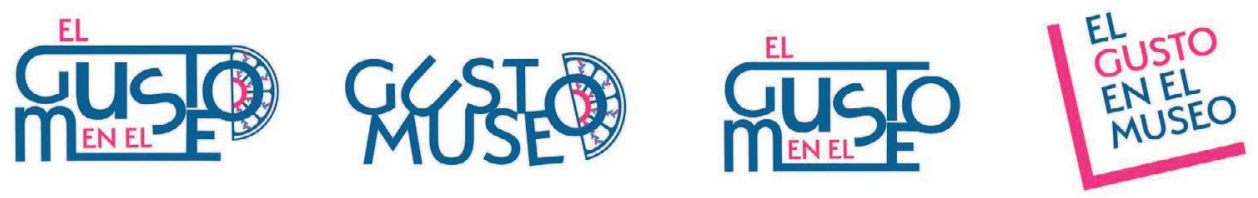

Figura 11. Propuestas iniciales.

Fuente: Elaboración propia. 
formalmente correcto, sino el flujo creativo, pues se entiende que estas son ideas crudas, que deben luego pasar por un posterior proceso de maduración.

Como se mencionó previamente, al momento de hacer la presentación al cliente se optó por un estilo democrático, que busca hacerle partícipe del proceso de toma de decisiones. Además, se optó por ponerles en contexto y presentar el proceso creativo desde sus inicios, en vez de concentrarse en la mera presentación de las propuestas finalistas. La siguiente figura muestra las propuestas presentadas como punto de partida.

\subsection{Fase de Emisión de Conclusiones}

Las conclusiones en diseño son el producto del proceso de iteración que surge de la retroalimentación recibida por parte del cliente y de la maduración de las ideas por parte del equipo creativo. Es la consolidación de propuestas formales o finalistas, las cuales son presentadas por el equipo de trabajo a los encargados de la toma de decisión.

En el caso de EGEEM, se presentaron tres finalistas, que pese a presentar personalidades totalmente distintas, tenían en común la misma aplicación tipográfica y cromática, variando la orientación de los caracteres y el isotipo. La siguiente imagen presenta el antes y el después, junto a la retroalimentación recibida.

\section{FEEDBACK}

EL

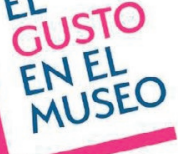

COLOCAR "MUSEO"

EN MAGENTA

\section{FEEDBACK}

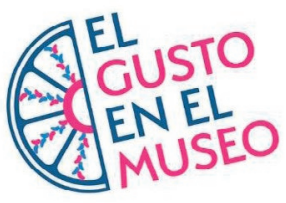

QUITAR MAGENTA

DEL PLATO

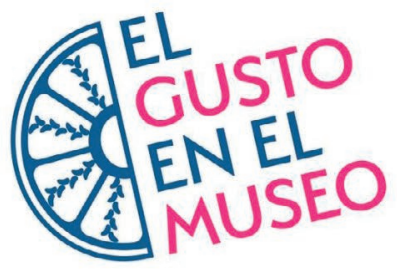

\section{FEEDBACK}

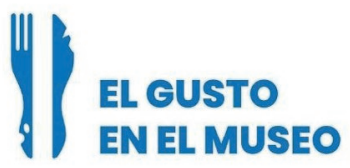

INTEGRAR CUCHARA Y

FORMAR ICONO MUSEOS

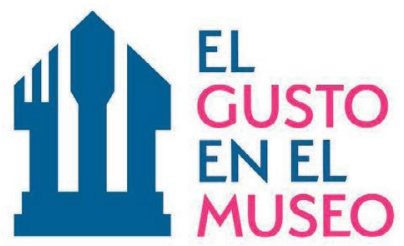

Figura 12. Iteraciones: antes y después de la retroalimentación.

Fuente: Elaboración propia. 

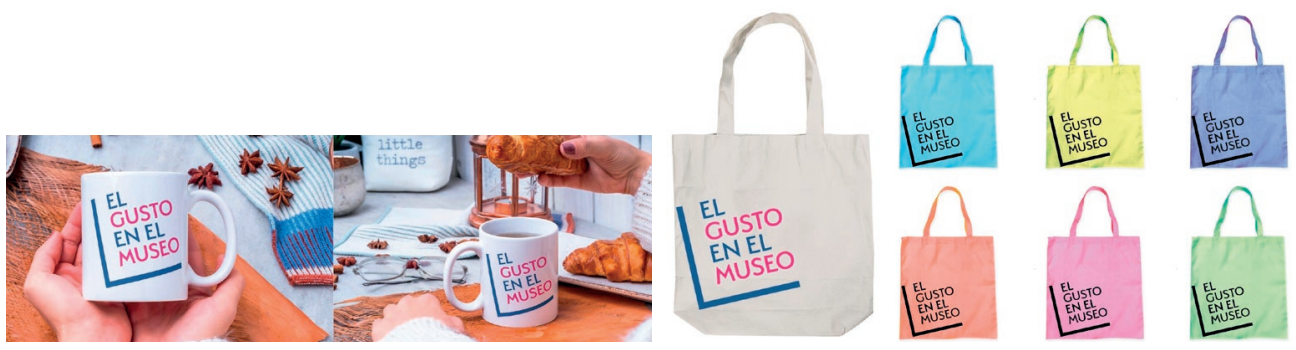

Figura 13. Prueba de concepto y aplicaciones de ejemplo. Fuente: Elaboración propia.

Tras un proceso de deliberación interna en el cual se ponderaron todas las propuestas, el cliente optó por seleccionar la primera opción. Como último paso y para validar su decisión antes de proceder con la definición del uso de la imagen creada en sus distintas ejecuciones, se presentó una prueba de concepto. En la misma se colocó, a modo de mockup, el finalista en dos aplicaciones comunes: una taza y una bolsa reutilizable.

\subsection{Fase de Publicación}

Los resultados de este trabajo pueden ser visualizados en el presente congreso y en el material vinculado al mismo. Sobre su significado, el manual de marca expresa lo siguiente: "la inclinación hacia la izquierda es un detalle que proporciona dinamismo moderno al logotipo. La esquina en forma de "L" representa el marco de un cuadro, el cual es un elemento característico de los museos tradicionales". Esta figura representa también la esquina de una mesa, lugar sobre el cual suelen disfrutarse los alimentos.

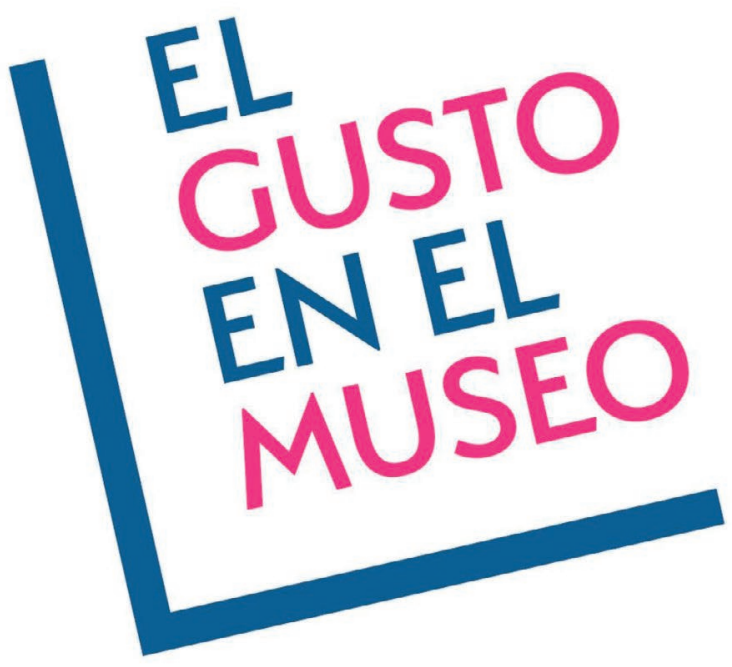

Figura 14. Logotipo seleccionado. Fuente: Elaboración propia. 


\section{Desarrollo del Manual de Marca o Brand Book}

Habiendo recibido el visto bueno del cliente, se procedió a la creación del manual de marca. También conocido como manual de identidad visual o de imagen corporativa, este instrumento tiene el propósito de mostrar la correcta utilización y aplicación de una identidad gráfica. Según lo descrito en el Manual de EGEEM: "el mismo contiene la información básica e imprescindible para el uso adecuado y reglamentario de los diferentes elementos del logotipo de El Gusto en el Museo, por lo que se sugiere leer detalladamente todo su contenido y seguir cada una de las indicaciones que se describen en los apartados de interés".

El objetivo de un brandbook es cuidar la imagen que se proyecta, sin dejar atrás aquellos aspectos que ayudan a fortalecer la cultura empresarial y el sentimiento de pertenencia. La utilidad de este instrumento radica en su claridad y en su capacidad de servir de guía ante los principales retos que se presentan al momento de ejecutar aplicaciones de una identidad visual. Su contenido varía según el tipo de proyecto y "la escuela" de la cual provenga el diseñador que lo creó. Sin embargo, es común que contenga total o parcialmente los siguientes componentes:

\section{Componentes del Manual de Identidad Corporativa}

- Símbolos de Identidad: logotipo original de reproducción; versiones en positivo, negativo, a línea; retícula de construcción; reducciones permitidas (100\%, 75\%,50\%, 25\%); disposiciones correctas e incorrectas; rotaciones correctas e incorrectas; fondos correctos e incorrectos; proporción de elementos, colores corporativos en Pantone, CMYK, RGB y tipografía corporativa.

- Papelería: tarjeta de visita, papel, sobre, folder con y sin bolsillo, portadas de carpetas, certificaciones, facturas.

- Impresos y publicaciones: etiquetas, literaturas, stickers, carteles, artes de prensa

- Uniformidad: rotulación de vehículos, uniformes del personal y equipo de trabajo, carné

- Material de promoción: lapiceros, camisetas, gorras, llaveros, memorabilia

- Señalética: con íconos y sin íconos

A modo de ejemplo, a continuación se presentarán algunos de los contenidos en el manual realizado por el diseñador Sergio Elías Taveras para el Congreso Internacional El Gusto en el Museo (EGEEM), incluyendo la Construcción gráfica, usos: permitidos y prohibidos,

\section{Construcción gráfica}

El siguiente gráfico, muestra la construcción de los elementos del logo sobre una cuadrícula en la que cada módulo $(X)$ representa una parte proporcional de la imagen.

El área de reserva es un espacio imaginario que rodea el logo y que protegerá la imagen de cualquier distracción visual. El área prevista para el espacio será proporcional a X.

\section{Usos: permitidos y prohibidos}

Dentro de los usos permitidos se encuentra la colocación sobre mágenes oscuras y elementos contratantes de fondo, fondos de color sólido con contraste, líneas y elementos decorativos al 

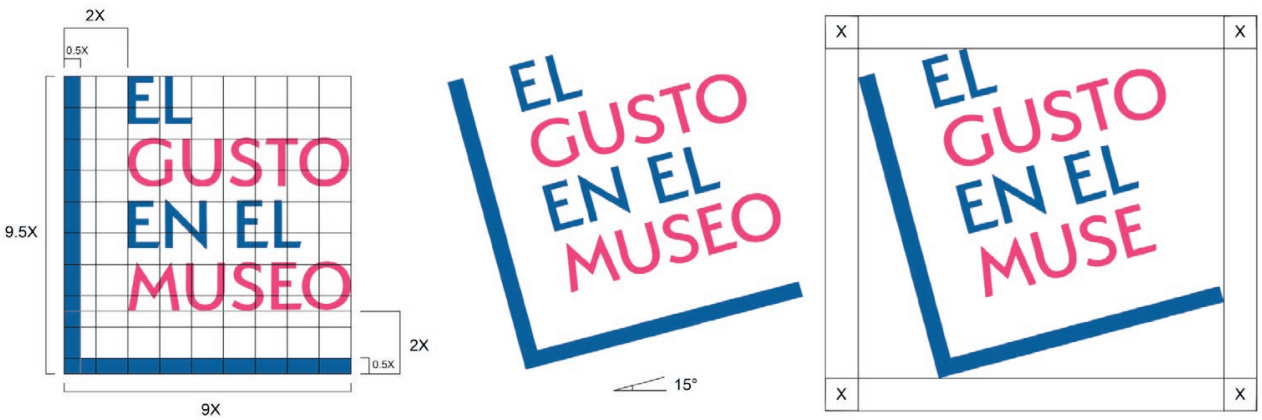

Figura 15. Construcción gráfica. Fuente: Brandbook de EGEEM.

lado de la esquina "L" del logo y disposición horizontal. Ejemplo de usos prohibidos son: alargar, aplanar, distorsionar, cambiar los colores, inversión de espacio y fondos con poco contraste.
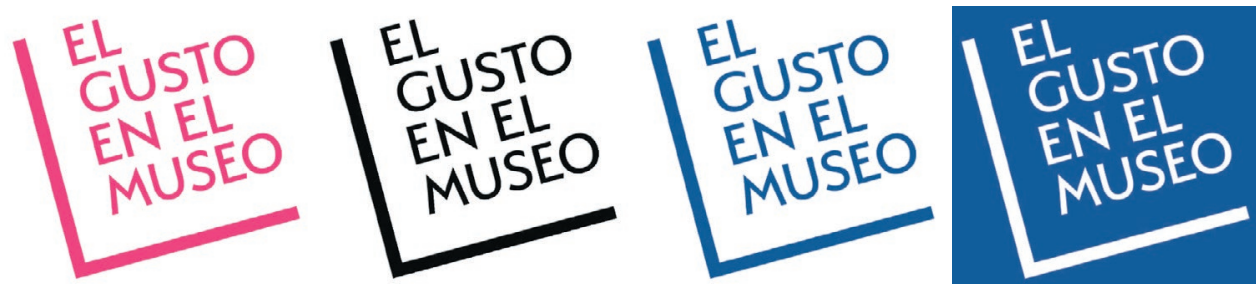

Figura 16. Versiones monocromáticas y en negativo. Fuente: Brandbook de EGEEM.

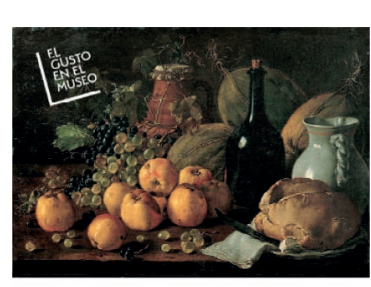

Imagen oscura y elementos contrastentes de fondo.

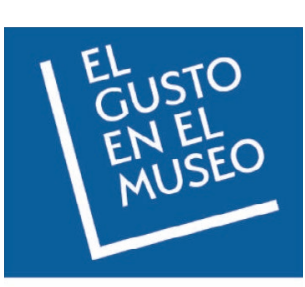

Fondos de color sólido con contraste.

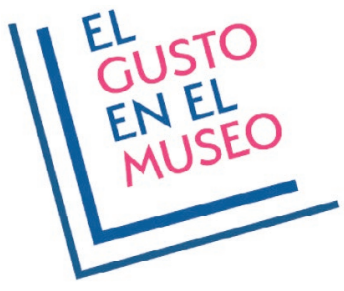

Líneas y elementos decorativos al lado de la esquina "L" del logo.

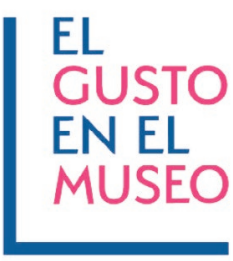

Disposición horizontal.

Figura 17. Usos permitidos.

Fuente: Brandbook de EGEEM.
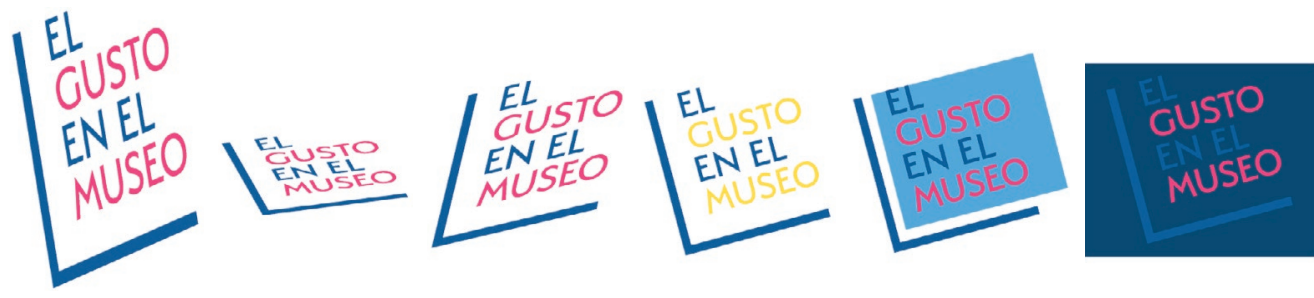

Figura 18. Usos prohibidos.

Fuente: Brandbook de EGEEM. 


\section{Ejecuciones}

Dentro de las ejecuciones incluidas en el Brandbook de EGEEM, se incluyeron la papelería, gafetes y material promocional como gorra, camiseta, pins y tazas, entre otros.

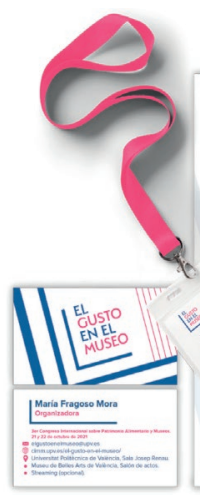

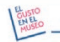

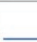
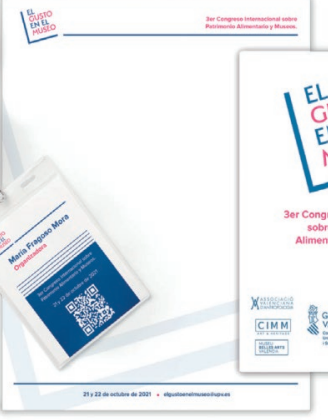
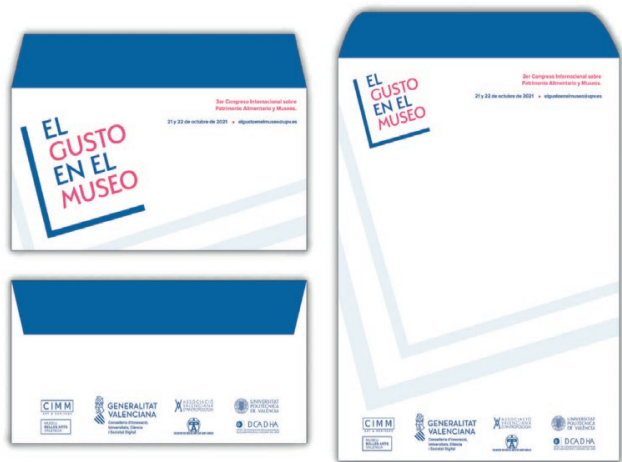

Figura 19. Papelería. Fuente: Brandbook de EGEEM.
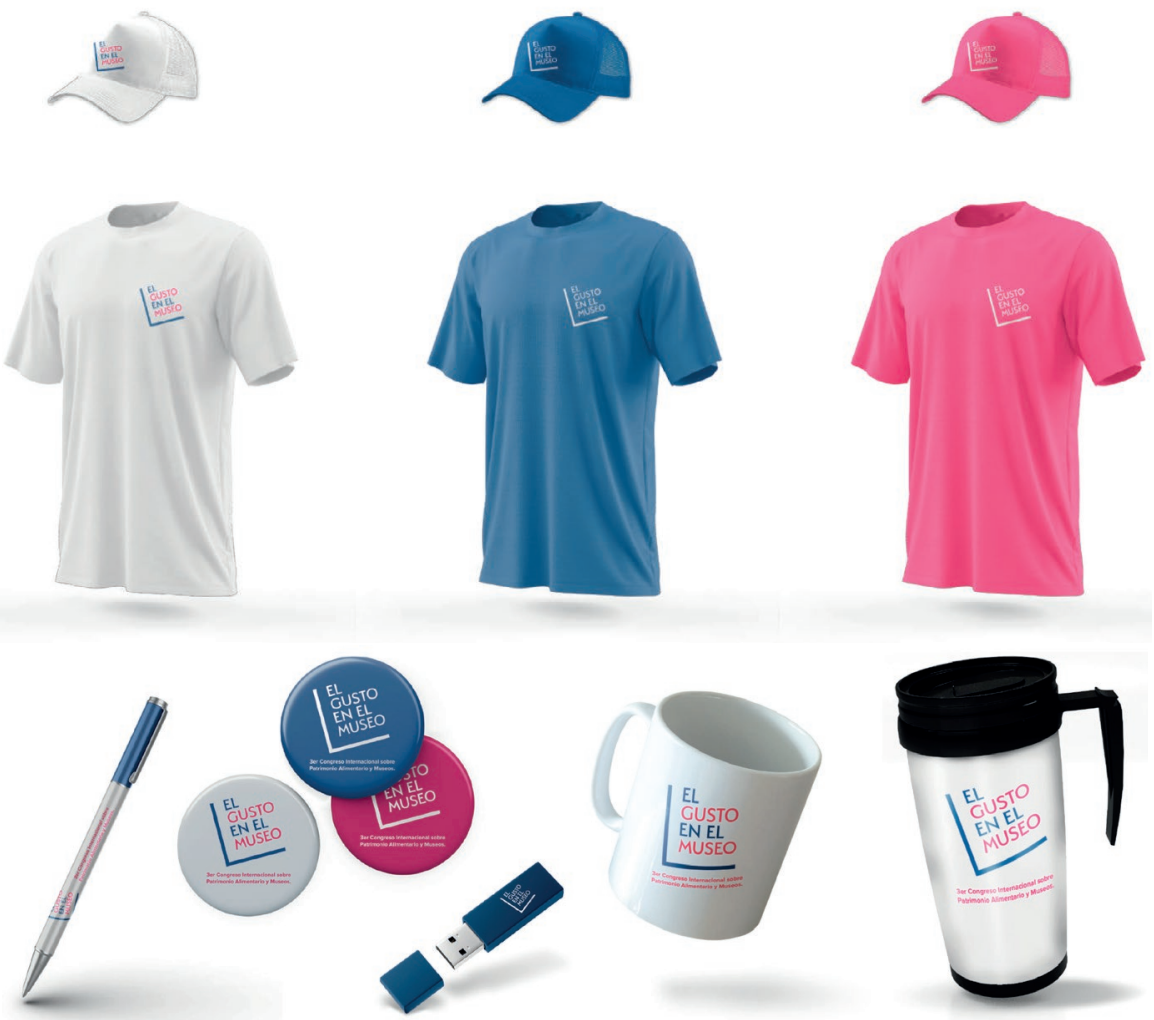

Figura 20. Material promocional.

Fuente: Brandbook de EGEEM. 


\section{Conclusiones}

El diseño gráfico, cuando se asume de forma responsable, es un proceso de investigación como cualquier otro, con la diferencia de que en vez de generar un resultado escrito y compuesto por palabras, obtenemos uno visual donde priman los píxeles, vectores y elementos cromáticos.

Según lo establecido al inicio, en el presente documento se procuró abordar, siguiendo los 5 pasos del método científico, preguntas en torno a la conexión que tienen el diseño gráfico y la producción intelectual con fines académicos. Se presentó el concepto de metodología del diseño, uniendo múltiples ideas en torno al mismo. Y, según lo expresado: se tomó como ejemplo la forma en que se realizó el abordaje del desarrollo de una identidad visual que vincula al diseño gráfico con la alimentación, la museografía y la producción académica. Permitiendo que la audiencia misma de su producto resultante, por tratarse en este caso de la imagen de este congreso, sea también testigo del proceso que llevó a su creación.

Al describir el proceso de creación de una identidad visual particular se utilizó la imagen del Congreso Internacional de Patrimonio Alimentario y Museos El Gusto en el Museo (EGEEM) como ejemplo y guía. Se presentó un análisis, desde la perspectiva metodológica, del proceso y motivaciones detrás de cada decisión dejando en el proceso pinceladas que pueden servir de guía para el desarrollo de proyectos con características similares. Así fue como una misma aplicación de diseño gráfico sirvió de ejercicio para la producción académica vinculada con la museografía y alimentación.

\section{Referencias}

BENNETT, A. (2006). Introduction: The Rise of Research in Graphic Design. Publicado en Design Studies. BONSIEPE, G. (1997). Design the blind spot of theory. Discursivity / Visuality.

COTTON, BOB. (1994). Biblioteca del diseño gráfico. Barcelona: Ed. Blume, Glosario.

CROSS, N. (1993). "Science and design methodology: A review". En: Research in Engineering Design, 5, 63-69.

GARGANTILLA, P. (2020). "¿Qué es el método científico? Estos son sus cinco pasos" ABC Ciencia. https://www.abc.es/ciencia/abci-metodo-cientifico-estos-cinco-pasos-201902170129_noticia.html [Consulta: Octubre 9, 2021].

HERNÁNDEZ SAMPIERI, R. (2014). Metodología de la Investigación. 6ta. edición. Mcgraw Hill Education. México.

MARTíNEZ SOSA, M. Y CALDERÓN MATA, L. (2007). "Propuesta de Proyecto Editorial para la ONG Hábitat para la Humanidad República Dominicana. Trabajo de Grado para optar por el título de Licenciadas en Diseño Gráfico. Universidad Apec.

MARTÍNEZ SOSA, M. (2003-2005) Apuntes de cátedra de las materias: Diseño Gráfico I, Prof. Genaro Philips. Universidad APEC. Licenciatura en Diseño Gráfico. Cuatrimestre enero- abril 2004.

Diseño Gráfico IV, Prof. Andrés Hernández. Universidad APEC. Licenciatura en Diseño Gráfico. Cuatrimestre enero- abril 2005. 
Psicología de la Percepción, Prof. María del Carmen Genao. Universidad APEC. Licenciatura en Diseño Gráfico. Cuatrimestre septiembre-diciembre 2005.

Tipografía, Prof. Fernando Rivas. Universidad APEC. Licenciatura en Diseño Gráfico. Cuatrimestre septiembre-diciembre 2004.

MEGGS, P. B. (2000) Historia del Diseño Gráfico. Ed. McGraw-Hill. México.

NOBLE, I., BESTLEY, R. (2005). Visual research an introduction to research methodologies in graphic design.

RAFF, J. (2012). "Theoretical Frameworks for the Conceptualization of Graphic Design in Use". En: Iridescent, 2(2), 10-21, https://doi.org/10.1080/19235003.2012.11428507.

SAMARA, T. (2005). Publication Design Workbook, A Real-World Design Guide. Ed. Rockport Inc., China.

TURNBULL, A. (2003). Comunicación Gráfica, Ed. Trillas. 


\title{
ILUSTRACIÓN, DISEÑO Y PATRIMONIO ALIMENTARIO
}

\author{
María Fragoso Mora \\ Universitat Politècnica de València.maframo@posgrado.upv.es
}

\begin{abstract}
Although the birth and recognition of the graphic illustration discipline can be considered recent, in an art as vast as this there are no limits to represent different objects that have their charm in a sense other than the meaning of sight. This is due to the fact that in the world of the illustration, communication and symbolic representation are prioritized in an aesthetic, adapted and exemplary support that can play in tune with a popularization content. For such a complex sense of representing taste, that is, the recreation of the palate and flavor, the illustration has been endowed with a lot of technique to represent eating rituals, food and gastronomy. These techniques can be the selection of complementary colors, the handling of textures, the elaboration of the drawing, the graphic synthesis, among others. In this study, the relationship that the illustration has had in the food sector is developed and different cases will be analyzed to elaborate the reflection. These cases reflect different manifestations of illustration of design in different cultures: the cinematographic animations of Studio Ghibli in Japan, the iconography and archetype of Mexican food in franchises and the emerging illustrators from different countries that generate current food identities.
\end{abstract}

Keywords: illustration, food heritage, food, design, graphic design, studio ghibli, mexican food, illustrators.

Resumen: Aunque el nacimiento y reconocimiento de la disciplina de la llustración puede considerarse reciente, en un arte tan vasto como este no existe límites para representar distintos objetos que tengan su encanto en un sentido diferente al visual. Esto se debe a que en el mundo de la llustración se prioriza la comunicación y representación simbólica en un soporte estético, adaptado y ejemplificador, que pueda jugar en sintonía con un contenido de divulgación. Para un sentido tan complejo de representar como lo es el gusto, es decir, la recreación del paladar y el sabor, la llustración se ha dotado de mucha técnica para representar ritos alimentarios, comida y gastronomía. Estás técnicas pueden ser la selección de colores complementarios, el manejo de texturas, la elaboración del dibujo, la síntesis gráfica, entre otras. En el presente estudio se desarrolla la relación que ha tenido la llustración en el sector de la alimentación y se analizarán distintos casos para elaborar la reflexión. Estos casos reflejan distintas manifestaciones de la llustración del diseño en diferentes culturas: las animaciones cinematográficas de Estudio Ghibli en Japón, la iconografía y arquetipo de la comida mexicana en franquicias y los ilustradores emergentes de distintos países que generan identidades alimentarias actuales.

Palabras clave: ilustración, patrimonio alimentario, alimentación, diseño, diseño gráfico, estudio ghibli, comida mexicana, ilustradores.

Citar como: Fragoso Mora, M. (2022). "Ilustración, diseño y patrimonio alimentario". En: Actas del III Congreso Internacional sobre Patrimonio Alimentario y Museos. 25-26 noviembre, 2021, Valencia, España. pp. 119-128. https://doi.org/10.4995/EGEM2021.2021.13286 


\section{Introducción}

Los límites de la representación gráfica se expanden más allá de los sentidos. Prueba de esto es que hoy en día convergemos entre miles de medios y expresiones estéticas que se adaptan a diferentes sectores, las bellas artes para la economía, la espiritualidad para el comercio, y muchas otras combinaciones más. También es el caso de la expresión gráfica de la "ilustración". Aunque el nacimiento y reconocimiento de la disciplina de la ilustración puede considerarse reciente, en un arte tan vasto como este no existe límites para representar distintos objetos que tengan su encanto en un sentido diferente al sentido de la vista. Esto se debe a que en el mundo de la ilustración se prioriza la comunicación y representación simbólica en un soporte estético, adaptado y ejemplificador, que pueda jugar en sintonía con un contenido de divulgación. Para un sentido tan complejo de representar como lo es el gusto, es decir, la recreación del paladar y el sabor, la ilustración se ha dotado de mucha técnica para representar ritos alimentarios, comida y gastronomía. Estas técnicas pueden ser la selección de colores complementarios, el manejo de texturas, la elaboración del dibujo, la síntesis gráfica, entre otras.

En el presente estudio se desarrolla la relación que ha tenido la ilustración en el sector de la alimentación y se analizan distintos casos para elaborar la reflexión. En un primer momento, se recapitula cómo se ha desarrollado la relación de expresiones gráficas (como la pintura, el dibujo y más tarde la ilustración) con la comida y la alimentación a lo largo de la historia. En un segundo momento, se habla de las características que visten a la ilustración del patrimonio alimentario. Y en un tercer momento, daremos pasos a casos de estudio que ejemplificarán distintas manifestaciones de la ilustración y del diseño en diferentes culturas: las animaciones cinematográficas de Estudio Ghibli en Japón, la iconografía y arquetipo de la comida mexicana en franquicias y los ilustradores emergentes de distintos países que generan identidades alimentarias actuales.

\section{Objetivos}

Los objetivos que se persiguen con este estudio son los siguientes:

- Comprender la evolución histórica de la disciplina de la ilustración como testimonio de ritos y tradiciones alimentarias.

- Identificar las características de la ilustración de la comida y la alimentación como propiedades logradas y distintivas en los medios de expresión gráficos.

- Esbozar el papel de la ilustración de la alimentación en diferentes medios de arte visual, como lo son los audiovisuales, el diseño y el sector comercial.

- Exponer 3 casos de estudio en diferentes culturas y geografías para ser una muestra representativa de las técnicas de la ilustración en el patrimonio alimentario.

\section{Desarrollo de la innovación}

\subsection{El posicionamiento de la ilustración actual}

No es un asombro reconocer que la representación gráfica de la vida y las cosas se vea explícito en la historia. A lo largo de los años, un sinfín de personas con manos hábiles se dedicaron a documentar la experiencia tangible e intelectual a través de formas y manchas. En el devenir del 
ser humano se encuentran múltiples muestras de esta intención gráfica desde antes de la formalidad histórica que supone la escritura. Porque antes de una intención codificada y alfabética, hubo una expresión sutil y sencilla pero completamente dotada de semántica, con esto se hace referencia a la expresión del dibujo, e incluso la pintura, mucho antes de su conceptualización. Las pinturas rupestres son el ejemplo más claro de dicha expresión, dónde el objetivo de su creación no era mucho menos estético, sino mucha veces meramente comunicativo y posiblemente espiritual.

La evolución de la expresión de lo gráfico ha tenido diversas variantes. Jaques Aumont (1992) en su obra La imagen, menciona que la construcción de imágenes gráficas crea relaciones con el espectador que las observa, esto gracias a los valores representativos o simbólicos que "entregan mensajes de acuerdo con la intención del autor y, utilizadas en contextos socioculturales específicos, pueden influir en la forma de pensar de las personas" (Menza, 2016, p. 267). Esta forma de comunicación se fue consolidando como una bella arte por medio del concepto de pintura, (posteriormente se reconocido el dibujo) y hasta su innegable implicación con el ejercicio de la arquitectura y las matemáticas. Sin embargo, el gran concepto que nos atañe en la presente investigación es ejercicio de la ilustración, una variante que sale de las artes plásticas y del diseño gráfico como la expresión más contemporánea de la expresión gráfica histórica.

Se puede considerar que la disciplina de la ilustración nace formalmente en el siglo XIX, al tiempo que nacen los primeros esbozos del diseño gráfico y la tendencia de las "arts \& crafts". Sin embargo, no hay que olvidar que ya en la Edad Media, cuando los copistas de los monasterios reescribían los inicios de libros, se tomaban la tarea de adornar y decorar dichos manuscritos con imágenes alusivas y llamativas, siempre a mano. Por algo se llamaban los manuscritos "miniados" por las miniaturas.

La ilustración tiene una antigüedad considerable en acción. Ha estado presente especialmente en el sector de los libros y, si acaso, podríamos mencionar que nace directamente del ejercicio editorial. Porque la ilustración nace para "iluminar", "dar luz", a la información escrita, se consolida como recurso necesario ante una masa poblacional que solía ser analfabeta, como lo fueron por mucho tiempo las pinturas eclesiásticas del románico del maestro de Tahull, los vitrales góticos de Notre Dame de París o los murales gigantes de Diego Rivera y Siqueiros.

Se considera que la ilustración "ha tenido gran importancia como un recurso de comunicación visual, y ha favorecido la comprensión de textos y transmisión de mensajes en ámbitos educativos, científicos y culturales, a través de medios como carteles, libros narrativos, educativos o científicos" (Menza, 2016, p. 267). Laura Varsky define a la ilustración como "un dispositivo comunicativo". Donde su actuación principal es "la construcción de discurso a partir de la imagen. Y en esa construcción se pone en juego la voz de quien ilustra. Su manera de ver al mundo, de interpretarlo y transmitirlo." Esta definición es un conjunto fresco y flexible que responde a la expresión de la ilustración hoy en día. Porque ya está creada para dar soporte y complemento a un texto escrito, sino para tener una voz propia que no llega a ser un discurso firme y establecido como lo podría ser una pintura. Hoy en día, se reconoce que la ilustración es una disciplina que nace contemporáneamente y tiene cabida en espacios académicos.

Sin embargo, el símil interesante para hablar de los ancestros de la ilustración es justamente rememorar la consideración de las pinturas rupestres. El dibujo prehistórico estaba dotado de vida y movimiento porque se implicaban directamente en la vida de sus autores. Al contrario del 
bodegón, por ejemplo, también llamado "naturaleza muerta" que representa una estática inmovible, solemne, que enmarca un cuadro entorno a objetivos alimentarios.

La ilustración hoy en día se abre caminos mediante diferentes canales. Uno de ellos, tal vez el más mediático, es el de las Redes Sociales. A partir de que las plataformas como Facebook, especialmente Instagram y recientemente Tik Tok, se consolidan como escaparates para el contenido audiovisual la industria de los creadores de arte gráfico y visual tomaron la oportunidad para que su propio perfil se convirtiera en un portafolio y más allá: los contenidos digitales en las Redes Sociales se han convertido en una gran muestra de curaduría, al punto de que la "curación de contenidos" es un término oficial y potente para la comunicación y el marketing. Justamente, la ilustración contemporánea ha aprovechado la situación, muestra de ello es la inmensa cantidad de artistas, diseñadores e ilustradores que están expresamente declarados como tal en la información de su perfil personal.

La manifestación de la ilustración en Redes Sociales responde directamente a los movimientos y tendencias de diferentes industrias. Mientras que para el mundo editorial se complementa con la escritura, como es el caso del Álbum Ilustrado donde narrativa y grafica son inseparables, la ilustración se ha valido para involucrarse en el mundo audiovisual, especialmente en la innovación, pero también en el sector comercial. La ilustración ahora, además de ser una expresión artística por sí misma, se usa también para vender.

Existen variedad de ejemplos de ello: la industria de la moda tiene como tendencia la selección de ilustradores para confeccionar piezas de ropa y accesorios de colección, los objetos de papelería y de uso personal han seguido la misma tendencia, y más aún, los comercios del sector de la hostelería no se han quedado atrás. Mientras que en la inmaculada figura del pintor se buscaba conseguir una obra individual para colocarla en una entidad de prestigio, público o privado, ahora los encargados de hoteles, restaurantes o incluso las PYMES, buscan decorar sus infraestructuras con motivos ilustrados o para configurar toda su identidad y comunicación corporativa.

Las diferentes técnicas de ilustración en el siglo XXI son una muestra flexible y dinámica de cómo la representación gráfica puede establecer un diálogo más íntimo y cercano con sus espectadores. Muestra de ello se desarrollará al detallar cómo se ha relacionado la ilustración contemporánea con el patrimonio alimentario y cuáles son los grandes atinos que tiene como oportunidad de posicionamiento para la industria y la recreación del entretenimiento.

\subsection{Dibujos deliciosos}

La injerencia que ha tenido la ilustración en la industria de la alimentación es un fenómeno particular. Pues ha trazado su propio camino a través de las múltiples expresiones que demuestra la ilustración hoy en día.

Un concepto popular para definirnos a este tipo de patrimonio alimentario es llamado la "ilustración gastronómica" que está presente en los modos de preparar alimentos, como lo son las recetas y también en la industria de la hostelería. Este tipo de ilustración se reconoce principalmente en la industria editorial, tanto en libros como en revistas que tienen una sección especial dedicada a la alimentación y a la preparación de alimentos. Sin embargo, también el llamado packaging, que es la técnica de crear embalajes y envases para productos, se ha valido de la ilustración para mejorar la comercialización de los alimentos. Hoy en día, la ilustración de comida, 
alimentos y modos de cocinar está muy presente en la web 2.0, donde las redes sociales y las plataformas digitales necesidad indiscutiblemente de una curación de contenidos multimedia. La ilustración, como se ha dicho anteriormente, ha tenido un papel cumbre para esta creación de contenidos, y el sector de la alimentación no se queda atrás.

Como se ha dicho, se pensaría que el bodegón sería el antecedente directo de la ilustración de alimentos y comida, sin embargo, se encuentra más similitud en la representación del rito alimentario expresado en las pinturas rupestres. La historia de la "ilustración gastronómica" o también Ilamada "Food Illustration" como concepto definitorio en inglés, se remite a los orígenes del diseño como herramienta de comercialización, desde los carteles hechos a mano que señalaban cafeterías y restaurantes, hasta los grandes anuncios espectaculares de gran tamaño que comenzaron a valerse del diseño gráfico para invitar a la audiencia al consumo.

Dentro de este tipo de ilustración, se puede encontrar la representación de las características propias del gusto ¿cómo se logra esta complementariedad? A continuación, presentamos aquellas características propias del arte plástico de la ilustración que permite esbozar los atributos del la comida y los alimentos:

- En la ilustración se encuentra una delimitación de los detalles tangibles de los alimentos, especialmente la capacidad de transmitir texturas, temperatura y densidad.

- La propuesta de colores y su alteración, permite que colores brillantes y con gran saturación den la sensación de ser apetecibles. Atributos indispensables para enmarcar el sentido del gusto.

- Búsqueda de la sencillez, y así lograr la capacidad de esbozar los platos de manera simple, aunque contengan diferentes ingredientes.

Estos tres atributos han permitido que la ilustración pueda representar los atributos de la comida y la alimentación de forma atractiva. Sin embargo, no es hasta ver una serie de ejemplos visuales que se puede ejemplificar esta teoría. Por ello, a continuación, se presentan tres casos de estudio que ejemplificarán como la ilustración de comida y alimentos está tomando camino en los medios y también en la industria propia de la alimentación.

\subsection{Comida animada: el caso del Studio Ghibli de animación en Japón}

Studio Ghibli es un estudio japonés de animación audiovisual que fue fundado en 1985 por el director de cine Hayao Miyazaki. Tiene un 23 largometrajes y 10 cortometrajes en su historia y múltiples premios por la crítica especializada de todo el mundo. Ha realizado diversas películas que han sido galardonadas y posicionadas dentro de la cultura popular, como lo es El viaje de Chihiro (2001), Mi vecino Totoro (1988), El castillo ambulante (2004), entre otras.

Las películas de Studio Ghibli se caracterizan por la técnica de animación 2D por tener unos paisajes iluminados con un gran nivel de detalle y por desarrollar temáticas entorno a la infancia, la vida cotidiana, las tradiciones japonesas, las relaciones familiares, las situaciones de problemáticas sociales, entre otras. Al ser una técnica de animación plástica 2D, es a partir de ilustraciones donde se desarrolla el movimiento de sus elementos y la intencionalidad gráfica. Por ello, una de las características que se quiere destacar en esta investigación es la presencia de la ilustración de comida y alimentos que aparecen en la mayoría de las películas; los cuales 
han sido muy característicos porque muestran un nivel mayor de detalle que otros elementos de la película como los personajes o los edificios.

De hecho, el estudio fue consciente de esta característica, pues en 2017, el Studio Ghibli Museum anunció la exposición "Delicious! Animating Memorable Meals" para representar y hablar de la experiencia alimentaria de los filmes. En la página del museo, en la presentación de la exposición, se lee como el estudio ha reconocido la importancia de esta representación gráfica:

Los fanáticos pueden recordar impresiones profundas de comida y escenas de comida en las películas de Studio Ghibli. (...) Las escenas de comidas informales están impregnadas de una enorme importancia narrativa. (...) Lograr un efecto dramático y crear comidas deliciosas y personajes que las disfruten (sus expresiones y gestos) proviene del poder de los dibujos finamente detallados. Alimentos que aún están calientes, que se ven suaves y tiernos, con el maravilloso sabor que se muestra en los rostros de quienes los comen: estas escenas de comidas son atractivas y encantadoras. No se necesita diálogo para transmitir la delicia y la felicidad. (Ghibli Museum, 2017)

La influencia de la comida en las películas de Studio Ghibli ha tenido tanta influencia en su público, que hay numerosos ejemplos de iniciativas que tratan de recrearlas. Como es el caso de la chef EN93, quien en su cuenta oficial de Instagram

(@en93.kitchen) se ha dedicado a recrear los platillos de las escenas de Studio Ghibli y con un número de 160 mil seguidores, ha dado una tendencia para que otros miles de usuarios sigan los pasos de consumir los alimentos de estas películas. De hecho, recientemente en 2021 se publicó el libro Las recetas de las películas del Studio Ghibli por la editorial Col\&Col Ediciones.

En 2021, en su cuenta de Twitter, el cofundador de Studio Ghibli, Toshio Suzuki ofreció una sesión de preguntas y respuestas, y una de las inquietudes que persistía en el público era la pregunta por la realización de la comida en las películas de Estudio Ghibli. El público preguntaba cómo se conseguía esa apariencia an atractiva y ese nivel de detalle. A lo que el con fundador respondió: "La razón por la que la comida luce tan bien es porque toda esa comida ya había sido cocinada por Miyazaki", haciendo alusión a la búsqueda perfecta del detalle por la cual el estudio ha alcanzado fama internacional.

El caso de la ilustración en los alimentos de las películas de Studio Ghibli es uno de los ejemplos más representativos de la cultura popular para hablar de este sincretismo entre diferentes sentidos, como el sentido audiovisual puede compaginar perfectamente con el sentido del gusto exponiendo características que hacen de la expresión artística una experiencia sensorial.

Studio Ghibli y su bagaje tradicional propios de la cultura en la que se inserta reconocen la valía de reconocer el patrimonio alimentario a través de la ilustración animada:

Dibujar comida es dibujar cultura e historia, lo que requiere una variedad de conocimientos y curiosidad para crear imágenes cinematográficas ricas. (...) Esperamos sinceramente que llegue a comprender la profundidad y riqueza de las escenas de comida que están llenas de vida. (www.ghibli-museum.jp, 2017)

La aceptación de la animación 2D, la ilustración del tipo "cartoon" o "anime" con muestras ya reconocidas y analizadas en espacios académicos y ahora, con la mirada desde el patrimonio alimentario, son también testimonios para el análisis de su influencia en la sociedad.

\subsection{El arquetipo y el ícono: el caso del diseño en la comida mexicana}

En el año 2010, la gastronomía mexicana fue declarada Patrimonio Cultural Inmaterial de la Humanidad por la Organización de las Naciones Unidas para la Educación, la Ciencia y la Cultura 
(UNESCO). Con este anunció se reconocía que la cocina en México es elemento crucial de identidad nacional, debido a su historia, creatividad, diversidad y trascendencia. (Fernández, 2016).

La mediaticidad que tiene la comida mexicana en el mundo ha dado nacimiento a una variedad grande de proyectos que tratan de llevar esa experiencia alimentaria a todos lados. Con esto nos referimos a las franquicias y restaurantes colocados fuera de la República Mexicana con la intención de llevar una experiencia extranjera a las calles de otros países. Como ha sido el caso de Taco Bell, Chipotle Mexican Grill o Chili's. Cabe destacar que, aunque el mercado de las franquicias de comida mexicana es significativo para este caso de estudio, es cierto que hay una curiosa uniformidad en restaurantes emergentes en muchos países donde se copia el estilo de comida mexicana sin pertenecer a ninguna corporación.

La característica que nos importa ahora de estas franquicias emprendedoras es el uso de la ilustración y el diseño que ha consolidado su imagen corporativa y que ha llegado a influir en la propia imagen de los alimentos que ofrecen. El ejemplo más representativo es el de Taco Bell, quien le ha vendido al mundo una imagen tradicional errónea del famoso platillo del "Taco". O Chili's, donde le da prioridad de su menú es presentar una mezcla variada de comida aparentemente picante pero que dista mucho de pertenecer a la tradicional comida mexicana reconocida por la UNESCO.

Dentro de las tendencias del diseño para la industria de la comida preparada, se destaca el llamado Food design para referirse a una disciplina que aplica al hecho gastronómico estrategias y métodos propios del diseño. Que al mismo tiempo "se entiende como una representación anticipada del acto alimenticio, aunque el concepto abarca mucho más que la pura decoración culinaria: desde la producción hasta la presentación, comunicación, comercialización, consumo del alimento... y su relación con todos los agentes involucrados" (Scoolinary, 2021). Sin embargo, además de la técnica del emplatado, que consiste en presentar alimentos en platos con fotografías estéticamente atractivas, lo que han hecho las franquicias arquetípicas de comida mexicana es modelar la imagen global que se tiene de este tipo de comida.

Para el diseño gráfico es fundamental jugar con sus elementos, como el color, el tamaño, la composición "de tal manera que se busque un objetivo visual y que el receptor logre decodificar e identificar el propósito, siempre cuidando la estética y la realidad de la imagen fotográfica" a la que están sujetos (García et al, 2020, p. 122). Y uno de los objetivos buscados para la promoción de una tradición alimentaria, es que un gran número de personas puedan apreciarla y disfrutarla:

"la gastronomía mexicana traspasa fronteras de forma significativa, por su historia, diversidad de ingredientes, técnicas, por su sabor, color, textura, aroma y los aportes nutricionales, por lo que cada día existen más restaurantes de comida mexicana en otras fronteras con una gran connotación e impacto en la sociedad. (García et al, 2020, p. 131)

Sin embargo, lo que han hecho las franquicias de cómica mexicana, es elaborar un diseño dinámico, limpio y "caricaturesco" de las formas de expresión de estos alimentos. Muchas veces manipulando su verdadera composición con tal de verse "atractivos" y casi "plastificados". Esto podría no verse exclusivamente en la comida mexicana. En la gastronomía china o la tailandesa, la italiana, la española, la japonesa, entre muchas otras, hay diferentes muestras de cadenas de restaurantes que buscan la adaptación de sus alimentos para llevar a todo el mundo. Solo que esta adaptación ha sido un cambio de identidad, de imagen y de elaboración para la comida mexicana. 
Anthony Bourdain, chef estadounidense con reconocimiento internacional especializado en comida mexicana expresó que "encontraba muy injusto que nuestra comida estuviera aún estereotipada como fritanga barata, pues la comida mexicana va más allá de los tacos o los burritos" (TKM en García et al, 2020, p. 132). Afortunadamente, iniciativas como el Conservatorio de la Cultura Gastronómica Mexicana (órgano consultivo de la UNESCO) o al Fundación Herdez tienen diferentes esfuerzos para conservar y difundir la tradición alimentaria en México desde sus orígenes y construcción histórica.

La ilustración y el diseño gráfico aplicados a la alimentación tradicional de cada país es una responsabilidad mediática, pues muchas veces la configuración gráfica afectará directamente al modo de posicionar un alimento y de compartirlo con más personas.

\subsection{Chefs de tinta: el caso de la ilustración alimentaria actual}

Como bien se ha mencionado anteriormente, la ilustración de alimentos y comida es una tendencia que va en alza no solo por su atractivo estético, sino también para su funcionalidad en muchos productos culturales. Ejemplo de esto es la siguiente lista de artistas que han innovado dentro de la ilustración de comida y alimentos.

- Melanie Chadwick. Es una ilustradora británica especializada en comida y mapas, los resaltan por su particular manera de los colores, las líneas y de toda la narrativa que atraviesan. Ha colaborado con diversas empresas para ilustrar la imagen corporativa, como Cornish Seasalt, Foodmentary, Ferment Magazine, American Airlines y Virgin Atlantic, entre otros. Tiene un curso en la plataforma Domestika de cursos asincrónicos titulado "Recetas ilustradas: crea dibujos deliciosos".

- Marinie Ruiz de Cabañas. Es una ilustradora española-mexicana que se decida a la ilustración de alimentos y colabora con diversos periódicos y publicaciones periódicas como El País, Buen Vida, Sobremesa. En boca de la propia artista, ella menciona que este tipo de expresión gráfica implica "pintar lo que comemos, lo que nos gusta, pintar nuestras tradiciones y nuestra cultura culinaria”, Afirma que por eso "la ilustración gastronómica tiene muchas variantes en el mundo dependiendo del ilustrador, donde viva y qué tipo de comida es la que pinta" (Ruiz de Cabañas, Palmera Magazine, 2021).

- Pier Paolo Spinazze. Es un artista italiano que se ha dedicado al streetpainting y al grafiti. Su propuesta se destaca por elaborar grafiti de comida para omitir y borrar mensajes de odio, especialmente aquellos que hacen referencia al racismo y la xenofobia.

- Chow Hon Lam. Es un ilustrador de Malasia también conocido como Flying Mous, que se dedica especialmente a la ilustración de humor, que ha permeado en otros proyectos de ilustración en ropa y tiras cómicas. Tiene una serie de ilustraciones donde convierte a los alimentos en personificaciones humanas en diferentes situaciones irónicas.

- Gretchen Röehrs. Es una ilustradora y diseñadora de moda estadounidense que ha configurado una exposición de ilustración de ropa intervenida a con diferentes alimentos reales.

- Pablo Fernández Tejón. Es diseñador, ilustrador y fundador del estudio gráfico ovetense Pixelbox que dedica u proyecto al año a hacer la sinergia entre alimentación y arte. En 
2015 presentó un proyecto titulado "llustradores a la mesa" donde hizo una selección de ilustradores para plasmar ilustraciones en platos.

Todos estos ilustradores han buscado maneras de exponer en su narrativa gráfica a los alimentos, su preparación, sus texturas, sus ingredientes y su manera de degustarlos. Cabe destacar que la lista de ilustradores de alimentos, ilustradores gastronómicos o también llamados "food ilustrators" es amplia y vasta, y con la exposición de las redes digitales, el catalogo de artistas va en aumento, así como la motivación para incursionar con técnicas graficas.

\section{Conclusiones}

El patrimonio alimentario representado en la ilustración tiene sus orígenes en tiempos remotos, desde el primer momento en que el ser humano fue capaz de representar en su vida cotidiana de manera gráfica, mucho antes de que comenzara la escritura. La expresión de los alimentos en las artes plásticas es un lugar común, pues el rito alimentario es parte inherente a una cultura, una tradición, un saber de valores, una relación social y espiritual también. Y esto no solo se le atribuye a las artes plásticas, sino también a la literatura y a otras disciplinas. En el caso de la reciente consolidación de la ilustración como disciplina artística, su relación con los alimentos y la comida ha marcado tendencia en diferentes sectores, especialmente en el comercial y el de la hostelería, pues es gracias a la implementación del diseño e ilustración, marcas enteras, corporaciones alimentarias, franquicias de restaurantes logran abrirse camino en el mercado a satisfacción de los consumidores.

De igual manera, la ilustración ha logrado configurar y desarrollar diferentes identidades gastronómicas a lo largo del mundo, como es el caso de los dos primeros casos de estudio. Tanto la comida japonesa se ha reinventado en la cultura popular gracias a Studio Ghibli en Japón, tanto como la comida mexicana se ha resignificado a lo largo del mundo gracias a franquicias como Taco Bell. La ilustración no ha sido inocente al momento de incrustarse en el mundo del patrimonio alimentario. Pero es una incursión que nos ha llevado a conocer innumerables propuestas de artistas que quieren revalorizar la comida como un arte, una manera de relacionarnos y una manera de expresarnos.

\section{Bibliografía}

(2015). "Comida ilustrada: Gretchen Röehrs". Itfashion. Consultado en: https://www.itfashion.com/ cultura/ilustracion/comida-ilustrada-gretchen-roehrs/

(2017). "Delicious! Animating Memorable Meals". Ghibli Museum. Consultado en: https://www.ghiblimuseum.jp/en/exhibitions/013127/

Cisternino (2015) ."Pon una ilustración en tu plato” República. Consultado en: https://www.republica. com/pan-del-dia/2015/10/22/pon-una-ilustracion-en-tu-plato/

(2020). "Una japonesa convierte en realidad la deliciosa comida de las películas de Ghibli” La Vanguardia. Consultado en: https://www.lavanguardia.com/cribeo/estilo-de-vida/20200816/482808563272/ japonesa-convierte-realidad-deliciosa-comida-peliculas-studio-ghibli-hayao-miyazaki-instagram. html 
(2020). "La vida diaria de la comida y bebida en divertidas ilustraciones". Old Skulls. Consultado en: https://www.oldskull.net/design/la-vida-diaria-de-la-comida-y-bebida-en-divertidas-ilustraciones/

(2021). "Recetas ilustradas: crea dibujos deliciosos". Domestika. Consultado en: https://www. domestika.org/es/courses/2008-recetas-ilustradas-crea-dibujos-deliciosos

Fernández. (2016). "Cómo llegó la gastronomía mexicana a ser patrimonio de la humanidad". Forbes. Consultado en: https://www.forbes.com.mx/forbes-life/ gastronomia-mexicana-patrimonio-de-la-humanidad/

García Hernández, et al. (2020). "El alcance de la gastronomía mexicana en otras fronteras a través del diseño gráfico por el medio de la Web”. En: Arte y diseño: discursos de la identidad cultural en América Latina. Núm. 101. Buenos Aires. Consultado en: https://fido.palermo.edu/servicios_dyc/ publicacionesdc/cuadernos/detalle_articulo.php?id_libro=819\&id_articulo=16929

Ibarra. (2021) ."Toshio Suzuki explica el diseño de la comida de las obras de Studio Ghibli”. PlayerOne. Consultado en: https://www.playerone.vg/2021/04/05/toshio-suzuki-comida-studio-ghibli/

Menza Vados. (2016). "La ilustración: dilucidación y proceso creativo". KEPES Grupo de Estudio en Diseño Visual, 13. Núm 13, pp. 265-296. Consultado en: https://revistasojs.ucaldas.edu.co/index. $\mathrm{php} /$ kepes/article/view/2770

Padilla. (2021). "Tamales, sal y pan de muerto: Por qué los alimentos son fundamentales para el Día de Muertos". Los Ángeles Times. Consultado en: https://www.latimes.com/espanol/vida-y-estilo/ articulo/2021-11-01/alimentos-comidas-dia-de-muertos

Ruiz de Cabañas. (2021). "Ilustración Gastronómica: Marinie Ruiz-de-Cabañas es la Artista que Pinta Comida". Palmera Magazine. Consultado en: https://palmeramagazine.com/ ilustracion-gastronomica/

Scoolinary Blog. (2021). "La importancia del diseño gráfico en la decoración culinaria". Scoolinary. Consultado en: https://blog.scoolinary.com/la-importancia-del-diseno-grafico-en-la-decoracionculinaria/

Valdes. (2020). "Con increíbles ilustraciones de comida, joven borra grafitis llenos de odio". Menuacapulco. Consultado en: https://menuacapulco.com/2020/12/29/ con-increibles-ilustraciones-de-comida-joven-borra-grafitis-llenos-de-odio/ 


\title{
MANJARES DE SEDA: FRUTOS Y BORDADO EN LOS MUSEOS DE LORCA
}

\author{
David Francisco Torres del Alcázar \\ Historiador del arte.Universidad de Murcia.davidfrancisco.torres1@um.es
}

\begin{abstract}
The embroidery tradition in Lorca dates back to the 16th century and underwent an extraordinary development at the beginning of the 20th century with the so-called golden age. Since then, embroidery has become a sign of the city's identity, characterised by a refined technique and an eminently naturalistic style, developed in noble materials on rich and sumptuous fabrics. Such is the development of this sumptuary art in Lorca, that there are several museums in the municipality that have embroidery as the axis of their exhibition discourses or make up their main collection. The muBBla, the White Brotherhood embroidery museum, and the MASS, the Blue Brotherhood museum, have among their collections an important number of silk and gold embroideries, some of which have been declared Artifacts of Cultural Interest. Among the collections of a biblical nature, there is a group of works that show pomegranates, grapes, dates and apples in silk. The cavalry of the explorers to the land of promise and the mantle of Bacchus exhibited in the MASS or the mantles of King Ahasuerus and that of Caesar Galerius treasured by the muBBla reveal the great iconographic symbolism of fruit related to history and religion.
\end{abstract}

Keywords: embroidery, fruit, Lorca, silk, gold, museum, iconography.

Resumen: La tradición del bordado de Lorca se remonta al siglo XVI y experimenta un desarrollo extraordinario a principios del siglo XX con la denominada época dorada. Desde entonces el bordado se ha convertido en un signo de identidad de la ciudad caracterizándose por una técnica depurada y un estilo eminentemente naturalista, desarrollado en materiales nobles sobre tejidos ricos y suntuosos. Tal es el desarrollo que ha experimentado este arte suntuaria en Lorca, que son varios los museos existentes en el municipio que cuentan con el bordado como eje de sus discursos expositivos o conforma su colección principal. El muBBla, museo de bordados, y el MASS, museo azul, cuentan entre sus colecciones con un importante número de bordados en sedas y oro, algunos de ellos declarados Bien de Interés Cultural. Entre las colecciones de carácter bíblico, destacaremos un conjunto de obras que muestran matizadas en sedas granadas, uvas, dátiles o manzanas. La caballería de los exploradores a la tierra de promisión y el manto de Baco expuestos en el MASS o los mantos del rey Asuero, y del césar Galerio atesorados por el muBBla nos desvelan el gran simbolismo iconográfico de los frutos relacionado con la historia y la religión.

Palabras clave: bordado, fruta, Lorca, seda, oro, museo, iconografía.

Citar como: Torres del Alcázar, D. F. (2022). "Manjares de seda: frutos y bordado en los museos de Lorca". En: Actas del III Congreso Internacional sobre Patrimonio Alimentario y Museos. 25-26 noviembre, 2021, Valencia, España. pp. 129-141. https://doi.org/10.4995/EGEM2021.2021.13628 


\section{Introducción}

Las colecciones de bordado de Lorca destacan por la variedad de sus temas, la riqueza de sus iconografías y la gran calidad técnica adquirida a lo largo de cientos de años de tradición. Arrancando como bordado puramente litúrgico en el siglo XVI, con motivo de la necesidad de surtir de bienes suntuarios de calidad al magno proyecto de construcción de la que debió ser la catedral de Lorca, y continuando con el bordado institucional propio del Ayuntamiento o los Patronos de la ciudad, tendrá su período de esplendor durante el primer tercio del siglo XX la llamada época dorada del bordado lorquino. Durante esos años se realizarán grandes obras de bordado de la ciudad destacando entre ellas sendos conjuntos destinados a decorar los tronos de las imágenes de las vírgenes titulares de las dos principales cofradías de la Semana Santa lorquina, ambos declarados Bien de Interés Cultural en 2005. Pero la pericia de las bordadoras lorquinas llega más allá de los esperados elencos de piezas destinadas a la devoción entorno a las imágenes religiosas o el bordado heráldico propio de las instituciones de la ciudad, y se desarrolla de forma extraordinaria en lo que se ha venido a llamar el bordado bíblico: aquel creado con el fin de representar la Historia de la Salvación en las singulares procesiones de Semana Santa lorquinas. Estos desfiles reviven cada año a personajes históricos y bíblicos dentro de un concepto catequético completamente alejado del patrón tradicional con el que se celebra en España la semana de pasión, y creando, aún hoy, una importante demanda de bordados para vestir a estos personajes.

Como podemos vislumbrar, esta realidad del bordado lorquino ha dado lugar a importantes colecciones textiles que son atesoradas por gran variedad de instituciones civiles y religiosas. Entre las primeras destacan el Excmo. Ayuntamiento y la Federación San Clemente, Patrón Lorca, con significativas colecciones de textiles que se remontan al siglo XV y se fundamentan en bordados de tipo heráldico e histórico entre los que sobresalen el Pendón de Lorca y los que conforman la Colección de la Vexilia, íntimamente unida a los hechos históricos y de armas de la ciudad.

Entre las religiosas debemos destacar la colección de la Real Hermandad de Santa María de las Huertas con un extraordinario manto bordado por las Hermanas Gilart en el obrador del Palacio Real por encargo de la reina Isabel II y entregado en 1857 (Belda, 2001), o el rico patrimonio atesorado por las cofradías de Semana Santa, en especial los Pasos Blanco y Azul. La existencia de estas colecciones dio lugar a la creación desde finales de los noventa de instituciones museísticas dedicadas a exhibir estas obras como parte de sus discursos expositivos o como eje principal de los mismos, jalonando la práctica totalidad del mapa de museos municipal.

Antes de adentrarnos en el conjunto de piezas que son objeto de estas líneas, creemos necesario recordar los tipos de instituciones museográficas existentes en la Región de Murcia atendiendo a la ley de museos autonómica (Región de Murcia, 1996). Debemos por tanto establecer fundamentalmente dos tipos: las colecciones museográficas como el MUPAEN o la Casa-Museo Nicolás Salzillo, que cuentan con fondos de obra artística que cumplen unos requisitos mínimos legales, y museos como el muBBla, museo de bordados Paso Blanco, el MASS, museo azul de la Semana Santa o el ciuFRONT, museo medieval de Lorca, que cuentan, más allá de un discurso expositivo establecido, un inventario de sus obras y una apertura regulada, con un gabinete de investigación, proyectos de enseñanza y divulgación, y, sobretodo, con un programa de conservación científica a cargo de personal cualificado. 
Entre las colecciones del MASS y del muBBla destacaremos en este escrito diferentes obras en las que se representan en su iconografía o programa decorativo motivos vegetales relacionados con especies frutales o representaciones de otros alimentos bordados en sedas y oro en las extraordinarias piezas que componen este acervo patrimonial lorquino a caballo entre la historia y la religión.

\section{Objetivos}

El bordado lorquino se ha venido desarrollando iconográficamente de un modo excepcional a la par de su evolución estilística y técnica. La necesidad de crear obras de gran simbolismo para que cumplieran su función en el seno de eventos culturales de importancia contrastada, ha dado lugar a que los talleres de bordados contaran con la colaboración de investigadores y conocedores de la historia bíblica sobretodo desde mediados del XIX hasta el segundo tercio del siglo siguiente. Sin duda Vicente Munuera Mieles será, según el historiador local Munuera Rico, la pieza fundamental entre los especialistas de este complejo entramado alegórico desde el punto de vista general de la procesión (Muñoz, 2005).

Siguiendo la estela de este gran especialista, el notable conocimiento que los directores artísticos tenían en estos temas y su destacado nivel de cultura general, permitió crear exquisitas obras de bordado que serán base de las diferentes ediciones que posteriormente se han realizado debido al deterioro de las piezas originales y la necesidad de contar con obras para su uso en las conmemoraciones correspondientes. La complejidad que van adquiriendo las manifestaciones culturales lorquinas Ileva a los artistas a realizar, especialmente en las Festividades del Corpus y las procesiones de Semana Santa las concordancias entre el antiguo y el nuevo testamento que se han venido desarrollando a lo largo de la historia del arte auspiciado desde la Edad Media por los Padres de la Iglesia hasta el siglo XVII (Belda, 2001). Desde el carácter marginal de las mismas ya en el XVIII se retomarán en Lorca a través de sus procesiones en el año 1855 con La entrada triunfal de Jesús en Jerusalén. Desde muy tempranas fechas los pasajes bíblicos escogidos necesitan de un cuidado repertorio iconográfico y ornamental que será objeto de estudio en estas líneas, centrándonos en las diferentes obras del patrimonio bordado de Lorca que incorporan frutas y alimentos.

\section{Simbolismo y bordado: las frutas en oro y sedas}

La incorporación de la fruta a la producción artística tiene su origen en tiempos muy tempranos encontrando ejemplos ya en el antiguo Egipto. Destacan así mismo los bodegones representados en época griega (recordemos el concurso en el que participaron Zeuxis y Parrasio rivalizando con la realidad), los recreados en mosaicos romanos o los propios de la pintura de la Edad Moderna, con la cesta de frutas de Caravaggio conservada en la Pinacoteca Ambrosiana de Milán a la cabeza. Aplicado al arte religioso es indudable la lectura metafórica que establece la simbología cristológica presagiando la Pasión de Cristo de mano de la granada, los espinos..., el amor de la Virgen por el mundo con la pera o el pecado a través de la manzana o el higo, sin olvidar que estas lecturas simbólicas no son, bajo ningún concepto, inequívocas y pueden plantear dobles significados y evocar otras simbologías.

Son limitadas las piezas existentes en las colecciones lorquinas con frutos bordados, concentrándose casi en exclusiva en los tesoros artísticos de Blancos y Azules. La fruta en la historia 
del arte son según Arango, y el bordado no es ajeno a ello, "símbolo de abundancia, desbordantes desde el ángulo del deseo de la fecundidad, o de las copas de los banquetes de los dioses en la literatura, muchas de las frutas han tomado una significación simbólica (...) que se han convertido, bien en la expresión de los deseos, o de prosperidad". Teniendo en cuenta el marcado carácter simbólico de las obras que conforman las colecciones de bordado de Lorca, esta aseveración bien puede ser aplicable en este caso. Las frutas se incorporan a los bordados con una clara vocación alegórica e iconográfica que analizaremos pieza a pieza a través de las colecciones del MASS y del muBBla.

\subsection{Frutos bordados en la colección del MASS, museo azul de la Semana Santa}

La primera noticia que se conoce sobre la incorporación a los desfiles de Semana Santa de Lorca de un grupo versado en el libro de los Números, y concretamente sobre la Tierra prometida, se remonta a 1863. En este año Blancos y Azules escriben una relación de las escenificaciones que realizaban en aquellas fechas incorporando la cofradía blanca Los doce exploradores que mandó Moisés a la tierra de promisión, germen de lo que hoy forma parte del discurso procesional de los Azules. Debe destacarse que, aunque pueda parecer impensable desde el punto de vista de la concepción que las cofradías tienen en la actualidad y la magnificación de su rivalidad, algunos grupos que con anterioridad pudieron desfilar con una cofradía, lo harán posteriormente en la contraría, algunas veces sin apenas cambiar el concepto e intencionalidad dentro de la procesión. Así pues, el Paso Azul incorpora a su desfile Los exploradores a la tierra de promisión sin vestiduras propias hasta 1992-8, cuando se crean ex profeso cinco mantos que, junto a la famosa capeta de Los Celajes obra de Francisco Cayuela de los años veinte del siglo pasado y procedente del grupo del Triunfo del Cristianismo, conformaron su estética de procesión hasta 2017, año del estreno de la versión actualmente vigente. Esta última será la que procederemos a analizar y conforma una versión mucho más rica iconográfica y decorativamente que la correspondiente a los noventa (Pérez, 2016).

Durante el último tercio del siglo XIX se incorpora a la procesión de las grandes cofradías lorquinas el libro del Apocalipsis dentro del concepto ya implantado de exaltación de las Sagradas Escrituras. El Paso Azul incorpora el grupo del Triunfo del Cristianismo y dentro de él se desarrollará la caballería del Triunfo que experimentará su primera gran puesta en escena bajo la presidencia de José María Castillo Navarro. Si bien aquella versión se bordaría durante los años setenta del siglo pasado, la actual es fruto del último quindenio del XX y se compone de diferentes dioses clásicos, algunos bautizados con el nombre correspondiente al Panteón romano y otros con el griego (Pérez, 2016). En este caso procederemos a analizar el manto de Baco por ser el único que incorpora frutas a su repertorio decorativo.

\subsubsection{Caballería de los Exploradores a la Tierra de promisión}

La configuración original del conjunto patrimonial que conforma la caballería de los exploradores estaba compuesta por seis mantos. Si leemos el pasaje bíblico en el que se fundamenta el grupo, apreciamos que se detalla con nombres y ascendencia a los doce enviados por Moisés como representantes de cada una de las tribus de Israel. A priori podríamos esperar un grupo compuesto por doce personajes y entender que se encontraba incompleto, máxime si tenemos en cuenta las diferentes vicisitudes de su creación, y que hace alusión a los príncipes electos de tribu: Samua, Safat, Caleb, Jigal, Falti y Josué representantes de las tribus de Rubén, Simeón, Judá, Isacar, Benjamín y Efraim respectivamente. 
Esta sensación fragmentaria se desvanece en la versión actual ya que se trata de un conjunto más simbólico que nominativo. Un elenco de seis mantos que, a excepción de la mencionada capeta de Los Celajes, aluden a pasajes y localizaciones bíblicas incorporando iconografía o decoración de frutos que pasamos a analizar de forma individualizada.

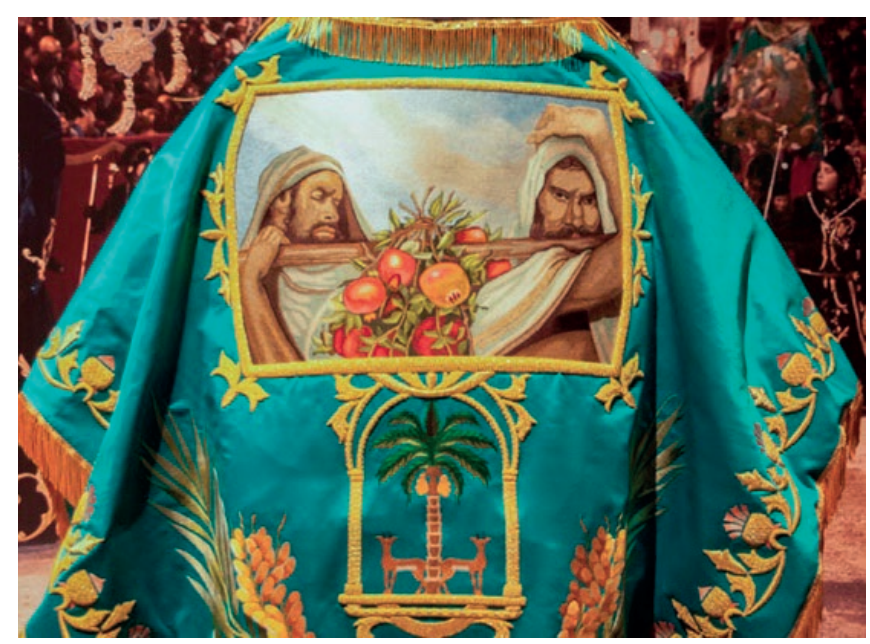

Figura 1. Manto de Caleb y Josué. Fuente: Navarro, D (2017).

El manto de Caleb y Josué está realizado sobre raso azul y representa bordado en sedas en su medallón central a dos hombres con barba portando un palo del que penden ramas de granado con abundantes frutos. Bajo el medallón aparece una palmera flanqueada por dos grandes ramas del mismo árbol acompañadas por sendos racimos de dátiles y el todo se cierra en una cenefa de oro y sedas de traza modernista. Si leemos detenidamente el texto bíblico, se dice que dos exploradores trajeron un palo del que pendía un racimo de uvas sin especificar quienes de los doce portaban los frutos. El director artístico, Miguel García Peñarrubia, decide que sean Caleb y Josué por ser los que se mantienen fieles al plan de Dios frente a las dudas del resto de los exploradores y justifica el azul del campo del manto que corresponde con el color de la cofradía. Fieles azules devotos y creyentes firmes en el plan de la Salvación. Se trata por tanto de una licencia artística que se suma a la incorporación de los dátiles que no se mencionan en la fuente que tan solo habla de las uvas (único fruto que pendía del palo), higos y granadas.

Técnicamente los frutos se resuelven con un matizado en sedas que busca una filiación clara por una estética modernista muy propia del bordado lorquino cuya época dorada se desarrolla a principios del siglo XX. Simbólicamente la granada hace alusión a los seiscientos trece mitzvá o preceptos de la Torá, pues se dice que ese es el número de semillas que alberga este fruto mediterráneo de gran fecundidad que tiene su origen cerca de Israel. En la iconografía cristiana la granada hace clara alusión a la Pasión por el color interno del fruto y se trata sin duda en este caso de una referencia clara a la castidad de María, ya que toda la procesión azul gira entorno a la imagen de su titular, la Virgen de los Dolores. 


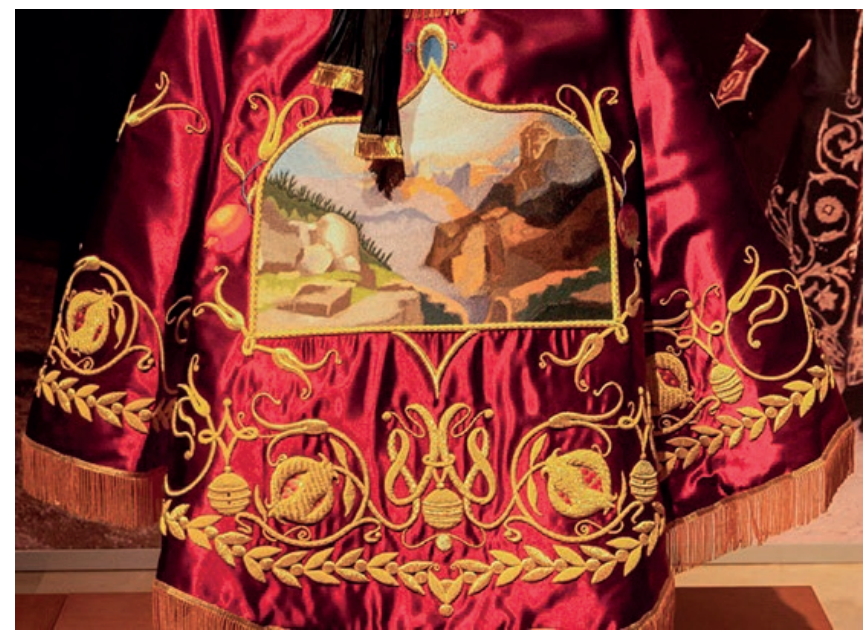

Figura 2. Manto del Monte Sinaí Fuente: Navarro, D (2017).

El manto del Monte Sinaí está bordado sobre raso de color granate y presenta un medallón central que nos muestra una vista de gran modernidad del sagrado monte de los judíos, enmarcado en una sencilla traza de oro flanqueada por dos granadas en sedas. El conjunto se cierra en una elegante cenefa de oro que alterna granadas y cascabeles en el mismo metal envueltas en una decoración que fluye con naturalidad por la bordura de la pieza (Blog Paso Azul, 2017). El director artístico, Joaquín Bastida Gil, compone en este caso un refinado trabajo que refuerza el simbolismo del monte Sinaí, lugar en el que Dios dictó a Moisés los requisitos que debía cumplir el Tabernáculo, el Arca, el Candelabro, las vestiduras de los Sacerdotes... y escenario emblemático de la entrega de las Tablas de la Ley. El color adquiere aquí un gran simbolismo como augurio de la Pasión que se hace presente mediante el campo de la pieza y las granadas que, en seda y en oro, conforman el manto de clara intención catecumenal.

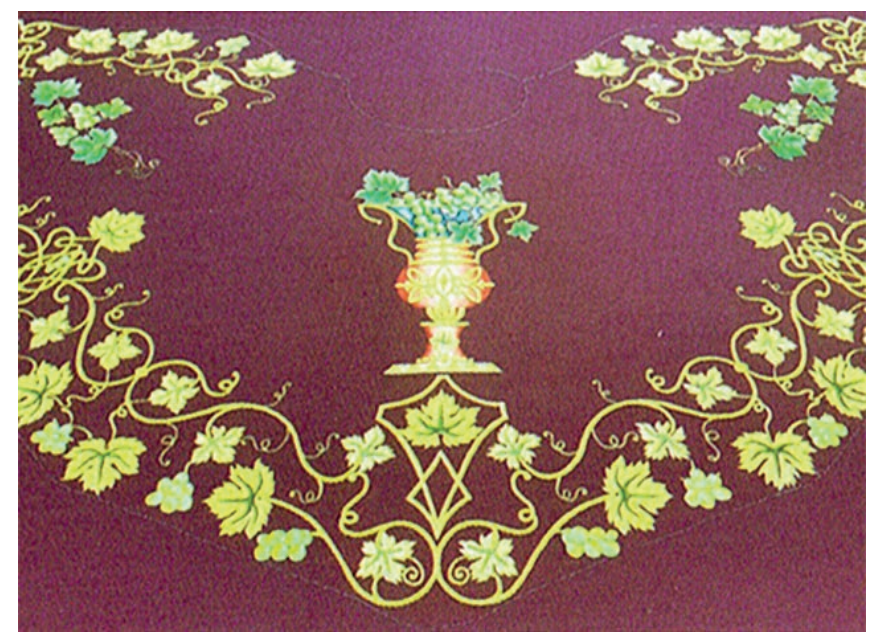

Figura 3. Manto de la jarra de uvas. Fuente: Bastida, J (2017). 
Del mismo artista, Bastida Gil, la caballería cuenta con otras dos obras: el manto del hallazgo de la Tierra prometida, fin último del grupo artístico, y el manto de la Jarra de uvas. Si bien el primero no cuenta con decoración de frutos y por tanto se aleja del estudio que nos ocupa, el segundo gira plenamente entorno a él. Sobre raso de color corinto vertebra la composición una gran jarra de inspiración judaica colmatada de racimos de uvas y hojas de parra como una clara metáfora del cáliz de salvación cristiana, que toma su iconografía de la tierra de promisión como lugar de salvación tras un camino de fe (Azul, 2017). A los pies del Sinaí el Pueblo Elegido dudó del plan de Dios y fue condenado a un largo camino para llegar a la Tierra prometida. Se trata por tanto de un claro paralelismo entre el antiguo y el nuevo testamento que enlaza directamente con la fe en Cristo, reforzado por la cenefa de hojas de parra, sarmientos y uvas que circundan el manto.

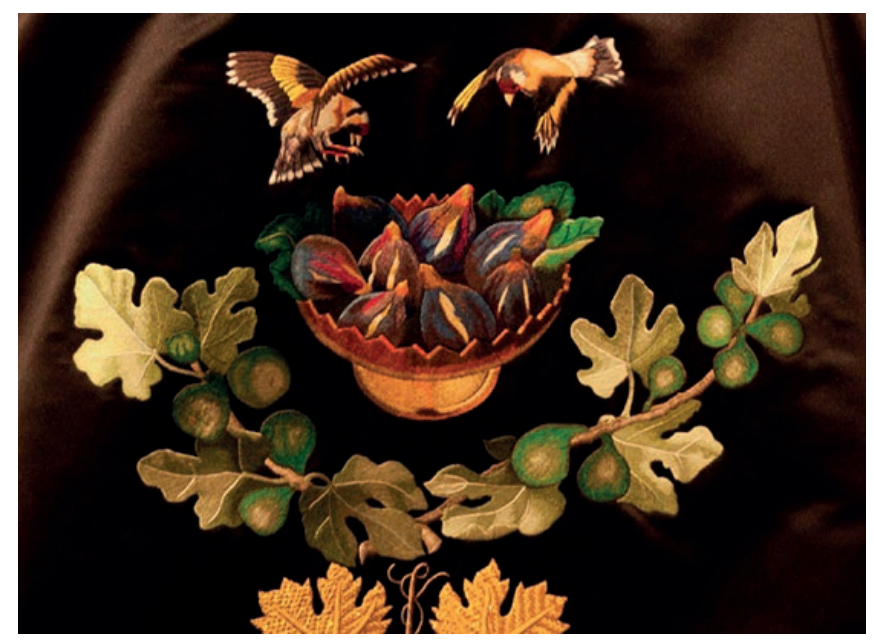

Figura 4. Manto de las brevas. Fuente: Navarro, D (2017).

El manto de raso negro de esta misma caballería, llamado popularmente "de las brevas", es obra de Miguel García Peñarrubia y nos muestra un cesto repleto de higos tempranos abiertos llamados "brevas", una variedad muy apreciada y de muy corta duración. Enmarcan el cesto unas ramas de higuera pajarera ricas en frutos, todo ello en sedas, y cierran el conjunto una cenefa hojas de parra en oro alternas de racimos de uvas de seda buscando un efecto menos acabado que otorga el protagonismo al motivo central que se corona con una pareja de pajaritos. El artista a elegido aquí unos jilgueros, tal y como se puede ver en afamadas obras como Sagrada Familia del pajarito de Murillo (hacia 1650) que atesora el Museo Nacional del Prado o la Virgen del Jilguero de Rafael (1505) que luce en las salas del museo florentino de los Ufizzi. La elección de esta familia de aves no es casual pues presenta una clara vocación de augurio de la Pasión. El fruto preferido de los jilgueros para alimentarse son las semillas y en especial las de cardo, material usado para la confección de la corona de espinas que impondrán a Jesús y que se convertirá en uno de los instrumentos de la Pasión. Los jilgueros revolotean sobre la cesta de higos abiertos símbolo del pecado, el pecado carnal concretamente, representando un claro triunfo de la fe. No olvidemos que las escrituras no especifican el fruto que manaba del árbol prohibido, los higos representan lo opuesto a la virginidad de María e incluso Miguel Ángel en la capilla Sixtina representa una higuera como árbol del conocimiento del bien y del mal. Cuenta 
la tradición cristiana que unos jilgueros quisieron quitarle las espinas a Cristo para aliviarle del dolor y como no pudieron, lo acompañaron con su canto en sus últimos momentos. Este manto por tanto, conformado por la cesta, los jilgueros y las ramas de higuera, cerrado por la cenefa de uvas y hojas de vid, configura una clara prefiguración de la pasión de Cristo que acaba en la muerte de Jesús representada por el color del manto.

\subsubsection{Manto de Baco. Caballería del Triunfo del Cristianismo}

Entre las piezas que conforman la caballería del Triunfo del Cristianismo destacaremos aquí el manto de Baco, dios del vino y los placeres. Sobre terciopelo de color azul ultramar y enmarcado ricamente en acantos de oro, representa a la propia deidad recostada blandiendo una copa y coronado de pampanos de vid. Baco pierde su mirada en los reflejos de una jarra metálica que debe contener el fruto de la viña acompañada de un rico bodegón compuesto de uvas y naranjas sobre un mantel de color lila. El manto presenta una forma mixtilínea potenzando sus estribos con grandes tarjetones de oro e incorporando en los extremos sendas hornacinas con veneras en seda que acogen figuras de filiación clásica. En esta obra José López Gimeno, director artístico de la pieza, selecciona claramente estos dos tipos de fruta con una la clara intencionalidad de aseverar el origen de la bebida identificativa del dios, el vino, y la naranja como símbolo de la plenitud del sol y prosperidad relacionada con los dioses del panteón. En este caso las frutas se nos presentan plenamente frescas recordando que no se marca el paso del tiempo debido al carácter inmortal de las deidades y que los placeres son eternos para Baco, no fugaces como lo son para los mortales.

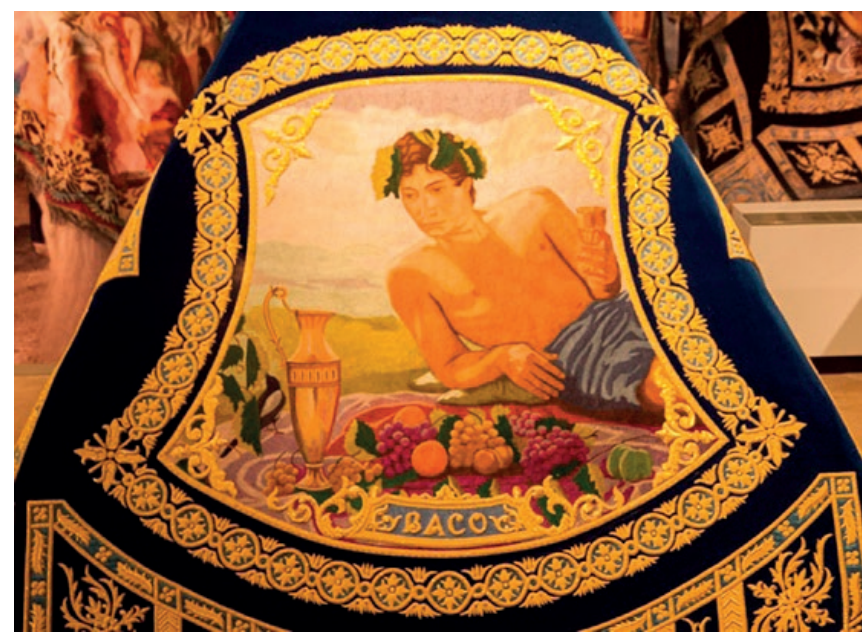

Figura 5. Manto de Baco.

Fuente: Navarro, D (2017).

\subsection{Frutos bordados en la colección del muBBla, museo de bordados Paso Blanco}

Si indagamos en la mencionada relación de grupos bíblicos publicada en 1863, nos encontramos con la escena denominada Ester coronada por Asuero enarbolándose como una prefiguración de la coronación de la Virgen, siguiendo el sentido mariológico que Ester adquiere en el siglo XIV con la publicación del Speculum Humanae Salvationes. Este grupo ha presentado varias 
configuraciones a lo largo de su historia y desapareció durante un tiempo para recuperarse en 2003 con una visión más global como grupo de Ester y Asuero. Ambos reyes en plano de igualdad vertebran un conjunto patrimonial que gira entorno a los mantos de los monarcas y se avalora con una riquísima caballería de escolta denominada El festín de Asuero por la extraordinaria riqueza de las piezas que las componen. Dentro del grupo destaca el manto correspondiente al rey Asuero que incorpora un bodegón de frutas en su escena central.

Como hemos comentado a la hora de fechar la incorporación del Libro del Apocalipsis a la Semana Santa de Lorca, será en 1870 cuando los Blancos sumen a su puesta en escena la llamada Visión de San Juan (Muñoz, 2005). Si bien se irá enriqueciendo paulatinamente hasta bien entrado el siglo XX, en 1885 ya tiraban del carro del Trono del Eterno cuatro caballos en alusión a los jinetes del Apocalipsis. La versión que procesiona en la actualidad corresponde a 1972, enriqueciéndose con decoraciones de oro y seda en 2001, fecha en la que se incorporan al manto del jinete del Hambre representaciones de uvas y espigas de trigo.

Finalmente en el tesoro artístico del muBBla destacaremos el manto de Galerio que, inspirado en el lienzo Rómulo y Remo amamantados por la loba que se conserva en los Museos Capitolinos de la ciudad eterna, incorpora cerezas y la higuera ruminal que se trasladaría como símbolo de Roma al foro, lugar dónde permanecerá hasta el 58 dC, año en el que se seca coincidiendo con el reinado del emperador Nerón, coincidencia que entendió como un mal augurio.

\subsubsection{Manto del Rey Asuero. Grupo de Ester y Asuero}

El manto de raso corinto que corresponde al rey Asuero ha de analizarse como un conjunto indisoluble acompañado del manto verde esmeralda de la reina. Ambos conforman una escena única que representa, tal y como se establece en el texto bíblico tras la adaptación establecida en el Concilio de Trento, el desmayo de Ester ante Asuero en el salón del trono. Ambos presentan medallones de gran aparato orlados por ricas decoraciones en oro y nos muestra en sedas la escena que dará lugar a la gran fiesta judía del Purim. La heroína hebrea tras el ayuno de tres días se presenta ante el rey y sufre un desmayo (Torres del Alcázar, 2009). Ante esta situación el poderoso rey de Persia ordena que sea atendida por sus doncellas y personal de la corte envuelta en un ambiente palaciego dieciochesco en el que destaca sobre la mesa gran profusión de frutas claro símbolo de abundancia y contraposición directa al ayuno de Ester. Con esta gran cesta de frutas la Comisión Artística del Paso Blanco nos muestra la abundancia y las riquezas del reino de Asuero configurados como un bodegón tradicional, envolviéndolo con amplitud de detalles bordados representando un distinguido servicio de oro y plata sobre un cuidado mantel. 


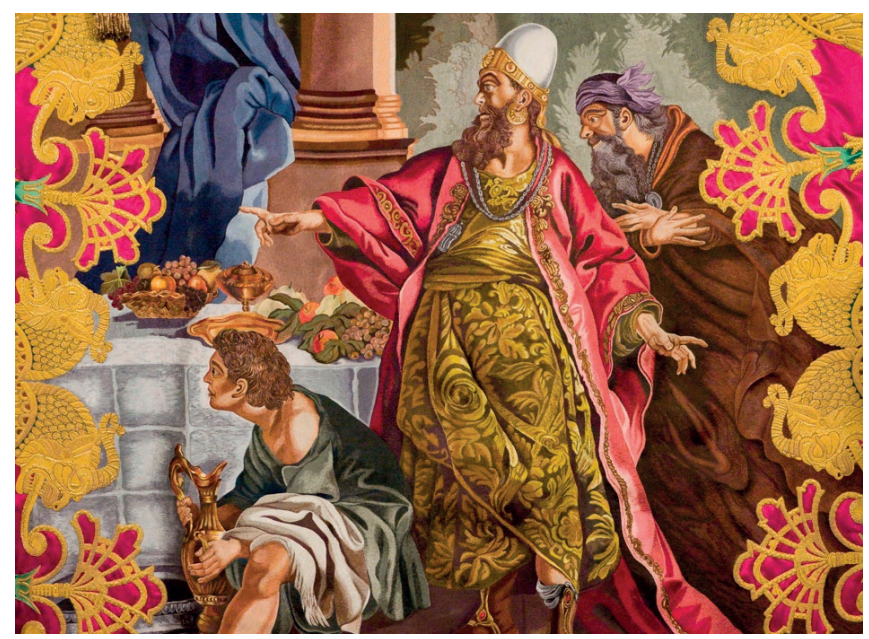

Figura 6. Manto del rey Asuero.

Fuente: Aledo, J (2010).

\subsubsection{Manto del Hambre. Jinetes del Apocalipsis}

Si bien el personaje del Hambre en la procesión del Paso Blanco hunde sus raíces en 1885, el manto que luce la representación actual responde a un patrón mucho más plástico y moderno y es uno de los cuatro jinetes del Apocalipsis, grupo con el que forma conjunto y guarda armonía por el estilo de los medallones y las trazas de las decoraciones que los enmarcan. Basado en el libro Apocalipsis 6:1-8, el afamado pintor Muñoz Barberán nos muestra sobre raso de color verde y en un medallón de gran tamaño la imagen bordada en sedas de una madre que porta a su hijo hambriento en brazos dotados de una estética expresionista alejada del tradicional naturalismo tan propio del bordado lorquino. El marco que cierra el tondo y la cenefa que envuelve el conjunto, obra del director artístico Gaspar López Ayala, incorporan en oro espigas de trigo muertas como augurio del hambre (Torres del Alcázar, 2007). El trigo se relaciona en la tradición cristiana de la vida tras la muerte fundamentada en la transubstanciación del pan durante la conmemoración de la Santa Cena en la eucaristía. Los bordados del manto se nos presentan ausentes de color más allá de las gamas neutras de los acantos de seda y los grises que presiden el medallón, hecho que refuerza la única incorporación de color natural que se hace a través de los racimos de uvas que presiden los estribos de la pieza en clara alusión a la Pasión de Cristo como único camino a la Salvación. 


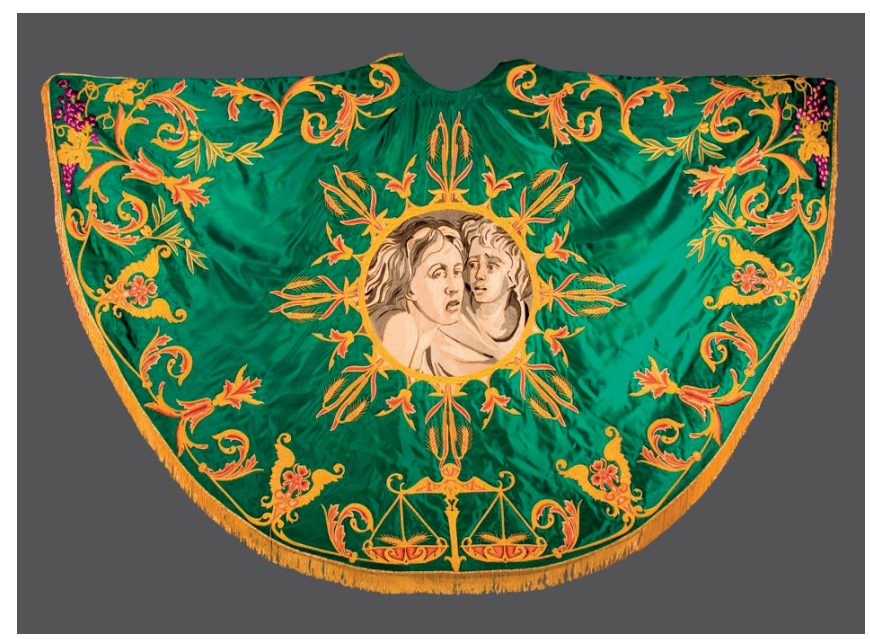

Figura 7. Manto del Hambre. Fuente: Clemente, J (2007).

\subsubsection{Manto de Galerio, llamado de La Loba}

Dentro del discurso propio de la Historia de la Salvación se integra el grupo correspondiente a los emperadores perseguidores de los cristianos como antagonistas a los que defenderán al Cristianismo. De este modo Diocleciano, Maximiano, Galerio, Maximino Daza o Juliano se enarbolan como figuras opuestas a Constantino o Teodosio. El manto de caballería de Galerio se incorpora al tesoro artístico del Paso Blanco como el más grande de la Semana Santa de Lorca (Torres del Alcázar, 2009). Realizado en terciopelo de color carmesí, color de las legiones romanas que será símbolo de la monarquía hasta la actualidad (Torres del Alcázar, 2021), en él campea un gran medallón de catorce mil centímetros cuadrados bordados en seda que representa a la loba con Rómulo y Remo a los pies de la Higuera ruminal. Según la mitología son hijos de la vestal Rea Silvia y de Marte, convirtiendo al dios de la guerra en padre de todos los romanos por ser Rómulo el primer rey de Roma. Marte como Marspiter alimenta a sus hijos convirtiéndose en pájaro carpintero portando unas cerezas que el director artístico, quien suscribe estas líneas, mantiene en número de tres por tratarse del número adscrito a la cofradía blanca. La tinción de los tejidos en color carmesí se ha venido obteniendo de diferentes orígenes a los largo de ha historia, siendo la más conocida y habitual a partir de la Edad Moderna el llamando por tradición en España tinción grana que tiene su origen en la cochinilla, y se desarrolla extraordinariamente durante el reinado de Carlos I de España ante la ingente cantidad de cochinilla venida de América. Durante el medievo, época que comienza a partir de la tetrarquía de la que formaba parte Galerio, la cereza será una de las fuentes vegetales habituales para obtener ropajes y decoraciones textiles de este distinguido color llamado entonces carmesinus, representando aquí el nacimiento de la monarquía romana en la figura de Rómulo de mano de los dioses (Adelamare y Guineau, 2000). 


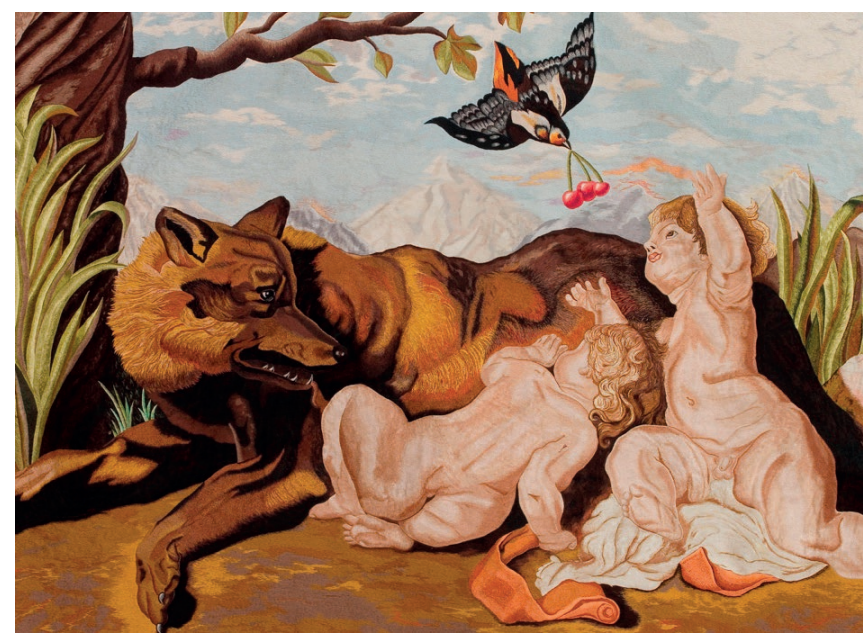

Figura 8. Manto de Galerio. Fuente: Aledo, J (2009).

\section{Resultados}

El simbolismo de la fruta no tiene una presencia muy numerosa en el tesoro artístico que conforma el bordado de Lorca. Como manifestación artística de larga tradición y arraigo que se mantiene a lo largo de los siglos, se basa en cuidados estudios iconográficos que tienen su origen en grandes conocedores de la historia bíblica y del simbolismo de sus representaciones, junto a la influencia de las grandes obras de arte de la historia de la humanidad. La fruta y los árboles de las que manan se incorporan a una selección de obras de bordado aportando un riquísimo significado que hunde sus raíces en la historia bíblica, la tradición, la cultura popular y el simbolismo. La fruta más representada será la uva, por su clara relación con la Pasión de Cristo, fin último de representación de la Semana Santa en general, si bien la de Lorca se nos presenta desde un punto de visa más triunfal con las miras puestas en la Resurrección. Las granadas, los dátiles, las naranjas... serán otros de los frutos representados pero no mostrarán la presencia abrumadora de las uvas. Técnicamente se resuelven en casi todas las obras desde una óptica naturalista alejándose tan sólo en unas pocas piezas en las que se abraza una estética más propia del modernismo y muy del gusto de la Lorca de principios del siglo XX, época de mayor esplendor de esta particular tradición de bordado lorquino.

\section{Conclusiones}

A pesar del elevado número de obras de bordado que conforma el patrimonio de Lorca, son menos de una decena las que incorporan la iconografía de la fruta a su lenguaje simbólico. En todas ellas la fruta adquiere un significado histórico y religioso de primer nivel fruto de una cuidada selección y de las condiciones en las que se presenta. La riqueza simbólica de las religiones judía y cristiana, junto a lecturas más trasversales de mano de la mitología greco-romana, desarrollan en estas obras una faceta alegórica de gran relevancia pero completamente eclipsada por el prestigio de la extraordinaria calidad técnica adquirida a lo largo de cientos de años de tradición. 
Las necesidades de vestir los personajes encargados de representar la Historia de la Salvación en las singulares procesiones de Semana Santa lorquinas han desarrollado una gran variedad de símbolos e iconografías más allá de las propias de las tradicionales fiestas de la semana de pasión. El significado de los frutos son una pieza muy importante dentro de este salomónico retablo que configura las colecciones de bordado creadas para dar vida a esta particular manifestación artística y cultural, aseverando y enriqueciendo el mensaje catequético de las obras de arte que conforman el tesoro artístico de Lorca formando un interesante diálogo entre la historia y la religión.

\section{Bibliografía}

ADELAMARE, F. Y GUINEAU, B. (2000). Colour. Making and using dyes and pigments. Nueva York: Thames \& Hudson.

ARANGO, M.A. (1995). Símbolo y simbología en la obra de Federico García Lorca. Madrid: Espiral Hispano Americana.

Azul (2017). N 27 marzo 2017. Lorca: Hermandad de Labradores - Paso Azul.

BELDA NAVARRO, C. (Com.). (2001). Arte en seda. La tradición del bordado lorquino. (Madrid, 2001-2). Madrid, España: Fundación Santander Central Hispano.

BLOG PASO AZUL (2017) “El Paso Azul estrenará la la nueva Caballería de Exploradores y la renovación de las Profetisas Egipcias en un año de récord para el taller de bordados". En: PASO AZUL, 6 de abril. <http://blog.pasoazul.com/el-paso-azul-estrenara-la-nueva-caballeria-de-los-exploradores-y-larenovacion-de-las-profetisas-egipcias-en-un-ano-de-record-para-el-taller-de-bordados> [Consulta: 29 de junio 2021]

MUÑOZ CLARES, M. (2005). “Estudio iconológico de los grupos bíblicos e históricos de las procesiones Iorquinas”. En: Munuera Rico, D., Muñoz Clares, M., Sánchez Abadíe, E. Perspectivas de la Semana Santa de Lorca. Murcia: Editora regional de Murcia y Ayuntamiento de Lorca.

PÉREZ SERRAHIMA, P. (2016). Apuntes azules. Una visión diferente del Paso Azul. Lorca: Página Maestra.

Región de Murcia. Ley 5/1996, de 30 de julio, de Museos de la Región de Murcia. BOE, 19 de noviembre de 1996, núm. 279, p. 34926-34935

TORRES DEL ALCÁZAR, D.F. (Com.). (2007). Muñoz Barberán. Pinceladas de oro y seda. (Lorca, 2007). Lorca, España: Servicio muBBla Publicaciones.

TORRES DEL ALCÁZAR, D.F. (2009). El muBBla museo de bordados Paso Blanco y capilla del Rosario. Lorca: Servicio muBBla Publicaciones.

TORRES DEL ALCÁZAR, D.F. (2021) "El guion de Juan II de Castilla, símbolo de la ciudad de Lorca". En: XXVII Jornadas de Patrimonio Cultural de la Región de Murcia. Murcia: Tres Fronteras. 425-432 



\title{
REFLEXIONES EN TORNO A LA REVALORIZACIÓN DEL PATRIMONIO ALIMENTARIO MARÍTIMO PESQUERO DE MALLORCA: LA EXPOSICIÓN TEMPORAL "DEL MAR A LA TAULA"
}

\author{
Diana Borràs Rhodes ${ }^{a}$, Joana Cifre Borràs ${ }^{b}$ \\ a Instituto d'Antropologia de les Illes (IAI). Miembro del grupo de investigación de Patrimonio Cultural y An- \\ tropología. Licenciada en Ciencias políticas y sociología. Especialidad antropología cultural, UCM. Máster \\ en Dirección de organizaciones en la economía del conocimiento, UOC.diana.borras@gmail.com \\ ${ }^{b}$ Historiadora, MA with honours. Universidad de Dundee, Reino Unido.joana.cifreborras@gmail.com
}

\begin{abstract}
In this article we describe the proposal for an exhibition on the subject of the maritime and fishing food culture of Mallorca, intended to be transmitted through the personal experiences of those who have lived off of said activity for several generations. Structured in eleven panels, the exhibition presents the food culture associated with artisanal fishing activities from the point of view of those who have dedicated their whole lives to it. The information was collected by means of an anthropological study with fishermen and their wives, fishmongers. Thus, seafaring and fishing traditions are presented in themes varying from life on board and work at sea to the mallorcan fish recipes and the preparation and conservation of the fish itself.
\end{abstract}

Keywords: intangible food heritage, anthropology, maritime fishing culture, temporal exhibition, fish, local produce.

Resumen: En este artículo se describe la propuesta expositiva realizada en torno a la cultura alimentaria marítimo pesquera de Mallorca que se quiere transmitir a través de las vivencias personales de los que han vivido durante generaciones de dicha actividad. Estructurada en once paneles la exposición presenta la cultura alimentaria asociada a la actividad pesquera artesanal desde el punto de vista de aquellos que le han dedicado su vida. Dicha información fue recogida mediante un estudio antropológico con pescadores y sus mujeres, las pescaderas. Así, la tradición del mar y la pesca se presenta en temas que varían desde la vida a bordo y el trabajo en el mar, hasta las recetas de pescado mallorquinas y la preparación y conservación del mismo.

Palabras clave: patrimonio alimentario inmaterial, antropología, cultura marítimo pesquera, exposición temporal, pescado, producto local.

Citar como: Borràs Rhodesa, D., Cifre Borràs, J. (2022). "Reflexiones en torno a la revalorización del patrimonio alimentario marítimo pesquero de Mallorca: la exposición temporal 'Del mar a la taula'". En: Actas del III Congreso Internacional sobre Patrimonio Alimentario y Museos. 25-26 noviembre, 2021, Valencia, España. pp. $143-155$. https://doi.org/10.4995/EGEM2021.2021.13925 


\section{Introducción}

Uno de los roles de los museos es el de investigar, perpetuar y transmitir a la sociedad el patrimonio cultural tangible e intangible, si bien el reto no está exento de polémicas. Así, por ejemplo, en su artículo sobre el patrimonio etnoantropológico en Galicia, Pereiro (Pereiro, 2012) analiza cómo el concepto de patrimonio cultural y los procesos de patrimonialización tienden a primar una visión folclórica que anula en sus representaciones tanto la pluralidad de identidades -primando por ejemplo lo rural frente a lo urbano- como silenciando necesarias evoluciones de las prácticas sociales de los actuales protagonistas.

En el ámbito más concreto de la alimentación las contradicciones y paradojas de los procesos de patrimonialización han sido también objeto de interesantes reflexiones por parte de la antropología. Espeitx por ejemplo los identifica como procesos selectivos que al fragmentar y descontextualizar sus componentes, no agotan una cultura alimentaria (Espeitx, 2004) mientras que Gascón y Mulet (Gascón y Mulet, 2020) advierten de que una vez creado el símbolo identitario éste se enfrenta al riesgo del anacronismo. Por su parte, Medina y Solanilla ( Medina y Solanilla, 2013), citando a Contreras (Contreras, 2007) sugieren que, en relación con las prácticas alimentarias, "la noción de patrimonio plantea cuestiones más complejas, ya que se trata de un patrimonio vivo, cambiante, en constante evolución, con toda la problemática que ello implica en su gestión y mantenimiento".

Escapar a estas contradicciones es difícil. No obstante, tener conciencia de dichos procesos ayuda a establecer propuestas que sin pretender abarcar la totalidad de la realidad asociada a un determinado patrimonio alimentario ofrezca elementos de identificación pasados y presentes. En este trabajo pretendemos reflexionar sobre algunos aspectos relacionados con los procesos de patrimonialización del pescado mediante una exposición temporal. La base para nuestras reflexiones es una propuesta elaborada para el Museo Marítimo de Mallorca en la que hemos participado activamente. La propuesta consiste en una exposición temporal, y en la elaboración del discurso narrativo se ha puesto especial cuidado en recoger no sólo los testimonios de la pesca artesanal más tradicional sino también el de sus evoluciones y de su situación actual. Para la construcción del relato se ha seguido una línea temática principal subdividida en dos ejes -el mar y la mesa- y una segunda línea temporal, mostrando para cada eje temático los cambios y las evoluciones identificados por los informantes.

En nuestra opinión, los ejes temáticos combinan un contenido clásico propio de los museos etnográficos -productos, utensilios de cocina, formas de cocción- con contenidos más próximos a la antropología social como por ejemplo los planteamientos de Jack Goody y que implican incluir la producción, distribución, preparación y consumo como elementos de los sistemas alimentarios. Además, de acuerdo con la terminología propuesta por Espeitx (Espeitx, 2004) sobre las concepciones de lo etnológico que predominan en los museos la exposición se enmarcaría en la categoría de exposición alternativa, en la cual más allá de mostrar formas de vida tradicionales la narración se hace eco de cuestiones actuales de interés social, si bien también cabe decir que no se ha renunciado a la incorporación tanto de elementos tradicionalistas -aparejos de pesca o técnicas de salazón de pescado ya inexistentes- como revisionistas - testimonios de las culturas y las formas de vida pasadas y presentes-.

Desde nuestro punto de vista, la idea que subyace al planteamiento expositivo es que la identidad local que realmente sigue viva en los portadores sólo se puede poner de manifiesto si 
se presta atención tanto a su memoria oral como a sus prácticas actuales con el fin de evitar un discurso meramente "tradicionalizador" que excluya a sus verdaderos protagonistas. A la vez, no se puede obviar que el contexto actual del consumo y producción del pescado local está inmerso en la llamada modernidad alimentaria. El público objetivo de la exposición es la población de Mallorca y la lengua vehicular es el catalán.

La propuesta expositiva ha presentado algunos retos ante la falta de objetos materiales con los que acompañar el discurso narrativo, por cuanto el museo cuenta con un fondo escaso y nosotras no disponemos de él. Tampoco se ha conseguido un material gráfico documental relacionado con las prácticas alimentarias pudiéndose afirmar que este está dominado en su práctica totalidad por los libros de recetas y por fotografías de platos. Además, hay que señalar que se prevén importantes limitaciones presupuestarias lo que obliga a una escenificación austera.

La elaboración del contenido ha sido realizada por tres antropólogas a partir de una investigación con fuentes primarias y secundarias. Las fuentes primarias consisten en la elaboración de trece entrevistas semiestructuradas a pescadores en activo y jubilados, y otras personas pertenecientes a familias de pescadores y que se relacionan de manera directa con las prácticas sociales de producción, consumo y comercialización del pescado como son las amas de casa, consumidores, vendedoras/es de pescado y restauradoras/es. Además, la exposición se hace eco de los resultados de una investigación exploratoria realizada por las mismas investigadoras durante los meses de confinamiento por la COVID-19 en los que se analiza, entre otros temas, el consumo de pescado antes y durante la pandemia, así como el conocimiento de recetas tradicionales relacionadas con el producto. La actividad se ha complementado con una investigación de archivos y fuentes bibliográficas en la cofradía a la que pertenecen los pescadores entrevistados (Cofradía de pescadores de Pollença, Mallorca) y con un panel de expertos, siendo estos/ as cocineros/as de las islas conocidos por su interés hacia el producto local de proximidad y la recuperación de platos propios de la tradición cultural mallorquina.

\section{Objetivos}

El objetivo general de la exposición es el de revalorizar entre la población autóctona la cultura marítimo pesquera de Mallorca y su producto y el de contribuir a la divulgación de los conocimientos sobre las culturas vinculadas al mar. Se pretende dar a conocer los hábitos y las prácticas alimentarias y culinarias en torno al producto del pescado de proximidad en la isla, tanto en el pasado como en el presente partiendo de la memoria oral comunitaria y fuentes bibliográficas.

Los objetivos pedagógicos que se plantearon son:

- Dar a conocer el concepto de patrimonio inmaterial marítimo-pesquero, sus dimensiones y la diversidad de actores implicados en su transmisión

- Sensibilizar sobre la diversidad y riqueza del pescado mallorquín de proximidad y de su gastronomía

- Sensibilizar sobre el carácter dinámico, inclusivo y cambiante del patrimonio vivo como eje de desarrollo sostenible de la sociedad

- Fomentar el desarrollo sostenible marítimo pesquero 
Una vez efectuado el trabajo de investigación se realizó la propuesta expositiva la cual se pensó como una exposición en la que se diera voz a los pescadores y a sus familias identificando los caracteres identitarios de su cultura alimentaria tanto pasada como presente. Por otra parte, con el objetivo de ayudar al establecimiento de nuevas relaciones entre la comunidad de pescadores y la sociedad mallorquina el foco se ha puesto tanto en las personas y sus prácticas sociales como en el producto y la gastronomía.

\section{Desarrollo de la innovación}

\subsection{El Museo marítimo de Mallorca}

El Museo Marítimo de Mallorca inició su actual recorrido institucional en el 2017 con la constitución del consorcio. Puesto que el personal es escaso, para el desarrollo de proyectos y acciones se recurre a la contratación de terceros. El museo actual responde a un proyecto descentralizado que pretende recoger las diferentes expresiones marítimas de la isla y las necesidades de sus comunidades (Forés, 2021). El museo consta de dos sedes, Ses Voltes en Palma y el Museu de la Mar del Port de Sóller.

El museo está situado en un antiguo oratorio y sus principales ejes temáticos son la carpintería de ribera, la pesca, el comercio y la emigración. El proyecto expositivo se distribuye en el exterior del edificio, la entrada, una sala expositiva y una sala de audiovisuales con el proyecto "La remor de memòria". Además, la capilla del oratorio situada en frente del edificio principal es utilizada para exposiciones temporales. El espacio pretende ser un emplazamiento de territorio para los residentes de la isla.

Uno de los aspectos que cabe mencionar en relación al Museo Marítimo es que implantó un proceso participativo a partir del cual se establecieron los cuatro ejes del museo y que son biodiversidad y patrimonio marítimo subacuático, flotante y terrestre. Además, de manera paralela, el museo desarrolló la acción "la xarxa dels dessitjos" en la que los visitantes podían dejar a modo de mensaje en una botella sus sentimientos en relación a la creación del nuevo museo. Como resultado de estos procesos, en 2019 se desarrollaron la acciones "Decàleg de bones practiques en torn de la mar" y la investigación en torno al patrimonio inmaterial y la memoria oral relacionada con las artes de pesca y que se concreta en el proyecto "El remor de la memoria". (Forés, 2021).

En el desarrollo de nuestro trabajo se tuvieron en cuenta los contenidos de estas dos acciones al existir algunos elementos identificativos a partir de los cuales el visitante puede establecer un diálogo entre la exposición temporal y la permanente, en especial con el proyecto "La remor de la memoria", un trabajo que recoge las vivencias y aspectos de la vida cotidiana de doce personas relacionadas con la historia marinera del Puerto de Sóller entre el periodo de entreguerras y el siglo XXI.

\subsection{El estudio exploratorio sobre el consumo de alimentos durante los meses de confinamiento decretados por el estado de alarma}

Una de las acciones de investigación desarrolladas en el marco del proyecto expositivo fue un estudio exploratorio cuyo objetivo era el de identificar los hábitos de consumo alimenticio antes y en situación de confinamiento de la población. El estudio se llevó a cabo porque pareció 
que tanto el conocimiento como la activación y salvaguarda del patrimonio cultural alimentario en las islas debía tomar en consideración el contexto provocado por la COVID-19. Además, el estudio pretendía obtener datos sobre los neodiscursos en torno a las prácticas alimentarias, comercialización, consumo y revalorización del producto local, en especial del pescado de proximidad y el objetivo principal fue desarrollar un proceso de reflexión que permitiera tener una visión holística del patrimonio alimentario asociado al pescado, incorporando sus procesos de adaptación a nuevas situaciones sociales. (Mulet, Borràs y Calvo, 2020)

El trabajo parte de la base de que la alimentación humana como objeto de estudio de la antropología incluye una dimensión simbólica y social (Contreras y Gracia, 2005.) Además, se considera que la alimentación es un hecho social formado por prácticas y conceptualizaciones que expresan y simbolizan los valores y las relaciones sociales de una sociedad determinada por lo que la comensalidad, los alimentos, su valoración social, sus usos y prohibiciones, son elementos cambiantes que conforman la realidad sociocultural de la alimentación en función de diversos procesos económicos, sociales o políticos.

La base empírica del estudio se llevó a cabo durante el confinamiento mediante una técnica de cuestionario en línea a una muestra no representativa formada por personas contactadas por WhatsApp y por correo electrónico usando la metodología de bola de nieve. El periodo de referencia de los datos es el mes de mayo de 2020, con retrospectiva a los momentos inmediatamente anteriores al confinamiento. El cuestionario consta de un total de 38 preguntas y el número total de respuestas fue de 330 personas residentes en 53 municipios de las islas. El estudio exploratorio se complementó con una entrevista semiestructurada al presidente de la empresa OPMallorcamar responsable de la gestión de la lonja del pescado de Palma y principal distribuidor del pescado de proximidad de la isla y con una observación de la subasta holandesa de pescado.

Los resultados de este trabajo han sido publicados en el artículo "Crisis sanitaria y alimentación: impactos del confinamiento en los hábitos alimentarios de la isla de Mallorca" (Mulet, Borràs y Calvo, 2020) y los elementos que forman parte del discurso narrativo de la propuesta expositiva son los directamente vinculados a la comercialización y al consumo actual de pescado y al conocimiento tanto de las especies locales como de elaboraciones culinarias transmitidas de generación en generación que los informantes declaran conocer.

Uno de los resultados más destacables del estudio es que las dos especies de pescado más consumidas se refieren a pescados no mediterráneos, como el salmón y el bacalao. En cuanto al conocimiento de especies locales y de recetas tradicionales la mayoría cita pescados y recetas propias de la isla si bien a partir de los datos podemos afirmar que existe una disociación entre los hábitos de consumo de pescado y dicho conocimiento, además de una clara tendencia a la simplificación, al mencionarse unos pocos platos de la rica cocina marinera de la isla y que según recetarios y otras fuentes secundarias supera el centenar.

\subsection{Las entrevistas a personas vinculadas al patrimonio inmaterial alimentario marítimo pesquero}

Cuando hablamos de tradiciones culturales y patrimonio alimentario marítimo pesquero es importante tener presente que hablamos tanto de productos comestibles como sobre todo de procesos culturales cuya base se encuentra en la pesca tradicional y artesanal, una realidad 
social que todavía hoy da lugar a procesos identitarios y a sentimientos de pertenencia a pesar de los procesos de modernización.

A la hora de iniciar el proyecto se consideró necesario poder entrevistar a personas directamente relacionadas con el patrimonio alimentario marítimo pesquero de la isla con el fin de poder obtener datos empíricos que permitieran describir el sistema alimentario relacionado con la cultura del pescado. Ante la existencia en la isla de varias cofradías se decidió llevar a cabo un estudio de caso de una de las localidades siguiendo en parte el modelo ya iniciado por el Museo Marítimo de Mallorca con su trabajo sobre la memoria oral del Puerto de Sóller.

El primer contacto se realizó con el patrón mayor de la cofradía de pescadores de la localidad seleccionada al que se le realizó una primera entrevista. El patrón facilitó los contactos con otros pescadores y ayudó a identificar otros posibles informantes entre personas no pescadoras pero relacionadas con familias de pescadores de la localidad. En total se realizaron trece entrevistas con representación de pescadores en activo y jubilados, mujeres de pescadores, vendedoras de pescado, personas relacionadas con la restauración y personas descendientes de familias de pescadores que no tienen relación directa ni con la pesca ni con su comercialización pero que son portadoras de conocimientos transmitidos en los ámbitos familiares. En total se han entrevistado a siete mujeres y seis hombres.

Con la realización de las entrevistas se pretendía acceder tanto a las representaciones culturales como a las prácticas cotidianas. Los ejes temáticos fueron la producción pesquera y la venta del producto, el consumo del pescado local, prácticas y hábitos alimentarios a bordo, prácticas y hábitos alimentarios de consumo de pescado en el ámbito doméstico y gastronomía y restauración. En todos los ejes se prestó atención tanto a la memoria oral como a las prácticas alimentarias actuales las cuales fueron estudiadas teniendo en cuenta a los actores, los productos o especies de pescado, las técnicas culinarias, los ingredientes y los utensilios de cocina.

El trabajo se complementa con fuentes secundarias -prestando atención a estudios históricos, antropológicos y etnográficos- y con la realización de un panel de expertos a reconocidos cocineros/as de la isla. Con las fuentes secundarias se pretendía profundizar en el conocimiento de las prácticas y representaciones sociales del pescado y su consumo en tiempos pasados mientras que el panel de expertos permite acceder al discurso más actual de la gastronomía en relación al producto y a su cocina tradicional. En nuestra opinión, con ello se consigue establecer una línea temporal atravesada tanto por continuidades como por cambios y evoluciones lo que ayuda a captar la atención del visitante, al apelar tanto a sentimientos de nostalgia e identificación, como a elementos de descubrimiento y conocimiento. La incorporación de la opinión experta de cocineros aporta al discurso expositivo la mirada de la gastronomía, uno de los ámbitos en los que se suele manifestar la construcción social del patrimonio inmaterial alimentario, si bien desde una óptica diferente por cuanto la intención no es la de mostrar elaboraciones culinarias o solicitar a los cocineros que pongan en valor determinadas especies sino más bien la de mostrar a los cocineros y gastrónomos como un tipo de actor que, al igual que las familias y los individuos, son herederos y transmisores de una interpretación del patrimonio que no se agota en la tradición.

Un aspecto que también queremos destacar es que gracias a la pluralidad de técnicas de investigación desplegadas así como de fuentes consultadas la propuesta desarrolla un discurso narrativo complejo y abierto que deja entrever la enorme riqueza del patrimonio inmaterial 
marítimo pesquero de la isla, el cual no puede agotarse en una única acción ni investigativa ni expositiva y de la cual siguen siendo protagonistas los pescadores, el ámbito doméstico, las personas y las diversas comunidades de la isla. Además, con la realización de entrevistas se ha podido preservar del paso del tiempo una parte del patrimonio inmaterial que irremediablemente se desvanece a medida que desaparecen los pescadores más veteranos. Se evita también un discurso patrimonializante desarraigado y descontextualizado al posibilitar que las personas con sus conocimientos y quehacer cotidiano sean el centro del discurso expositivo.

\section{Resultados}

El resultado del proceso investigativo descrito es una propuesta de exposición temporal para el Museo Marítimo de Mallorca que se ha pensado para un público local familiar y adulto. La exposición lleva por título "De la mar a la taula" y consiste en una instalación formada por once paneles blancos con texto en azul y subtítulos en rojo. El texto se acompaña con dibujos y fotografías, tanto antiguas como actuales. Abrirá la exposición un panel en el exterior con un texto de bienvenida al visitante en el que consta un breve resumen de los objetivos de la exposición y los agradecimientos a los informantes. Los paneles, que colgarán del techo, estarán impresos en ambas caras. Una serie de cajas blancas de cartón de diferente tamaño se colocarán en el suelo para ayudar al visitante a marcar el recorrido. Se prevé además que puedan servir de soporte físico para objetos complementarios obtenidos en préstamo como por ejemplo miniaturas de artes de pesca tradicionales realizadas por pescadores de la zona.

El contenido narrativo es el resultado de un proceso de análisis tanto de los datos empíricos como de las fuentes bibliográficas consultadas. La versión definitiva ha sido contrastada con el patrón mayor de la cofradía de pescadores.

La estructura del contenido expositivo es la siguiente. Un primer panel explicativo introduce a los visitantes el concepto de patrimonio inmaterial y de salvaguarda y tiene por título "Les cuines marineres, un ric patrimoni cultural inmaterial". Un último panel titulado "Cultures del peix a Mallorca: sostenibilitat i transmissió" se dedica a modo de cierre a explicar la situación actual del sector y la continuidad del oficio de pescador e incluye también resultados del estudio exploratorio y del panel de expertos. El contenido del resto de paneles se estructura en dos grandes apartados, el mar y la mesa. Cada panel cuenta con un título y una frase representativa cuyo origen puede ser popular, una frase de algún informante o una cita de alguna fuente bibliográfica. 


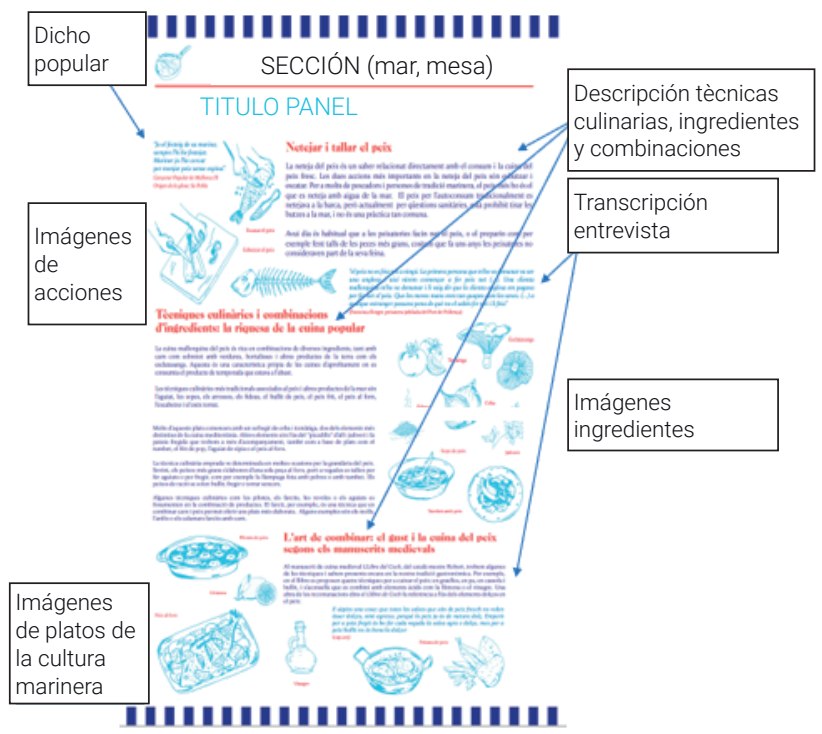

Figura 1. Ejemplo de panel "Del mar a la Taula". Fuente: Diana Borràs (2021).

Cada panel cuenta con diferentes subapartados cuyos textos explicativos se complementan con breves transcripciones de entrevistas además de con dibujos o fotografías. La incorporación de transcripciones parciales se usa como recurso para establecer puentes comunicativos entre la memoria oral de los informantes o portadores y el resto de la comunidad. Por otra parte, en cada panel se hace referencia a los principales cambios evolutivos con el fin de introducir junto a la dimensión territorial la dimensión temporal. A continuación, exponemos el título de cada panel (traducido al español), que acompañamos con una breve descripción del contenido y con algunas reflexiones. Como veremos, los contenidos se enmarcan en la categoría de exposición alternativa propuesta por Espeitx (Espeitx, 2004) por cuanto muestran cuestiones actuales de interés social como puedan ser la sostenibilidad, el impacto del turismo o la globalización. Por otra parte, estos actúan en diferentes ámbitos de la manifestación del patrimonio como el natural, el material y el inmaterial (valores y costumbres).

Las cocinas marineras, un rico patrimonio inmaterial. El panel explica qué se entiende por cocina marinera y la importancia de la cocina como elemento que nos acerca a la herencia del pasado y a la cultura alimentaria del presente. Se expone también el concepto de patrimonio inmaterial de la UNESCO. Uno de los aspectos destacables de este panel es que en la definición de la cocina marinera se introducen los elementos que conforman su complejidad y que caracterizan el patrimonio alimentario como una entidad viva en constante evolución al ser fruto tanto de las tradiciones como de las innovaciones sociales. Así, se habla de conocimientos, usos, costumbres, de transmisión generacional; de entornos como las barcas, las casas, los restaurantes, y de saberes acumulados en la familia o los recetarios.

El producto de la mar. Uno de los aspectos a destacar de este panel es que ofrece información sobre el número de especies capturadas y comercializadas por los pescadores mallorquines 
de proximidad y que supera el centenar. El panel explica los dos tipos de pesca de proximidad existentes, arrastre y pesca artesanal, la temporalidad de las capturas y la necesidad de tener en cuenta los ciclos biológicos para tener una pesca sostenible. A continuación, se nombran algunas de las especies desaparecidas o en peligro de extinción. La segunda cara del panel está dedicada a la comercialización del pescado con una visión temporal a medio plazo lo que permite explicar, entre otros fenómenos sociales, el impacto del turismo en el incremento de la demanda.

El visitante se encontrará con un fragmento de entrevista que relata la temporalidad de las capturas, con dibujos de algunas de las especies más populares, así como de las especies en extinción y con dibujos de los dos tipos de pesca de proximidad. En cuanto al texto relativo a la comercialización, este incorpora diversas imágenes de los años 50-60 tanto de la venta en el muelle como a pie de barca, las cuales se muestran junto con imágenes actuales reforzando así la idea de cambio y adaptación.

Respecto al turismo nos interesa apuntar que su consideración escapa a la visión del mismo como mecanismo mercantilizador del patrimonio inmaterial tal y como exponen por ejemplo Gascón y Mulet (Gascón y Mulet, 2020), puesto que el objetivo de la exposición no es el de escenificar la gastronomía local para el visitante foráneo sino el de evidenciar ante la población autóctona que el patrimonio es una realidad viva en continuo proceso de adaptación y cambio y que la llegada del turismo vino acompañada de innovaciones, adaptaciones y revalorizaciones.

Artes de pesca, saberes transmitidos. El hilo conductor son las artes de pesca y sus evoluciones. La descripción incluye el concepto de arte de pesca y una explicación de cómo cada arte se corresponde con la captura de un tipo de especies. La dimensión temporal y la memoria oral están presentes en la narración con el relato de la desaparición de algunas de estas artes, que se escenifican gráficamente. A continuación, se explican las principales evoluciones tecnológicas como por ejemplo la mecánica, la maquinilla, la sonda o el GPS, todos ellos elementos que han revolucionado la capacidad de captura. Con la incorporación de los cambios tecnológicos se pone de manifiesto que la noción de patrimonio alimentario aborda cuestiones complejas entre las cuales no pueden obviarse los contextos de producción, que a su vez determinan el consumo.

El valor del pescado: economías y hábitos de consumo. Ya en la mesa, este panel introduce aspectos históricos relativos al consumo de pescado en la isla, con una explicación relativa a las diferencias existentes entre las comunidades de la costa, y los pueblos del interior en los que predominaba el consumo de salazones y pescados importados como el arenque y el bacalao. Se explica también que el consumo viene determinado por factores sociales, económicos y de clase además de por la capacidad de captura y de accesibilidad y se hace hincapié en la existencia de diferentes valoraciones culturales en relación a las distintas especies, que se ejemplifican con fragmentos de entrevista.

La narración continúa con una caracterización de la cocina marinera como cocina de aprovechamiento, en la que todas las capturas se vendían o se consumían, y se explica que en las comunidades pesqueras existían mecanismos de redistribución y reciprocidad. En la otra cara, se narran aquellos cambios socioeconómicos que han tenido un mayor impacto en los hábitos de consumo entre los que destacan los procesos migratorios y de urbanización y la incorporación de la mujer al mercado laboral. Cierra el panel un texto relativo a las alteraciones en los 
comportamientos alimentarios como el consumo de productos industriales y precocinados. El texto se acompaña entre otras con imágenes de comida precocinada.

Conservar los alimentos de la mar. La conservación del pescado es una necesidad social que asegura el abastecimiento y la distribución además de permitir alargar la vida del producto. Las técnicas de conservación son saberes transmitidos y desde tiempos remotos, cuando no existían neveras, ingredientes como el agua, el aguardiente, la sal, el aceite, el vinagre y más recientemente el hielo se han utilizado para conservar el pescado. El panel explica el uso de cada una de estas técnicas en la cultura marinera de Mallorca, con menciones a recetarios antiguos, declaraciones de los entrevistados y algunas recetas todavía hoy muy populares. El panel destaca además la importancia del escabeche en la cocina tradicional como una de las técnicas más características de la cocina de aprovechamiento, la revolución que supusieron las neveras y el hielo industrial y la importancia actual de este último para la conservación óptima del pescado.

Cocina de barca y Cocina marinera doméstica. Hablar de patrimonio alimentario marítimo pesquero es hablar de dos grandes ámbitos, la vida de a bordo, donde nos encontramos con una cocina de barca hoy en decadencia pero que es la base de una parte importante del patrimonio inmaterial existente, y por otra la vida del ámbito doméstico, en el que nos encontramos con la cocina familiar, sobre todo cotidiana, y con las prácticas de conservación del pescado, muchas de ellas ya inexistentes como los salazones, pero todavía presentes en la memoria oral. Tanto para la cocina de a bordo como para la cocina doméstica se tienen en cuenta los productos utilizados, más numerosos en el ámbito doméstico, así como las técnicas más habituales las cuales presentan en la cocina de abordo características adaptativas al medio marino, como por ejemplo evitar las frituras que comportan un elevado riesgo en medios inestables. Al igual que en el resto de paneles se mencionan los cambios sociales en relación a las prácticas alimentarias.

El panel de la cocina de abordo se estructura en los siguientes temas: cocina a bordo; almorzar, comer y cenar; comprar al día y provisiones; del fogón al camping gas; ollas, calderones y utensilios de cocina; técnicas de cocción y saber comer pescado ( "destriar" o "no fer espines").

El de la cocina doméstica gira en torno a la cocina del pescado en la casa de los pescadores. Se identifican los ingredientes, que incorporan hierbas y verduras, y las técnicas de cocción, que ahora incluyen el horno, las empanadas o las frituras, así como los denominados "platos antiguos" de la cocina marinera doméstica, tanto los que se continúan elaborando o los que ya han caído en desuso como las albóndigas de pulpo o la caldera de tortuga. Se incide una vez más en el concepto de cocina de aprovechamiento y se explica que era habitual que las capturas no aptas para la comercialización, pero sí para el consumo, formaran parte de la dieta de las familias de pescadores.

Ambos paneles se hacen eco de los cambios introducidos en los últimos años, como por ejemplo la importancia de la pesca recreativa en el mantenimiento del consumo de determinadas especies, y la irrupción de nuevos productos como el pescado ultracongelado o procesado.

Cocina marinera y restauración. Hemos mencionado con anterioridad que la llegada del turismo vino acompañado de importantes cambios sociales entre los cuales destacan un desarrollo importante de la restauración, procesos migratorios y nuevos hábitos de ocio. Todos estos cambios supusieron la introducción de innovaciones y procesos de aculturación que modificaron la gastronomía marinera. El panel relata como uno de los hechos sociales que más incidieron en la aparición de una nueva cultura del pescado con nuevas técnicas de cocción y revalorización de 
determinadas especies fue la contratación de mujeres mallorquinas como cocineras en casas de familias adineradas de veraneantes. Por otra parte, los restaurantes se convirtieron en los lugares donde se ofrecía la cocina tradicional tanto de abordo como la cocina doméstica, además de platos más acordes a los gustos de los turistas. Supuso también un importante incremento de la demanda y la incorporación progresiva de especies foráneas muy apreciadas en los lugares de origen tanto de veraneantes como de población migrante trabajadora.

Hoy en día, con la globalización, es indudable que los restaurantes continúan siendo lugares de innovación y recreación de la cocina del pescado con adaptaciones a las nuevas modas gastronómicas entre las cuales tenemos la revalorización del producto local cocinado con ingredientes propios de otras tradiciones culinarias. Además, la globalización comporta la introducción de nuevos productos procesados, congelados y de piscifactoría.

Manipular y cocinar el pescado es el título del panel número nueve. En él se pretende relatar cómo se limpia y corta el pescado, cuáles son las técnicas culinarias y las combinaciones de ingredientes más características de la cocina popular, como por ejemplo el sofrito, y cuáles eran las combinaciones que aparecen en los manuscritos medievales. El contenido del panel se enriquece con el vocabulario específico relacionado con la "cultura del pescado" como escatar, esbutzar, fer llengues o morralla, con la descripción de las técnicas culinarias como los guisos, la cocción al horno, la fritura, las albóndigas o los rellenos, y con descripciones de las mezclas de ingredientes que dan lugar a platos muy característicos de la cocina mallorquina. Se explica además que la técnica utilizada dependía sobre todo del tamaño del pescado. Como el resto de paneles, el texto se combina con dibujos de los platos mencionados y con algunas fotografías. La segunda cara del panel relata, con transcripciones, algunas recetas contadas por los y las informantes y se mencionan los platos de pescado y las técnicas culinarias que los cocineros y cocineras que han participado en el panel de expertos han identificado como más características.

Con el título de Transmitir los saberes culinarios: oralidad, recetas y recetarios se introduce el tema de los recetarios entendido como uno de los instrumentos de transmisión de los platos que conforman la cocina popular. El panel pretende hacer reflexionar sobre el arte de la transmisión culinaria y la importancia del testimonio de los recetarios como documentos que permiten identificar los alimentos consumidos en determinados contextos y momentos históricos. La reflexión se acompaña con algunos apuntes históricos sobre los recetarios de Mallorca y los saberes alimentarios marineros. Por último, se describe el mundo de los recetarios hoy día, sus posibles clasificaciones y cómo en la actualidad al hablar de recetarios hay que incluir tanto la televisión como las nuevas tecnologías.

\section{Conclusiones}

La variabilidad y complejidad de los procesos alimentarios y de sus prácticas sociales exigen que se muestren sus múltiples espacios económicos, sociales e individuales, así como sus diferentes temporalidades. Además, las propuestas en torno a la patrimonialización de la cultura alimentaria deben apelar tanto a la nostalgia como a la realidad actual de la producción, comercialización y consumo.

En el caso del pescado, donde el producto local está hoy íntimamente ligado a una pesca artesanal que es fruto de innovaciones tecnológicas y cambios normativos, la musealización 
del producto a través de una exposición temporal permite la recreación de un discurso narrativo temporal realizado desde el presente y en el que el testimonio de los portadores reflejan las tensiones sociales y económicas que en la actualidad caracterizan al consumo del producto local y entre las que cabe destacar los desajustes entre los tiempos naturales de la producción y las tendencias homogeneizadoras de la sociedad urbana y globalizada.

El mantenimiento de la diversidad cultural y la comprensión del patrimonio cultural inmaterial de las comunidades pesqueras, así como su puesta en valor frente al fenómeno de la globalización debe partir de una exploración de los orígenes de dicho patrimonio poniendo el foco en las prácticas sociales de aquellas personas que, con adaptaciones, continúan trabajando en el marco de local.

\section{Bibliografía}

ALEGRET, J.L Y GARRIDO, A. (2019). "Un exemple de revalorització del patrimonio cultural del peix: l'espai del peix de Palamós" en RevistaDrassanes (26), pp. 86-97. <https://revistadrassana.cat/ index.php/Drassana/article/view/618> [Consulta: 30 de junio de 2020]

CONTRERAS, J. (2019). “La alimentación contemporánea entre la globalización y la patrimonialización” en el Boletín de Antropología. Universidad de Antioquia, Medellín, vol. 34, N. ${ }^{\circ}$ 58, pp. 30-55.<https:// www.academia.edu/48768626/La_alimentaci\%C3\%B3n_contempor\%C3\%A1 nea_entre_la_ globalizaci\%C3\%B3n_y_la_patrimonializaci\%C3\%B3n_Jes\%C3\%BAs_Contreras > [Consulta: 30 de junio de 2020]

CONTRERAS, J. y GRACIA, M. (2005). Alimentación y cultura. Perspectivas antropológicas. Barcelona: Editorial Ariel.

ESPEITX, E. (2004) "Patrimonio alimentario y turismo: una relación singular" en Pasos Revista de Turismo y Patrimonio Cultural, vol n², pp. 193-213. <http://www.pasosonline.org/Publicados/2204/ PS040204.pdf > [Consulta: 27 de junio de 2021]

FORÉS, A. (2021)." Museu Marítim de Mallorca, el naixement d'un museu a principis del segle XXI" en Drassana, (28), 143-156. < https://revistadrassana.cat/index.php/Drassana/article/view/659> [Consulta: 30 de junio de 2021]

GRACIA, M. (1996) “Antropología de la alimentación” en Prat, J. y Martínez, Á. editores. Ensayos de antropología cultural. Homenaje a Claudio Esteva-Fabregat. Barcelona: Ariel antropología

GASCÓN, j. y MULET, M. (2020) "Patrimonialización de la alimentación y la producción agraria: una introducción" en Quaderns 36 (2) 2020, pp.143-250. <https://publicacions.antropologia.cat/ quaderns> [Consulta: 27 de junio de 2021]

MEDINA, F.X. y SOLANILLA, L. (2013). "Patrimonio alimentario, institucionalización y medios digitales" en PH Investigación (en línea) n¹, dic.2013, pp.55-74. <http://www.iaph.es/revistaph/index.php/ revistaph/article/view/4019> [Consulta: 27 de junio de 2021]

PEREIRO, X. (2012). "La concepción del patrimonio etnoantropológico en Galicia: visiones legales y prácticas institucionales" en Revista Andaluza de Antropología, núm.2: Patrimonio cultural y derechos colectivos, pp.25-47. <http://www.iaph.es/revistaph/index.php/revistaph/article/ view/4019> [Consulta:4 de julio 2021] 
PRATS L. "Antropología y patrimonio" en Prat, J. y Martínez, Á. editores. Ensayos de antropología cultural. Homenaje a Claudio Esteva-Fabregat. Barcelona: Ariel antropología.

RAMÓN-MARQUÉS, N. editora científica (2020). Actas II congreso Internacional sobre Ptrimonio Alimentario y museos. El gusto en el museo 2020 (II Congreso Internacional de Patrimonio Alimentario y Museos). Editorial Universidad Politécnica de Valencia. <http://ocs.editorial.upv.es/ index.php/EGEM/EGEM2020/paper/viewFile/13198/6027> [Consulta: 25 de junio 2021]

SALAS, P. y TORRES, J. M. (2012). Història de la Confraria de Pescadors del Port de Pollença. Cent anys de vida marinera. Pollença: El Gall Editor. 



\title{
EL MUSEU DE MALLORCA APUESTA POR EL ARTE Y LA GASTRONOMÍA
}

\author{
Maria Gràcia Salvà Picó ${ }^{a}$, Pablo José Acover Cateura ${ }^{b}$ \\ a Directora Museu de Mallorca. Secció Etnològica de Muro. Museu Monogràfic de Pollentia. \\ mdm.mgsalva@conselldemallorca.net \\ b Profesor asociado a la Universidad de Alicante. Departamento de Historia Medieval, Moderna. Cien- \\ cias y Técnicas Historiográficas. pablo.alcover@ua.es
}

\begin{abstract}
Art from the palate and the word. The Museum of Mallorca, has started a line of research and dissemination of analysis of works of art in its permanent collection through gastronomy. To this end, three series of lectures-workshops have been organized, with great public success, on medieval food, on wine and on chocolate. The objective of the communication is to publicize these activities, as well as to present the new line of museum research around the study of art through a taste for gastronomy.
\end{abstract}

Keywords: museums, gastronomy, medieval food, mancerinas and jícaras, wine, chocolate, Mallorca.

Resumen: Arte desde el paladary la palabra. El Museu de Mallorca, ha iniciado una línea de investigación y de difusión de análisis de obras de arte de su colección permanente a través de la gastronomía. A tal efecto se han organizado tres ciclos de conferencias-taller, con gran éxito de público, sobre alimentación medieval, sobre el vino y sobre el chocolate, El objetivo de la comunicación es dar a conocer estas actividades, así como presentar la nueva línea de investigación del museo entorno al estudio del arte a través del gusto por la gastronomía.

Palabras clave: museos, gastronomía, alimentación medieval, mancerinas y jícaras, vino, chocolate, Mallorca.

Citar como: Maria Gràcia Salvà Picó, M.G., Acover Cateura, P. J. (2022). "El Museu de Mallorca apuesta por el arte y la gastronomía". En: Actas del III Congreso Internacional sobre Patrimonio Alimentario y Museos. 25-26 noviembre, 2021, Valencia, España. pp. 157-170. https://doi.org/10.4995/EGEM2021.2021.13855 


\section{Introducción}

El Museu de Mallorca, es un equipamiento público situado en pleno centro histórico de Palma de Mallorca. Se encuentra ubicado en la calle de la Portella, antigua vía de comunicación romana, posiblemente marítima, que conduce desde la plaza de Santa Eulalia hasta el mar. Su sede es un antiguo palacio, hecho construir por Luís Ballester de Togores Salas, primer conde de Aiamans, en 1635. El casón fue remozado en el siglo XIX, en estilo neogótico, por la marquesa Catalina de Zaforteza y de Togores. La apariencia actual corresponde a esta última intervención, aunque conserva la planta pentagonal barroca, perceptible en el patio, y fragmentos arquitectónicos góticos. En el subsuelo se conservan estructuras pertenecientes a la época andalusí. Es pues un testimonio de la evolución histórica y edilicia de Mallorca desde el siglo XIII hasta el siglo XXI. Pasó a propiedad pública en el año 1968, cuando la familia Zaforteza, última propietaria, lo vendió al Ayuntamiento de Palma, quién a su vez lo cedió al Estado en 1971.

El día 2 de noviembre de 1961, este año se cumple su sesenta aniversario, se decretó la creación del Museo de Mallorca, con el objetivo inicial de preservar las especiales características y singularidades del arte mallorquín en sus diferentes manifestaciones, y con el fin de ofrecer a los investigadores y a los turistas, todos aquellos objetos de interés artístico, arqueológico o etnológico que fuesen una muestra del arte, la cultura y la manera de vivir del pueblo mallorquín a lo largo de los siglos. Su sede inicial fue la Casa de Cultura de Palma, que actualmente ocupa el Arxiu del Regne de Mallorca, y desde 1976 se trasladó a la casona de la calle Portella, número 5 de Palma, también conocida como la Gran Cristiana.

Para la exposición permanente se contó con las colecciones del antiguo Museo Provincial de Bellas Artes de la Lonja, creado en 1915 y primer museo público de la isla, diversas colecciones arqueológicas propiedad del Estado; y especialmente los bienes atesorados por la Sociedad Arqueológica Luliana, fundada en 1888, cedidos en depósito al nuevo museo. Así mismo se contó con donativos o depósitos que entidades públicas, particulares o el propio Estado efectuaron
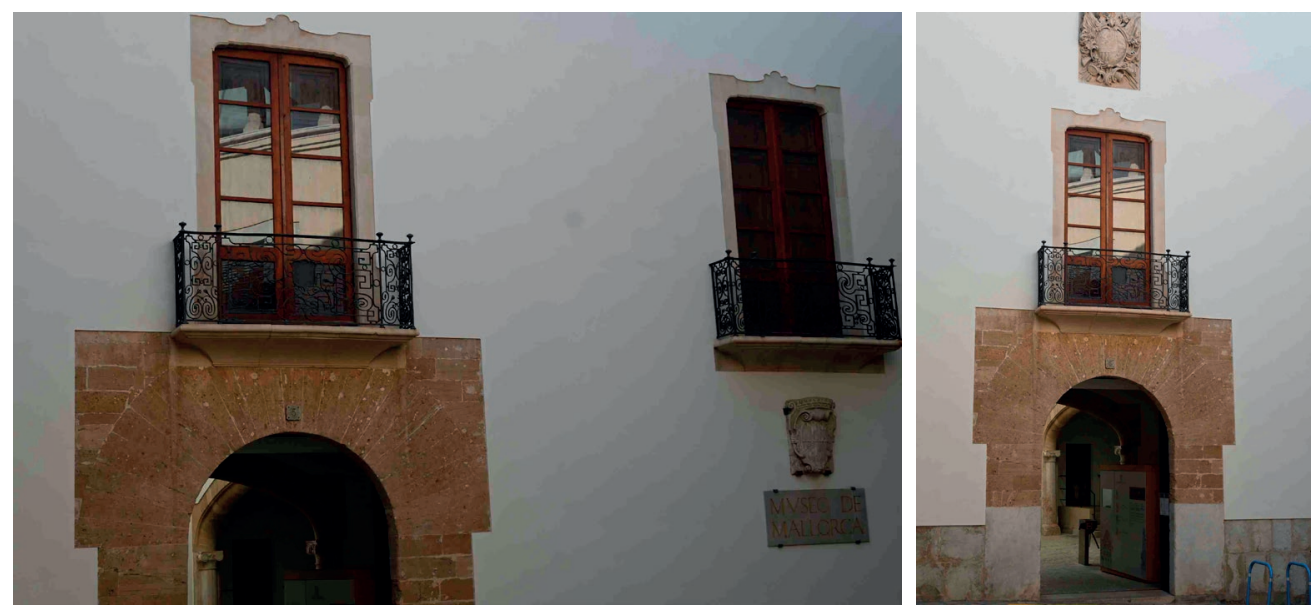

Figura 1. Entrada principal del Museu de Mallorca, en Palma. Corresponde a la reforma efectuada en el siglo XIX. Fuente: Elaboración propia. 
en su momento. Se trata pues de un museo general de Historia y Bellas Artes representativo de la cultura mallorquina, con obras que van desde la Prehistoria hasta los primeros movimientos modernos del siglo XX.

La titularidad del museo es estatal, adscrito al actual Ministerio de Cultura y Deporte, aunque su gestión fue transferida al Gobierno de las Islas Baleares en 1984, y desde el año 2019 es gestionado por el Consell Insular de Mallorca. Lo conforman tres sedes, la principal en Palma y dos secciones, la Etnológica en Muro, y el Museo monográfico de Pollentia, sito en Alcudia, en el que se muestran los materiales arqueológicos procedentes de la ciudad romana de Pollentia. Depende del museo, el área de reserva de Son Tous, almacén dónde se depositan, catalogan y guardan los objetos procedentes de las excavaciones arqueológicas de la isla.

En una primera etapa, iniciada en 1976 y finalizada en 2002, se abrieron cinco salas para exponer el arte gótico, situadas en el entresuelo y en la planta noble. Contenían piezas de arquitectura, de pintura de los siglos XIII y XV, de escultura y de cerámica de los siglos XIII al XVI. Éstas fueron las primeras estancias que se abrieron al público.

Paulatinamente se fueron inaugurando las salas del arte de los siglos XVI al XX, todas ellas situadas en las plantas noble y superior. Se expuso el arte del Renacimiento y del Barroco, en 1979; el arte de la época islámica, en 1981; el arte del siglo XIX, en 1983; el Modernismo y el siglo XX, en 1985; las artes industriales de los siglos XIII al XVIII, en 1989; y finalmente, el arte del siglo XVIII, en 1990.

El 20 de diciembre del 2000, se inauguraron trece salas dedicadas a la Prehistoria. Las diferentes dependencias estaban situadas en los sótanos y en el subsuelo del antiguo jardín, espacio recuperado tras la excavación llevada a cabo en 1998, en la que se descubrieron los restos de una casa islámica, sobre la que se habían construido los dos edificios góticos, germen del primer palacio renacentista.

El programa museográfico se dio por concluido con la apertura de ocho nuevas salas situadas en la planta baja y el sótano, inauguradas el 25 de marzo del 2002, dedicadas al talayótico final, a las colonizaciones, a la romanización y a la época tardo antigua.

La apariencia actual del museo es consecuencia de la remodelación iniciada en 2009, costeada por el entonces Ministerio de Educación, Cultura y Deportes. En aquel entonces se efectuó una rehabilitación integral del edificio, dotándolo de nuevas instalaciones y de mejoras en la accesibilidad arquitectónica. El 23 de julio de 2015, se abrieron los espacios dedicados a mostrar las colecciones de Bellas Artes y las Artes Decorativas desde el siglo XIII hasta comienzos del siglo XX, distribuidos en dos de las plantas del museo. En el tercer piso, se destinaron dos salas para acoger las exposiciones temporales. El nuevo programa obligó el cierre de las salas destinadas a la exposición de los importantes fondos arqueológicos que custodia el museo. ${ }^{1}$

Desde 2019, con la nueva dirección, se han efectuado algunos cambios. La exposición permanente de la tercera planta se ha remodelado casi completamente, a raíz de una cesión importante de obra pictórica propiedad de CaixaBank, procedente de la Fundación Sa Nostra Caixa de Baleares, entidad creada en Baleares en 1882. A corto plazo, se reabrirán las salas dedicadas a mostrar la arqueología balear y la musealización del yacimiento arqueológico situado en el subsuelo, correspondiente a una edificación andalusí.

$\overline{1}$ Guia del Museu de Mallorca. Sales de Belles Arts i Decoratives. Segles XIII al XX. Palma, 2015. 
Paralelamente a las grandes intervenciones, hemos iniciado un nuevo programa de actividades con el fin de incentivar la visita del público local que por diversos motivos, desconocía la existencia del principal museo de la isla o simplemente hacía tiempo que no lo frecuentaba. Según nuestra opinión, los museos tienen que ser espacios polifónicos, de diálogo y escenario de temas que interesen a la sociedad. Estos tres supuestos nos llevaron a organizar unos ciclos de conferencias combinados con talleres de degustación, en los que se proponía una nueva lectura de la colección de obras de arte desde un punto de vista alimentario y gastronómico. Generalmente el sentido de la vista es el que prima cuando se visita un museo, el resto de sentidos parecen o son incluso prohibidos, ¿por qué no dejarlos entrar y ampliar la percepción del arte a través del gusto?

Empezamos el ciclo con la alimentación medieval, continuamos con el vino y acabamos con el chocolate, una manera dulce de detener estas actividades debido a la irrupción de la pandemia provocada por el COVID19, que nos obligó a cerrar el museo hasta el mes de mayo de 2020. Durante este año no hemos podido reactivar estas conferencias-taller, pues las limitaciones siguen siendo muchas pero tenemos más ideas para desarrollar en los años venideros. A continuación iremos desgranando los ciclos y la evaluación de sus resultados.

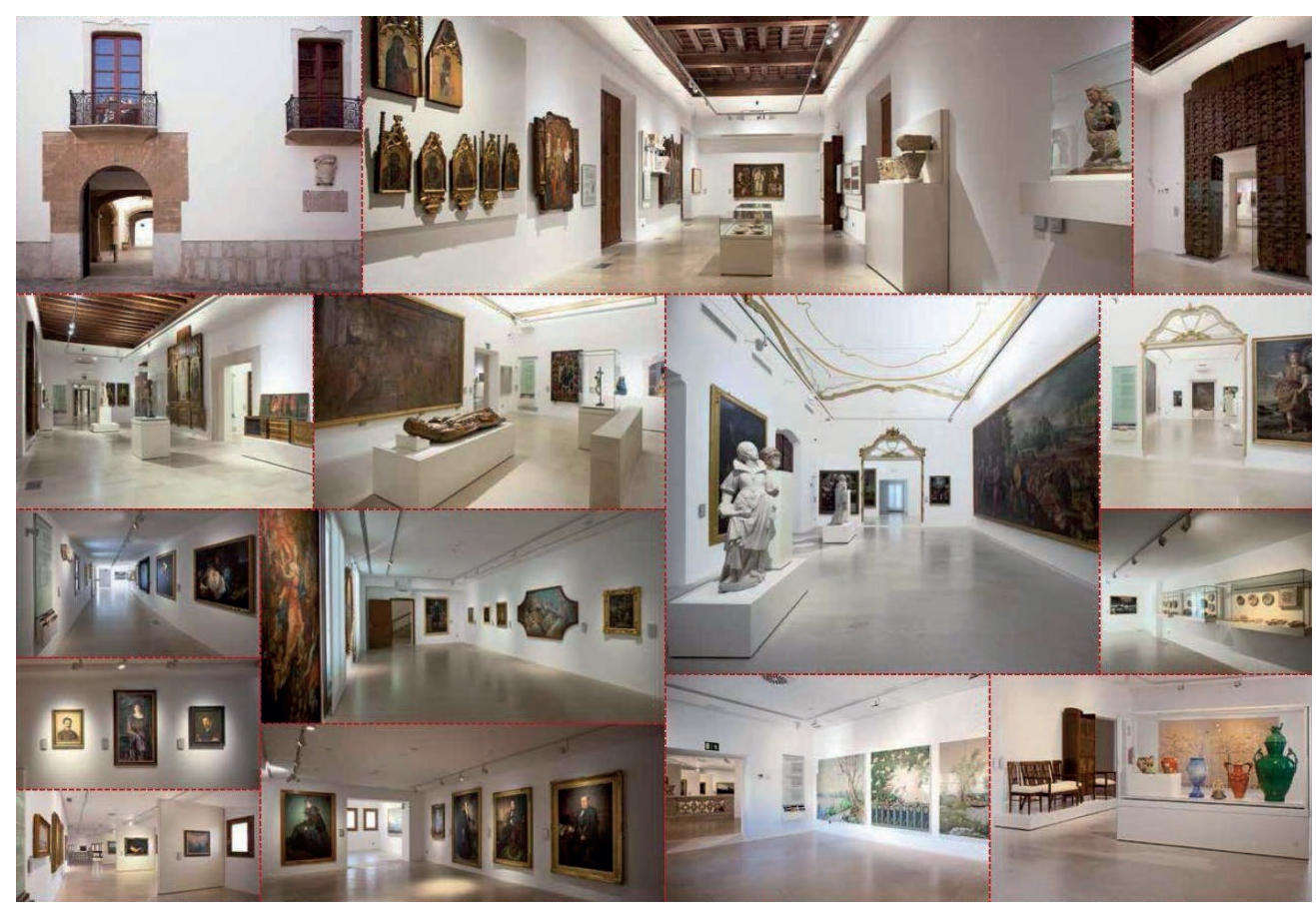

Figura 2. Interior del museo rehabilitado en 2015. El discurso museográfico se inicia en el siglo XIII, salas de la planta noble y continúa en el tercer piso con el siglo XIX.

Fuente: Elaboración propia. 


\section{Objetivos}

La sociedad actual demuestra, cada vez más, un interés por todo lo relacionado con la alimentación. Esta inclinación se refiere tanto a la nutrición, como a la tecnología de la elaboración de los alimentos, relacionadas con dos preocupaciones esenciales de la población, la salud y la economía. Los avances en la investigación sobre alimentación son muchos y variados. Casi todos conocemos qué es el aceite Omega 3 y en qué alimentos se encuentra, calculamos los hidratos de carbono, controlamos las grasas saturadas, tomamos vitaminas y nos informamos de los efectos beneficiosos o perniciosos para nuestra salud de los productos. Consecuentemente, hoy la ciencia puede recomendarnos con precisión qué comer y qué no. Sin embargo, aunque el conocimiento sobre alimentación nunca ha estado tan avanzado, hoy la obesidad es un problema global. Desde los años 80 del siglo XX, han aumentado considerablemente los malos hábitos alimentarios, con la consecuente aparición de diversas enfermedades, convirtiéndose en uno de los principales puntos de atención de la salud pública mundial. Para la Organización Mundial de la Salud (OMS), uno de los desafíos de Occidente será luchar contra la obesidad, infantil y adulta, debido al aumento paulatino e imparable de una dieta poco saludable y por el sedentarismo. En suma, la alimentación y la gastronomía son hoy temas de gran actualidad, que interesan al público y que se pueden interpretar desde una perspectiva artística. Santos, santas, reyes, reinas, duques, duquesas, obispos y la población anónima representada en retablos, cuadros, todos y todas, comían y bebían.

La alimentación es transversal y permite analizar extensos periodos de la Historia. Mediante la comida, los sistemas de producción y los tipos de consumo, se puede abarcar la historia de todas las civilizaciones que han dejado su huella en Mallorca. Economía, sociedad, arte, política, cultura, son elementos de una civilización que tienen una relación directa e incluso privilegiada con la alimentación. No podía ser de otra manera al ser la comida y la bebida imprescindibles para la supervivencia. Comer y beber tienen también el lado hedonista, condicionado por el gusto exquisito de las clases altas y por el sentido de exotismo y exclusividad que se manifiesta a través de este placer mundano.

La transversalidad y pluridisciplinariedad con el que se puede trabajar la alimentación, nos ha permitido organizar unos ciclos de conferencias y degustaciones entorno a la exposición permanente del Museo. La difusión de la colección permanente a través de la observación desde una perspectiva alimentaria ha sido su objetivo primordial.

\section{Desarrollo de la innovación}

Desde el año 2019 hasta el advenimiento de la pandemia, se organizaron tres ciclos de conferencias y talleres de degustación. Se trataron temas, elegidos en función del diálogo con la colección permanente del museo y las preferencias del público. Para el primero, celebrado en octubre de 2019, bajo el título La alimentación medieval a través de los tesoros del Museo de Mallorca, se escogió la alimentación de los siglos XIII-XV, impartido por un especialista en esta materia y época, el Dr. Pablo José Alcover Cateura.

La dieta bajo medieval mallorquina se basaba en dos alimentos esenciales, el pan y vino, junto con ellos, las carnes y pescados, cuyo consumo dependía de la época del año y la clase social, cuanto más humilde se comía más pescado y menos carne. Las verduras y frutas estaban presentes en el menú diario de los más pobres, y rara vez eran consumidas por las clases altas, al vincularse a comida de campesinos. Los embutidos obtenidos en las matanzas y los quesos obtenidos de la leche de vacas, cabras y ovejas, les permitían nutrirse todo el año. 


\section{CONFERÈNCIES SOBRE}

\section{L'ALIMENTACIÓ MEDIEVAL A TRAVÉS DELS TRESORS DEL MUSEU DE MALLORCA}

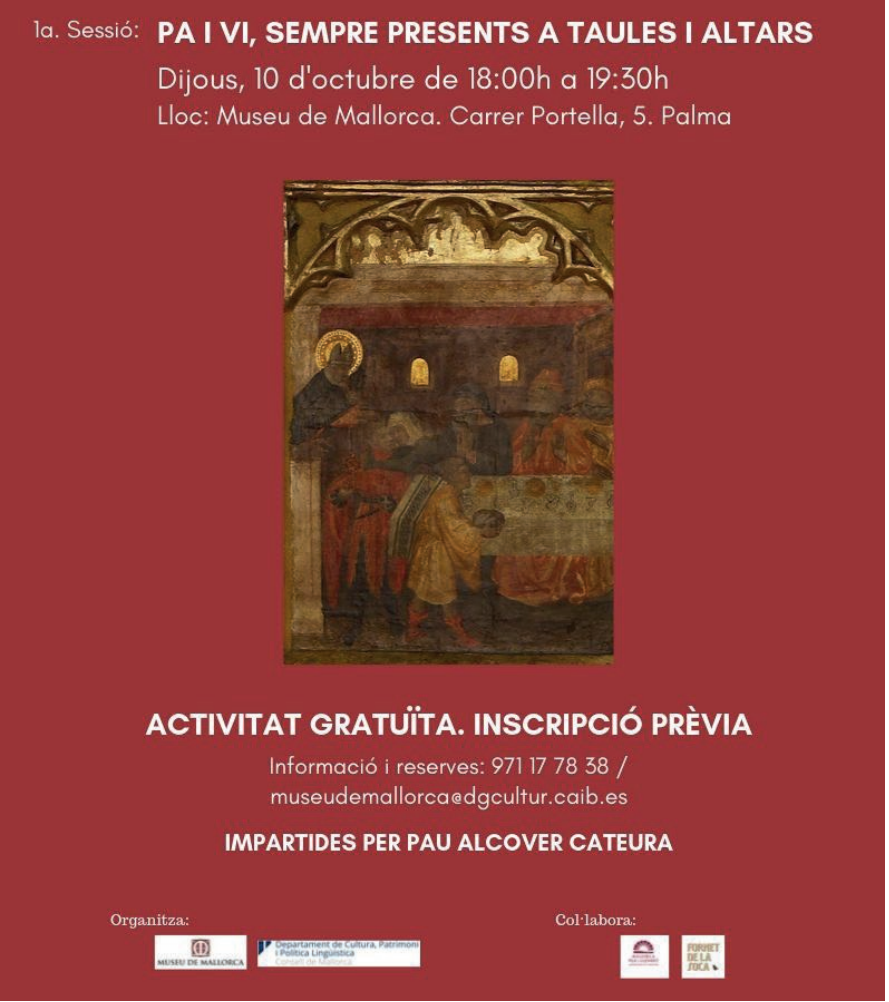

Figura 3. Primer ciclo de conferencias en los que se establece una relación entre arte y gastronomía. Fuente: Museu de Mallorca.

Pa i vi, sempre presents a taules i altars, sirvió para conocer los tipos de panes que se consumían. Cada persona tomaba, de término medio, entre ochocientos gramos y un kilo diarios. En el Retaule de sant Nicolau, sant Antoni i santa Clara, de finales del siglo XIV, una de las joyas del gótico balear, conservada en el museo, hay representada una escena inspirada en una cena de una familia aristocrática mallorquina. En ella se aprecian panes redondos y blancos, elaborados con cereales candeales, propios de los ricos, cristianos y judíos. Además, también se pueden ver panes blancos alargados, el primer testimonio gráfico del llonguet, el pan candeal que continua siendo el más típico de la ciudad de Palma. En la mesa del retablo hay pintadas copas de vidrio para el vino. El vidrio era el material más caro para la elaboración de estas piezas cotidianas, que debido a su transparencia ayudaba a prevenir el envenenamiento de los comensales. Resulta muy interesante el uso de jarras de vino y agua, ya que conservamos objetos similares de la misma época. 

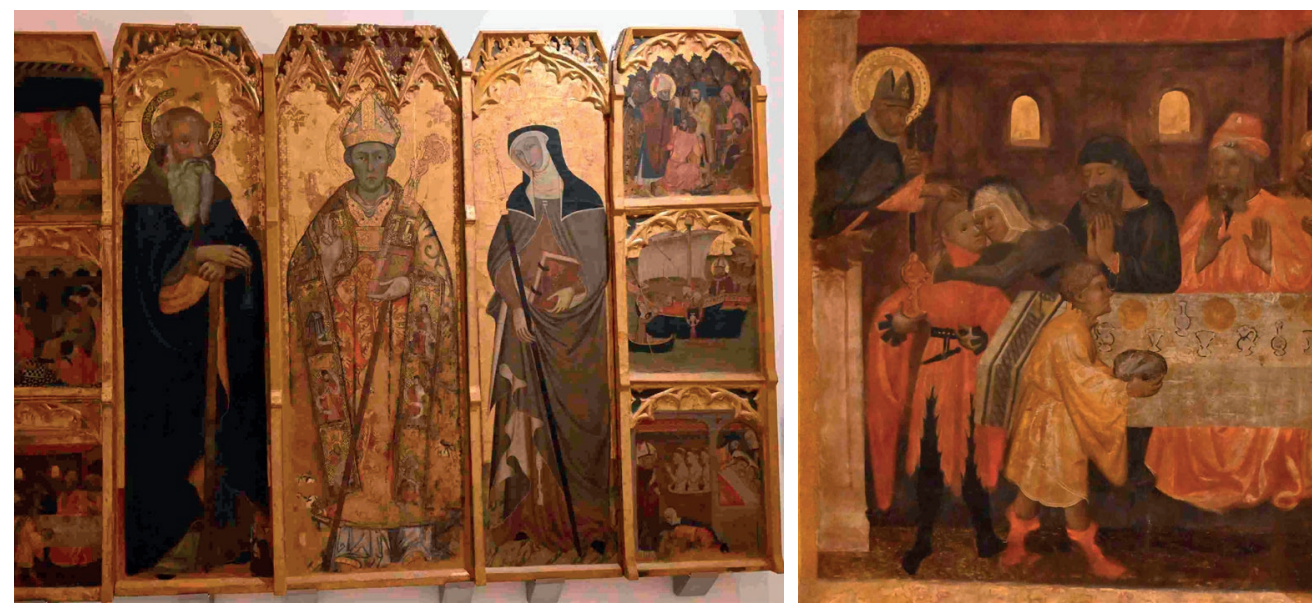

Figura 4. Retablo de San Nicolás, san Antonio y santa Clara, atribuido a Pere Marçol, Maestro de Santa Eulalia y Maestro de Santa Margarita, finales del s.xv. Detalle del compartimento inferior izquierdo, en el que se aprecian panes, jarras y otros utensilios, encima de una mesa, similar a las que había en las clases nobles. Fuente: Museu de Mallorca.

Asimismo, se procedió a una lectura con respecto al papel de las mujeres por lo que se refiere a la elaboración y venta de pan. Se sabe que a pesar de ser ellas las que se encargaban de amasar, junto con los esclavos, no tenían el mismo respeto que los hombres panaderos, que lo horneaban, proceso mejor visto que el anterior. El vino, líquido sagrado y profano, era consumido exclusivamente por hombres, en tabernas y hostales. A las mujeres, les estaba prohibido fuera de la mesa del hogar, ya que tenían a su cuidado a los hijos. Además de ir desgranando los conceptos generales, en torno al líquido elemento, se fueron introduciendo anécdotas. Por ejemplo los verdugos, podían beber públicamente pero tenían que traer la copa de su hogar, ya que se decía que la sangre de los condenados era fuente de enfermedades.

La segunda conferencia, Carns i peixos, plaers terrenals, sirvió para analizar el papel que tuvo el consumo de carne y pescado en el calendario bajo medieval, el cual se dividía entre los días carnales y los no carnales, en los que exclusivamente se comía pescado. Se describieron las carnicerías y pescaderías, los alimentos autorizados, así como los preceptos sobre la cocción de los alimentos, auspiciados por las diferentes confesiones religiosas. Los judíos debían obedecer la kashrut, la cual les prohibía consumir animales terrestres con pezuñas hendidas o rumiantes, tales como vacas, ovejas, cabras o ciervos y los pescados sin escamas, aletas dorsales y laterales. En contraposición, los cristianos no tenían restricciones alimentarias. La presencia de ciervos, gamos o jabalíes, fauna local en aquellos momentos y hoy extinguida en la isla, estaba presente en las mesas y recetario de las clases señoriales. Así como también platos cocinados con orcas, focas, delfines, salmones o atunes. En el Llibre del Coc, recetario del siglo XV, se describen recetas de abstinencia a base de salmón, tales como salmón en pan o salmón en cazuela, mientras que en el Llibre de Sent Soví, fechado en el siglo XIV, hay recetas de fritos de delfín o una salsa para atún. Por último, en el Llibre d'aparellar de menjar, del siglo XIV, se recogen recetas de salsa para jabalí, ciervo y gamo, entre otras. 
En la última conferencia, Formatge i embotits, aliments per a sobreviure a la fam, se enumeraron los alimentos elaborados para sobrevivir a los duros inviernos, época en la que el huerto casi no producía frutas y verduras. Los quesos curados de cabra, oveja roja mallorquina o de oveja y cabra, parmesano, caciocavallo, queso de Tronchón y los embutidos, tales como el bacón, la sobrasada, la longaniza o la butifarra, estaban presentes en las mesas, tanto los productos de elaboración local como los de importación. Los quesos los podía comercializar directamente cualquier vecino que los produjera o los importara y se vendían en las queserías, mientras que los embutidos se ofrecían en las carnicerías públicas, con el precio de venta regulado por las autoridades locales. La sobrasada, de origen italiano y que todavía hoy se consume en el sur de Italia, se ha convertido en uno de los productos icónicos de la isla, junto con la todavía más famosa ensaimada. En los inventarios de los almacenes de las casas populares y nobles del siglo XV, se citan las sobrasadas, elaboradas para el consumo cotidiano o para regalar a las amistades. Su consumo más habitual era como el de hoy, untada sobre pan.

El segundo ciclo, El vi de la nostra terra. Història i actualitat d'un producte mediterrani, estuvo motivado por el hecho que el museo conserva entre sus fondos, obras relacionadas con la producción y consumo del vino. El líquido elemento, que forma parte de nuestra cultura, nos sirvió de hilo conductor para estudiarlo de una forma pluridisciplinar, desde la enología, la etnografía o la sociología. Los estudios biológicos, agrícolas y vitivinícolas, nos permiten saber todo lo relacionado con la cepa de la cual se extrae la uva, hasta el proceso de elaboración del elixir. Entre otros objetos, el museo tiene un amplio repertorio de vasos fabricados expresamente para

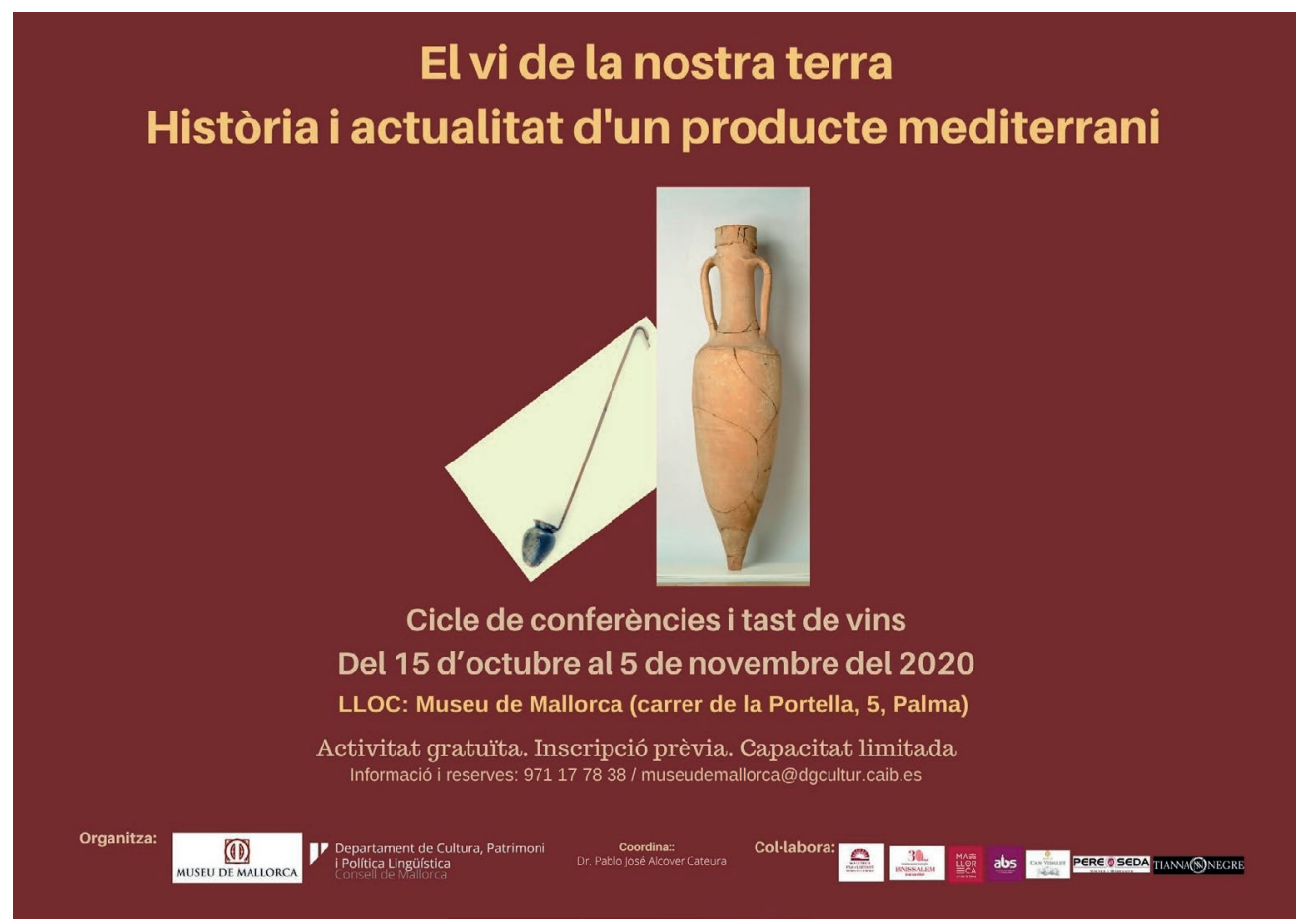

Figura 5. Cartel informativo del segundo ciclo de Arte y gastronomía, dedicado al vino. Fuente: Museu de Mallorca. 
contener o beber vino, desde la época griega, e incluso anteriores. Ánforas vinarias, cálices, jarras, copas de vidrio y otros objetos fueron diseñados expresamente para contener, saborear o hacer libaciones con el vino. A partir de la época medieval y hasta la Edad Moderna, se usaron escudillas o vasos de cerámica, para las clases populares y copas de cristal, opción preferida por las clases alta y eclesiástica. En retablos y cuadros, aparecen en múltiples ocasiones, mesas puestas con alimentos y contenedores de alimentos. Ver estas obras desde la perspectiva vinaria es una manera de ofrecer nuevas formas de interpretación de las obras de arte.

En Vi: beguda divina y humana. Dels inicis llegendaris al seu consum diari a la Mallorca del segle XVIII, impartida por el Dr. Miguel Garí, se enmarcó en una lectura histórica del vino desde sus remotos orígenes hasta el siglo XVIII. De Hipócrates a Arnau de Vilanova, se resaltaron los efectos beneficios de sus efluvios y consumo, por su alto poder nutriente, como transportador de las encimas de los alimentos, como digestivo y de utilidad para mejorar el sistema nervioso.

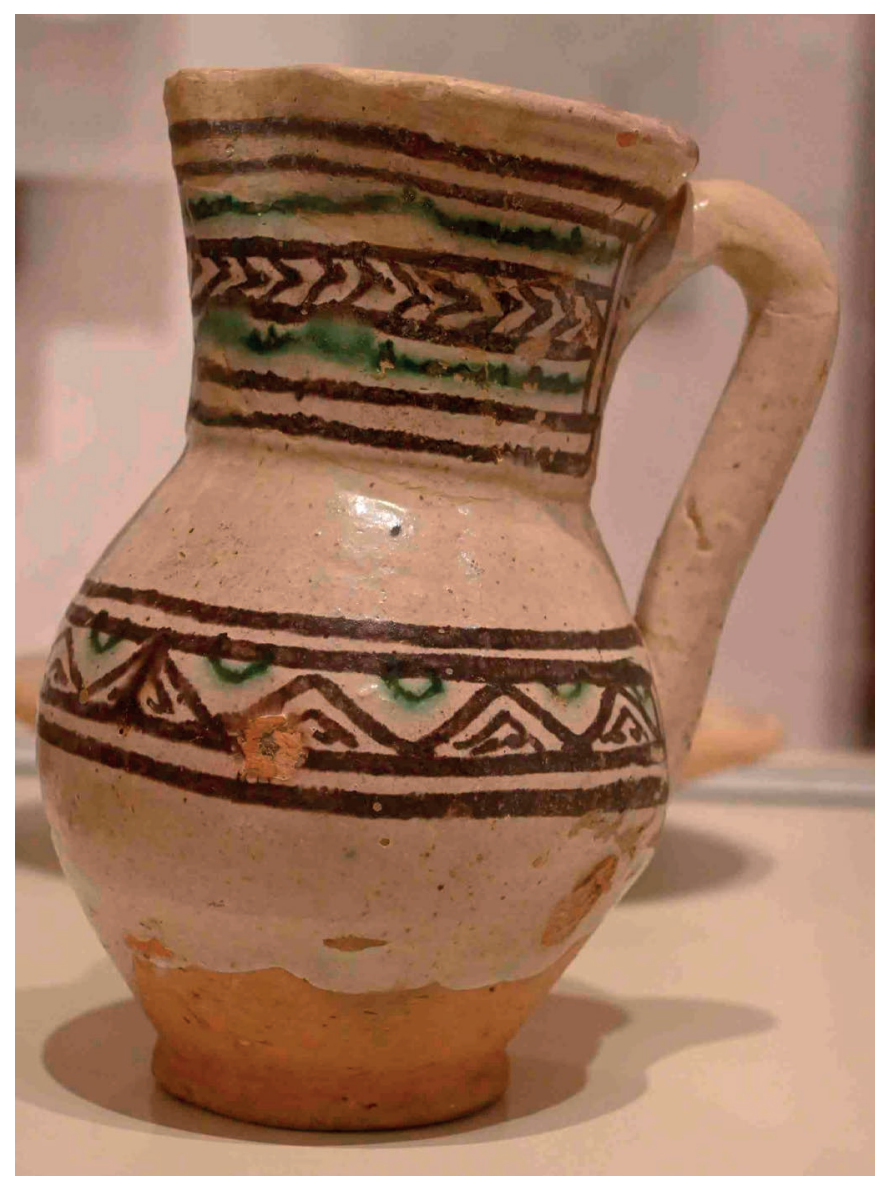

Figura 6. CJarra de loza de verde y manganeso fechada en el siglo XIV. Posiblemente fue usada para contener vino y/o agua.

Fuente: Museu de Mallorca. 
La segunda conferencia El consum de vi a Mallorca i a la Mediterrània. Una visió des de l'antropologia, presentada por la Dra. Margalida Mulet, fue temática y cronológicamente una continuación de la anterior. Como muestra gráfica se aportó las fotografías antiguas que posee el museo, relacionadas con el tema. Desde mediados del siglo XX, se pasó progresivamente de consumir uno a dos litros de vino diarios por persona adulta, a consumir una media de un vaso semanal de vino. Este menor consumo, redundó en una mejora en la producción de los caldos, anteriormente fabricados de manera doméstica, sin grandes aspiraciones relacionadas con la calidad del producto.

El Dr. José Mariano Escalona, profesor de la UIB y miembro del programa de recuperación de cepas isleñas antiguas, presentó las investigaciones efectuadas en este campo, las cuales han dado como resultado la identificación, recuperación y siembra de cepas antiguas que habían quedado en desuso. En su charla, Mallorca, terra de bon vi. Les varietats de vinya autòctones de l'illa, explicó el funcionamiento biológico de la viña. Así mismo se destacó la época de esplendor de la producción vinícola de la isla en el siglo XIX a causa de la filoxera que arrasó las vides francesas. Desde hace unos años, ha habido un segundo auge vinario debido a la recuperación de la producción, destacando los vinos elaborados con las variantes locales de callet y manto negro, la proliferación de bodegas y la demanda del mercado centroeuropeo.

La última conferencia Un ofici amb glamur. Conèixer l'art del sommelier a Mallorca, cerró el ciclo y fue expuesto por Daniel Arias, actual presidente de la Asociación de Sommeliers de Baleares. Su objetivo principal fue explicar el oficio de somelier, lo cual fue de mucha utilidad para poner en práctica lo aprendido en la cata de vinos que se efectuó en el patio del museo, ofrecida por las bodegas agrupadas bajo las denominaciones DO Mallorca, Pla i Llevant y DO Binissalem.

A raíz de la cesión al museo de un conjunto de objetos de cerámica de la colección Marroig, propiedad del Consell de Mallorca, se nos ocurrió iniciar una nueva línea de investigación en torno a la nueva colección del museo y el consumo de chocolate. Bartomeu Marroig Mesquida, coleccionó entre otros objetos, jícaras y mancerinas de Alcora y de otros talleres, objetos diseñados ex profeso para la bebida de los dioses, fechados desde finales del siglo XVIII a principios del XIX. Las cerámicas se expusieron y con la intención de dar a conocer al público dichos objetos y dado el éxito de los dos ciclos anteriores, organizamos una serie de conferencias y talleres de degustación relacionados con la historia del chocolate y su consumo en Mallorca. Esta fue la última actividad que se pudo efectuar presencialmente debido a la irrupción del COVID19. La intención fue ofrecer una visión transversal y pluridisciplinar del uso del chocolate, desde una perspectiva histórica, a los métodos de fabricación, sus valores nutricionales y médicos hasta el anecdotario, la tradición, la desmitificación o mitificación del producto. El ciclo constó de dos conferencias, una cata y una ruta del chocolate. El paseo se inició en el museo y continuó por las principales confiterías y chocolaterías, hoy en día casi inexistentes, por el centro histórico de Palma. Es también una forma de preservar la memoria histórica culinaria y gustativa.

En El regal americà. Dels orígens de la xocolata a la seva consolidació com aliment quotidià a Mallorca al segle XVIII, impartida por la Dra. María de los Ángeles Pérez Samper, se enumeraron sus orígenes legendarios en América hasta su llegada a Mallorca en el siglo XVIII. Exclusivo entre las clases adineradas, en un primer momento y paulatinamente consumido por las clases sociales económicamente menos solventes. Se remarcó su vinculación con el pecado de la gula, uno de los siete capitales, y los recelos que su consumo provocó en algunos sectores conservadores de la Iglesia. 


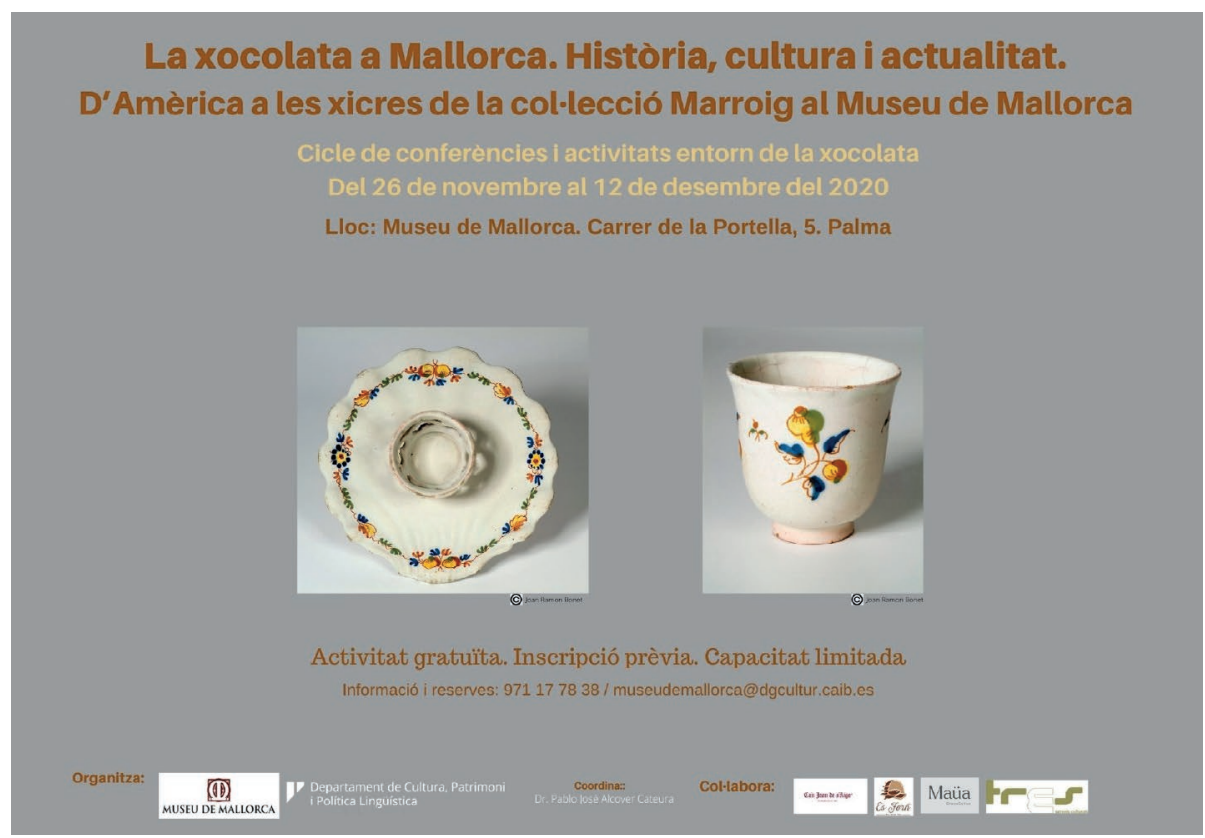

Figura 7. Tercer ciclo de Arte y gastronomía, dedicado a la relación entre la colección del museo y el chocolate.

Fuente: Museu de Mallorca.

Por otra parte, Catalina Torres presentó una conferencia titulada Les xicres de la col/lecció Marroig, ceràmiques per a la xocolata, en la que analizó el consumo de chocolate en los siglos XVIII y XIX a partir obras de arte, además de explicar los protocolos de su consumo.
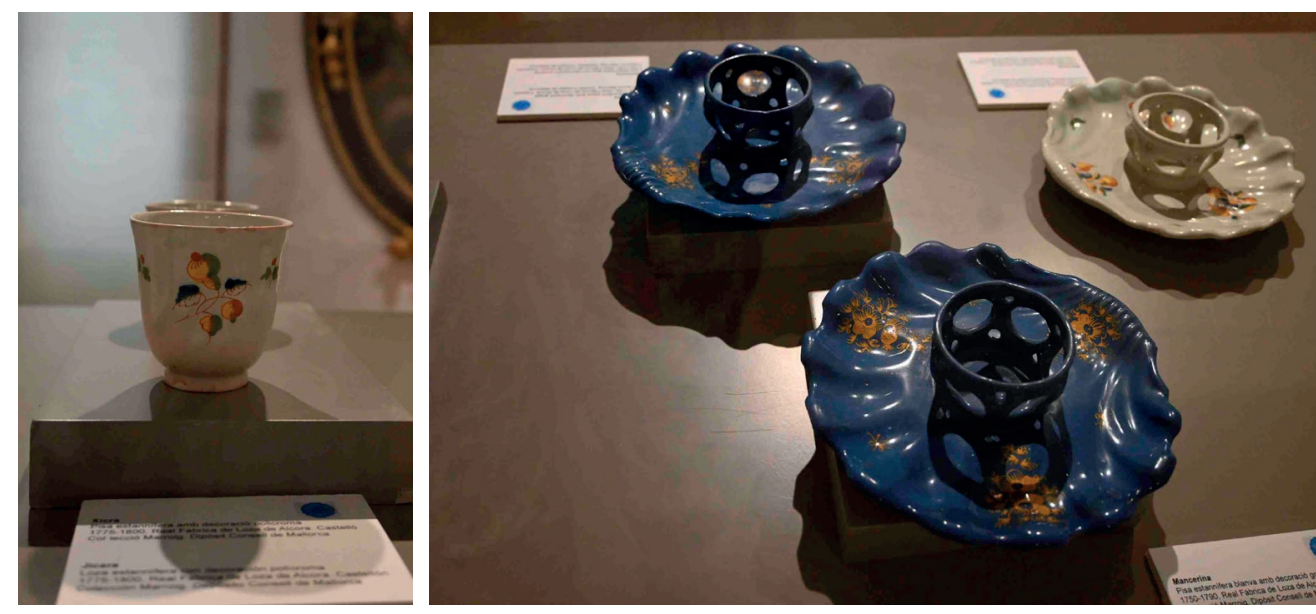

Figura 8. EJícaras de la serie Ramillete, fechadas en 1775-1780 y mancerinas azules fechadas entre 1775-1790, manufacturadas en la Real Fábrica de Loza de Alcora (Castellón). Colección Marroig. Fuente: Museu de Mallorca. 
Las otras dos actividades giraron en torno a la degustación de chocolate. Tastem la xocolata. Taller teoricopràctic, dinamizada por el Dr. Josep Tur, consistió en una cata de chocolates a partir del reconocimiento de texturas, colores, sabores, intensidad y olores. Finalmente, el paseo gastronómico por algunas de las más antiguas chocolaterías de Palma de Mallorca, quizás de las más antiguas de Europa, y la degustación de los chocolates calientes, blancos, negros, con o sin leche, hizo las delicias de los asistentes.

\section{Resultados y conclusiones}

El principal resultado de relacionar la colección del museo con la gastronomía fue el aumento del interés del público local por conocer o revisitar el museo. Las actividades efectuadas contribuyeron a aumentar las cifras de visitantes los años 2019 y 2020. ${ }^{2}$ Este hecho fue recogido por la prensa local, que señaló al Museo de Mallorca como uno de los más visitados por locales y extranjeros. ${ }^{3}$ Por lo que también tuvo un efecto mediático. Además hay que destacar el acierto de difundir la exposición permanente a través de la alimentación y la reivindicación del conocimiento y consumo de los productos locales en un momento de crisis de la agricultura isleña. ${ }^{4}$ Por otra parte, hemos iniciado nuevas lecturas de la colección. Lo comenzamos con la relectura de las piezas a través de la indumentaria de alta costura ${ }^{5}$ y ahora lo hacemos mediante la gastronomía y la difusión de las tradiciones culinarias. Como comentábamos antes nuestra intención es estudiar, recuperar y difundir la industria chocolatera que desde el siglo XVIII, cuando se inició, fue en aumento hasta que en la actualidad, prácticamente ha desaparecido en Mallorca. Entendemos por tanto que contribuye a reforzar el papel de centro de investigación que tienen que ser los museos. Estos estudios se verán ampliados con la exposición de artilugios y maquinarias de elaboración del chocolate en la Secció Etnològica de Muro, que depende del Museu de Mallorca, cuando se reabra después de su rehabilitación arquitectónica y museográfica.

La difusión del gusto, la gastronomía en la Prehistoria y en la Antigüedad, son otros temas pendientes que esperamos poder llevar a cabo cuando se reabran las salas dedicadas a la Arqueología Balear, actualmente cerradas al público.

Y ya para acabar, nos gustaría unir la colección del museo, con recetarios antiguos y recrearlos con las nuevas tendencias gastronómicas que están llevando a cabo cocineras y cocineros tanto de renombre como los autores anónimos que siguen cocinado las mismas recetas desde hace siglos. Gusto por la tradición y por la innovación.

\footnotetext{
2 Se contabilizaron más de 500 personas.

3 En Onda Cero Mallorca, programa Más de Uno, Ràdio de les Illes Balears, programa Darrer Vol a Formentera y Ona Mallorca, programa Espais desde l'Antropologia y los periódicos Última Hora y Diario de Mallorca.

4 En el programa Taula Voraç de Radio Nacional, el periodista Manuel Julbe, premio Pau Llull de Gastronomía, destacó que: "En los últimos veinte años, pocos actos culturales han conseguido más entusiasmar al público. El Museo de Mallorca está en la onda. La alimentación es cultura y la gastronomía es una puerta a conocer los ricos fondos del Museo, porque conocer es proteger". En Onda Cero Mallorca, programa Más de Uno, Ràdio de les Illes Balears, programa Darrer Vol a Formentera y Ona Mallorca, programa Espais desde l'Antropologia, junto con los periódicos Última Hora y Diario de Mallorca, informaron sobre el acierto de la programación y la divulgación de temas gastronómicos en el museo.

5100 Anys de Glamur. Art i moda: un diàleg de la Collecció Antoni de Montpalau amb el Museu de Mallorca. Museu de MaIlorca del 31 d'octubre de 2019 al 28 de febrer de 2020. Palma de Mallorca. Catàleg digital.
} 


\section{Bibliografía}

ABAD ALEGRÍA, F. (2009). Líneas maestras de la gastronomía y la culinaria españolas (siglo XX). Barcelona: Trea.

ALBALA, K. (2002). Eating Right in the Renaissance. Berkeley: University of California Press.

ALBALA, K. y EDEN T. (2011). Food and Faith in Christian Culture. Berkeley: University of California Press.

ARMANIOS, F. y ERGENE, B. (2018). Halal Food: A History. Oxford: Oxford University Press.

BARCELÓ CRESPÍ, M. y ROSSELLÓ BORDOY, G. (1996). Terrissa: dades documentals per a l'estudi de la ceràmica mallorquina del segle XV. Barcelona: Canon.

BLECH, Z. Y. (2009). Kosher Food Production. Iowa: John Wiley \& Sons.

Bober, P. P. (2001). Art, Culture, and Cuisine: Ancient and Medieval Gastronomy. Chicago: Chicago University Press.

BOLÒS i MASCLANS, J. Ceràmica grisa i terrissa popular de la Catalunya medieval. Barcelona: Universitat de Barcelona.

CARTAY ARTULO, R. (1991). Historia de la alimentación del Nuevo Mundo. Caracas: Fundación Polar y Universidad de los Andes.

CHOMSKY, D. (2009). Cocina judía para celebrar la vida. Comidas de fiesta según fuentes hebreas clásicas, la Cábala y la tradición. Barcelona: Trea.

CONCA MESSINA, S. A. et. al. (2019). A History of Wine in Europe, 19th to 20th Centuries, Volume II: Markets, Trade and Regulation of Quality. London: Springer Nature.

CONTRERAS, J. (1995). "Introducción" en Contreras J. Alimentación y cultura: necesidades, gustos y costumbres. Barcelona: Universitat de Barcelona.

CONTRERAS, J., GRACIA, M. (2014). "La prevención de la obesidad en España: una lectura crítica desde la antropología" en ETNICEX, vol. 4, p. 41-61.

FLANDRIN, J. L. y MONTANARI, M (2004). Historia de la alimentación. Barcelona: Trea.

FREEDMAN, P. et al. Food. History of Taste. Berkeley: University of California Press.

GARCÍA SOLER, M. J. (2001). El arte de comer en la antigua Grecia. Madrid: Biblioteca Nueva.

GIACOSA, I. G. (1994). A Taste of Ancient Rome. Chicago: Chicago University Press.

HUICI MIRANDA A. (2016). La cocina hispano-magrebí durante la época almohade. Barcelona: Trea.

JACINTO GARCÍA, L. y TOVAR, R. (2007). Un banquete por Sefarad. Cocina y costumbres de los judíos españoles. Barcelona: Trea.

ROSSELLÓ BORDOY, G. y BALTASAR COLL T. (1997). La cerámica popular en las Islas Baleares. Palma de Mallorca: Àmbit.

LUJÁN, N. (2019). Historia de la gastronomía. Madrid: Debate. 
MCNEIL, C. L. (2009). Chocolate in Mesoamerica: A Cultural History of Cacao. Berkeley: University Press of Florida.

MONTANARI, M. (1997). La fame e l'abbondanza. Firenze: Laterza.

MONTANARI, M. (2006). La comida como cultura. Barcelona: Trea.

MONTANARI, M. (2019). Gusti del medioevo. I prodotti, la cucina, la tavola. Firenze: Laterza.

PADILLA, J. I. et al. (1998). Ceràmica medieval i postmedieval: circuits productius i seqüències culturals. Barcelona: Universitat de Barcelona.

PÉREZ SAMPER, M. A. (1998). La alimentación en la España del Siglo de Oro. Lleida: Vall d'Onsera.

PÉREZ SAMPER, M. A. (2011). Mesas y cocinas en la España del siglo XVIII. Barcelona: Trea.

PÉREZ SAMPER, M. A. (2019). Comer y beber: Una historia de la alimentación en España. Barcelona: Trea.

PUIGGRÒS i JOVÉ, J. M. (2019). La cultura de la vinya i el vi a Catalunya, de l'edat mitjana als temps actuals. Barcelona: Universitat de Barcelona.

SANTACANA MESTRE, J. (2011). Lo sagrado y lo abominable. La cocina de los pueblos prerromanos de España. Barcelona: Trea.

TOUSSAINT-SAMAT, M. (2009). History of Food. Oxford: John Wiley \& Sons.

SELLA MONTSERRAT J. (2009). Comer como un rey. Las mesas de Amadeo I de Saboya y Alfonso XII de Borbón. Barcelona: Trea. 


\title{
"LIQUIDUM NON FRANGIT JEJUNUM": LA POLÉMICA RELIGIOSA EN TORNO AL CHOCOLATE Y SU REFLEJO EN EL ARTE DE LA EDAD MODERNA
}

\author{
Vanesa Quintanar Cabello \\ Universidad de Valladolid
}

\begin{abstract}
Among the foods that arrived in Europe from America at the beginning of the Modern Age, cocoa (Theobroma cacao) was undoubtedly one of those that produced the greatest interest among Europeans who, from the first testimonies, showed an ambivalent posture between fascination and fear towards a product to which all kinds of properties were attributed. One of the most sceptical sectors with cocoa was the Catholic Church, considering that its consumption could go against the rules of fasting. This controversy was the subject of numerous texts and required the intervention of Cardinal Brancaccio to settle it. Based on the aforementioned texts, this article considers how this controversy about the consumption of chocolate and its subsequent abandonment could have been transferred to the world of art. To this end, the main artistic images of chocolate produced in Spain in the seventeenth and eighteenth centuries will be analysed, showing the characteristics and evolution in the presentation of the product and all the elements surrounding its consumption (tableware, consumers, environments...) with the aim of demonstrating the parallel development of the religious controversy and its artistic representation in Spain.
\end{abstract}

Keywords: chocolate; Religion; Catholic Church, Art, Modern Ages.

Resumen: De los alimentos que llegaron a Europa procedentes de América a comienzos de la Edad Moderna, sin duda, el cacao (Theobroma cacao) fue uno de los que mayor interés produjo entre lo europeos que, desde los primeros testimonios, mostraron una postura ambivalente entre la fascinación y el miedo hacia un producto al que se le adjudicaba todo tipo de propiedades. Uno de los sectores más escépticos con este alimento fue la Iglesia, al considerar que su consumo podía ir en contra de las normas del ayuno católico. Esta polémica fue objeto de numerosos textos e hizo necesaria la intervención del cardenal Brancaccio para zanjarla. A partir de los citados textos, el presente artículo plantea cómo esta polémica en torno al consumo del chocolate y su posterior abandono pudo tener su traslación al mundo del arte. Para ello, se analizarán las principales imágenes artísticas del chocolate producidas en España en los siglos XVII y XVIII, mostrando las características y evolución en la presentación del producto y de todos los elementos que rodeaban su consumo (la vajilla, los consumidores, los ambientes ) con el objetivo de demostrar el desarrollo paralelo de la polémica religiosa y de su representación artística en España.

Palabras clave: chocolate; Religión, Iglesia Católica, Arte, Edad Moderna.

Citar como: Quintanar Cabello, V. (2022). "'Liquidum non frangit jejunum': la polémica religiosa en torno al chocolate y su reflejo en el arte de la Edad Moderna". En: Actas del III Congreso Internacional sobre Patrimonio Alimentario y Museos. 25-26 noviembre, 2021, Valencia, España. pp. 171-183. https://doi.org/10.4995/EGEM2021.2021.13337 


\section{Introducción. Primeras impresiones sobre el cacao}

Cuando los españoles llegaron al continente americano, el árbol del cacao (Theobroma cacao) era ya considerado una planta especial que conectaba con la divinidad y cuyos frutos tenían prestigiosos usos, como servir de moneda o como materia prima para elaborar una bebida ritual.

Tal y como señalan José Pardo-Tomás y María Luz López Terrada (1993), las primeras menciones seguras en textos europeos al cacao y sus diferentes usos, incluido el alimenticio, vendrían de la mano de Hernán Cortés y de Pedro Mártir de Anglería. El primero desembarcó en abril de 1519 en las costas de Tabasco y, ya en su primera carta informe al emperador Carlos V, hace mención del cacao, «un fruto como la almendra que ellos venden molido; y tiénenlo en tanto valor que se trata por monedas en toda la tierra y con ella se compran todas las cosas necesarias en los mercados y otras partes» (Cortés, 1886: 94). Por su parte, Pedro Mártir de Anglería no solo hace mención del cacao en sus textos, sino que realiza, además, una de las primeras distinciones entre los diferentes usos que de este se hacía en Mesoamérica. Así, en la quinta de sus Décadas del Nuevo Mundo, redactada entre 1521 y 1523 para el papa Clemente VII, ofrece una distinción entre sus usos como moneda y como bebida e incluye además una expresiva alabanza a sus cualidades (Anglería, 1944: 393).

Sin duda, uno de los elementos que centrarán la atención de estos primeros testimonios serán, sin duda, los efectos sobre sus comensales. Quizás el más polémico de todos ellos lo constituía el aumento de la libido. Uno de los primeros en hacerlo notar es Bernal Díaz del Castillo que, al hablar de las costumbres de Moctezuma en su Verdadera Historia de la Conquista de la Nueva España, alude abiertamente a las propiedades afrodisíacas «de cierta bebida hecha del mismo cacao», que el soberano azteca usaba «para tener acceso con mugeres» (Díaz del Castillo, 1837, Vol. II: 93).

En relación con esto, la capacidad de despertar pasiones es otro de los elementos destacados por el escritor y comerciante italiano Francesco Carletti, que subraya en sus escritos su carácter adictivo, al señalar que «acostumbrándose a ella se vuelve cosa viciosa, y que con dificultad se puede dejar de beber cada mañana o durante el día por la tarde... Es por tanto, una sustancia adictiva» (Carletti, 1976: 61-63).

Cargado de estas y otras connotaciones, como sus efectos vigorizantes o su capacidad para aplacar la sed, los primeros cargamentos llegaron en 1585 a Sevilla procedentes de Veracruz (Harwich, 2018: posición 980) y, en pocos años, se inició un fluido comercio y una intensificación en la explotación de las plantaciones de cacao con el fin de abastecer la demanda a ambos lados del Atlántico. A ello contribuyó la adaptación al gusto europeo y su «hibridación», con el fin de «cruzar la barrera etnocéntrica del gusto y ser aceptado como una bebida normal por parte de los españoles y criollos» (Coe y Coe, 1996: 112-115), fundamentalmente mediante tres estrategias: la adición de ingredientes procedentes de Europa a la receta original, en especial el azúcar, la adición de especias conocidas y su consumo como bebida caliente y no fría como solían hacer los aztecas.

A pesar de este proceso de adaptación, tal y como señala Carmen Simón (2010), durante el siglo XVI y principios del siglo XVII el chocolate se mantiene prácticamente como un secreto disponible solo para la corte española. Los primeros cargamentos de chocolate procedente de América iban a parar directamente a la corte, donde a menudo llegaba como obsequio enviado directamente por los virreyes (Pérez Samper, 1996: 118), lo que explica que la documentación de 
Palacio no registre de manera oficial las primeras remesas (Simón, 1997: 61). A partir de su consumo limitado, se creó todo un ritual de prácticas codificadas, que incluía un amplio despliegue de utensilios para su preparación, servicio y degustación. El hecho de formar parte de esa «red de consumo» se convirtió en sí mismo en un signo de distinción (Fattacciu, 2009: 61).

De esta manera, el chocolate se convirtió en pocos años en una bebida de moda entre las élites, primero españolas y después europeas, que se consumía tanto en ayunas como para la merienda, especialmente entre las mujeres de la aristocracia (Huetz de Lemps, 2011: 784) y que en el siglo XVIII se extendió a otras áreas de Europa y, salvando las distancias en la calidad, a otras capas de la sociedad.

\section{La polémica religiosa frente al consumo de chocolate}

Frente a la pasión mostrada por la nobleza española frente a la bebida americana, su uso (y abuso) suscitó sin embargo un gran escepticismo en otros sectores de la sociedad, especialmente, entre los miembros de la Iglesia Católica. Así, lejos de considerarlo un tema anecdótico, numerosos moralistas se vieron obligados a intervenir por miedo a que su consumo pudiera ir en contra de las normas que sobre el ayuno había establecido la Iglesia católica. La polémica principal se centraba en el hecho de si el chocolate podía consumirse o no durante el periodo de ayuno. Los defensores señalaban que, al fin y al cabo, se trataba de una bebida. Los detractores, sin embargo, argumentaban que sus especiales características saciantes lo convertían en un verdadero alimento y que, por tanto, debía evitarse su consumo.

Uno de sus principales detractores fue, sin duda, el moralista León de Pinelo que, para dar forma a su argumentación, publicó en 1636 su obra Question moral si el chocolate quebranta el ayuno eclesiástico. Como resumen de su postura, baste señalar cómo, con cierta ironía, Pinelo respondía a los que señalaban que el chocolate era una simple bebida:

a este tono pudiera también decir, que la leche, el Atole, las poleadas, i aun unos guevos blandos, una pechuga de ave molida i desatada en caldo, por ser cosas que se beben no eran parte a quebrantar el ayuno (Pinelo, 1636: 113).

En esa misma línea planteará sus argumentos Gaspar Caldera de Heredia en su Tribunal Medicum, Magicum y Politicum (1638), donde señala que el chocolate, debido a su naturaleza, no puede ser consumido antes de comulgar (en Harwich, 2018: Posición 1445).

Otros, sin embargo, plantean serias dudas sobre la validez de estos argumentos y se inclina por su consumo. Este es el caso del teólogo Tomás Hurtado que, en su Chocolate y tabaco, ayuno eclesiastico y natural: si este le quebrante el chocolate, y el tabaco al natural, para la Sagrada Comunión... (1645), que comienza su obra sentenciando que "convienen casi todos, que si uno por enfermedad o flaqueza de estómago bebe en día de ayuno chocolate, no quebrante el precepto porque le bebe por medicina" (Hurtado, 1645: fol 2v.)

Lo irresoluble de esta polémica obligó a que, finalmente, el mismo cardenal Francesco Maria Brancaccio tuviera que dictar sentencia en 1664 y que fue recogida después en su tratado De chocolatis potu diatribe. Según Brancaccio,

El chocolate es una bebida, comparable al vino o a la cerveza, y obedece por ende a la regla establecida por santo Tomás de Aquino según la cual: liquidum non frangit jejunum; con tal, sin embargo, que no se contravenga la ley de la naturaleza que obliga a la templanza en toda cosa y que el chocolate no sea ingerido con la intención de quebrantar el mandamiento de la iglesia (Harwich, 2018: Posición 1454). 
Al margen de las distintas posiciones, lo que esta polémica ponía en evidencia era la necesidad social de aplacar todos aquellos elementos que pudieran constituir una subversión de los principios sociales y religiosos establecidos, incluidos los alimentos procedentes de las colonias. Como señala Irene Fattacciu:

Cacao provoked strong reactions because it was linked to Mesoamerican culture, and its exotic associations with energy, sexuality and abundance made it a potentially subversive element both in the colonies and in Spain (...) This latter quality was the one that aroused polemics and caused sensation, but it was also the source of cacao's success in Europe (Fattacciu, 2009: 61).

Con la llegada del siglo XVIII y la sentencia realizada por Brancaccio, la polémica religiosa y social en torno al chocolate parece desvanecerse: apenas se publican textos sobre este asunto, el tema se trata con un mayor desapego y fundamentalmente desde un punto de vista médico, como las obras del médico Tomás Cortijo Herraiz en su Discurso apologético médico astronómico de 1729 o la de Antonio Lavedán Tratado de los usos, abusos, propiedades y virtudes del tabaco, café, té y el chocolate, de finales del siglo XVIII, centradas en los efectos de su consumo y abuso sobre la salud.

\section{La representación del chocolate en el siglo XVII}

\subsection{Siglo XVII}

Como hemos visto, España fue puerto de entrada y lugar de consumo exclusivo del chocolate durante décadas. Por ello, resulta lógico que la mayor parte de las representaciones del chocolate en el siglo XVII en Europa se concentren en esta zona, aunque fuera, como veremos, de manera implícita.

Porque si algo llama poderosamente la atención es que la imagen del chocolate en el arte español del siglo XVII se realiza generalmente a través de objetos y otros alimentos asociados indisolublemente a su preparación y consumo, pero el chocolate no se muestra de manera explícita, salvo alguna excepción. Son las chocolateras, molinillos, tazas, salvillas o jarras de agua las que sirven para indicarnos que nos encontramos ante los preparativos de una típica merienda de la aristocracia española del siglo XVII. De entre todos estos objetos y por la especial relación geográfica con el producto analizado, merece destacarse la numerosa presencia de cerámica americana, especialmente procedente de la región mexicana de Tonalá, que gozó de buena fama en la época y que a menudo aparece representada en los bodegones donde aparecen servicios de chocolate, aunque también se muestran junto a otros productos y objetos para la preparación y degustación de comida.

Sin lugar a duda, uno de los mejores ejemplos de ocultación del producto e integración de la cerámica mexicana en una escena de servicio de chocolate se encuentra en la obra Bodegón con un cofre de ébano (1652) de Antonio de Pereda

Además de un gran despliegue de elementos, destaca la presencia del cofre que da precisamente título a la obra y que, posiblemente, serviría para mantener guardado con llave el cacao, evitando así posibles hurtos. Y, en el colmo del detallismo, «in Pereda's cozy still-life, the chocolate accompanies not only some colonial Mexican pottery, but also a jar of water -a regular follow-up to the often-bitter brew» (Bendiner, 2004:171) Encontramos por tanto en esta pintura no solo la representación de un servicio de chocolate con todo tipo de detalles, sino el deseo

\footnotetext{
$\overline{1}$ Museo del Hermitage (número de inventario: ГЭ-327).
} 
claro de mostrar con ello el lujo y la distinción a través de objetos (y alimentos) exóticos solo disponibles en aquel momento para las élites.

Sin llegar a ese lujo de detalles, todos los ejemplos localizados muestran al menos un elemento que nos indica que estamos ante los preparativos de una bebida de chocolate. El más evidente es la chocolatera, que encontramos, por ejemplo, en el Bodegón con servicio de chocolate (ca.1640) de Juan de Zurbarán², el Bodegón con caza (ca.1647) de Francisco Barrera³ o en el Bodegón con sandía anónimo ${ }^{4}$, entre otros.

Además de chocolateras, también encontramos en cuadros del siglo XVII español jícaras, como en el anónimo Bodegón con fruta y vajilla ${ }^{5}$; salvillas, como puede apreciarse en Limones, naranjas, taza y rosa (1633) de Francisco de Zurbarán6; infernillos de carbón, como el que aparece en Febrero. Bodegón de invierno (1640) de Francisco Barrera (figura 1)7 o molinillos para conseguir la espuma, como en Bodegón con servicio de chocolate (ca. 1640) de Juan de Zurbarán ${ }^{8}$

Varios de estos elementos también se encuentran en el Bodegón con servicio de chocolate de Juan de Zurbarán del Museo de Besançon que, además, presenta rasgos llamativamente «mundanos» y modernos para la época. Quizás en clara relación con ellos, esta obra destaca por ser el único cuadro español del siglo XVII localizado donde se representa explícitamente el chocolate, que asoma con claridad en la taza. Aunque sin presencia explícita del chocolate, esa modernidad y gusto por los detalles de Juan de Zurbarán se confirma en el ya mencionado Bodegón con servicio de chocolate del Museo de Kiev donde «los objetos (...) pierden la fuerza solemne y monumental que nace del severo aislamiento en que los muestra Francisco, y tienden a agruparse en composiciones complejas, de esquema triangular en profundidad» (Pérez Sánchez, 1983: 77).

Además de los objetos para la preparación y degustación del chocolate que sirven, salvo en el excepcional cuadro de Juan de Zurbarán, para representar indirectamente al chocolate, otro de los elementos que caracteriza su imagen en la pintura española del siglo XVII es el hecho de estar acompañado de otros alimentos. En este sentido, podemos hablar de dos tipos de alimentos.

Por un lado, en los ejemplos localizados se encuentran aquellos alimentos que se consumían asiduamente junto al chocolate, constituyendo así una merienda prototípica de la época. Destacan sobre todos estos alimentos los llamados barquillos de soletilla, que aparecen, entre otros, en Melocotones, pescado, castañas, caja de dulces, molinillo de chocolate y jícara lacada (ca.1635) de Antonio Ponce ${ }^{9}$ o en los ya citados Febrero. Bodegón de invierno de Francisco Barrera y Bodegón con un cofre de ébano de Antonio de Pereda, entre otros. Además de los barquillos, otros bollos y tartas o incluso panes, como los que aparecen en Escena de cocina

\footnotetext{
2 Musée des Beaux-Arts et d'Archéologie de Besançon (número de inventario: 896.1.85).

3 En el mercado anticuario de Madrid en 1995. Mencionado en Jordan W.B. y Cherry P., Spanish Still Life from Velázquez to Goya, 1995: 108.

4 F. Mont, Nueva York (Fuente: Fondazione Zeri).

5 Colección privada (subastado en Asta Sotheby's el 14/01/1994, n. 121).

${ }^{6}$ Norton Simon Museum (número de acceso: F.1972.06.P).

7 Museo Nacional del Prado (número de catálogo: P008213).

8 Museo de Arte Occidental y Oriental de Kiev (número de inventario: 51 ЖK).

9 Colección particular, Barcelona. Citado por Moreno (2015: 820).
} 


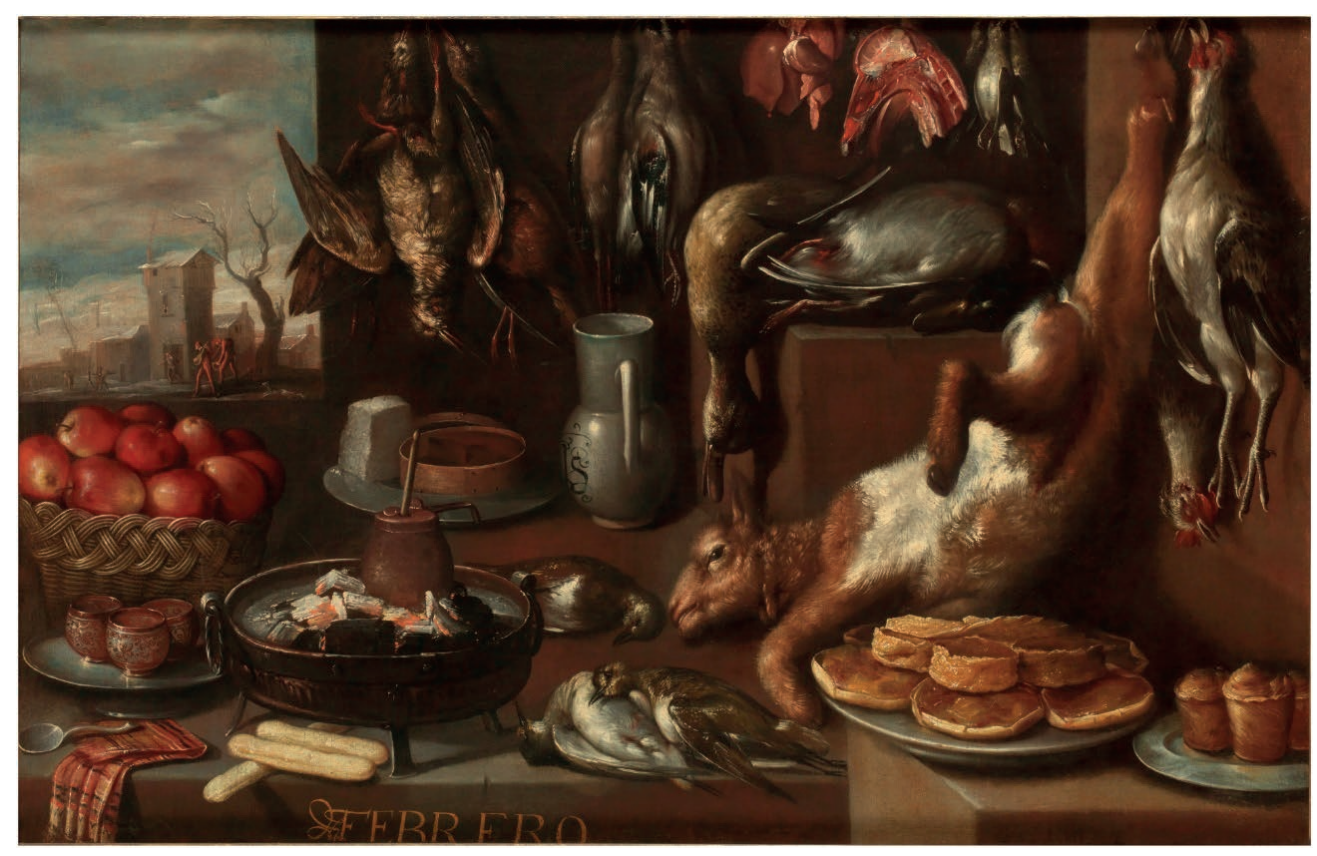

Figura 1. Francisco Barrera. Febrero. Bodegón de invierno. 1640.

Fuente: https://www.museodelprado.es/

(alegoría de la virtud perdida) (ca.1650) de Antonio de Pereda ${ }^{10}$, completan la lista de alimentos ligados directamente al consumo del chocolate.

Pero, además de estos productos, el chocolate (o los preparativos de este) aparece junto a otros alimentos que, a priori, no guardan relación con él. Destaca en este sentido la presencia de frutas: cítricos, como en Limones, naranjas, taza y rosa de Francisco de Zurbarán; manzanas (Febrero. Bodegón de invierno de Francisco Barrera) o frutas de verano, como melocotones (Melocotones, pescado, castañas, caja de dulces, molinillo de chocolate y jícara lacada de Antonio Ponce) o sandías (Bodegón con sandía anónimo). Además de las frutas, encontramos otros alimentos, como la volatería en Bodegón con caza de Francisco Barrera, así como en el Bodegón con servicio de chocolate y pájaros muertos de Francisco Barranco, o piezas de carne, en el mencionado Febrero de Barrera.

Sin ser propiamente un alimento, resulta llamativa la presencia de flores en tres de los ejemplos localizados. Destaca entre ellos uno de los pocos cuadros donde el género no es el bodegón, sino que se trata de una obra de temática religiosa: La joven Virgen (ca. 1632) de Francisco de Zurbarán ${ }^{11}$. Sobre la presencia de los diferentes elementos de este cuadro, incluidas varias florecillas esparcidas por el suelo, Norman Bryson señala:

\footnotetext{
10 Penrhyn Castle, The Douglas Pennant Collection (National Trust) (NT: 1421752).

${ }^{11}$ Metropolitan Museum of Art (número de acceso: 27.137).
} 
La capacidad de ver lo que es insignificante con visión aclarada se presenta como un don espiritual y en la virgen joven los objetos de la naturaleza muerta (flores, libro, tijeras, tapiz, taza de chocolate, cesto de la ropa) son atributos de la santidad, signo de gracia y pureza (Bryson, 2007: 80).

Con una connotación muy diferente, el propio Bryson destaca también la presencia de las flores en otro bodegón de Francisco de Zurbarán, en este caso Limones, naranjas, taza y rosa. En este caso, desde el punto de vista de Bryson, la presencia de flores sería un signo de sensualidad que remite al sentido del olfato, acorde con el aroma del propio chocolate. Según Bryson, de este cuadro destaca «la cuidadosa colocación de la fruta y el ramito de flor de naranjo, e invoca la fragancia de la rosa y el aroma del chocolate en el momento de alzarlos de su sitio para captar su olor» (Bryson, 2007: 76). Una lectura muy diferente a la que hace sobre este bodegón Julián Gállego, para quien todos los elementos del cuadro de Zurbarán no son otra cosa que un homenaje a la Virgen (Gállego, 1984: 202), lo que conectaría con las connotaciones marianas que Bryson apreciaba en el caso de la representación de la virgen niña.

Con mayor seguridad puede dotarse de connotaciones sensuales la delicada flor que descansa junto a las jícaras apiladas en el Bodegón de Juan de Zurbarán del Museo de Besançon, pues, como ya señalamos anteriormente, predomina la sensualidad en todo el cuadro, así como el gusto por lo material y lujoso, una lectura más improbable en el caso de los cuadros de su padre.

Sea cual sea la connotación de las flores, su presencia al lado de alimentos a priori ajenos al chocolate debe entenderse no tanto como una manera de mostrar elementos de una receta, sino como una manera de contextualizar la escena dentro de un ambiente noble. El chocolate, junto a flores, codiciadas piezas de carne, volatería, bollos y dulces, así como una suntuosa vajilla, conforman un «paisaje gastronómico» que en el siglo XVII español solo era posible encontrar en las casas más acomodadas.

Un último elemento a tener en cuenta en la representación del chocolate en la pintura española del siglo XVII es la presencia humana en estas escenas. Sobre este elemento, hay que señalar que tan solo en una escena de las localizadas aparece representada la figura humana: Escena de cocina (alegoría de la virtud perdida), de Antonio de Pereda. Si tenemos en cuenta el título y lo representado en este cuadro, resulta cuando menos significativo que la única presencia humana junto al chocolate o a los instrumentos para su preparación sea en una obra de fuertes connotaciones alegóricas negativas. Así, lo que vemos en la imagen no es otra cosa que una cocina que acusa los excesos del convite que acaba de finalizar. Rodeados de restos de comida y de decenas de utensilios de cocina desparramados por el suelo, la cocinera parece pedir ayuda al soldado, que, mientras la observa, se sirve vino. Tras el caos de la escena y el dramatismo de los personajes se esconde una imagen de fuerte simbolismo en la que Pereda parece advertir de las consecuencias de los excesos humanos y del riesgo que ello supone para la virtud. De entre todos los elementos, tres objetos situados en el suelo junto a la muchacha parecen resumir a la perfección esta idea: el candelero con la vela apagada y truncada, la cerámica rota y, sobre ella, una chocolatera cuya tapa y molinillo se han salido de su sitio con el impacto.

\subsection{Siglo XVIII}

Como vimos en el apartado de introducción, el consumo del chocolate aparece completamente normalizado en la vida de los españoles en el siglo XVIII, aunque sigue siendo fundamentalmente una costumbre cotidiana perteneciente a las clases acomodadas. 
Por lo que respecta al arte, el chocolate mantiene a lo largo del siglo XVIII su presencia en la pintura española, no solo con un número creciente de obras respecto a la anterior centuria, sino también de manera diferente.

La primera gran novedad en su representación dentro de los bodegones dieciochescos españoles es que el chocolate se muestra en muchos de ellos de manera explícita. Lo encontramos en forma de pastillas, por ejemplo, en el famoso Bodegón con servicio de chocolate y bollos (1770) ${ }^{12}$ de Luis Meléndez y en el Bodegón con panes, servicio de chocolate, uvas y melón del mismo autor ${ }^{13}$. Pero, sobre todo, aparece representado líquido y servido (o incluso ya consumido) en las tazas, como en las obras de Juan Bautista Romero, Bodegón de fresas y chocolate (ca. 1775) $)^{14}$ o en Bodegón ${ }^{15}$.

La segunda novedad, en clara relación con la anterior, es la enorme sensualidad que se muestra en la representación del chocolate en este tipo de imágenes. Con llamativa frecuencia encontramos cómo el contenido de la taza parece rebosar y salirse del recipiente, como en los ya mencionados bodegones de Romero. En otros casos, las tazas solo muestran ya los restos de la bebida e incluso aparecen volcadas en la mesa, como en Bodegón de merienda con melero, jarro, chocolatera y dos jícaras de José López Enguídanos ${ }^{16}$, ya de comienzos del siglo XIX.

Estas marcas que denotan su consumo son la prueba indirecta de presencia humana en las escenas, que continúa sin mostrarse explícitamente, con la excepción de La chocolatera de Félix Lorente ${ }^{17}$. Los servicios de chocolate ya no aparecen, pues, como conjuntos que están ahí para ser admirados, sino para ser disfrutados. La rigidez generalizada del siglo anterior da paso a composiciones más dinámicas e incluso, en algunos casos, dominadas por un cierto caos en el que alimentos e instrumentos aparecen representados con escaso decoro y entre los cuales encontramos, por ejemplo, un indolente gato, como en Bodegón con chocolate, frutas y gatos de Juan Pedro Peralta ${ }^{18}$.

En contraste con ese cierto tono desenfadado, otros ejemplos mantienen el recato de la pasada centuria, como en el caso del Bodegón con servicio de chocolate y bollos de Meléndez (figura 2). El contexto, en este caso, podría servir para explicar la formalidad conservadora de su representación. Este cuadro formaba parte de cuarenta y cuatro bodegones pintados entre 1759 y 1774 para el príncipe de Asturias, el futuro Carlos IV, que tenía como objetivo representar en pinturas los productos naturales de España. A pesar de la pretensión de Meléndez de ofrecer una mirada cuasi científica a su representación, los resultados en general distaron mucho de alcanzar dicho objetivo, lo que explicaría que finalmente la serie no fuera a parar al Real Gabinete de Historia Natural como pretendía Meléndez.

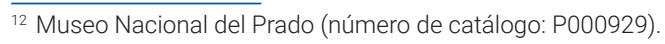

${ }^{13}$ Colección August Oetker.

${ }^{14}$ North Carolina Museum of Art de Raleigh (número de objeto: G.52.9.184).

${ }^{15}$ Museo de Bellas Artes de Bilbao (número de inventario: 82/428).

${ }^{16}$ Colección particular, Colombia. Expuesto en la exposición «ln the presence of things: Four centuries of European Still-life Painting», Lisboa, Calouste Gulbenkian Foundation. 12 febrero-2 mayo 2010.

17 Colección Juan Abelló.

${ }^{18}$ Real Academia de Bellas Artes de San Fernando (número de inventario: 1398).
} 


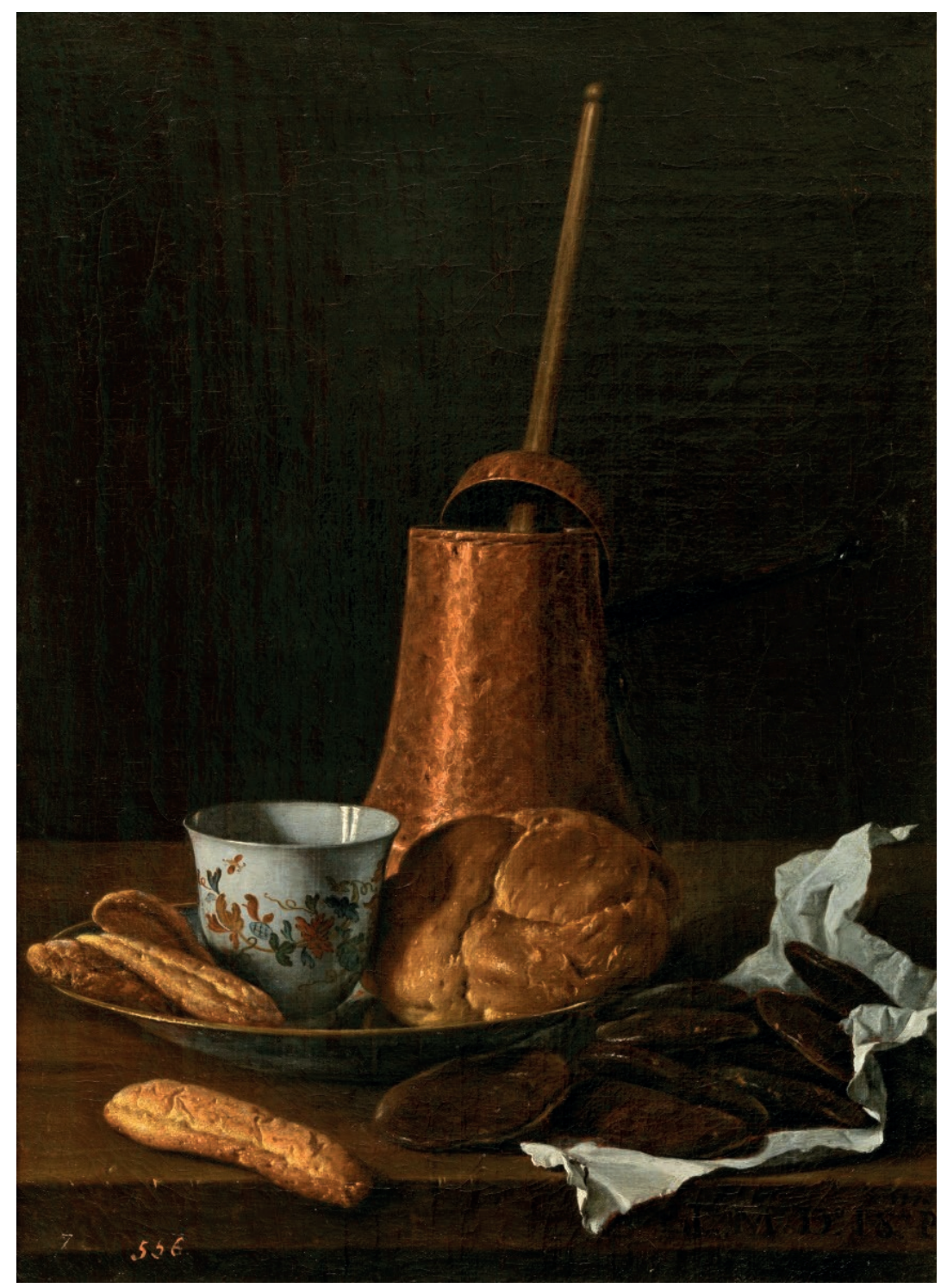

Figura 2. Luis Meléndez. Bodegón con servicio de chocolate y bollos. 1770 Fuente: https://www.museodelprado.es/

A diferencia de este carácter especialmente distinguido y preciso, este mismo autor presenta el chocolate en un tono más distendido y más cercano a las formas de sus coetáneos en Bodegón con panes, servicio de chocolate, uvas y melón, donde encontramos una «salva con pie que sostiene en su centro una taza mejicana de Guadalajara, y alrededor de ellas unas jícaras, también de Guadalajara (Méjico), muy próximas a la labor de Salvatierra de los Barros (Badajoz)» (Gutiérrez, 1983: 165). Además, la disposición tanto de la vajilla como de los bollos 
y los pequeños paquetes en los que solían guardarse las especias reflejan un tono mucho más relajado que en el anterior bodegón.

Junto a la presencia explícita del chocolate y una mayor sensualidad en la presentación de este producto, que denota además una innegable presencia humana en la escena, pero en clara relación con ellos, hay que destacar como rasgo de su imagen en el siglo XVIII español que el carácter de distinción y protocolo de estas escenas no es tan marcado como en el siglo anterior. Si bien encontramos elementos de las vajillas que solamente estarían al alcance de personas adineradas, especialmente en las obras de Romero que «expresan un mundo de refinamiento y exquisitez, de sedas, encajes y porcelanas, un tanto singular en nuestra pintura» (Pérez Sánchez, 1983: 107), en general, parece que la representación del chocolate huye de la ostentación del siglo XVII. Los exquisitos objetos de Pereda o las despensas rebosantes de Barrera dan paso a contextos más sencillos o desenfadados, con un mobiliario más discreto o que incluso desaparece, como en el Bodegón de fresas y chocolate de Romero, donde el mantel se ha colocado directamente sobre el suelo en lo que parece ser una «merienda veraniega al aire libre» conformada por «un postre de fresas, azúcar, chocolate, bizcochos y pan, sobre un limpísimo mantel blanco con encajes». Todos estos elementos son «presentados como si estuvieran destinados a una sola persona: el espectador» (Jordan y Cherry, 1995: 171).

Pero los bodegones no fueron las únicas manifestaciones artísticas que a lo largo del siglo XVIII sirvieron para representar la difusión y el consumo del chocolate en España. Junto a estas escenas, las artes decorativas fueron un testigo especialmente valioso, pues en ellas el chocolate no es mostrado solo como un delicioso dulce, sino como el punto culminante de un evento social, el del «refresco».

Quizás esta importancia social explica su representación en las artes decorativas españolas, especialmente en las cocinas de las casas más acomodadas, concebidas en aquel momento como el centro de la vida en el hogar, donde no solo se cocinaba, sino que servían de punto de encuentro para veladas y tertulias. Esta transformación de un espacio íntimo en un espacio social explica la moda de decorar las cocinas nobles con azulejos procedentes de las fábricas de Valencia, por lo que se conocieron popularmente con el nombre de «cocinas valencianas», y en los que el chocolate ocupaba un lugar principal y exclusivo entre las bebidas estimulantes. Además del producto, y a diferencia de su representación en los bodegones, la presencia humana no solo es patente en este tipo de representaciones, sino que adquiere un papel absolutamente principal, como muestra la cocina valenciana presente en el Museo Nacional de Artes Decorativas de Madrid ${ }^{19}$ o los azulejos que se conservan en el Museo Nacional de Cerámica y Artes Suntuarias González Martí20.

\section{Conclusiones}

Desde los primeros contactos con el cacao, los europeos fueron conscientes de que estaban ante un producto especial. Como vimos al inicio de este artículo el chocolate se convirtió en pocas décadas en un alimento lleno de connotaciones, entre las que pronto sobresalieron sus supuestas cualidades afrodisíacas y su consumo compulsivo.

\footnotetext{
${ }_{19}$ Museo Nacional de Artes Decorativas de Madrid (número de inventario: CE05135).

${ }^{20}$ Museo Nacional de Cerámica y Artes Suntuarias González Martí (número de inventario: CE1/00804).
} 
Ante ello, como vimos, numerosos teólogos, especialmente en España e Italia, cuestionaron si el consumo del chocolate podía suponer un perjuicio muy grave para los fieles que, considerándolo interesadamente o de buena fe una simple bebida, podían estar incurriendo en el grave pecado de quebrantar el ayuno cristiano. Este largo y complejo debate, en el que se invocaron a las grandes figuras de la cristiandad, confirmaba que los prejuicios que el chocolate había adquirido desde su conocimiento no solo no habían desaparecido, sino que se habían hecho más palpables durante su expansión en Europa, una vez constatada que la pasión por este producto no era solo una cuestión bárbara, ni siquiera algo propio de europeos que, asentados en aquellas tierras, habían corrompido su alma, sino algo que amenazaba con convertirse en un problema generalizado.

Ante este problema, cabe preguntarse si el arte fue sensible y lo reflejó de alguna manera. A la luz de los ejemplos localizados puede considerarse que sí.

En primer lugar, frente al enorme éxito del producto y si comparamos la representación artística del chocolate con otros productos americanos también exitosos, como el pavo ${ }^{21}$, destaca la presencia relativamente escasa del cacao en el arte europeo de la Edad Moderna, tanto de la planta (de la que no se ha consignado ni una sola representación artística) como del chocolate. A diferencia de otros productos, como el pavo o el maíz, que son introducidos rápidamente en el arte europeo de aquella época, la representación del chocolate es mucho más tardía y no hace su aparición hasta el siglo XVII. Ausente en el arte del siglo XVI, pues, el chocolate permanece aún una centuria más con una representación muy restringida y podría decirse que eminentemente española. Dos razones, ya apuntadas a lo largo del texto, podrían explicar esta escasa presencia.

Por un lado, el propio contexto de la llegada y difusión del chocolate. Como ya quedó mostrado, el cacao y el producto derivado del mismo, el chocolate fue consumido durante muchos años casi exclusivamente por la nobleza española. Este carácter casi «clandestino» podría explicar su ausencia en el campo de la representación a lo largo del siglo XVI y su discreta representación en el siglo XVII.

Pero, junto a las razones históricas, consideramos que un elemento que podría resultar clave para el «ocultamiento» artístico del chocolate podría encontrarse en la polémica religiosa que generaba su consumo. Como ya quedó reflejado, el encaje del chocolate en la dieta de los europeos, tanto de aquellos que vivían en territorio americano como de aquellos que lo consumían en Europa, resultó problemático, pues su uso (y abuso) podía entrar en conflicto con los principios católicos, incitando a sus fieles a incurrir en graves pecados como el de la gula, la lujuria o el quebrantamiento del ayuno. Se trataba, pues, de un alimento paradójico que, por un lado, despertaba fuertes pasiones y, por otro, era considerado altamente peligroso para la integridad espiritual de sus consumidores y también para su salud, como advirtieron los médicos desde los primeros contactos con este alimento.

Ambas razones parecen argumentos de peso para que los artistas y las personas que encargaban las obras prefirieran no hacer un excesivo alarde del consumo de este polémico producto. Estos mismos argumentos pueden ayudarnos a comprender la peculiar representación de este producto en el siglo XVII. Salvo la excepción ya comentada del Bodegón con servicio de chocolate de Juan de Zurbarán, la abrumadora mayoría de las representaciones localizadas de ese siglo no muestra el producto en sí. Se trata, en prácticamente todos los casos, de lo que

\footnotetext{
${ }^{21}$ Ver Quintanar Cabello, Vanesa, La llegada y adaptación de productos americanos en Europa y su representación en el arte europeo de la Edad Moderna [tesis doctoral], 2021.
} 
podríamos denominar una representación metonímica en la que el continente sustituye al contenido. Chocolateras, molinillos o jícaras nos dan pistas sobre su contenido, pero el chocolate no se hace explícito.

Además de su representación metonímica, la ausencia directa o indirecta de presencia humana en las obras del siglo XVII incide también en una imagen de clandestinidad y secreto de este producto. Como vimos en el apartado correspondiente, tan solo un cuadro, Escena de cocina (alegoría de la virtud perdida) de Antonio de Pereda, nos muestra figuras humanas y, de manera muy significativa, se trata de una obra que nos habla de las fatales consecuencias de la falta de virtud y decoro.

Por contraste frente a estas características estables a lo largo del siglo XVII, destaca el significativo cambio que su representación experimenta a lo largo de la centuria siguiente, especialmente en la segunda mitad del siglo XVIII.

En primer lugar, y en contraste con la representación metonímica generalizada que observamos en el siglo XVII, los cuadros de la siguiente centuria sí muestran el producto mismo de manera explícita y variada. Lo vemos en forma de pastillas (Bodegón con servicio de chocolate y bollos de Luis Meléndez) o ya preparado como bebida (Bodegón de fresas y chocolate de Juan Bautista Romero).

La segunda diferencia importante entre la representación del chocolate en ambos siglos es la presencia directa o indirecta de personas en el siglo XVIII. En el caso de España, los cuadros siguen sin mostrar explícitamente las figuras, con la excepción de La chocolatera de Félix Lorente, pero sí lo hacen de manera indirecta, al mostrar dulces a medio comer, tazas vacías o bizcochos sumergidos en las tazas a punto de ser degustados. En contraste con la pintura, las artes decorativas españolas, como las cocinas valencianas ya comentadas, sí muestran a los comensales.

Lógicamente, detrás de este notable cambio en la representación podemos deducir un cambio de mentalidad general y respecto al consumo del chocolate en particular. A lo largo del siglo XVIII la polémica en torno a los perjuicios espirituales del chocolate queda completamente abandonada y sus comensales no parecen tener que mortificarse por su consumo. Además de ello, la pujanza económica y social de la clase burguesa, así como el paulatino predominio de una mentalidad que valoraba y fomentaba una actitud más sensual hacia la vida, con un creciente valor del ocio y las actividades que fomentasen la sociabilidad, ayudaron no solo a que el chocolate pudiera ser degustado y valorado sin prejuicios, sino a que se convirtiera en un verdadero ritual a través del cual las clases acomodadas encontraban una excusa cotidiana para sociabilizarse. Otro rasgo de esta mentalidad era también romper el rígido protocolo alimentario dominante en siglos anteriores, lo que explicaría que el chocolate sea representado en el siglo XVIII en contextos mucho más relajados e informales.

\section{Referencias}

BENDINER, K. (2004). Food in painting: from the Renaissance to the present. Londres: Reaktion Books.

BRANCACCIO, F. M. (1664). De chocolatis potu diatribe. Romae: per Zachariam Dominicum Acsamitek à Kronenfeld, Vetero Pragensem,

BRYSON, N. (2007). Volver a mirar. Cuatro ensayos sobre la pintura de naturalezas muertas. Madrid: Alianza. 
CARLETTI, F. (1976), Razonamientos de mi viaje alrededor del mundo (1594-1606). México: UNAM.

CHERRY, P. (1999). Arte y Naturaleza. El Bodegón Español en el Siglo de Oro. Madrid: Fundación de Apoyo a la Historia del Arte Hispánico.

COE, S. y COE, M. (1996). The true History of Chocolate. Londres: Thames and Hudson.

DÍAZ DEL CASTILLO, B. (1837). Historia verdadera de la conquista de la Nueva España. París: Librería de Rosa.

FATTACCIU, I. (2009).I "Cacao: From an exotic curiosity to a Spanish commodity. The diffusion of new patterns of consumption in eighteenth-century Spain". En: Food and History. Revue de I'Institut Européen d'Histoire de l'Alimentation, 7(1), 53-78, https://doi.org/10.1484/J.FOOD.1.100635.

GÁLLEGO, J. (1984). Visión y símbolos en la pintura española del Siglo de Oro. Madrid: Cátedra.

HARWICH, N. (2018). Historia del chocolate. Barcelona: Pensódromo 21.

HUETZ DE LEMPS, A. (2011). "Bebidas coloniales y el auge del azúcar". En: Flandrin, J.L. y Montanari, M., Historia de la Alimentación. Gijón: Trea, pp. 781-796.

HURTADO, T. (1645). Chocolate y tabaco, ayuno eclesiastico y natural: si este le quebrante el chocolate, y el tabaco al natural, para la Sagrada Comunión... Madrid: por Francisco García.

JORDAN, W. B. y CHERRY, P. (1995). El bodegón español de Velázquez a Goya. Madrid: El Viso.

LAVEDÁN, A. (1796). Tratado de los usos, abusos, propiedades y virtudes del tabaco, café, té y chocolate. Madrid: En la Imprenta Real.

LEÓN PINELO, A. de (1636). Question moral: si el chocolate quebranta el ayuno eclesiastico: tratase de otras bebidas i confecciones que vsan en varias provincias. Madrid: Por la viuda de Iuan Gonçalez.

MARTIRE D'ANGHIERA, P. (1944). Décadas del nuevo mundo. Buenos Aires: Editorial Bajel.

MORENO, J. (2015). La naturaleza de Indias en la plástica de la Edad Moderna [Tesis Doctoral]. Málaga: Universidad de Málaga.

PARDO-TOMÁS, J. y LÓPEZ TERRADA, M.L. (1993). "Las primeras noticias sobre plantas americanas en las relaciones de viajes y Crónicas de Indias (1493-1553)". Valencia: Cuadernos Valencianos de Historia de la Medicina y de la Ciencia, 40, CSIC-UV - Instituto de Historia de la Medicina y de la Ciencia López Piñero (IHMC).

PÉREZ SAMPER, M. A. (1996). "La integración de los productos americanos en los sistemas alimentarios mediterráneos". En: XIV Jornades d'Estudis Històrics locals. La Mediterrània, àrea de convergència de sistemes alimentaris (segles V-XVIII). Palma: Institut d'Estudis Baleàrics. Govern Balear, Conselleria d’Educació, Cultura i Esports: 89-148.

PÉREZ SAMPER, M. A. (2019). Comer y beber: Una historia de la alimentación en España. Madrid: Cátedra.

PÉREZ SÁNCHEZ, A. E. (1983. Pintura española de bodegones y floreros de 1600 a Goya. Madrid: Museo del Prado y Ministerio de Cultura.

SIMÓN PALMER, M. C. (2010). "El impacto del Nuevo Mundo en los fogones españoles". En: Oltreoceano. Rivista sulle migrazioni, 4, pp. 51-63. https://doi.org/10.1400/197594. 



\title{
LA ALIMENTACIÓN COMO ACCIÓN, UNA EXPERIENCIA PERFORMÁTICA
}

\author{
Nuria Faba Muñoz \\ Estudiante de doctorado de la Universidad Politécnica de Valencia
}

\begin{abstract}
Food, throughout history, has been the object of being represented by various artistic techniques and disciplines. As is the case with video or action art. Artists who resort to action to express an idea have multiple elements such as: space, time, sound, light, objects, spectators and their own body. These artistic actions, in which improvisation and cadence are added to the articulation of these elements, are what many curators, artists and theorists call performances. The purpose of this article is to make known what performance consists of and who are the key performers, specifically those who have worked in the line of food and the actions that derive from it. Everyday actions such as shopping, cooking, eating, or socializing. All this is understood through the works of a selection of performing artists such as: Bobby Baker, Martha Rosler, Rirkirit Tiravanija, Antoni Miralda, Àlvar Calvet, Patty Chang or Romira de Novellis, among others. Each performer offers a very particular vision implicit in the daily action linked to food.
\end{abstract}

Keywords: food, performance, artistic experience, action art, performers.

Resumen: La alimentación, a lo largo de la historia, ha sido objeto de ser representada por diversas técnicas y disciplinas artísticas. Como es el caso del vídeo o del arte de acción. Los artistas que recurren a la acción para expresar una idea, cuentan con múltiples elementos como: el espacio, el tiempo, el sonido, la luz, los objetos, los espectadores y su propio cuerpo. Estas acciones artísticas, en las que a la articulación de estos elementos se les suma la improvisación y la cadencia, son las denominadas por muchos curadores, artistas y teóricos como performances. El propósito del presente artículo es dar a conocer en qué consiste la performance y quienes son los artistas performers clave, en concreto los que han trabajado en la línea de la alimentación y en las acciones que de esta se derivan. Acciones cotidianas como el comprar, el cocinar, el comer o el relacionarse. Todo ello es entendido a través de las obras, de una selección de artistas performers como: Bobby Baker, Martha Rosler, Rirkirit Tiravanija, Antoni Miralda, Àlvar Calvet, Patty Chang o Romira de Novellis, entre otros. Cada performer, ofrece una visión muy particular implícita en la acción cotidiana vinculada a la alimentación.

Palabras clave: alimentación, performance, experiencia artística, arte de acción, performers.

Citar como: Faba Muñoz, N. (2022). "La alimentación como acción, una experiencia performática". En: Actas del III Congreso Internacional sobre Patrimonio Alimentario y Museos. 25-26 noviembre, 2021, Valencia, España. pp. 185-203. https://doi.org/10.4995/EGEM2021.2021.13290 


\section{Introducción}

El tema alimentario y el propio acto de comer, han sido abordados a lo largo de la historia por las humanidades de una manera transversal, ofreciendo una gran variedad de posicionamientos teóricos, estéticos y críticos. Porque comer no es sólo alimentarse, el acto de comer puede ser considerado como un acto político, de compromiso con los seres que nos rodean y con el planeta. Considerado como vehículo de acercamiento social, político y económico. Durante el acto de comer se generan una multitud de sucesos y temas a tratar, ajenos o no a la temática alimentaria como pueda ser: la tradición, la identidad y la sociabilización, entre otros. Es lógico que desde el arte se muestre su interpretación a todos estos aconteceres, desde disciplinas clásicas hasta disciplinas más actuales, propias de la acción y el vídeo. La irrupción del vídeo en el arte, se muestra tanto como una herramienta de documentación de la acción como obra final.

En el presente artículo se pretende ofrecer una visión sobre la alimentación actual desde el arte, en concreto desde la performance. Para ello es relevante realizar un recorrido por conceptos fundamentales para su comprensión, se intentará definir qué es una acción, una performance, el papel del performer. Se pretende realizar un repaso por los artistas performers que han abordado esta disciplina, tratando de mostrar la evolución de la performance y su implicación en el tema que nos acontece: La alimentación.

Como se muestra en la bibliografía, se quiere mostrar los trabajos de artistas performers que han trabajado en la línea de la alimentación y con las acciones que se generan a su alrededor. Acciones cotidianas como el comprar, el recolectar, el cocinar, el comer o el relacionarse. Todo ello es entendido a través de las obras, de una selección de artistas performers como: Bobby Baker, Martha Rosler, Rirkirit Tiravanija, Antoni Miralda, Àlvar Calvet, Patty Chang o Romira de Novellis, entre otros. Cada artista, en su trabajo performático, ofrece una visión muy particular implícita en la acción cotidiana, vinculada a la alimentación. La huella de esta acción puede ser muy diversa, suscitando reacciones muy dispares en los espectadores lejanas a la indiferencia.

Se realizará un análisis del trabajo personal de performance ¿Comes conmigo?, que presenté como artista performer en julio de 2021 relativo al trabajo de investigación doctoral sobre la alimentación actual. A través de esta acción performática se pretende abordar aspectos relativos a el qué, el cómo, el porqué y el con quién, de la alimentación actual. En concreto se abordará el acto cotidiano de comer. El objetivo principal de esta performance consiste en poder visualizar la resiliencia alimentaria y la resiliencia social respecto al acto cotidiano de comer.

\section{Objetivos}

Como principal objetivo se pretende:

- Ofrecer la visión particular del arte sobre la alimentación a través de la performance.

Existen otros objetivos que lo secundan:

- Definir conceptos clave para la comprensión del arte de acción, en concreto de la performance.

- Recopilar fuentes referenciales que muestren el trabajo de diversos artistas clave en el campo de la performance, que abarquen temas relativos a la alimentación.

- Mostrar el trabajo artístico personal y de investigación sobre la alimentación actual. 


\section{La performance como expresión artística, origen y desarrollo}

\subsection{La performance, origen etimológico}

Para poder comprender en qué consiste, quizás sería conveniente realizar un repaso por el origen etimológico de la palabra performance. Revisando las investigaciones de varias figuras teóricas como la estadounidense Amelia Jones o como la historiadora de arte británica RoseLee Goldberg, recogidas en el libro de Juan Albarrán: Performance y arte contemporáneo, discursos, prácticas y problemas. (Albarrán, 2019), sobre el estudio de la performance.

Seguidamente se da paso a parafrasear el significado del término: si bien existen varios significados para el sustantivo performance, tanto en inglés como en francés, tales como: actuación, espectáculo, representación, etc, para los hispanohablantes el término, adquirido del inglés, se ha identificado como arte de performance.

Para el diccionario de la Real Academia Española se destaca la siguiente definición:

"Actividad artística que tiene como principio básico la improvisación y el contacto directo con el espectador"

Conforme se describe en el libro de Juan Albarrán (anteriormente mencionado), las investigaciones de Amelia Jones van más allá, dando paso a realizar un análisis etimológico sobre el verbo, el sustantivo y el adjetivo, en la lengua inglesa (to perform, performance y performative), del que podemos concluir sus usos a través de la historia.

\footnotetext{
"To perform: hacer, hacer bien, entretener. Etimología: inglés medio, del anglo-francés parfumer, alteración de performer, parfurnir, de par-, per-, <totalmente>( del latín per-)+ furnir, <completar>. Primer uso conocido, siglo XIV.
}

Performance: la ejecución de una acción; representar un personaje de una obra; la eficiencia con la que tiene lugar una acción. Primer uso conocido siglo XV.

Performing: < de, relativo a, o constitutivo de una parte ( como el arte dramático) que implica la actuación frente al público>; ejemplo: las <artes performativas>. Primer uso conocido, 1889.

Performative: el acto de hacer o representar o <de, relativo a o constitutivo de un arte (como el arte dramático) que implica la participación de un público>; en lingüística, <relativo a una expresión que sirve para efectuar una operación o que constituye la ejecución del acto específico en virtud de su declaración>. primer uso conocido, en 1995."

Siguiendo con Albarrán: si bien se contextualiza el origen del vocablo inglés performance en el siglo XIV, en un periodo marcado por el incipiente surgimiento del ocio en sociedades burguesas protocapitalistas; es en el siglo XIX cuando el término es utilizado para designar formas del teatro profesionalizado, en un contexto de sociedades más complejas. Y en el siglo XX es cuando surgen nuevos sentidos relacionados con la teoría del lenguaje.

Pero si queremos hablar más exactamente de cuando se generalizó el concepto performance, cabría decir que fue a finales de los 70. Hasta la fecha se habían utilizado otros conceptos para designar otras propuestas artísticas no objetuales ahora vinculadas a la performance, estas propuestas se conocen bajo los siguientes conceptos: arte de acción, el happening, event, body art, body works o art corporel. 
A finales de los 70 el concepto de la performance se desvincula del papel que un actor realiza en el teatro y pasa a ser un concepto primordial para hablar el presente, pasado y futuro de prácticas que nutren y amplían las artes visuales.

En 1979 la historiadora de arte RoseLee Goldberg a través de su libro Performance. Live Art 1909 to the Present. (Goldberg, 1979) y posteriormente ampliado en 1988 con una variación en el título: Performance Art. From Futurism to the Present, (Goldberg, 1988) que fue traducido al castellano en 1996, como búsqueda de conciencia histórica y buscándole un sitio dentro de las instituciones. Goldberg da un nuevo enfoque al estudio de la performance a través de asumir su deuda con las vanguardias. Es por ello que sitúa como antecedentes lejanos el futurismo y el dadaísmo junto con algunas experiencias constructivistas, surrealistas y las innovaciones teatrales de finales del siglo XIX. Surgieron figuras como John Cage y Merce Cunninghan y posteriormente entre los años 60 y 70 surgen artistas que trabajan en el movimiento artístico Fluxus, el posminimalismo, la danza y el arte conceptual.

La performance se alimenta del arte de vanguardia, del teatro, de la danza de las artes visuales... se convierte en un arte transdisciplinar. Por tanto surge como ruptura con el arte burgués y se presenta como una práctica de proyectos estético-políticos con tinte progresista que intenta institucionalizarse.

La performance por su carácter presencial se describe como un arte vivo, en tiempo real, que conjuga la cotidianidad con el arte, de una manera híbrida.

En 2011 y como respuesta irónica a la investigación histórica y al afán de posicionar la performance dentro del marco institucional por parte de Goldberg, surge un proyecto pseudohistoriográfico y ficticio titulado This is the Performance Art, de la artista Mel Brimfield. Su trabajo es presentado a través de vídeos, fotografías, escritos, re-enactments entre otros documentos que desvirtúan a través del empleo de la parodia, algunos datos históricos sobre la performance añadiendo de su propia cosechas datos ficticios. This is the Performance Art, representa una sátira hacia la figura del crítico de arte de carácter pedante que ha asistido a numerosas performances y que se pronuncia a través de otros autores. Brimfield también utiliza anacronismos, relaciones imposibles y el humor como eje central invitando a reconsiderar la veracidad de las fuentes utilizadas para los escritos de historiadores de arte como Goldberg. Quizás parezca un ataque hacia el trabajo historiográfico pero en realidad a mi entender lo que presenta es un cuestionamiento de todo lo que implica incluir a la performance en la categoría de arte elevado, qué se omite, qué prácticas son realmente performance, el tono mesiático...todo ello es cuestionado a través de la sátira.

"...Parecía que imitar las estrategias curatoriales de las instituciones y sus materiales explicativos era una manera eficaz de destacar las infravaloradas relaciones con el activismo,el teatro, la comedia, la música y la danza en la historia del live art"

Investigando en el origen del concepto, encontramos la investigación sobre los enunciados performativos que posteriormente desembocaron en las teorías de la performatividad de género generadas por Judith Butler, a finales de los años 80. Se cimientan en parte en la discusión entre los filósofos John L. Austin y Jacques Derrida sobre dichos enunciados performativos. Fue el filósofo John L. Austin el padre del adjetivo "performativo", el cual empleó este término en 1955 y posteriormente compilaría en su libro titulado Cómo hacer cosas con palabras, (Austin, 1962), en el que muestra sus teorías sobre los actos del habla, diferenciando dos enunciados: el enunciado 
constatativo y el enunciado performativo. El enunciado es performativo cuando no se describe nada, estando en un contexto circunstancial se realiza un acto. Posteriormente amplía el concepto de performativo también para los enunciados constatativos ya que estos también dependen de las condiciones. Austin formula una taxonomía de las diferentes formas que se tiene de hacer algo al decir o enunciar algo, distinguiendo tres actos: el acto locutivo (decir algo es hacer algo), el acto ilocutivo (al decir algo estamos haciendo algo) y el acto perlocutivo (porque decimos algo, estamos haciendo algo) y es en el acto ilocutivo donde se reconoce el acto esencial de la palabra.

Los enunciados performativos pues no registran o distinguen nada, no son ni verdaderos ni falsos y el acto de expresar la oración es realizar la acción y dependen de las condiciones o circunstancias.

Aunque no en su investigación no consiguió resultados claros, sí que fue interesante su influencia en las investigaciones posteriores de otros teóricos de campos transversales.

Para el filósofo posestructuralista Jacques Derrida, pese a valorar la recuperación por parte de Austin del carácter pragmático que posee el lenguaje, de su materialidad y de su gran poder para provocar cambios. Para Derrida la gran carga performativa no reside en el emisor, como decía Austin, sino de que este enunciado haya sido anteriormente dicho y ya escuchado por otros. Por tanto su sentido el enunciado es decodificable, alterable, se puede prestar a la repetición y sobrevive al emisor.

Tanto para Austin, Derridas como para Butler, lo performativo queda vinculado al discurso, al lenguaje. Por tanto es Diana Taylor quien realiza una distinción entre lo performativo y lo performático. Taylor defiende que el término performático se refiere a la forma adjetivada no discursiva de la performance.

Sin embargo en el mundo del arte contemporáneo esta distinción no ha tenido gran aceptación, puesto que el adjetivo performativo es usado de manera indistinta para cualquier trabajo relacionado con la performance, aunque sí que es verdad que en un sentido más corporal que discursivo es el llamado performance art.

La performance por tanto se consolida a finales de los años 80 como consecuencia de estudios teóricos y prácticos con carácter interdisciplinar. Debido a esta renovación, de la amplitud que podía abarcar el término, se pudo trasladar la performance al ámbito del teatro, de la danza, el performance art, incluso un acto cotidiano como un concierto o el acto de hacer la compra y como en el caso de mi investigación al acto de comer. Todos estos actos implican la interacción entre las personas que comparten el espacio y el tiempo. Por tanto todo ello provoca un desplazamiento epistemológico superando las limitaciones de las disciplinas académicas tradicionales.

Schechner en diálogo con el antropólogo Victor Turner, propuso como principal característica de la performance el concepto de restauración de la memoria. Con ello hacía referencia a los rituales, hábitos y rutinas que se suelen reproducir de una manera prácticamente consciente, en las que no existe una autoría, ni un original estable con lo cual estas acciones o rituales no son simples copias. En estos rituales el performer no se comporta como si fuera del todo él o ella, sino que está en un estado casi ajeno a su persona. Esta colaboración entre Scechner y Turner, crea una base antropológica sobre el Estudio de Performance que se desarrollará posteriormente como son los dramas sociales, memorias corporizadas y ritos. 
Durante los años 90 en el contexto anglosajón se fueron consolidando los Estudios de la Performance en los ámbitos académicos. Sin embargo en 2012 surge cierta resistencia por parte del traductor Rafael Segovia Albán en su traducción del libro al castellano de Schechner Performance Studies. An Introduction (Schechner, 2002). En la traducción decidió utilizar otros términos para sustituir la palabra performance, como: función, representación, actuación...entre otras, fue entendido como un gesto de resistencia hacia una palabra proveniente del inglés, un idioma hegemónico capaz de colonizar otros contextos. La crítica propuso que en vez de traducir el texto de Schechner, quizás hubiese sido más acertado redactar un libro desde el contexto del pensamiento mexicano.

Performance es un vocablo que según muchos teóricos entre ellos Anne Johnson, que no pueden traducirse al castellano.

Tal y como defiende Albarrán en su libro Performance y arte contemporáneo, discursos, prácticas y problemas (Albarrán, 2019), hasta hace relativamente poco tiempo, contados investigadores de la historia del arte y de los fenómenos artísticos dentro del marco de un territorio tan interdisciplinar como es la performance, han adquirido visibilidad. Albarrán propone que quizás se debería reciclar o actualizar los marcos teóricos y las metodologías empleadas por la disciplina humanística que focaliza su mirada más en la marginación del cuerpo que en los rituales, los activismos o actos de la vida cotidiana.

Según la investigación del performer y académico Bartolomé Ferrando en su libro El arte de la performance, elementos de creación, (Ferrando, 2009) parte de la definición del término performance, como término inglés cuyo origen proviene de la palabra francesa parformer que a su vez se deriva de la palabra latina per-formare. Término que abarca un gran abanico de formas de hacer, de actuar o de intervenir que desembocan en otras manifestaciones muy dispares entre sí. Pluralidad que propicia a prácticas que se multiplican, se solapan, interfieren unas con otras, se cruzan incluso llegando a desbordarse a sí mismas.

Se podría concluir que la performance en su intento por definirla ofrece cierta resistencia, ya que posee un carácter espectral, la performance ofrece la dualidad de estar siempre presente a la vez que en otro lugar.

Pero sí que se podría intentar comprender sus cualidades, características al igual que los elementos de los que se nutre. Para ello a continuación se da paso a hablar los factores temporales y espaciales, del cuerpo de la performance, de la idea, del alejamiento de la representación, de la relación comunicativa del performer con los asistentes, de la interacción con el público y su participación así como la importancia del contexto.

Para Bartolomé Ferrando existen modos de hacer dentro del arte de acción estos son: la performance, el happening, el evento y la maniobra. Happening o performance happening es cuando importa el hecho participativo y maniobra cuando se refiere a lo imperceptible o lo mínimo que se manifiestan en algunas performance. Siguiendo con Bartolomé se puede entender mejor la performance si conocemos los factores y elementos de los que se nutre. 


\subsection{Factores y circunstancias de los que se nutre la performance}

Para que una performance sea exitosa, es decir: que esté bien conseguida y que tenga interés para el espectador, depende de diversos parámetros como de la energía que mueve y genera como de la atención que suscita en los demás.

La performance es eficaz cuando es portadora de una energía, fuerza interior o un grado de intensidad elevado que deriva de la atención y de los siguientes factores y elementos: el espacio, el tiempo, el cuerpo, la no representación, la idea, el contexto, la participación, el hecho comunicativo y la energía que se genera.

En toda performance se produce un acoplamiento entre el espacio y el cuerpo, el cuerpo se prolonga por un espacio envolvente. El espacio pasa a formar parte activa de la acción, es tan importante ese espacio que envuelve al cuerpo o al objeto como el propio cuerpo, el espacio pasa a ser presencia haciéndose perceptible. Una performance se puede adueñar del espacio invadiéndolo y haciéndolo suyo, sin importar sus dimensiones.

Dentro del factor espacial, la iluminación juega un papel fundamental, ya que enfatiza aquel gesto o acción que el performer quiere acentuar. Incluso hay performance que se sirven de espacios virtuales, con imágenes pregrabadas con las que el sujeto interactúa en un territorio visual y sonoro. La presencia del espacio es un factor importante, el espacio es la huella de la acción.

Realizar un recorrido en el espacio es hacerlo simultáneamente en el tiempo. Cada acción está compuesta por tiempos distintos, cada una tiene su propia latencia, su propia cadencia y de su propio espacio específico. Es por ello por lo que Bartolomé Ferrando afirma que múltiples espacios-tiempo nos miran desde la unicidad de la acción. En el performer un ejercicio importante es conocer, el ritmo, la latencia personal de uno mismo para tomar consciencia del propio tiempo. Alejando pensamientos para que ocurra el vacío. Otro ejercicio interesante consiste en la repetición de un gesto, de esta manera el tiempo se percibe suspendido en sí mismo, se genera una temporalidad diferente. Tomar consciencia del tiempo subjetivo implica una mirada interna de la cadencia personal, esta cadencia es transmitida por empatía al espectador.

En la mayoría de los casos, una acción no tiene una secuencia lógica, está expuesta a interrupciones y cambios de ritmo. Se puede alternar entre un ritmo acelerado y un ritmo lento, pudiendo llegar a ese silencio rítmico que es la pausa, como un silencio vivo pero a su vez cargado de energía, en el que todo ocurre.

En la mayoría de las performances el tiempo no es lineal, pasa a ser circular, a superponerse, a entrar en bucle pero con variaciones, es un tiempo expuesto a que sucedan cosas.

Pero más allá del factor espacio-tiempo existe un factor determinante que es la presencia del cuerpo del performer. El cuerpo del performer al integrarse en la práctica consigue ser el resultado de la misma. El artista se expone en conjunción con la obra, es la obra o parte muy importante de ella.

Hablar del cuerpo del performer es hablar de la unidad entre el cuerpo y la mente, ya que el pensamiento se construye a través del cuerpo, pero el cuerpo del performer se deja llevar, deja que fluyan acontecimientos, para poder sentir con mayor intensidad la acción que está realizando. 
El cuerpo deambula por el espacio temporal dejándolo fluir al relacionarse con otros objetos, siendo estos una prolongación del propio cuerpo. El cuerpo también lo constituye el llenar el espacio de murmullos, carraspeos, gritos o palabras. Existe una cierta elasticidad del cuerpo del performer respecto a los límites corporales, en un ejercicio de descubrimiento y autodescubrimiento. Muchos performers utilizan prácticas de vaciado a modo de purificación corporal y mental antes de realizar una performance como: ayuno, abstinencia sexual o ejercicios de concentración, entre otros. Permitiendo, en muchos casos que el cuerpo se mimetizara con el espacio, por ejemplo como es el caso de la artista performer Ana Mendieta su cuerpo se mimetiza y se funde con la naturaleza, en otros casos el performer se mimetiza con la música, sus gestos y guiños se convierten en música muda pero visible.

El cuerpo en otras ocasiones es mostrado como soporte de la intervención, convirtiéndose en materia que soportaba heridas, mordeduras, quemaduras...o como soporte de otros objetos que se derramaban o se dejaban caer sobre el mismo con todo esto el público empatiza y puede llegar a sentir las sensaciones de dolor, de repulsión o puede sentir el erotismo, la ternura entre otras sensaciones. El cuerpo sin límites, en otros casos se ha dejado conocer como un cuerpo biotecnológico en el que el artificio y la naturaleza están distanciados por una ligera línea.

La audiencia de una performance se encuentra con un performer que interviene en el espacio-tiempo relacionándose con otros elementos o con su propio cuerpo. Este performer no representa sino que fluye y genera acontecimientos inesperados, generando verdad. Se resiste a la teatralidad, a la representación, que en algunas performance este distanciamiento está más marcado que en otras. Existe una cierta voluntad de alejamiento de la representación, se busca nuevos modos de relación entre el performer y los objetos, alejándose de las normas habituales de proceder o de uso. La performance hace un guiño al desorden pero manteniéndose distante del caos. La performance rompe con las normas tradicionales de relación, de uso, de ritual pero dentro de unos límites que en cierto modo no están descontrolados del todo. Porque la distancia entre el arte y la vida es ínfima.

Por otro lado, la performance no nace de la nada, una performance nace de una idea. Como mínimo existe una intención, una idea como punto de partida que en la performance puede derivar en ideas secundarias propias de la influencia de factores como: el espacio-tiempo, la interacción con los objetos, con el propio cuerpo y con el público. En toda esta articulación de elementos se genera la energía necesaria para que la performance sea eficaz.

Lo que está claro es que existe una intención, por parte del performer, de comunicar, normalmente generando empatía en el otro, con la intención de hacer sentir y activando la capacidad de imaginar. En la intención de comunicar no está implícito el deseo de que el receptor llegue a alguna conclusión similar a la que pueda tener el emisor, a mi modo de ver en la intención del emisor va un " ahí lo dejo y haz lo que quieras con ello".

Sí que es cierto, que para que una performance sea eficaz también ha de estar muy interiorizada la idea en el emisor, ha de ser cierta y veraz para el performer.

En la performance es especialmente significativo el carácter ambiguo que esta posea, ello hará que sea posible una multitud de lecturas, aunque se corre el riesgo de que si es demasiado ambiguo no se llegue a ninguna interpretación por ello es importante el contexto en el que se materialice la acción. 
En cuanto a la participación, hay performers que consideran importante poder invitar al público a intervenir, pero para otro grupo de artistas performers piensan que no es necesario ya que por el simple hecho de que estén presentes en la acción ya están participando en ella.

\subsection{Fuentes referenciales de la performance y alimentación}

Es necesario conocer figuras claves y representativas del arte de acción aunque la mayoría de ellos no trabajasen en torno al tema de la alimentación. En el presente artículo se intenta realizar un recorrido por sus trabajos más significativos enfatizando en aquellas figuras que posteriormente han llegado a trabajar en torno al tema alimentario en sus performances.

\subsubsection{Contextualización del surgimiento de las figuras clave de la performance}

Para poder contextualizar a todos estos artistas referenciales de la performance actual, la investigadora y docente de Historia del arte Amalia Martínez, realiza un repaso por la historia del arte. En su libro De Andy Warhol a Cindy Shermann, (Martínez, 2000) describe de una manera muy concisa como fue el nacimiento de un arte de acción como consecuencia de un rechazo, por parte de los artistas emergentes, hacia la mercantilización de la obra de arte y como repulsa hacia una sociedad de consumo.

Fué en la segunda mitad de la década de los años 60, cuando un grupo de jóvenes artistas surgen con ideas revolucionarias respecto a la trayectoria materialista y mercantilizada de la obra de arte. Quisieron romper con el culto burgués por las artes tradicionales como la pintura o la escultura. Por esta razón surgen conceptos como: instalación, ambiente, happening, performance, arte del cuerpo, arte de la tierra, entre otros. Nuevas formas artísticas vinculadas a la influencia temporal y a la vida. surge un arte de investigación sobre su propia naturaleza como lenguaje y con su contexto social, político y económico. Surge el arte del concepto para manifestarse como idea. Pero en años posteriores todo este arte fue absorbido por el propio sistema al que se oponían.

En la segunda mitad del siglo XX, la actividad artística ya no se identifica con la creación de objetos, ha pasado a identificarse con la creación de situaciones en las que el espectador se implica de forma activa o de forma pasiva, siendo integrante o testigo de la misma. Hay que reconocer que el accionismo aunque pertenece a la segunda mitad del siglo XX sus cimientos son deudores de las vanguardias.

Es fundamental resaltar como figura del Accionismo norteamericano a John Cage, que fue precursor de un arte experimental en el que a modo de un todo, articulaban diversas disciplinas como: la danza, la música, imágenes proyectadas, la poesía y la pintura. Todo el conjunto estaba regido por el azar, la improvisación y la simultaneidad. Ejemplo de ello fue la obra que realizó en colaboración con Merce Cunningham en 1952 titulada Theater Piece N11.

Otro referente es el grupo japonés Gutai, los cuales fundieron varios elementos provenientes del vanguardismo pictórico con otros elementos de la caligrafía y con el teatro oriental. Cuadros que resultan del gesto de danzar con los pies cargados de pintura, salpicando sobre un papel extendido en el suelo.

En Europa como pioneros del arte de acción se destaca el grupo Fluxus en el que participaron artistas como George Maciunas, Wolf Vostell, Josep Beuys, Ben Vautier, Henry Flynt y Nam June Paik. 
Ven Vautier decía que Fluxus es el continente para las ideas, como modo de presentarlas, unas veces será la escritura, la fotografía...lo equiparaba a la continuación de la maleta de Duchamp.

En España el referente más importante como iniciador del arte de acción o accionismo fue el grupo ZAJ (fundado por Walter Marcheti y Juan Hidalgo y a los que posteriormente se uniría Esther Ferrer).

En Viena se fundó en 1965 el Grupo de accionismo Vienés, integrados por Otto Muehl, Herman Nitsch, Günter Brus y Rudolf Schwarzkogler, incluyeron en sus manifestaciones artísticas los ritos ancestrales en los cuales aunaban las fuerzas de exaltación del sexo y de la muerte.

Pero fue Allan Kaprov quien en 1958 utilizó por primera vez el término happening para designar una acción, vaticinaba el fin de la pintura y el surgimiento de un arte participativo en el que se conjugaron todos los sentidos y engloba multitud de materiales: una silla, luces, neones, agua, humo, comida, un perro y una multitud de cosas... que se complementaban con acciones insólitas. El azar también pasó a formar parte de los happenings como ingrediente fundamental. Kaprov llega a la formulación del happening como deudor de la pintura de acción y de las obras de ensamblaje que se utilizaron para configurar entornos. Su objetivo era crear espacios envolventes en los que se articulaban las pinturas-collages, los objetos con las acciones con la intención de generar empatía en el espectador.

Fue en 1965 cuando Kaprov publicó un libro titulado Assemblages, Environments and Happenings, en el que explicaba cómo se había llegado al puro accionismo, es decir al happening, partiendo de las obras de ensamblaje. Para ello desarrolló una técnica de acción-collage que al acumularlos generaba un enviroment que era un ambiente en el que involucra al espectador, incorporando elementos como la luz y el sonido, para atrapar psicológicamente al espectador y por último incorpora los happenings, que eran acciones colectivas. Con todo ello consigue derribar barreras, con la intención de que el arte se funda con la experiencia, en resumidas cuentas, con la vida.

Un artista clave es Wolf Vostell que aunque residía en España y era de origen alemán. Su obra era participativa, realizaba acciones-decollage en la calle, en la que se invitaba a los transeúntes a participar buscando un significado en los carteles desgarrados. En los años sesenta fue un gran promotor del happening, como crítica social, denunciando la injusticia, la violencia y la deshumanización propiciada por el uso masivo de la tecnología, por consumir productos tecnológicos. En sus instalaciones utilizaba elementos industriales de desecho contrastados con elementos orgánicos como plantas o animales, porque para él el ser humano se mueve entre dos parámetros: la naturaleza y la cultura. En 1962 publicó Dé-collage, era la revista de difusión internacional de las ideas del grupo de acción Fluxus.

Y como integrante fundamental desde su creación del colectivo Fluxus es imprescindible nombrar a Josep Beuys. En los primeros años sesenta participó en numerosas acciones pero posteriormente se centró en su obra personal en la que articulaba de un modo indivisible su obra, vida y pensamientos. Josep Beuys junto a su obra ha sido un referente indispensable para el arte que se fué desarrollando a partir de la segunda mitad del siglo XX. En su obra buscaba la conquista de la libertad a partir de una redefinición poética de la relación del ser humano con la naturaleza, ésta como elemento animado.

Beuys con su obra proclama la fusión del arte con la vida para alcanzar el desarrollo hacia la libertad y la espiritualidad de la sociedad. Pretende desligar el arte de la academia, el arte lo extrapola a la política, a la economía y al pensamiento, porque para Beuys el verdadero capital del 
ser humano es su creatividad. A diferencia de las acciones y happenings del grupo Fluxus, que eran participativas, en las acciones de Beuys el público no era partícipe de la acción, muestra un papel de testigo de la acción en la que el artista que a modo de sumo sacerdote va desarrollando los acontecimientos como si de un Chamán se tratase.

Entre sus acciones son de especial interés destacar: Cómo explicar los cuadros a una liebre muerta (1965) o Me gusta América y le gusto a América, conocida como Coyote (1974).

Con sus acciones e instalaciones, Josep Beuys reclama un cambio de paradigma para el arte dirigiéndose más hacia un enfoque social.

Es cierto que existen otros artistas, a parte de los anteriormente citados, como: Gina Pane, Bruce Newman, Ana Mendieta, Judy Chicago, Marina Abramovic, Carolee Schneemann o Francis Alÿs...entre otros muchos, que han sido referentes indiscutibles para lo que hoy llamamos performance. Pero para no hacer demasiada extensa la lista y para poder concretar en el tema de la alimentación y la performance, se da paso en el siguiente apartado a conocer a artistas performers que se aproximan al tema alimentario.

\subsubsection{Artistas performers vinculados a la temática alimentaria}

Como ya se hizo referencia en el artículo titulado La alimentación actual desde la visión crítica de las humanidades (Faba, 2020) publicado en las actas de El gusto en el museo 2020, II Congreso internacional sobre patrimonio alimentario y museos, se ha realizado una selección de artistas que con sus performances hacen referencia al tema alimentario.

Artistas como: Martha Rosler, Patty Chang, Romira de Novellis, Rirkirit Tiravanija, Antoni Miralda o Àlvar Calvet. Cada uno de estos artistas han abordado la alimentación desde diferentes puntos de vista para reflejar sus diferentes inquietudes. La alimentación por tanto ha sido tratada desde perspectivas diversas: de género, el espacio doméstico, intercambios en las redes sociales o el despilfarro de comida.

De la artista Martha Rosler ha sido interesante destacar tres obras de videoperformance: $A$ Budding Gourmet, The East is Red, the West is Bending y Semiótica de la cocina. En su obra, Marta Rosler, sitúa a la mujer en el espacio doméstico que le ha sido reservado, la cocina. Espacio donde intenta con sus acciones deconstruir el papel tradicional de la mujer. La comida, la publicidad y los programas televisivos de cocina, en los cuales se transmiten los valores y pautas de género, reclaman la atención de la artista. Se establece una asociación entre arte y gastronomía y género. De un modo irónico proyecta la idea de la mujer que intenta conseguir un estatus social para su familia a través de recetarios de cocina sofisticada y de la adquisición de novedosos aparatos electrónicos. Emulando el mundo de la publicidad y los canales televisivos de cocina. (Rosler, 1975).

Otra artista que trabaja el tema de género asociado a la comida es Patty Chang. Es una artista multidisciplinar, que trabaja en performance, video, escritura o instalación. Su obra es el producto de la investigación de diversos temas complejos de una manera simultánea. Según se puede ver en su página web, podemos apreciar como en sus performances la artista visualiza la experiencia de lo femenino, estableciendo una conexión entre la comida y el cuerpo. Refleja conductas patológica, como la gula como reacción violenta al ideal de belleza que impone la sociedad. (Chang, 1998).

La performer Romira de Novellis, la conexión que se establece entre arte y gastronomía es de denuncia del despilfarro de alimentos, en un mundo globalizado y capitalista. En sus performances, 
Romira expresa a través de su cuerpo, articulando movimientos repetitivos, sus dudas, preguntas y críticas hacia una sociedad capitalista. Estableciendo su propio cuerpo como centro de su investigación. Entre las siguientes obras, cuyo tema en común es el despilfarro de la comida en los países de occidente: Tentativas de resurrección, La última cena, Bella ciao, Augurii e Infierno. (Novellis, 2019).

De Rirkrit Tiravanija es imprescindible hablar de su obra, ya que es una combinación entre fabricación artesanal de objetos, realización de performances y de instalaciones, recreando espacios que incentivan a que la gente interactúe, dejando que ocurran los acontecimientos. Su obra está marcada por la movilidad entre la cultura occidental y la cultura tailandesa. (Tiravanija, 1990).

Antoni Miralda es un artista multidisciplinar español. Desde la década de 1960, su trabajo ha desarrollado el objeto, el ceremonial, las acciones e intervenciones en el espacio público, la comida y el concepto Food Cultura. Algunas de sus esculturas son comestibles. Utiliza un lenguaje vibrante y participativo, basado en la celebración de los sentidos, del color, de la vida y de lo imaginario. (Miralda, 1960). Food Cultura es una fundación privada creada por el artista Antoni Miralda y la chef Montse Guillén. Han generado una plataforma donde se expone el concepto de "Food Cultura" desde la visión conjunta de la alimentación, la práctica artística y la exploración antropológica.

\subsection{Trabajo artístico personal y de investigación sobre la alimentación actual. Nuria Faba}

Como artista visual y multidisciplinar, incluyendo la performance en mis proyectos personales, he considerado conveniente poder mostrar mi trabajo artístico que se vale de las diferentes técnicas y disciplinas para abarcar proyectos cuyo tema principal es la alimentación. Mis proyectos son multidisciplinares porque recurro a diferentes técnicas y disciplinas según quiera hablar de un aspecto u otro de la alimentación. Por ello en mi obra se pueden encontrar desde esculturas, retratos en acuarela, vídeos interactivos, videoacción y performances siempre dentro del marco de la instalación. Realizo proyectos artísticos de implicación social, de género, con la naturaleza y con una marcada preocupación por la alimentación.

Las performance suelen ser participativas por lo menos en alguna parte de la misma. En las que el espectador, sin saberlo, es invitado a formar parte de la obra.

La alimentación actual, es tratada en mis proyectos desde la instalación audiovisual e interdisciplinar incorporando la performance como un ingrediente artístico muy potente que completa "la receta". Abordando diferentes aspectos relativos a la alimentación, como: la composición de los alimentos que consumimos, el origen, las labores de recolección, la compra, la contaminación del entorno por plásticos y microplásticos y el acto cotidiano de comer. Respondiendo a cuestiones tan relevantes como es: el qué, el cómo, el por qué, el para qué y el con quién de nuestro acto alimenticio. Realizando un guiño a los alimentos ecológicos, prácticas tradicionales de extracción y recolección de alimentos y a la resiliencia alimentaria y social, que gira en torno al acto cotidiano de comer.

A través de estos proyectos artísticos pretendo generar en el espectador una mirada crítica sobre la alimentación, al adentrarse en el recorrido envolvente de la instalación audiovisual e interdisciplinar y performática.

Los proyectos que considero más relevantes son los siguientes:

Naturalmente artificial es una instalación multidisciplinar realizada en 2014, que aborda el tema de la supremacía del ser humano a través de la problemática que suscita el uso de 


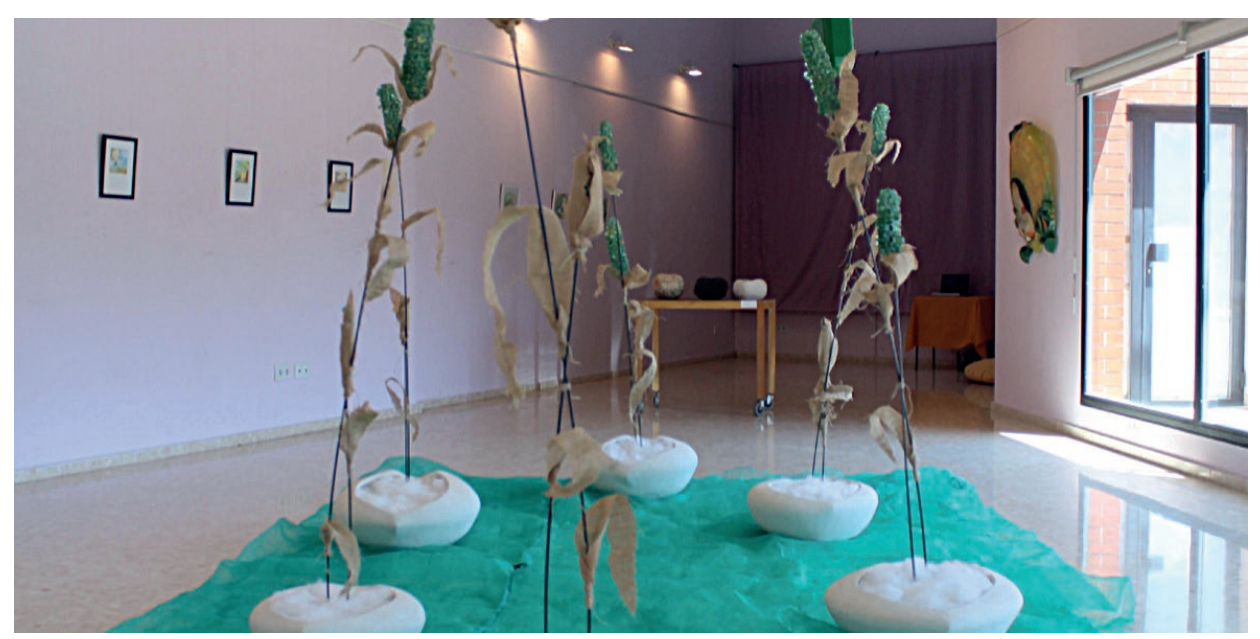

Figura 1. Nuria Faba, Naturalmente artificial, instalación, 2014. Fuente: Faba, N (2014).

transgénicos en la alimentación actual. El ser humano se otorga el derecho de crear y manipular todo lo que cae en sus manos de una manera poco responsable para la salud de las personas y del medioambiente.

ALIMENTARS-E, 2015, es una instalación escultórica y audiovisual, que pretende visualizar aspectos de nuestra cotidianidad como la publicidad, la compra o la acción de comer, para reflexionar acerca de nuestras elecciones alimentarias. Se abordan temas como la identidad, el consumo y la práctica alimenticia, con la expectativa de que como mínimo resulte inquietante.

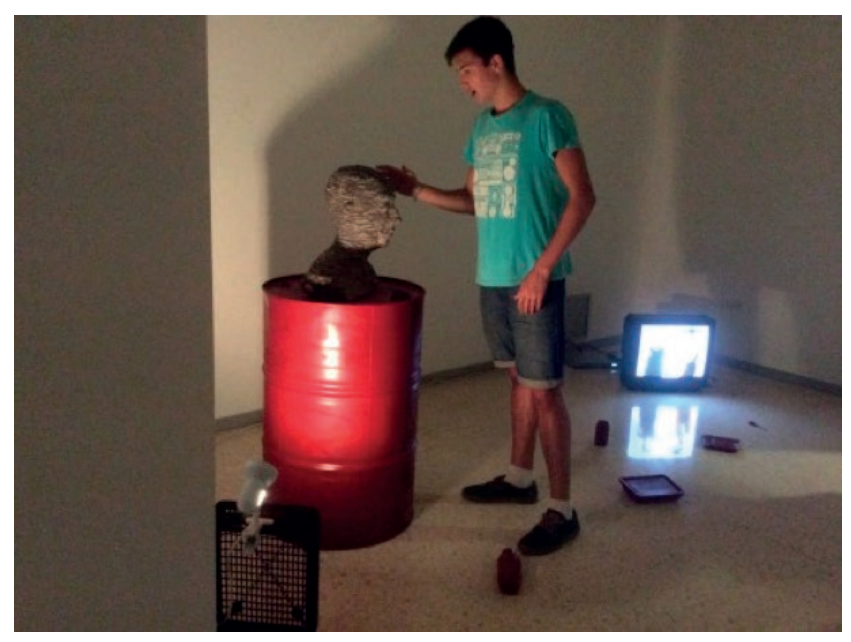

Figura 2. Nuria Faba, ALIMENTARS-E, instalación, 2015.

Fuente: Faba, N (2015). 

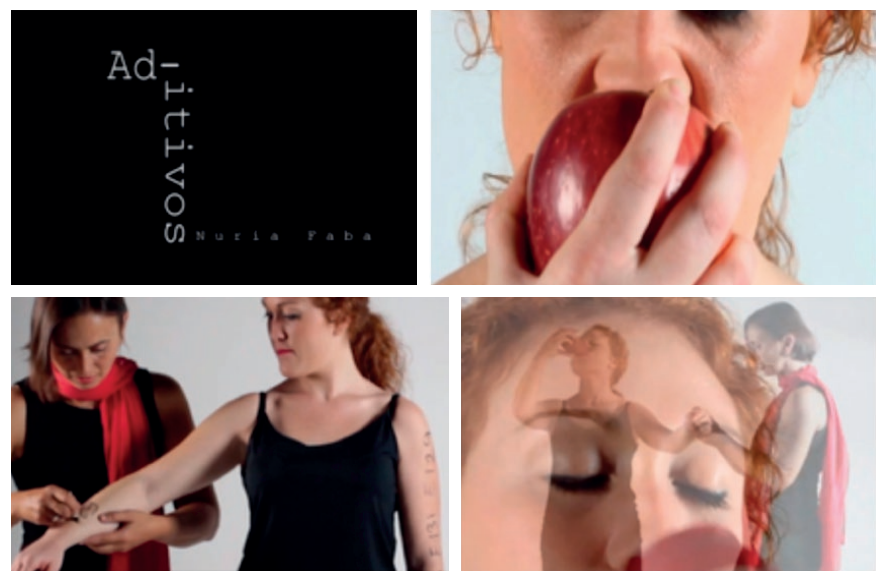

Figura 3. Nuria Faba, Ad-itivos, fotogramas de la videoperformance perteneciente a la instalación ALIMENTARS-E, 2015. Fuente: Molero, E (2015).

En este proyecto de instalación audiovisual se presenta una video performance titulada: Ad-itivos disponible en: https://www.youtube.com/watch?v=QcwFVFRahJs

A través de esta acción se pretende visualizar los aditivos alimentarios que se van acumulando en nuestro organismo durante la ingesta de alimentos procesados, frente a los beneficios de los alimentos naturales.

Polimorfosis, proyectando polímeros, es un proyecto de instalación audiovisual realizado en 2019. Su objetivo principal es hacer visible la contaminación que sufre el planeta a causa de los polímeros. Cómo afectan a la salud medioambiental y a los ecosistemas que lo habitan.

Se pretende mostrar cómo esta contaminación afecta a la tradición de la práctica pesquera local, a la vida marina y a la gente que habita el territorio, y hace hincapié en aspectos como: la

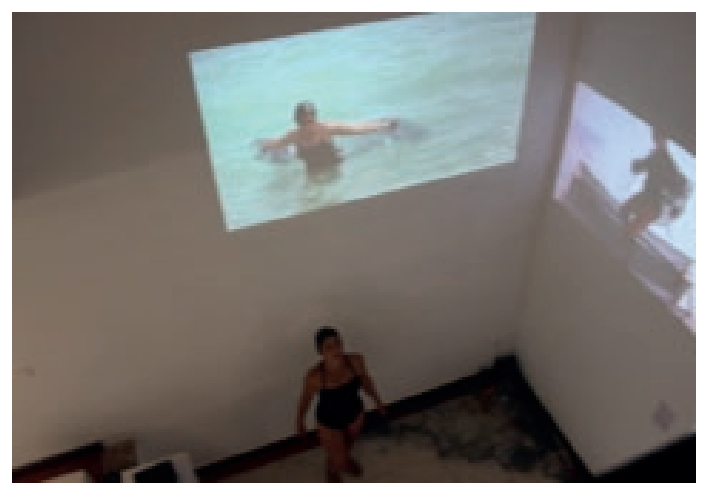

Figura 4. Nuria Faba, Bañista in site y Bañista outsite, video acción, Polimorfosis, proyectando polímeros, 2019. Fuente: Castellano, S (2019). 

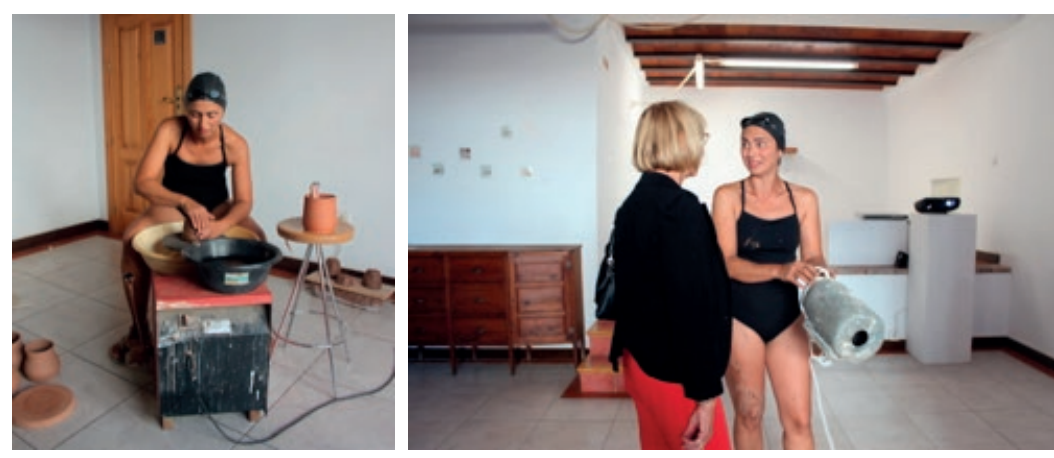

Figura 5. Nuria Faba, Calufos, performance, Polimorfosis, proyectando polímeros, 2019. Fuente: Castellano, S (2019).

repercusión en la salud de las diferentes especies que habitan el planeta, entre ellos el ser humano. Al ingerir estos plásticos y microplásticos, de forma accidental, pasan a formar parte de la cadena trófica. La instalación engloba esculturas, fotografía, vídeo acción y performance en directo.

Las piezas de vídeo acción Bañista in site y Bañista outsite, muestran la contaminación de nuestros mares y océanos por la presencia de plásticos y microplásticos que ingieren peces y moluscos y en último caso las personas llegando a formar parte de nuestra cadena trófica.

También se presentó una performance titulada Calufos, que hace referencia a las pulperas de cerámica que antiguamente se empleaban y cómo se ha ido sustituyendo por otras de plástico. En esta performance que se realizó el día de la inauguración, contó con la interacción del público, la acción consistía en hacer calufos a torno y luego trocearlos como si fueran anillas de calamar o ventosas del pulpo y la performer se dirige al público para que este le ayude a ponérselo por el cuerpo.

Inmersión Ama es un proyecto realizado en 2020 de instalación audiovisual y gráfico. Resultado de la investigación sobre la alimentación actual, que deriva en el modo de extracción de alimentos, como es el caso de las buceadoras Ama de Japón. Desde una visión femenina y ecológica.

En este proyecto se desarrolla la idea de la identidad femenina dentro de la labor pesquera tradicional. Se quiere visibilizar, la labor que durante siglos ha desempeñado la mujer como recolectora y procesadora de alimentos para el hogar. En esta instalación se fija el punto de vista en la sociedad oriental, concretamente en las buceadoras Ama de Japón. Buceadoras longevas que llegan incluso a la edad de 80 años en activo, realizando diariamente inmersiones para la extracción de distintos moluscos como ostras y orejas de mar, entre otros. Las buceadoras Ama realizan múltiples inmersiones diarias a pulmón, algunas de ellas llegan a bajar profundidades superiores a los $20 \mathrm{~m}$.

Desde una mirada ecológica se quiere hacer una llamada de atención y de denuncia por la contaminación medioambiental que sufren las aguas que conforman los mares y océanos del planeta. Debido a la presencia de elementos radioactivos y de metales pesados que pueden llegar a formar parte de la cadena trófica de moluscos, peces... y en última instancia de la de los humanos, por su ingesta.

Para ello la performer se hace pasar por una buceadora Ama y es grabada buceando a pulmón recolectando moluscos. 


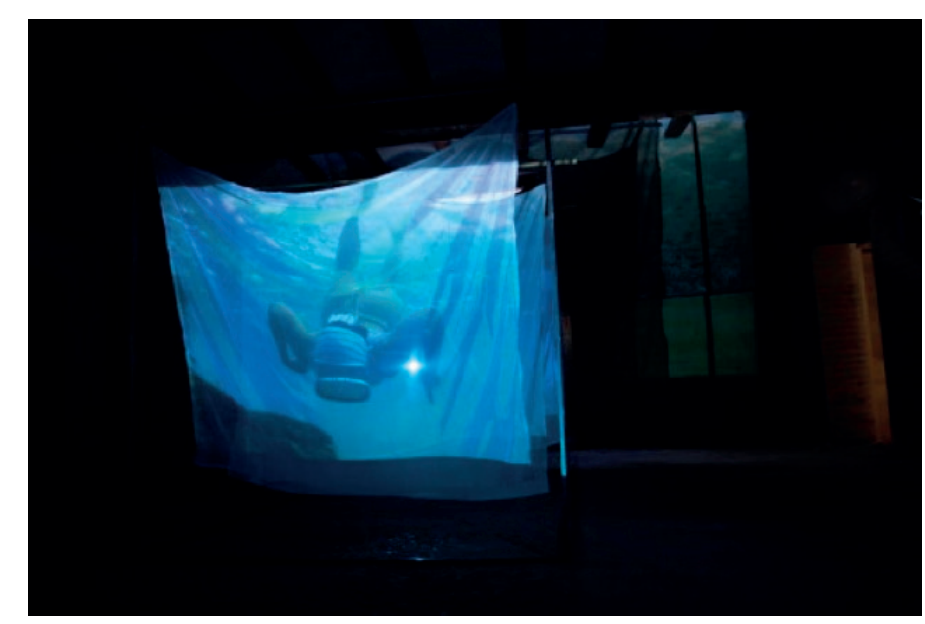

Figura 5. Nuria Faba, Ama II, videoperformance, Inmersión Ama, 2020. Fuente: Faba, N (2020).

Y como último proyecto recién presentado, en septiembre de 2021, está el proyecto que lleva por nombre ¿Comes conmigo?, es un proyecto de instalación performática, audiovisual y gráfica. En el que se conjugan distintas disciplinas como son: la video performance, el retrato en acuarela y la fotografía.

Con todo ello se pretende generar un marco interdisciplinar y envolvente, en el que se traslade al espectador a un ambiente de reunión en torno a una mesa y a la comida, haciendo que sea parte activa de la misma. En el que se pretende evidenciar el qué, el cómo, el por qué y el con quién, de la alimentación actual. Se presenta una mesa en la que ha acontecido una acción, un

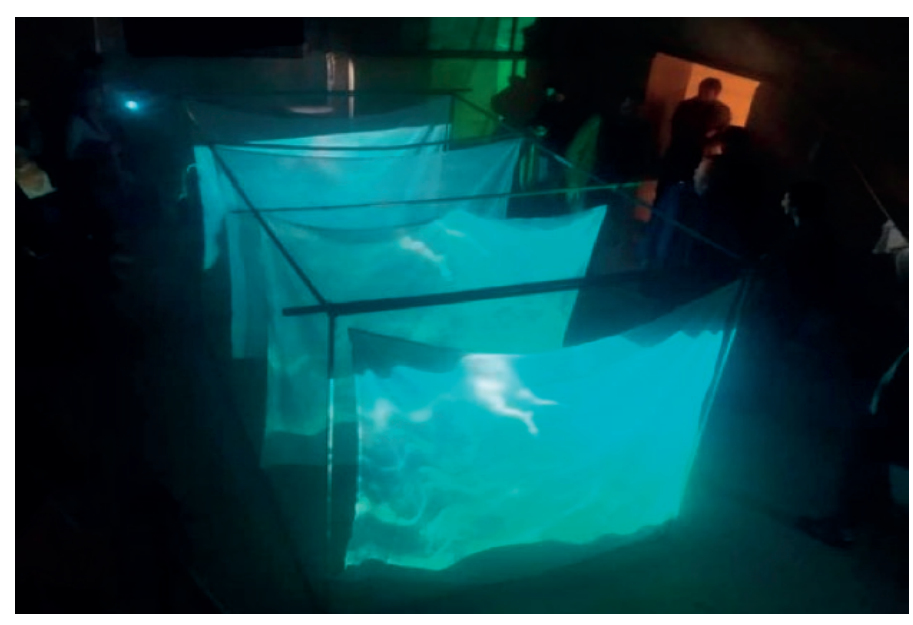

Figura 6. Nuria Faba, Ama II, videoperformance, Inmersión Ama, 2020. Fuente: Faba, N (2020). 

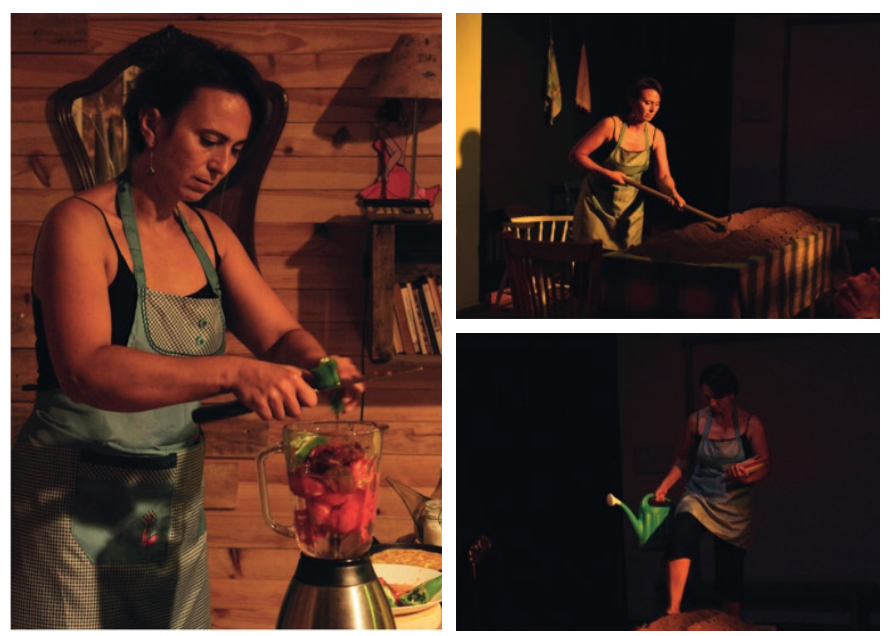

Figura 7. Nuria Faba, ¿Comes conmigo?, performance, documentación fotográfica, 2021. Fuente: Roque, J (2021).

ritual en torno al acto cotidiano de comer, esta acción se materializó en una performance que fue documentada en vídeo y en fotografía que posteriormente se muestra en el segundo acto: en la instalación performática, audiovisual y gráfica.

El acto cotidiano de comer es tratado desde la perspectiva del ritual, de la recolección, de la elaboración de alimentos, de la sociabilización, de la consciencia, saber qué se está comiendo, dónde, cuándo y con quién. Todo ello desde la visión artística de resiliencia alimentaria.
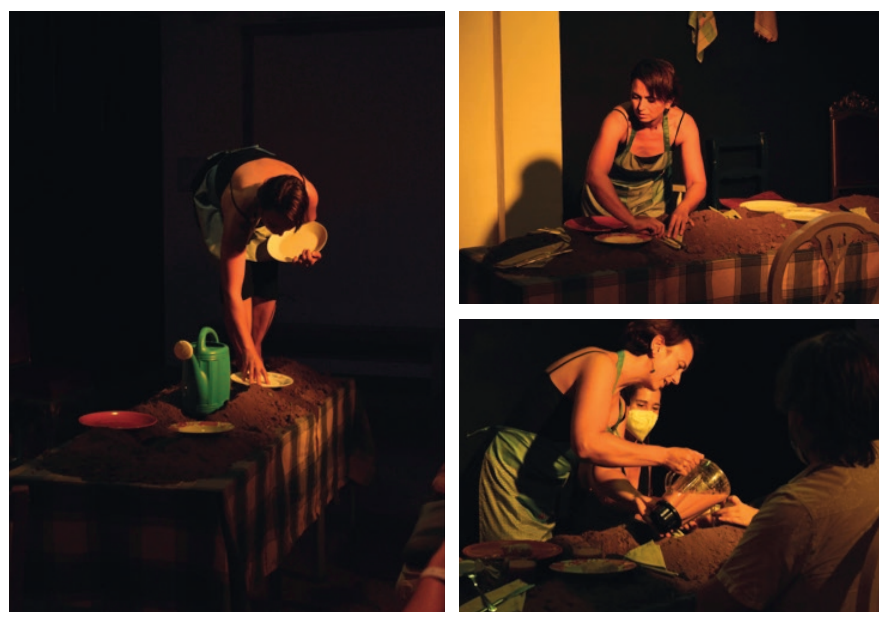

Figura 8. Nuria Faba, ¿Comes conmigo?, performance, documentación fotográfica, 2021. Fuente: Roque, J (2021). 


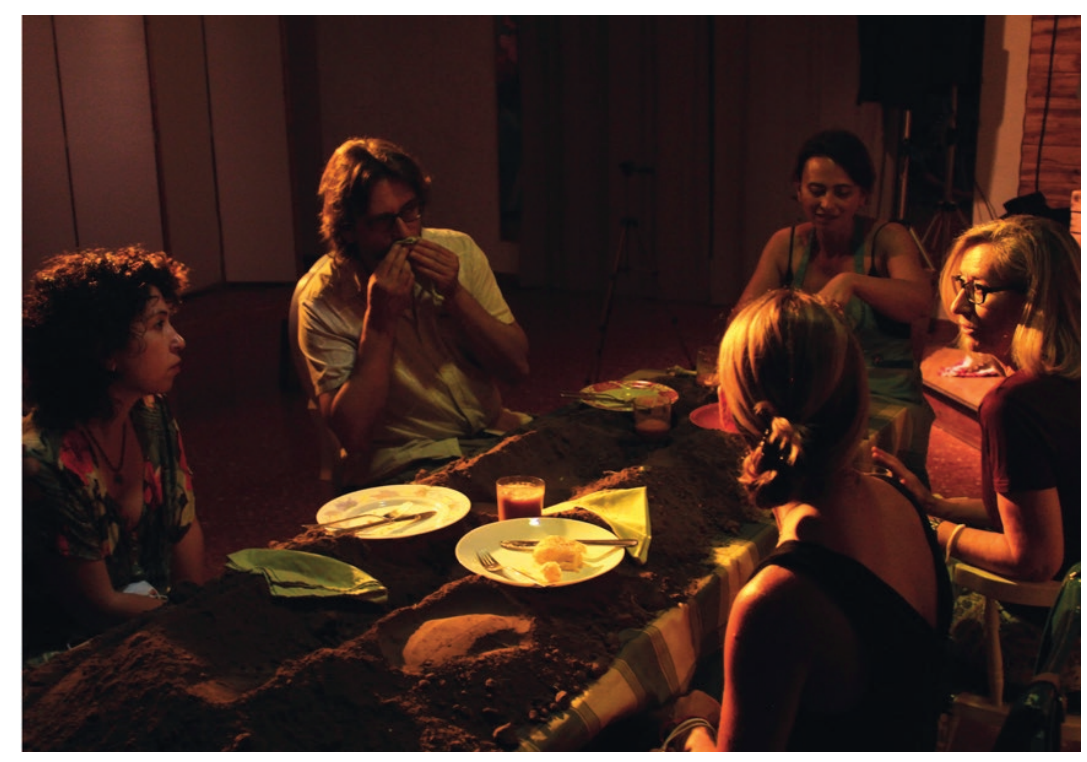

Figura 9. Nuria Faba, ¿Comes conmigo?, performance, documentación fotográfica, 2021. Fuente: Roque, J (2021).

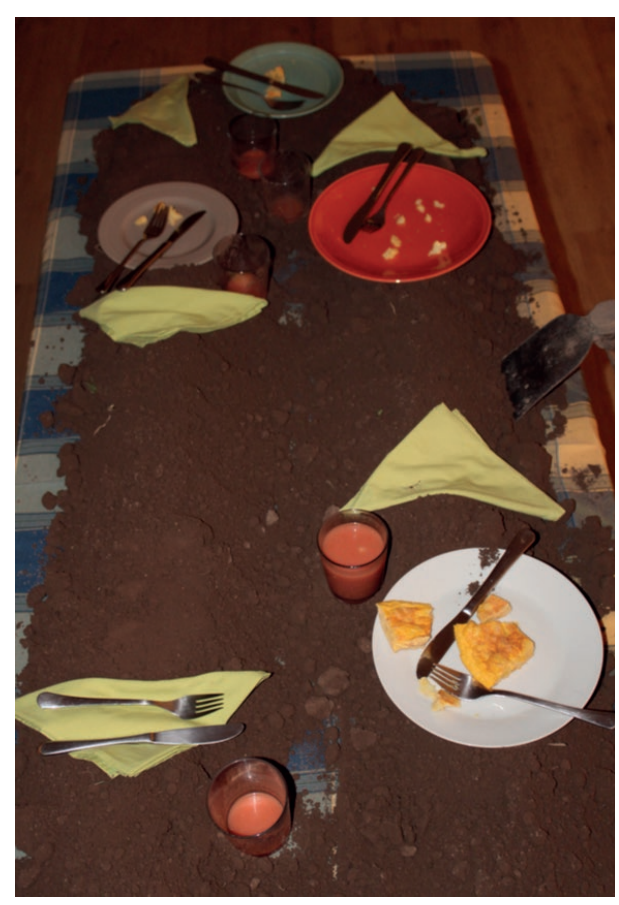

Figura 10. Nuria Faba, ¿Comes conmigo?, performance, documentación fotográfica, 2021. Fuente: Faba, N (2021). 


\section{Conclusiones}

A través del presente artículo, se ha podido reflejar la visión particular del arte respecto a la alimentación, en concreto desde la performance.

Mediante la Investigación y el análisis se ha conseguido abordar la performance desde su origen etimológico, definiendo conceptos clave para la comprensión del arte de acción, en concreto de la performance.

Se ha mostrado un panorama en el que la sitúa en el contexto de la historia del arte. Para ello se han recopilado y testimoniado fuentes referenciales que apoyan el discurso alimentario. Seleccionando obras de diferentes autores y disciplinas que constatan los cambios que se han producido entorno a la alimentación, el consumo de alimentos y el acto cotidiano de comer desde la mirada de la performance.

Se han presentado proyectos artísticos personales, cuyo tema principal es tratar de visualizar la alimentación actual, desde la visión de la videoinstalación, gráfica, escultórica y performativa. Fruto de la trayectoria artística e investigadora relativa a los estudios de licenciatura en bellas artes, máster en producción artística y doctorado en arte e investigación de la UPV.

\section{Referencias}

\section{Libro}

ALBARRÁN, J. (2019). Performance y arte contemporáneo, discursos, prácticas y problemas. Madrid Cátedra.

AUSTIN J. (1962). Cómo hacer cosas con palabras. Massachusetts: Harvard University Press.

FERRANDO, B. (2009). El arte de la performance, elementos de creación. Valencia: Mahali.

GOLDBERG, R. (1979). Performance. Live Art 1909 to the Present. New York: Harry N. Abrams.

GOLDBERG, R. (1988). Performance Art. From Futurism to the Present. NewYork: Harry N. Abrams.

GOLDBERG, R. (1996). Performance Art. Desde el Futurismo hasta el Presente. Barcelona: Ediciones Destino.

MARTÍNEZ, A. (2000). De Andy Warhol a Cindy Shermann. Valencia: Editorial UPV.

SCHECHNER, R. (2002). Performance Studies. An Introduction. London: Routledge.

\section{Página web}

MARTHA ROSLER. <http://www.martharosler.net>[Consulta: 8 de septiembre 2021]

PATTY CHANG. <http://www.pattychang.com >[Consulta: 15 de septiembre 2021]

ROMIRA DE NOVELLIS. <https://www.romina-denovellis.com/infernovenice>[Consulta: 5 de octubre 2021]

\section{Blogs}

FABA MUÑOZ, N. (2014). <https://nuriafaba.tumblr.com> [Consulta: 10 de octubre 2021] 



\title{
EL EXILIO COMPARTIDO. COMIDA, ARTE Y NOSTALGIA
}

\author{
Javier Leñador González-Páez
}

Universidad de Sevilla. jlenador@us.es

\begin{abstract}
This paper pursues to highlight nostalgia's capacities that may contribute to experience different feelings, e.g., social attachments and empathy. Considering nostalgia as an emotion that may be trigger by sensorial stimuli, such as those coming from the olfactory and gustatory senses, food might be a great booster for nostalgia. That way, gustatory experiences may be richer, shared and even reflective mediated by nostalgia feelings. Hence, the paper will focus on those expositive oeuvres that ask for the participation of the public not only visually but gustatorily, making the taste its central concern. Only when the position of taste in the museum is explained and the processes involved in nostalgia analyse will we concentrate on our main purpose: to associate nostalgia's psychological potentialities with gustatory oeuvres in order to make their political statement stronger.
\end{abstract}

Keywords: nostalgia, Proust effect, gustatory art, critical art, food.

Resumen: Con el presente título queremos hacer referencia a las capacidades socializadoras y empáticas que la nostalgia puede procurar al sintiente. Si entendemos la nostalgia como una emoción que puede ser activada por estímulos sensitivos entre los que se encuentra el gusto y el olfato, la comida puede ser un gran impulsor nostálgico, lo que podría hacer la experiencia gustativa todavía más rica, compartida y, como veremos, hasta reflexiva. El trabajo centra su análisis en aquellas obras museísticas -las que circulan dentro del circuito expositivo de las bellas artes- que involucran al público no solo visualmente, sino a través del gusto, convirtiéndolo en elemento central de su experiencia y su mensaje crítico. Tras ver el papel del gusto en el museo y explicar la experiencia y los procesos orgánicos de la nostalgia, nuestro objetivo será el de vincular las potencialidades psicológicas de la nostalgia (socialización, reducción de prejuicios, fomento de la inspiración, etc.) con dichas obras gustativas bajo la premisa que la experimentación nostalgica puede mejorar la eficacia política y crítica de tales obras.

Palabras clave: nostalgia, efecto Proust, arte gustativo, arte crítico, comida.

Citar como: Leñador González-Páez, J. (2022). "El exilio compartido. Comida, arte y nostalgia". En: Actas del III Congreso Internacional sobre Patrimonio Alimentario y Museos. 25-26 noviembre, 2021, Valencia, España. pp. 205-215. https://doi.org/10.4995/EGEM2021.2021.13929 


\section{El gusto: un sentido tradicionalmente alejado de la estética}

Incluso hoy día, la comida está desacralizada en el museo, confinada en una sala más o menos lustrosa llamada cafetería-restaurante. En el resto del complejo, la comida de cualquier tipo está vetada y el propio acto de comer es visto como una falta de respeto para con la institución museo, o peor, con el Arte (así en mayúsculas). Por lo general lo más que encontramos sonrepresentaciones artísticas de alimentos, siendo el caso más obvio es el de los bodegones, o en todo caso, alimentos reales utilizados con fines hápticos y sobre todo visuales, pero no gustativos, como el plátano de Cattelan - de hecho, fue noticia que alguien desafiara las reglas sociales y se lo comiera. En alguna ocasión podemos presenciar performances dondeel actuante es el único que puede comer, pero el arte que utiliza los alimentos para ser ingeridos y degustados por el público es todavía marginal a pesar de que su presencia en el mundo arte a raíz la explosión performativa, instalativa y relacional acaecida hacia la décadade los 60.

Todavía hoy, cuando se habla del gusto en la institución arte no se habla del sentido degustativo, ese que empleamos cada poco al realizar cualquier comida. Se habla del gusto entendido como discernimiento estético, que nace por metonimia del primero, y que, sin embargo, se ha llevado todo el protagonismo desde el nacimiento de la estética como cienciae incluso antes. Se ha dado entonces la paradoja de que todos los filósofos, estetas y connoisseurs han hablado del gusto al tiempo que relegaban el propio sentido del gusto a laszonas abisales de la estética.

En este sentido, Carolynn Korsmeyer (1999) atendió de manera magistral a las razones fisiológicas e históricas que han hecho separar, desde la estética y disciplinas afines, a los sentidos en dos grupos: unos de primer orden o elevados - vista y oído- y otros de segundoorden, vilipendiados -tacto, olfato y gusto. Atendiendo a razones espirituales e históricas, los sentidos de segundo orden están en contacto directo -o casi para el caso del olfato- con la materia que les procura las sensaciones, lo que los hace mucho más corpóreos. En unatradición teológica y filosófica donde el cuerpo era poco más que un continente impuro parael alma, su corporeidad llevaba a su devaluación. Además, en especial el tacto y el gusto, procuraban un placer que podían llevar al exceso - glotonería y desenfreno sexual-, lo queponía en jaque la virtud y constata una fundamentación moral. De igual forma, atendiendo ala epistemología, los sentidos elevados nos darían más información que los degradados al estar sus propiedades más categorizadas y ser más discernibles - para el caso de la vista pensemos en la cantidad de gradaciones y especificaciones que podemos realizar en torno al

color y la forma. Un sentido hacia el que también apuntan los formalistas, que no ven en los estímulos aprehendidos por los sentidos relegados una estructuración de sus cualidades; sus matices tienden a mezclarse y perderse. Finalmente, para hablar de su fundamentación cognitiva y fisiológica, que es la que parapeta a la estética como ciencia, Korsmeyer nos presenta a Kant, quien basa la apreciación estética en el requisito del desinterés. Un requisitoimposible de cumplir por el sentido del gusto en tanto responde a un interés fisiológico vital:el hambre. Además, Kant considera al olfato y el gusto como eminentemente subjetivos, donde apenas participa la razón, por lo que se relacionan con el placer personal y no puedendar lugar a juicios con visos de universalidad, otro de sus requisitos para la experiencia estética. Fue eso lo que lo llevó a dividir los gozos procurados por los sentidos bajo dos categorías diferenciadas: lo bello y lo estético para los sentidos elevados y lo meramente placentero y agradable para los minusvalorados. 
Pero a nuestro juicio, estas fundamentaciones, aunque sensatas y dialécticas, no dejarían de responder a cuestiones superiores que han sido ya apuntadas por Pierre Bourdieu. Este considera que la visión kantiana del desinterés y otros requisitos estéticos similares serían fruto de una construcción histórica fundada por aquellos que tenían el suficiente tiempo librepara la contemplación desinteresada y ostentaban una posición de poder en el entramado social que les permitía imponer su criterio teleológico y estético. Dicho de otro modo, la jerarquía de las artes y su valor estético se correspondería con la jerarquía de los consumidores, lo que hace que los gustos funcionen como marcadores de clase y que la separación entre sentidos estéticos y no estéticos se base en cuestiones sociales, religiosas ymorales y no naturales, posteriormente universalizados a través de la educación (Bourdieu, 1984).

\section{La nostalgia como emoción y como experiencia}

La nostalgia se puede definir brevemente como una emoción de carácter ambivalente en la que se entremezcla placer y dolor al recordar un evento pasado. Aunque la emoción nace conla propia cultura, el término como tal no aparece hasta el 22 de junio en 1688 en el campo médico, cuando Johannes Hofer la acuña en su tesina titulada Dissertatio medica de nostalgia oder Heimweh. Su etimología responde a la unión de dos vocablos griegos: nostos (retorno,a la patria según Hofer) y algios (dolor o tristeza). Así, en un principio, la nostalgia tuvo unaconnotación negativa, pues se consideraba una enfermedad que Hofer identificaba en los soldados suizos movilizados a otras latitudes del continente europeo, presentándose como una turbación de la imaginación en la que solo se contemplaba el regreso a la patria y que solía llevar a la acedia o estados depresivos, propiciando, en algunos casos, la muerte del enfermo (Hofer, 1992). Así, si bien es cierto que los orígenes arrojan una visión negativa y una referencia al espacio geográfico, con los años el término se irá transformando, virando hacia una consideración neutra o positiva y trasladándose al espacio temporal. Ya no se habladel regreso -imaginado- a la patria, sino a un tiempo pasado.

Hoy día, la nostalgia se considera un concepto en auge, en especial en la esfera social, pues culturalmente vivimos más que nunca en un mundo fuertemente nostálgico, donde el pasado ocupa un papel relevante y las creaciones culturales y mercantiles que llaman a la nostalgia son numerosas. De hecho, Bauman considera que no encontramos en "la era de la nostalgia" (Bauman, 2017), palabras que entendemos suficientes para justificar el tema de nuestro trabajo.

Pero nuestro interés no se centra en la esfera social, sino en la individual, en la emocional y experiencial de la nostalgia. Y aquí, uno de los primeros grandes analistas no lo encontramosen la psicología o en campos afines, sino en la literatura, en la figura de Marcel Proust, cuyaobra ecuménica En busca del tiempo perdido (1913-1927) se construye temática y compositivamente en torno a la nostalgia. En ella se analiza una experiencia evocadora concreta que ha trascendido a la posteridad: ese momento en el que el protagonista se lleva una magdalena a la boca y una fuerte emoción lo embarga, llevándolo a rememorar recuerdos de su infancia en Combray. Es esta experiencia concreta la que nos hará de guía a la hora deexplicar algo más en profundidad la fenomenología de la nostalgia.

\section{1 ¿Qué le ocurrió a Proust al morder su magdalena? La experiencia nostálgica explicada}

[...] Abrumado por el triste día que había pasado y por la perspectiva de otro tan melancólico por venir, me llevé a los labios una cucharada de té en el que había echado un trozo de magdalena. Pero en el mismo instante en que aquel trago, con las migas del bollo, tocó mi paladar, me estremecí, fija mi atención en 
algo extraordinario que ocurría en mi interior. Un placer delicioso me invadió, me aisló, sin noción de lo que le causaba. Y él me convirtió las vicisitudes de la vida en indiferentes, sus desastres en inofensivos y su brevedad en ilusoria, todo del mismo modo que opera el amor, llenándose de una esencia preciosa; pero, mejor dicho, esa esencia no es que estuviera en mí, es que era yo mismo. Dejé de sentirme mediocre contingente y mortal. ¿De dónde podría venirme aquella alegría tan fuerte? Me daba cuenta de que iba unida al sabor del té y del bollo, pero le excedía en mucho, y no debía de ser de la misma naturaleza. ¿De dónde venía y qué significaba? ¿Cómo llegar a aprehenderlo? Bebo un segundo trago, que no me duce más que el primero; luego un tercero, que ya me dice un poco menos. Ya es hora de pararse, parece que la virtud del brebaje va aminorándose. Ya se ve claro que la verdad que yo busco no está en él, sino en mí. El brebaje la despertó, pero no sabe cuál es y lo único que puede hacer es repetir indefinidamente, pero cada vez con menor intensidad, ese testimonio que no sé interpretar y que quiero volver a pedirle dentro de un instante y encontrar intacto a mi disposición para llegar a una aclaración decisiva. Dejo la taza y vuelvo hacia mi alma. [...] Y de pronto el recuerdo surge. Ese sabor es el que tenía el pedazo de magdalena que mi tía Leoncia me ofrecía, después de mojado en su infusión de té o de tila, los domingos por la mañana en Combray [...]. Ver la magdalena no me había recordado nada, antes de que la probara; quizá porque, como había visto muchas, sin comerlas, en las pastelerías, su imagen se había separado de aquellos días de Combray para enlazarse a otros más recientes; iquizá porque de esos recuerdos por tanto tiempo abandonados fuera de la memoria, no sobrevive nada y todo se va disgregando! [...] Combray entero y sus alrededores, todo eso, pueblo y jardines, que va tomando forma y consistencia, sale de mi taza de té. (Proust, 2016, pp. 66-71)

Esta verdadera re-vivencia de una experiencia pasada es lo que Proust llamó moments bienheureux (momentos dichosos) (Epstein, 2004), escenas que creemos que quedan esencializadas a la perfección en los extractos recién enunciados como intensas, emotivas, frugales, vitales, trascendentes, evocadoras. Momentos que han sido reproducidos ampliamente en multitud de obras literarias y cinematográficas, como en Ratatouille, cuandoel crítico gastronómico Anton Ego recuerda su infancia al probar el plato que Remy le ha preparado o en Una receta familiar, película singapurense basada en la relacional emocionaly familiar con la cocina. También se pueden leer en obras literarias mucho más recientes quela de Proust, como Aromas, de Philippe Claudel, o El dios de las pequeñas cosas, de Arundhati Roy; e incluso ha sido utilizado con fines mercantilistas en campañas de publicidad, como la de cocinas Teka.

Indudablemente, el poder de la imaginación y la memoria son esenciales en tales experiencias evocadoras como las de la magdalena. Concretamente, participa el tipo de memoria que se conoce como episódica, que guarda información respecto a eventos o episodios temporales y sus relaciones espacio-temporales y siempre toma un sentido autobiográfico. Todo dentro de un desarrollo totalizador e indiferenciado que involucra a la memoria semántica, el otro tipo de memoria que guarda información cognitiva y no perceptiva, como símbolos y datos y su relación (Tulving, 1972).

Si profundizamos en el proceso de rememoración que se encuentra en esos momentos felices, Proust se refiere de manera tácita a la memoria involuntaria. Al contrario de la memoria voluntaria, que es un proceso donde se recupera información adrede, la involuntaria trae los recuerdos a la conciencia con aparente espontaneidad, sin pretenderlo (Berntsen, 1996). De hecho, Proust nos dice en el texto referenciado que el "recuerdo surge" (Proust, 2016) como si fuera de manera espontánea, sin su propia voluntad. El literato es consciente de esta diferencia capital, y es que, en el mismo volumen de su obra, Proust nos habla de la memoria voluntaria en sentido peyorativo -al menos para la generación de imágenes emocionalmente atractivas: "Pero como lo que yo habría recordado de eso serían cosas venidas por la memoria voluntaria, la memoria de la inteligencia, y los datos que ella da respecto al pasado no conservan de él nada, nunca tuve ganas de pensar en todo lo demás de Combray" (Proust, 2016, p. 66). Y es que parece que esta 
es una verdad generalizable, pues estudios científicos demuestran que el recuerdo involuntario, frente al voluntario, permite la recuperación de más episodios concretos y mayores respuestas emocionales y corporales en tanto activa en mayor medida la memoria episódica específica, asociados con mayores dosis de revivencia y emocionalidad (Berntsen y Hall, 2004).

Ahora bien, ¿cómo podemos explicar la transición o el juego de la imaginación que posibilita el gozo presente en base a un recuerdo? ¿Cómo transita nuestra mente de la magdalena que comemos hoy a la que comimos muchos años atrás en nuestra infancia?

Para explicarlo recurriremos a la teoría de Russell Epstein (2004), que hace uso del concepto de fringe contextual information con el que William James explica el paso de un momento de consciencia a otro. Esta información contextual o marginal a la que James alude es aquellaque rodea a la información sensitiva más sobresaliente o nucleus en una experiencia dada -en este caso, las experiencias sensitivas más notorias de la magdalena en el presente, como su sabor- y está formada por tres componentes: una débil memoria de pensamientos y sensaciones precedentes, un entendimiento de la relación entre el actual pensamiento focal ylas sensaciones u otros pensamientos que puedan ser relevantes y un sentimiento hacia el queel objetivo de nuestra consciencia se dirige. Normalmente solo nos percatamos del núcleo sensitivo, pero en ocasiones esta información relacional se nos hace consciente gracias a la memoria involuntaria. Esta memoria es la única capaz de traer la información contextual deun evento y la red de asociaciones que involucra, pues es una información que no había sidoracionalizada y la hace ahora consciente, haciendo que las sensaciones tengan una presenciaemocional tan viva como las presentes y nucleares. Todo esto es posible gracias a la labor del hipocampo, pues una vez este ha recibido un estímulo de los sentidos lo completa con elementos que estaban asociados con otros estímulos que seguían el mismo modelo en el pasado. La información es posteriormente transmitida al córtex, donde se evoca un nuevo pensamiento conscientemente experimentado, una imagen mental capaz de emocionarnos (Epstein, 2004).

Hasta ahora no hemos hablado más que del proceso en sí y hemos hecho mención a estímulos de manera general, pero, ¿ese proceso puede variar en función del tipo de estímulo que lo active? La realidad es que ese fuerte impacto nostálgico puede venir de un estímulo visual o sonoro, como habremos sentido muchos de nosotros, e incluso del propio juego de la mente, de forma endógena. Sin embargo, tanto Proust como la ciencia concuerdan en que son precisamente los estímulos percibidos por esos órganos de segundo orden los que más capacidad evocadora tienen. En el propio extracto, Proust nos dice que el estímulo visual de la magdalena no le causó tal experiencia aduciendo a una suerte de sobreestimulación visual. Es decir, había visto tantas magdalenas antes que la asociación con las pretéritas magdalenas de Combray se había borrado. Esto puede hacernos llegar a la conclusión de que mientras menos repetido sea el estímulo, más probables son los moments bienheureux. Tendría sentido entonces que sentidos no tan sobreestimulados como olfato y gusto, así como los estímulos que no se han hecho cotidianos, sean más efectivos en la formación de experiencias intensamente nostálgicas. Y esto lo ratifica la ciencia en tanto queda demostrado que los olores -es por todos sabido el importante papel que el olfato tiene en la propia experiencia gustativa- recuperan recuerdos más emocionales que los estímulos visuales y verbales y que aún son más evocadores cuanto más distintivos y novedosos son (Herz y Schooler, 2002). Esto se debe a que los activadores olfativos excitan más la amígdala de lo que lo hacen los auditivos o visuales y se asocian de forma más directa con el lobo temporal y límbico, la región más "emocional" del cerebro y allí 
donde se encuentra el hipocampo, encargado del procesamiento positivo de la memoria (Reid et al., 2015). De igual manera, se ha confirmado que los activadores olfativos son más efectivos que los visuales trayendo memorias de la infancia al presente. Por tanto, los olores son mejores evocadores de eventos que ocurrieron mucho tiempo atrás (Bruijn y Bender, 2018), lo que nos llevaría a una diferenciación de activadores según el órgano receptor-distancia del recuerdo que corre en el mismo sentido que nuestra hipótesis sobre la sobreestimulación.

Creemos que todos estos estudios sobre el olfato se pueden extrapolar al sentido del gusto dada la ya comentada dependencia entre ambos. Además, en la propia experiencia culinaria se ven involucrados todos los sentidos, tanto los más obvios, como el olfato y el tacto -este último es el que permite apreciar las diferentes texturas de los alimentos en la boca- comola vista y el oído al valorar la apariencia visual de los alimentos y el sonido que estos puedenhacer al quebrarse o al morderlos y que nos pueden ayudar a valorar algunas de sus cualidades, como el punto de cocción o la frescura. Realmente, la experiencia culinaria en condiciones normativas es sensiblemente totalizadora.

\section{1 ¿Podemos hablar de una experiencia estética?}

Estos moments bienheureux o agudamente nostálgicos creemos que cumplen con la caracterización de las experiencias -el concepto de An Experience- que Dewey define como un suceso experimentado subjetivamente con unidad propia, donde se mezcla lo intelectual con lo emocional de manera indiscernible y que es en sí misma conclusiva. Deweyda a esas experiencias la cualidad de estéticas, una estética basada no en los materiales - como las obras de arte visuales-, sino por medio de esa integración conclusiva per se gratificante (Dewey, 2005). Es esta la idea de partida que los estetas de los cotidiano como Thomas Leddy (2012) y Yuriko Saito (2007) utilizan para fundamentar sus teorías y que bienpodrían servir para otorgar a experiencias sensitivas como las culinarias el estatus deexperiencias estéticas, desoyendo las teorías kantianas y poskantianas. En realidad, una ideasimilar fundamenta la concepción artística que Proust tenía de su obra. Lo que hace el escritor, según Epstein, al describir sucesos como el de la magdalena -en realidad hay otros similares a lo largo del libro- es crear una suerte de metáforas que funcionan como digresiones que brotan de la narrativa principal para eludirla momentáneamente y que emulanel proceso que supone vivir esos momentos dichosos que nos hacen olvidar el presente. De esta manera, lo que Proust persigue es capturar la esencia de las cosas, es decir, una estructura estable de memorias y conocimiento que él creía que existía fuera del tiempofenomenológicamente experimentado, esto es, de manera secuencial. Esto se conseguiría solo de dos formas, a través de la memoria involuntaria y el arte. El primero ayuda a crear elfenómeno directamente en la mente con cualquier objeto; el segundo lo hace "ficticiamente" al presentar al observador con una serie de recursos o topos/símbolos que crean una red de asociaciones (Epstein, 2004). Como vemos, una concepción muy similar a la de las experiencias de Dewey y que refuerza la posibilidad de abrir una vía propia para suvaloración estética.

\section{Hacia una teoría de la nostalgia en el arte: el aprovechamiento de sus beneficios psicológicos en la dimensión crítica de las obras de arte}

Una vez apuntado el valor estético de las experiencias nostálgicas, nuestra labor ahora será traer a escena estudios recientes en el campo de la psicología que caracterizan la nostalgia como una emoción eminentemente positiva y proactiva. Contradiciendo lo que antes era supuesto, la 
nostalgia está lejos de provocar un estado comparable a la ataraxia o el puro sentimentalismo, sino que se erige como una emoción compensatoria y orientada hacia el futuro que promueve la actividad (Wildschut et al., 2006; FioRito y Routledge, 2020). Es precisamente por ello que creemos en la experiencia estética de la nostalgia como un arma para la acción -mental o física- que podría llevar incluso a potenciar la dimensiones críticas, morales y políticas de las obras de arte.

La primera consecuencia positiva de la nostalgia es el incremento de la socialización o de la interacción social. La nostalgia es social en un doble sentido: en sus contenidos y en su alcance. En cuanto a lo primero, la mayoría de los recuerdos nostálgicos rememoran un evento rodeado de nuestros amigos y familiares. Un estudio realizado por Wildschut y sus compañeros revela que los objetos de rememoración más repetidos durante un sentimiento de nostalgia fueron las personas (33\%), seguido de los eventos (28\%), los cuales solían ser grupales. De este modo, el acceso a estructuras relacionales positivas previas lleva a una suerte de optimismo a la hora de crear o fortalecer lazos sociales (Wildschut et al., 2006). Encuanto a su alcance, estudios recientes concluyen que las experiencias nostálgicas tienden a compartirse (FioRito y Routledge, 2020), de modo que sería una herramienta valiosa para entablar conversaciones e intercambiar pareceres, pudiendo dar lugar a debates sobre la eficacia política de la obra o sobre las vicisitudes morales del asunto que es puesto de relievepor la obra. Y no solo eso, sino que además pueda ayudar a reducir los prejuicios para con la gente con la que el individuo está interactuando. Esta reducción sigue las lógicas relacionadas con la interacción social, pero siendo mediada por la empatía y estando condicionada por lacualidad de los recuerdos rememorados. Es habitual que los recuerdos evoquen ternura, caloro familiaridad invocando a personas significativas de nuestro pasado, por lo que gracias a laempatía, estas cualidades sean trasladadas al grupo externo, reduciendo los prejuicios que pudieran sentir hacia ellos y siendo más proclives a establecer un acercamiento (Sedikides y Wildschut, 2019).

El segundo beneficio que merece la pena señalar es el de la potenciación de la inspiración. Estudios psicológicos señalan que la nostalgia fortalece distintos recursos psicológicos, comola señalada conectividad social y la autoestima, lo que lleva a que los individuos sean más proclives a proyectar nuevas ideas y nuevos planes (Stephan et al., 2015). Esto creemos quees fundamental para que la obra trascienda, para que los individuos afectados emocionalmente por la obra no solo se vean informados de una determinada situación o se queden en un primer estadio presidido por la indignación, la rabia o la pesadumbre. Graciasa la nostalgia, las probabilidades de ser reactivos e incluso tomar acción a favor de la causa se ven incrementadas. De hecho, estudios demuestran que aquellos afectados nostálgicamente son más proclives a donar tiempo y dinero para determinada causa, es decir,se muestran más caritativos gracias a la mediación de la empatía promovida por la nostalgia(Zhou et al., 2012).

Relacionado con este último encontramos la estimulación de la creatividad y que supondría la materialización del punto antes señalado. La nostalgia puede llevar a crear obras de arte, asociaciones, empresas, escritos, etc., siguiendo la lógica señalada por Stephan y sus compañeras, acoplándose el incremento del optimismo comentado por Cheung (Cheung et al., 2016). Este optimismo se relaciona con la adopción de opciones con más riesgos, menosconservadoras, lo que se proyecta en una apertura de miras que puede beneficiar a la creatividad al fomentar un pensamiento más flexible que incluye distintas categorías cognitivas, cambio de aproximaciones y el uso de asociaciones lejanas (van Tilburg et al., 2015). 
Podemos entonces concluir con la idea demostrada de que los efectos de la nostalgia sobre nuestro cuerpo y nuestra mente son positivos y movilizadores a pesar de poder verse acompañados de alguna nota negativa o agridulce asociadas eminentemente por la pérdida de lo rememorado (Sedikides y Wildschut, 2019). Beneficios sociales como el incremento de la interacción social, la reducción de prejuicios, la caridad o la inspiración cambiarán el modo en el que vemos nuestro entorno, haciéndonos más proclives a la movilización políticay social. Indudablemente, también ha de hallarse una predisposición de tipo racional y moralpara llevarla a cabo, pero la nostalgia puede dar ese paso que de otro modo nunca daríamos,haciendo de la obra de arte una herramienta más efectiva en la consecución de sus fines políticos o sociales.

En este mismo sentido, también creemos que la entrada en un museo nos puede hacer estar más activos cognitivamente, pues esperamos que algunas obras -especialmente en museos contemporáneos - demanden cierto esfuerzo cognitivo. Esta predisposición es lo que creemos que puede hacer trascender la experiencia nostálgica más allá de un primer estado puramente sensible y que se relaciona directamente con los tres órdenes ascendentes de la nostalgia sistematizados por Fred Davis. La nostalgia de primer orden o simple se trataría poco más de una sentimentalización del pasado, mientras que la de segundo orden o reflexivasería cuestionarse el porqué de esa sentimentalización, preguntarse si realmente ese pasado era tan bello o si, a pesar de esa nostalgia, seguimos prefiriendo el presente. La nostalgia detercer orden o interpretada es la que creemos que puede potenciarse en un museo por las causas aludidas, y se trataría de un análisis fenomenológico que nos llevaría a plantearnos elpropio proceso nostálgico (Davis, 1979). En este último nivel se daría cabida a cuestiones detipo moral y político tales como: ¿es legítima o recomendable esta experiencia en estas circunstancias? ¿supone mi nostalgia, mi sentimiento placentero, una desconsideración haciaotros agentes implicados directa o indirectamente en la obra? Serían este tipo de preguntas las que podrían hacer considerar al individuo cuestiones políticas y éticas a partir de la nostalgia desde un polo cognitivo, lo que, unido a los propios beneficios psicológicos directosde la emoción, podrían potenciar el cuestionamiento de la realidad social y la toma de partido.

Intentemos ahora trasladar estas ideas tres a ejemplos concretos de obras museísticas.

La primera obra que traemos se titula Padded Cell y fue realizada por Jennifer Rubell en 2011 para el evento Performa Arts' Red Party en Nueva York. Se trataba de una caja- habitación espartana de 2,5 x 5 metros que contaba únicamente con una puerta y una bombilla; la sorpresa se encontraba en sus paredes y techo, recubiertos enteramente por 1600 ladrillitos de algodón de azúcar (Yoneda, 2011). De este modo, al visitante se le daba la oportunidad de entrar e ir destruyendo la cubrición de la habitación al ir comiéndose algodón de azúcar, un dulce que con facilidad puede evocar a nuestra infancia. Sin embargo, bajo estaestética de estímulos apacibles se escondía una crítica ya desde el propio nombre de la obra,que hace referencia a las salas de aislamiento acolchadas que se podían ver con frecuencia en los psiquiátricos. Esta referencia explícita y las sensaciones claustrofóbicas que se podíangenerar en los espectadores podían potenciar la dimensión política de la obra, a la que la propia artista alude al hablar del "lado oculto del placer, su precio, y la posibilidad de dar a ese placer su propio castigo", lo que creemos que revierte en una crítica a la sociedad hedonista, donde el placer se busca maníaca, compulsivamente.

El segundo ejemplo es, sin duda, el más popular. Se trata de la obra Untitled (pad thai), realizada por Rirkrit Tiravanija por primera vez en 1990 en la galería Paula Allen de Nueva York 
y posteriormente reescenificada en otras localizaciones, algunas de gran prestigio, como el MoMA. Este happening cumbre del arte relacional pretendía, ante todo, crear comunidad, pero también tenía una visión crítica que el propio artista reconoce en una entrevista al aludir de manera indirecta al colonialismo y al nacionalismo identificado en la comida (Yao, 2019). Y es que en el pad thai fue, según cuenta la historia popular, un invento de un general que quería crear un plato que fuera identificado como genuinamente tailandés, algo que logró añadiendo a los fideos chinos elementos típicos de la identidad nacional tailandesa como los cacahuetes, el chili y el tamarindo. La acción fue sencilla, cocinar, servir y comer pad thai para todo aquel que pasara por la galería y quisiera participar. Como Tiravanija reconoce (Yao, 2019), el pad thai en aquel momento estaba iniciando su internacionalización, por lo que aún era un producto exótico, lo que puede ser un potenciador o un inhibidor de la nostalgia según lo antes expuesto. Si el plato suponía una sensación totalmente nueva, que no estaba almacenada en la memoria, sería poco probable que resultara en una experiencia nostálgica. Sin embargo, si no era una comida habitual, sino que solo había sido probado en otro lugar - por ejemplo, en un viaje a Tailandia- o se había comido algo muy similar, con ingredientes similares, las probabilidades de encender el recuerdo emocional aumentarían. Lo que resulta de nuestra teoría y de los estudios psicológicos es que, de darse una emoción nostálgica en el receptor, la socialización ya facilitada por la obra se vería favorecida, los prejuicios para con la cultura tailandesa disminuidos, la empatía para con el artista tailandés y su condición de extranjera potenciada e incluso la dimensión crítica implícita revelada.

El tercer y último ejemplo que traemos in extenso se trata de Enemy Kitchen, un proyecto iniciado por Michael Rakowitz en 2003 y todavía en activo. El proyecto se basa en enseñar,cocinar y dar a probar a los viandantes comida típica iraquí desde un camión. La obra trasciende con mucho los límites de la galería, pues involucra a distintos colectivos alejadosdel mundo del arte contemporáneo, como chefs iraquíes o menores en riesgo de exclusión social. Sin embargo, la obra fue concebida por el propio artista como un proyecto artístico, siendo la cocina no un fin en sí mismo, sino un medio para la consecución de otros que teníanque ver con dar a conocer la comida iraquí y, sobre todo, desestigmatizar su cultura y a sus ciudadanos. Para entenderlo debemos valorar el contexto en el que se gestó la obra, en el quelas tropas americanas ocupaban Iraq tras la conclusión de la guerra del Golfo y se vivía una tensa crisis diplomática. Esta situación llevó a que la comunidad iraquí en Estados Unidos fuera vista con otros ojos y que ellos mismos renegaran en cierto sentido de su identidad, porejemplo, al rotular sus restaurantes tradicionales bajo la etiqueta de comida mediterránea enlugar de iraquí (Boucher, 2018). De manera similar a la obra de Tiravanija, este gran proyecto busca potenciar los lazos sociales en los encuentros, pero sobre todo disminuir las hostilidades y los prejuicios hacia una minoría como la iraquí. Creemos que la propia narrativa de la obra es ya efectiva en este sentido, pero la nostalgia, sin duda, podría potenciarla; podría ayudar a sentir ese exilio de los iraquíes, a compartirlo emocionalmente

A estas tres obras se le podrían unir muchas otras, como muchas del artista español Antoni Miralda - por ejemplo, The Seattle Banquet (1973) habla de la multiculturalidad de grandes ciudades como hemos visto indirectamente en los dos últimos ejemplos-, los famosos caramelos de González-Torres en su S/T (Para un hombre en uniforme, 1991) o algunas de las obras de artistas actuales presentes en la exposición Trapholt, Museum of Modern Art and Design en Kolding, Dinamarca. 


\section{Conclusiones}

De esta manera hemos creído no solo explicarla nostalgia, su experimentación y sus procesos, sino también cómo esta emoción, desde lo sensitivo y emocional, puede potenciar ladimensión política o crítica de la obra. Indudablemente, no podemos asegurar que la emoción esté presente tal y como no podemos pretender que la tristeza o la sublimidad de una obra sea sentida por todo el público. Nuestra capacidad de conmovernos tiene un fuerte componente aleatorio y desconocido.

Sin embargo, la ciencia apunta a que hay sentidos que pueden ser más efectivos en esa conmoción emocional. Así, el sentido del olfato y del gusto parecen ser más emocionales y evocadores que el resto, propiciando que las posibilidades de que sintamos nostalgia aumenten. Es ahí donde entra la comida como gran activador, como uno de los medios más idóneo para vivenciar experiencias estéticas hasta ahora poco consideradas en el mundo de las bellas artes.

\section{Referencias}

BAUMAN, Z. (2017). Retrotopía. Barcelona, Paidós.

BERNTSEN, D. (1996). "Involuntary autobiographical memories". Applied Cognitive Psycjology, vol. 10, pp. 435-454. https://doi.org/10.1002/(SICI)1099-0720(199610)10:5\%3C435::AIDACP408\%3E3.0.CO;2-L

BERNTSEN, D., \& HALL, N. M. (2004). "The episodic nature of involuntary autobiographical memories". Memory and Cognition, 32(5), pp. 789-803. https://doi.org/10.3758/BF03195869

BOUCHER, B (2018). 'It's a Strange Communion': Artist Michael Rakowitz on Why He Set Up an Iraqi Food Truck Outside the MCA Chicago. <https://news.artnet.com/art-world/iraq-cooking-michaelrakowitz-enemy-kitchen-1198394)> [Consulta: 22 de agosto de 2021]

BOURDIEU, P. (1984). Distinction: A social critique of the judgement of taste. Cambridge, Harvard University Press.

BRUIJN, M. J. DE, \& BENDER, M. (2018). "Olfactory cues are more effective than visual cues in experimentally triggering autobiographical memories". En: Memory, 26(4), 547-558. https://doi.org/10.1080/09658211.2017.1381744

CHEUNG, W. Y., SEDIKIDES, C., \& WILDSCHUT, T. (2016). "Induced nostalgia increases optimism (via social-connectedness and self-esteem) among individuals high, but not low, in trait nostalgia". Personality and Individual Differences, 90, 283-288. https://doi.org/10.1016/j.paid.2015.11.028

DAVIS, F. (1979). Yearning for Yesterday: A Sociology of Nostalgia. Nueva York, The Free Press.

DEWEY, J. (2005). Art as Experience. Nueva York, Perigee.

EPSTEIN, R. (2004). "Consciousness, art, and the brain: Lessons from Marcel Proust". Consciousness and Cognition, 13(2), 213-240. https://doi.org/10.1016/S1053-8100(03)00006-0

FIORITO, T. A., \& ROUTLEDGE, C. (2020). "Is Nostalgia a Past or Future-Oriented Experience? Affective, Behavioral, Social Cognitive, and Neuroscientific Evidence". Frontiers in Psychology, Vol. 11, junio, artículo 1133. https://doi.org/10.3389/fpsyg.2020.01133 
HERZ, R. S., \& SCHOOLER, J. W. (2002). "A Naturalistic Study of Autobiographical Memories Evoked by Olfactory and Visual Cues: Testing the Proustian Hypothesis". University of Illinois Press, 115(1), pp. 21-32. https://doi.org/10.1017/CB09781107415324.004

HOFER, J. (1992). "Dissertatio medica de nostalgia oder Heimweh (1688)". En: PRETE A. (Ed.), Nostalgia. Storia di un sentimento. Milán, Raffaello Cortina Editore.

KORSMEYER, C. (1999). Making Sense of Taste: Food anf Filosophy. Ithaca, Cornell University Press.

LEDDY, T. (2012). The Extraordinary in the Ordinary: the Aesthetics of Everyday Life. Buffalo, Broadview Press.

PROUST, M. (2016). En busca del tiempo perdido, 1. Por el camino de Swann. Madrid, Alianza.

REID, C. A., GREEN, J. D., WILDSCHUT, T., \& SEDIKIDES, C. (2015). "Scent-evoked nostalgia”. En: Memory, 23(2), pp. 157-166. https://doi.org/10.1080/09658211.2013.876048

SAITO, Y. (2007). Everyday Aesthetics. Oxford, Oxford University Press.

SEDIKIDES, C., \& WILDSCHUT, T. (2019). "The sociality of personal and collective nostalgia". En: European Review of Social Psychology, 30(1), pp. 123-173. https://doi.org/10.1080/10463283.20 19.1630098

STEPHAN, E., SEDIKIDES, C., WILDSCHUT, T., CHEUNG, W. Y., ROUTLEDGE, C., \& ARNDT, J. (2015). "Nostalgia-Evoked Inspiration: Mediating Mechanisms and Motivational Implications". En: Personality and Social Psychology Bulletin, 41(10), pp. 1395-1410. https://doi.org/10.1177/0146167215596985

TULVING, E. (1972). "Episodic and semantic memory". En: Tulving, E. \& Donaldson, W. (Eds.), Organization of Memory.Cambridge, Academic Press.

VAN TILBURG, W. A. P., SEDIKIDES, C., \& WILDSCHUT, T. (2015). "The mnemonic muse: Nostalgia fosters creativity through openness to experience". Journal of Experimental Social Psychology, 59, 1-7. https://doi.org/10.1016/j.jesp.2015.02.002

WILDSCHUT, T., SEDIKIDES, C., ARNDT, J., \& ROUTLEDGE, C. (2006). "Nostalgia: Content, triggers, functions". En: Journal of Personality and Social Psychology, 91(5), pp. 975-993. https://doi.org/10.1037/0022-3514.91.5.975

YAO, P (2019). The Lives of Objects: Rirkrit Tiravanija in Conversation. <https://www.mplus.org.hk/en/ magazine/the-lives-of-objects-rirkrit-tiravanija-in-conversation/> [Consulta: 22 de agosto de 2021]

YONEDA, Y (2011). Padded Cell is a Room Lined with 1,600 Cones of Cotton Candy. <https://inhabitat. com/padded-cell-is-a-room-lined-with-1600-cones-of-cotton-candy/> [Consulta: 29 de agosto de 2021]

ZHOU, X., WILDSCHUT, T., SEDIKIDES, C., SHI, K., \& FENG, C. (2012). "Nostalgia: The gift that keeps on giving". En: Journal of Consumer Research, 39(1), pp. 39-50. https://doi.org/10.1086/662199 



\title{
LAS COCINAS Y LA COMIDA EN LA OBRA CINEMATOGRÁFICA DE PEDRO ALMODÓVAR
}

\author{
Gerardo Jesús García Olivares \\ Doctor en Industrias Culturales y de la Comunicación. Universitat Politècnica de València.
}

\begin{abstract}
Pedro Almodóvar's cinema has contributed in a veiled way to the construction of the gastronomic identity outside the borders of Spain due to the degree of internationalization that his cinema has. In Almodóvar's cinema, the kitchen as a space is essential to present conflicts, entangle the plot or reach the end. A differentiation can be made between cuisine and food in his cinema, while the kitchen is a marker of classes or customs, the food is transversal to the social conditions of its characters and presents many dishes rooted in a territory. This use of the kitchen and food by the director has contributed enormously to bring the dishes of Spanish gastronomy as a soft power and to the construction of an idea of what is eaten in Spain and where it is made and consumed.
\end{abstract}

Keywords: food, internationalization of culture, food, kitchen, Pedro Almodóvar, cinema.

Resumen: El cine de Pedro Almodóvar a contribuido de manera velada a la construcción de la identidad gastronómica fuera de las fronteras de España debido al grado de internacionalización que tiene su cine. En el cine de Almodóvar la cocina como espacio es fundamental para presentar conflictos, enredar la trama o llegar al desenlace. Se puede hacer una diferenciación entre cocina y comida en su cine. Mientras que la cocina es un marcador de clases o de costumbrismo, la comida es transversal a las condiciones sociales de sus personajes y presenta muchos platos enraizados a un territorio. Este uso de la cocina y la comida por porte del director ha contribuido enormemente a llevar los platos de la gastronomía española a modo de poder suave, así como a la construcción de un ideario sobre qué se come en España y dónde se elabora y se consume.

Palabras clave: comida, internacionalización de la cultura, cocina alimentario, Pedro Almodóvar, cine.

Citar como: Jesús García Olivares, G. (2022). "Las cocinas y la comida en la obra cinematográfica de Pedro Almodóvar". En: Actas del III Congreso Internacional sobre Patrimonio Alimentario y Museos. 25-26 noviembre, 2021, Valencia, España. pp. 217-230. https://doi.org/10.4995/EGEM2021.2021.13405 


\section{Introducción}

El cine del director Pedro Almodóvar ha contribuido de manera velada a la construcción de la identidad gastronómica fuera de las fronteras de España debido al grado de internacionalización que tiene su cine y a la potencia de sus imágenes. Para este director, las cocinas como espacio físico y simbólico son fundamentales en la construcción de sus relatos cinematográficos. En el cine de Almodóvar, la cocina como espacio es imprescindible para presentar conflictos, enredar la trama o llegar al desenlace. Se puede realizar una diferenciación entre cocina y comida. Mientras que la cocina es un marcador de clases o de costumbrismo, la comida es transversal a las condiciones sociales de los personajes que nos presenta. Lleva a cabo constantes referencias a muchos platos enraizados a un territorio determinado.

En este artículo se pretende abordar el uso de la cocina y la comida por parte del director en su amplia producción cinematográfica, y mostrar cómo esto ha contribuido enormemente a llevar los platos de la gastronomía española a modo de poder suave (o como se conoce en inglés powersoft) en el campo de las relaciones internacionales a la influencia en este caso por elementos de componentes culturales como lo puede ser el cine, la literatura, el arte y ahora la comida. El cine de este director ha contribuido enormemente a la construcción de un ideario internacional sobre qué se come en España y dónde se elabora o se consume. También ha servido para mostrar qué platos son propios de determinadas regiones.

\section{Objetivos}

Esta breve comunicación tiene como objetivo mostrar que, a partir del cine, se ha construido una imagen de la cocina como espacio, y se ha mostrado el repertorio culinario cotidiano y la comensalidad de la cultura española. Esta imagen del cocinar y de la cocina ha sido utilizada por el director manchego como un elemento más de su filmografía. Tanto los alimentos sencillos (tortilla de patatas, jamón, flan y otros productos alimenticios) y las cocinas humildes, alicatadas con trozos de azulejos, como las más lujosas, decoradas con piezas de diseño, se muestran, no como un mero decorado, sino como un espacio material pero especialmente simbólico. En estos lugares ocurren situaciones fundamentales que componen la trama de su cine, donde los personajes expondrán sus argumentos, confesarán secretos, serán víctimas de violencia y aplicarán la justicia propia. También serán espacios de encuentro y de enorme humanidad.

La internacionalización del cine de Pedro Almodóvar (con premios como Óscar, Bafta, Globos de Oro, César, entre otros) provoca que también las cocinas y la comida que aparecen en sus películas hayan trascendido los límites de la geografía española. Si dentro del power soft español está posicionar la cocina española como marca España, antes que este objetivo fuera trazado de una manera expresa por los organismos públicos dedicados a ellos como Acción Cultural Española, el cineasta lo lleva haciendo de manera silenciosa desde hace años. Así, el gazpacho, los barquillos y las tapas, las cañas, la tortilla de patatas, el jamón o la paella llegan al panorama internacional de la mano de su cine desde hace décadas.

\section{Desarrollo}

Dentro de la Memoria 2019 de Acción Cultural Española, la entidad pública que acoge las actividades culturales para internacionalizar la cultura española, consta que durante ese año se 
desarrolló un proyecto que aún se puede ver en Google Arts \& Culture, España: cocina abierta, el cual cuenta con la participación de la Real Academia de Gastronomía y el Museo del Traje. En esta plataforma cultural se puede observar una buena muestra de la cocina española y sus protagonistas. Desde las grandes figuras de la restauración hasta la arquitectura del vino. Esto significa que la cocina es un elemento más a internacionalizar de la producción cultural de un país y una forma de softpower de dicho país.

Ese mismo año la cinta Dolor y Gloria no sólo fue seleccionada para competir como película de habla no inglesa ante la Academia de las Artes y Ciencias Cinematográficas de Estado Unidos que concede el premio Óscar, sino que la película se mantuvo por semanas en cartel en ese país. En la quinta semana, según la empresa de marketing digital ComScore acumulaba más de dos millones de dólares de recaudación y se mantenía en cartel en 111 cines. En esta película, los protagonistas comen jamón de la misma manera que en otras de sus cintas consumen tortilla de patata o paella. Esto muestra la importancia del papel de la cocina en su cine y como este está construyendo una representación del modo de comer en España.

Este gran escaparate visual que es el cine de Pedro Almodóvar en el plano internacional también lo es para las cocinas y los platos que en él se reflejan. Ya en 1988 con la candidatura por la Academia de Artes y Ciencias Cinematográficas de Estados Unidos, conocida en inglés como AMPAS (Academy of Motion Picture Arts and Sciences), la mítica receta de gazpacho descrita por Carmen Maura había llegado a Estados Unidos. Consiguiendo, así, incorporarla en el imaginario gastronómico español que el director refleja con su cine.

Desde los orígenes de la filmografía de Pedro Almodóvar, los alimentos son un elemento profundamente plástico. Esto puede verse en el cortometraje Salomé, donde recurre germinalmente a la comida en el título, ya que el mismo está realizado con tipografías obtenidas a partir de una sencilla sopa de letras y estrellas. El resto de los créditos están hechos de masa horneada y, en ellos, se pueden apreciar estrellas bañadas de chocolate. Al parecer este es el mismo material que utiliza en el título principal del cortometraje.

Para Pedro Almodóvar las escenas que transcurren en la cocina contribuyen a tensar el argumento y enriquecer la trama. No solo los alimentos, sino la forma de adquirirlos. El cine de Pedro Almodóvar refleja la vida de las mujeres españolas. Por este motivo, los mercados también aparecen retratados en sus películas. Esto se ve, por ejemplo, en la conversación sobre el patatas que tienen las vecinas protagonistas de Pepi, Luci, Bom y otras chicas del montón (1980). En este filme también se pude ver como se prepara un plato tradicional: el bacalao al pil pil.

Laberinto de pasiones (1982) quizá sea una de las películas en donde la alimentación está menos presente de forma específica. Sin embargo, hay claras referencias a los bares y las terrazas como forma de comensalidad española. Corrían los años de lo que se conoció como el "pelotazo", en donde el lujo se extendía a muchas clases sociales. Era más común comer fuera que en casa, por eso en su cine los personajes disfrutan de restaurantes y terrazas. Estas últimas no solo son un espacio de alimentación, sino que también son la extensión culinaria de la casa y la representación del acto de tomar el fresco propio de la zona mediterránea. En estas zonas las altas temperaturas nocturnas provocan que las personas compartan comida en un entorno abierto más agradable. Además, se trata de nuestra forma de comida callejera en un entorno socioeconómico óptimo. 
En la anticlerical Entre tinieblas (1982) comienza a aflorar su paleta colorista. Por momentos, en su cine, hay instantes de puro costumbrismo y el color se adueña de la pantalla con frutas escarchadas de los pasteles elaborados por la rocambolesca Congregación de las Esclavas Redimidas para recolectar fondos. El diacitrón o cidra era, en los siglos XVI y XVII, un dulce que además tenía valor medicinal. También se trataba de un regalo que se daba a monarcas y a reyes. La fruta escarchada es un tema muy recurrente en la pintura de bodegones, ya que era propia su producción en la España de ese tiempo. Las monjas la usaban para decorar sus postres. En la película se pueden ver algunas prácticas que todavía es posible observar en algunos bares, como la de anunciar con dibujos y textos en tiza las especialidades de la casa y la carta. Este trabajo era un oficio y lo realizaban personas que se trasladaban de ciudad a ciudad a cambio de una pequeña retribución.

En la película hay una clara referencia a unos de los productos más conocidos de la charcutería española. Se trata del chorizo de Cantimpalo de la homónima localidad Segoviana, que cuenta con la IGP (Indicación Geográfica Protegida). Este aparece cuando la Madre Superiora del convento, que es adicta al crack, le da la lista de las cosas que comprar a una de la monjas de menor rango.

No es extraño que, dentro de la trama, la cocina esté tan presente y que las protagonistas ofrezcan algunos de sus productos en el Rastro de Madrid. Esto demuestra que la cocina conventual es aún una realidad viva en España y que todavía permanece en los cientos de obradores que ofrecen sus productos. Alguno, incluso, comercializándolos por internet. Además de esta comida, en la cinta se observan las tradicionales latas de galletas Guillón, así como la sangría (otro coctel muy extendido en nuestro país) en la escena de la fiesta que da la Madre Superiora y que finaliza la película.

De 1984, con claras referencias al neorrealismo italiano, es la película ¿Qué he hecho yo para merecer esto? El director elige el producto más emblemático de la gastronomía española, el jamón, para transformarlo en un elemento de defensa. Gloria lo usa como objeto contundente, para defenderse de las agresiones machistas que le da su marido, un desgastado jamón del que solo queda el hueso. Además del jamón, aparecen alimentos muy arraigados a la cultura alimentaria española, como el Agua de Vichy o el bocadillo de tomate frito. Este último se presenta como último recurso alimentario en una familia de escasos recursos que habita en el suburbio de Madrid.

La cocina, como espacio sofocante y decisivo, es un emblema en la cinematografía de Pedro Almodóvar y un excelente escenario para algunas escenas de crímenes. Bien porque cuentan con objetos que pueden ser auténticas armas como cuchillos (es el caso de Volver), o bien el mismo hueso de jamón de ¿Qué he hecho yo para merecer esto?

En todo su cine las paredes no son solo un elemento donde los actores interpretaran a sus papeles, sino una expresión y testigo de la moda, colores y materiales de la época. El empapelado de las cocinas, que no se contaban con azulejos, era una práctica recurrente en las viviendas humildes. Las propias mujeres las cambiaban habitualmente. Es posible decir que, en cuanto a la dirección de arte en Almodóvar, tantos las paredes como los suelos no pasan inadvertidos, sino que adquieren un protagonismo y le aportan identidad a los personajes.

En la película, también pueden verse los armarios de cocina de la marca Forlady, que una niña con poderes telequinéticos moverá cuando ayude a empapelar la cocina a Gloria. El nombre 


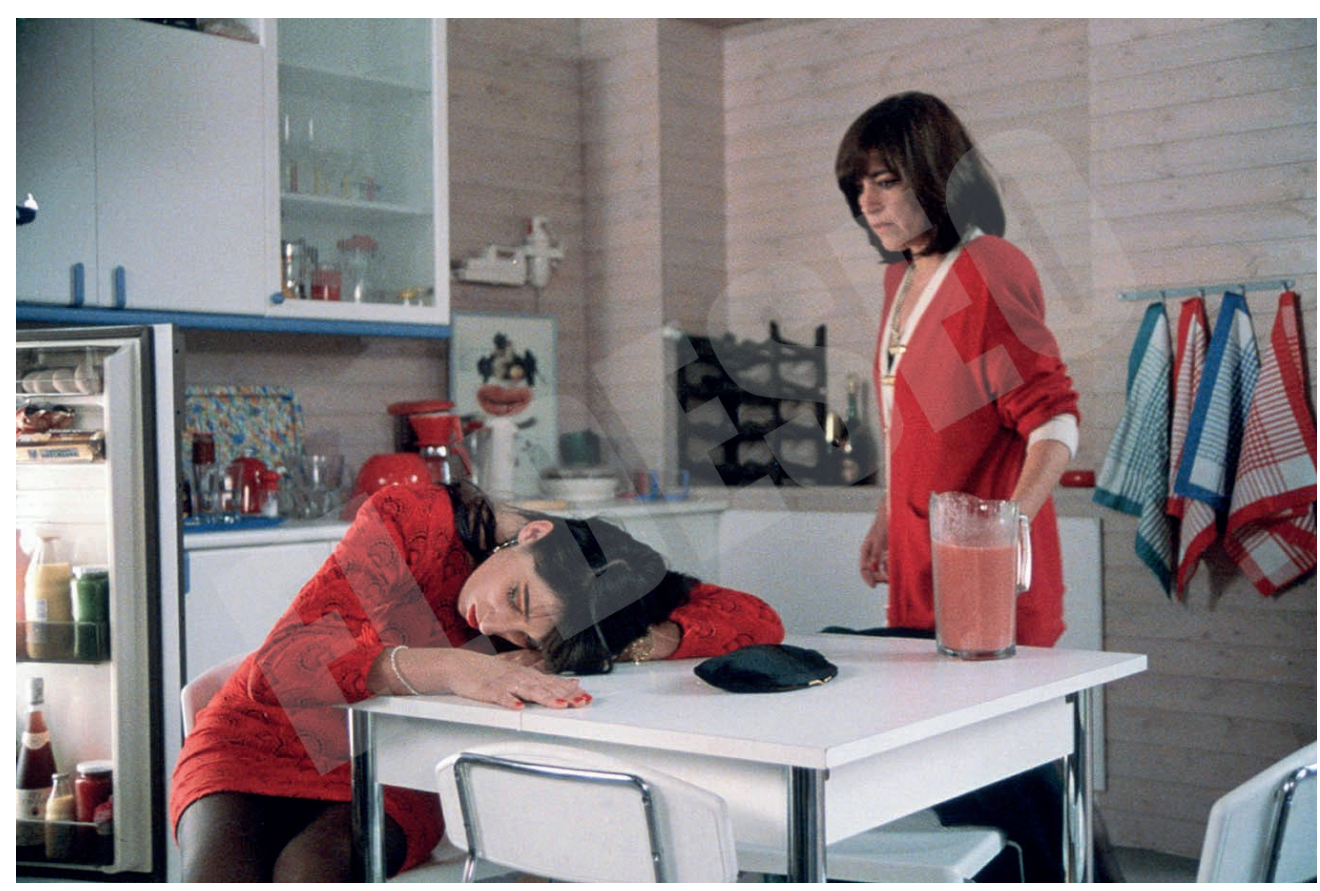

Figura 1. Fotograma del filme Mujeres al Borde de un ataque de nervios - 1988 - El Deseo.

en inglés de estos armarios lleva una velada referencia al papel de las mujeres del momento. Su papel como amas de casa era casi una condición obligada y carecían de derechos. Por ejemplo, abrir una cuenta bancaria sin la autorización de su esposo no fue posible hasta 1978. Estos armarios se popularizaron a partir del año 1967, sobre todo acompañando a las vivienda de carácter social. Los muebles de cocina Forlady, un referente en el sector de la decoración, se posicionaron en 1967 y llegaron a tener su propia línea de juguetes para niñas comercializados por la marca Payá.

No libre de polémicas estuvo marcada Matador de 1986. En esta película abordaba, como en otras tantas obras de su cinematografía, la violencia de género cuando en España el tema todavía era tabú. En Matador podemos ver a una madre clerical que comparte con su hijo, previa bendición, una sopa de fideos, un lenguado meunière y un flan. Este postre será uno de los platos que estará presente en la mayoría de su producción posterior.

La cocina adquiere importancia, aún cuando no hay comida, en la cinematografía de Pedro Almodóvar en La Ley del Deseo del año 1987. Carmen Maura come frugalmente una rodaja de salchichón. Va a la casa de su hermano Pablo, cineasta, y lava los platos sucios de una cocina. En la película, como en otras del director, el homenaje al artista Edward Hopper es evidente; ya sus personajes deambulan en restaurante, bares y sitios de comida rápida como los que retrataba el pintor. En este caso se pueden apreciar refrescos y otras comidas rápidas desperdigadas en le mesa. La gran presencia de bares en la película refuerza el cliché del número de locales de este tipo en nuestro país. 
El diseño gráfico es otras de las obsesiones del cineasta. En este caso relacionado con los alimentos que aparecen en las etiquetas de marcas emblemáticas de bebidas españolas como Osborne o Freixenet, así como la etiqueta de Anís la Castellana. El espectador puede observar esta última en la trastienda del bar donde los personajes debaten sobre un guion de cine. Los personajes pasan de puntilla sobre la comida, ensaladas, sándwich tostadas y desayunos porque lo que importa no es la comida, sino la bebida.

Los cambios sociales que vivía España en los años que se rodó en la Ley del Deseo se ponen de manifiesto en la película por medio de escena en donde se puede ver el primer Burger King que se inauguró en España en la plaza de los Cubos en Madrid. La marca llevaba solo diez años en el país y en esos años de bonanza también abrió el primer McDonald’s en 1981. Los hábitos alimentarios de los españoles estaban cambiando.

El gazpacho otro plato internacionalizado de la cocina española y que hoy se puede apreciar como ejemplo en restaurantes de tapas de Los Ángeles se da cita en Mujeres al borde de un ataque de nervios rodada en 1988. Como se comentó al principio del artículo la protagonista describe ante la policía cada uno de los ingredientes de la receta omitiendo los morfidales un potente somnífero que la protagonista quiere camuflar en esta sopa fría para que su expareja se duerma en casa y poder hablar con él. La misma Tilda Swinton iba recordar que adoraba beber gazpacho durante el rodaje The Human Voice de 2020 en el video de presentación que acompaña a su último cortometraje rodado en plena pandemia.

La comida y las cocinas está presente en todas sus películas y es uno de los grandes embajadores de España, ya que ha llevado platos de la comida de las clases populares, y hasta platos de los más regionales, al centro de la pantalla. La comida menos patrimonializada, pero la más arraigada a determinadas identidades y repertorios locales, se puede ver en su cine. En ¡Átame! de 1989 hace clara referencias a las sociedades gastronómicas tan presente en la cultura vasca, el comprar el turrón por gramos en la tienda de dulce. Un poco de costumbrismo que rivaliza con productos dulces industriales. Algunos ejemplos de ello son los Blody Mary que curan la resaca y el pisto ofrecido como cocina casera que añora Marina (interpretada por Victoria Abril) y que elabora en la pantalla la misma madre del director en un lebrillo de cerámica. 0 el desayuno que Ricki le ofrece de zumo, yogur y frutas; otra de las identidades alimentarias españolas. Vale la pena recordar que la mezcla de café (con leche o sin ella), el pan acompañado de tomate, aceite de oliva o mermelada y mantequilla, y el zumo o la pieza de fruta es un desayuno propio de la patrimonializada dieta mediterránea.

Tacones Lejanos rodada en el año 1991, que obtuvo el Cesar a mejor película extranjera, es una de las cintas del director donde menos presente esta la comida, quizás por que el personaje principal Becki del Páramo no ha vivido en España durante años. No aparecen cocinas, sino mesas en donde se come de manera frugal. Totalmente colorista, se apuesta por alimentos que componen bodegones en fruteros de mesas para dar color a las escenas. Uno de los principales detalles es la presencia de un bocadillo de pasta de avellanas, conocida bajo la marca comercial Nocilla, que Rebeca merienda siendo niña. La mezcla de chocolate en pan ha sido una de las meriendas más difundidas en la alimentación española. Junto con el pan con chocolate que retoma en Dolor y gloria, como se detallará luego.

En Kika de 1993 llegamos a la cocina colorista, folclorizada, cargada de objetos como la olla a presión, la aceitera, las piezas de cerámica, las cortinas a cuadros, los fruteros, el utillaje y los 


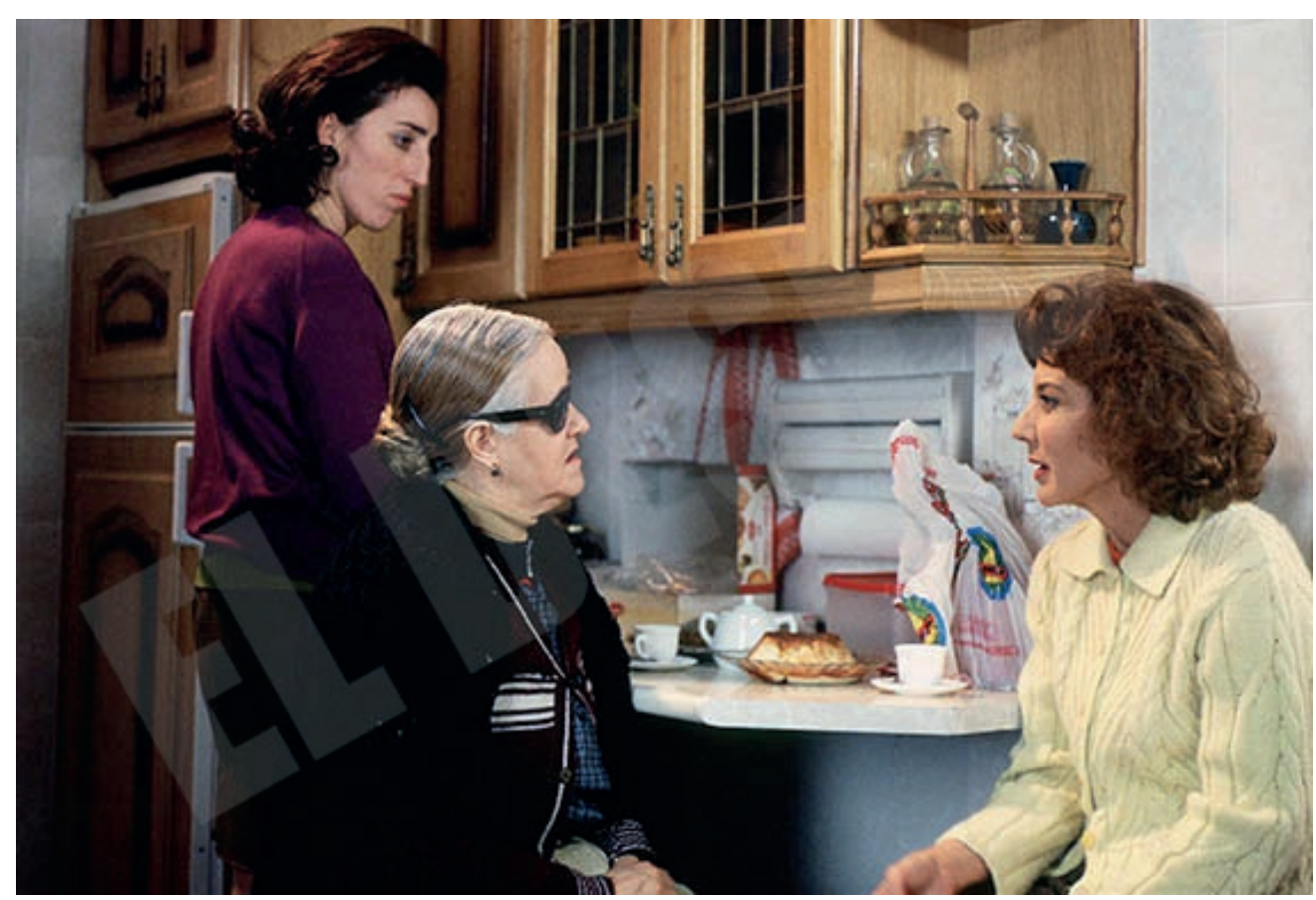

Figura 2. Fotograma del filme La flor de mi secreto - 1995 - El Deseo.

paños de cocina que cuelgan de las paredes, que luego repetirá en otras de sus cintas. En este caso, la cocina es el lugar preferido para perpetrar una simulación de secuestro y es fundamental en la trama.

La paella, el plato español por excelencia y emblema de la gastronomía española, aparece en el film La flor de mi secreto del año 1995. Este plato es el gran protagonista culinario de la película y el que completa la triada: tortilla, paella y gazpacho. Platos que se pueden ver en esta como en otras películas. Y que se complementan con las berenjenas de Almagro, producto de la localidad que, al final de la cinta, un corro de encajeras de bolillo menciona en una canción. Además, la paella desencadena una discusión a causa de la diferencia de opiniones que tienen los protagonistas sobre su temperatura.

En esta película, tiene lugar uno de los diálogos más potentes del cine del director. Entre el costumbrismo y el teatro, se encuentra la pequeña cocina de Rosa que vive en el extrarradio de Madrid. Este diálogo hace referencia a la cocina misma española, la cafetera italiana, los calamares a la romana, el flan casero que es un talismán en el cine del director, y los pimientos que la madre interpretada por Chuz Lampreave ha asado a su hija.

Pedro Almodóvar recurre a la cocina como metáfora de la pasión en la película Carne Trémula de 1997. La chabola donde vive el joven Víctor, interpretado por Liberto Raval, arde hasta consumirse por culpa de una sartén puesta al fuego por Ángela Molina, en el papel de Clara. Las cocinas de su cine están llenas de color, construyendo un espacio luminoso en donde lo femenino fluye. No son un espacio de confinamiento o reclusión de lo femenino, sino como los 
gineceos de la antigua Grecia. El lugar en donde las mujeres podrán expresar sus emociones y donde los hombres no aparecen y, si lo hacen, invaden la tranquilidad de la cocina con una marcada masculinidad estereotipada por el machismo o la masculinidad tóxica. En esta película un hombre violento trata de resarcirse cocinando rabo de toro al brandy y terminará matando a su propia esposa.

Esta cocina, como la de Kika o Volver, se muestra como un espacio tradicional de donde penden morcillas o pimientos y enceres ya en desuso. Sin embargo, marcan el espacio transformándolo en algo anticuado y, en algunos casos, los objetos se convierten en coloristas rondando lo camp.

La esqueixada es el plato elegido por el cineasta en Todo sobre mi madre de 1999, filme con el que ganaría el Óscar a mejor película extranjera. Este plato, propio de la gastronomía catalana, lo pide la actriz Huma Rojo después de cada representación. Es un plato ligero, fresco a base de pescado cebolla, pimiento y tomate. La comida no adquiere gran importancia en la película, pero sí las cocinas y la mesa donde se debatirán algunos de los diálogos más importantes que componen la trama. Nos moveremos desde la cocina viva, colorida y luminosa (donde Manuela, el personaje principal, servirá frugales ensaladas a su hijo en Madrid) a la lúgubre cocina con reminiscencia de los 70 de la casa precaria donde se irá a vivir en Barcelona. En ella come productos envasados, a modo de alimentación de subsistencia, debido al dolor por el que atraviesa el personaje. Se reconoce todo el tiempo la bondades culinarias de Manuela, pero no se observa que las ponga de manifiesto salvo en casos puntuales. Ella muestra su duelo por medio de la comida, salvo en algún momento donde los personajes beben cava; otra bebida puramente española.

En la cinta Hable con ella del 2002, nominada en dos categorías a los Óscar por mejor director y guion original, la cocina será el lugar en el que se puede escuchar un grito (como si de una película de Hitchcock se tratara) cuando la protagonista encuentra una culebra y convence al otro protagonista masculino para que le de muerte. Así, la cocina es el espacio donde se pone de manifiesto una de las supersticiones de Lydia González, protagonizada por Rosario Flores, que anticipará el fatal desenlace de la torera.

Como si de una matrioshka se tratase, dentro de la película aparece otro filme, un claro homenaje al cine mudo y a la película The Incredible Shrinking Man de 1957. En El increíble hombre menguante de Almodóvar, la cocina también está presente. Ya no como espacio o como alimento, sino como experimento científico. Amparo, la protagonista de este cortometraje, está investigando una sustancia que será una revolución en el mundo de la nutrición. Al ser ingerida en un acto de heroicidad desafiante, desencadenará que el protagonista comience a menguar hasta hacerse diminuto y poder entrar en el cuerpo de ella.

Los personajes beben cerveza en formato de caña, una de las formas de beber cerveza que compite en popularidad con las pintas británicas. Otra referencia a la cocina española son las imágenes de los extensos paisajes de olivos de Córdoba, que rodean a la Ermita de Nuestra Señora de Araceli de Lucena. Viene bien recordar que España es el primer país a nivel mundial dedicado a este cultivo y que el aceite de oliva es uno de los productos más destacados de la culinaria española.

Las ciudades españolas están marcadas por la migración. Esto lo sabe bien Pedro Almodóvar, quien migró desde su Calzada de Calatrava natal a Madrid. Lo primero que llevan los migrantes a su nueva residencia es su propio repertorio culinario y esto está presente en la filmografía del 


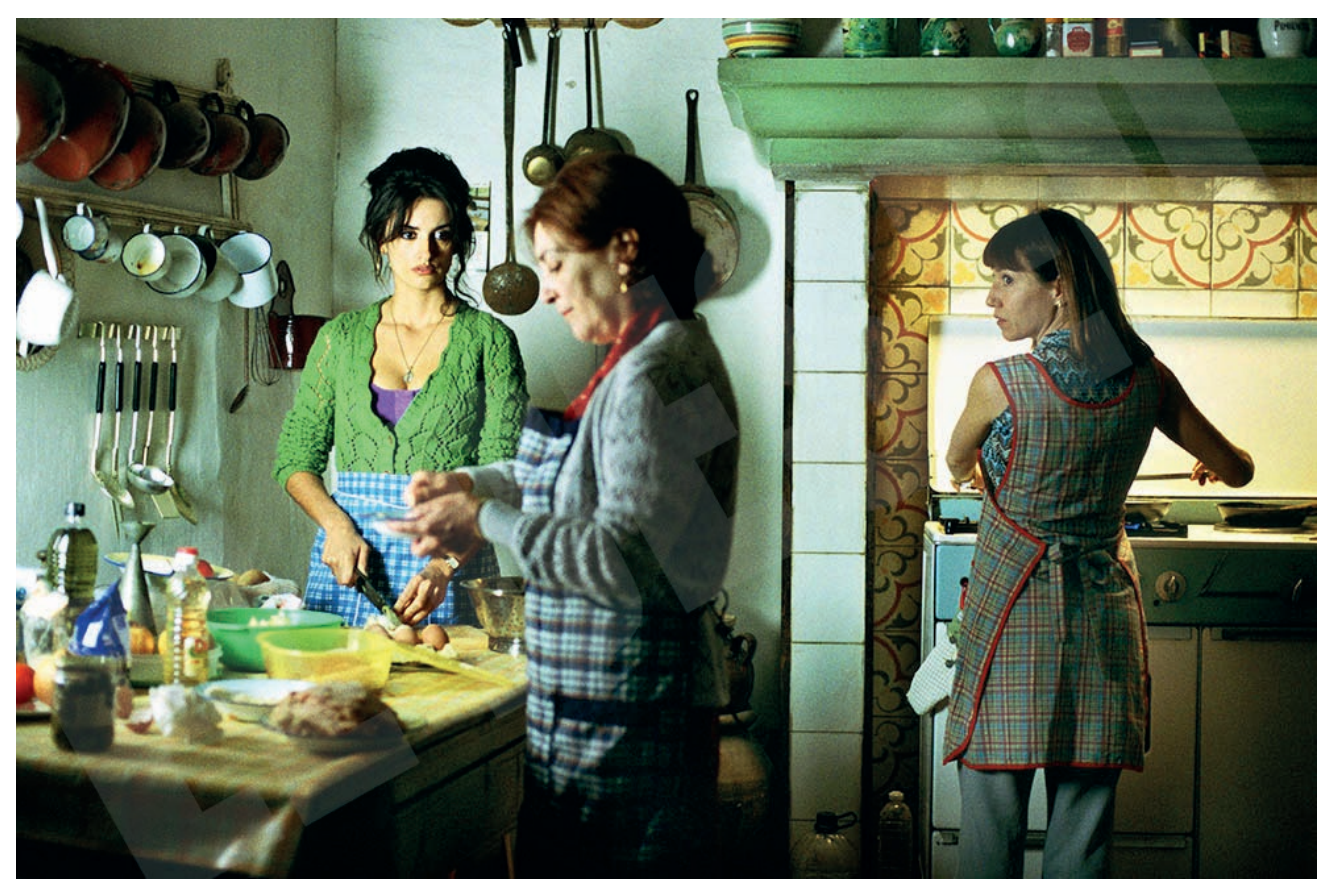

Figura 3. Fotograma del filme Volver - 2006 - El Deseo.

director. Los lazos con el pueblo de origen se mantienen y se manifiestan en la dieta. Los migrados suelen incorporar productos que traen del pueblo cada vez que lo visitan, como narra en La flor de mi secreto o Volver.

En La mala educación de 2004 el actor Francisco Boira da vida al personaje de Juan, un transexual que ha migrado de un pueblo de Galicia a Valencia. En una de sus visitas a su localidad natal se pueden ver algunas verduras depositadas en el pajar sobre periódicos viejos, a modo de conservación. Al regresar de visitar a su madre, llevará del pueblo quesos y chorizos. En la cinta se pueden apreciar bodegones en fruteros, los cuales aportan el color propio de las películas del director.

También hace hincapié en la comida del internado en donde pasa su infancia el protagonista. En él tiene una lugar una potente imagen, que recuerda a San Hugo en el Reflectorio hacia 1655 de Zurbaran, cuando los padres de la congregación rodean la mesa mientras el niño Ignacio canta por motivo del cumpleaños del padre director.

Volver, junto con La flor de mi secreto y la recientemente estrenada Madres Pararelas (2021), es la película donde existen más referencias a la comida, a las cocinas y la forma de comer. En esta película del año 2006, ganadora de dos Globos de Oro, aparecen barquillos, lomo con pimientos y rosquillas. Se vuelve a hacer referencia a uno de los platos de la Mancha, que las protagonistas llevarán en cajas de plástico perfectamente señalizadas a la ciudad luego de una visita al pueblo por el día de muertos. Esta vez, una madre, confundida con un fantasma, será la que prepare las viandas. 
Raimunda protagonizada por Penélope Cruz se verá afectada por unas trágicas circunstancias ocurridas en una cocina mientras gestiona un restaurante. Para solucionarlo pedirá ayuda a las vecinas y preparará un menú del día, algo propio en la cocina española. El menú (formado por morcillas, mantecados y lomo cedido por las vecinas y traído del pueblo) será la primera comida que consumirá en su restaurante un equipo de producción.

En Los abrazos rotos de 2009 la cocina, se presenta como espacio de confesiones en donde los protagonistas establecen diálogos clarificadores de la historia principal o se plantean conflictos. El gran protagonista es el desayuno: zumo de naranja café, leche, frutas, las tostadas con aceite; el desayuno mediterráneo por excelencia.

Finalmente, tal y como pasa en otras películas, el protagonista monta Chicas y maletas. Se trata de una película apócrifa que es, a su vez, una película dentro de la propia película. Aquí el flan y las magdalenas también son mecionados.

La cocina como espacio panóptico, desde donde se puede controlar las acciones de todo lo que ocurre en la casa, lo podemos encontrar en La piel que habito de 2011. Como en Volver, los cuchillos de gran tamaño van presagiando el fatal desenlace que tendrán algunos personajes. Marilia, desde la cocina, vigilará con videocámaras todo lo que ocurre en la casa y cada mañana, durante el desayuno, hormonará a Vera, interpretada por Elena Anaya. Finalmente, entre los cajones de la cocina se esconde la pistola que dará muerte a su propio hijo.

El agua de Valencia, cuyo origen se remonta a 1959, aparece en Los amantes pasajeros de 2013. Aunque la película transcurre en un avión, aparecen elementos del repertorio gastronómico, como este coctel, el cual cuenta con ingredientes como el zumo de naranja, la ginebra, el vodka, el azúcar y el cava. La tripulación lo reparte entre los pasajeros, después de haberle agregado somníferos para dormirlos ante un inminente accidente aéreo. La comida se hace presente en su cine, aún cuando por razones de espacio no puede elaborarse o se prepara en la diminuta cocina de un avión.

En el año 2016 Almodóvar rueda Julieta. En el filme, el personaje, angustiado por la ausencia de su hija, va marcando el paso del tiempo con las tartas de cumpleaños que tira a la basura cada año en que su hija está ausente. En toda la dirección de arte de sus filmes es posible apreciar objetos que acompañan a los personajes, que dan identidad y suponen su historia personal. No son objetos colocados solo como attrezzo, sino que componen al personaje.

Almodóvar, gran amante de las piezas de cristal que el mismo colecciona y con las que construye bodegones que después fotografía, también es amante de la cerámica. Esto se manifiesta en cada una de sus películas a través de suelos, estanterías y paredes; así como con piezas de cerámicas que los personajes utilizarán para beber, comer o, incluso, de lapiceros. En Julieta podemos ver referencias a diversos artistas. Al igual que en otras cintas como en La piel que habito, en donde se puede ver obras de Louise Bourgeois, o en Dolor y gloria con los Pérez Villalta. En el caso de Julieta, la referencia a artistas españoles llega de la mano de Miquel Navarro con una escultura, El hombre sentado, elaborada por uno de los personajes.

La cerámica se encuentra en piezas de la casa Sargadelos, la cual aparecerá en muchas de sus películas. En esta casa, afincada en Galicia, donde transcurre parte del guion, se elabora cerámica desde principios del siglo XIX. En el filme, la cerámica acompaña al personaje principal, ya que se pueden ver las mismas piezas en las distintas viviendas que irá teniendo. También 
se aprecian de azulejos con motivos marinos y un extraordinario botijo con forma de sandia en el centro de la mesa que acompañará una conversación clave en el guion entre dos de los personajes. Esta pieza originaria, seguramente, de la localidad de Manises o de Talavera, hoy día considerada Patrimonio de la Humanidad Cerámica, que compone lo que se llamo cerámica de engaño propio del siglo XVIII y que se popularizó a mediados de los 50 como piezas decorativas de las casa populares.

En Julieta, la cocina es casi un faro desde donde se puede ver el mar. Se trata de un espacio colorista desde donde podrá observar el estado del mar ante una de las tragedias que acontecen en la trama. Por otro lado, la casa donde vive el padre también recurre a la cocina como espacio tradicional. Junto a ella hay una huerta donde el hombre produce sus propias hortalizas y elabora las conservas que se pueden ver en los armarios.

En Dolor y gloria del año 2020, ya podemos ver al Almodóvar actual. Muestra, a modo de contraste, la cocina de diseño que el personaje de Salvador Mallo tiene de mayor. Desde ella, rememora la casa-cueva de su infancia, en la localidad valenciana de Paterna. Se presenta como cine dentro de cine disfrazado de recuerdo. En la cocina actual, los electrodomésticos más modernos y tecnológicos se camuflan entre coloridas paredes y obras de arte. Estas también usan la comida como elemento plástico, es el caso de obra de Maruja Mallo: Racimo de Uva de 1944. El personaje tiene problemas digestivos por lo que la comida que aparece son platos de jamón, el omnipresente flan y tortillas de huevos. Además, su asistente personal le pide a su cocinera que le triture la comida, debido a su dolencia, mientras pela patatas. En la cocina se pueden observar algunos de los bodegones que el mismo Pedro Almodóvar ha creado y fotografiado.

En contrastaste con esta cocina, la comida de la infancia de la que habla el director hace referencia al pan y su elevado precio en la España del racionamiento. Durante el filme se pude apreciar como la cocina de la casa-cueva va adquiriendo forma y color. Pasa de ser un espacio inhóspito a uno lleno de vida, donde se mostrará una técnica utilizada por la construcción popular consistente en el aprovechamiento de restos de azulejos de casas nobles para alicatar cocinas y baños. En la cocina de Jacinta, de donde pende una bombilla que recuerda al Guernica de Picassso, comerán magdalenas, le ofrecerá una tortilla de patatas o se beberá zumo de naranja; un producto propio del levante donde se ambienta esa parte de la historia. Amante el director de los elementos gráficos, se muestran latas de aceite, pimentón u olivas que se reciclan como macetas de geranios y humanizan la vida en la casa-cueva.

Jacinta de mayor le reprochará al hijo, cuando este le pide que coma unas magdalenas integrales, que estas carecen de valor por su aspecto "renegridas". Con ello el director pone de manifiesto los cambios que estamos viviendo en la alimentación contemporánea. El mismo papel tiene el muffin de arándanos que comerá un de los personajes en su última película.

En el cortometraje La voz humana de 2020, no hay comida pero sí varias escenas que trascurren, como en todo el cine de Pedro Almodóvar, en la cocina. Una cocina inerte, de escaparate, rodeada de objetos de diseño. Un espacio casi traumático como el diálogo de Cocteau, en el que la soledad y la angustia del personaje se ven reflejados en los electrodomésticos y elementos de la cocina. No hay comida, el aspecto es de una habitación lujosa, pero totalmente inhóspita.

En la cinta Madres paralelas, estrenada el 8 de octubre de 2021, la cocina volverá a formar parte vital de la vida de los personajes. Se retoma la cocina como escenario en el que se realizan confesiones, se establecen conflictos y se presenta la naturaleza de los personajes. Durante 
toda la película aparecen alimentos como la tortilla de patatas, las morcillas y los pasteles. Los barquillos y las flores se convierten en marca de identidad de la ruralidad que quiere transmitir el director. Esto se aprecia cuando visitan a Arturo, el antropólogo forense interpretado por Israel Eljalde, y Janis, el personaje de Penélope Cruz. Acuden a una casa situada en una localidad donde van a exhumar una fosa común con restos de fusilados por el franquismo. La vivienda denota esencialidad rural, pero con color, luz y brillo: morteros, botijos, cocinas de mampostería, fruteros, especieros, jamones a medio consumir y estanterías con cortinas en lugar de armarios.

\section{Resultados}

Tras el el análisis de toda la filmografía del director Pedro Almodóvar (compuesta por 22 películas y 2 cortometrajes) se puede apreciar que en su cine se diferencia entre cocina y comida. La cocina será, en un número importante de ocasiones, el espacio y contexto simbólico donde se desarrollen elementos de la trama que darán vida a cada una de las películas. En sus cocinas, podremos descifrar la condición social de sus personajes. Por otro lado, la comida será lo que se muestre como forma de identidad local, defina los personales de los personales o señale las restricciones alimentarias por salud de los mismos.

La cocina, ya sea la más rural o la más vanguardista, donde aparecen piezas de diseño mezcladas con obras de arte, mostrará al espectador qué comen y cómo se come. Se convierte es una forma de transmitir al espectador no solo la naturaleza y la vida social, sino también la intimidad de los personajes. Los objetos que adornan las cocinas hablan de ellos, de su devenir. No son objetos que se muestren como mero atrezo, sino que se verán como parte de sus gustos personales. También se apreciará si hay alimentos a medio consumir, tapados o preparados para ser consumidos.

A diferencia con la cocina, donde se aprecia el condicionante de clase social mostrando espacios lujosos y otros extremadamente humildes, en la comida se apreciará cierta transversalidad a través de los platos. Veremos si son comidos por personas de clases acomodadas o más humildes, pero, donde más se marca la diferencia es entre la comida de diferentes localidades. Cada ciudad tiene un repertorio de platos que le son propios como los barquillos y rosquilletas de la Mancha, las tostadas con tomates de Andalucía o la esqueixada de Cataluña. Tal y como pasa en la actualidad, si bien hay unos repertorios gastronómicos pertenecientes a la Alta Cultura, existen otros que no reconocen condición social como la paella, la tortilla de patatas o el jamón entre otros.

\section{Conclusiones}

De la misma manera que en otros cines (como en el italiano, el francés o el americano) la comida da carácter, naturaliza a los personajes con comidas como la pasta, una baguete o batidos y hamburguesas, respectivamente; en el cine de Pedro Almodóvar hay una diferenciación entre cocina y comida. Sin embargo, ambas construyen una identidad visual y alimentaria que el director lleva a la pantalla y que impele de manera internacional. La cocina española (cocina y comida) se replica en otras partes del mundo de la mano del turismo, de cocineros españoles de reconocida trayectoria internacional y también del cine. Así la cocina se transforma en esa manera de poder suave cultural que el país traslada al plano internacional. 
La construcción de la identidad alimentaria se realiza con las diferentes capas del sistema alimentario. Desde las más periféricas, como la comida rápida en manos de multinacionales, hasta la comida más tradicional que se a diarios se cocina en cada casa. El cine, en general, permite la construcción de un ideario alimentario de un país. Por escenas del cine de Yasujiuro Ozu hemos podido aprender las formas de comer en Japón. Por Fellini la trascendencia que la pizza y la pasta tienen en la gastronomía italiana y mundial. $Y$ en el caso de un director como es Pedro Almodóvar (en que su cine ha recibido 2 Óscar, 5 Bafta, 2 Globos de Oro, 2 en Festival de Cannes, 2 en el de Venecia en el que se incluye el de honor a su trayectoria además de los 10 Goya, entre otros) sirve para reflexionar sobre cómo su cine sitúa a la comida española en el panorama internacional al nivel de los ejemplos antes citados. La cocina como espacio y la comida como marcador de identidad se percibe en la presencia de nuestra comida en culturas alimentarias que distan de la alimentación mediterránea. Lo que convierte a su cine en un excelente embajador culinario de este país.

\section{Bibliografía}

\section{Libro}

Almodóvar, P., \& Strauss, F. (2001). Conversaciones con Pedro Almodovar. Madrid: Ediciones AKAL.

Duncan P., Peiró B. (2013). Los Archivos de Pedro Almodóvar. Cologne, Taschen.

Méjean, J. M. (2007). Pedro Almodóvar. Barcelona: Ediciones Robinbook.

\section{Página web}

Google \& Arts España cocina abierta. < https://artsandculture.google.com/project/spanishgastronomy> [Consulta 19 de octubre de 2021]

\section{Películas}

Pepi, Luci y Bom y otras chicas del montón (Dir. Pedro Almodovar). [DVD]. Ester Rambal Coromina. 1980.

Laberinto de Pasiones (Dir. Pedro Almodovar). [DVD]. Musidora. 1982.

Entre tinieblas (Dir. Pedro Almodovar). [DVD]. Tesauro. 1983.

¿Qué he hecho yo para merecer esto ? (Dir. Pedro Almodovar). [DVD]. Tesauro. 1984.

Matador (Dir. Pedro Almodovar). [DVD]. Lolafilms. 1986.

La Ley del deseo (Dir. Pedro Almodovar). [DVD]. El Deseo. 1987.

Mujeres al borde de un ataque de nervios (Dir. Pedro Almodovar). [DVD]. El Deseo. 1988.

¡Átame! (Dir. Pedro Almodovar). [DVD]. El Deseo. 1989.

Tacones Lejanos (Dir. Pedro Almodovar). [DVD]. Canal + y El Deseo. 1991.

Kika (Dir. Pedro Almodovar). [DVD]. Ciby 2000. 1993.

La Flor de mi Secreto (Dir. Pedro Almodovar). [DVD]. El Deseo. 1995. 
Carne Trémula (Dir. Pedro Almodovar). [DVD]. El Deseo, Ciby 2000 y France 3 Cinéma. 1997.

Todo sobre mi madre (Dir. Pedro Almodovar). [DVD]. El Deseo, Renn Productions, France 2 Cinéma y Vía Digita. 1999.

Hable con ella (Dir. Pedro Almodovar). [DVD]. El Deseo. 2002.

La mala educación (Dir. Pedro Almodovar). [DVD]. El Deseo. 2004.

Volver (Dir. Pedro Almodovar). [DVD]. El Deseo. 2006.

Los abrazos rotos (Dir. Pedro Almodovar). [DVD]. El Deseo. 2009.

La piel que habito (Dir. Pedro Almodovar). [DVD]. El Deseo, Blue Haze Entertaimnment, Canal+ España, Televisión Española, ICAA y FilmNation Entertainment. 2011.

Los amantes pasajeros (Dir. Pedro Almodovar). [Netflix]. El Deseo, Renn Productions y France 2 Cinéma. 2013.

Julieta (Dir. Pedro Almodovar). [Filmin]. El Deseo. 2016.

Dolor y gloria (Dir. Pedro Almodovar). [Netflix]. El Deseo. 2019.

La voz humana (Dir. Pedro Almodovar). [Filmin]. El Deseo. 2020.

Madres Paralelas (Dir. Pedro Almodovar). [Sony Picture]. El Deseo, Sony Pictures, RTV Remotamente Films. 2021.

\section{Vídeo de Internet (Youtube, Vimeo...)}

Salome Youtube < https://www.youtube.com/watch?v=1FJW6BbcjFQ\&t=73s > [Consulta: 18 de octubre de 2021] 


\title{
LA CULTURA DE LA ALIMENTACIÓN. PATRIMONIO GASTRONÓMICO DE LAS SOCIEDADES EN PROCESO DE CAMBIO Y SU DIFUSIÓN
}

\author{
José Aniorte Pérez a , Borja Guilló Soler b, Rafael Martínez García c, Isabel Picó \\ Ledesma d, Marian Tristán Richarte ${ }^{\mathrm{e}}$ \\ a aniorte.gestion@gmail.com, binfo@museopusol.com, c fundacion@museopusol.com \\ d03015208@gva.es, ${ }^{e}$ comunicacion@museopusol.com
}

\begin{abstract}
This communication approaches those cultural manifestations that, around food, are shown in the School Museum of Puçol (Elche). It is divided into four sections, related to the essential functions of any museum: conservation, research and dissemination, as they are developed in this museum, whose spaces reflect, in a transversal way, food, understood in its various meanings. In the first place, the traditional agricultural processes of the Camp d'Elx -and of the Mediterranean environment- are described, associated with cereal, vine and olive crops. Second, it describes the preparation and consumption of food at home from these products, recipes and processes compiled thanks to the recovery of oral memory. Thirdly, it talks about catering establishments and the buying and selling of food-related products in markets and retail stores. Finally, it addresses the dissemination that the museum carries out of the aforementioned, that is, the dissemination of social processes and practices related to food, understood both in the formal educational context and in the museum's own dynamics.
\end{abstract}

Keywords: museum, heritage, food, consumption, Mediterranean, agriculture, education.

Resumen: La presente comunicación se aproxima a aquellas manifestaciones culturales que, en torno a la alimentación, se muestran en el Museo Escolar de Puçol (Elche). Se divide en cuatro apartados, relacionados con las funciones esenciales de todo museo: conservación, investigación y difusión, tal y como se desarrollan en este, cuyos espacios reflejan, de manera transversal, la alimentación, entendida en sus varias acepciones. En primer lugar, se explican los procesos agrícolas tradicionales del Camp d'Elx -y del entorno Mediterráneo-, asociados a los cultivos del cereal, de la vid y del olivo. En segundo lugar, se describe la elaboración y el consumo de alimentos en el ámbito doméstico a partir de estos productos, recetas y procesos compilados gracias a la recuperación de la memoria oral. En tercer lugar, se habla de los establecimientos de restauración y de la compra-venta de los productos relacionados con la alimentación en mercados y comercios minoristas. Por último, se aborda la difusión que desde el museo se lleva a cabo de lo anteriormente descrito, es decir, la divulgación de los procesos y prácticas sociales relacionados con la alimentación, entendida tanto en el contexto educativo formal como en la dinámica propia del museo.

Palabras clave: museo, patrimonio, alimentación, consumo, Mediterráneo, agricultura, educación.

Citar como: Aniorte Pérez, J., Guilló Soler, B., Martínez García, R., Picó Ledesma, I., Tristán Richarte, M. (2022). "La cultura de la alimentación. Patrimonio gastronómico de las sociedades en proceso de cambio y su difusión". En: Actas del III Congreso Internacional sobre Patrimonio Alimentario y Museos. 25-26 noviembre, 2021, Valencia, España. pp. 231-246. https://doi.org/10.4995/EGEM2021.2021.13332 


\section{Introducción: el Museo Escolar de Puçol}

El Museo Escolar de Puçol se encuentra en la pedanía ilicitana homónima y conserva fondos etnográficos de carácter material e inmaterial relacionados con la vida considerada tradicional de su entorno ${ }^{1}$. Desde sus inicios, este museo, surgido en la década de los setenta como resultado de un proyecto educativo que trascendió las aulas del colegio de esta partida rural, caminó junto a una comunidad que ya entonces lo hizo suyo y lo ha venido arropando en todas aquellas iniciativas que ha liderado.

A caballo entre las décadas de los sesenta y setenta, el profesor García Fontanet -joven maestro recién destinado al colegio de Puçol- puso en marcha una experiencia pedagógica que contextualizaría la modesta escuela en su medio, utilizando la cultura local como recurso didáctico (Martínez et. al., 2019). Fueron unos años de radicales transformaciones en la sociedad y en la economía españolas, cambios que también afectaron al Campo de Elche. La masiva urbanización y la pérdida progresiva de conocimientos relacionados con el mundo agrario, entre otros, informaron una coyuntura de crisis percibida con preocupación por parte de los/as docentes destinados/as en los pequeños centros unitarios dispersos por el extenso término ilicitano, que se dispusieron a "combatir" esa suerte de desarraigo instalada en el seno de la comunidad rural (García y Pérez, s.f).

En este contexto, la incorporación al aula de materias y conocimientos relacionados con el mundo natural y cultural del entorno, vinculó estrechamente a la escuela con la sociedad rural. Desde principios de la década de los setenta, el alumnado comenzó a estudiar las faenas agrícolas y otros oficios en vías de desaparición, recopilando la memoria oral de las personas mayores del Campo de Elche, iniciando, así, su estudio etnográfico. Con el objetivo de recuperar y poner en valor el patrimonio de la zona, comenzaron a realizarse donaciones de objetos a la escuela, principalmente de antiguas herramientas y menaje, que fueron restaurados, estudiados y expuestos en el aula por los/as escolares. De esta forma, se consiguió involucrar a la comunidad en el proceso de puesta en valor de su cultura, dando lugar a una relación profunda y multidireccional de la que ambas, colegio y pedanía, se beneficiaron.

Consecuencia directa de la experiencia educativa puesta en marcha en Puçol -que consiguió aplicarse en escuelas de pedanías vecinas-, es el Museo Escolar (de Puçol), fundado en 1979 y reconocido en 1992. Entre otros premios y distinciones, en 2009, el proyecto educativo del museo sería incluido por la UNESCO en el Registro de Buenas Prácticas de Salvaguarda del Patrimonio Cultural Inmaterial².

\footnotetext{
1 Creemos oportuno establecer una precisión en cuanto al concepto de "tradición" en su acepción etnográfica, concepto que a menudo se emplea, quizás, indiscriminadamente. Probablemente, la memoria del campo definido como "tradicional", aquella que se decide conservar en el colegio de Puçol a partir del último tercio del siglo XX, un campo por entonces poblado de acequias y cultivos hortícolas, en buena medida era resultado de las transformaciones sobrevenidas a comienzos de la pasada centuria, cuando la instalación de motores eléctricos en el territorio hizo posible elevar aguas procedentes del tramo final del Segura y de algunos de sus azarbes. Por tanto, aunque continuó utilizándose un utillaje arcaico, habida cuenta de que el Camp d'Elx -como el resto del territorio español- no se mecanizaría hasta la década de los sesenta, el hecho de elevar agua merced a motores y las consecuencias derivadas de ello no permite hablar de sociedades tradicionales sensu stricto.

2 https://ich.unesco.org/es/BSP/-00306 (UNESCO, Organización de las naciones Unidas para la Educación, la Ciencia y la Cultura).
} 


\section{Objetivos}

Los objetivos que se plantean en la presente comunicación son los siguientes:

1. Dar a conocer el Museo Escolar de Puçol, incluido por la UNESCO en el Registro de Buenas Prácticas de Salvaguarda del Patrimonio Cultural Inmaterial (2009).

2. Describir el patrimonio material e inmaterial vinculado a la gastronomía existente en el museo.

3. Explicar la difusión que se realiza de este patrimonio en el museo.

\section{Desarrollo de la innovación}

\subsection{Cultivos tradicionales del Camp d'Elx}

El Museo Escolar de Puçol exhibe la trilogía de cultivos mediterránea, cuya presencia en nuestras tierras fue mayoritaria hasta el siglo XX (Lacarra, Sánchez y Jarque, 1997). A partir de las primeras décadas de la pasada centuria, cuando fue posible regar el Camp d'Elx, como se ha indicado, con aguas elevadas del Bajo Segura, comenzaron a extenderse otros cultivos que, en adelante, compartirían "mesa y mantel" con las históricas producciones ilicitanas, que iniciaron su retroceso ${ }^{3}$.

Gozálvez, (1977: 115) en su conocida obra sobre la geografía agraria de la comarca, sostiene que "[la] implantación [de los cultivos hortícolas] en superficies importantes se inicia en los años veinte de nuestro siglo, posibilitados por Riegos de Levante [...]". Tanto la regresión experimentada por los cereales como su sustitución por cultivos hortícolas se pone de manifiesto cuando, más adelante, este autor afırma que "[el trigo y la cebada] son cultivos en regresión [y que] suelen aprovechar los rastrojos de pimientos y melones" (Gozálvez, 1977: 120), producciones hortícolas que, junto a otras, alcanzaron un importante crecimiento a lo largo del novecientos.

Con carácter general, la exposición del museo -resultado de un trabajo de investigación dilatado en el tiempo, en el que el concurso de la comunidad, a través del colegio, resultó decisivo- obedece a diferentes formas de presentación (Hernández, 1994). En cuanto a los cultivos que nos ocupan, aunque los aperos y el resto de objetos se muestran utilizando un criterio tipológico que atiende a aspectos formales, este se combina con otro funcionalista al incorporar murales y fotografías en los que se representa el medio original y escenas con la función o el manipulado de aquellos. En general, se puede afirmar que la exposición relacionada con estos cultivos se corresponde con un planteamiento didáctico -sin excluir la emotividad o el entretenimiento-, aquel que busca instruir y educar, tal y como se explicita en el proyecto educativo original que dio origen al museo.

En concreto, los procesos del cereal y del olivo -no así el correspondiente al viñedo- se exponen en dos espacios diferenciados, habida cuenta de que el museo dispone de un área de exposición al aire libre estrechamente vinculada con las salas merced a cerramientos transparentes. Así, frente al ciclo del cereal -labranza, siembra, recolección y trilla- que se muestra en el interior del museo, en el exterior se exhibe la era, el pajar y diferentes rulos de piedra y

\footnotetext{
${ }_{3}$ En nuestra zona se constituyeron tres sociedades de riegos: en 1906, Nuevos Riegos El Progreso; en 1917, la Real Compañía de Riegos de Levante; en 1923, Riegos El Porvenir.
} 
herramientas, expuestos y revalorizados en un medio recreado artificialmente. El proceso de obtención del aceite, mostrado en el interior, se complementa con la visión de un olivo en el exterior.

En lo que respecta al cereal, el museo exhibe la preparación del terreno, la labranza, la siembra, la recolección y la trilla, procesos que fueron objeto de un monográfico en su revista ${ }^{4}$. Los aperos para preparar el terreno (tablas, traíllas), labrar (arados, rejas), cosechar (hoces, zoquetas) y trillar (trillos, palas de aventar, recogedores, tamices...) se muestran junto a los yugos (se utilizaban con tracción animal), horcates, frontiles o aguijadas, además de la indumentaria tradicional y diferentes enseres de esparto y mimbre, como capazos, seras o cestas. Una trilladora fabricada por la casa Ajuria (modelo T 110) permanece almacenada en las instalaciones del museo a la espera de una pronta restauración (Figura 1).

En cuanto al viñedo, igualmente en regresión a lo largo del XX, Gozálvez (1977: 129) habla de que "los pissaors y bodegues en desuso existentes en casi todas las casas de labranza construidas antes de 1950 nos hablan de una total elaboración casera del vino, en buena parte para autoconsumo". Así lo atestiguan tanto las pequeñas dimensiones de los lagares conservados como las del resto de enseres e instalaciones empleadas. El museo también conserva

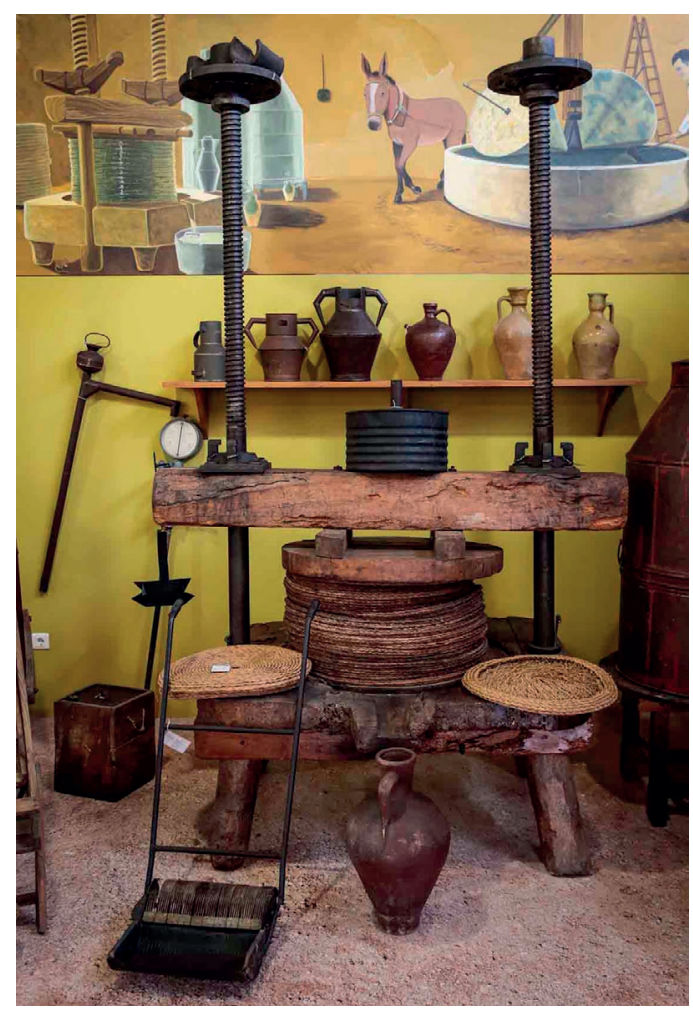

Figura 1. Prensa de aceite expuesta en el Museo Escolar de Puçol. Fuente: Elaboración propia.

\footnotetext{
${ }_{4}$ El Setiet. Boletín Informativo del Museo Escolar Agrícola de Puçol, nº 8, invierno de 1998.
} 
estrujadoras (una de ellas fabricada en Monóvar, Alicante), toneles, cántaros, pellejos o podones, entre otros, herramientas y útiles propios de un cultivo que a lo largo del siglo XX irá reduciendo drásticamente su extensión.

En cuanto a las tareas relacionadas con el cultivo del olivo -tildado como "residual" por Gozálvez (1977: 137) en los setenta y como "secundario" por Brotons (1985: 184), diez años más tarde-, se exhibe un molino de aceite y varias prensas (algunas fabricadas en Alcoy, Alicante), entre las que destaca una de base de piedra y husillos de madera. Zafras, tinajas y medidas, cribas o carretillas ofrecen una visión del utillaje generalmente utilizado en las diferentes faenas asociadas a la recolección de la aceituna y la obtención del aceite.

Producciones como la almendra y la ñora también tienen su reflejo en las salas del museo. Actualmente en retroceso, el almendro, que en los setenta llegó a ocupar miles de hectáreas de extensión en el Campo de Elche, nunca fue abundante en el entorno de Puçol, no obstante lo cual, el museo ha venido recibiendo diversas donaciones de maquinaria asociada a su cultivo. Su expansión se inició en el tránsito de los siglos XIX y XX gracias al bombeo de aguas del Segura, ya mencionado. El museo exhibe una máquina de partir almendra del primer tercio del siglo XX, construida en la fábrica de Silvestre Ivars, de Benissa (Alicante); una separadora de mediados del siglo XX, fabricada por Borrell, en Denia (Alicante) y una descortezadora, probablemente, también de la primera mitad del novecientos.

El pimiento para pimentón, "bola" o ñora también era uno de los cultivos hortícolas más extendidos a comienzos de los setenta, cuando el proyecto educativo iniciaba su andadura (Gozálvez, 1977: 116). Previo a su secado natural, numerosa mano de obra femenina se encargaba de abrir a mano este producto, actividad que, en el Camp d'Elx, se mecanizó tardíamente, empleando máquinas fabricadas en la zona, alguna de las cuales se muestra en el museo.

Mención aparte merece la palmera datilera, cuyo cultivo se encuentra ampliamente representado en el museo, que conserva y exhibe, entre otros, los enseres tradicionalmente utilizados para subir por los estipes de estas plantas y realizar los diferentes trabajos (recolectar, podar, polinizar, encaperuzar...), propios de cada época del año. La selección, preparación y venta del dátil, así como la elaboración y el trenzado de palma blanca -artesanía secularmente asentada en Elche, relacionada con la festividad del Domingo de Ramos- se muestran en un espacio que reproduce el porche de las casas de campo características de la zona. Al igual que en otras áreas del museo, grandes murales pintados explican estas actividades y el entorno en el que se realizan.

Finalmente, el museo conserva una serie de piezas como recogedores de higos o desgranadoras de maíz, así como enseres relacionados con la caza (de bisbitas y anátidas, entre otras especies), actividades otrora importantes en el área que nos ocupa, con las que se complementaba la dieta de sus vecinos/as (Gozálvez, 1977: 120 y 136).

\subsection{El consumo del producto y los procesos realizados en el ámbito doméstico}

Como se ha mencionado, el Museo Escolar de Puçol abarca en su exposición, en sus líneas de investigación y en su labor de recuperación, la memoria de las formas de vida tanto del medio rural como del medio urbano. Estas eran maneras de vivir muy diferentes, en cuanto a lo laboral, en cuanto a los servicios públicos de los que se disponían y, especialmente, en cuanto a la socialización de los individuos. Pero algo tenían en común: la escasez de recursos, las estrecheces diarias y el esfuerzo ímprobo por la supervivencia. 
Es cierto que, en el campo, los aprietos eran menos; si bien el trabajo era muy duro su fruto aseguraba el alimento suficiente para todo el año. En la ciudad, donde se solía trabajar a jornal en la industria alpargatera, se cobraba semanalmente con seguridad, pero había que administrar bien ese jornal, generalmente escaso. A partir de cierta edad era habitual que los/as niños/as abandonaran los estudios para ponerse a trabajar, contribuyendo así a la economía familiar.

En ambos casos, no se disponía ni de luz eléctrica ni de agua corriente, pero llegó un momento en que la ciudad comenzó a disfrutar de estos servicios, que se demoraron durante décadas en el medio rural. Esto nos lleva a un punto importante: la costumbre ancestral de cocinar a la leña subsistió en el campo ilicitano hasta bien entrado el siglo XX, así como disponer de un aljibe de agua de lluvia para beber y guisar.

En el agro ilicitano la casa solía ser una vivienda unifamiliar, en la que la cocina formaba parte de las estancias interiores. En el Museo Escolar de Puçol se recrea una cocina tradicional, cuyo centro era la chimenea u hogar, abierta y de media altura. Sobre ella había una gran repisa, en la que se disponían las ollas de barro y otros enseres propios de este espacio. Delante de la chimenea se colocaba una pequeña mesa baja en la que la familia se sentaba para realizar las comidas, pero también para pasar la sobremesa y calentarse en invierno al calor del fuego. En muchos casos, en la cocina se ubicaba la puerta del horno de leña, si es que estaba adosado a la casa; en otras ocasiones, el horno era una pieza exenta que se encontraba en el exterior de la vivienda (Figura 2).

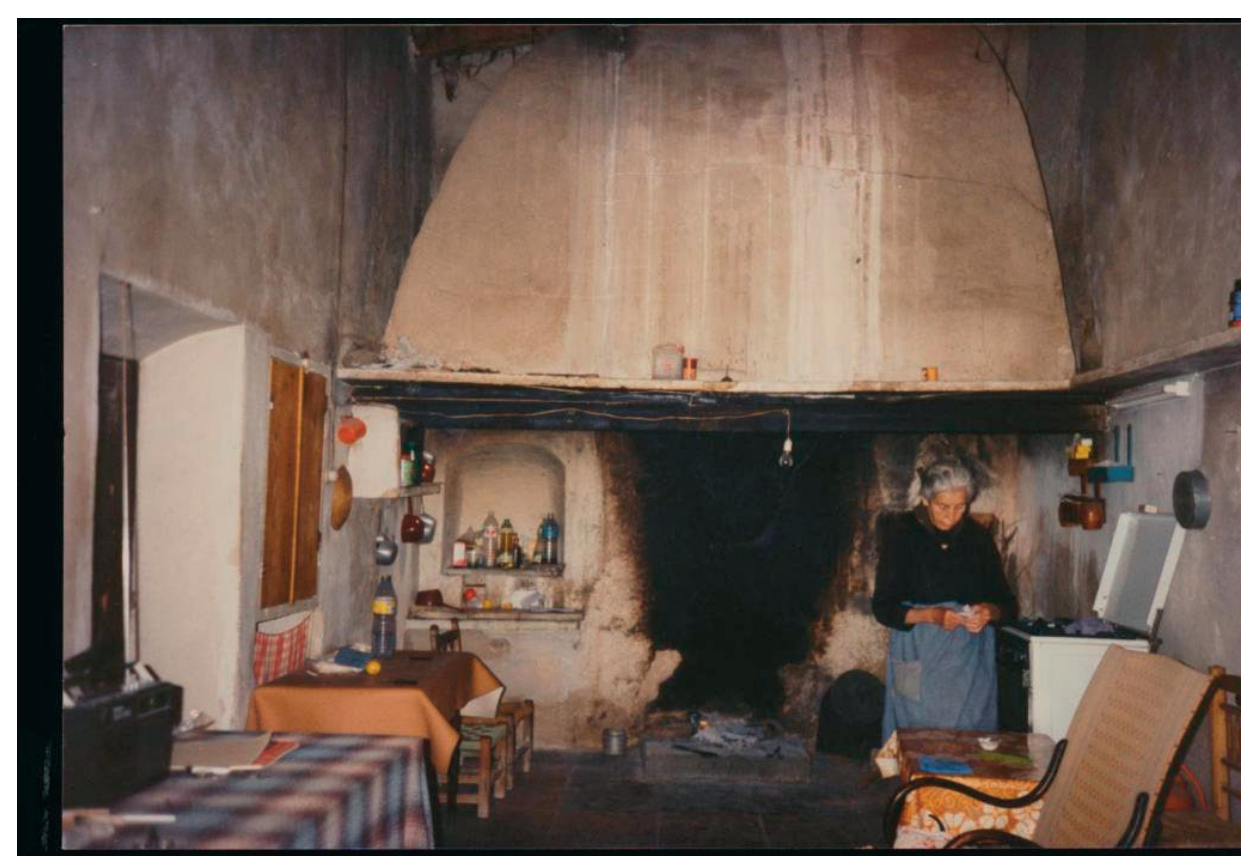

Figura 2. Cocina de una casa tradicional del Camp d'Elx, con la chimenea como elemento central. La cocina de gas y los restos de ceniza en la chimenea ponen de manifiesto la convivencia de ambos métodos de cocción (c..1990). Fuente: Elaboración propia. 
En cuanto a su relación con la alimentación, no eran menos importantes otras estancias. Tan indispensable como la propia cocina era la cambra, una buhardilla en la que se guardaba desde el grano hasta el embutido de la matanza o algunos melones, atados a una caña colgada del techo, de manera trasversal.

Adosada a la cocina se encontraba otra estancia, de pequeñas dimensiones -recreada, asimismo, en el museo-, que actuaba principalmente como despensa. Se trata del pastaor, en el que, además de almacenar alimentos, se amasaba el pan que el ama de casa horneaba semanalmente. En él se ubicaban las orzas con productos de la matanza, pequeñas zafras con aceite de oliva y otros recipientes en los que se preservaban los alimentos, como la fresquera o carnera, una especie de jaula portátil, de malla mosquitera, que colgaba en un lugar fresco para favorecer la conservación de lo que se guardaba en ella. También se ubicaba aquí la artesa, las rasquetas y todo lo necesario para amasar. Una receta típica que se preparaba los días de horneado era la coca a la calda, una torta de masa de pan, con aceite y sal, que requería de poca cocción y que se introducía en el horno a la espera de que este se calentara lo suficiente para meter el pan.

No exclusivamente con la conservación de los alimentos, podemos relacionar las dependencias del hogar campesino, una de ellas de extrema importancia era el corral para criar animales. Y es que esta actividad era primordial en la alimentación familiar, ya que surtía la cocina de carne, aunque fuera en ocasiones contadas. El corral se situaba en la parte trasera de la casa, hacia el norte, y consistía en un espacio más o menos cuadrado, tapiado en sus cuatro lados y en parte sin techar, donde los animales se criaban libremente, pues no les acechaba ningún peligro exterior. Se solía tener gallinas y pollos, algún pavo, patos y ocas, pero también una o dos cabras que surtirían de leche fresca todos los días; y conejillos de indias. Mención aparte merecen los conejos, que no se criaban en libertad por la dificultad que supone atraparlos. En principio, ocupaban grandes agujeros exteriores excavados en el suelo y rodeados de espino, en los que vivían libremente. Cuando se quería atraparlos había que disponer una trampa de lazo unas horas antes y esperar a que uno de los animales quedara prendido. Esta arcaica costumbre decayó hacia el segundo tercio del siglo XX, adoptándose las conejeras como el método más utilizado para su cría.

Tampoco se criaba en el corral a los cerdos, que disponían de su propio espacio en las cochiqueras o marraneras, pequeños recintos independientes en parte techados, separados del resto de dependencias. En cada casa se criaba uno o dos cerdos para el consumo familiar, pero a veces se criaba alguno más para vender. Conocemos, sin embargo, casos de familias con menos recursos que criaban cerdos a medias con otra familia.

La matanza del cerdo era un evento de extrema importancia, pues surtía a la despensa familiar de carne y embutidos para muchos meses. Se realizaba a comienzos del invierno, con el objetivo de que el frío ayudase a curar y conservar los productos. Además del embutido es interesante destacar cómo se conservaba la carne tras la matanza para disponer de ella durante un largo periodo de tiempo: se fileteaba y se iba disponiendo por capas dentro de orzas de barro, vertiendo encima la manteca del cerdo derretida, que actuaba como aislante una vez se solidificaba. Cuando quería extraerse la carne, primero se debía retirar la capa de grasa que la envolvía, la cual se aprovecharía para cocinar o para untar sobre el pan en el almuerzo. 
La comida diaria era de aprovechamiento, sacando el máximo partido a todos los alimentos, pues las sobras de una receta podían ser empleadas como base para nuevos platos. Los huesos de la carne se aprovechaban para hacer un caldo, la cabeza del bonito en salazón se añadía a un guiso, o los sobrantes del puchero o cocido se freían con ajo para hacer ropa vieja.

La lista de ingredientes de un mismo plato podía variar a lo largo del año en base a los productos de temporada. En la época de invierno, la paella de arroz incluía las verduras de estación: alcachofas, guisantes y habas o ajos tiernos. Tras la matanza, a la paella se le podía añadir magra de cerdo, o bien morcillas para acompañar a un arroz con cebolla y patata. En verano, quienes pasaban unos días en las barracas a la orilla del mar, cocinaban una paella de pescado a la que se podían añadir algunas gambas.

La cocina se adaptaba diariamente a la despensa familiar. Predominaban los guisos, que admitían todo tipo de ingredientes, aprovechando la variedad de hortalizas y legumbres. La carne y el pescado frescos eran considerados productos de "lujo que pocas veces se podían permitir. La costum era comprar dos dotzenes de sardines de bota, una cavalla, un bonítol, un bacallar blanc i poques coses mes. Aixó era suficient per a el consum familiar semanal" (sic) (Brotons y Soler, 1986: 72).

Las familias de agricultores, antes de comenzar la jornada de trabajo, preparaban migas o gachamiga, en cualquier caso, un desayuno muy calórico y energético necesario ante el desgaste físico que suponían los trabajos agrícolas. También desayunaban grandes tazones de sopes, una infusión de hierba luisa con azúcar o un tazón de leche de cabra, acompañadas con pan o rosquillas. Para la parada del almuerzo en el campo era común el pan con aceite, que podía ir acompañado de alguna sardina o un trozo de bacalao.

A mediodía, la proximidad entre el hogar y las tierras de labranza permitía a muchos agricultores comer en sus propias casas. De no ser así, la sombra de un árbol era un buen lugar para hacer una pausa para la comida. Las cenas se llevaban a cabo junto a toda la familia en la cocina, al amparo del calor y la luz de la chimenea. No había mucha diferencia entre ambas comidas principales en lo que a variedad de ingredientes se refiere pues, como ya se ha comentado con anterioridad, la escasez de recursos impedía al ama de casa cocinar de forma variada. No obstante, los guisos solían reservarse para la comida principal, pues eran comidas excesivamente calóricas para la cena, en la que se acudía más a los hervidos. Las técnicas de cocción eran de los pocos recursos a los que se recurría para variar dichas recetas.

La gastronomía tradicional del Camp d'Elx incluye entre sus muchas recetas desconocidas un guiso llamado granyons de forment (Brotons y Soler, 1986: 73). Este potaje, denominado en otros rincones como olleta de blat, lleva grano de trigo picado y hervido, junto con verduras de temporada.

Otro de estos platos tradicionales es el conocido como pebreres en l'olla. Se picaba ñora o pimiento rojo, ajo, patatas, judías verdes y cebolla y se añadía a la olla con agua hirviendo, laurel, clavo y aceite de oliva. Una vez casi terminada la cocción, se cascaban unos huevos, se añadían a la olla y se removía. Para terminar, se agregaba un poco de almendra frita picada, un poco de harina y agua.

Aprovechando la cabeza de un bonito en salazón también se preparaban tallarins amb cap de bonito salat. Los tallarines eran caseros. Para su elaboración, sobre una madera o una losa de mármol, se estiraba la masa con la ayuda de un rodillo. Quien no disponía de uno utilizaba 
una botella de cristal, que realizaba la misma función. Cuando la masa estaba lo suficientemente fina, se plegaba varias veces para facilitar el corte. Este se llevaba a cabo con la ayuda de un cuchillo de cocina, dando forma a los tallarines. Finalmente, se estiraban y se dejaban secar encima de la madera. Para este guiso se aprovechaba la cabeza del bonito en salazón, que no se comía normalmente, cociéndola junto con cebolla y tomate fritos y hortalizas. Cuando el caldo estaba listo se añadían los tallarines y se dejaban hervir hasta que estuviesen cocinados.

Las habas más tiernas de la cosecha se cocían, con su vaina incluida, para hacer pantalonets, un hervido de esta legumbre aliñado con aceite, vinagre y sal.

Los días señalados en el calendario, las amas de casa realizaban comidas que requerían mayor elaboración. Los domingos se reservaban para la paella o el arroz con costra. Esta última receta, que ha quedado como plato emblemático en localidades como Aspe, Elche y Orihuela, entre otras poblaciones, se lleva a cabo en un perol de barro. Además de la carne de pollo o conejo, se le añade embutido frito: longaniza blanca, longaniza roja y otros embutidos típicos de esta zona como el blanquet y el botifarrón. Tras la cocción del grano se completa cubriendo este con huevo batido. El perol se puede llevar al horno o puede ser colocado bajo una costrera, que ya se menciona en el Llibre de $\mathrm{Coch}^{5}$. Esta es una especie de tapadera de metal sobre la que se colocan las brasas para que el huevo infle como en un soufflé.

\subsection{La comercialización de los alimentos: mercados, comercios minoristas y restauración}

\subsubsection{El comercio en la ciudad: la tienda de ultramarinos}

Poco se recuerdan ya los comercios de coloniales originales (también conocidos como ultramarinos, colmados, mantequerías, tienditas, abastos, abacerías, abarrotes, desavíos...). Hoy contamos con las grandes superficies de alimentación, con los supermercados y, en los barrios, con esos pequeños negocios regentados habitualmente por inmigrantes. También fue así como nacieron muchas de esas tiendas de comestibles, allá por el siglo XIX, fundadas -en origen- por antiguos habitantes de las colonias españolas, que venían a comercializar los productos procedentes de esas tierras. De ahí el nombre de "ultramarinos", porque vendían productos de ultramar, del otro lado del mar, productos de importación como el café, el chocolate o especias como el azafrán. En 1847, en Elche ya había ocho tiendas de especiería y ultramarinos (Ramos, 1973:191).

La mujer de la ciudad, el ama de casa o la dona de la familia, acudía a estas tiendas a hacer la compra. La costumbre, al entrar en estos negocios de carácter eminentemente familiar, era "pedir la vez", esto es, preguntar el orden de espera o quién era el/la último/a en la cola. La venta a granel, es decir, sin que el producto estuviera previamente empaquetado o envasado, pudiendo pagar la cantidad que la clientela desease, era la forma habitual de comprar. Excepto las conservas -ya cerradas-, los ultramarinos ofrecían a granel casi cualquier producto de consumo, para lo que no podía faltar el papel de estraza: legumbres, embutidos y quesos, dulces, café molido, especias, harina, aceite, vino... Para pesar y tomar medidas de los comestibles, el/a tendero/a hacía uso de una báscula (para el género de mayor tamaño)

\footnotetext{
El Llibre del Coch, de Robert de Nola, es un recetario cuya edición más antigua conservada data de 1520. En este documento - en el que se menciona la costrera - ya aparece la receta de arros en caffola al forn, la que de momento parece ser la primera receta documentada del arroz con costra: "la cassola sobre vn foch de carbo / e damunt met vna cuberta de ferro carregada be de foch per que en tal manera exira de alli com si era stada cuyta al forn [...]".
} 
y una balanza. En el mostrador no podía faltar la bomba de aceite, que extraía la cantidad de producto demandada de un bidón situado en su parte inferior. La clienta llegaba con su propio recipiente vacío, para que se lo rellenasen con la cantidad deseada de aceite.

Dado que se trataba de negocios de "vecindario" y familiares, todos y todas se conocían, siendo tal la confianza que era habitual que el tendero "fiase" a los/as clientes/as, es decir, les permitiera llevarse el género sin pagar, comprometiéndose a hacerlo en otra ocasión.

Además de la compraventa, estas tiendas eran lugares habituales de socialización. Los vecinos y vecinas aprovechaban el momento de la compra para hablar, para contarse las novedades, para la xarradeta diaria.

En la mayoría de ocasiones, estos locales, más que tiendas parecían almacenes, dado que las estanterías estaban repletas de conservas. Los ultramarinos del Museo Escolar de Puçol recrean esta sensación: latas de todo tipo, envases y cajas se colocan en las lejas, que llegan hasta el mismo techo. Una recreación en la que se exponen muchos de los productos y marcas más comercializados.

“Con el paso del tiempo y ante la necesidad de diferenciación en un mercado cada vez más competitivo, fueron apareciendo las distintas marcas con dibujos y colores" (Abad, Beltrá, Lucas y Ortega, 1999: 88 y 89), leemos en Los inicios de la modernización en Alicante, 1882-1914 sobre el azafrán, hecho que se puede extrapolar a otros productos. La diversidad de marcas, los envases decorados, coloridos y de calidad, como el del pimentón "La Carriola" (cuyo logo se identifica con un caballero sentado en un hermoso carro) o las cajas de membrillo, que eran reutilizadas como costurero o para guardar las fotografías familiares, abundan en esta tiendita.

Las piezas expuestas nos ayudan a apreciar, además, la evolución en el diseño de marcas que actualmente continúan en activo. "Cola-Cao" es una de ellas, una marca que pasó de hacer uso de una imagen esclavista de los agricultores negros del chocolate (cargando, encorvados, los capazos de vainas) a publicitar una escena más dulce, de un hombre y una mujer, agricultores del cacao, con una sonrisa en sus rostros. Expuestas también pueden verse cajas de metal de "Cola-Cao" con la imagen de la madre americana sirviendo el desayuno a sus hijos e hijas. Otros productos coloniales que hicieron uso de la típica imagen de la mujer negra de ultramar son los chocolates "La Paraguaya" o "Buana-cacao". Algunos productos, no obstante, poco han cambiado su visual, como "Norit", que ha continuado haciendo uso del cordero blanco desde entonces, o "La lechera" con su chica holandesa vertiendo leche. También destacan aquellas empresas que, dado que vendían típicos productos españoles, explotaban los estereotipos de la flamenca, la gitana o los toros y toreros, como Manolete.

Especial mención merecen las sardinas "de bota" (la sardina entera, salada y prensada -entre el marco y la puerta, para obtener fácilmente los filetes limpios de piel y escamas-), que se colocaban en la "bota" o caja redonda, en la puerta de los ultramarinos, símbolo de la importancia en la época de los salazones.

\subsubsection{El bar/café}

Otro lugar de socialización por excelencia, punto de encuentro habitual para la sociedad, era el bar, pero solo para los hombres. El bar -café o taberna- presentaba, de facto, ciertas limitaciones para las mujeres solas, quienes, habitualmente, solo entraban acompañadas de un varón, de su 
marido, principalmente. Era el lugar de reunión de obreros, labradores y comerciantes, quienes pasaban horas de tertulia, tomando un café o una copa, fumando -algunos escriben sobre el ambiente tan saturado que había-, jugando o escuchando música; incluso, en ocasiones, las charlas daban paso al cierre de negocios.

En el museo se expone el Café/Bar Comercio, que se ubicaba en la Plaça de Baix de Elche, con una gran colección de botellas resultado de las constantes donaciones recibidas. El vino, el anís o "paloma" (3 - 4/5 partes de agua y 1 - 2/5 partes de anís, tomado con el aperitivo), el moscatel y los licores como el coñac y el de café eran, en principio, las bebidas más consumidas (la cerveza se impone como el producto estrella más adelante, avanzado el siglo XX). Muchas de las botellas expuestas están estampadas con imágenes características de la ciudad, la Dama de Elche y las palmeras, principalmente. Algunas proceden de las antiguas fábricas de bebidas ilicitanas, como Vda. de J. Pérez Sánchez, Salas, Vda. de Mariano Pérez Sánchez, sifón higiénico "La Ideal", Productos Fayos -sifones-, Anisete "Che" (de José Vicente Ibarra), Anís Sys (de Salas y Sirvent) o Anís País ${ }^{6}$ (Figura 3).

La higiene y la limpieza en estos negocios, así como en otros muchos -dada la falta de educación sanitaria-, era pobre, su regulación legal llegará más tarde, con el cambio de siglo. Vicente Villalobos, propietario del Bar Villalobos, en el centro de Elche (en activo desde 1901 -primero, como "Casa Barceló"- hasta 2020), relataba en una entrevista (inédita) cómo su abuelo y su padre, propietarios originales del local, preparaban sus famosos bocadillos de atún con un tenedor y sus dedos desnudos.

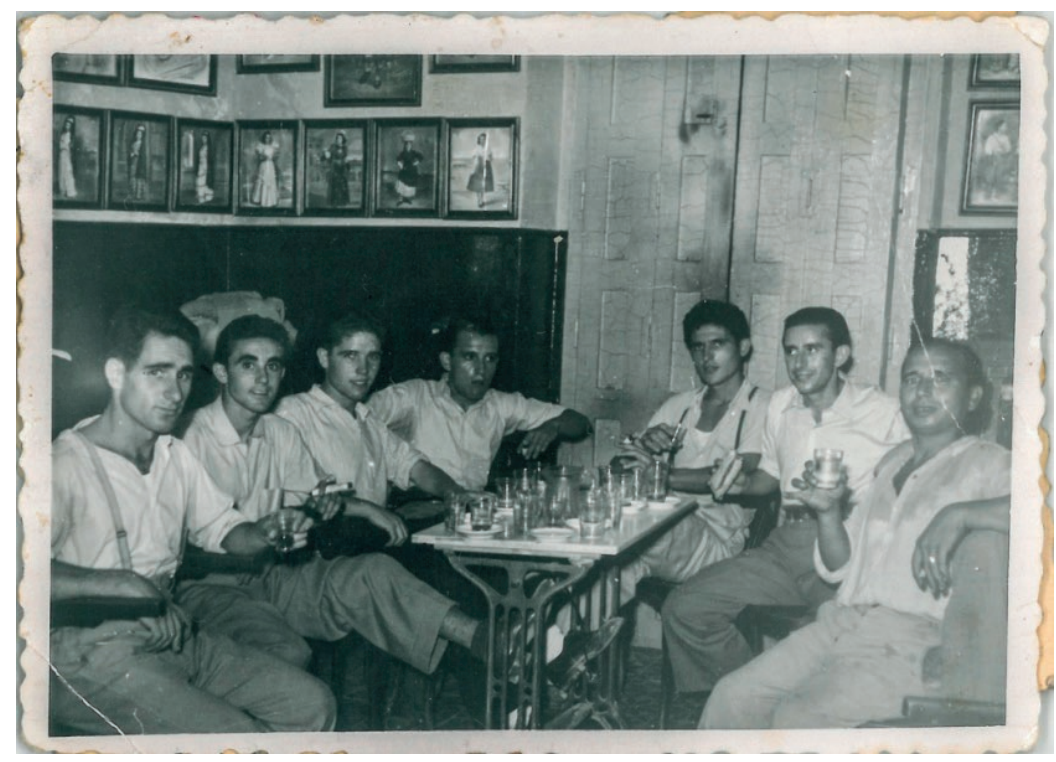

Figura 3. Miembros de la Coral Ilicitana (c. mediados del siglo XX). (Donante: José Juan Alicante Sánchez).

\footnotetext{
${ }^{6}$ El Setiet. Boletín Informativo del Museo Escolar Agrícola de Puçol, nº 18, 2007, p.69.
} 
Los estereotipos, tanto por nacionalidad como por género, vuelven a repetirse en estos locales, que decoraban sus paredes con carteles publicitarios de bebidas o calendarios, protagonizados en gran parte por mujeres exuberantes.

\subsubsection{El carrito de los helados o "chambilero"}

Otro elemento relacionado con los hábitos alimentarios expuesto en el museo es el carrito de los helados. Conocido popularmente como "chambilero", este negocio ambulante vendía por las calles, principalmente a los niños y niñas, polos, mambos, cortes, horchata, cebada, limón y "chambis" o "xambis" (de ahí su nombre). El "xambi" consistía en dos pastas de barquillo o galleta entre los que se colocaba el mantecado, confeccionado con un artilugio de metal, tipo cajetín, del tamaño de la galleta que, al deslizarlo, permitía hacer el corte de mantecado más o menos grueso. Este helado fue inventado e industrializado por los americanos, que lo llamaron "sándwich". Dada la afluencia del turismo americano a nuestro país -especialmente en el Levante- y, por tanto, la demanda de "sándwiches", los heladeros lo incorporaron en sus carritos, que, con el paso del tiempo, posiblemente por una deformación fonética, derivó a la palabra "chambi" (Tristán, 2020).

Los vasos en los que repartían bebidas, como limonada, eran de cristal, puesto que el plástico aún no existía. Los niños y las niñas se la bebían cerca del carrito, pues luego había que devolver el vaso para que el "chambilero" lo fregase. Además de estas bebidas veraniegas, en algunos carritos también se vendían botellines de gaseosa, como el puesto ambulante de Vicente Salvador, que solía ubicarse en la puerta del campanario de la basílica de Santa María de Elche (Pérez, 1996: 40). El carrito que se muestra en el museo es de Helados Parisol, denominado así porque su antiguo propietario, alojado en París, añoraba el sol de España.

\subsubsection{El mercado}

El día de mercado -el sábado- era la jornada de compra por excelencia y la población de la ciudad aumentaba considerablemente, dado que las familias del campo se desplazaban a la ciudad para abastecerse de comestibles (los "ultramarinos" aún no habían llegado a las afueras). Solía viajar el matrimonio -dejando a los hijos e hijas en casa-, a caballo o en un carretet entoldat, a primera hora de la mañana, para poder regresar a medio día y comer todos y todas juntos/as. La jornada era tan importante para el comercio de la ciudad, que las tiendas de comestibles abrían antes, para atender a la población rural.

En el verano de 1888 se inauguró el nuevo mercado de abastos en Elche, con tres grandes y espaciosos pabellones. El cambio de siglo provocó -entre otras cosas- tanto la regulación de la higiene en los mercados (y en otros ámbitos), como la estabilización del calendario de celebración y la construcción de edificios específicos para tal fin (Ponce, 1999: 195). Por tanto, el mercado deja las calles y las plazas -la Plaza Mayor en el caso de Elche- y se asienta de forma permanente en esta nueva construcción. El nuevo mercado reunía, así, la venta de todos los productos y materiales, puesto que, con anterioridad, los puestos se colocaban en una plaza u otra de la ciudad, según lo que vendían: las frutas y verduras en la Plaza de la Fruta, el esparto en la Plazuela de las Barcas, etc. (Ramos, 1973: 191). 
La xarradeta tampoco podía faltar en este momento, igual que pasaba en los ultramarinos. "Lo del mercat, moltes vegades, era sols un pretexte que se buscaba per a poder conversar i reunirse" (Brotons y Soler, 1986: 61). Era costumbre que, mientras la mujer hacía la compra semanal, el marido entrase al bar o café, buscando ese momento de tertulia.

\subsubsection{El comercio en el campo}

Las tiendas de comestibles llegan de forma más tardía al campo, durante la primera mitad del siglo XX, siendo la única opción hasta entonces el desplazarse a la ciudad en día de mercado. Estos negocios unían la venta de conservas y de carne al servicio de bar o café, algo no tan habitual en los ultramarinos de la ciudad. Estas tiendas, de marcado carácter humilde, solían ocupar locales anexos a la vivienda habitual del tendero, es decir, que no eran construcciones independientes, sino que el propietario vivía junto a la tienda, como una habitación más de la casa, a la que se accedía por una entrada paralela a la principal. No obstante, la rutina habitual en el medio rural, antes de que hubiese excedente suficiente para la venta comercial, era intercambiar alimentos con el vecindario.

\subsection{La actividad escolar}

El Proyecto Educativo-Museístico tiene como principal actividad la educación de los/as escolares. Es en Puçol donde el patrimonio y la cultura local se convierten en recursos didácticos y, al mismo tiempo, se ponen en valor. El Museo Escolar, con más de 100.000 ítems, conforma el museo etnográfico de Elche y se erige como una fuente inagotable de conocimiento y un recurso educativo excepcional. El alumnado del colegio recibe una educación adaptada al entorno, donde la experimentación y comprensión de las realidades culturales son un recurso inagotable.

En la actualidad, la escuela se compone de cuatro aulas, en las que estudian alrededor de 55 niños y niñas de 3 a 12 años. Una de las características que hace de este centro una escuela singular es que en la misma clase hay alumnado de distintos niveles y diferentes edades trabajando al mismo tiempo. Esta vertiente propiamente educativa, no sólo se da a través del colegio, sino también a través del museo. Toda la información que se comparte entre los diferentes agentes que intervienen en el Proyecto, ayuda al entendimiento de la cultura tradicional del municipio de Elche y de su entorno.

Gracias a la actividad denominada Guía de Museo, los/as escolares visitantes aprenden de la mano de los/as escolares del colegio, quienes explican la exposición, además de participar en talleres y experiencias con las que se contribuye a la permanencia del conocimiento tradicional.

El entorno en el que nos encontramos propicia el cuidado y la conservación del huerto escolar y el trabajo de la botánica. El alumnado participa activamente en su mantenimiento y está profundamente concienciado de la importancia de cuidar el medio. En el proceso, plantan las semillas, las riegan y recogen la cosecha. Siempre teniendo presente la temporada óptima de verduras y frutas como la coliflor, el brócoli, la romanesco, la ñora, la alcachofa o la vid.

Señas gastronómicas de identidad del Camp d’Elx son los dátiles y las granadas, que no podrían faltar en los jardines de Puçol. De las palmeras no sólo recibimos sus frutos, sino también realizamos actividades como el trenzado de palma blanca o les atxes, una especie de antorchas que se utilizan para iluminar el camino a los Reyes Magos el 5 de enero. 
En Elche contamos con la Denominación de Origen Protegida de la granada mollar, una variedad que el alumnado estudia, conoce y disfruta cada año celebrando el día de la granada y haciendo la recolección de la misma en los frutales que rodean la instalación.

Gracias a la profunda relación multidireccional entre colegio y comunidad, el Proyecto Educativo es depositario de recetas tradicionales de la zona, compartidas a través de la memoria oral de las personas mayores del vecindario. En vías de desaparición estaba el penjoll de mazapán, donde ingredientes como la clara de huevo, el azúcar, el limón y la almendra molida hacen que se consiga obtener una pasta uniforme a la que se le da forma de corazón para, posteriormente, llevarla al horno de leña tradicional, ubicado en el jardín interior. Esta tradición ilicitana era frecuente entre las abuelas como regalo a sus nietos/as en días señalados, especialmente en el santo o el cumpleaños.

La coca a la calda o los "mantecaos" navideños se realizan cada año para que el alumnado conozca las recetas y de esta forma nos aseguremos de que van a ser transmitidas, confiando así en que pasen de generación en generación y no se pierdan.

La estrecha relación que existe entre el colegio, la sociedad y el museo facilita la realización de actividades en las que participa toda la comunidad educativa. Dos ejemplos son el concurso de postres y la elaboración de buñuelos, ambas con recetas tradicionales de la zona (Figura 4 y 5 ).

\section{Resultados}

Desde hace décadas, el Proyecto Educativo-Museístico de Puçol viene desarrollando una activa labor patrimonial en el municipio de Elche y su entorno. Conservar la memoria de la gastronomía

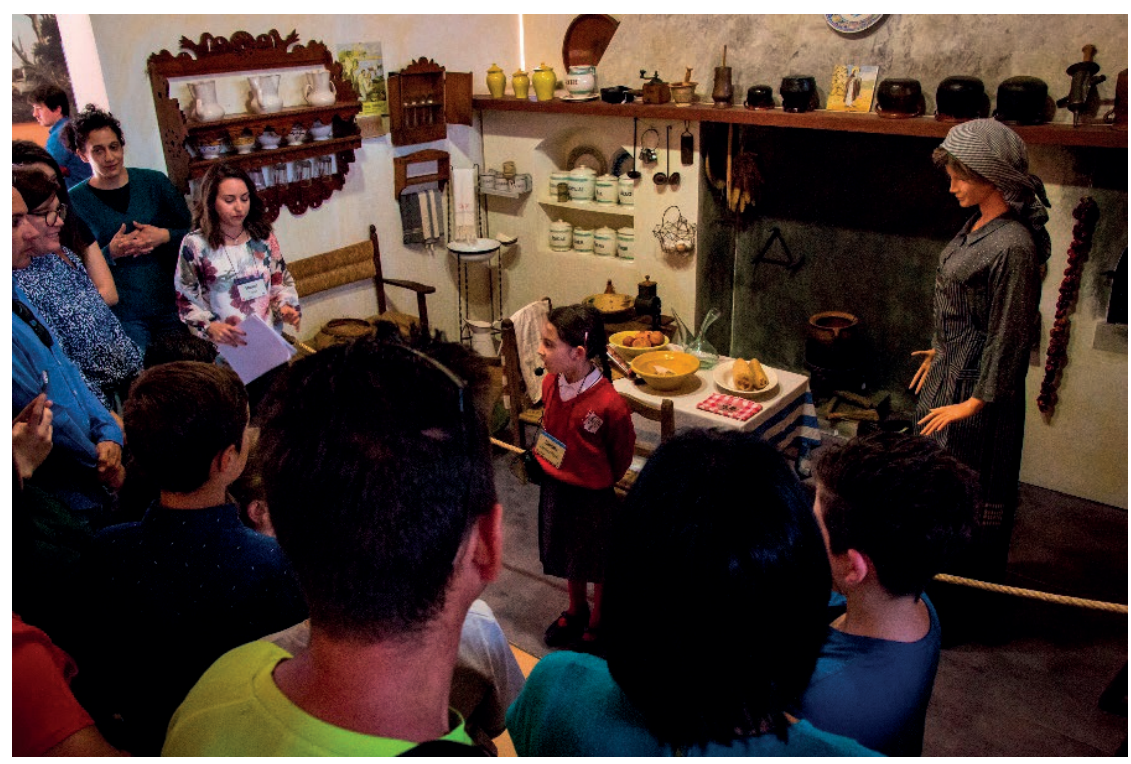

Figura 4. Actividad Guía del Museo en la reproducción de la cocina tradicional de la casa de campo (2018). Fuente: Elaboración propia. 
local siempre fue una de las líneas de investigación desarrolladas por el colegio, cuyos/as alumnos/as recopilan recetas autóctonas, elaboran productos tradicionales, cultivan productos típicos, aprenden ancestrales técnicas agrícolas y otras prácticas domésticas relacionadas con la alimentación y conocen mercados y tiendas antiguas. Todo ello gracias a la activa labor desarrollada por una comunidad educativa volcada en un proyecto que, con el tiempo, trascendió los límites de la pedanía.

El montaje y la guía de exposiciones, la realización de talleres y la edición de publicaciones relacionadas con la alimentación constituyen la consecuente plasmación de una experiencia pedagógica que ha impulsado el conocimiento y el reconocimiento de la cultura local.

\section{Conclusiones}

Tras décadas de existencia, este Proyecto no solo ha sido capaz de asentarse en el seno de la comunidad, sino que ha obtenido importantes reconocimientos nacionales e internacionales, entre otros, el otorgado por la UNESCO en 2009. Su origen, en la pedanía rural, lo convierten en un temprano referente de museos comunitarios creados "de abajo arriba", surgidos de la misma sociedad civil, en unos años de trascendentales cambios experimentados en el país. La recuperación, cuando menos, de la memoria de la sociedad ha convertido al Museo Escolar en un centro de cultura tradicional que conserva, investiga y divulga la historia cotidiana del territorio en el que se asienta. No obstante, lo conseguido en Puçol trasciende sus límites geográficos, pues configura una praxis sostenida en el tiempo, por completo replicable en otros entornos y realidades.

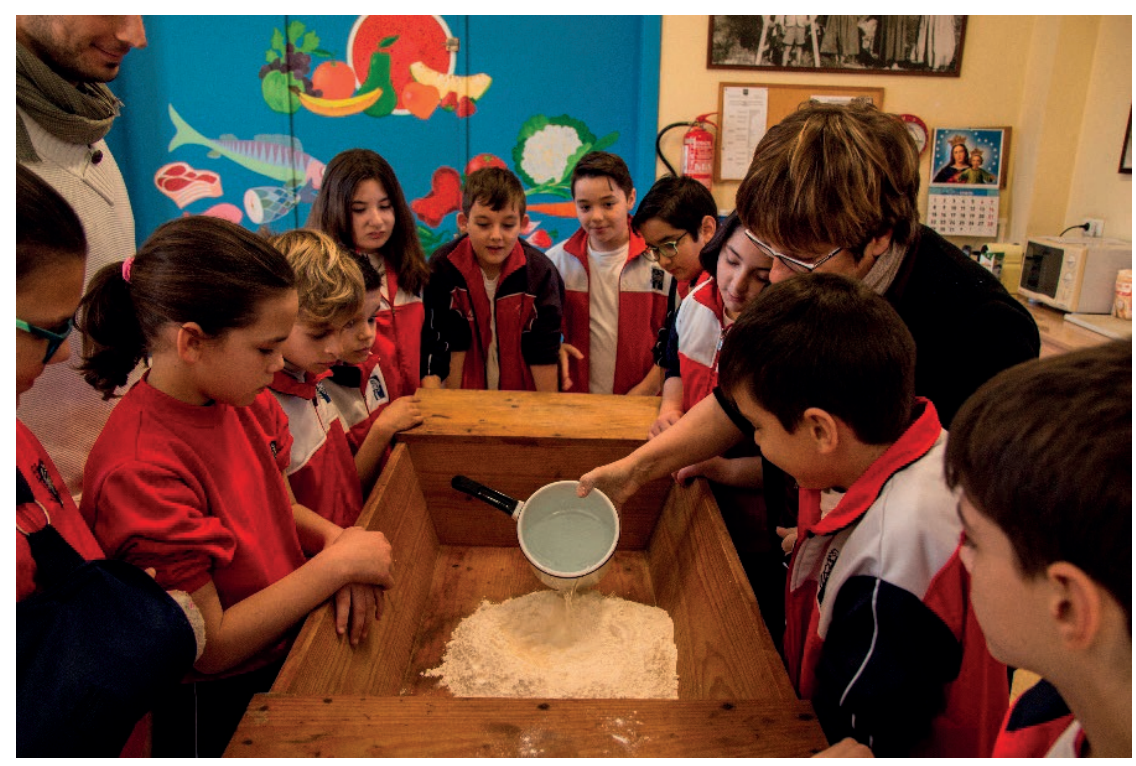

Figura 5. Taller de amasado de pan (2018). Fuente: Elaboración propia. 


\section{Referencias}

ABAD SALA, J., BELTRÁ ZARAGOZA, D., LUCAS GÓMEZ, F. J. y ORTEGA PÉREZ, J. R. (1999). "La vida, el azafrán y el mármol". En: Los inicios de la Modernización en Alicante 1882-1914. Alicante: Caja de Ahorros del Mediterráneo, pp. 88-89.

BROTONS GARCÍA, B. (1985). La agricultura ilicitana, de ayer a hoy. Alicante: Caja de Ahorros Provincial de Alicante.

BROTONS GARCÍA. B. y SOLER VICENTE. A. (1986). S'ha perdut una cultura del Camp d'Elx. Elche: el autor, pp. 73, 72.

GARCÍA FONTANET, F. y PÉREZ ALBERT, J. (s.f.). Proyecto: Centro Escolar del Camp d'Elx para la Integración al Medio, en fotocopia.

GOZÁLVEZ, V. (1977). El Bajo Vinalopó. Geografía Agraria. Valencia: Departamento de Geografía, Universidad de Valencia, pp.115, 120, 129, 137, 116, 136.

GREGORI BERENGUER, J.J. (1998). "Un fresco en la sociedad tradicional valenciana en el último compás del siglo XIX", en Valencianos del 98. Valencia: Diputación de Valencia, Museu d’Etnologia, p.15 y 16.

HERNÁNDEZ HERNÁNDEZ, F. (1994). Manual de museología. Madrid: Síntesis, pp. 201-230.

LACARRA, J., SANCHEZ, X. y JARQUE, F. (1997). Las Observaciones de Cavanilles doscientos años después, vol. IV. Valencia: Bancaja, p. 338.

MARTÍNEZ GARCÍA, R., PICÓ LEDESMA, I, ANIORTE PÉREZ, J., TRISTÁN RICHARTE, M. y SANCHO QUEROL, L. (2019). POEM. Proyecto Educativo-Museístico. Museo Escolar de Puçol. Elche: Proyecto Puçol.

PÉREZ SORIANO, F. (1996). "Los Comercios" en García Fontanet, F. La calle de El Salvador. Elche: Museo Escolar de Puçol, p. 40.

PONCE HERRERO, G. (1999). "La modernización de los servicios” en Los inicios de la Modernización en Alicante 1882-1914. Alicante: Caja de Ahorros del Mediterráneo, p. 195.

RAMOS FOLQUÉS, A. (1973). La industria, el comercio y la agricultura en Elche. Elche: el autor, pp. 185-191.

El Setiet. Boletín Informativo del Museo Escolar Agrícola de Puçol (1998), n 8. Elche: Museo Escolar de Puçol. <www.museopusol.com/media/descargas/23.pdf> [Consulta: 17 de julio de 2021].

El Setiet. Boletín Informativo del Museo Escolar Agrícola de Puçol (2007), n 18. Elche: Museo Escolar de Puçol. p.69. <www.museopusol.com/media/descargas/14.pdf> [Consulta: 17 de julio de 2021].

TRISTÁN RICHARTE, M. (2020). "¡Ya viene el chambilero!". www.museopuçol.com/es/ blog/?cat=5\&id=115\&dat=06\%202020 [Consulta: 17 de julio 2021]. 


\title{
PASTA, UN ARTE CON MUCHA CIENCIA
}

\author{
Andrea Ainsa ${ }^{\mathrm{a} 1}$, Adrián Honrado ${ }^{\mathrm{a} 2}$, Pedro Marquina ${ }^{\mathrm{a}}{ }^{3}$, J. Antonio Beltrán ${ }^{\mathrm{a} 4}$, \\ Juan Calanchea a5 \\ aAgroalimentario de Aragón IA2. Universidad de Zaragoza, España. \\ a1 andreaainsa6@gmail.com, ${ }^{22}$ adrihonfri@gmail.com, ${ }^{a 3}$ pmarquin@gmail.com, a4jbeltran@unizar.es, \\ a5calanche@unizar.es
}

\begin{abstract}
Pasta is one of the most popular dishes in the world made with durum wheat as its history and regulation show. Its consumption became widespread in the 15th century, but it was in the 16th century when pasta became a frequent meal among people with few resources due to its versatility and economy. This has been recorded in books, paintings, and advertising posters from different eras. Pasta as food is so iconic that a museum based in Rome, Italy, was dedicated to it in 1993. Its history reveals fusion and eclecticism that has promoted an interesting progression from the point of view of culinary creation, but also a technological and gastronomic perspective, by increasing the existent composition and offer. From the 15th century to the present, pasta has gone from being basic sustenance to a more complex and select food, but thanks to its excellent sensory acceptance, it has never lost its popular character, nor its affordability. Therefore, faced with such a noble and recognized food, there is nothing left but to try to enrich it and continue its legacy by incorporating other ingredients such as fish or seaweed, to continue promoting its enriching transculturation.
\end{abstract}

Keywords: pasta, wheat, history, creation, art, nutrition, gastronomy.

Resumen: La pasta es uno de los platos más populares del mundo hecho con trigo duro como lo muestra su historia y regulación. Su consumo se generalizó en el siglo XV, pero fue en el siglo XVI cuando se hizo una comida frecuente entre la gente de pocos recursos debido a su versatilidad y economía. Esto ha quedado registrado en libros, pinturas y carteles publicitarios de distintas épocas. La pasta como alimento es tan emblemática que se le dedicó en 1993 la fundación de un museo con sede en Roma, Italia. Su historia revela fusión y eclecticismo que ha promovido una progresión interesante desde el punto de vista de la creación culinaria, pero también desde una perspectiva tecnológica y gastronómica, al incrementar la composición y oferta existente. Desde el siglo XV hasta la actualidad la pasta ha pasado de ser un sustento básico a un alimento más complejos y selecto, pero aun así y gracias a su excelente aceptación sensorial nunca ha perdido su carácter popular, ni su asequibilidad. Por eso, frente a tan noble y reconocido alimento no queda sino tratar de enriquecerlo y continuar su legado incorporando otros ingredientes como pescado o algas, para seguir promoviendo su enriquecedora transculturación.

Palabras clave: pasta, trigo, historia, creación, arte, nutrición, gastronomía.

Citar como: Ainsa, A., Honrado, A., Marquina, P., Beltrán, J.A., Calanchea, J. (2022). "Pasta, un arte con mucha ciencia". En: Actas del III Congreso Internacional sobre Patrimonio Alimentario y Museos. 25-26 noviembre, 2021, Valencia, España. pp. 247-263. https://doi.org/10.4995/EGEM2021.2021.13365 


\section{Introducción}

La museología es considerada por muchos como una disciplina científica independiente, cuyo objeto de estudio es la actitud específica del hombre frente a la realidad, para otros es una ciencia social surgida de disciplinas científicas documentales y contribuye a la comprensión del hombre en la sociedad (Stránsky, 1980). Por su parte, el patrimonio, se puede comprender como el "conjunto de bienes culturales y naturales, tangibles e intangibles, generados localmente, y que una generación hereda/transmite a la siguiente con el propósito de preservar, continuar y acrecentar dicha herencia" (De Carli, 2006). Desde la museología se entiende lo patrimonial como una cualidad de un patrimonio inmaterial o material que se determina por poseer tres características inseparables, que deben ser identificadas por el grupo en cuestión: pertenencia, identidad y herencia (Garma y Sansoni, 2002).

Con base en lo anterior, el patrimonio alimentario se convierte en algo esencial para estudiar, analizar y comprender, pues juega un importante papel en la configuración de la cultura de los pueblos, y de la forma cómo estas actúan y han actuado entre sí, a lo largo del tiempo. Alimentarse es tan esencial para el ser humano como el acto de respirar, formando parte de la existencia misma del hombre. Los alimentos han sido determinantes en la evolución de la raza humana; llevándonos de ser cazadores y/o recolectores hasta agricultores y explotadores de recursos naturales (Calanche, 2018). Comer es necesidad, pero también es bienestar y placer. Por eso la comida está vinculada de forma indisoluble a la cultura y el folklore de los pueblos; siendo sus alimentos factores determinantes ya que están condicionados a la disponibilidad de recursos existentes en el ámbito circundante de las comunidades. No obstante, la alimentación como patrimonio y acervo trasciende en el tiempo y es capaz de evolucionar. Gracias a las transculturaciones, fusiones y evoluciones en los ámbitos tecnológicos, gastronómicos y culinarios (Calanche, 2018). Dentro de esta perspectiva el presente estudio pretende abordar un tema curioso, interesante y digno de estudio acerca del nacimiento y evolución de un alimento emblemático, la pasta.

La historia de la pasta muestra su comienzo tras el aprendizaje por parte del hombre del cultivo de cereales, así como de su posterior molienda. Debido en gran parte a las buenas condiciones climatológicas de diferentes lugares, se incrementó la siembra y producción de pastos, entre ellos de un cereal en específico, el trigo. Este cereal era manipulado con el fin de conseguir una harina, la cual se mezclaba con agua para obtener una masa que se secaba al sol con el objetivo de mejorar su conservación, pero a su vez, también su forma de transporte. Es así como nacieron nuevos alimentos hasta entonces desconocidos como lo son hoy en día el pan, la cerveza y la pasta (Giménez, 1961).

En el siglo XV, la pasta únicamente se consumía de forma ocasional en la cocina italiana, lo que se debía a lo rudimentario de su proceso de fabricación con apenas la utilización de un molino clásico con el que molturar el trigo. Seguido a esto, se procedía a un amasado manual en el que se le daba el formato que por aquel entonces resultaba más sencillo, el espagueti, debido a su facilidad para realizarlo manualmente. Por último, se realizaba un secado durante un largo periodo de tiempo colgando la pasta, aquellas largas hebras de masa, en varillas a la sombra. Aunque este proceso ha ido evolucionando a lo largo del tiempo, la materia prima con la que se realiza este tradicional alimento y a la vez, tan especial plato, siempre ha sido el trigo duro (Triticum durum) debido a su alto contenido en proteína lo que le atribuye una gran bondad desde el punto de vista nutritivo. 
La pasta de precaria preparación en la edad media se cocinaba sola, o con azúcar y especias, aunque muchas veces estos últimos ingredientes se les incorporaba por recomendaciones médicas. Estas modificaciones (recetas) con el paso del tiempo fueron dando paso hasta las recetas que hoy se conocen y degustan habitualmente en todo el mundo. Italia fue un punto de inflexión para el cambio de percepción de la pasta; ya que durante el renacimiento en el año 1421 Bartolomé Platina, mejor conocido como de Sacchi, revolucionó la cocina y en especial el modo de ver, hacer y comer la pasta. Así finalmente pasó a la posteridad como el creador de la cocina italiana e impulsor de la actual y reconocida gastronomía italiana. A partir de este momento, ya la forma común de consumir pasta con la mano fue sustituida gradualmente por el tenedor de cuatro puntas de invención reciente para la época (Guerrero, 2019).

El consumo de pasta empezó a generalizarse y a hacerse frecuente entre la gente humilde en el siglo XVI cuando, además, se fueron ampliando los formatos utilizados. Este producto era muy asequible debido a su bajo coste y gran versatilidad. En 1700 se dio comienzo a una época de prosperidad para este tradicional alimento que hasta entonces se había obtenido en grandes superficies artesanales mezclando harina con agua y amasando con los pies como en otros alimentos (el vino), pero esto suponía una falta de higiene además de cantidades limitadas de producción. Debido a este aumento de popularidad, en el siglo XVIII se construyó una pequeña empresa pionera en la elaboración de pasta. Ya en 1823, y con años de experiencia en la elaboración de pasta, se propuso un sistema basado en el "uomo di bronzo" (hombre de bronce) un mecanismo que mejoraría este problema y facilitaría su fabricación obteniendo mayores cantidades y una mejor calidad del producto. Debido a la buena aceptación de los consumidores italianos y, por ende, mayor consumo, en el siglo XIX, se produjo una mayor industrialización. Finalmente, en 1950, este consumo se comenzó a expandir por todo el mundo para llegar al lugar que ocupa hoy en día.

La pasta no sólo ha mostrado esta evolución en su fabricación, sino que también lo ha experimentado en su forma de preparación culinaria. Ya en el siglo XV se han podido hallar diversas recetas de pasta en una antigua publicación titulada "Libro de arte coquinaria". Sin embargo, a finales del siglo XIX, la producción de pasta seca como producto industrial seguía siendo minoritaria como muestra el recetario italiano más importante del momento, es decir el Pelegrino Artusi titulado "La scienzia in cucina e l'arte de mangiare bene" de 1891 donde solo 10 recetas de las 800 que eran en total correspondían a platos de pasta seca. Durante el siglo XX, el consumo de pasta seca se extendió rápidamente en la sociedad comenzándose a "poner de moda" su elaboración tras lo cual se crearon diferentes platos como lo han demostrado numerosos cocineros y chefs tanto en libros de recetas como en sus respectivas ofertas gastronómicas.

En el caso particular de España, existen múltiples ejemplos de recetarios donde se menciona la pasta desde el siglo XVII hasta la actualidad. Ya en 1837 cuatro recetas de pasta aparecen en "El manual del cocinero" publicado por Mariano de Rementería. Aunque en años posteriores no se le presta demasiada atención a la pasta, a principios del siglo XX se inicia su consumo en otro formato, y se habla de los canelones, que durante mucho tiempo fue un plato dominical obligado de la burguesía catalana y, además, atractivo de los restaurantes más modernos de Barcelona. A su vez, también se hacen muy populares las cazuelas de fideos típicas en Cataluña, con grandes campañas publicitarias, y las "fideuas levantinas" que principalmente se preparaban con productos obtenidos de la matanza y más tarde se modernizaron con marisco como ingrediente único. Durante los años 80, una potente campaña de Pastas Gallo protagonizada por Karlos Arguiñano 
y Sofía Loren causó que este alimento pasase a un lugar privilegiado en la gastronómica ibérica y lo que se consideraba comida de pobres y de cuarteles se convirtió en un deseado plato querido por niños, deportistas y por aquellos que cuidaban su alimentación, más desde una perspectiva hedónica (Díaz, 2017). Es muy difícil que exista hoy en día, especialmente dentro del marco de la creciente globalización en que se vive, una cocina original o pura, sin influencias externas, porque éstas siempre, afortunadamente, existen para diversificar y enriquecer la dieta alimentaria (Calanche, 2009).

\section{El propósito}

En primer lugar, el objetivo de este estudio es divulgar la importancia de un alimento milenario y trascendente como lo es la pasta, desde la perspectiva de la alimentación del hombre a lo largo de su historia, con el fin de garantizar y preservar su acervo cultural, así como el rol que ha desempeñado a través del tiempo, lo que constituye para la museología, un objeto de estudio imprescindible. En segundo término, pretende identificar y valorar las propuestas existentes en la actualidad para tan noble alimento, y que constituyen para un ecléctico movimiento vanguardista la conjugación ideal entre ciencia, tecnología y arte culinario que da lugar a una excelente propuesta gastronómica.

\section{Desarrollo de la innovación}

La pasta siempre ha sido considerada un alimento básico con una gran aceptación debido a su fácil producción, transporte y almacenaje además de su versatilidad y economía. Como se ha podido ver a lo largo de su historia, la pasta ha experimentado un gran cambio tanto a nivel industrial como a nivel gastronómico. Con el paso del tiempo, la incorporación de diferentes salsas que atribuyen diferentes sabores, además, de otras matrices alimentarias que les otorga propiedades nutricionales y sensoriales a los platos elaborados con pasta ha ido cobrando importancia. Para seguir la tradición de innovar con un alimento básico y tradicional como es la pasta, se ha recurrido a la idea de incorporar nuevos ingredientes en su fabricación con el fin de conseguir mayores beneficios nutricionales con el alimento propio y no exclusivamente con la adición de salsas en sus platos. Esta nueva propuesta puede partir del uso de alimentos tradicionales, tales como: carnes, pescados, verduras, especias, huevo y/o cereales; o de otros alimentos no tradicionales, los que se denominan en inglés como novel foods -innovadores- que abarcan especialmente algas, otros cereales como la espelta, hongos e hidrolizados entre otros. Desde la linea de investigación SEA2PASTA desarrollada por el Grupo de Referencia "Calidad y Tecnología de la Carne A04_17R" de la Facultad de Veterinaria de la Universidad de Zaragoza, se pretende avanzar hacia nuevas propuestas alimenticias que integren de manera armoniosa distintos elementos de la dieta para lograr pastas de cereales con múltiples ingredientes en su composición que además han sido desarrolladas bajo la concepción de "alimento hecho a la medida" para beneficiar a la mayor cantidad de personas posibles tomando en cuenta su amplia variedad de gustos, criterios y sobre todo requerimientos (Figura 1). 


\title{
28coarta
}

\author{
Del mar a la pasta...
}

Figura 1. Logo de la linea de investigación en pasta, del Instituto Agroalimentario de Aragón (IA2).

El nuevo concepto ofrece una alternativa gastronómica que puede al mismo tiempo jugar con los sabores de la propia pasta y de las salsas que se le incorporen. Todo ello surge de una combinación de influencias del entorno, del régimen alimentario y/o del intercambio cultural. Al encontrarse España situada en una zona mediterránea, disponiendo tanto de montaña (tierra) como de océano y mares (mar), se piensa en llevar la idea de incorporar esta variada oferta de la zona, a este alimento básico y de amplia expansión a nivel mundial. Aunado a lo anterior, los tiempos han cambiado y la preocupación actual por la alimentación saludable y de calidad hace pensar en diferentes ingredientes que presenten beneficios nutricionales con la utilización de fuentes alternativas como cereales y alimentos no convencionales tanto para aquellos consumidores o clientes que lo desean como para aquellos otros que lo tengan como necesidad debido a alguna enfermedad o intolerancia alimentaria.

Como ya se ha destacado con anterioridad, las influencias culturales son muy importantes en el desarrollo de cualquier innovación y en especial cuando se trata de alimentación. La incorporación de algas para conseguir un alimento a un estilo "más oriental", de hongos foráneos para obtener un toque "más exótico" y/o de especias para obtener un producto con un sabor "peculiar" más intenso son algunas de las muestras de la transculturación en este apreciado alimento que han logrado enriquecerlo, favoreciendo su globalización. Además, es bien sabido que la pasta enriquecida con compuestos bioactivos (es decir aquellos que presentan un beneficio específico para la salud humana respaldados por la veracidad científica) y que proceden de fuentes como el pescado o las algas; tras su cocción para alcanzar el punto conocido como "al dente" antes de su ingesta representa una forma eficaz para mejorar la nutrición humana (Ainsa et al., 2021).

\section{Resultados}

La pasta actualmente es el resultado de un proceso dinámico, en permanente cambio debido a que se va ajustando a las diferentes épocas y tiempos que discurren desde su aparición. Sin duda alguna, en la actualidad, este alimento ha sido mejorado desde un punto de vista global. Se han introducido variedad de sabores combinados, logrando además incrementar su valor nutricional y su aceptación por parte de los consumidores. A día de hoy, se puede afirmar sin temor a equivocarse que se trata de un "alimento funcional" que logra el propósito establecido desde un punto de vista hedónico, gracias a la generación de particulares y acertadas sensaciones. En tal sentido, los hallazgos de esta comunicación muestran las evidencias de todo lo que ha sido, es y será este alimento. La pasta es el testimonio de una línea de tiempo admirable que necesita ser registrada, protegida, exhibida y exaltada. Todo un ejemplo, digno de admirar y para lo cual la museología se constituye en un elemento clave de entre otras muchas maneras. 
En los hallazgos, al constatar las diferentes pinturas y escritos existentes, ha quedado en evidencia el progreso de la pasta tanto en su fabricación como en su preparación, Este hecho ha representado un verdadero "salto tecnológico" donde el tiempo ha sido testigo de este vertiginoso avance, sobre todo en lo que a elaboración se refiere, pasando del más puro y rudimentario proceso manual hasta el más sofisticado mecanismo industrial. En los inicios del cultivo de trigo, las familias realizaban las labores del campo de forma manual y asimismo se realizaba el aprovechamiento de este cereal tras su cosecha, tal y como se puede observar en las pinturas de la Figura 2.

Así el proceso inicial de fabricación de la pasta se llevaba a cabo empleando un molino tradicional con una capacidad limitada de hasta 1000 kg, en el mejor de los casos, y que podían girar a razón de unas 60 vueltas por minuto. Tras la molienda se obtenía la sémola, producto burdo que posteriormente requería de un tamizado de donde se obtenía la "semolina" con la que se elaboraría la pasta. A diferencia de la cosecha y molienda, esta operación era exclusivamente realizada por mujeres y aunque todo se hacía de forma manual, ya se observaban importantes avances en el secado con el fin de facilitar su transporte. Muchas iconografías antiguas muestran este laborioso proceso (Figura 3).

Como se ha mencionado previamente en el caso específico de la pasta, la evolución en su proceso de fabricación introdujo nuevas maquinarias dentro de la que destaca el emblemático
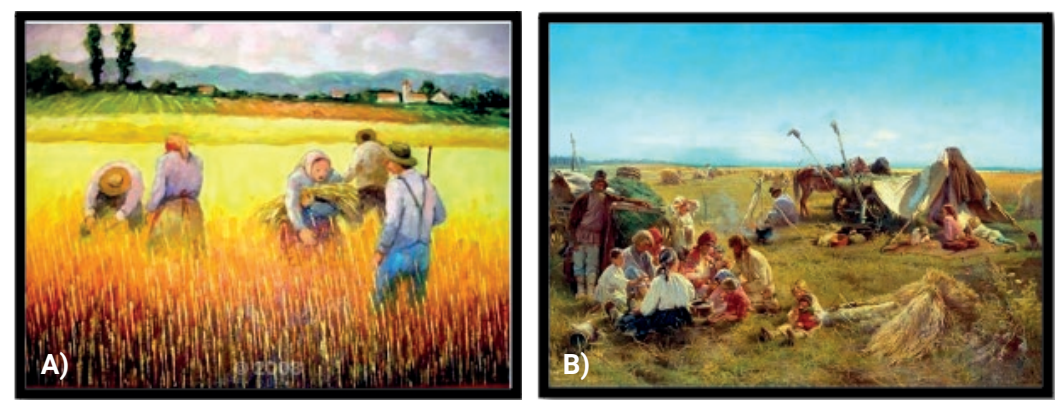

Figura 2. A) Campo de trigo de Fernando Ikoma (2008) y B) Almuerzo campesino durante la cosecha de Konstantin Makovsky (1871).
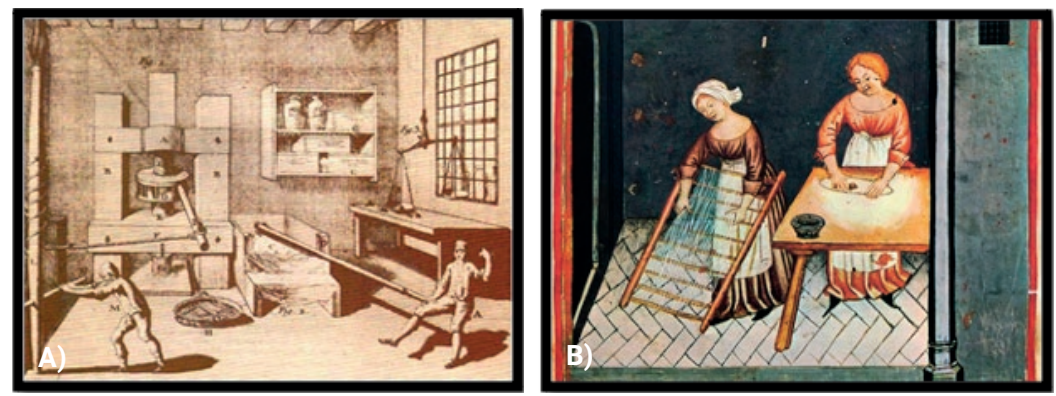

Figura 3. A) Molienda de trigo y B) Tamizado de sémola (Talla del año 1300). Fuente: https://www.baroque.it/cucina-barocca/storia-della-pasta-e-del-pomodoro.html 
"uomo di bronzo" (Figura 4). Este mecanismo pionero en su época permitió una mejora industrial de magnitud con lo cual se llegó a producir hasta $125 \mathrm{~kg}$ en 2 horas y evidentemente con una calidad mucho más homogénea. En este momento, ya se había producido una migración desde un proceso empírico, manual y limitado a las mujeres con más de arte que de ciencia, hacia un proceso mecanizado dominado por la tecnología y con la participación de hombres. Gracias al desarrollo e incorporación de máquinas y más aún después de la revolución industrial, los viejos procesos transmitidos de boca a oído y legados de una generación a otra, comienzan a coexistir con planos, formulaciones y especificaciones impresas en documentos, progresando hasta convertirse en las sofisticadas industrias que existen en la actualidad.

Este progresivo cambio en la forma de "hacer la pasta" y el aumento del "cómo comer la pasta", es decir su consumo; dio lugar a otros muchos cambios entre los que destacan los distintos formatos de presentación. En la actualidad existen un amplio número de formatos que proporcionan un gran abanico de posibilidades gastronómicas que se han ido incrementado con el tiempo. Aunque antiguamente algunos de esos formatos ya se conocían, como es el caso de la lasaña o los fideos que se elaboraban comúnmente con masa fresca, el resto de los formatos se denominaban genéricamente como macarrones.

De hecho, el término maccaronaro se refería no sólo al que vendía la pasta ya cocida, sino que también al que la producía. Se dividieron en dos categorías: el que tenían una ubicación fija y los vendedores ambulantes. Los primeros la cocinaban en su propio kiosco, en una olla grande, los macarrones venían servidos todavía calientes. Ya que aún no existía el tomate, los únicos condimentos eran aceite, sal, pimienta y los muchos quesos que se rallaban sobre los macarrones regalándole su sabor único e inimitable. Los segundos, en cambio, atravesaban la ciudad con una cesta en el cuello en el cual se transportaban los macarrones cocidos. A pesar de no ser siempre calientes consiguieron gran éxito ya que los "maccheroni" podían alimentar a toda la familia por pocas monedas (Makkeroni, 2017). El término pasta no se utilizó con el significado que se le da hoy en día, nada menos que hasta el siglo XX. Hasta entonces hablar de pasta habría significado referirse a una masa genérica para pizzas, tartas o preparaciones parecidas, así mismo los distintos formatos de pasta no se percibían como diferentes formas del mismo producto gastronómico, así, los maccheroni eran maccheroni y los vermicelli eran vermicelli, sin

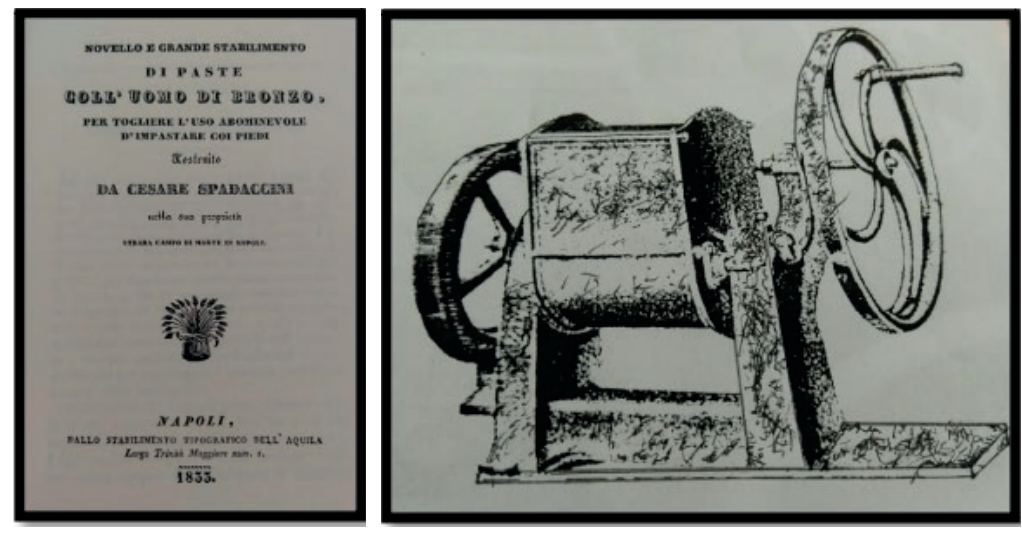

Figura 4. "il uomo di bronzo" iconografía antigua de elaboración de pasta. Fuente: http://www.medagliani.com/luomo-di-bronzo/ 
más (Coronna, 2016). En 1824 se menciona por primera vez la palabra spaguetti en la ópera titulada "Los macarrones de Nápoles" para dar nombre a la pasta seca con forma de "cordón" que se elaboraba en la época y que se comía con la mano como muestra la pintura de la Figura 5.

La costumbre de comer con la mano refleja otro interesante hecho cultural asociado a las buenas prácticas higiénicas durante la preparación y consumo de alimentos en épocas pasadas. La introducción de cubiertos y especialmente de tenedor y cucharas con el protocolo que "sentarse a la mesa” implica, conllevó a una transición positiva desde el punto de vista de la higiene personal y la sanidad pública.

Por otro lado, en cuanto a la pasta, se comienza a escribir y llevar registros de recetas y procedimientos específicos para elaborarla, especialmente los tradicionales macarrones. La figura 6 muestra la primera receta documentada de este tipo de pasta, en un libro publicado en 1390

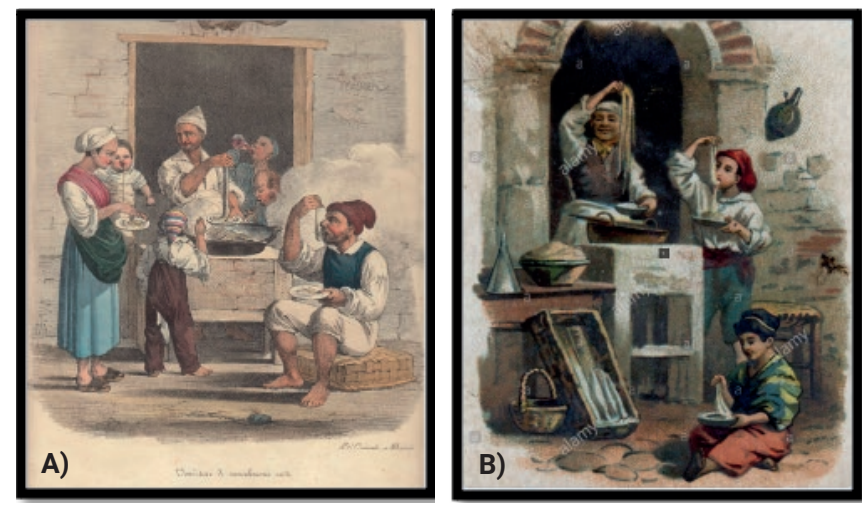

Figura 5. A) II Maccaronaro, Venditore di Spaghetti, Hjalmar Morner (1827) y B) Maccaronaro, un cuisinier preparant les pates macaroni (maccheroni) dans les rues de Nápoles. 1845. Anonimus (www.alamy.com).
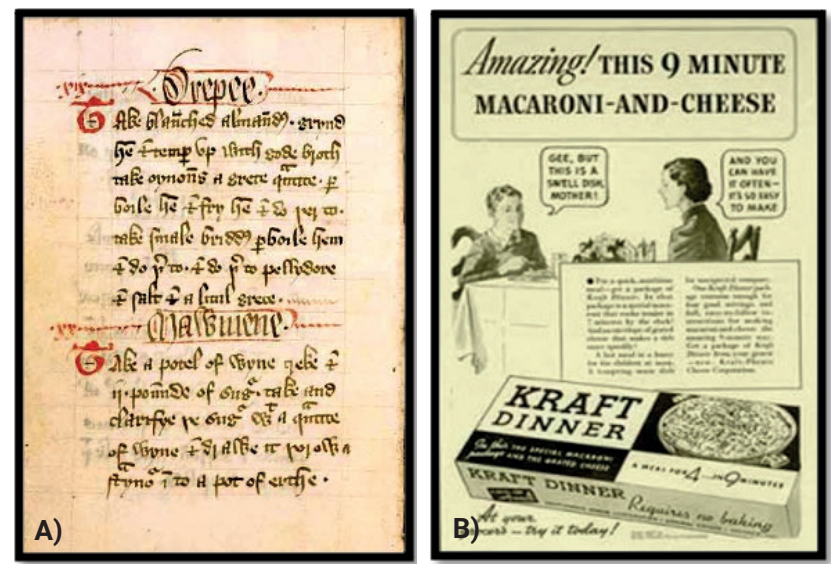

Figura 6. A) Receta original para Makerouns (1390) y B) Macarrones precocinados (1930). Fuente: Quesada (2016). 
de título "Forme of cury" que recopila las recetas elaboradas por los cocineros del rey Ricardo II de Inglaterra (A). La segunda imagen (B) por su parte, corresponde a una instrucción de uso del año 1930, siete siglos después, para macarrones precocinados en los Estados Unidos de América durante la gran depresión como comida barata y de fácil preparación.

El proceso de innovación de la pasta ha ido progresando y han surgido maneras de clasificación según su forma y corte tanto para pasta fresca como seca. En el siglo XXI, ya existen infinidades de pastas alimenticias, las especiales, las alargadas, cortas y por supuesto las rellenas, todas en centenares de formatos que se pueden encontrar tanto en supermercados como en restauración (Figura 7).

Como se ha dicho diversas clasificaciones han ido apareciendo a lo largo del tiempo, pero en todas ha estado recurrente la idea de la "pasta especial". Se trata o denomina como pasta especial aquella que se elabora con ingredientes adicionales al trigo que le atribuyen distintas características sensoriales (colores, sabores, olores o aspectos) o que simplemente logran una mejora nutricional. Todos ellos han sido indispensables en la cultura de la pasta, pero sin duda, la gastronomía también ha tenido un papel fundamental en todo esto. Como se podía leer en alguna publicación del siglo XV, los macarrones sicilianos podían cocinarse con caldo, leche o leche de almendras y servirse con queso rallado, azúcar y especias.

La sazón de quien preparaba el plato elaborado a base de pasta de trigo se constituía en un elemento determinante para su preferencia y aceptabilidad por parte de los miembros de la
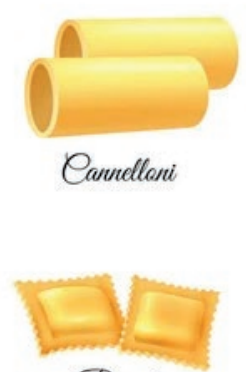

Raviali
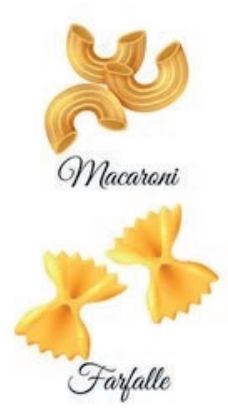

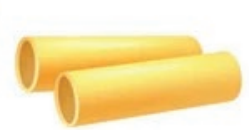

Rigateni

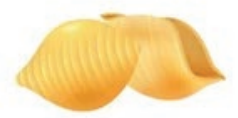

Conchigliette

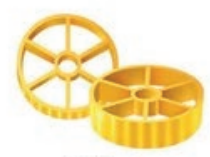

Ruate

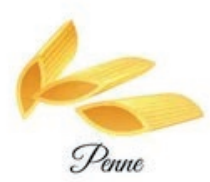

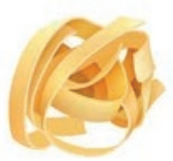

Fettucaine

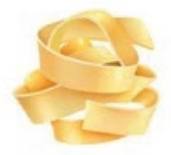

Sagliatdle

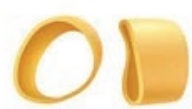

Ditaleni

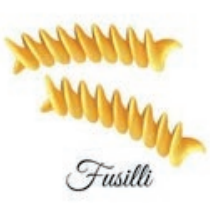

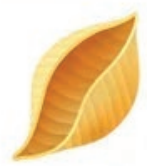

Conchiglie
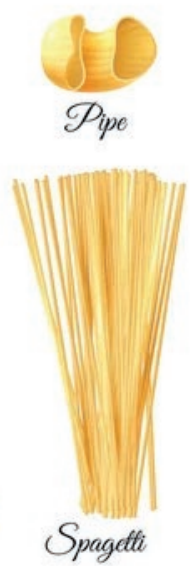

Figura 7. Formatos más comunes para pasta alimenticia. Fuente: https://es.vecteezy.com/arte-vectorial/475961-tipos-de-pasta-infografia 
sociedad. No obstante, como consecuencia de la masificación y el progreso la inclusión de salsas fue cambiando de cierto modo este toque peculiar que daban los cocineros de calle. Ahora la pasta, escurría salsa y este hecho fue el causante de la introducción del tenedor para poder comerla. El antiguo tenedor para trinchar que hasta entonces presentaba dos puntas, debido al pujante consumo de espagueti se le añadieron dos puntas más con el fin de que los susodichos se enrollasen bien. La figura 8, muestra este cambio en el hábito de consumo a través de viejas publicidades de inicios del siglo XX.

Después del siglo XX se ha producido en el caso de la pasta alimenticia una fusión extraordinaria entre tecnología, marketing y gastronomía, que va quedando reflejado a lo largo del tiempo gracias al arte, la historia y la publicidad. A continuación, y a modo de ejemplo se exponen algunos ejemplos muy ilustrativos que se han producido en España (Figura 9). En 1926, aparecía un cartel de unas pastas alimenticias al estilo italiano en el cual figuraba un cocinero comiendo espaguetis a la vieja usanza, es decir con la mano. Más tarde, este tipo de publicidad siguió vigente y en el año 1950, surgieron otros carteles como el de macarrones de la marca "Pedragosa", en el que ya se ve el sofisticado uso del tenedor de varias puntas para comer macarrones y por último el de tallarines de la marca "Castillo" donde queda claro la preferencia de los niños ante este tipo de alimento. Esto último, pasa a ser un hito para la industria de la pasta alimenticia que identifica y dirige esfuerzos hacia un público infantil ahora muy ávido de este alimento.

En todos los carteles mostrados anteriormente se trataba de pasta simple, aunque ya se incorporaban diferentes formatos por lo que el avance desde una perspectiva general era evidente. Desde entonces y hasta ahora, han surgido nuevas recetas para la fabricación de pasta, pero ahora fortaleciendo el carácter de "especial". Y así, han surgido muchas de diferentes colores con el fin de ser más atractivas visualmente y además en algunos casos pretendiendo lograr un beneficio nutricional. Algunos ejemplos de esto serían las pastas de verduras de diferentes
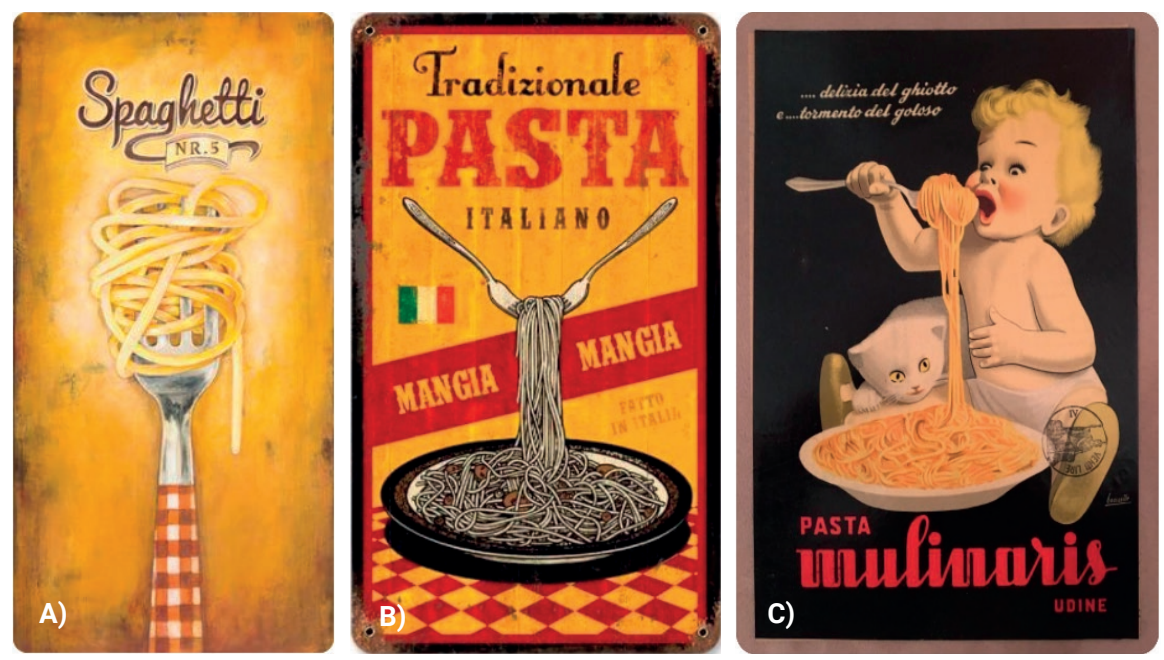

Figura 8. A) Boceto de una etiqueta, B) Publicidad comercial de una marca y C) Placa de Metal "vintage". Fuente: eu.art.com, jackandfriends.com y Old Italian food de R. Rosi. (www.pinterest.com) 
colores o la pasta con tinta de calamar para dar ese color negro que sea llamativo para el consumidor (Figura 10).

Cada día surgen nuevas gamas de pasta especiales con distintos sabores, ingredientes y propósitos un ejemplo de ello es la colección "Sabores" de la empresa aragonesa "Pastas Alimenticias Romero S.A.", con sus ofertas de pasta "con ajo y picante" y la otra al "limón y pimienta" (Figura 11).

El consumidor, ya conociendo y disfrutando de lo tradicional ahora desea que se le ofrezca algo más, sin necesidad de recurrir para esto siempre a la elaborada confección que ofrecería la restauración como opción gastronómica y por esa razón nuevos tipos de pasta, ahora con una definición que comienza a hacerse ambigua, surgen como propuestas de innovación y desarroIlo. Un ejemplo de lo anterior se tiene con el lanzamiento de los productos "la pasta del mar" que lejos de ser una linea tradicional que mantiene el trigo como ingrediente y elemento culinario
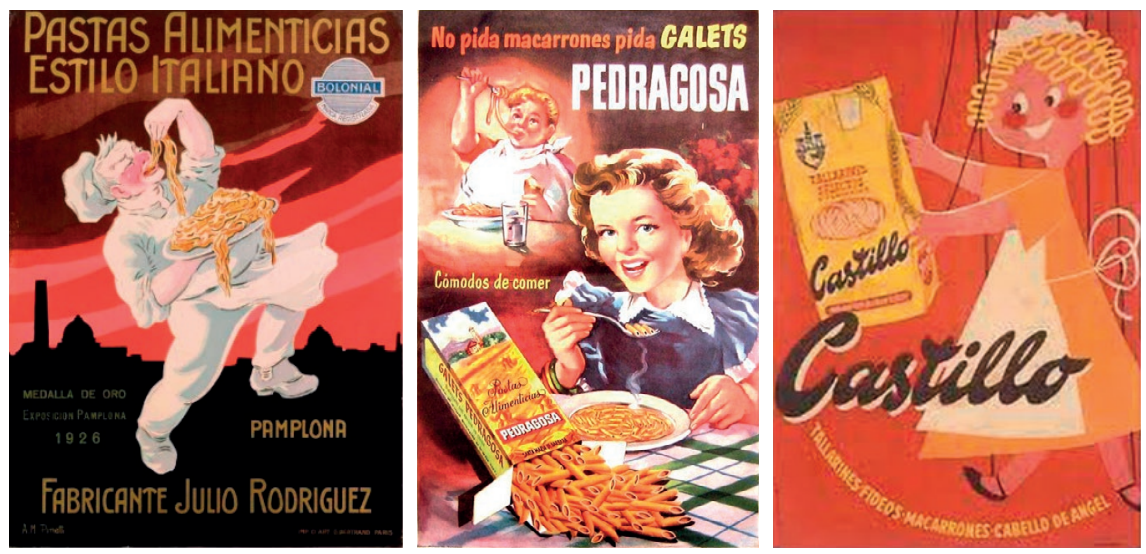

Figura 9. Anuncios comerciales de pasta alimenticia a través del tiempo. Fuente: Alimentos con Historia: Pastas alimenticias (Díaz, 2017).
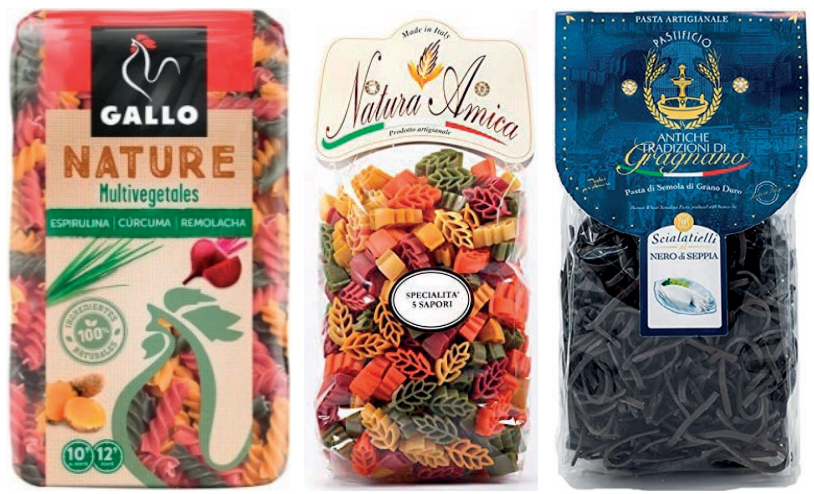

Figura 10. Pastas alimenticias del tipo especial en el siglo XXI. Fuente: www.pastasgallo.com, www.olivenoelausitalien.com y www.lb.brate.com 
principal lo sustituye por surimi de pescado extruido, a semejanza de la semolina, usando formatos corrientemente empleados por la industria de la pasta (Figura 12).

La pasta del mar constituye un ejemplo interesante, digno de quedar registrado en la historia de lo que constituye una deformación originada por una profunda influencia gastronómica de la mano de un cocinero hacia un concepto tradicional como lo es la pasta de trigo. Sin embargo, no es menos cierto que ésta surge dentro de esa corriente innovadora que busca diversificar el consumo de pescado que es un alimento de nobles bondades al igual que el trigo. Otro ejemplo, de la adaptación de la pasta a los tiempos que discurren, es la aparición de propuestas basadas en cereales distintos del trigo, con un noble propósito, hacer este tipo de alimento bien sea laminado o extruido accesible para todo tipo de consumidores incluyendo aquellos que por razones de salud (enfermedad celiaca, alergia o intolerancia) no pueden consumir trigo.

A pesar de que parezca que esta propuesta es novedosa, realmente no lo es del todo pues desde la cocina italiana siempre existieron alternativas para los productos obtenidos de la semolina, un claro ejemplo de esto lo constituían los "gnocchi" preparados a base de patatas hervidas. La figura 13 exhibe algunos de los productos que pretenden cubrir esta oferta de "pasta sin trigo".

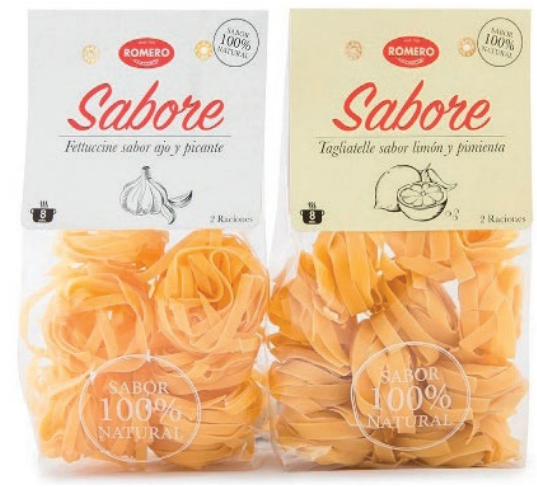

Figura 11. Pastas especiales de la marca Romero además en formato nidos que le dan un carácter gourmet. Fuente: www.pastasromero.com

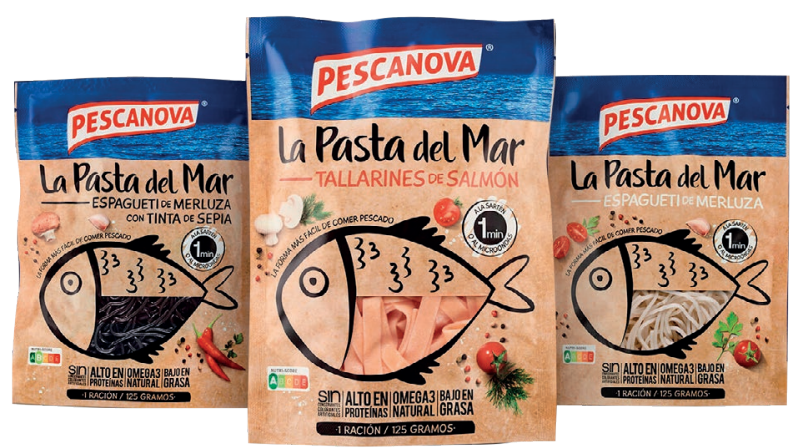

Figura 12. La Pasta del Mar, oferta gastronómica a base de pescado que emula pasta alimenticia. Fuente: www.pescanova.com 
A pesar del propósito que desee lograr la innovación introducida en el campo de la pasta alimenticia cabe destacar que desde el punto de vista de la legislación española vigente (Real Decreto 2181/1975 modificado en el 2013) todos estos innovadores alimentos de los que se han hecho referencia no son ni llegarán a ser, salvo que la norma se modifique, reconocidos como "pasta alimenticia" pues no se ha usado trigo durum en su fabricación. Por ello la propuesta de este ensayo, no busca sustituir el trigo en el diseño de los nuevos alimentos funcionales hechos a la medida, sino que apuesta por una conjugación armoniosa sensorialmente hablando, atractivo desde el punto de vista del mercado y garante del noble legado que posee el trigo como fruto de la tierra y del trabajo del hombre. Salvo aquellos casos, en que una oferta incluyente de elaboración y claro está salvando las distancias pertinentes, permita llegar a todo tipo de público. Desde el punto de vista socio-cultural e histórico la innovación pretende continuar manteniendo la esencia de la pasta como alimento derivado del trigo. Un alimento que además de aportar los nutrientes necesarios y todavía más, si se encuentra enriquecida con otros ingredientes, sea capaz de llevar a los consumidores por esas sensaciones que solo la verdadera pasta puede dar.

Antes de concluir, cabe una mención especial para el rol de la pasta dentro de la sociedad a lo largo de la historia. La pasta suele estar presentes en momentos de compartir y regocijarse en la compañía de seres queridos y como muestra de afecto. También se asocia a humildad y simpatía en personajes famosos de la historia o simplemente hace alusión a hechos sociales que marcan y han marcado la historia del hombre. En la figura 14, se observa, en primer lugar (A), la presencia de la pasta en el séptimo arte, el cine, en una película infantil inolvidable (la dama y el vagabundo, 1955, WaltDisney ${ }^{\circledR}$ ) para destacar un momento especial entre dos amantes.
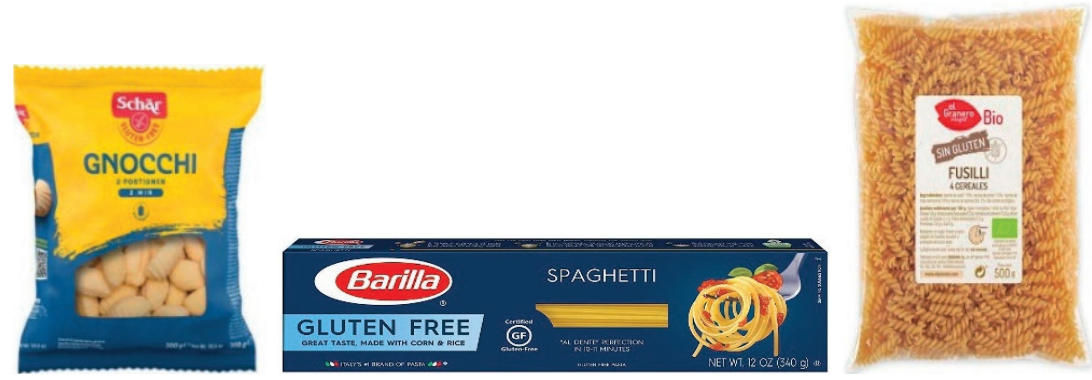

Figura 13. Pastas sin gluten: A) Ñoquis de patatas, B) Espaguetis de maíz y C) Fusillis de 4 cereales. Fuente: www.smartfooding.com, www.barilla,com y www.elgranero.com
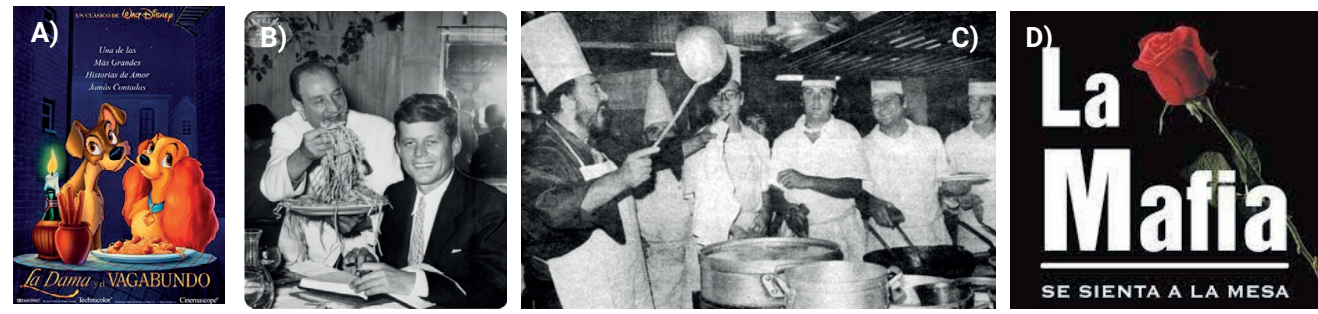

Figura 14. Imágenes diversas de personajes reales y ficticios de la historia. Fuente: Google Images (2021). 
En segundo término (B), se muestra una ilustración del icónico presidente de USA J.F. Kennedy degustando un plato de linguini Alfredo junto a su creador Alfredo Di Leio durante su visita a Roma (1957). Seguidamente se observa al famoso tenor L. Pavarotti cocinando pasta durante su visita a Bilbao en el restaurante el Bermeo en 1978. Por último, destaca el logo (2021) de una empresa con más de 20 años de trayectoria en España, dedicada a la elaboración y venta de pasta que aprovechando la tradición culinaria de una tierra (Sicilia) la vinculó a una de las más famosas organizaciones clandestinas, surgida también en su mismo seno.

\section{A manera de conclusión}

La pasta más allá de un alimento es una acervo histórico y cultural que prevalecerá en el tiempo para las generaciones futuras. La mejor forma de salvaguardar ese legado es mantener en lo posible su esencia viva y sin intromisiones. Promover su consumo y garantizar el suministro en cantidad y calidad de los ingredientes necesarios para su preparación. Tanto su fusión como su evolución gastronómica debe ser armoniosa y respetando los rasgos diferenciadores que la caracterizan. No obstante, como el producto de la mente del hombre que es no está exenta de ser modificada, pudiendo ser sometida a mejoras eclécticas mediante combinaciones tecnológicas, culinarias y artísticas que, pese a que supongan cambios en el alimento, sigan manteniendo desde un punto de vista técnico y económico, su esencia como el producto emblemático que es, ya que hoy en día resulta indispensable para las dietas de muchos seres humanos en cualquier parte del mundo como resultado de la postmodernidad que caracteriza a este siglo XXI.

\section{Referencias}

AINSA, A. IRANZO, L. HONRADO, A. MARQUINA, P. RONCALÉS, P., BELTRÁN, J. y CALANCHE, J. (2021). "Effects of cooking over the stability of fatty acids as bioactive compounds in enriched pasta with a fish by-product". En: Cereal chemistry. https://doi.org/10.1002/cche.10481

DE CARLI, G. (2006). "Los museos latinoamericanos”. En: La gaceta de museos, 37 (febrero - mayo), pp. 8-11.

CALANCHE, J. (2009). "Influencias culturales en el régimen alimentario del venezolano". En: Anales Venezolanos de Nutrición, 22(1), pp. 32-40.

CALANCHE, J. (2018). La alimentación en la sociedad venezolana: un devenir histórico. Editorial Académica Española.

CORONNA, C. (2016). L'alto forno. http://www.laltoforno.com/acerca-la-pasta-una-cuestion-identidad/ [Consulta: 15 de septiembre de 2021]

DÍAZ YUBERO, I. (2019). "Pastas alimenticias". En: Díaz Yubero, Ismael. Alimentos con historia. Madrid: Mercasa.

España. Decreto 2181/1975, de 12 de diciembre, por el que se aprueba la Reglamentación TécnicoSanitaria para la Elaboración, Circulación y Comercio de Pasas Alimenticias. BOE, 13 de septiembre de 1975, núm. 220. 
GARMA, E. y SANSONI, A. (2002). “Museo y desarrollo personal. La apropiación personal del contexto patrimonial como desafío museológico". Tesis de grado. Universidad Tecnológica Equinoccial, Quito, Ecuador.

GIMÉNEZ, O. (1961). Del trigo y su molienda. Buenos Aires: Editorial Universidad de Buenos Aires.

GUERRERO NAVARRETE, A. (2019). Diseño de tenedor para plato fuerte. Instituto tecnológico de Celaya, México.

QUESADA, F. (2016). Macarrones con queso. https://www.frquesada.com/macarrones-con-queso/ [Consultada: 2 de septiembre de 2021].

MAKKERONI. (2017). Historia de la pasta, los "maccaronari". https://makkeroni.cat/historia-de-lapasta-los-maccaronari/ [Consultada: 25 de agosto de 2021].

STRÁNSKY, Z. 1980. "Museology - Science or Just practical museum work?" En: Museological Working Papers, 1, pp. 42-44.

"La historia de la pasta italiana - documental historia - historia de la comida. La Ha de Italia" Youtube $<$ https://www.youtube.com/watch?v=D6tScU_AYp8>. 



\title{
COMUNICACIÓN CULINARIA EN REPÚBLICA DOMINICANA: TECNOLOGÍA, CHEFS, FOOD STYLISTS Y FOODIES
}

\author{
Maricha Martínez Sosa ${ }^{\mathrm{a} 1}$, Lucero Liriano ${ }^{\mathrm{a} 2}$, Georgina Batista Schrils ${ }^{\text {a3 }}$ \\ ${ }^{a}$ República Dominicana \\ a1 info@marichams.com, a1 Lucero.liriano@gmail.com, ${ }^{a 1}$ gbatista1903@gmail.com
}

\begin{abstract}
Technological development has transformed what we eat and how we enjoy it. Gastronomy has evolved, and this is reflected in the progressive use of innovative formats and communication platforms, which have also influenced the rituals of food socialization. The popularity of new media has led to an increase in the creation of gastronomic content in the Dominican Republic. In order to address it, this research has been carried out taking two axes as a point of analysis: the bibliography on the food heritage of this Caribbean country and the profiles of subjects, brands, and initiatives that serve as digital ambassadors of this culinary culture and use the networks to generate impact on society.
\end{abstract}

Keywords: chefs, communication, culinary, Dominican Republic, food stylists, foodies, gastronomy, technology.

Resumen: El desarrollo tecnológico ha transformado qué comemos y cómo lo disfrutamos. La gastronomía ha evolucionado y esto se refleja en el uso progresivo de innovadores formatos y plataformas de comunicación, que han influenciado también los rituales de socialización de los alimentos. La popularización de los nuevos medios ha propiciado que la creación de contenido gastronómico en la República Dominicana aumente. Para abordarla se ha hecho la esta investigación tomando como punto de análisis dos ejes: la bibliografía en torno al patrimonio alimentario de este país caribeño y los perfiles de sujetos, marcas e iniciativas que fungen como embajadores digitales de dicha cultura culinaria y se valen de las redes para generar impacto en la sociedad.

Palabras clave: chefs, comunicación, culinaria, República Dominicana, food stylists, foodies, gastronomía, tecnología.

Citar como: Martínez Sosa, M., Liriano, L., Batista Schrils, G. (2022). "Comunicación culinaria en República Dominicana: tecnología, chefs, food stylists y foodies". En: Actas del III Congreso Internacional sobre Patrimonio Alimentario y Museos. 25-26 noviembre, 2021, Valencia, España. pp. 263-282. https://doi.org/10.4995/EGEM2021.2021.13408 


\section{Introducción}

Mucho se ha cambiado desde que la transmisión y supervivencia del acervo culinario recaía sobre el formato oral. El desarrollo tecnológico ha transformado qué comemos y cómo lo disfrutamos, influenciando los rituales de socialización de los alimentos. La gastronomía en República Dominicana también ha evolucionado, esto se refleja en el uso progresivo de innovadores formatos y plataformas de comunicación. Aquellos que han elegido las artes culinarias como profesión cuentan con nuevos aliados. Desde los "reality shows" en los que amateurs muestran su proeza en la cocina ante las cámaras por la victoria, hasta quienes retocan los alimentos detalladamente. Tecnologías y perfiles antes inexistentes, narran la historia de recetas, experiencias de su consumo y proveniencia de sus ingredientes. Entre ellos encontramos categorías como food stylists, que resaltan la esencia de los platos, y foodies que buscan magníficas creaciones.

Luego de presentar una selección de la bibliografía gastronómica en la República Dominicana, este documento enlista sujetos que se han abierto camino en este sector. A través del análisis de la literatura existente se pretende iniciar la recolección del trabajo e identificación de perfiles de abanderados y embajadores digitales de la gastronomía que más allá de los fogones, están detrás de los libros, programas y dispositivos.

\section{Objetivos}

\section{- Objetivo General}

Identificar perfiles de abanderados y embajadores de la gastronomía que engrandecen la calidad culinaria de la República Dominicana.

\section{- Objetivos Específicos}

- Presentar la evolución de la alimentación en la República Dominicana, su entorno y plataformas actuales para la comunicación gastronómica.

- Identificar los principales actores del ecosistema comunicacional dominicano en materia culinaria.

- Definir las nuevas ramas profesionales, así como las herramientas que las impulsan.

- Compilar parte de la literatura y publicaciones existentes sobre gastronomía dominicana.

\section{Desarrollo de la Innovación}

El presente documento analiza el ecosistema comunicacional gastronómico: antecedentes, bibliografía y principales actores en los medios digitales.

\subsection{Antecedentes}

Los elementos que componen la identidad cimentan las raíces sociales de los pueblos "a través de los imaginarios simbólicos compuestos por tradiciones, lenguas, hábitos, gastronomía, celebraciones, rituales y expresiones artísticas, entre otros. Para su construcción, como 
definición social, se requiere una conciencia histórica y un proceso de valoración colectiva" (Martínez Sosa, 2020).

La gastronomía, arte de la buena preparación y relación de los alimentos, ha evolucionado a través de los años como resultado de las diferentes interacciones sociales, culturales y migratorias que impactaron el devenir histórico, y por consecuencia culinario, de los pueblos. Ejemplo de ello es la República Dominicana, cuyo menú ofrece mezclas culturales, sumadas a la diversidad de climas y ecosistemas.

Gracias a investigadores como Marcio Veloz Maggiolo, se ha recapitulado la información histórica y científica disponible acerca de la gastronomía indígena. Los taínos, primeros habitantes de la isla, basaron su alimentación en el cultivo de yautía, auyama, mapuey, yuca, guanábana, jobos, entre otros. Lo que pescaban era complementado con preparaciones como el casabe de yuca, elaborado con utensilios como el guayo y el cibucán (especie de colador); y mabí, una bebida fermentada. Obras como las de Hugo Tolentino Dipp permiten entender qué sucedió con la alimentación a partir de la llegada de los españoles (1492) con la introducción de técnicas, tradiciones, alimentos típicos e ingredientes que se volverían fundamentales, como el arroz, los plátanos y la carne ganadera.

El sazón que hoy nos caracteriza llegó con los africanos, quienes vinieron como esclavos y trajeron jengibre, molondrón, malagueta y otras especias, así como la técnica de sofreír ajo y cebolla. Otros grupos con aportes culinarios fueron los cocolos de las Antillas Menores, los árabes e italianos. Estos procesos migratorios y las importaciones facilitadas por la globalización de los mercados han resultado en un variado menú, con trazas de sincretismo cultural, que se ha integrado en las tradiciones y cotidianidad dominicana.

\subsection{Gastronomía dominicana, hoy}

Al igual que diferentes elementos de esta cultura, la culinaria ha sido el resultado de las circunstancias y necesidades de la población. Según el portal RutaGourmet.do, es un fenómeno:

\footnotetext{
Esencial de nuestro patrimonio cultural inmaterial que se crea y transforma en cada bocado, en cada cocción, en cada aroma, llena del sabor de lo que somos, de nuestro origen. Es una cocina sabrosa, que invita siempre a la celebración. Se crea y recrea un espacio común, un mapeo colectivo que refleja nuestras costumbres y tradiciones culinarias, utilizando como base aspectos culturales e históricos del país.
}

Características de la gastronomía dominicana son su variedad, practicidad y resiliencia. Se distinguen técnicas artesanales, algunas heredadas de los taínos, nuestros primeros artesanos, quienes elaboraban manualmente sus herramientas. Hoy, hay quienes se identifican como artesanos gastronómicos por sus conocimientos de comida e ingredientes criollos, por desarrollar innovaciones en el área, ser reconocidos por su experiencia y tener vocación y aptitud por la cocina dominicana (López, 2021).

La diversidad de platos típicos incluye "la bandera" (arroz blanco, habichuelas guisadas y carne); sancocho (sopa de distintas carnes y tubérculos); mangú (puré de plátanos verdes, acompañado con rodajas de queso, salami o huevo); morir soñando (bebida de leche con jugo de naranja), entre otros. 

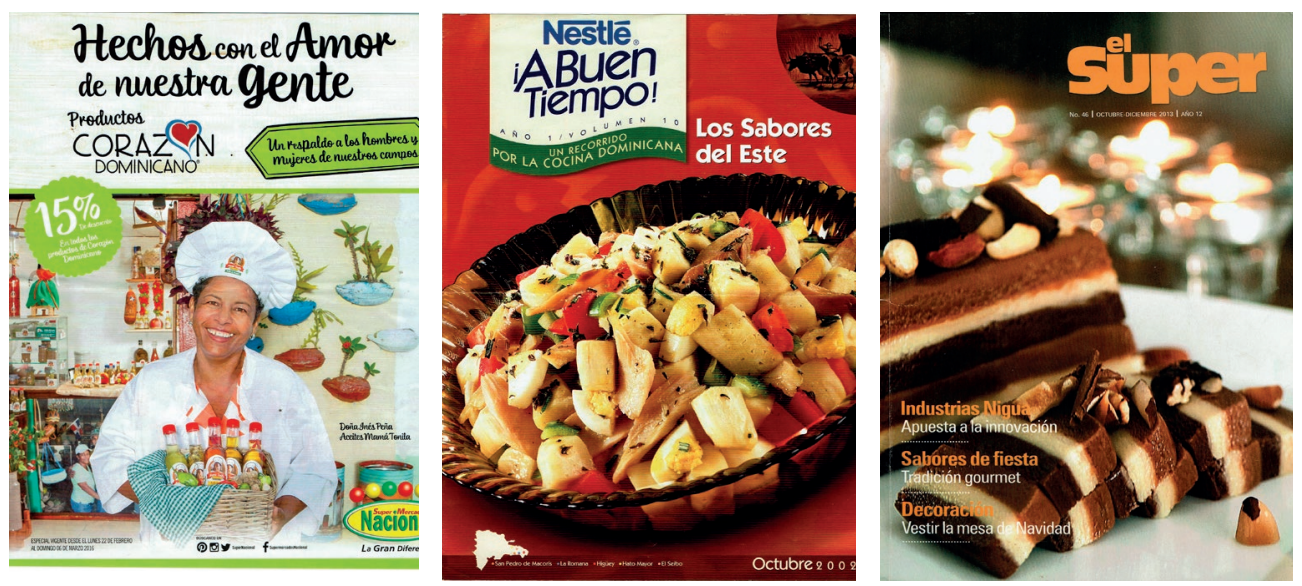

Figura 1. Publicaciones gastronómicas dominicanas, parte de una colección privada.

Fuente: Biblioteca de Isis Mercedes Flaquer.

\subsection{Comunicación, tecnología y gastronomía}

La tecnología ha modificado la variedad de los ingredientes y la preparación de los alimentos, evolucionando hasta influir en cómo disfrutamos y nos comunicamos respecto a ellos. Del boca a boca se pasó a las publicaciones impresas, radio, televisión, internet y redes sociales. Hasta hace poco el protagonismo lo tenían los medios masivos tradicionales, especialmente la televisión y, en las zonas de mayor urbanización, gozaban de gran prestigio los medios impresos. En las grandes ciudades este apogeo lo han ido conquistando las plataformas digitales y redes sociales, pues cuanto más remotas las comunidades, menor es la penetración de los medios de comunicación. Las zonas rurales y aquellas con mayores niveles de pobreza son frecuentemente excluidas de esta evolución, existiendo aún comunidades que no disponen de cableado eléctrico o cobertura telefónica (Martínez Sosa, 2020).

La gastronomía se ha valido del medio audiovisual y ha facilitado el crecimiento de importantes figuras. En la televisión, se han destacado Eugenia Rojo, Deyanira Jackson, Jacqueline Henríquez, Wendy Gómez, Rosanna Ovalles, Wandy Robles y Leandro Díaz, entre otros. Han sido también producidos programas de temporada que resaltan ofertas gastronómicas particulares de una región o época del año, siendo ejemplo: "Chakall y Mangú", serie auspiciada por Nestlé que presentó aventuras del chef Chakall. A través de la plataforma Youtube, se encuentran: "Cocina Casera RD" con David Richardson Santana, "Cocinando con Ros Emely", "Simple by Clara", "Cocinando con Yolanda", "Chef Manu”, "Dominican Food TV", "El sazón de Mika".

Los periódicos (Diario Libre, Listín Diario, Hoy, El Caribe, El Día, etc.) con frecuencia incluyen artículos gastronómicos y, dentro de ellos, es común encontrar encartes en formato de revista o recetario coleccionable. Reconocidas marcas como Induveca, Rica, Maggi, Nestlé, Knorr, Supermercados Nacional y Supermercados La Cadena, los han utilizado para conectar con sus clientes y fomentar el consumo de determinados productos. Dentro de las revistas impresas, aún se edita Aldaba Gourmet, del Listín Diario y, ya fuera de circulación, fue destacable Gastroteca, editada por el chef Emil Vega y reconocida por su alta calidad. 


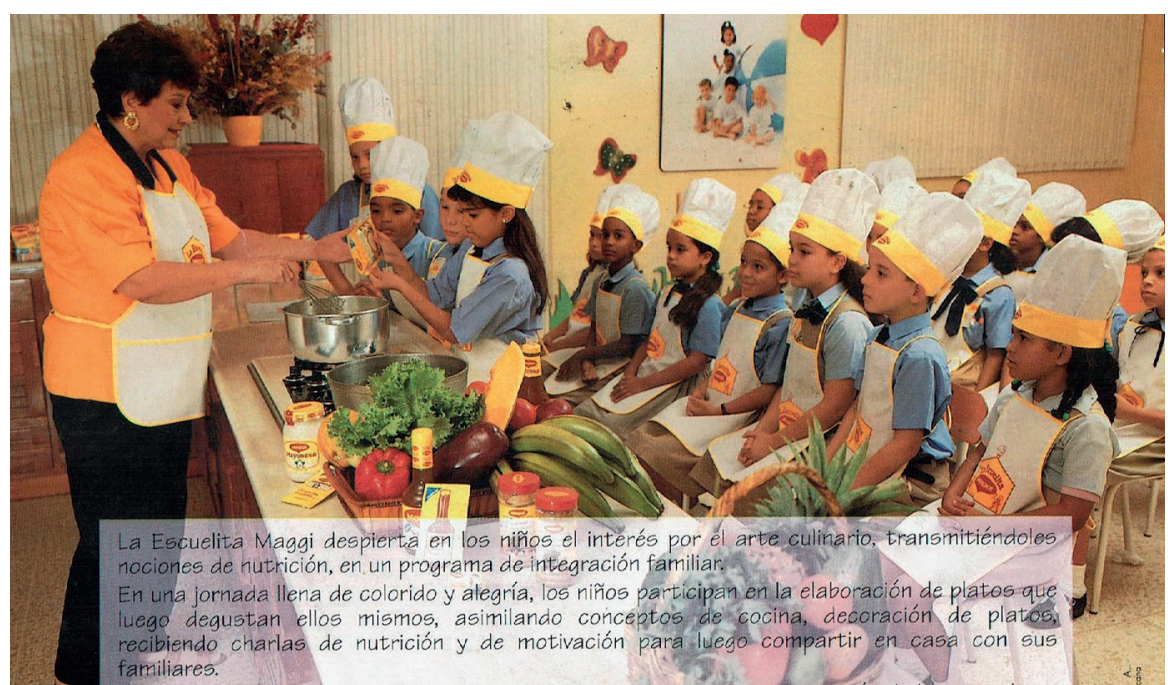

Figura 2. Imagen promocional de la Escuelita Maggi. Fuente: Calendario Maggi 1995.

Ciertos grupos empresariales, basándose en la promoción del patrimonio inmaterial dominicano, han apostado a la distribución y comercialización de productos de inspiración o elaboración local. Dentro de estas iniciativas de responsabilidad social corporativa, resulta admirable la labor realizada por el Grupo CCN a través de propuestas como: Orgullo de mi Tierra, Arte de Café y Corazón Dominicano (Martínez Sosa, 2020), y de Maggi, a través de sus recetarios y de la Escuelita Maggi, una iniciativa educativa que benefició varias generaciones.

\section{Resultados}

La creación de contenido gastronómico dominicano es cada vez mayor y se ha optado por abordarla a través de una investigación bibliográfica y una observación en medios sociales. El objetivo es identificar los perfiles de sujetos, marcas e iniciativas que fungen como embajadores digitales de dicha cultura culinaria, generando impacto en la sociedad.

\subsection{Producción bibliográfica}

Con frecuencia buscan investigar, informar, promover y actualizar el imaginario gastronómico dominicano. Cada autor lo hace desde su propia experiencia, mostrando influencias de su época, estética, escuela y técnica. En "Biblio-Hemerografía de la cultura tradicional y popular de la República Dominicana" (Pérez, 2009), se enlistan 89 piezas escritas sobre gastronomía criolla publicadas en libros, revistas y periódicos. Son el resultado de la producción intelectual de reconocidos nombres como Marcio Veloz Maggiolo, Dagoberto Tejeda Ortiz, Bernardo Vega, Fradique Lizardo, Carlos Esteban Deive, Manuel García Arévalo, Juan B. Nina, Carmenchu Brusíloff, Xiomarita Pérez y Nexcy D’ León, entre otros. 

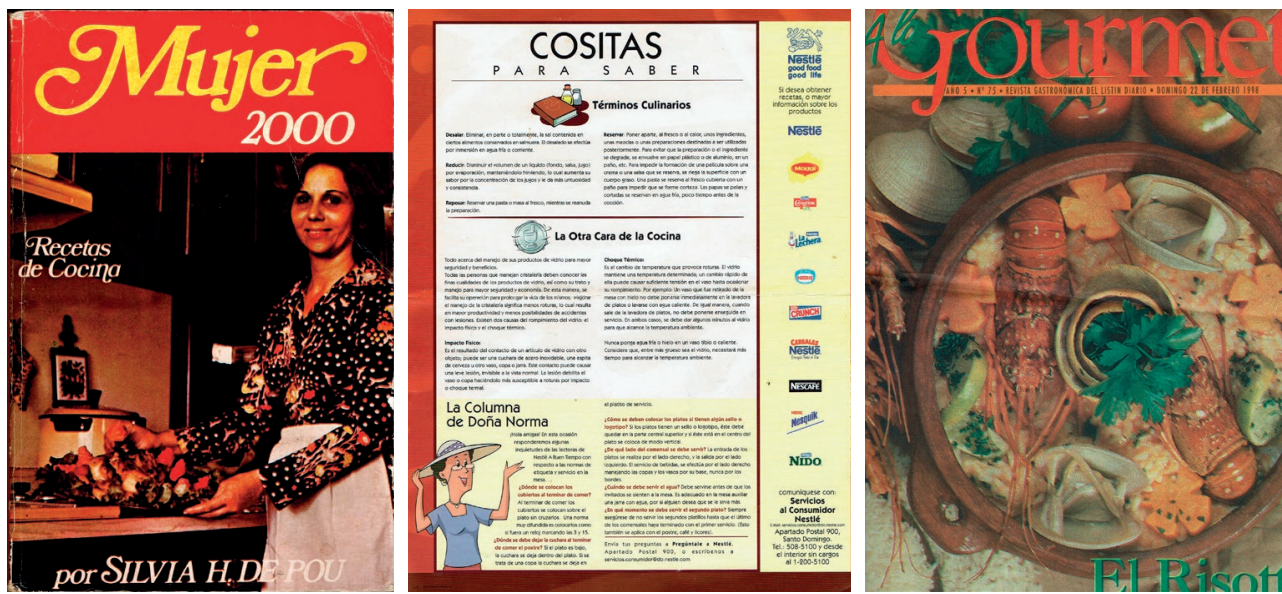

Figura 3. Publicaciones gastronómicas dominicanas, parte de una colección privada. Fuente: Biblioteca privada de Isis Mercedes Flaquer.

Para organizar estos hallazgos y presentar parte de la bibliografía gastronómica dominicana se creó una tabla. Más de 130 elementos fueron incluidos y organizados cronológicamente desde 1927 hasta este 2021, uniendo en una misma casilla los libros con varias ediciones o tomos, y los autores con varias publicaciones en un mismo año.

\section{Selección de la bibliografía gastronómica de la República Dominicana (1927-2021)}

Tabla 1. Bibliografía gastronómica de la República Dominicana(1927-2021), organizada por fecha, autory título.

\begin{tabular}{|c|c|c|}
\hline Fecha & Autor & Título \\
\hline 1927 & Ramón Emilio Jiménez & $\begin{array}{l}\text { Al amor del bohío. Tradiciones y costumbres } \\
\text { dominicanas }\end{array}$ \\
\hline 1938,1939 y 1940 & Amanda Ornes de Perelló & Manual de Economía Doméstica \\
\hline 1955 & Amanda Ornes de Perelló & Cocina Criolla \\
\hline 1959 & Ligia Vidal de Bornia & La Cocina Dominicana \\
\hline 1965 & Ligia Vidal de Bornia & Dominican Typical Meals / Comidas típicas dominicanas \\
\hline 1971 & Ligia Vidal de Bornia & La Cocina Ligia \\
\hline 1972 & Mercedes Amiama Tió & El arte de la cocina \\
\hline 1973 & Estrella Betances de Pujadas & Recetas Dominicanas \\
\hline 1976 & Guillermina González & Cocina dominicana y platos internacionales \\
\hline $1976,1980,2002$ y 2015 & Silvia Henríquez de Pou & Mujer 2000 \\
\hline 1976 & Gladys Chabebe de Cruzado & Primer libro de cocina dominicana publicado en EE.UU. \\
\hline 1977 & Ladies Guild of Santo Domingo & Recetas Dominicanas / Dominican Recipes \\
\hline 1979 & Adria Vidal de Mañón & Un tesoro de comidas completas \\
\hline 1981,1986 y 2007 & Miriam de Gautreaux & La magia del azúcar \\
\hline 1982 & Nilda Abreu de Suriel & Los menús de la Navidad \\
\hline
\end{tabular}




\begin{tabular}{|c|c|c|}
\hline Fecha & Autor & Título \\
\hline 1982 & Ladies Guild of Santo Domingo & Libro de Cocina / Cook Book \\
\hline 1983 & Esperanza de Lithgow & Cocina fácil \\
\hline 1984 & Estrella Betances de Pujada & Recetas dominicanas y del Caribe \\
\hline 1985 & Gaby Lehrer & Pollo Gourmet \\
\hline \multirow[t]{4}{*}{1988} & Licorera Brugal y Co. y José Chez & El ron en la historia dominicana \\
\hline & Checo & Vocabulario del ron \\
\hline & & 267 cócteles con Brugal \\
\hline & & Epigramas sobre el ron Brugal 1906-1911 \\
\hline 1988 & Valerie Grullón y Susan Pichardo & $\begin{array}{l}\text { A Taste of the Caribbean. Remembrances and Recipes } \\
\text { of the Dominican Republic }\end{array}$ \\
\hline 1991 & Mercedes Amiama Tió & 50 años de experiencia en el arte de la cocina \\
\hline 1992 & Ligia Vidal de Bornia & La Cocina Ligia en microondas \\
\hline 1993 & María Ramírez de Carías & La Cocina Dominicana \\
\hline 1996 & Yolanda Zouain de Castellanos & Mis 100 recetas con harina de maíz \\
\hline 1996 & $\begin{array}{l}\text { Marianela Castro, Luz María } \\
\text { Alcántara y Eunice Colón }\end{array}$ & Cocina dominicana \\
\hline 1996 & Bernardo Vega & Las frutas de los taínos \\
\hline 1997 & Yolanda Valdés de Del Monte & Hoy cocino yo \\
\hline 1998 & Kilma Canaán de Fernández & Cocinado en casa \\
\hline 1998 & Susana Byas & La cocina cocola de la tía Susana \\
\hline 1999 & José Ramón López & La alimentación y las razas \\
\hline 1999 & Elizabeth Sánchez & Consejos múltiples de cocina y algo más \\
\hline 1999 & Socorro Castellanos & Con los cinco sentidos. Las mejores recetas de Buenas \\
\hline & & Tardes a la Orden T.V. \\
\hline 1999 y 2006 & Juan B. Nina & El origen de la cocina dominicana \\
\hline 2000 & Elba Ysidora & Gourmet Fácil Festivo \\
\hline 2000 & Chea de Ortíz & Cocinando con Chea de Ortíz \\
\hline 2000 & Juan B. Nina & La cocina de las Américas \\
\hline 2001 y 2006 & Xilia Hernández & CocinArte \\
\hline 2002 & Mercasid & El arte de cocinar en casa \\
\hline 2003 & Roberto Cassá & $\begin{array}{l}\text { Raíces y desarrollo de un orgullo dominicano. Historia } \\
\text { de la cerveza en la República Dominicana }\end{array}$ \\
\hline 2003 & Claudia López & Cocinar es fácil \\
\hline 2004 & José Del Castillo & Agenda de fin de siglo \\
\hline 2004 & Eugenia Rojo & Recetas de la cocina de Eugenia Rojo \\
\hline 2004 & Chea de Ortiz (Mercedes Manzano) & Ensaladas, salsas y aderezos \\
\hline 2005 & Esperanza de Lithgow & Entremeses fáciles para ti \\
\hline 2005 & Chea de Ortiz (Mercedes Manzano) & Arroz para todos los gustos \\
\hline 2005 & Elba Ysidora & Gourmet Fácil. El pequeño gran libro de los sándwiches \\
\hline & & Gourmet Fácil. La Biblia de las salsas \\
\hline
\end{tabular}




\begin{tabular}{|c|c|c|}
\hline Fecha & Autor & Título \\
\hline 2005 & "Recetas de ayer y de hoy" & Recetas de ayer y de hoy \\
\hline 2005 & $\begin{array}{l}\text { Alejandro Paulino Ramos y Aquiles } \\
\text { Castro publican }\end{array}$ & Diccionario de cultura y folklore dominicano \\
\hline 2005 & Clara González e llana Benady & Aunt Clara's Dominican Cookbook \\
\hline 2006 & Eugenia Rojo & Cocina Cocina \\
\hline 2006 & Juan B. Nina & La cocina caribeña (historia y recetas) \\
\hline 2007 & Juan B. Nina & $\begin{array}{l}\text { Los dulces dominicanos (historia y recetas) } \\
\text { Folklore Gastronómico del Sur }\end{array}$ \\
\hline 2007 & Omar Paíno Perdomo & $\begin{array}{l}\text { Hongos comestibles de la República Dominicana. Guía } \\
\text { de campo }\end{array}$ \\
\hline 2007 & Brenda Gil & El arte del cocinao \\
\hline 2007 & Estela Aristy & Cocina criolla dominicana \\
\hline 2007 & Hortensia Sousa de Baquero & Recetas con sabor espiritual \\
\hline 2007 & Clara González e Ilana Benady & Traditional Dominican Cookery \\
\hline 2007 & $\begin{array}{l}\text { Marcio Veloz Maggiolo y Hugo } \\
\text { Tolentino Dipp }\end{array}$ & Gastronomía Dominicana. Historia del sabor criollo \\
\hline 2007 & Clarislandia Quiñones & Cocina Fácil Dominicana \\
\hline 2008 & $\begin{array}{l}\text { Clara Cabrera y Rosa Fiorinelli de } \\
\text { Albert }\end{array}$ & Cocina saludable \\
\hline 2008 & $\begin{array}{l}\text { Recopilación de } 31 \text { autores de los } \\
\text { que se encuentran Dolly Molinari } \\
\text { de Esteban, Margot Flaquer de } \\
\text { Sánchez y Sonia Saviñón de } \\
\text { Sánchez }\end{array}$ & Café de la leche. Nuestras recetas favoritas \\
\hline 2008 & Editora Corripio y Ana Alcántara & $\begin{array}{l}\text { My Mother's Kitchen. A Collection of Special Recipes by } \\
\text { Ana Alcántara \& Friends }\end{array}$ \\
\hline 2008 & Eugenia Rojo & El libro rojo de Eugenia \\
\hline 2008 & Juan B. Nina & $\begin{array}{l}\text { Bebidas Típicas Dominicanas } \\
\text { Diccionario Gastronómico Dominicano } \\
\text { Cócteles Dominicanos }\end{array}$ \\
\hline 2009 & Juan B. Nina & La cocina vegetariana dominicana \\
\hline 2009 & Mike Mercedes & Las recetas del maestro Mike Mercedes \\
\hline 2009 & Bismar Galán & $\begin{array}{l}\text { Sancocho dominicano. Persistencia y simbolismo de un } \\
\text { plato }\end{array}$ \\
\hline 2009 & Jacayaguila Carmona y Jorge Diep & 20 restaurantes gourmet y 20 diseñadores fashion \\
\hline 2009 & Jimmy Hungría & Gastronomía musical y bibliografías en construcción \\
\hline 2009 & Kin Sánchez & Nuestra verde navidad \\
\hline 2009 & Xilia Hernández & Mi amigo el arroz \\
\hline 2009 & Eugenia Rojo & Ligero y Gourmet \\
\hline 2010 & Delcy Mata & $\begin{array}{l}\text { Recetas dominicanas. El mágico secreto de la cocina } \\
\text { criolla }\end{array}$ \\
\hline
\end{tabular}




\begin{tabular}{|c|c|c|}
\hline Fecha & Autor & Título \\
\hline 2010 & José Rafael Sosa & Las Recetas del Doctor \\
\hline 2010 & Bismar Galán & $\begin{array}{l}\text { Sancocho dominicano: persistencia y simbolismo de un } \\
\text { plato }\end{array}$ \\
\hline 2011 & $\begin{array}{l}\text { Cruz Altagracia López Genao } \\
\text { "Yonki" }\end{array}$ & La magia de elaborar dulces \\
\hline 2011 & Zaida Lovatón de Sanz & 100 recetas y más de Doña Zaida \\
\hline 2011 & Adolfo Castañón & Conferencias Magistrales 2010 \\
\hline 2011,2013 y 2014 & Pasteurizadora Rica & Herencia Gastronómica Dominicana \\
\hline 2011 & Carmen Taveras & La cocina natural del nuevo siglo \\
\hline 2011 & Marisol Jorge & Cocina gourmet rápida \\
\hline 2011 & Sergio Ottato & El vino, Sócrates y yo \\
\hline 2011 & Xilia Hernández & $\begin{array}{l}\text { Postres y bebidas } \\
\text { Guarniciones y más } \\
\text { Carnes, aves, pescados, mariscos, panes y panecillos } \\
\text { Bocaditos, entradas, sopas, cremas y ensaladas }\end{array}$ \\
\hline 2012 & Benilda Llenas & Las bondades del plátano \\
\hline 2012 & $\begin{array}{l}\text { Vincenzina Egidi Balzarini (Doña } \\
\text { Enza) }\end{array}$ & Cocina Familiar de Doña Enza \\
\hline 2012 & Restaurante Porter House & Dominicana, la República de Sabores \\
\hline 2012 & Mari Núñez & Cómo Cocinar al Estilo Dominicano \\
\hline 2012 & Arturo Féliz-Camilo & Las recetas de Mamá Pura \\
\hline 2012 & Miriam de Gautreaux & Antología de la Repostería Dominicana. Siglos XX-XXI \\
\hline 2012 & Socorro Castellanos & El sabor de mi tierra \\
\hline 2013 & Juan B. Nina & $\begin{array}{l}\text { Los helados dominicanos } \\
\text { Folklore Gastronómico del Cibao }\end{array}$ \\
\hline 2013 & Arturo Féliz-Camilo & $\begin{array}{l}\text { Los mejores postres dominicanos } \\
\text { Diccionario Culinario Dominicano } \\
\text { El sazón de la cocina dominicana } \\
\text { Longaniza Dominicana, los secretos de la mejor lon- } \\
\text { ganiza del Caribe }\end{array}$ \\
\hline 2014 & Esperanza de Lithgow & La Olla Mágica de Esperanza Lithgow \\
\hline 2014 & Leandro Díaz & Cocinando sin ITBIS \\
\hline 2014 & Rosa María Gómez "La Chefa" & La Nueva Cocina Dominicana de La Chefa \\
\hline 2014 & Hugo Tolentino Dipp & Itinerario histórico de la gastronomía dominicana \\
\hline 2014,2016 y 2017 & Marivell Contreras & El sabor de las letras \\
\hline 2015 & Juan B. Nina & $\begin{array}{l}\text { Folklore Gastronómico del Este } \\
\text { El sabor del agua. Recetas de pescados y mariscos del } \\
\text { Caribe } \\
\text { Gastronomía de Cuaresma. Historia y recetas }\end{array}$ \\
\hline 2015 & Dominique Barkhausen & Eat, Love, Vita \\
\hline
\end{tabular}




\begin{tabular}{|c|c|c|}
\hline Fecha & Autor & Título \\
\hline 2016 & Juan B. Nina & Antropología de las frituras. Historia y recetas \\
\hline 2016 & Inés Páez (Chef Tita) & La Nueva Cocina Dominicana \\
\hline 2016 & Annie Camacho & Mis dulces tentaciones \\
\hline 2016 & Fundación Sabores Dominicanos & $\begin{array}{l}\text { Identificando la esencia y los matices de nuestros } \\
\text { sabores }\end{array}$ \\
\hline 2017 & Juan B. Nina & $\begin{array}{l}\text { Historia de la cocina taína } \\
\text { Herencia africana en la gastronomía dominicana. } \\
\text { Historia y recetas }\end{array}$ \\
\hline 2017 & María Marte & Soñar, luchar, cocinar \\
\hline 2017 & Francisco de Padua Morales & El mangú \\
\hline 2017 & Doña Rosa Fiorinelli de Albert & La Cocina de Rossette \\
\hline 2017 & Arturo Feliz Camilo & $\begin{array}{l}\text { Longaniza Dominicana: Los secretos de la mejor } \\
\text { Longaniza del Caribe }\end{array}$ \\
\hline 2018 & Inicia (recopilación de autores) & Sabores Ancestrales \\
\hline 2019 & Arturo Feliz Camilo & $\begin{array}{l}\text { La Magia de Unas Habichuelas Sabrosas: Habichuelas } \\
\text { Dominicanas }\end{array}$ \\
\hline 2020 & Sagrario Hernández & $\begin{array}{l}\text { Recetas Dominicanas: } 10 \text { recetas que debes probar en } \\
\text { esta cuarentena }\end{array}$ \\
\hline 2021 & $\begin{array}{l}\text { Clara González, Verónica Cervera, } \\
\text { Erica Dinho, Alejandra Graf y Layla } \\
\text { Pujol }\end{array}$ & Yo cocino latino \\
\hline 2021 & Esperanza Lithgow & Entremeses Fáciles Para Ti \\
\hline
\end{tabular}

Fuente: Elaboración propia. Basado en Hungría (2018) y Pérez (2009).

Interesantes libros extranjeros resaltan recetas preferidas de figuras dominicanas con proyección internacional: "The Metropolian Opera Cookbook" (Bondagree, 1988) muestra platos del laureado diseñador Oscar de la Renta; el libro "Jazz Cooks" (Young y Stankus, 1992) incluye la versión del cerdo asado dominicano con arroz del reconocido músico Michel Camilo. Para los deportistas "Diamond Dishes: From the Kitchens of Baseball's Biggest Stars" (Loria, 2011) muestra los gustos de dominicanos en las Grandes Ligas del Béisbol.

\subsection{Identificación de perfiles}

La evolución en materia de comunicación y estilos periodísticos ha sido influida por el surgimiento de nuevos medios digitales como: blogs, Facebook, Instagram, Twitter, Google Maps, Tik Tok y otros, en los cuales se promueve y aprovecha el contenido generado por los usuarios. Se aprecia un cada vez más minucioso cuidado por los detalles y, en algunos casos, altísimas frecuencias de publicación. Se apuesta a cautivar de manera visual y escrita con estímulos que despiertan el interés del receptor, atrapando su imaginación y deseo. Se observa también una reducción de costos en herramientas especializadas como hielo falso y stands, circunstancias que han permitido que hoy la comunicación culinaria tenga un ecosistema más avanzado y complejo. A raíz del escenario descrito han surgido nuevos perfiles como: 
Foodie: persona que muestra un gran interés en el disfrute de la comida. El término fue acuñado luego de que en 1984 el New York Times publicara el artículo "British Find Food Need Not Be Stodgy", luego de un banquete celebrado en Londres por el lanzamiento del libro "The Official Foodie Handbook" de Ann Barr y Paul Levy, en que se describe el concepto foodie. Hoy vemos en redes sociales a foodies que salen en búsqueda de las nuevas ofertas gastronómicas y luchan por ser los primeros en mostrar sus hallazgos.

Food Stylist (Styling): se dedican al arte del "estilismo de alimentos" y, junto al chef, captan la esencia de los platos y representan visualmente sus sabores. En una producción audiovisual hacen que el producto se vea lo más estilizado y apetecible posible. Buscan estimular la compra y captar la atención de la audiencia con emplatados creativos, ingeniosas herramientas y trucos. Dentro de sus retos está la popular publicidad engañosa (Molins, 2015), pues al incentivar el consumo de alimentos cuidando los detalles de manera extrema, a veces la apariencia del resultado dista de la preparación habitual. Hay restaurantes que contratan food stylists para que velen porque los platos transmitan las mismas emociones que atrajeron al comensal.

Chefs: el Diccionario de la Real Academia de la Lengua Española lo define como una voz tomada del francés chef ('jefe'), que se emplea en español con los sentidos de "jefe de cocina de un restaurante" y, especialmente, cocinero profesional de grandes dotes y reconocido prestigio. Actualmente, academias especializadas ofrecen carreras en el área gastronómica y títulos de cocineros con distintos niveles en la jerarquía de la cocina, como los chefs y su asistente, el "sous chef" o "segundo jefe".

Periodistas culinarios (gastronómicos): se dedican al estudio, recopilación e investigación del sector gastronómico, velando por su difusión y promoción a través de los medios. Requiere estar al día con las tendencias e innovaciones de recetas, técnicas, restaurantes, chefs, etc. Puede recaer en diferentes géneros del periodismo, teniendo gran fuerza los críticos que se enfocan en la interpretación de la propuesta gastronómica y proceden a su calificación (Universidad San Francisco de Quito, 2021). Inicia su auge en República Dominicana hacia 2016.

La popularización de algunos de estos términos es reciente y el tamaño de las producciones en las cuales suelen verse involucrados puede variar desde pequeños proyectos hasta enormes campañas de marketing. Para hacer una producción comunicacional culinaria transmedia, por ejemplo, pueden intervenir directamente 5 roles: el chef que prepara el plato, el food stylist que lo estiliza, el fotógrafo experto en iluminación y en captar la esencia de cada propuesta, el foodie que comparte información, y el periodista culinario que difunde esta información en medios de comunicación tradicionales y digitales.

Con el crecimiento de la industria alimentaria, la comunicación gastronómica se ha convertido en un pilar financiero que da a conocer y promocionar este popular elemento de una cultura, mientras genera retribución económica. Por ello, la gastronomía es una de las principales áreas de la Economía Naranja, que abarca actividades de carácter cultural que producen bienes y servicios. Para contribuir con el desarrollo de la misma, se han habilitado múltiples capacitaciones y proyectos. Sirven de ejemplo las inversiones realizadas a la Industria de La Piña, el Proyecto de Mapeo de la Gastronomía, la Escuela Gastronómica Típica en Samaná y la Fábrica Artesanal del Conconete Dominicano (Sabores Dominicanos, 2016). Las capacitaciones, por su parte, han abarcado las áreas de crítica gastronómica 


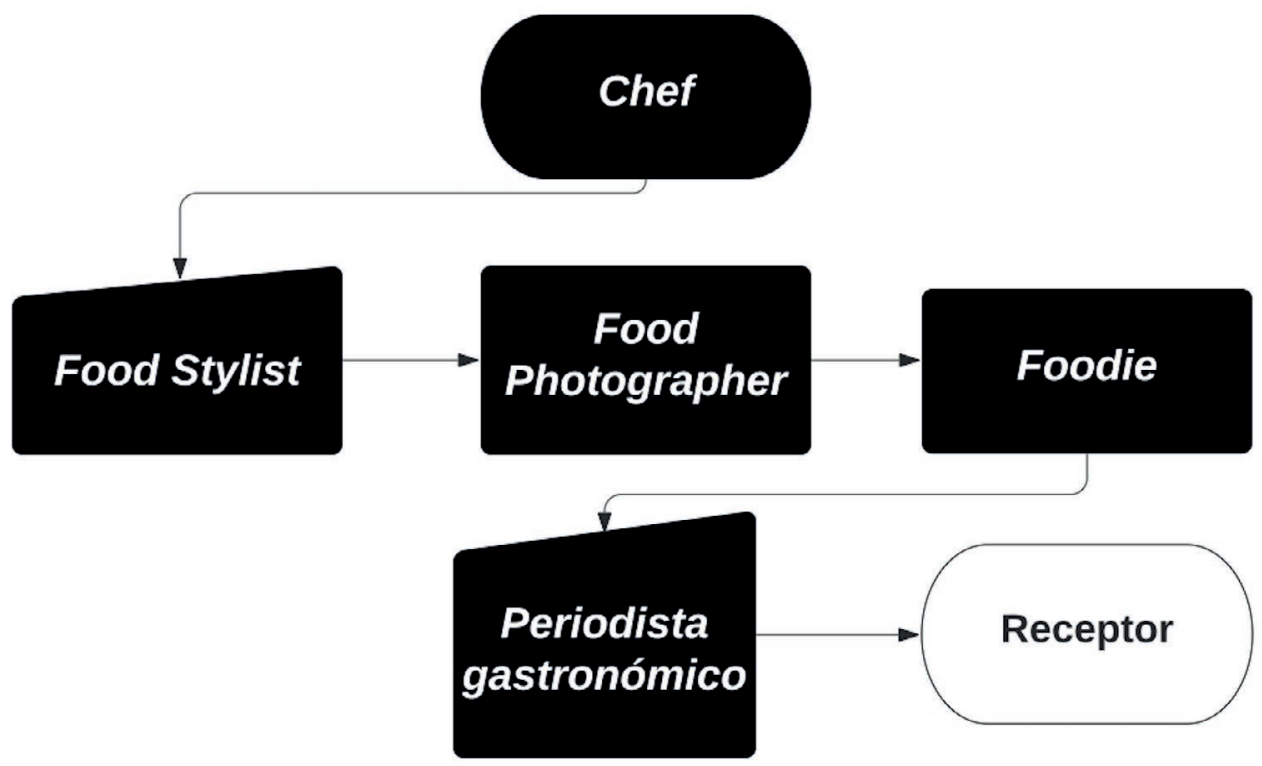

Figura 3. Flujograma de roles que pueden intervenir en una producción comunicacional gastronómica. Fuente: Elaboración propia.

y Gastro Ficción, además del diseño de un Bachillerato Técnico en modalidad Servicios Gastronómicos. Estas iniciativas son comunicadas a través de eventos como "La gastronomía y el periodismo para hacer marca del país".

\subsection{Embajadores Gastronómicos Digitales}

Para la selección de los integrantes del siguiente listado de foodies, chefs y periodistas gastronómicos, se consideró lo siguiente:

- Actividad semanal, tomando como medio Instagram: frecuencia en la cual se mantiene activa la cuenta.

- Cantidad de seguidores: número de seguidores que les gusta y apoyan el contenido.

- Calidad de las publicaciones: manera en la cual las publicaciones realizadas enganchan al receptor.

- Engagement de seguidores: interacciones de los seguidores con la cuenta.

- Premios y reconocimientos: galardones que aumentan la confianza e interés del cliente.

- Publicaciones Impresas: ayuda visual para apreciar de otra manera las imágenes e información. 
Chefs, foodies y periodistas gastronómicos relevantes en República Dominicana, 2021.

Tabla 2. Chefs, foodies y periodistas gastronómicos relevantes en República Dominicana, 2021.

\begin{tabular}{|c|c|c|}
\hline Categoría & Nombre & Link de Instagram \\
\hline \multirow[t]{10}{*}{ Foodies } & Bocao & https://www.instagram.com/bocao/ \\
\hline & Rincones & https://www.instagram.com/rincones_rd/ \\
\hline & Burger Bastards & https://www.instagram.com/burgerbastards/ \\
\hline & TheFoodLifeDR & https://www.instagram.com/thefoodlifeofdr/ \\
\hline & FitfoodiesRD & https://www.instagram.com/fitfoodiesrd/ \\
\hline & Vaina de Flaca & https://www.instagram.com/vainadeflaca/ \\
\hline & AlacartadorRD & https://www.instagram.com/alacartadord/ \\
\hline & Vaina de Gordo & https://www.instagram.com/vainadegordo/ \\
\hline & TheBurgerCatador & https://www.instagram.com/theburgercatador/ \\
\hline & TasteltRD & https://www.instagram.com/tasteitrd/ \\
\hline \multirow[t]{19}{*}{ Chef } & Jacqueline Henríquez & https://www.instagram.com/jacquelinchefrd/ \\
\hline & Nikol Morillo & https://www.instagram.com/nikolmorillo/ \\
\hline & Leandro Díaz & https://www.instagram.com/chefleandrodiaz/ \\
\hline & Carolina Arias & https://www.instagram.com/chefcarolinaarias \\
\hline & María Marte & https://www.instagram.com/chefmariamarte/ \\
\hline & Keily Manuel Busby E. & https://www.instagram.com/kmbusbye/ \\
\hline & Eliana Mateo & https://www.instagram.com/elianamateo/ \\
\hline & Gina Vicini & https://www.instagram.com/ginavicini/ \\
\hline & Manuel Méndez & https://www.instagram.com/chefmanurd/ \\
\hline & Cristina M. Báez & https://www.instagram.com/cris_baez/ \\
\hline & José Manuel Lombardero & https://www.instagram.com/josemlombardero/ \\
\hline & Julissa Pieter & https://www.instagram.com/chefjulird/ \\
\hline & Chef Tita & https://www.instagram.com/lacheftita/ \\
\hline & Paulette Tejada & https://www.instagram.com/paulettetejada/ \\
\hline & Haydée Salcedo Objío "Chef Dede" & https://www.instagram.com/chefdederd/ \\
\hline & Francis Pena & https://www.instagram.com/francispenachef/ \\
\hline & Erik Malmsten & https://www.instagram.com/cheferikmalmsten/ \\
\hline & Yuri (Chef Pandita) & https://www.instagram.com/chefpandita/ \\
\hline & Laura Amelia & https://www.instagram.com/lauraamalialabaker/ \\
\hline \multirow{4}{*}{$\begin{array}{l}\text { Periodismo } \\
\text { Gastronómico y } \\
\text { Foodie }\end{array}$} & RutaGourmetDO & https://www.instagram.com/rutagourmetdo/ \\
\hline & Ivonne Soriano (Paladar de paseo) & https://www.instagram.com/paladardepaseo/ \\
\hline & Juan de Dios Valentín (Foodie and Traveler DR) & https://www.instagram.com/foodieandtravelerdr/ \\
\hline & Elaine Hernández (Bocatips) & https://www.instagram.com/bocatips/ \\
\hline
\end{tabular}

Fuente: Elaboración propia. 


\subsection{Otras iniciativas}

En el transcurso de esta investigación fue evidente que la bibliografía y los perfiles presentados son solo una fracción del amplio y dinámico espectro gastronómico dominicano, y se entiende relevante mencionar las siguientes iniciativas:

\section{- Día Nacional de la Gastronomía Dominicana}

El 2018 fue especial para la cocina y gastronomía dominicana pues fue reconocida con el nombramiento de un día dedicado para su celebración. A partir de ese año, el segundo domingo de diciembre es el "Día Nacional de la Cocina y Gastronomía Dominicana". Este decreto, aprobado por la cámara de Diputados, es la Ley 20-18 de la Constitución. La iniciativa para la creación de este día parte de rescatar los platos de nuestro país que puede que hayan quedado en el olvido, al igual que hacer sobresalir aquellos que nos caracterizan de manera internacional.

\section{- Premio Nacional a la Gastronomía Dominicana}

La Asociación Nacional de Gastronomía y Hostelería (AGH) es la encargada anualmente de organizar la gala de Premios Nacionales a la Gastronomía Dominicana, donde se hace reconocimientos a los restaurantes, chefs e iniciativas más importantes del año. Sus categorías premiadas son "Categoría Premio del Público", "Categoría Premio a la Iniciativa en la Gastronomía”, "Categoría Premio a la Excelencia Gastronómica”, "Categoría Premio Marca País”.

- Televisión: Mazola Academy y Master Chef

Las competencias de reality TV tienen producciones de alto nivel en escenografía y diseño, sin embargo, se les da más énfasis a los concursantes que a la comida. La pionera nacional en
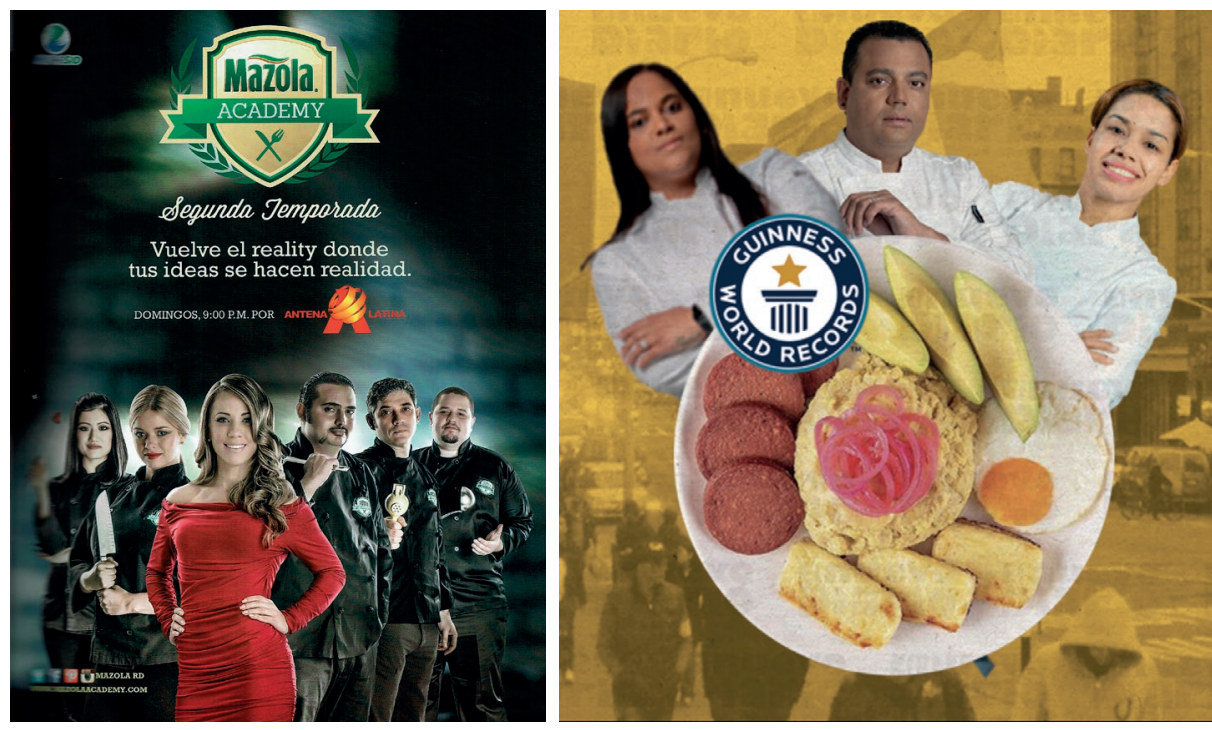

Figura 5. Imágenes promocionales de Mazola Academy y del Premio Guinness al Mangú más grande del mundo.

Fuente: el Súper y El Nuevo Diario. 
este formato fue Mazola Academy, que data de 2012. Allí, 18 integrantes elegidos por jueces competían en cada episodio formando equipos en los que se buscaba impulsar el talento y la creatividad gastronómica dominicana, y que eran evaluados tanto en sabor como en estilismo. Cuando llegó por primera Masterchef Dominicana, 3 mil personas asistieron a postularse y 3 millones de dólares se invirtieron en el estudio de 17,700 pies cuadrados que posicionó a la República Dominicana a la vanguardia de la televisión regional. En 2021 este programa ya tiene tres modalidades diferentes: "Masterchef", "Masterchef Junior", "Masterchef Celebrity".

\section{- Museografía y organización de información: Mapeo gastronómico}

Uno de los beneficiados de la segunda Convocatoria Nacional de Proyectos Culturales fue la iniciativa del mapeo gastronómico liderada por la gestora cultural Olga Valdez y la chef Dévaki Pratt. El portal RutaGourmet.do afirmó que este "hizo un levantamiento de informaciones en las 10 macro regiones de nuestra geografía nacional, estableciendo un marco teórico específico para cada una, con el objetivo de rescatar recetas, técnicas, instrumentos y/o costumbres existentes en cada provincia del país". Esta iniciativa presentó también una exposición multisensorial en Ágora Mall en agosto de 2016, incluyó presencia en redes sociales y una página web que, a la fecha, está inactiva.

\section{- Fundación Sabores Dominicanos}

Organización sin ánimo de lucro cuyo objetivo es desarrollar, impulsar e implementar proyectos para la valorización y desarrollo del sistema gastronómico dominicano, con el fin de posicionar al país a nivel internacional. Crearon en el 2015 la Propuesta Gastronómica RD 20-20, iniciativa que buscaba la evolución de la cultura culinaria y que fue implementada por el impulso que genera la gastronomía al turismo y a las fuentes de trabajo. A través de este proyecto nació el Portal Gastronómico Dominicano, espacio multifuncional para la difusión y promoción de la cocina tradicional criolla. Esta Fundación es también responsable de la iniciativa Premios Nacionales de Periodismo y Literatura Gastronómica que impulsa investigación, valoración y difusión de la literatura gastronómica dominicana. Por su parte el proyecto de Salvaguarda Acervo Culinario Dominicano une a un equipo de investigadores y cocineros que realiza inventarios de recetas de platos y bebidas dominicanos con el fin de preservar esta rama del patrimonio dominicano.

\section{- Record Guiness: Mangú}

La República Dominicana en distintas ocasiones se ha propuesto romper un récord mundial para entrar en el aclamado libro de los Récords Guinness. En el 2017 el programa Despierta América y la Comunidad Dominicana en Nueva York crearon la versión más grande registrada de uno de los platos criollos más icónicos: el mangú. En esa época se alcanzó un peso promedio de 645 libras de plátano verde, cebolla encurtida, salami, queso y huevos fritos. La dedicación de seguir expandiendo los límites de nuestra gastronomía hizo que, el 1 ro de octubre de 2021 y con un total de 1,000 libras, la diáspora dominicana volviera a romper el récord del mangú más grande del mundo esta vez moldeado con la forma del país y con plátanos obtenidos en Tamayo, provincia Bahoruco. Los encargados de coordinar la hazaña fueron los chefs María Marte, Amilkar y Pamela Gonell en el marco del evento Flavor Fusion Fest.

\section{- Semana Gastronómica Digital}

Los periodistas y foodies Paladar de Paseo y Foodie and Traveler DR, crearon el concepto de la Semana de la Gastronomía Dominicana Digital donde llevaron a las redes sociales un 
homenaje a la historia y al desarrollo de la cocina dominicana, presentando aportes de grandes chefs como Leandro Díaz, Manuel Méndez (Chef Manu), Martín Omar, Chef July, Noemí Díaz, Jacqueline Henríquez, Rodolfo Mesa (Chef Ramch), La Chefa Gómez, Chef Tita, Deyanira Jackson, Le Chef Francisco, Carolina Arias, Odalís Rodríguez, Arturo Feliz y Clara González.

\section{- Creación y promoción de Rutas Gastronómicas}

Apreciando el valor que puede llevar a las comunidades, han surgido diversas iniciativas para consolidar rutas e itinerarios de turismo gastronómico. Estos invitan a probar platos y sabores icónicos, mientras se conocen las tradiciones, empresas e instituciones detrás de los mismos. Entre estas se destacan las Rutas: de la Miel, del Casabe, del Banano y del Chivo, que forman parte del "Proyecto de Fortalecimiento del Mecanismo de Desarrollo del Turismo Sostenible Basado en la Comunidad en la Región Norte, República Dominicana". Este proyecto ha sido implementado por el Ministerio de Turismo (MITUR) y el Instituto Nacional de Formación Técnico Profesional (INFOTEP) en coordinación con el Ministerio de Economía, Planificación y Desarrollo (MEPyD), y bajo la asistencia técnica y financiera de la Agencia de Cooperación Internacional del Japón (JICA).

\section{Conclusiones}

La gastronomía es una extensión de la cultura que lleva tantos años de desarrollo como el ser humano mismo. Esta ha sufrido incontables cambios tanto en su registro de sabores como en las formas en que estos se obtienen, experimentan y comunican. Mientras el tratamiento de la imagen y la narrativa utilizadas evidencian los avances, tendencias y cánones de cada época, el aumento y democratización de las tecnologías ha favorecido el surgimiento de un ecosistema mucho más avanzado y complejo.

Tras haber iniciado la identificación de perfiles de abanderados y embajadores digitales e ilustrado la evolución de la comunicación de la gastronomía en la República Dominicana. Se deja abierta la invitación a que se continúe esta línea de investigación, a que se mapee el ecosistema comunicacional dominicano en materia culinaria, evaluando a profundidad las herramientas, plataformas y sujetos que se van abriendo camino en esta área en base a experimentación, innovación y creatividad.

Los nuevos roles y formas de interactuar, difundir y promocionar la gastronomía criolla tienen a su alcance estrategias multiplataforma y la posibilidad aprovechar al máximo la comunicación transmedia. Esto, sumado a la creciente popularidad de la Economía Naranja, presenta un panorama esperanzador en el que sea posible aprovechar la gastronomía para alimentar el cuerpo, conectar comunidades, potenciar sus capacidades de desarrollo y engrandecer la calidad culinaria de las naciones.

\section{Referencias}

BENCOS, A. (2020). Fundación Sabores Dom: Importancia de su labor. <https://silohubierasabido. wordpress.com/2020/01/13/fundación-sabores-dom-importancia-de-su-labor/> [Consulta: 9 de octubre de 2021]. 
DELGADO MERADON, P. (2019). Gastronomía dominicana. Historia del sabor criollo (2 de 2) <https:// www.elcaribe.com.do/gente/cultura/apuntes-de-infraestructura/gastronomia-dominicanahistoria-del-sabor-criollo-2-de-2/> [Consulta: 9 de octubre de 2021].

DELGADO MERADON, P. (2019). Gastronomía dominicana. Historia del sabor criollo (1 de 2). <https:// www.elcaribe.com.do/gente/cultura/apuntes-de-infraestructura/gastronomia-dominicanahistoria-del-sabor-criollo-1-de-2/> [Consulta: 9 de octubre de 2021].

HUNGRÍA, J. (2018). "Apuntes para una bibliografía gastronómica dominicana”. En: Acento. <https:// acento.com.do/opinion/apuntes-una-bibliografia-gastronomica-dominicana-1-2-8600794.html> [Consulta: 15 de octubre de 2021].

TOLENTINO DIPP, H. (2018). Apuntes en torno al itinerario histórico de la gastronomía dominicana <http://saboresdominicanos.org/incia-saludable/apuntes-en-torno-al-itinerario-historico-de-lagastronomia-dominicana> [Consulta: 8 de octubre de 2021].

SANCHEZ DESCHAMPS, B. SUAZO REYES, L y ARAUJO BRITO, E. (2016). Impacto de la Oferta Folklórica y Gastronómica del Restaurante JALAO como Atracción Turística Complementaria de la Ciudad Colonial de Santo Domingo. <https://bibliotecaunapec.blob.core.windows.net/tesis/TESIS_ Cl_ATH_04_2016_ET170190.pdf> [Consulta: 8 de octubre de 2021].

CAMPOS, J. (2016). "Artesanos de la gastronomía dominicana". <https://listindiario.com/ la-vida/2021/03/21/662101/artesanos-de-la-gastronomia-dominicanas.

RUTA GOURMET DO (2016). "Mapeo de la Gastronomía Dominicana" cierra con exposición. <https:// rutagourmet.do/mapeo-de-la-gastronomia-dominicana/>.

FLORENTINO, V. (2016). "De la cocina a la TV”. El Caribe.

PÉREZ, X. (2009). Biblio-Hemerografía de la cultura tradicional y popular de la República Dominicana. República Dominicana: Editora Amigo del Hogar.

PORTILLO, M. (2014). "Listado de libros de cocina dominicanos" cierra con exposición. < [http://recetadeliciosa.blogspot.com/2014/10/listado-de-libros-de-cocina-dominicanos.html/].

EL CARIBE. (2021). Mangú dominicano establece Record Guinness en New York. <[https://www. elcaribe.com.do/gente/estilo/dominicanos-romperan-record-guinness-con-el-mangu/].

ZABALA, J. (2017). Dominicanos romperán Record Guinness con el mangú. <[https://do.municipiosaldia. com/ultramar/item/27451-mangú-dominicano-establece-record-guinness-en-new-york/].

ASONAHONORES (2018). Diputados convierten en Ley "Día Nacional de la Cocina y Gastronomía Dominicana". < <https://www.asonahores.com/diputados-convierten-en-ley-dia-nacional-de-lacocina-y-gastronomia-dominicana/]>.

MINISTERIO DE EDUCACIÓN DE LA REPÚBLICA DOMINICANA (2018). Bachiller Técnico en servicios gastronómicos. < <https://www.ministeriodeeducacion.gob.do/docs/direccion-de-educaciontecnico-profesional/BFcT-tuh001-3-bt-servicios-gastronomicospdf.pdf]>.

INSTITUCIONAL DOMINICANA (2018).Periodismo gastronómico en The Foodie Studies. < [http://www. institucionaldominicana.com/periodismo-gastronomico-the-foodie-studies/]>. 
Maricha Martínez Sosa, Lucero Liriano, Georgina Batista Schrils

NODAL CULTURAL (2015). Periodismo gastronómico en The Foodie Studies. < [https://www. nodalcultura.am/2016/02/cultura-y-gastronomia-dominicanas/>.

VELASCO, M. USFQ (2021).Periodismo Gastronómico: ¿Qué Es Y Para Qué Sirve? < [https://noticias. usfq.edu.ec/2021/10/periodismo-gastronomico-que-es-y-para.html>.

LARROUSECOCINA (2020). El Chef de cocina: su origen y su historia. < [https://laroussecocina.mx/ nota/el-chef-de-cocina-su-origen-y-su-historia/]>

REAL ACADEMIA ESPAÑOLA. Definición de chef. <[https://dle.rae.es/chef/]> 


\title{
RESIDUOS DE COCO. ARTE Y VERMICOMPOSTADO PARA SU REUTILIZACIÓN
}

\author{
Maria Desamparados Soriano a , Francisco García b', Laura Garcia-España c \\ a Departamento de Producción Vegetal. Universitat Politécnica de Valencia. asoriano@prv.upv.es

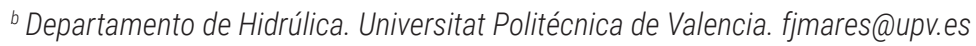 \\ c Departamento de Biología Vegetal. Universitat de Valencia. laugars2@alumni.uv.es
}

\begin{abstract}
Coconut waste is difficult to eliminate and although it is useful as a substrate in gardening, its long life makes it useful for other activities, being widely used within the art to make crafts and decorative works both in jewelry, ornaments, instruments, etc.. In addition, some parts of the coconut with difficult reuse after agro-industrial use can be processed by composting transforming it into a useful resource as a fertilizer, given its high proportion of nutrients. Its usefulness in art is mentioned and the results related to the reuse of coconut waste from a start-up in Ecuador after the agro-industrial use of coconut are presented. The composted waste was prepared by adding rabbit manure and water, and analyzed at different stages of the composting process. During the waste transformation process, parameters such as temperature and humidity were controlled, a high temperature is required to disinfect the final product and maintaining humidity around $60 \%$ to facilitate the process. The results show the nutrient richness of the final product, suitable for use as a fertilizer, having begun trials to be used also as a substrate $v$ for plant development. The study is part of a Cooperation Project of the Polytechnic University of Valencia in the School of Agronomy and Rural Environment.
\end{abstract}

Keywords: coconut plant, waste, vermicompost, resources.

Resumen: Los residuos de coco son difíciles de eliminar y aunque presentan utilidad como sustrato en jardinería, su larga vida los hace útil para otras actividades, siendo muy utilizado dentro del arte para realizar manualidades y obras decorativas tanto en joyeria, adornos, instrumentos, etc. Además algunas partes del coco con dificil reutilización tras u uso agroindustrial puede procesarse por compostado transformándolo en un recurso útil como fertilizante, dada su alta proporción en nutrientes. Se menciona su utilidad en el arte y se presentan los resultados relativos a la reutilización de residuos de coco procedentes de una empresa emergente de Ecuador después de la utilización agroindustrial del coco. Los residuos compostados se prepararon adicionando estiercol de conejo y agua, y se analizaron en diferentes etapas del proceso de compostaje. Durante el proceso de transformación del residuo se controlaron parámetros como la temperatura y la humedad, se precisa una temperatura elevada para realizar la desinfección del producto final y manteniendo la humedad alrededor del $60 \%$ para facilitar el proceso. Los resultados muestran la riqueza en nutrientes del producto final, apto para su utilización como fertilizante, habiéndose iniciado los ensayos para poder utilizarse también como sustrato v para el desarrollo vegetal. El estudio se enmarca dentro de un Proyecto de Cooperación de la Universitat Politécnica de Valencia en la Escuela de Agronomia y del Medio Rural.

Palabras clave: planta de coco, residuos, vermicompostaje, recursos.

Citar como: Soriano, M. D., García, F., Garcia-España, L. (2022). Residuos de coco. Arte y vermicompostado para su reutilización. En Actas del III Congreso Internacional sobre Patrimonio Alimentario y Museos. 25-26 noviembre, 2021, Valencia, España. pp. 281-290. https://doi.org/10.4995/EGEM2021.2021.14899 


\section{Introducción}

La reutilización de los residuos es una investigación dirigida hacia la gestión, tratamiento y aprovechamiento de los residuos agroindustriales para la producción de productos útiles como insumos de otros procesos industriales, ha sido y está siendo uno de los temas prioritarios en los campos de la biotecnología, agroquímica y ciencias medioambientales. Por otro lado, las normativas europeas, nacionales y autonómicas, incorporan capítulos específicos sobre los residuos derivados de la actividad agrícola y ganadera dado que su tratamiento requiere especificidades propias, debido a sus posibles orientaciones estratégicas. La detección de contaminantes emergentes en todos los compartimentos ambientales, así como en muchos residuos, ha creado, en los últimos años, la necesidad de desarrollar procedimientos para su eliminación que puedan aplicarse como técnicas de biorremediación. La utilización de los procesos de compostaje se emplean como estrategias para el aprovechamiento y el reciclado de residuos orgánicos y, por ende, para el tratamiento y valorización de los biorresiduos agrícolas; esto puede proporcionar enmiendas orgánicas que mejoren la calidad del suelo y favorezcan el desarrollo vegetal. La necesidad de mejorar, proteger y conservar la calidad de los suelos y su funcionalidad con el fin de incrementar la producción y la seguridad alimentaria, junto con el reciclado de residuos, constituyen una de las bases que marcan el camino hacia la sostenibilidad y contribuyen, en gran parte, a llevar a cabo de manera exitosa las directrices de la economía circular, tanto en el presente como en el futuro.

Actualmente de los residuos agroindustriales del coco sólo se aprovecha el $17 \%$ de la cubierta y parte media de los cocos, siendo el $83 \%$ restante considerado como residuo.

En arte el coco ha sido utilizado para manualidades desde hace años, llegando a encontrarse verdaderos museos del coco. En estos museos se pueden ver fotografias, informaciòn sobre la palma de coco y sus derivados, artesanías elaboradas con materiales extraídos de la planta, asi como herramientas y utensilios que se usan como decoración o en cocina, etc.

Por otra parte, cada vez en mayor medida se buscan fertilizantes orgánicos que actuén mejorando la fertilidad del suelo, sobre sus propiedades físicas, químicas y biológicas y mejoren

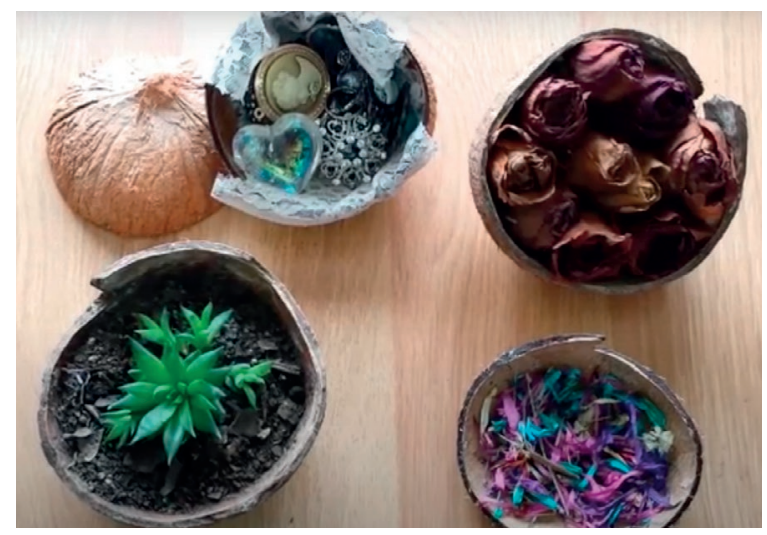

Figura 1. Reutilización de la cascara de coco.

Fuente: https://www.bing.com/videos/search?q=artesania+en+coco+museos\&\&view=detail\&mid= 3FBA7F93C283008070FC3FBA7F93C283008070FC\&\&FORM=VDRVR 


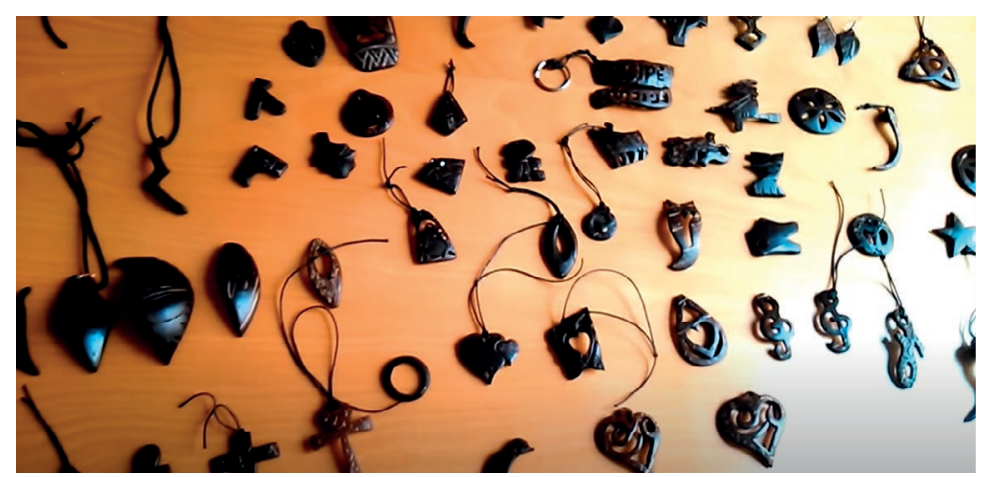

Figura 2. Reciclando cáscara de coco! - Bing video. Artesania con cascara de coco de Antonio Palazón. Fuente: https://www.youtube.com/watch?v=aeb3ilESVc4V.

I.a pérdida de materia orgánica del suelo Actualmente se plantea un escalamiento del proceso de aprovechamiento de los residuos del coco que beneficie a las comunidades que lo cultivan.

La obtención de materia orgánica a partir de residuos minimiza el daño medioambiental apuntando hacia una agricultura más sostenible. Siendo el proceso de compostaje una interesante alternativa que facilita el reciclado y reutiliza los residuos convirtiéndolos en compost.

Por todo lo anterior, el presente trabajo pretende dar una visión de su reutilización tanto en arte y como fertilizante de este residuo por su utilidad en ambos campos.

\section{Metodología}

\subsection{Material vegetal utilizado}

El coco es el fruto de Cocus nucifera (familia Arecaceae), se trata de un árbol originario de Asia. Se comercializa como fruta fresca o destinado con fines industriales, y se cosecha entre los 5 y 6 meses. Posee elevado contenido de agua y azúcares.

Existe gran cantidad de variedades. Se desarrolla en terrenos arenosos y salinos, tolerante al viento necesitando un clima sueve para su crecimiento. Su fruto presenta propiedades medicinales, y nutricionales, presentando una gran utilidad desde el punto de vista artesanal.

\subsection{Preparación del experimento}

Se utilizan residuos de coco para su transformación en un experimento de compostaje. En una primera fase se seleccionaron los residuos de coco de la parte exterior de la corteza, media e interior, Se trituraron utilizando un molino de cuchillas (Biotriturador VIKING 4000), hasta alcanzar un tamaño aproximado de $1 \mathrm{~cm}$ de longitud (Figura x). Los residuos triturados se mezclaron con estiércol de conejo parcialmente transformado procedente de las granjas de la ETSIAMN. Las proporciones de las mezclas fueron 1:1:1 (residuo, estiércol, agua). Las mezclas se homogeneizaron introduciendo una cantidad de $25 \mathrm{~kg}$ en recipientes de PVC de 32 litros. Se habilitaron tres recipientes para el compostaje, para realizar repeticiones suficientes. Seguidamente se les añadió agua a las muestras preparadas para compostaje en cantidad suficiente para lograr una humedad del $70-85 \%$. En 

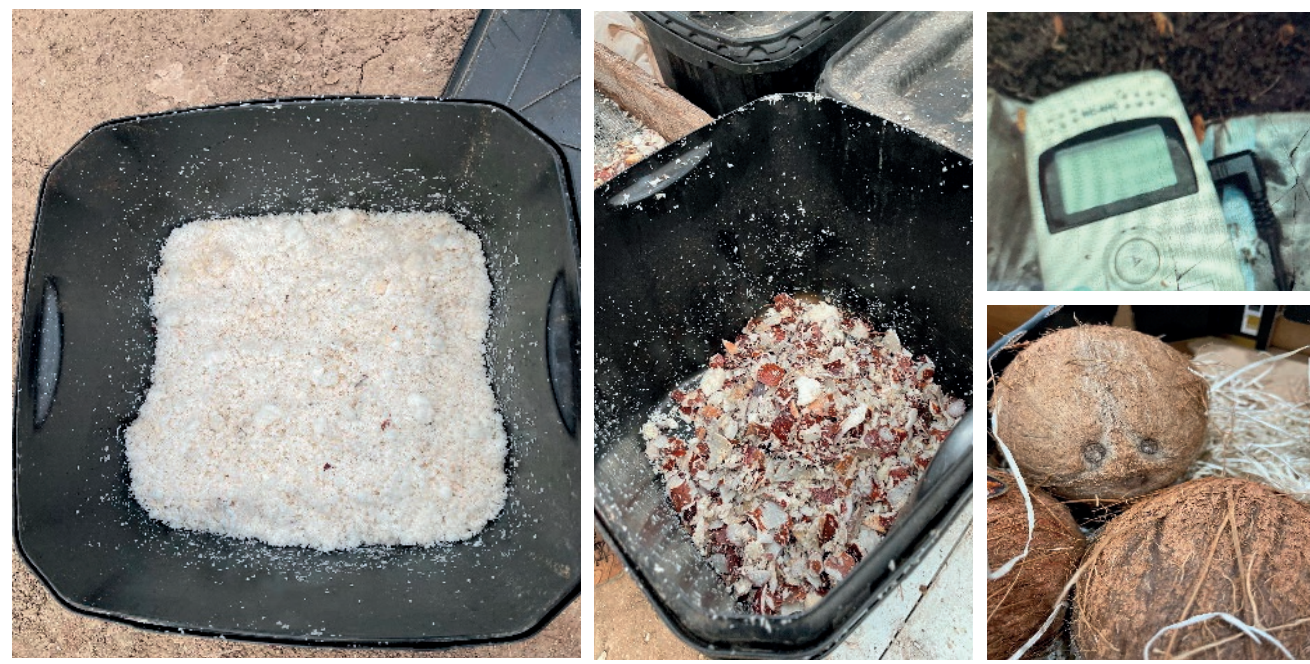

Figura 3. Residuos de coco. Termómetro

Fuente propia.

las mezclas preparadas para compostar, la humedad se mantuvo siempre por encima del 50\%, y nunca bajando del valor crítico a partir del cual la actividad biológica podría detenerse según indican autores como Moreno y Moral (2008). Finalmente se taparon los recipientes dejándolos en condiciones de oscuridad y con una temperatura inicial entre 25 y $29^{\circ} \mathrm{C}$. Para realizar todas estas experiencias se habilitó una planta en los recintos de la Escuela Técnica Superior de Agronomía de la Universidad Politécnica de Valencia dedicada al tratamiento de los residuos. Durante 4 meses se controló la humedad y la temperatura. Se voltearon las pilas con una frecuencia semanal para asegurar una correcta aireación de éstas y mantener la humedad.

Al cabo de este periodo se tomaron las muestras, se secaron y analizaron realizando determinaciones como el contenido en materia orgánica, nitrógeno total y análisis elemental (Métodos Oficiales Ministerio Agricultura, 1991). Se utilizó un microscopio electrónico de barrido HITACHI mod. S-4100 con sistema de captación de imágenes EMIP 3.0 y sistema de microanálisis RONTEC f) cañón de emisión de campo con detector BSE AUTRATA.

\section{Resultados y Discusión}

\subsection{Utilidad y uso del coco}

El coco presenta gran utilidad en industrias de alimentos, cosméticos, textil, etc. Al mismo tiempo que por su contenido en aceite, resistente a altas temperaturas y con elevado contenido en grasas saturadas. El agua de coco contiene minerales, vitaminas, proteínas, carbohidratos y antioxidantes, siendo una bebida isotónica e hidratante.

La cáscara se utiliza en los cultivos como abono, pudiendo ser además aprovechado para el ganado. Contiene ácido laúrico que se utiliza para producir jabones, detergentes y champús. También se utiliza como fragancia y cosméticos. 


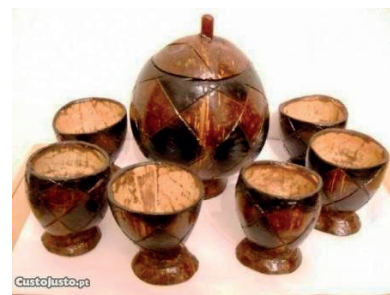

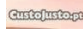
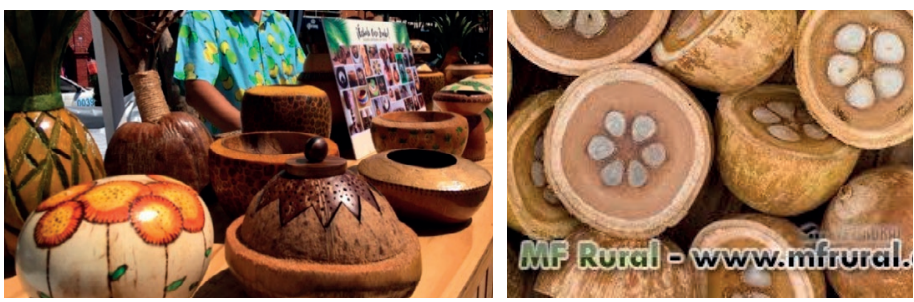

Figura 4. Museos del coco.

Fuente: https://www.mfrural.com.br/.

Como propiedades medicinales tiene a regular la presión sanguínea, los niveles de azúcar y colesterol, además tiene propiedades antibacterianas, antifúngicas, antiinflamatorias y antisépticas, además presenta un alto grado de protección solar.

El coco ha sido utilizado para manualidades desde hace años, en todas las partes del coco pulpa, corteza y malla, llegando a encontrarse verdaderos museos del coco. En estos museos se pueden ver fotografías, información sobre la palma de coco y sus derivados, artesanías elaboradas con materiales extraídos de la planta, así como herramientas y utensilios que se usan como decorativos o en cocina, etc. Igualmente se utilizan para elaborar artesaria decorativa de tipo pendientes y pulseras.

\subsection{Producto final del compostaje}

El contenido de C se encuentra alrededor del 20\%. Valores elevados si comparamos con otros residuos como el palmito (7\%) o el arroz (3\%). La pulpa del coco seco contiene más de un $60 \%$ de aceite. Los residuos de coco poseen proteínas con un promedio del $22 \%$ de proteína.

Con un contenido en materia seca del $92 \%$, un $22 \%$ de proteína cruda y un $16 \%$ de cenizas. Este valor destaca si lo comparamos con otros residuos como el arroz con un valor medio de proteína tan solo alrededor del 10\%.

La Tabla 1 muestra los resultados de la caracterización de los residuos de coco así como del estiércol de conejo (EC), y en la Tabla 2 se indica el manejo de los residuos, humedad, pH y relación $\mathrm{C} / \mathrm{N}$ de las mezclas.

Desde el punto de vista del compostaje hay que señalar que el residuo de coco posee un contenido de humedad y una relación $\mathrm{C} / \mathrm{N}$ elevada, para obtener una mezcla adecuada se requiere un residuo que pueda aportar elevados nutrientes, en este sentido, el estiércol de conejo aporta un contenido importante de nitrógeno (1,5\%) que no tiene nuestro residuo de coco $(0,6-1,0)$.

Aunque el compostaje de este residuo por si solo puede ser factible, se recomienda su mezcla con otros residuos que contengan características adecuadas de manera que se acelere y mejore el rendimiento del proceso de compostaje. Existen muchas referencias en la bibliografía en las cuales se lleva a cabo técnicas de tratamiento con residuos de poda (Day y Shaw, 2001; Goldstein, 2004; Smidt., 2009; Haug, 2014; Abbasi et al., 2015; Rekasi et al., 2019).

Los contenidos de humedad del residuo son muy elevados situándose entre 80 y $85 \%$ mientras que el contenido del estiércol de conejo es ligeramente inferior (48,8\%). Como es obvio, la salinidad de los estos residuos agrícolas es baja (entre 0,3 y 0,8 dS. $\mathrm{m}^{-1}$ ) y la del estiércol de 
conejo es bastante más elevada $\left(2,1 \mathrm{dS} \cdot \mathrm{m}^{-1}\right)$. El pH del residuo de coco es de 5,9. El carbono total varía alrededor del $20 \%$ estando la relación C/N inicial en 45,3.

Parámetros como son los nutrientes tales como fósforo, potasio, calcio y magnesio, presentan los valores característicos de residuos agrícolas y complementan el medio nutritivo adecuado para los organismos que deben llevar a cabo el proceso. Respecto al sodio, indicar de la misma manera que es muy bajo para los residuos agrícolas (de 0,1 a 0,03\% de $\mathrm{Na}_{2} \mathrm{O}$ ) y más elevado para el estiércol de conejo (1,8\%). Respecto al residuo de conejo nuestros valores son semejantes a los mostrados en los trabajos de Soliva, (2001); Gong et al., (2018); Li et al., (2013); Boluda et al., (2014); Lim et al., (2016).

Tabla 1. Caracterización analítica de los residuos agrícolas (entre paréntesis se indica la desviación estándar, n=3).

\begin{tabular}{lcc}
\hline Parámetro & R. Coco & Estiércol de conejo \\
\hline Humedad \% & $75,3(0,4)$ & $48,8(2,4)$ \\
CE $\left(\right.$ dS. m $\left.^{-1}\right)$ 1:10 & $0,7(0,1)$ & $2,1(0,0)$ \\
pH 1:10 & $5,7(0,0)$ & $8,2(0,0)$ \\
Carbono Total $(\%)$ & $42,2(1,1)$ & $38,6(0,8)$ \\
Relación C/N & $42,3(1,0)$ & $25,7(0,6)$ \\
\hline
\end{tabular}

Después de aproximadamente 4 meses tras haber iniciado el proceso se consideró finalizado y se procedió a la evaluación de las características del compost obtenido (Tabla 2).

Tabla 2. Características físicas y químicas del compost obtenido (entre paréntesis se indica la desviación estándar, n=3).

\begin{tabular}{lc}
\hline Parámetro & Coco \\
\hline Humedad \% & $45(0,2)$ \\
Densidad (g /cm3) & $0,8(0,1)$ \\
CRA \% & $85(2,9)$ \\
CE $\left(\mathrm{dS} . \mathrm{m}^{-1}\right)$ 1:10 & $1.9(0,1)$ \\
pH 1:10 & $7,8(0,1)$ \\
Carbono Total (\%) & $23,5(0,1)$ \\
Relación C/N & $14,5(0,4)$ \\
CIC $\left(\mathrm{cmol}_{.} \cdot \mathrm{kg}^{-1}\right)$ & $44,2(2,0)$ \\
\hline
\end{tabular}

El estudio del análisis elemental muestra la abundancia de silicio, potasio y calcio como constituyentes principales seguidos de otros macronutrientes como aluminio, sodio y magnesio (Figura 5).

\subsection{Microscopía electrónica y Espectroscopia infrarrojo de transformada de Fourier (FTIR)}

El estudio de las características de los residuos permite por IR la identificación de los grupos químicos que muestran los cambios que se producen durante el proceso de compostaje (Figura 5). 

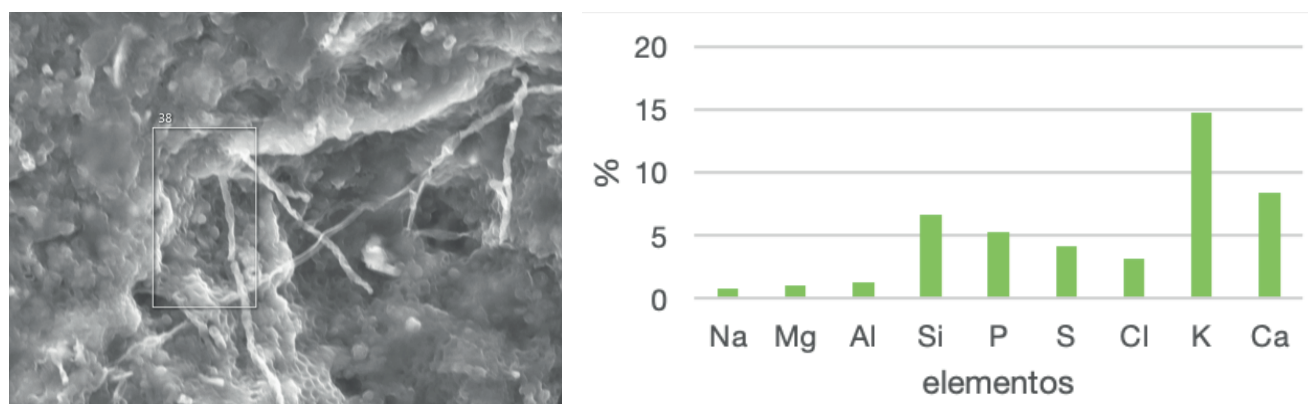

Figura 5. Imágenes SEM del residuo de coco. Resultado del análisis elemental del residuo de coco.

Al analizar los espectros obtenidos se asignaron los picos a los grupos funcionales presentes en los materiales de acuerdo a sus respectivas señales. La banda más amplia alrededor de los 3000 a 4000 cm-1 corresponde al estiramiento del grupo hidroxilo debido al enlace de hidrógeno de los compuestos poliméricos como alcoholes, fenoles y ácidos carboxílicos típicos de la celulosa y la lignina. Los picos entre 1720 y $1730 \mathrm{~cm}^{-1}$ son debidos a la vibración del estiramiento del enlace CO producido por grupos carboxílicos iónicos o sus esteres. Alrededor de 1600 a 1400 $\mathrm{cm}^{-1}$ se muestran las vibraciones delos grupos carboxílicos, siendo además la señal de 1600 $\mathrm{cm}^{-1}$ corresponde con las vibraciones del doble enlace $\mathrm{C}=\mathrm{C}$ del anillo aromático de la lignina. La señal en $1033 \mathrm{~cm}^{-1}$ es característico de los grupos de la celulosa. El estudio de la evolución del proceso permite observar la disminución de las bandas propias de grupos aromáticos por transformación del residuo así como la disminución de celulosa y grupos $\mathrm{OH}$. Las fotografías obtenidas por microscopia muestran la evolución y transformación de las fibras del residuo y la mineralización de la muestra.

\section{Conclusiones}

La planta de coco ha sido utilizada desde antiguo por sus diversas funciones estando relacionada desde antaño con el arte, siendo numerosas sus aplicaciones en manualidades y obras de arte, encontrándose muestras en museos y exposiciones a lo largo de la historia.

La reutilización de residuos por compostado ha supuesto un nuevo campo para transformarlo en recurso, al obtener un producto apto para su utilización como abono por su riqueza en materia orgánica y nutrientes.

Tanto los ejemplos recogidos en museos como la comercialización de los productos obtenidos indican la utilidad de esta planta en diversos medios, que pueden introducirse además en el ámbito docente en los estudios de Bellas Artes y en el estudio y aplicación agronómica de residuos.

\section{Agradecimientos}

Trabajo realizado en el marco del Proyecto de Cooperación de la Universitat Politècnica de València. Programa Adisedo Cooperación. Años 2020-2022. «TíTULO DEL PROYECTO: Evaluación de la sostenibilidad del establecimiento de una fábrica artesana de productos de coco en la subregión de Sanquianga (departamento de Nariño, Colombia)». 


\section{Bibliografía}

ABBASI, S. A., NAVEEM, M., ABBASI, T. ( 2015). "Vermicomposting of phytomass: limitations of the past approaches and the emerging directions". En: Journal of Cleaner Production. 93, pp. 103-114.

HUANG K, LI FS, WEI YF, FU XY, y CHEN, XM. (2014). "Effects of earthworms on physicochemical properties and microbial profiles during vermicomposting of fresh fruit and vegetable wastes". En: Bioresour Technol., 170, pp. 45-52. https://doi.org/10.1016/j.biortech.2014.07.058 PMID: 25118152.

REKASII, M., MAZU, N., DRASKOVITS, E., BERNHARDT, B., SZABO, A., RIVIER, P.A., FARKASS, C., BORSANYI, B., PIRKO, B. y MOLNAR, S. (2019). "Comparing the agrochemical properties of compost and vermicomposts produced from municipal sewage sludge digestate". En: Bioresource Technology, 291, 121861, https://doi.org/10.1016/j.biortech.2019.121861.

YONG, WJWH. (2009). "Chemical composition and biology in cooconut (Cocos nucifera L.)" Molecules: 14 , pp. 5144-5164. 


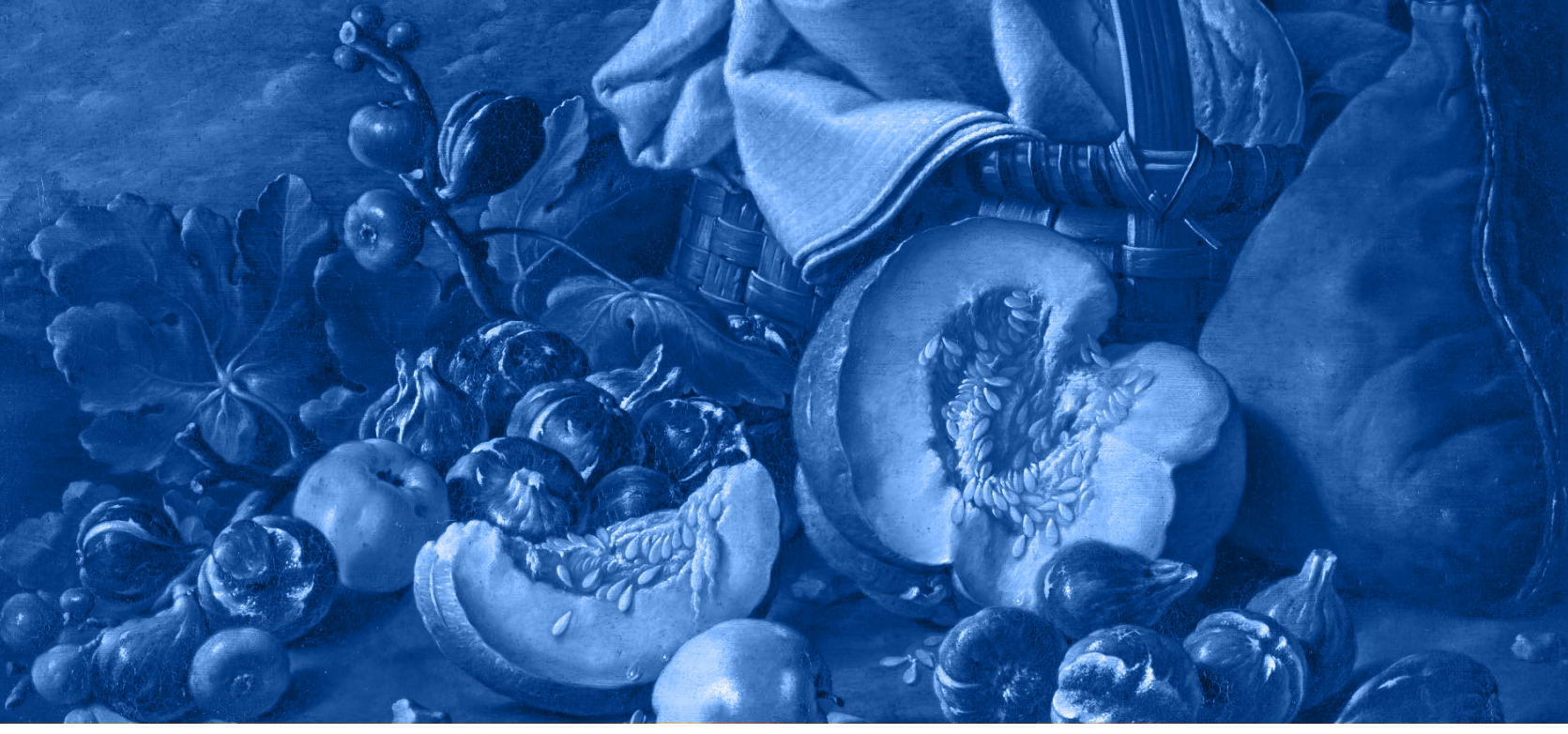

\section{EL GUSTO EN EL MUSEO 2021}

\section{ACTAS III CONGRESO INTERNACIONAL SOBRE PATRIMONIO ALIMENTARIO Y MUSEOS}

\section{Edición científica: Núria Ramón-Marqués}

El gusto en el museo 2021 es una monografía que pretende aunar en un mismo espacio de diálogo, por un lado, la particular casuística de los museos alimentarios como espacios patrimoniales a través de las identidades locales. Por otro lado, se centra en vincular las obras de arte como fuentes de documentación alimentaria, todo ello con el propósito de crear un espacio multidisciplinar de dialogo en torno al patrimonio alimentario.

Los trabajos que se presentan en este segundo volumen son el resultado del III Congreso Internacional sobre Patrimonio Alimentario y Museos celebrado en la Universitat Politècnica de València los días 25 y 26 de noviembre en el que, la aportación de varios investigadores de diferentes nacionalidades, se considera fundamental para el avance en las investigaciones sobre el patrimonio alimentario, su gestión, y el lugar que ocupa en los museos.

UNIVERSITAT POLITECCNICA DE VALÈNCIA

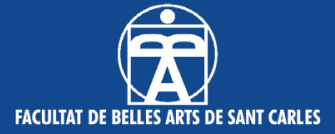

- DCADHA DPTO. DE COMUNICACIÓN AUDIOVISUAL DOCUMENTACIÓN E HISTORIA DEL ARTE

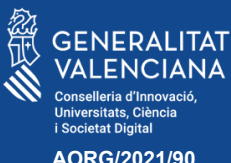

AORG/2021/90 